Faculdade de Arquitetura e Urbanismo

Universidade de São Paulo

DEMÓSTHENES MAGNO SANTOS

\title{
A HISTÓRIA DA CONSTRUTORA ALFREDO MATHIAS \\ 1950 - 1985
}

São Paulo

2013 


\section{DEMÓSTHENES MAGNO SANTOS}

\section{A HISTÓRIA DA CONSTRUTORA ALFREDO MATHIAS \\ $1950-1985$}

Dissertação de Mestrado apresentada ao Curso de Pós-Graduação da Faculdade de Arquitetura e Urbanismo da Universidade de São Paulo para a obtenção do título de Mestre.

Área de Concentração:

História e Fundamentos da Arquitetura e do Urbanismo

Orientador: Prof. Dr. Paulo Julio Valentino Bruna

São Paulo

2013 
Autorizo a reprodução e divulgação total ou parcial deste trabalho, por qualquer meio convencional ou eletrônico, para fins de estudo e pesquisa desde que citada à fonte.

\footnotetext{
S237h A história da Construtora Alfredo Mathias 1950-1985 /

Demósthenes Magno Santos. - São Paulo, 2013.

$X X X$ p. : il. + CD-ROM

Dissertação (Mestrado - Área de Concentração: História e Fundamentos da Arquitetura e do Urbanismo) - FAUUSP.

Orientador: Paulo Júlio Valentino Bruna

1. Arquitetura moderna - São Paulo (SP) 2. História da arquitetura - São Paulo (SP) 3. Incorporação imobiliária - São Paulo (SP) 4. Mercado imobiliário - São Paulo (SP) 5. Mathias, Alfredo I. Título
} 
Nome: Santos, Demósthenes Magno

Título: A História da Construtora Alfredo Mathias - 1950 - 1985

Dissertação apresentada à Faculdade de Arquitetura e Urbanismo da Universidade de São Paulo para obtenção do título de Mestre em Arquitetura.

Aprovado em

Banca Examinadora

Prof. Dr. Instituição:

Julgamento: Assinatura:

Prof. Dr. Instituição:

Julgamento: Assinatura:

Prof. Dr. Instituição:

Julgamento: Assinatura: 
Aos meus pais

Cleuza Luíza Côrtes Santos

Altamiro José dos Santos (in memoriam) 
Dedico este trabalho a Manuel José Nicieza Rubio que me ensinou amar a arquitetura. 


\section{Agradecimentos}

A todos que de uma forma ou de outra contribuíram para a realização deste trabalho, principalmente aos profissionais que fizeram parte da construtora, a Reinaldo Forner e, in memoriam, a Mauro Rossignolli entre outros. A Heloisa e ao Prof. Dr. Marcio Moysés de Oliveira pelos comentários pertinentes. A Maria do Carmo Mathias Maffei pelo carinho que me recebeu e por suas memórias.

Ao Prof. Dr. Paulo Julio Valentino Bruna, por sua dedicação e colaboração no decorrer desta pesquisa, sempre apresentando observações importantes em seus comentários. 


\section{Resumo}

Santos, Demósthenes M.. A história da Construtora Alfredo Mathias 1950-1985. 2013286 f. Dissertação (Mestrado) - Faculdade de Arquitetura e Urbanismo, Universidade de São Paulo, São Paulo, 2013.

O presente trabalho tem por objetivo analisar a história do engenheiroarquiteto Alfredo Mathias e da construtora que leva o seu nome. Formado pela Escola Politécnica da Universidade de São Paulo em 1929, foi testemunha das profundas modificações que a cidade sofreu, evoluindo da cidade eclética, símbolo da sociedade cafeeira para a metrópole industrial e de serviços do final do século XX. A cidade de São Paulo, desde os anos trinta, funcionou como pano de fundo para um dos maiores protagonistas do processo de verticalização desta cidade. Atuou na indústria da construção civil como incorporador, construtor e industrial. Soube cercar-se dos melhores profissionais de sua época, como também tirar partido das oportunidades surgidas no mercado imobiliário como de suas limitações. A intenção deste trabalho é recuperar sua trajetória e sua produção em relação à cidade e ao campo arquitetônico. A narrativa foi elaborada a partir dos testemunhos dos profissionais que trabalharam em sua construtora e em estudos de caso. $O$ período analisado coincide com a fase de grande desenvolvimento do país e também de grande instabilidade política e econômica.

Palavras-chave: Arquitetura moderna - São Paulo, História da Arquitetura, Historia da Cidade de São Paulo, Mercado Imobiliário - São Paulo, Incorporadores - São Paulo 


\section{Abstract}

Santos, Demósthenes M.. The History of Construtora Alfredo Mathias 1950-1985. 2013286 f. Dissertação (Mestrado) - Faculdade de Arquitetura e Urbanismo, Universidade de São Paulo, São Paulo, 2013.

This study aims to analyze the history of engineer-architect Alfredo Mathias and construction company that bears his name. Graduated from the Escola Politécnica da Universidade de São Paulo in 1929, has witnessed the profound changes that the city suffered, evolving from eclectic city, symbol of coffee society to the industrial metropolis and service of the late twentieth century. The city of São Paulo, since the thirties, served as a backdrop for one of the biggest players in the process of uprighting this city. He worked in the construction industry as a developer, builder and industrial. Knew how to surround himself with the best professionals of his era, as well as take advantage of opportunities arising in the housing market as its limitations. The intention of this work is to recover his trajectory and his production to the city and the architectural field. The narrative was drawn from the testimony of the professionals who worked for his construction company and case studies. The sample period coincides with the period of great development of the country and also of great political and economic instability.

Keywords: Modern Architecture - São Paulo, History of Architecture, History of São Paulo City, Real Estate Market - São Paulo, Developers - São Paulo 


\section{Lista de Figuras}

Figura 1 - Palácio da Justiça 76

Figura 2 - Faculdade de Direito do Largo São Francisco 76

Figura 3 - Giancarlo Palanti 78

Figura 4 - Edifício Conde de Prates 79

Figura 5 - Hospital São Joaquim 81

Figura 6 - Edifício Copan 83

Figura 7 - Galeria Califórnia 83

Figura 8 - Edif. Nações Unidas 83

Figura 9 - Conjunto Nacional 83

Figura 10 - Galeria Sete de Abril - acesso pela Rua Bráulio Gomes 84

Figura 11- Galeria Sete de abril - pisos 85

Figura 12 - Centro Comercial Presidente - fachada 89

Figura 13 - Edifício Grandes Galerias- perspectiva do lançamento 90

Figura 14 - Rampas de acesso das Grandes Galerias 92

Figura 15 - Pisos e aberturas: Grandes Galerias 93

Figura 16 - Painéis elevadores: Grandes Galerias 93

Figura 17 - Lançamento da Galeria Rua Nova Barão 94

Figura 18 - Centro Comercial Bom Retiro - detalhe 95

Figura 19 - Fachadas do Centro Comercial Bom Retiro 95

Figura 20 - Osvaldo Terreri, caricatura 97

Figura 21 - Ed. Sta Odila e Sta Sofia, fachada 98

Figura 22 - Ed. Sta Odila e Sta Sofia - detalhe 98

Figura 23 - Shopping Iguatemi 100

Figura 24 - Fachada original do Shopping Iguatemi 101

Figura 25 - Palácio Anchieta - Câmara dos Vereadores de São Paulo 102

$\begin{array}{ll}\text { Figura } 26 \text { - Centro Empresarial Lubeca } & 104\end{array}$

Figura 27 - Centro Empresarial Lubeca, Esplanada 105

Figura 28 - Perspectiva do Portal do Morumbi 106

Figura 29 - Pagina 5 do prospecto de vendas do Portal do Morumbi 107 
Figura 30 - Anuncio Sistema Fácil

Figura 31- Planta com a assinatura do arquiteto no edifício na esquinas das avenidas São João com Ipiranga

Figura 32 - Cine Rivoli ou Jussara, plantas

Figura 33 - Cine Rivoli ou Jussara, Corte Longitudinal detalhamento

Figura 34 - Cine Rivoli ou Jussara, Detalhamento

Figura 35 - Cine Rivoli ou Jussara, Detalhamento

Figura 36 - Cine Rivoli ou Jussara

Esquerda: vista da platéia vista para a tela de projeção;

Direita: detalhe do balcão

Figura 37- Cine Rivoli ou Jussara, vista da Sala de espera do andar térreo

Figura 38 - Cine Rivoli ou Jussara, Fachada - vista da marquise

Figura 39 - Edifício Conde Prates

Figura 40 - Edifício Conde Prates - 1952

Acima: perspectiva do prédio com o volume escalonado;

Abaixo: perspectiva do projeto substitutivo de 1950

Figura 41- Edifício Conde Prates - 1952

Planta do Andar Tipo - anterior a proposta final das fachadas

Figura 42 - Edifício Conde Prates - 1952

Perspectiva dos primeiros estudos da fachada: já apresenta a

definição do volume prismático e a esplanada envolta em pilares

Figura 43 - Edifício Conde Prates, vistas da esplanada

Figura 44 - Edifício Conde Prates - 1952

Acima: vista do interior dos escritórios,

Abaixo: acesso para a Rua Líbero Badaró

Figura 45 - Edifício Conde Prates - 1952

Planta do Andar Tipo reformulado por Palanti

Figura 46 - Edifício Conde Prates - 1952

Perspectiva do edifício reformulada por Palanti 
Figura 47 - Edifício Conde Prates - 1952

Fotomontagem com a perspectiva do edifício reformulada por Palanti

Figura 48 - Perspectiva dos Edifícios Chipre e Gibraltar e Cine Trianon - 1952

Alfredo Mathias e Giancarlo Palanti

Figura 49 - Edifícios Chipre e Gibraltar e Cine Trianon - 1952

Figura 50 - Edifícios Chipre e Gibraltar e Cine Trianon - 1952

Estudo das fachadas para a Avenida Paulista

Figura 51-Cine Trianon - 1952

Acima: Planta da sala de projeção localizada no subsolo

Abaixo: corte longitudinal da sala do subsolo

Figura 52 - Edifícios Chipre e Gibraltar e Cine Trianon - 1952

Fotos do conjunto em 2003

Figura 53 - Edifícios Chipre e Gibraltar e Cine Trianon - 1952

Foto do conjunto em 2013

Figura 54 - Edifícios Chipre e Gibraltar e Cine Trianon - 1952

Foto do conjunto em 2013

Figura 55 - Edifício Lili, Rua Barão de Tatuí, 351 - 1953

Estudos iniciais - perspectiva

Figura 56 - Edifício Lili, Rua Barão de Tatuí, 351 - 1953

Estudos iniciais - perspectivas internas

Figura 57 - Edifício Lili, Rua Barão de Tatuí, 351 - 1953

Planta do Subsolo

Figura 58 - Edifício Lili, Rua Barão de Tatuí, 351 - 1953

Planta do Pavimento Térreo

Figura 59 - Edifício Lili, Rua Barão de Tatuí, 351 - 1953

Planta do Pavimento Tipo

Figura 60 - Edifício Lili, Rua Barão de Tatuí, 351 - 1953

Planta do Pavimento de Cobertura

Figura 61 - Edifício Lili, Rua Barão de Tatuí, 351 - 1953

Planta do Ático 
Figura 62 - Edifício Lili, Rua Barão de Tatuí, 351 - 1953

Cortes

Figura 63 - Edifício Lili, Rua Barão de Tatuí, 351 - 1953

Estudos de Fachada

Figura 64 - Edifício Lili, Rua Barão de Tatuí, 351 - 1953

Fachadas

Figura 65 - Edifício Lili, Rua Barão de Tatuí, 351 - 1953

Detalhe da Escada e Marquise

Figura 66 - Edifício Lili, Rua Barão de Tatuí, 351 - 1953

Detalhe da Lareira

Figura 67 - Edifício Lili, Rua Barão de Tatuí, 351 - 1953

Fachada Principal - estado atual

Figura 68 - Edifício Lili, Rua Barão de Tatuí, 351 - 1953

Fachada Principal - detalhe

Figura 69 - Edifício Lili, Rua Barão de Tatuí, 351 - 1953

Fachada Principal - detalhe da marquise

Figura 70 - Biblioteca Pública Martinico da Silva Prado - Araras - S.P. - 1954

Placa Comemorativa

Figura 71 - Biblioteca Pública Martinico da Silva Prado - Araras - S.P. - 1954

Estudos das Fachadas - Perspectiva - Giancarlo Palanti

Figura 72 - Biblioteca Pública Martinico da Silva Prado - Araras - S.P. - 1954

Fotos do local

Figura 73 - Concurso para o Paço Municipal de São Paulo - 1952

Estudos das Fachadas - Perspectiva - Giancarlo Palanti

Figura 74 - Hospital são Joaquim da beneficência Portuguesa - 1957

Figura 75 - Centro comercial Presidente

Esquerda: acesso pela Rua Vinte e Quatro de Maio, 116

Direita: fachada para a Rua Dom José de Barros

Figura 76 - Centro comercial Presidente

Plantas: subsolo, pavimento térreo e pavimento tipo 
Figura 77 - Centro comercial Presidente

Esquerda: escadas rolantes sobre o vazio;

Direita: rampa de acesso

Figura 78 - Centro comercial Presidente

Esquerda: escadas rolantes sobre o vazio;

Direita: vista da clarabóia

Figura 79 - Grandes Galerias

Fachada para a Avenida São João, 439

Figura 80 - Grandes Galerias

Planta parcial do $1^{\circ}$ pavimento

Figura 81 - Grandes Galerias

Planta parcial do $1^{\circ}$ pavimento

Figura 82 - Grandes Galerias

Fachada para a Avenida São João, 439

Detalhes da Fachada

Figura 83 - Grandes Galerias

Fachada para a Avenida São João, 439

Detalhe da laje e pisos, detalhe do guarda-corpo

Figura 84 - Grandes Galerias

Detalhes dos pisos

Figura 85 - Grandes Galerias

Detalhes dos pisos

Figura 86 - Grandes Galerias

Detalhes dos pisos, vistos através dos vazios

Figura 87 - Grandes Galerias

Painel em cerâmica de Bramante Buffoni

Figura 88 - Conjunto de dois edifícios á Alameda Lorena 1041

Protótipos para a execução do Portal do Morumbi

Projeto João Henrique da Rocha

Figura 89 - Conjunto de dois edifícios á Alameda Lorena 1041

Protótipos para a execução do Portal do Morumbi

Projeto João Henrique da Rocha 
Figura 90 - Conjunto de dois edifícios á Alameda Lorena 1041

Protótipos para a execução do Portal do Morumbi

Projeto João Henrique da Rocha

Figura 91 - Condomínio Portal do Morumbi-

Implantação

Figura 92 - Condomínio Portal do Morumbi

Projeto executivo: planta do andar tipo com 3 dormitórios

Figura 93 - Condomínio Portal do Morumbi

Projeto executivo: planta do andar tipo com 4 dormitórios

Figura 94 - Condomínio Portal do Morumbi

Projeto executivo: planta do andar térreo

Figura 95 - Condomínio Portal do Morumbi

Projeto executivo: planta da cobertura

Figura 96 - Condomínio Portal do Morumbi

Projeto executivo: Clube - planta do andar inferior

Figura 97 - Condomínio Portal do Morumbi

Projeto executivo: Clube - planta do andar superior

Figura 98 - Condomínio Portal do Morumbi

Projeto executivo: Clube - corte da piscina externa

Figura 99 - Condomínio Portal do Morumbi

Fotos atuais

Figura 100 - Condomínio Portal do Morumbi

Fotos atuais

Figura 101- Condomínio Portal do Morumbi

Fotos atuais

Figura 102 - Condomínio Portal do Morumbi

Fotos atuais

Figura 103 - Condomínio Portal do Morumbi

Fotos atuais

Figura 104 - Condomínio Portal do Morumbi

Fotos atuais 
Figura 105 - Condomínio Portal do Morumbi Fotos atuais

Figura 106 - Condomínio Portal do Morumbi

Fotos atuais

Figura 107 - Condomínio Portal do Morumbi

Fotos atuais do Portão do Morumbi

Figura 108: Alfredo Mathias (1906 - 1979) 
$\begin{array}{ll}\text { Agradecimentos } & 7\end{array}$

Resumo 8

Abstract 9

Lista de Figuras $\quad 10$

1. Introdução 20

$\begin{array}{ll}\text { 1.1. Objetivo e Justificativa } & 21\end{array}$

1.2. Características do Período Estudado:

a cidade como pano de fundo

1.2.1. Evolução Urbana da Cidade de São Paulo (décadas de 1930 e 1940) 22

1.2.2. O Plano de Avenidas 25

1.2.3. Período de 1940 a 1960

1.2.4. Período de 1961 a 1985

1.3. Organização dos Capítulos 40

2. O Mercado Imobiliário de São Paulo nos anos 1930 A 1985

2.1. O Processo de Industrialização 43

2.2. O Complexo Industrial Matarazzo 46

2.3. O Processo de Verticalização da Cidade entre 1930 E $1940 \quad 48$

2.4. A Criação de um Modelo 56

2.5. Os Principais Agentes do Mercado Imobiliário na Cidade de São Paulo 58

2.5.1. Construtora Adolpho Lindenberg 63

2.5.2. Construtora Hindi Cia. Brasileira de Habitações 64

2.5.3. Construtora Romeu Chap Chap 65

2.5.4. Construtora Sobloco 66

2.5.5. Construtora Luciano Wertheim 67 
2.5.6. Construtora Albuquerque \& Takaoka

2.5.7. Construtora Alfredo Mathias S.A. 69

3. Alfredo Mathias, Engenheiro-Arquiteto 74

4. A História da Construtora Alfredo Mathias S.A. 63

5. Projetos Selecionados: Estudos de Caso 111

5.1. Giancarlo Palanti 112

5.1.1. Cine Rivoli ou Jussara - 1951

5.1.2. Edifício Conde de Prates - $1952 \quad 117$

5.1.3. Edifício Chipre / Gibraltar e Cine Trianon - 1952

5.1.4. Edifício na Rua Barão de Tatú, 351

5.1.5. Biblioteca Pública Martinico Prado - Araras - 1953

5.1.6. Propostas para o Paço Municipal de São Paulo - 1952

5.2.1. Hospital São Joaquim da Beneficência Portuguesa - $1957 \quad 145$

5.3.1. Centro Comercial Presidente - $1962 \quad 158$

5.3.2. Grandes Galerias - atual Galeria do Rock - $1962 \quad 162$

5.4. Condomínio Portal do Morumbi- $1973 \quad 170$

6. Considerações Finais 193

7. Referências Bibliográficas 195 
APÊNDICE A - Palácio da Justiça Clovis Beliváqua 202

APÊNDICE B - Edifício da Faculdade de Direto do Largo São Francisco 206

APÊNDICE C - Edifício Conde de Prates 208

APÊNDICE D - Biblioteca Municipal Martinico Prado - Araras 212

APÊNDICE E - Edifício Rua Barão de Tatúi, 351 214

APÊNDICE F - Edifícios Gibraltar e Chipre $\quad 217$

APÊNDICE G - Cine Belas Artes (antigo Cine Trianon) 220

APÊNDICE H - Edifício à Rua Martiniano de Carvalho esquina com Rua Humaitá 222

APÊNDICE I - Hospital São Joaquim da Beneficência Portuguesa 224

APÊNDICE J - Edifício e Galeria Sete de Abril 226

APÊNDICE K - Centro Comercial Presidente 234

APÊNDICE L - Grandes Galerias $\quad 240$

APÊNDICE M - Rua Nova Barão 247

APÊNDICE N - Centro Comercial Bom Retiro 251

APÊNDICE O - Edifício Princesa Isabel 254

APÊNDICE P - Edifico Savoy 257

APÊNDICE Q - Edifício Veiga Filho 259

APÊNDICE R - Edifício na Avenida angélica 262

APÊNDICE S - Edifícios Santa Odila e Santa Sofia 264

APÊNDICE T - Edifício Avenida Angélica com Rua Baronesa de Itu 267

APÊNDICE U -Edifício Avenida Higienópolis esquina Rua Itacolomy 270

APÊNDICE V -Shopping Center Iguatemi 273

APÊNDICE W - Edifícios Monfort, Chatel, Avignon e Djon 275

APÊNDICE X - Esplanada Granja Julieta 278

APÊNDICE Y - Condomínio Portal do Morumbi 280

APÊNDICE Z - Centro Empresarial Lubeca 284 
1. Introdução 


\subsection{Objetivo e Justificativa}

O objetivo deste trabalho é resgatar a trajetória do arquiteto Alfredo Mathias e de sua produção arquitetônica, que demonstrou ser possível conciliar os interesses econômicos com uma arquitetura de qualidade e produzir lucros consideráveis para seus investidores e clientes, nas palavras de Pereira Leite, Mathias possuía o verdadeiro "toque de Midas".

O interesse no levantamento histórico desta construtora parte de duas premissas: a primeira pessoal, desde os meus quinze anos o nome Alfredo Mathias fez parte do meu imaginário seja pela afetividade dos projetistas que lá trabalharam, seja pelo seu carisma e, principalmente, por suas obras.

O segundo ponto é o acadêmico: o processo de verticalização da cidade, a atuação dos incorporadores no mercado da construção e as influencia desta atuação sobre a arquitetura da cidade. Chama a atenção que raramente o nome Alfredo Mathias apareça em trabalhos acadêmicos mesmo tendo construído obras de vulto como: o Centro Empresarial São Paulo, o Condomínio Portal do Morumbi, o Shopping Center Iguatemi, várias galerias do centro como As Grandes Galerias (atual Galeria do Rock), o Palácio Anchieta (sede da Câmara Municipal de São Paulo) e vários edifícios pela cidade. Obras que se destacam não apenas pela qualidade arquitetônica como pela tecnologia empregada na sua construção.

Outra qualidade deste empreendedor era a lealdade com seus clientes haja visto uma história contada pelo Sr. Luiz Fernando Mazzuquelli, sobrinho de Alfredo Mathias, sobre uma cliente que havia comprado um apartamento da construtora havia trinta anos e, depois deste tempo apresentou problemas de vazamentos; esta senhora foi reclamar com o próprio Mathias o ocorrido, o qual não hesitou em mandar uma equipe reparar o problema. 
A cidade de São Paulo foi o pano de fundo para realização deste trabalho assim como a figura do incorporador imobiliário, agentes que contribuíram no processo de verticalização da cidade e na maioria das vezes permanecem na obscuridade.

\subsection{Características do Período Estudado: a cidade como pano de fundo}

\subsubsection{Evolução Urbana da Cidade de São Paulo (décadas de 1930 e 1940)}

Os anos de formação do arquiteto correspondem ao período de profundas modificações na cidade, desde as obras iniciadas na gestão do prefeito Fábio Prado (1931), como: a Biblioteca Municipal, O Estádio do Pacaembu, túneis da Avenida Nove de Julho e parques infantis; coincide também com o "Plano de Avenidas" de 1930, idealizado por Prestes Maia e Ulhôa Cintra (Silva, 2004).

Ao longo da Era Vargas e do Estado Novo foram lançados os fundamentos da metrópole que emergiria após a Segunda Guerra Mundial, firmou-se o modelo expansionista, rodoviarista e verticalizador que seria reforçado nas décadas seguintes.

As décadas de 1930 e 1940 trouxeram a consolidação do processo de industrialização brasileira, onde ocorreram dois importantes momentos: os anos de recuperação pós-crise de 1929 e o período da Segunda Guerra Mundial. A economia cafeeira perde espaço para outros produtos, concomitantemente, o Estado de São Paulo se consolida como principal pólo industrial e econômico, sendo sua capital o principal foco desse processo (Silva, 2004).

Do desenvolvimento da industrialização e do crescimento econômico houve a aceleração do processo de urbanização. O município de São Paulo tinha em 1930 cerca de 890 mil habitantes, em 1933 já passava de um milhão de habitantes e em 1945 já eram 1,80 milhões na região metropolitana. Os anos 
30 em diante foram marcados pela intensificação dos fluxos migratórios internos, que se tornaram mais importantes que a chegada de imigrantes estrangeiros.

Na São Paulo de 1930 dois traços marcantes da urbanização brasileira já estavam delineados: o crescimento extensivo e a verticalização (ainda restrita a área central). A incessante atividade do parcelamento do solo implicou em uma explosão da demanda por serviços públicos, por infra-estrutura e pela implantação e manutenção de um extenso sistema viário carroçável. Essa atividade de parcelamento e de ocupação das periferias deu-se juntamente a implantação de um sistema de transportes baseado principalmente nos veículos automotivos. Há de se ressaltar que esses dois elementos se articulam a um sistema de acesso à moradia popular baseados na casa própria e na autoconstrução (Silva, 2004).

A ocupação efetiva dos loteamentos mais afastados dependia da conexão com o centro e com o resto da cidade. Dos anos 20 aos anos 40 materializou-se a transformação de uma cidade cujo transporte público funcionava basicamente sobre trilhos em uma cidade onde o transporte sobre pneus se tornou hegemônico.

Os serviços de transporte público (bonde elétrico), distribuição de energia elétrica, da iluminação pública, do fornecimento de gás e de telefonia eram operados pela Companhia Light \& Power (cuja lucratividade, desde os anos 20, fora comprometida pela concorrência dos ônibus, pelo congelamento tarifário - desde 1909 - e pelo aumento dos custos de operação decorrentes dos congestionamentos na área central).

A Light propôs à prefeitura um plano de investimentos e de modernização dos serviços vinculados a um aumento das tarifas, esse plano ficou conhecido como Plano Light e se opunha ao outro de Ulhôa Cintra e de Prestes Maia (mais tarde conhecido como Plano de Avenidas), que se propunha justamente um 
modelo de desenvolvimento urbano de orientação rodoviarista e da priorização do transporte individual.

Os dois planos eram antagônicos e excludentes e a proposta da Light nunca foi aceita. Dois fatores foram importantes também para a consolidação da urbanização extensiva: a Lei do Inquilinato de 1942, que inibiu a produção rentista de moradias e a instituição, em 1937, do sistema de vendas a prestação. O crescimento demográfico e a crise da produção rentista empurraram a população de baixa renda para a autoconstrução em lotes periféricos na sua maioria desprovidos de infra-estrutura, comprados a prazo e acessíveis através dos ônibus.

A verticalização constituiu um dos marcos da urbanização brasileira e São Paulo foi o grande ícone deste fenômeno, porém só adquiriu proporções de peso a partir das décadas de 1960 e 1970 (Ficher, 1994), antes disso, os edifícios altos e áreas verticalizadas constituíam toda uma simbologia associadas à idéia de modernização, progresso e aos êxitos econômicos da metrópole.

A passagem dos anos 20 aos 30 coincidiu com a mudança dos modelos arquitetônicos aplicados às construções verticais: nos anos vinte o ecletismo era largamente usado dando grande ênfase às fachadas frontais e nos anos 30 os edifícios foram marcados pelo estilo Art-déco com o despojamento ornamental identificado como estilo modernizado.

A construção de edifícios em condomínio disseminou somente a partir dos anos 40 coincidindo com o desestímulo da produção rentista decorrente da vigência da Lei do Inquilinato de 1942.

O período de 1930-1945 foi marcado pela realização de grandes obras públicas que consolidaram o modelo de desenvolvimento urbano adotado pela cidade nas décadas seguintes. A reforma administrativa de Fábio Prado 
aumentou em muito a capacidade de arrecadação municipal, foram também importantes os dispositivos legais como o Decreto-Lei Federal $n^{\circ} 311$, de março de 1938, que acelerou o processo e limitou o valor das indenizações.

\subsubsection{O Plano de Avenidas}

Em 1930 foi apresentado de forma mais acabada o "Plano de Avenidas" de Prestes Maia e Ulhôa Cintra, sua principal ênfase era: a consolidação de um sistema viário que combinava a implantação de um perímetro de irradiação e um sistema de avenidas radiais e perimetrais. O perímetro de irradiação ampliaria o Centro Novo e superaria o congestionamento do restrito triângulo histórico (Campos, 2002).

As avenidas radiais fariam a ligação com os bairros periféricos e o sistema perimetral se articularia com avenidas radiais, constituindo as bases para uma progressiva expansão territorial da cidade.

A administração Fábio Prado (1934-1938) materializa um novo compromisso político, que além das intervenções viárias, sua principal característica foi à implantação de políticas sociais aliadas a um programa de modernização administrativa. Deu-se a incrementação na arrecadação, o que proporcionou a essa gestão uma considerável capacidade de investimento. Sua principal marca foi a implantação de equipamentos educacionais, culturais e de lazer (parques infantis, bibliotecas públicas, equipamentos desportivos, etc.). Durante sua gestão tiveram início as construções da Biblioteca Municipal e do Estádio do Pacaembu, concluídos por Prestes Maia.

Após a implantação do Estado Novo em 1937, sucedendo a Fábio Prado (1938-1945), Prestes Maia assume a prefeitura e sua administração foi totalmente alinhada com o modelo de desenvolvimento urbano rodoviarista, expansionista e liberalizante em relação aos interesses da promoção imobiliária. Durante sua gestão a idéia da implantação do metrô foi definitivamente postergada em proveito da implantação do seu Plano de Avenidas. 
Os primeiros anos de sua gestão tiveram grande comprometimento orçamentário com os importantes projetos iniciados por Fábio Prado. Após a conclusão destas obras lançou-se a seu ambicioso sistema viário, cabe destaque à implantação de grande parte do perímetro de irradiação: o início do alargamento da Avenida Liberdade, a complementação da Avenida São João, a abertura das avenidas Vieira de Carvalho, Duque de Caxias, Amaral Gurgel e Rui Barbosa, a construção da Ponte Grande (atual Ponte das Bandeiras) e o projeto de retificação do rio Tietê. Nem todas as obras que figuravam no Plano de Avenidas foram implantadas como, por exemplo, a Avenida Itororó (futura 23 de Maio) ou a ligação do Anhangabaú com a Avenida Tiradentes (muitas dessas obras seriam implantadas nas décadas seguintes).

A gestão Prestes Maia significou a superação de um urbanismo de orientação estética e sanitarista em proveito das preocupações viárias. A cronologia dessa metamorfose torna inevitável sua associação com a transformação de São Paulo, de capital da economia cafeeira em uma cidade que se preparava para a nova era industrial.

Entre as influências identificáveis no plano destaca-se a obra do novaiorquino Nelson Lewis, "The Planning of the Modern City" (1916), co-autor da lei de zoneamento de Nova York, primeira cidade a regulamentar os arranha-céus.

Lewis tentava conciliar a construção em altura com exigências de insolação, impondo um perfil escalonado para os grandes edifícios. Representante do movimento City Efficient'l que havia sucedido aos sonhos regeneradores do movimento City Beautiful ${ }^{2}$. Também foram identificadas

\footnotetext{
' City Efficient Movement: consiste em adotar políticas de transporte público adequadas a um sistema viário que permita fluidez e eficiência na circulação urbana, contribuindo desta forma para o desenvolvimento econômico, social e ambiental da cidade.

2 City Beautiful Movement: tem sua origem no conceito Park Movement do arquiteto paisagista Frederick Law Olmsted, a especificidade desta teoria está na idéia de que a cidade deveria ser estruturada pelos parques, onde os parques estruturam o desenho, define o traçado e indica os fluxos. (Lima, 2004)
} 
referências ao francês Eugène Hénard, autor do conceito do "perímetro de irradiação" e ao naturalista alemão Joseph Stübben, que sistematizou as estruturas viárias e concebeu o esquema radial-perimetral. Combinando esses dois conceitos, Ulhôa Cintra e Prestes Maia haviam estabelecido o arcabouço essencial do plano - unindo o princípio centralizador presente na idéia de Hérnard com a expansão ilimitada da área urbana, permitida na concepção de Stübbemn.(Campos, 2006)

O Plano de Avenidas compõem-se de um capítulo introdutório, a título de justificativa; dois capítulos sobre legislação; três capítulos com o conteúdo essencial do plano, enfocando soluções viárias - perímetro de irradiação, radiais, perimetrais, várzea do Tietê - incluindo as propostas estéticomonumentais e dois capítulos finais com apêndices e complementos.

Prestes Maia na introdução do plano, destaca o crescimento vertiginoso da cidade que já se aproximava um milhão de habitantes, as intenções da Light em relação a mudanças no transporte urbano e as possibilidades de aproveitamento da várzea do Tietê. As diretrizes que fossem tomadas naquele momento seriam cruciais para a evolução urbana da cidade, no entanto, o Plano de Avenidas não traz um repertório legislativo organizado como componente de suas propostas:

"não há minutas para leis de zoneamento, código de obras ou normas para arruamento - ao contrário, por exemplo, do Plano Agache." (Campos, 2006)

Em vez de propor uma legislação reguladora, o autor enfoca as questões que condicionam o financiamento das obras viárias, como a desapropriação e as contribuições da melhoria.

A desapropriação com revenda era um dispositivo utilizado pelos urbanistas desde o século XIX como forma de financiar as obras viárias. Este 
expediente Haussmann utiliza no início do processo de reurbanização de Paris, logo derrubado pela pressão dos proprietários. Pereira Passos, no Rio de Janeiro, esboça a mesma intenção, porém igualmente vencida pelos interesses imobiliários. Para Prestes Maia esse recurso seria em parte dispensável e contrário ao espírito das nossas instituições, tal tirada não o impede de revelar seus verdadeiros motivos, que levantariam grande oposição aos próprios melhoramentos.

Prestes Maia desenvolve justificativas, traçados, larguras e secções transversais das vias, qualidades estéticas, condicionantes técnicas, alternativas, reportando-se sempre a exemplos estrangeiros.

O perímetro de irradiação seria uma larga avenida circular que receberia o fluxo das vias radiais antes que estas chegassem ao centro antigo. Para o autor essa solução seria preferivel às outras propostas apresentadas como o alargamento das ruas existentes, política dispendiosa adotada na virada do século sem grande êxito, está a par, por exemplo, das propostas urbanísticas de Le Corbusier, mas tende a ver apenas o lado utópico e inexeqüível: excessivamente "futuristas", ao menos para a época.

A moldura verde criada nas gestões de Antônio Prado, Victor Freire e Bouvard deveriam ceder lugar às pistas de automóveis (para o autor a eliminação de praças e canteiros em benefício do tráfego seria justificada pela criação simultânea de um sistema de grandes parques em torno da cidade).

O desenvolvimento de um novo centro à oeste do Anhangabaú seria uma tendência a ser reforçada pelo perímetro de irradiação formado pelas ruas entre o Anhangabaú e a Praça da República, região preferencial da elite paulistana.

O "Centro Novo" ou "Cidade Nova" surgiria como opção de um novo espaço de centralidade; de fato não houve uma verdadeira 
"descentralização" na proposta do Plano de Avenidas, pelo contrário, o perímetro ampliando a área central, reforça a centralidade existente e evita o recurso de subcentros ou cidades-satélites como saídas para descongestionar o "Triângulo" (Silva, 2004), ao mesmo tempo permite que o "novo centro", intimamente ligado ao "centro-velho", ganhasse importância igual ou superior ao antigo.

Do perímetro de irradiação partiria uma hierarquia de avenidas radiais e secundárias, que se bifurcariam em sub-radiais. O sistema radial perimetral, com raios e aros sucessivos, permite estruturar uma expansão urbana ilimitada, mantendo o caráter centralizador da forma radiocêntrica; sua aplicação é justificada por Prestes Maia pelas experiências Internacionais: os planos de Stübben para Colônia, de Burnham para Chicago e de Bartolomew para St. Lovis. As radiais seriam ligadas por dois circuitos perimetrais suplementares: um interno (Avenidas Angélica e Paulista mais um bulevar a ser criado no leito da São Paulo Railway, que seria transferida para a margem direita do Tietê) e outro externo (as avenidas marginais do Rio Tietê, traçadas por Ulhôa Cintra, e do Rio Pinheiros, previstos pela Light e Companhia City).

A maioria das vias radiais terminaria no perímetro de irradiação, porém alguns traçados diametrais atravessariam a cidade de ponta a ponta, cruzando o círculo central. A Avenida Anhangabaú e a Avenida Itororó, então em projeto, se uniriam no "sistema Y", que atravessaria a área central em desnível, ocupando o Vale do Anhangabaú, desimpedido pela demolição do prédio da Delegacia Fiscal, ligando o Parque do Anhangabaú à Praça dos Correios. Uma nova ligação (atual Avenida Prestes Maia) ligaria o vale à Avenida Tiradentes e à Ponte Grande (atual Ponte das Bandeiras). 
O "sistema Y" formaria a Diametral Norte-Sul, outro análogo seria desta vez na direção Leste-Oeste, que uniria a Avenida São João, por meio de um túnel sob o Largo de São Bento ao Parque Dom Pedro Il.

Circunscrito no perímetro de irradiação a Diametral Leste-Oeste funcionaria como o lado norte de um quadrilátero. Desenvolvendo esse tema geométrico, Prestes Maia imagina os demais trechos: o lado oeste seria formado pelas Ruas Xavier de Toledo, Conselheiro Crispiniano e Antônio Godoy, o lado Leste ligaria a Praça da Sé ao Largo do Palácio (atual Pátio do Colégio) por um eixo monumental e o lado Sul unindo a Ladeira do Carmo à Rua Benjamin Constant e ao Viaduto de São Francisco e o Largo da Memória.

O plano previa a criação de conjuntos monumentais: o lado leste do quadrilátero, no interior do perímetro de irradiação formaria um eixo monumental denominado "Conjunto Sé-Palácio-Estrela", a Praça da Sé, aberta em 1910, seria prolongada na direção do atual Pátio do Colégio, onde surgiria um palácio monumental para sediar o Governo do Estado e atrás deste edifício, a ladeira General Carneiro seria transformada em uma sucessão de terraços simétricos desembocando na praça rotatória, criada por Cochet na entrada do Parque D. Pedro II, esta que já formava uma "meia-estrela" com sete vias irradiantes, seria completada criando-se finalmente a Petit Étoile paulistana ou "Praça da Estrela".

Destaca-se um novo arranjo para o Vale do Anhangabaú: a substituição do antigo Viaduto do Chá permitiria que um novo viaduto fosse construído no eixo da Praça do Patriarca e grandiosos edifícios dominariam o vale transformando-o de um recanto, antes aprazivel criado por Bouvard, em um fórum triunfal, onde a identidade volumétrica seria mantida com o uso de cúpulas e na face Sul do conjunto seria dominado por uma única torre em estilo "moderno" para a Câmara Municipal, sob a qual passariam os braços do "Sistema Y" (as Avenidas Itororó e Anhangabaú). 
Outros conjuntos foram previstos, como: a Ponte Grande em um classicismo modernizado, o Congresso Estadual na Praça da República, em forma de capitólio neoclássico e diversos equipamentos para o Parque do Estado - batizado como Parque das Cabeceiras do Ipiranga (Campos, 2002).

Os parâmetros estéticos que pontuam as soluções traduzem, em função da legitimação ideológica, contemplada por meio do uso de uma roupagem artística sobre o arcabouço estrutural das propostas viárias do plano. A conveniência entre os estilos era normal na época e cada linguagem tinha sua destinação "apropriada": o neocolonial serviria para usos mais amenos, os grandes edifícios públicos requeriam a nobreza do neoclássico e os novos equipamentos da cidade moderna (estações, viadutos) poderiam assumir um tom mais arrojado (moderno).

A terceira parte do plano trata dos sistemas de transporte urbano individual e coletivo nas suas relações com o sistema viário. Tal ênfase não é acidental, envolveu o monopólio e os interesses da Light, a renovação de sua concessão e a crescente concorrência dos ônibus.

O Plano do pré-Metrô, apresentado em 1926 pela empresa canadense (Light), era concorrente direto do Plano de Avenidas, cujas propostas viárias seriam inviabilizadas se as intenções da Light vingassem. Maia por sua vez, emprega um cabedal técnico ainda maior, da forma mais exaustiva e atualizada enfoca sucessivamente as seguintes questões: as estradas de ferro no contexto urbano (com a localização das linhas e terminais, passagens de nível, trafego de subúrbio), os bondes (com o traçado das linhas, velocidades, paradas, eficiência, etc.), o metrô (com tipos de via, escala, custos e suas disputas com os bondes), as vantagens das duas opções, a possível integração e o automóvel (com os aspectos de congestionamento, estacionamentos, etc.). 
Maia estuda os sistemas de Paris, Londres, Berlim, Viena, Madri, Nova York, Chicago, Pittsburgh, St. Louis, Cleveland, Cincinatti, Detroit, Filadélfia, Buenos Aires, entre outras cidades, propondo para São Paulo a combinação entre o controle estatal e regime de concessão, com a garantia da concorrência entre as concessionárias e a divisão das linhas de transporte coletivo como complementos e reforços para o sistema viário radial-perimetral.

Segundo a proposta do Plano de Avenidas seria quebrado o monopólio da Light e os bondes não formariam a espinha dorsal do sistema de transporte, pois considerava o automóvel um dom inseparável da modernidade e do crescimento urbano como indutores da expansão urbana, automóveis e ônibus seriam integrados, na qualidade de principais meios de transporte.

\subsubsection{Período de 1940 a 1960}

Entre 1940-1960 a cidade se compacta com a verticalização e a ocupação de loteamentos encravados em bairros já formados. A área urbana se expande e a ocupação periférica já se impõe como estratégia de moradia para a população de baixa renda, que direcionada pela indústria, ultrapassa os limites do município.

A cidade cresce na proporção da importância que assume na economia do país, com mais de dois milhões de habitantes no final de 1940, fazendo dela depositária de elevados fluxos migratórios e de profundas desigualdades sócioespaciais. São Paulo se organiza como cidade policêntrica, com subcentros estruturados em vários bairros como: Pinheiros, Lapa e Santo Amaro. Essa época também contemplou: a exuberância do Centro Novo (Cinelândia, restaurantes, hotéis e comércios), a transferência da Sede do Governo para os Campos Elíseos e o início do deslocamento do comércio de luxo do Centro Novo para a região da Avenida Paulista e dos Jardins. 
Com a transferência das elites para o outro lado da cidade (o sudoeste), onde se instalaram os bairros exclusivos, inicia-se, no final do século XIX, o abandono do centro tradicional da cidade, esse processo se completaria nos anos de 1960 de forma contundente. Em 1950, na região central, quase 90\% da área licenciada era para edifícios não residenciais.

Neste período, São Paulo e o Distrito Federal concentraram $60 \%$ do investimento nacional privado em novas construções. Na conjuntura da Segunda Guerra Mundial, a propriedade imobiliária se intensificou como campo de investimentos da indústria, do comércio e da exportação agrícola. O capital incorporador se consolidou como agente de produção do ambiente urbano e as condições para esse dinamismo foram em grande parte, dadas durante a permanência de Prestes Maia como prefeito.

A City of São Paulo Improvements and Freehold Land Company Ltd. (Companhia City), empresa de origem inglesa, que desde a primeira década do século XX introduziu um novo padrão de urbanização para os bairros exclusivos da população de alta renda (o bairro jardim), ao longo dos anos 40 cria bairros além do rio Pinheiros, completando os trabalhos de loteamento de outras áreas e conclui a venda de seus loteamentos no Jardim América, no Pacaembu, no Alto da Lapa e na Bela Aliança.

Nos anos 50 lança o loteamento do Jardim Guedala, no Morumbi, assim, todas as terras adquiridas em 1911 estavam definitivamente loteadas. A importância da Cia. City está não só em redesenhar o espaço das áreas residenciais das elites, como também sua força impulsionadora na ocupação do setor sudoeste por essa camada da população.

Os fundos previdenciários, as companhias de capitalização, as caixas econômicas e as empresas de seguros expandiram os créditos e financiamentos em construções de grandes edifícios comerciais e residências, assim como em conjuntos populares. Nos subúrbios, onde a atividade imobiliária 
se restringia ao loteamento e venda de terrenos isolados, a partir dos anos de 1950, se introduziu a construção e venda de casas financiadas compreendendo vários quarteirões.

A verticalização que nas primeiras décadas era predominantemente comercial passa a residencial, ultrapassa os limites do centro e se insinua na direção sudoeste. Nos anos de 1940 e 1950, os mesmos bairros-jardins destinados a casas isoladas passam a ser liberados para edifícios com múltiplos usos para atender as pressões de proprietários dos terrenos e nas áreas centrais destacam-se os apartamentos tipo quitinete em edifícios que chegam a quase trinta pavimentos. Essas unidades incluem-se em uma nova modalidade de empreendimentos: grandes edifícios em sistema de condomínio lque introduzem programas e projetos inovadores) e prédios residenciais com centenas de unidades (que destinavam o pavimento térreo para comércio e serviços). Os anos de 1950 são marcados então pelo surgimento de edifícios que agregam múltiplas atividades, como: cinemas, comércios, restaurantes e incorporam galerias comerciais em ruas internas aos quarteirões.

Estes empreendimentos se pulverizaram principalmente no centro, nos bairros que o circundam e marcando presença também na Avenida Paulista. A linguagem modernista, que grande parte deles se incorpora, e as dimensões de altura e a extensão dos terrenos que ocuparam, resultou das demolições decorrentes das obras do Plano de Avenidas e se impuseram na paisagem, são os casos: do Edifício Copan, na Avenida Ipiranga; do Conjunto Metrópole, na Avenida São Luis; da Galeria Califórnia, na Rua Barão de Itapetininga; de vários edifícios da Praça Roosevelt; dos edifícios São Vito e Mercúrio, junto ao Mercado Municipal; do Edifício Paris - Roma - Rio, na Bela Vista; do Edifício Radar, no Brás; do Edifício Seguradora Brasileira, na Liberdade; do Notre Dame, na Vila Buarque e da Galeria Nações Unidas e Conjunto Nacional, na Avenida Paulista. 
Estes e outros empreendimentos sintetizaram a construção de uma paisagem metropolitana: nos bairros centrais eles se justapõem aos testemunhos de arranque da industrialização do final do século XIX (a casa geminada e vilas operárias) e aos edifícios monumentais das primeiras décadas do século XX e na Avenida Paulista as casas dos barões do café.

Nessa mesma perspectiva de reconhecimento da condição de vida metropolitana se incluem os conjuntos construídos em São Paulo pelos Institutos de Aposentadoria e Pensões no período pós-guerra. São paradigmas do início de uma produção significativa de habitação social no Brasil, nesses conjuntos estiveram envolvidos arquitetos compromissados com os princípios dos Congressos Internacionais de Arquitetura Moderna. Destacam-se os conjuntos residenciais Japurá (na Bela Vista), Baixada do Carmo, Santa Cruz e Mooca.

Os efeitos da valorização dos terrenos e mudanças de atuação dos empreendedores imobiliários, associados às possibilidades de despejos devidas ao congelamento de alugueis pela Lei do Inquilinato de 1942, ampliaram o mercado de compra e venda de habitações e tiveram repercussões implacáveis para a estratégia de moradia da população de baixa renda.

Parcelas da população de baixa renda que não tinham condições de adquirir um lote ou resistiam a se distanciar dos centros de empregos, estima-se que em torno de $8 \%$ da população paulistana (em 1968), viviam em cortiços. Cerca de $60 \%$ dessas famílias se concentravam nas áreas centrais, embora fossem vistos também em cortiços em bairros como Santana, Lapa, Vila Maria, Penha, Ipiranga, Saúde, Ibirapuera, Santo Amaro e Pinheiros.

Na década de 1940 se encontram as primeiras referências a favelas em São Paulo (embora venham a se desenvolver em larga escala nos anos de 1970). Nos anos de 1960 estimativas apontam em torno de 700 mil moradores em "condições de habitações infra-humanas", incluindo os cortiços e favelas. 
Em 1957 um estudo pioneiro mapeia esta face paulistana que é parte indissociável nos processos de construção de uma modernidade metropolitana, onde: a segregação sócio-espacial se manifesta em sua forma esquemática, que persistiria por décadas, grande concentração de ricos no setor sudoeste e grande concentração de pobres nas periferias em todas as direções.

Embora inúmeros estudos tenham sido realizados, um novo plano para São Paulo viria a ser elaborado em 1968, o Plano Urbanístico Básico, mas nem chegou a ser encaminhado à Câmara Municipal. As iniciativas da administração municipal em relação à periferia foram marcadas por sucessivas anistias nos anos de 1950 e 1960, que regularizaram extensas páreas de ruas não oficiais.

No campo do urbanismo uma prática inovadora se daria nas formas de controle do uso e ocupação do solo, com: a demarcação de zonas, articulação de índices urbanísticos definidores de funções, recuos, coeficientes de aproveitamento e taxas de ocupação.

Entre os anos de 1940 e 1950 inúmeros decretos foram emitidos definindo extensas áreas exclusivamente residenciais e vias destinadas à verticalização. Embora fragmentária, a regulamentação definiu um território contínuo e com preciso significado no contexto da cidade. Paralelamente aos decretos foram elaborados estudos de leis gerais de zoneamento em 1947, 1949, 1952 e 1955. Em 1955 o formato de uma lei geral de zoneamento para São Paulo (que só viria a ser aprovada em 1972) já estava absolutamente definido e o setor por ela atingido já estava devidamente submetido ao novo código, por meio das leis parciais. 
Período iniciado com o golpe militar e pela gestão Faria Lima, marcado com grandes obras viárias que consagrariam o império do automóvel na cidade, termina com a redemocratização e a primeira eleição para prefeito após o regime autoritário. Acentuam-se $\mathrm{O}$ crescimento extensivo e desordenado, a verticalização, a expansão da periferia e os déficits urbanos. Tensões políticas culminam em movimentos sociais urbanos e uma cultura de resistência. A Grande São Paulo assume o perfil decididamente moderno, passando de metrópole industrial a megalópole terciária, tornando-se não só em tamanho, a primeira cidade do país.

A indústria automobilística já estava consolidada e despejava seus produtos sobre o precário sistema viário da capital, cujo congestionamento agravara-se continuamente. Entre 1964 e 1974 ocorreram as seguintes obras: as primeiras vias expressas da cidade foram abertas (as Avenidas 23 de Maio, Rubem Berta, as Marginais dos rios Pinheiros e Tietê), o alargamento da Avenida Paulista, construção do complexo viário de entroncamento (entre a Avenida Paulista, a Rua da Consolação e a Avenida Rebouças), construção do "Minhocão", alargamento da Rua Iguatemi (para tornar-se a Avenida Faria Lima) e abertura das Avenidas Bandeirantes (no vale do Córrego da Traição), Brás Leme e boa parte da Radial Leste.

Na década seguinte seriam abertas as avenidas: Aricanduva, Luiz Inácio de Anhaia Melo (na Vila Prudente), Marquês de São Vicente, Ermano Marcheti, Luiz Carlos Berrini, Juscelino Kubitschek, Sumaré (sua continuação, a Paulo VI e sua ligação com a Avenida Brasil), Roque Petroni Jr, Vicente Rao, Salim Farah Maluf (antiga Avenida Tatuapé) e a Avenida Afonso de Taunay, estas últimas, depois da construção do túnel pertencente ao complexo viário Maria Maluf, formariam com a Avenida dos Bandeirantes o primeiro Anel Viário da Capital. 
Nos anos de 1960 foram implantadas importantes perimetrais no setor Sudoeste tornando seu sistema viário bem mais desenvolvido que o as demais regiões da cidade. Essas perimetrais foram as Avenidas: Paulista, Brasil (completada pela Henrique Schaumann), Faria Lima, Luis Carlos Berrini e Marginal do Rio Pinheiros.

As perimetrais são de especial interesse para o setor imobiliário, quando se trata do valor dos terrenos, a razão deste fenômeno é que as radiais, mesmo que atravessando bairros de alta renda (como as avenidas Rebouças ou Nove de Julho), acaba conduzindo majoritariamente o transporte público e seus usuários, cujo destino final é a periferia. As perimetrais ligam bairros de alto padrão entre si e grande parte de seus usuários é de alta renda, por isso (ao contrário das radiais) elas atraem fortemente os interesses imobiliários e têm seus terrenos altamente valorizados, exemplos clássicos disso são as avenidas: Paulista, Faria Lima, Luiz Carlos Berrini e a Marginal do Rio Pinheiros.

A classe dominante produz três segregações no quadrante sudoeste: a de suas moradias, a de seus empregos e a do comércio e serviços dos quais se serve. Faça-se a comparação dele com a zona Leste, o setor mais populoso da cidade, uma enorme região-dormitório, em que há relativamente poucos empregos, tanto nos setores de comércio e serviços como industrial (Villaça, 2004).

Nota-se que dessa maneira a classe dominante tenha passado a trabalhar mais perto de casa. Como a cidade crescia e a burguesia e alta classe média eram forçadas a morar cada vez mais longe, elas reduziam relativamente (embora não eliminassem) o ônus de seus deslocamentos para o trabalho, para a escola dos filhos, para seus profissionais liberais, serviços e lazer, trazendo-os para mais perto de suas residências. Quanto mais iam para os Jardins, para o Morumbi e depois para a Granja Viana, Tamboré, Aldeia da Serra e Alphaville mais aquelas classes puxavam seus empregos, comércio e serviços na mesma direção (Villaça, 2004). 
Dois notáveis exemplos de empreendimentos, pelo seu pioneirismo, emblemáticos desse processo foram: o Shopping Center Iguatemi (de meados dos anos 60) e o Centro Empresarial São Paulo, cujo primeiro bloco data dos anos de 1970 e localizava-se incrivelmente longe, mas antecipava o crescimento da "cidade das elites" em sua direção.

Paralelamente a essas mudanças no plano espacial, intensifica-se o abismo que passa a separar os ricos e pobres no Brasil, fazendo que nosso maior problema não seja propriamente a pobreza, mas sim a diferença assustadora de renda e de poder político entre os mais ricos e os mais pobres. Até a década de 1950 praticamente não havia favelas em São Paulo e a população que morava em cortiços era pequena. A classe popular tinha condições de comprar - e de fato comprava - um lote na periferia (freqüentemente com $8 \mathrm{~m}$ de frente por $25 \mathrm{~m}$ de fundo) em loteamentos clandestinos, mas raramente ocupava terrenos grilados, nele realizava suas construções pelo sistema de mutirão, conseguindo assim moradias que em termos de solidez superavam em muito as existentes nas favelas de hoje.

De 1964 a 1972, identificou-se 17 decretos e 18 leis regulando o zoneamento na cidade e de 1972 a 1984, 62 leis. A maioria das alterações introduzidas referia-se a bairros de classe média alta, localizados no quadrante sudoeste da cidade.

Em janeiro de 1970 foi inaugurada a Praça Roosevelt, na segunda metade da década de 1970 o Parque do Carmo, em maio de 1982 o Terminal Rodoviário do Tietê e notadamente a obra de maior impacto na cidade foi o Metrô. Interessante que esta monumental obra, o Metrô, foi iniciada pela Prefeitura Municipal de São Paulo, como um empreendimento municipal. A partir de 26-09-1975 começa a operar a linha Norte-Sul, primeiro do Jabaquara à Vila Mariana e depois até a Liberdade, sem contar a estação Sé, devido a sua complexidade e as alterações no traçado da futura linha Leste- 
Oeste, que ali se integraria a Norte-Sul, que só foi inaugurada em 1978 e o primeiro trecho da linha Leste-Oeste foi inaugurado em 10-03-1979.

\subsection{Organização dos Capítulos}

No capítulo 2 "O mercado imobiliário de São Paulo nos anos 1930 a 1985", apresentamos a literatura pesquisada sobre o panorama do mercado imobiliário de São Paulo, sua origem e principais atores.

A influência do excedente do capital oriundo da indústria e do comércio como: a estratégia de investimento (antes da Lei do Inquilinato de 1942), a estratégia de renda para aposentadorias ou viuvez, os profissionais envolvidos (vários destes estrangeiros) e a análise da criação de um modelo que se repetiria desde os anos trinta até os anos setenta com pequenas alterações.

No capítulo 3: "Alfredo Mathias Engenheiro-arquiteto", trata-se do relato dos familiares sobre sua biografia.

No capítulo 4: "A História da Construtora Alfredo Mathias", narramos a trajetória da empresa por um levantamento cronológico das suas obras emblemáticas. A narrativa tem como base o depoimento de profissionais que trabalharam na construtora em vários períodos, bem como o levantamento da literatura pesquisada, na maioria dissertações de Mestrado e Doutorado que, de uma forma ou de outra, fazem referencias à construtora.

No capítulo 5: "Projetos selecionados: estudos de casos", catalogamos 11 entre os principais edifícios, como sendo os mais emblemáticos para estudo de caso, com sua localização e dados de sua construção, devidamente demonstrados nos 26 anexos .

No capítulo 6: "Considerações finais". 
2. O Mercado Imobiliário de São Paulo nos anos 1930 A 1985 
"A reprodução do capital na indústria da construção apresenta certas características que constituem uma das condições do aparecimento da promoção imobiliária". (Topalov, apud Souza, 1994)

A figura do incorporador imobiliário foi definida no Brasil pela Lei 4591 de 16 de dezembro de 1964 como:

"Pessoa jurídica ou física, comerciante ou não, que embora não efetuando a construção, compromissa e efetiva a venda de frações ideais de terreno objetivando a vinculação de tais frações a unidades autônomas, em edificações a serem construídas ou em construção sob o regime condominial ou que meramente aceite proposta de efetivação de tais transações, coordenando e levando a termo a incorporação e responsabilizando-se, conforme o caso, pela entrega, preço e determinadas condições das obras concluídas". (Pereira Leite, 2006)

Pereira Leite salienta a confusão que imperou no Brasil entre especulação e incorporação imobiliária, citando os estudos de Fonseca ${ }^{3}$, esclarece que não se pode confundir o proprietário da terra urbana como "suporte para a valorização do capital" com a categoria dos incorporadores, estes:

"... utilizam o lote urbano para reproduzir seu capital, vendendo cotas e realizando a obra, ou compondo o custo do imóvel construído, da forma a melhor viabilizar sua venda, diminuindo seus riscos". (Pereira Leite, 2006)

A figura do incorporador e a verticalização confundem-se com o processo de industrialização da cidade de São Paulo, segundo Maria Adélia de Souza, o processo de produção e apropriação do espaço urbano dado:

\footnotetext{
3 Fonseca, A.C.P. - A promoção Imobiliária e a Construção da Cidade de São Paulo 1970-2002 2004, Tese de Doutorado apresentada a Faculdade de Arquitetura e Urbanismo da Universidade de São Paulo, São Paulo.
} 
"... a existência de uma relação entre o capital imobiliário, o capital financeiro, o capital fundiário e o capital produtivo, que no processo de verticalização realizam num espaço/tempo limitado uma estratégia de interesse mútuo." (Souza, 1994)

As décadas de 1930 e 1940 marcam a consolidação e o aprofundamento do processo de industrialização do país, compreendendo a recuperação da crise de 1929 e a Segunda Guerra Mundial (1939-1945) períodos de restrições às importações que influenciaram no desenvolvimento de uma indústria de substituição.

O desenvolvimento econômico acelera o processo de urbanização, o município tinha em 1930 cerca de 890 mil habitantes, em 1933 esse número ultrapassa um milhão de habitantes (da Silva, 2004), no final dos anos 1940, segundo Sarah Feldmam, chega a quase seis milhões de habitantes (Feldmam, 2004). A partir da década de trinta os fluxos migratórios internos tornam-se mais importantes que a chegada de imigrantes estrangeiros; a cidade se compacta com a verticalização e a ocupação de loteamentos encravados em bairros já formados, a área urbana se expande com a ocupação da periferia como estratégia de moradia da população de baixa renda.

\subsection{O Processo de Industrialização}

Segundo Warren Dean4, a economia cafeeira gerou as condições para o arranque industrial nas primeiras décadas do século XX, a situação geográfica da cidade serviu de ligação para as ferrovias que se abriam para o oeste cafeeiro e o porto de Santos.

\footnotetext{
4 Warrem Dean (1932-1994) - historiador e professor do departamento de História da New York University, professor visitante nas Universidades de São Paulo e do Paraná; destacou-se no Brasil por dois livros publicados na década de 1970: "A industrialização de São Paulo" e "Rio Claro: um sistema brasileiro de grande lavoura, 1820-1920".
} 
A cidade de São Paulo torna-se o centro de negócios de importação/exportação e das atividades bancárias. A imigração, originalmente voltada ao cultivo do café, gerou uma classe operária numerosa e o crescimento do interior possibilitou o aumento de mercados consumidores de manufaturados que começavam a ser fabricados na capital. Outro ponto abordado eram as constantes mudanças da burguesia rural que se afastavam dos locais de plantio do café e seus lucros nem sempre eram reinvestidos em novas plantações sendo estes transferidos para as indústrias (Mendes, 2011).

Os primeiros distritos industriais surgiram nos bairros do Belenzinho, Brás e Mooca, outro de menor importância surgiu no bairro da Lapa junto à Estrada de Ferro Sorocabana. Segundo Phillip Gunn, os primeiros empreendimentos industriais com produção em larga escala com vilas industriais e instalações sociais foi a fábrica de gelo e cerveja "Cia Antártica Paulista" em 1888 na Água Branca (Gunn e Correia, 2005).

Na Zona Leste, através do vale do Tamanduateí, os citados bairros tornam-se as principais localidades fabris do final do século XIX. Em 1889, no Belenzinho, o Conde Antonio Álvares Penteado funda a Fábrica Santana para a produção de sacos de café e açúcar, em 1908 a indústria foi transformada em companhia limitada com o nome de "Companhia Nacional de Tecidos de Juta", posteriormente vendida ao engenheiro e industrial Jorge Street ${ }^{5}$ e esta permaneceu em sua propriedade até 1923 quando foi vendida aos empresários Arnaldo Guinle e Numa de Oliveira.

Ainda na zona Leste, em São Miguel Paulista, um consórcio de empresários norte-americanos e brasileiros (incluindo Horácio Lafer - Grupo

\footnotetext{
5 No ano de 1912 Jorge Street funda a Fábrica Maria Zélia, entre os trilhos da Central do Brasil e o Rio Tietê, em 1916 inaugurou sua vila operária - a Vila Maria Zélia, com cerca de duzentas casas e instalações sociais - Philip Gun e Telma de Barros correia - "A industrialização Brasileira e a dimensão Geográfica dos estabelecimentos. - Revista Brasileira de Estudos urbanos e Regionais - ANPUR, volume 7, número 1 - maio de 2005.
} 
Klabin, Antonio Ermírio de Morais - Grupo Votorantin - e Numa de Oliveira) fundou a Companhia Nitro-Química. Esse empreendimento foi o resultado da transferência das instalações fabris dos Estados Unidos da companhia Chatillon Corp. Em conseqüência à criação da fábrica em 1940, novos bairros residenciais foram gerados, incluindo a Vila Nitro-Química, Vila Americana, Cidade Nitro-Americana e Nitroperária (Gunn e Correia, 2005).

No bairro do Ipiranga os irmãos Jafet fundaram a Companhia "Fiação, Tecelagem e Estamparia Ypiranga Jafet". No mesmo bairro, em 1907, a empresa escocesa "J.B. Coats" constrói a Fábrica de Linhas Corrente, com cerca de cinqüenta casas para os operários.

Na Mooca são construídas duas tecelagens: a "Regoli, Crespi \& Cia" (1897)6 e a "Fábrica de Tecidos Labor" (1900). Outra, para a produção de papel e embalagens, a "Fábrica São Simeão" (1900) com sua vila operária, conhecida como Vila Boyes. Em 1904 a empresa inglesa de calçados "Clark" também funda sua fábrica no bairro e, posteriormente, nos anos 1930 e 1940 novas fábricas têxteis se instalam no bairro como o "Cotonifício Guilherme Giorgio" (Gunn e Correia, 2005).

Na região Sul havia uma variedade de indústrias (várias com suas vilas operárias): "chapéus Ramenzoni", no Cambuci; a "Cooperativa das Fábricas de Chapéu", na Vila Prudente; a "Companhia Lacta" (chocolates) e a fábrica de cigarros e charutos "Cigarros Sudan", na Liberdade. Na região sudoeste, já na cidade de São Caetano, a "Cerâmica Privilegiada", posteriormente "Cerâmica São Caetano".

\footnotetext{
6 Segundo Phillip Gun, em 1906 a companhia é reorganizada e transformada no "Cotonifício Rodolfo Crespi". A fábrica expandiu-se consideravelmente vindo a se transformar num complexo industrial de larga escala, com mais uma unidade têxtil e outra fábrica de tingimento a "Companhia Paulista de Aniagem", todas na Mooca.
} 
No vetor Norte da cidade, próximos das estradas de ferro e do Rio Tietê, foi construída a sede da "Grande Destilaria da Várzea" (1889). O distrito da Água Branca, na margem direita do rio, passa a abrigar as fábricas de produção de vidro: a "Fábrica Santa Marina Vidraria", a fábrica "Cisper" e posteriormente (já nos anos 1950) a Fábrica "Nadir Figueiredo". Vários empreendimentos ultrapassam as divisas do município invadindo outras cidades como a "Cia. Cerâmica Industrial de Osasco" e o "Cotonifício Beltrano (1923).

Nas primeiras décadas do século XX, junto à estrada de Ferro Sorocabana, várias fábricas de carnes e enlatadas são atraídas para a cidade como o "Frigorífico Wilson do Brasil" (1934). Ainda em Osasco, são instaladas fábricas de palitos de fósforos, como a Fábrica Granada entre outras.

\subsection{O Complexo Industrial Matarazzo}

As Indústrias Reunidas Francisco Matarazzo (IRMF) tem seu início em 1900, no Brás, com a abertura do Moinho Matarazzo, em 1904 a oficina de ensacamento de cereais foi separada dando origem à nova fábrica têxtil a "Fábrica de Tecelagem Mariângela". Em 1919 o grupo fundou a fábrica "Metalúrgica Matarazzo", ainda no distrito do Brás. Em 1935, no mesmo bairro, comprou a "Tecelagem Ítalo-Brasileira de Sedas", fundada pelos italianos Crespi e Puglisil, em 1907 é renomeada "Tecelagem Brasileira de Seda" (Gunn e Correia, 2005).

Na Mooca comprou a Fábrica de Papel São Simeão e um lote de terras que daria origem a Vila Operária Boyes ${ }^{7}$ e fundou as fábricas de óleo vegetal e de fósforos "Sol Levante". A fábrica de fósforos, posteriormente foi vendida para a "Companhia Fiat Lux". Ainda na Mooca, entre 1910 e 1915 incorporam uma refinaria de açúcar e uma fábrica de sal. Décadas mais tarde (1941) fundaram

\footnotetext{
7 Entre 1919 e 1929 construiu cerca de cem casas para os operários da, uma loja comercial para os produtos da companhia e instalações médicas.
} 
uma indústria química que deu origem ao bairro de Ermelino Matarazzo. Ainda na região Leste, no Tatuapé, em 1951 fundaram outra tecelagem de seda, a "Tecelagem de Seda do Sítio do Piqueri".

Ao longo das linhas da ferrovia, em São Caetano, adquirem a firma "Pamplona \& Cia" ${ }^{8}$, responsáveis pela fabricação de sabão e óleos vegetais e adquirem uma carpintaria para produção de caixas e maquinaria para a produção de pregos (Gunn e Correia, 2005).

Na década de 1920, as indústrias são reorganizadas e transferidas para o bairro da Água Branca: a Fábrica Pamplona, a refinaria de açúcar e a fábrica de óleo Sol Levante, além do escritório central. Em 1927 o grupo comprou uma companhia de produtos de mineração e implantou mais quatorze unidades fabris com uma área aproximada de $140.000 m^{2}$ (Gunn e Correia, 2005).

A construção de habitações para os operários sempre foi prática das empresas do grupo, em 1962 as empresas possuíam somadas 744 moradias, a maioria na capital (419 unidades).

Warrem Dean salienta que o setor industrial era totalmente marginal dentro da economia voltada para a exportação, o café gerou uma procura pela produção industrial, além de custear grande parte das despesas gerais econômicas e sociais. Já nos anos vinte São Paulo havia se tornado o maior centro industrial do país e em 1940 o maior da América Latina. O processo foi inverso com relação ao café que perdia gradativamente sua importância em relação ao crescimento industrial.

O aumento das exportações no setor provocou o interesse de bancos estrangeiros em investir nas indústrias, estes investimentos eram feitos de modo a incentivar as indústrias paulistas, principalmente o empresário imigrante e em

8 Em 1924 reformulam a fábrica e adicionam novos equipamentos para a fabricação de seda artificial. 
1930 registra-se que os imigrantes dominavam a indústria paulista (Mendes, 2011).

\subsection{O Processo de Verticalização da Cidade entre 1930 E 1940}

"O Investimento na construção de edifícios em altura está relacionado aos processos de urbanização, industrialização, diferenciação social e dos negócios... no investimento em infraestrutura nas áreas centrais e na necessidade de multiplicação do solo urbano por parte do capital imobiliário diante do aumento de preço da terra, especialmente nas áreas centrais de São Paulo, e de estratégias de valorização de áreas urbanas recém loteadas ou a serem subdividas, ou seja, da especulação imobiliária." (Silva, 2010)

Em 10 de novembro de 1937 Vargas promoveu o Golpe do Estado Novo. Preparado com meses de antecedência, os partidos foram suprimidos, o Congresso Nacional, os legislativos estaduais e as câmaras municipais foram fechados. Representantes de esquerda presos e uma nova constituição, de caráter fascista, foi redigida pelo ministro da Justiça Francisco Campos. As eleições de 1938 canceladas e o candidato de oposição Armando de Salles Oliveira, exilado. Contudo, a postura intervencionista abriria a oportunidade para as ambiciosas iniciativas de remodelação urbana, onde o "Novo Brasil" exigia quadros capazes de simbolizar a reorganização institucional e regeneração social almejados.

As concepções urbanísticas do Estado Novo foram a monumentalidade, impondo eixos e massas simétricas e os arranjos axiais. As composições simétricas sugeririam uma visão urbana condizente à concepção corporativa e unificada da sociedade inerente ao estado autoritário. 
"O volume dos edifícios seria proporcional à importância das novas instituições e seu papel no reordenamento do Brasil: sua linguagem arquitetônica, clássica, porém "racionalizada", exprimia intenções modernizadoras que não pretendiam abalar as tradicionais estruturas de dominação. "(Campos, 2002)

Segundo Marcel Steiner Giglio de Oliveira em sua dissertação de mestrado:

"De certo modo, pode-se afirmar que a postura do governo Vargas com relação às vertentes arquitetônicas não teve uma direção clara. Balançava-se entre a modernidade de vanguarda e 0 Art Déco, ainda que ambos convergissem para o funcionalismo, utilitarismo e estandardização. Sem contar com o neocolonial, o estilo missões e os estilos pitorescos, como o Normando e o Tudor, que também foram tema de diversos edifícios públicos construídos nesse período." (Oliveira, 2008)

Em São Paulo o caráter intervencionista do Estado Novo vinha de encontro com as aspirações do industrialismo, porém as classes ligadas à expansão urbana não viam com bons olhos seus instrumentos reguladores 9 (Campos, 2002).

\footnotetext{
9 Luiz Ignácio de Anhaia Melo, embora considerado uma sumidade do urbanismo moderno, entrou várias vezes em conflito com os proprietários de imóveis, como a polêmica Lei n 3008 de 1926, que adotava a cobrança de $100 \%$ dos custos da taxa de calçamento dos proprietários, o controle do crescimento urbano com a criação da taxa de ocupação máxima em dois terços da área do terreno para qualquer edificação; combateu a lei de loteamentos, aprovada em 1923, que permitia a abertura de ruas particulares à margem de exigências legais e $\circ$ Ato $n^{\circ} 25$, que proibia a construção em ruas particulares (na óptica da administração pública, se as ruas não estavam legalizadas, as construções também seriam não estavam). Dentro da visão liberal da época o direito dos proprietários sobrepunha-se aos códigos municipais.

"Baseados na consagração inconteste do direito de propriedade pela jurisprudência brasileira, da Constituição de 1891 ao Código de 1917, os juízes tendiam a favorecer os donos de imóveis. Em 1930, o debate acirra-se: as construções em ruas particulares multiplicavam-se, a prefeitura relutava em aprová-las e os proprietários recorriam à justiça." (Campos, 2002)
} 
A filosofia do novo regime, cujos temas eram: o intervencionismo, o nacionalismo e a centralização; buscava um representante do urbanismo "científico" e de neutralidade técnica. O nome de Anhaia Melo estava queimado desde o polêmico Ato Municipal $n^{\circ} 129$, dessa maneira a opção em 1938 era clara: ou a visão reguladora de Anhaia Melo ou o autor das concepções viárias expansionistas do Plano de Avenidas. Em sete de maio de 1938, Prestes Maia assumiria o cargo no qual permaneceria até o final de 1945.

Prestes Maia recebeu a máquina estatal modernizada e com arrecadação multiplicada. Em 1935 a prefeitura havia arrecadado 76 mi contos de réis e em 1943 o valor era quase 250 mil contos de réis anuais. Com o término das obras iniciadas na gestão anterior ${ }^{10}$ e com os recursos arrecadados, pode iniciar as ambiciosas intervenções do Plano de Avenidas, outros facilitadores foram os instrumentos criados pelo Estado Novo para as intervenções do poder público.

Começou a época das grandes obras, abrindo e alargando ruas, onde Prestes Maia: terminou o alargamento de Rua Benjamim Constant completando o "triangulo ampliado" idealizado por Vitor Freire; iniciou o alargamento da Avenida Liberdade, da Avenida São João até o Largo Padre Péricles; fez o prolongamento da Avenida Rebouças até o Jardim Europa; criou

\footnotetext{
10 Maia recebeu a prefeitura do seu predecessor, o industrial e fazendeiro Fábio Prado. Membro de uma das famílias mais tradicionais da cidade (protagonistas do complexo cafeeiro e exportador) era filho de Martinho da Silva Prado Júnior, sobrinho do ex-prefeito Antônio Prado, era casado com Renata Crespi, filha do Conde Rodolfo Crespi, rico fabricante de tecidos; formado em engenharia na Bélgica, foi diretor da Confederação Industrial do Brasil (criado em 1933), seus interesses abrangiam terras, fazendas de café e outras empresas.

Sua administração foi marcada por um programa consistente de realizações amparado em diretrizes ideológicas afinadas como novo perfil social da cidade: com um programa modernizador propunha a superação de conflitos de classes por meio da racionalização, regulamentação e integração das classes trabalhadoras. Entre seus primeiros atos estão o atendimentos à população por meio de equipamentos públicos, educativos e culturais ("... localizar playgrounds nos gramados inúteis e dispendiosos dos jardins do Parque D. Pedro II, da Luz, das praças da República, Buenos Aires e outras." - Melo, pg. 52-54); dentro as iniciadas em sua gestão estão: a abertura da avenida Nove de Julho, o novo Viaduto do Chá, com sua galeria - atual Galera Prestes Maia, os túneis da Avenida Nove Julho, a Biblioteca Municipal Mário de Andrade, o Estádio do Pacaembu entre outras.
} 
as praças 14 Bis e Alexandre de Gusmão; criou também a Avenida Vieira de Carvalho, entre a Praça da República e o Largo do Arouche; o alargamento da Avenida Duque de Caixas entre o Largo do Arouche e a estação da Estrada de Ferro Sorocabana (Campos, 2002).

O maior destaque de sua administração, contudo, foi o Anel Viário (o perímetro de irradiação) que contornaria a área central de São Paulo organizando o tráfego e descongestionando o "triângulo".

O perímetro de Irradiação passaria pela Rua de São Luiz, ao lado da biblioteca municipal, propondo que os proprietários facilitassem a intervenção cedendo às faixas de desapropriação visando os lucros da valorização decorrente da obra.

"Com a construção do prédio da nova biblioteca municipal e também do edifício Ester o traçado do Anel de Irradiação entre a Praça da República e Rua Xavier de Toledo, conforme previsto no Plano de Avenidas ficou prejudicado, pois ambos ficavam exatamente no eixo da avenida. Quando Prestes Maia sucedeu a Fábio Prado em maio de 1938, o traçado foi imediatamente revisto, sendo deslocado para o leito da própria Rua São Luiz." (Lefrève, 1999)

Os traçados seguintes reproduziam o que fora proposto pelo Plano de Avenidas: viadutos sobre os grotões da colina central (viadutos Jacareí e Dona Paulina, unidos pelo alargamento da Rua Maria Paula), ampliação da Praça João Mendes, a avenida na ladeira do Carmo (Avenida Rangel Pestana), a Avenida Mercúrio (contornando o Parque D. Pedro ll e o Mercado municipal), o alargamento da Avenida Senador Queiroz (desembocando na Avenida Ipiranga no ponto em que esta se encontra com a Avenida Conceição - atual Casper Líbero). 
A implantação do perímetro de Irradiação começou com o alargamento da Avenida Ipiranga seguida da Avenida Senador Queiroz, depois seguiram com as desapropriações no restante do trajeto, construindo as pontes sobre o Tamanduateí contornando o Parque D. Pedro II e finalizando com o trecho mais difícil, sobre a colina central e Bexiga. Entre o Viaduto Jacareí e Largo do Riachuelo Maia adquiriu um quarteirão para a implantação do Paço Municipal (onde atualmente se encontra a Câmara Legislativa de São Paulo) ${ }^{11}$. Consideradas como pontos nobres do "centro novo", as avenidas São Luiz e Ipiranga são prolongadas até a Rua da Consolação (Somek, 1987).

"A mudança da Casa Mappin ou Anglo Brasileira para a Praça Ramos de Azevedo (1939), a abertura da Rua Marconi (1938) e a construção do novo Viaduto do Chá (1938), foram fatores que concorreram para essa integração" (Muller apud Somekh, 1987).

Prestes Maia elaborou uma cuidadosa regulamentação arquitetônica visando garantir uma ocupação homogênea e de qualidade a exemplo do que já ocorria nas ruas Marconi e Xavier do Toledo, porém de maneira menos rígida:

"Enterrando definitivamente os limites de altura preconizados na cidade desde os tempos de Vitor freire. Maia liberava e incentivava o crescimento vertical, desde que associado às novas ligações viárias." (Campos, 2002)

Ao contrário das alturas máximas estipuladas, a nova legislação impunha uma altura mínima de 39 metros no alinhamento e, por uma seqüência de escalonamentos, até 115 metros. Incentivava a substituição dos prédios existentes por prédios com 39 metros de altura no alinhamento, favoreceu os equipamentos que criassem:

\footnotetext{
11 A construção do Palácio Anchieta foi executada pela Construtora Alfredo Mathias em 1968, os estudos iniciais são de autoria do arquiteto Oscar Niemeyer, segundo o arquiteto Paulo Bruna, na época da construção o projeto foi modificado dentro da construtora.
} 
"... recuos, galerias, colunatas ou arcadas, equivalentes a uma ampliação dos passeios utilizáveis para mesas de cafés, bares, etc." (Campos, 2002)

Marquises e revestimentos nobres foram impostos por lei, assim como o tratamento dos passeios. ${ }^{12}$ Alturas maiores que $80 \mathrm{~m}$ poderiam ser atingidas por meio de corpos escalonados em "pontos focais ou de grande interesse arquitetônico a juízo da prefeitura". É o caso do edifício do Banco de Estado de São Paulo que tirou partido dessa resolução situado no eixo da Avenida São João, sua volumetria escalonada, ganhou um perfil nova-iorquino, reforçado pelo coroamento com 120 metros de altura.

Luiz Otávio da Silva afirma:

“... edifícios altos e áreas verticalizadas constituíam uma simbologia que encontrou seu espaço na própria história da cidade. Eles eram associados à idéia de modernização, de progresso e aos êxitos econômicos da metrópole. Durante as décadas de 1920, 1930 e 1940, estabeleceram-se os alicerces para o desenvolvimento desse fenômeno." (da Silva, 2007)

Entre as décadas de 1940 e 1960, constituem um período de grandes modificações: a cidade se compacta com a verticalização de loteamentos em bairros já formados e a área urbana se expande para a periferia. A partir da Segunda Guerra Mundial, pela primeira vez, o Brasil se torna exportador de bens industriais e São Paulo cresce em importância frente à economia do país (Singer, 2004).

\footnotetext{
12 O Código Artur Sabóia (1936) estipulava para o "centro-novo" o controle de altura visando garantir coerência volumétrica e estética para as ruas que formavam a nova área "nobre" de São Paulo. A padronização arquitetônica (inclusive a imposição de acabamentos finos na altura do pav. Térreo) era considerada requisito indispensável para qualificar os empreendimentos. "A imposição de diretrizes estético-volumétricas sobre as iniciativas particulares era um meio de conciliar a visão liberal, de uma cidade amparada em obras privadas, com as qualidades simbólicas que deveriam diferenciar os espaços dominantes na capital paulista." (Campos, pg. 509)
} 
A produção imobiliária se intensifica com o investimento dos lucros da indústria, comércio e da exportação de produtos. O capital incorporador se consolidou como agente de produção do ambiente urbano. O número de plantas aprovadas na cidade de São Paulo cresce vertiginosamente: em 1940 a área construída anual gira em torno de $1.600 \mathrm{~m}^{2}$ e na década de 1960 esse número sobe para sete milhões de $\mathrm{m}^{2}$.

"Do ponto de vista da tecnologia, os primórdios da verticalização brasileira podem ser contados pelo "embate" entre a opção pelo emprego de estruturas metálicas e moldagem da estrutura em concreto armado. A segunda opção significava a constituição de um modo de produção muito mais nacionalizado do que o emprego de estruturas metálicas, geralmente projetadas $e$ produzidas no exterior. A partir de 1926, com o estabelecimento da indústria de cimento no país, a segunda opção passou a significar uma opção ainda mais nacional. Foi principalmente no período de restrições às importações, durante a Segunda Guerra Mundial, que se consolidou o emprego do concreto armado." (da Silva, 2007)

Essa intensa atividade ocorreu em vários segmentos do mercado imobiliário, a verticalização, antes restrita ao centro e predominantemente comercial, passa a residencial e se insinua na direção Sudoeste e nos bairrosjardins algumas vias são liberadas para verticalização com múltiplos usos, liberação esta, fruto das pressões dos proprietários dos terrenos (Somekh, 1987)

"Iniciou-se um período rentista, já que as áreas de maior concentração de arranha-céus coincidiam com a dos valores imobiliários, o que impulsionou, a partir de 1930, "a procura cada vez mais intensa da construção vertical como forma de ampliação das rendas imobiliárias..." A maioria dos edifícios era construída com fins lucrativos, visando o aluguel das unidades. Ao mesmo tempo, a proposta de uma diversidade maior na utilização dos espaços acabou por valorizar tais empreendimentos, cujo programa estabelecido possibilitava habitar e trabalhar no mesmo edifício." (Villa, 2006) 
Verifica-se que a partir dos anos 1930, quando houve o aumento da produção de edifícios para alugar, a aceitação desse tipo de moradia ainda era visto com ressalva por arte do "público-alvo", pois permaneciam associados aos estigmatizados cortiços. Luiz Octávio da Silva ainda salienta em que os anos trinta coincidem com:

"... as mudanças dos modelos arquitetônicos aplicadas às construções". (da Silva, 2007)

O modernismo dava seus primeiros passos, nestes anos coincidem com a emergência do Art Déco, com seu despojamento ornamental, identificado como estilo modernizado. ${ }^{13}$

Segundo Maria Adélia A. de Souza, a Lei do Inquilinato de 1942, causaria uma profunda alteração na forma de produzir edifícios.

"O aluguel deixa de ser uma atividade rentável e inicia-se um processo de produção para a venda. Surge a incorporação - os condomínios." (Souza, 1994)

Nas zonas centrais tem um aumento significativo de apartamentos tipo "quitinete", Maria Adélia ainda afirma que a primeira experiência desse tipo de moradia para a classe média baixa, foi feita por um português (cujo nome é ignorado) que possuía um hotel na Rua do Gasômetro e com as alterações do código de obras transformou-o num prédio de apartamentos, as vendas do imóvel em sua nova função se deram de forma extremante rápida, tornando-se um dos mais bem sucedidos negócios imobiliários da época. (Souza, 1994)14

13 "Até os anos 1920, o ecletismo ainda era largamente utilizado, inclusive na arquitetura de
edifícios. Do ponto de vista da morfologia urbana, a verticalização deu-se sobre um parcelario
colonial, caracterizado por lotes estreitos e profundos e seus edifícios não apresentavam recuos
nem de frente nem laterais. Internamente, esses edifícios procuravam reproduzir os programas
arquiteturais das edificações não-verticalizadas." - (da Silva, 2007).
14 Segundo Maria Adélia esse tipo de venda como condomínio era expressamente proibido
pela lei - o código de obras, não permitia a construção deste tipo de apartamento (que tivesse
apartamentos com banheiros internos ventilados por tubos. Em 1952, Oscar Niemeyer projeta o 
É de se observar que a construção de edifícios em condomínio disseminou-se a partir dos anos quarenta, casando com o desestímulo à produção rentista decorrente da lei do Inquilinato de 1942. Outro fator relevante no período 1930 a 1945 foi a legislação que ao longo do tempo foi adaptada visando acompanhar ou regulamentar as "tendências" da época.

\title{
2.4. A Criação de um Modelo
}

O programa dos edifícios de apartamentos é relativamente recente. Segundo Nádia Somekh, os primeiros edifícios de apartamentos produzidos na cidade de São Paulo datam do ano de 1910, projetados por Samuel das Neves e Victor Dubugras.

Como citado anteriormente, no primeiro momento esse tipo de habitação coletiva seria relacionado aos cortiços, portanto, a idéias de: pobreza, promiscuidade e insalubridade. Localizaram-se principalmente nos arredores do centro histórico como opção de moradia para comerciantes e suas famílias (Queiroz, 2008).

\begin{abstract}
"Foram propriedades particulares advindas da economia cafeteira que garantiam às familias quatrocentonas entressafras, aposentadorias e viuvezes confortáveis. O aluguel foi, naquele tempo, um rendimento ótimo, talvez o melhor deles, muito melhor que ações." (Lemos, 1990)
\end{abstract}

As origens do programa destes apartamentos remontam o modelo da casa colonial brasileira, embora a grande influência na produção dos edifícios de apartamentos seja francesa.

Edifício Montreal (Avenida Ipiranga esquina com Avenida Casper Líbero), concebido como hotel e posteriormente vendido como condomínio; fato que foi logo denunciado. Sucedesse então a alteração do código de obras permitindo os banheiros internos com ventilação por tubulação. "Esse procedimento é um das marcas de São Paulo: o seu código de obras sempre irá ser alterado em benefício do incorporador." (Souza,1994) 
“... a então remodelada capital francesa representava um importante referencial cultural para classes dominantes de outras grandes cidades... Seu modelo de habitação, consolidado nos apartamentos produzidos durante a Belle Epoque do século XIX, visava atender às necessidades espaciais da classe ascendente do período." (Queiroz, 2008)

A espacialidade dos apartamentos paulistanos, desde as primeiras décadas até as mais recentes, tem como referência o apartamento parisiense, Fábio Queiroz aponta seis características principais:

1) A divisão da planta em cômodos, como estratégia de organização de USOS;

2) A estanqueidade funcional de espaços, com a vinculação de atividades a cômodos determinados;

3) A existência de uma relação de hierarquia entre espaços;

4) A tripartição da habitação como agrupamento de cômodos em zonas Social, Íntima e de Serviços;

5) A articulação dos cômodos por meio de corredores e dispositivos de circulação;

6) A existência de uma relação de hierarquia também entre circulações, separadas para o uso de patrões e empregados, inclusive no âmbito coletivo do edifício.

Nos anos 1940, após o fim da Segunda Guerra Mundial, os Estados Unidos emergem como grande potência mundial e observa-se a disseminação do "estilo de vida americano". Nesse período em decorrência da Lei do Inquilinato de 1942, que congelou os aluguéis, as construções, destinadas à locação deixaram, por anos, de ser um investimento interessante. 
Nesta época o mercado imobiliário se profissionaliza e surge a figura do incorporador imobiliário. De acordo com Carlos Lemos, foi a partir da influência dos agentes imobiliários que seria produzida as alterações no Código de Obras, permitindo, por exemplo, a aprovação de edifícios com unidades tipo quitinetes ou diminuindo os afastamentos obrigatórios. Dessa época, também, que se estabeleceram definitivamente o programa mínimo de sala, dormitórios, banheiros, cozinha e área de serviço como padrão, constituindo uma versão reduzida da planta burguesa (segundo, Villa, 2002 - apud, Queiroz, esse modelo chegou até a década de 1970 como produto rentável e seguro para o investidor).

Nos anos 1980, nos apartamentos compactos de dois dormitórios tornamse comuns o terceiro quarto reversível (nada mais que o dormitório de empregada acrescido de uma porta que o ligava à circulação da área intima).

\subsection{Os Principais Agentes do Mercado Imobiliário na cidade de São Paulo}

O processo de verticalização de São Paulo está relacionado diretamente como os processos de urbanização, da industrialização, das mudanças da legislação urbana, no investimento em infra-estrutura nas áreas centrais e a necessidade de multiplicação do solo urbano por parte do capital imobiliário.

Joana Mello de Carvalho e Silva afirma que além dos fatores sócioeconômicos havia a mudança no padrão cultural: até os anos 1920 o referencial era a cultura européia, em especial a francesa, a partir dos nos 1930, principalmente dos anos 1940 o referencial são os Estados Unidos da América.

"O arranha-céu, as avenidas e o transporte individual se tornam ícones da civilização almejada, transformando a paisagem da cidade e aparecendo nas revisões da legislação e códigos urbanos a partir do final dos anos 1920..." (Silva, 2010) 
Dentro deste contexto, os membros da elite paulistana promovem a verticalização das áreas centrais da cidade. Maria Adélia, citando Nádia Somekh divide a evolução dos edifícios em São Paulo em cinco períodos (Souza, 1994):

1 Período: década de 1910, correspondente ao início do processo, fortemente vinculado à construção estrangeira. Desta época merece destaque o primeiro edifício de concreto armando da cidade, datado de 1907/1908, na Rua Direita esquina com Rua São Bento (no entanto, segundo Lemos, o primeiro prédio de concreto na cidade foi projetado pelo arquiteto Cristiano das Neves em 1920), o primeiro de apartamentos foi o Palacete Riachuelo e o primeiro a receber elevador, foi o edifico do Hospital Santa Catarina, em 1918.

$2^{\circ}$ Período: década de 1920, marcada por edifícios de apartamentos para locação, em geral levantados por famílias da elite paulistana, raros os prédios comerciais. Destacam-se deste período o Edifício Sampaio Moreira - projetado por Cristiano Stockler das Neves e o Edifico Martinelli, projetado por seu proprietário e inaugurado em 1929.

3० Período: décadas de 1930 e 1940, consolidação da fase rentista iniciada na década anterior, os edifícios de aluguel ainda eram a melhor opção de investimento. As construções apresentam duas fases distintas separadas pela Guerra: a anterior com a predominância do estilo Art-nouveau e a posterior com edifícios Art-dèco. Os bairros dos Campos Elíseos, Barra Funda e Higienópolis, serão os palcos para estes edifícios ${ }^{15}$.

$4^{\circ}$ Período: 1947 a 1964, correspondente ao início das incorporações e a forte verticalização da cidade. A Lei do Inquilinato de 1942 promoveria uma profunda alteração na forma de moradia na cidade: o aluguel deixa de ser

\footnotetext{
15 As grandes famílias ainda continuam como protagonistas destas construções: Sarti, Henrique
} Jovino, Augusto Barreto, Luiz Médici, Porchat, entre outras - a Identidade da Metrópole, pg. 93. 
uma atividade rentável e inicia-se o processo de produção para venda, surge à incorporação e os condomínios. Desenvolvem novos programas como o apartamento tipo quitinete, vários prédios são lançados "a preço de custo". 16

$5^{\circ}$ Período: A partir de 1964, neste período as incorporações estão voltadas exclusivamente à produção de apartamentos de dois, três ou mais dormitórios, estando muito sensíveis à crise e medidas governamentais. O programa dos apartamentos se altera com os aumentos de banheiros, elevadores, etc.

A verticalização tornou-se o novo ramo de investimento dos membros da elite paulista e estrangeira. No processo participaram vários arquitetos como Eduardo Kneese de Mello (1906-1994), Vilanova Artigas (1915-1985), Hélio Duarte (1906-1989), Abelardo de Souza (1908-1981), Ícaro de Castro Mello (1913-1986), Rino Levi (1901-1965), Oswaldo Bratke (1907-1997), Oswaldo Corrêa Gonçalves e arquitetos estrangeiros que se estabeleceram na cidade no entre guerras: o francês Jacques Pilon (1905 - 1962), o austríaco Bernard Rudofsky (1905-1988), a italiana, depois naturalizada brasileira, Lina Bo Bardi (1914-1977) e os italianos Giancarlo Palanti (1906-1977), Daniel Calabi e Gian Carlo Gasperini, os poloneses Lucjan Korngold (1897-1963) e Victor Reif(1909-1998), o ucraniano Gregori Warchavchik (1896-1972) e o alemão Herbert Duschenes (1914-2003), entre outros.

Dentre os incorporadores e construtoras que estes profissionais ou prestavam serviços ou fizeram parte de seu quadro de funcionários cabe citar as Construtoras: Luz-Ar, Três Leões, Moderna - posteriormente Construtora Segre \& Racz, Alfredo Mathias, Auxiliar, Dácio A. de Moraes S/A, Pacheco Fernandes, Dantas Ltda, Renato Cecchi Cia. Ltda, Sociedade Civil e Construtora e a

\footnotetext{
16 Segundo Carlos Lemos, apud Maria Adélia, a expressão foi usada pela primeira vez pelo engenheiro Cipriano Marques Filho em 1947, idealizador e precursor da incorporação de edifícios. Em princípio ele (o incorporador) escolhia o terreno, arrebanhava os compradores que se cotizavam para pagar o terreno, o projeto e a construção; como engenheiro e líder do processo cobrava uma taxa de administração. Seu primo Carlos Caldeira Filho foi o primeiro a registrar a expressão em São Paulo.
} 
Companhia Nacional de Investimentos, todas envolvidas com a incorporação de edifícios na área central de São Paulo dentre outras (Silva, 2010).

Dentre os incorporadores do período aparece a polêmica figura do espanhol João Artacho Jurado, dono da Construtora Monções, que embora não sendo nem arquiteto ou engenheiro atuou no mercado imobiliário. Como não podia legalmente assinar seus projetos contornou o problema trabalhando em parceria com engenheiros como Luís Diógenes Zeppelini, Aurélio Marazzi, Guinio Patella e João Birman, que assinavam a responsabilidade técnica perante o CREA e dos órgãos públicos (Franco, 2008).

"Jurado foi pressionado e punido algumas vezes pelo CREA por causa de uma fiscalização mais rígida que era exercida em certos períodos, não só nas obras como também nas placas de obra. Segundo as normas vigentes, o nome dele não poderia aparecer num tamanho maior que o do engenheiro responsável, o que acontecia com certa freqüência e era alvo de críticas dos concorrentes e desafetos." (Franco, 2008)

Joana Mello também salienta que os profissionais de origem estrangeira tinham que se sujeitar ao trabalho em parceria com profissionais brasileiros ou em construtoras devido ao não reconhecimento do diploma profissional pelo estado brasileiro. ${ }^{17}$

Além dos impedimentos profissionais, a Constituição Federal de 1937 estabelecia diferenças dos direitos e garantias individuais entre brasileiros e estrangeiros, entre as restrições estava à limitação de livre circulação no país, acesso a cargos públicos e o direito de propriedade. Tais direitos só foram

\footnotetext{
17 "Decreto Federal no 23.569 de dezembro de 1933, estabelecendo que somente aqueles formados no exterior em escolas ou institutos técnicos superiores [que tivessem] revalidado os seus diplomas de acordo com a legislação federal do ensino superior até aquela data poderiam exercer a profissão de arquiteto no país". Pg. 56
} 
restituídos com a promulgação da nova Constituição de 1946 restabelecendo a democracia no país.

Nos anos considerados os de maior verticalização da cidade (1960 a 1980), Pereira Leite faz um estudo de caso das principais empresas construtoras e incorporadoras:

"se possível, com posicionamentos mercadológicos diferentes" (Pereira Leite, 2006)

Por este critério selecionou as seguintes empresas: a Construtora Adolpho Lindenberg, a construtora Hindi Cia. Brasileira de Habitações, a Construtora Anhembi (depois Construtora Romeu Chap Chap), a Construtora Sobloco, a Construtora Luciano Wertheim, a Construtora Albuquerque \& Takaoka e a Construtora Alfredo Mathias.

"As empresas selecionadas tiveram grande destaque no cenário imobiliário paulista e mesmo nacional. Por exemplo, a Construtora Adolpho Lindenberg ... Romeu Chap Chap, titular da empresa de mesmo nome, sucessora da Anhembi, em sociedade com Moacir Ferreira de Souza... Esses incorporadores ficaram conhecidos pela execução de diversos edifícios de alto padrão... Luciano Wertheim titular da construtora homônima, também completou meio século em 2003, com uma imagem positiva junto aos seus clientes. A "Hindi" também se tornou uma marca de sucesso, ainda utilizada na revenda de seus apartamentos, mais de vinte anos após ter encerrado suas atividades. A "Sobloco" teve uma atuação expressiva no mercado de apartamentos residenciais. Tornou-se ainda mais famosa por seus projetos de desenvolvimento urbano, em especial, pelo empreendimento da Riviera de são Lourenço, em Bertioga. A Construtora Albuquerque \& Takaoka foi a pioneira na realização de grandes conjuntos residenciais de médio e alto padrão, ao lançar o Condomínio "Ilha do Sul", em Alto de Pinheiros e, em seguida, em razão do audacioso empreendimento de Alphaville, em Barueri e Santana de Parnaíba. A construtora Alfredo Mathias realizou vários projetos de vulto, com o Shopping Iguatemi, e o Portal do Morumbi.(Pereira Leite, 2006) 


\subsubsection{Construtora Adolpho Lindenberg}

A Construtora tem sua origem a partir do escritório de engenharia criado por Adolpho Lindenberg ${ }^{18}$ em 1953 para a construção de casas de alto padrão, atendia pessoalmente os potenciais compradores e em conseqüência desenvolveu extensa rede de relacionamentos de potenciais clientes, os quais não só o indicavam para novos negócios ou para a aquisição de terrenos para a construção de edifícios.

Em 1958, se associa aos engenheiros Alberto Du Plessis e Plínio Vidigal Xavier da Silveira, sendo as atribuições divididas: a área comercial para Lindenberg, a técnica para Du Plessis e a administrativa para Silveira.

A construtora aposta na verticalização para o segmento de alta renda e, em 1960, inicia a construção do primeiro edifício de apartamentos no bairro de Higienópolis (o Edifício Princesa Isabel). Em 1961, lança o edifício Dom João V, na Avenida Higienópolis, com área privativa de aproximadamente $400 \mathrm{~m}^{2}$. Nessa época adota o estilo que seria sua marca registrada o neoclássico.

Na década de 1970, período de grande expansão, desenvolve obras no Rio de Janeiro, Brasília, Manaus, no Paraguai e Nigéria, no entanto, já no final da década, com a diminuição das vendas do segmento residencial, as construções empreitadas de terceiros já ultrapassavam as incorporações em área construída. Após uma viagem à Grécia, Lindenberg idealizou uma "arquitetura mediterrânea" que foi um sucesso de vendas - o famoso estilo "mediterrâneo".

Com o grande crescimento, a empresa recorreu a empréstimos bancários a fim de bancar sua expansão (em 1976 os empréstimos beiravam a totalidade do patrimônio liquido). Devido ao surto inflacionário a construtora muda sua

\footnotetext{
${ }_{18}$ Adolpho Lindenberg formou-se engenheiro civil pela Universidade Mackenzie em 1949.
} 
estratégia e passa a trabalhar com o regime de administração, onde o aumento dos insumos era repassado ao cliente final. Essa estratégia, porém não foi suficiente para blindar a empresa, cujos lucros eram reduzidos e insuficientes para fazer frente às despesas oriundas dos empréstimos. Em 1979 é aprovado o pedido formal de concordata (neste ano o Balanço Patrimonial registra um prejuízo de $\mathrm{R} \$ 50$ milhões de cruzeiros).

Nos anos subseqüentes a empresa se retraiu, tendo uma recuperação lenta, contudo a empresa contava com o prestígio e o reconhecimento público, dada as inovações e trajetória da companhia. A construtora foi responsável pelo desenho que marcaram seus empreendimentos: o "Neoclássico" e o "Mediterrâneo", além de introduzir a personalização dos acabamentos dos apartamentos.

\subsubsection{Construtora Hindi Cia. Brasileira de Habitações}

Arquiteto (1959) pela Universidade Mackenzie, Anuar Hindi funda a "Hindi Companhia Brasileira de Habitações" em 1967, mesmo ano da criação do Banco Nacional de Habitação, o BNH.

A empresa buscava alto grau de eficiência com a execução de projetos extremamente racionalizados que pudessem ser repetidos várias vezes visando à redução dos custos e o prazo de execução da obra, a estratégia era embutir a inflação nos preços de venda, daí a velocidade ${ }^{19}$.

O foco da construtora no mercado residencial era a classe média, produzindo apartamentos de dois, três e quatro dormitórios (normalmente quatro apartamentos por andar), no auge do sucesso da construtora chegou a ter mais de seis mil funcionários. A empresa era extremamente verticalizada,

\footnotetext{
19 Dada a disponibilidade na época, eram procurados terrenos com tamanho suficiente em que pudesse "encaixar" o os projetos padronizados.
} 
tendo em seu corpo de funcionários arquitetos, engenheiros e funcionários dos canteiros de obras.

Na década de 1970, além da inflação, enfrentou os problemas do fornecimento do cimento, o encarecimento da mão-de-obra e a mudança do zoneamento (1972) e o conseqüente aumento do preço dos terrenos que, em conjunto, desestimulavam o lançamento de novos empreendimentos. A empresa procurou se adaptar ao período transformando a incorporadora numa construtora prestadora de serviços. Dada a estrutura verticalizada da empresa e da dependência das decisões à pessoa do fundador, que muito o sobrecarregava e entendendo que os riscos eram demasiados preferiv encerrar suas atividades em 1983.

"A Hindi foi responsável por muitas inovações. Além do modelo organizacional, um empreendedor controlando uma sociedade de capital aberto, com ações na Bolsa de Valores... buscando racionalização da obra revolucionaram o padrão construtivo em geral, como a adoção das tarefas de mão de obra, os caixilhos em perfis de alumínio e os elevadores com cabines padronizadas". (Pereira Leite, 2006)

\subsubsection{Construtora Romeu Chap Chap}

Fundada em 1960 com a denominação de Construtora Anhembi, foi o resultado da parceria de Romeu Chap Chap e Moacyr Ferreira de Souza, cujo primeiro trabalho foi o projeto de um prédio de apartamentos em São Vicente, outras obras sucederam com a parceria principalmente na região do Paraíso, onde Chap Chap conhecia muita gente. No início os trabalhos eram divididos: Moacyr cuidava das obras e Chap Chap das incorporações.

A estratégia da empresa foi a construção de prédios de alto padrão a preço de custo e os lucros provinham das vendas das frações do terreno e das taxas de administração da obra. Nos anos 80 lançou algumas obras a preço 
fechado, utilizando a correção monetária como instrumento de correção, os resultados, longe dos esperados, demonstraram ser um desastre.

"Cheguei a gastar um apartamento por mês para pagar os custos financeiros". (Pereira Leite, 2006)20

Com os riscos do mercado devido ao surto inflacionário, das mudanças de regras e de governos, induziram a construtora para o segmento de alto padrão, atuando em bairros consolidados como Higienópolis e Paraíso; procurava junto com seus arquitetos atender todos os desejos e expectativas dos clientes.

A empresa cuidava da incorporação, construção e vendas das unidades, compatibilizava até no ano 2006, 88 edifícios construídos com 3400 apartamentos entregues.

\subsubsection{Construtora Sobloco}

Resultado da parceria dos engenheiros Luiz Carlos Pereira de Almeida e Mario Najm, formados pela Escola Politécnica da Universidade de São Paulo (1949), a Sobloco Construtora S/A fui fundada em 1958 para atuar no mercado de pavimentação por blocos de concreto visando o mercado de Brasília, não alcançando os resultados almejados concentraram suas atividades no mercado de obras públicas no estado de São Paulo. Na década de 1960, com a fundação do Branco Nacional de Habitação - BNH passaram a atuar no mercado de habitações populares.

Para viabilizar as incorporações, em geral, a construtora se associava aos donos dos terrenos que eram pagos com uma participação no empreendimento:

20 Entrevista de Romeu Chap Chap a Ricardo Pereira Leite, 2006, pg. 152. 
"Para convencê-los, fazíamos um plano que deveria ter o mérito de também nos convencer quanto à viabilidade do novo projeto. Esses estudos eram desenvolvidos com profissionais (arquitetos, projetistas de estrutura e instalações, consultores etc.) "a risco", no menor prazo possivel. O importante era a agilidade". (Pereira Leite, 2006) ${ }^{21}$

Para se defenderem da inflação, antes da criação da correção monetária, a empresa contava com a velocidade da construção e a compra antecipada dos materiais. A definição do produto era feita por meio da maximização da relação custo/benefício, aproveitando todo o potencial do terreno, sem sofisticações arquitetônicas:

"A estratégia do Sobloco ficava no meio termo entre o projeto padrão adotado pela Hindi e a personalização da Lindenberg". (Pereira Leite, 2006)

No início dos anos 80, com o surto inflacionário, a construtora muda de estratégia e passa atuar no mercado de desenvolvimento urbano, sendo o mais famoso o loteamento lançado em 1984 em Bertioga: a Riviera de São Lourenço.

\subsubsection{Construtora Luciano Wertheim}

Formado engenheiro civil pela Escola Politécnica da Universidade de São Paulo em 1948, funda a construtora em 1952, sendo o seu primeiro edifício vertical construído na Alameda Barros, cujos recursos vieram do empréstimo pedido à Associação Paulista de Medicina. A empresa não possuía grandes recursos e a estratégia era adquirir os terrenos a prazo e vender $30 \%$ do negócio a investidores.

21 Entrevista de Luiz Carlos Pereira de Almeida a Ricardo Pereira Leite, 2006, pg. 160. 
Nos anos 70 a empresa utiliza os financiamentos do $\mathrm{BNH}$ em dois empreendimentos: um edifício comercial e outro residencial em Moema, as vendas foram terceirizadas. A escolha dos terrenos se baseava no feeling de Luciano.

Considerando-se avesso a riscos, o fundador optou por não alavancar a empresa e para diminuir as incertezas quanto à definição dos produtos, visitava pessoalmente os plantões de vendas dos concorrentes. Dentre "as incertezas" destacava a demora da aprovação dos projetos, o que era necessário para a liberação dos recursos pelo BNH e alta da inflação do período.

\subsubsection{Construtora Albuquerque \& Takaoka}

Fundada em março de 1951, pelos engenheiros Renato Albuquerque e Jojiro Takaoka, formados pela Poli em 1949, já trabalhavam juntos desde o último ano da faculdade. Dedicavam-se a prestação de serviços a terceiros e a execução de obras públicas; ; o primeiro grande projeto foi a construção de 150 casas em São Caetano para a família Jafet. No período de 1951-1955, tornaram-se uma das maiores empresas do país, construindo pontes, viadutos, edifícios públicos e escolas.

A partir do início da década de 1960, a empresa reduz sua participação no setor de obras públicas, iniciando a construção de prédios de apartamentos financiados pelo Sistema Financeiro da Habitação.

Takaoka visitava regularmente edifícios concluídos pelos concorrentes visando à melhoria dos seus produtos, destas visitas começou a valorizar os halls dos prédios, jardins e áreas de lazer.

No início da década de 1970 lança o Condomínio llha do Sul, conjunto de seis prédios, de vinte pavimentos, totalizando 480 apartamentos no bairro de Alto de Pinheiros. Com uma proposta inovadora, o condomínio propunha a 
inclusão dos prédios em uma grande área verde e equipamentos de lazer, com quatro piscinas, ginásio de esportes, salões de jogos, festas, restaurante, cinema, teatro e praças. A aceitação de início foi difícil, pois os potenciais compradores receavam os custos do condomínio, demorando 18 meses para vender todas as unidades (as vendas em geral demoravam um mês), onerando a construtora com os juros dos financiamentos obtidos para a execução da obra.

Em 1973 lança seu mais ousado empreendimento, um loteamento, nos moldes dos grandes projetos americanos, com toda a infra-estrutura, o terreno escolhido ficava na Rodovia Castelo Branco, a antiga Fazenda Tamboré, entre os municípios de Barveri e Santana do Parnaíba (5,5 milhões de metros quadrados), recebeu o nome de Alphaville, homenageando o filme de JeanLuC Godard.

"Inicialmente projetado para ser um Centro Comercial e Industrial, em 1975 Alphaville lançou o primeiro loteamento residencial fechado, atendendo à intuição de Takaoka, que pretendia atender a demanda de moradia dos gerentes e diretores das empresas." (Pereira leite, 2006)

Em 1994, Takaoka não acreditando na possibilidade de sucessão, propôs ao sócio a divisão da empresa, veio a falecer neste mesmo ano.

\subsubsection{Construtora Alfredo Mathias S.A.}

A história da construtora Alfredo Mathias é o objeto de estudo desta dissertação e será visto nos capítulos adiante.

Segundo Ricardo Pereira Leite, na conclusão de sua Dissertação de Mestrado, as empresas estudadas apresentavam como padrão uma estrutura verticalizada onde seus sócios dividiam as atividades da incorporação e construção, havia uma procura sistemática pelas inovações tecnológicas onde o crescimento de forma geral era o norte, de maneira geral sofreram com o 
período inflacionário, sendo que algumas acabaram por encerrar suas atividades ou se retraíram em função da crise. 
3. Alfredo Mathias, Engenheiro-Arquiteto 
Segundo D. Lizete22, Alfredo Mathias era o irmão mais velho de uma de seis irmãos: Odila, Cesário, Jorge, $\operatorname{Simão}^{23}$ e Maria do Carmo. Nasceu em São Paulo em 1906, filho de pais sírios, estudou no colégio Rio Branco e formou-se engenheiro-arquiteto pela Escola Politécnica da Universidade de São Paulo em 1929.

Depois de formar-se ingressou no corpo técnico da prefeitura de São Paulo onde trabalhou como engenheiro na Diretoria de Obras Públicas sendo responsável pela fiscalização das obras do Palácio da Justiça e do edifício da Faculdade de Direito do Largo de São Francisco. Em 1931 participou no Congresso de Habitação e, com a eclosão da Revolução Constitucionalista de 1932, alista-se e serve como major na Delegacia Técnica de Itatinga.

Com o término da revolução constrói casas de alto padrão no Jardim Bonfigliolli para famílias tradicionais como a Lunardelli e a própria Bonfigliolli. Nos anos quarenta faz vários empreendimentos, principalmente na região do Centro Novo a preço de custo, tornando-se um dos primeiros incorporadores da cidade, destaca deste período a construção do edifício do Hospital São Joaquim para a Beneficência Portuguesa, projeto de Hypolito Gustavo Pujol e Oscar Defilippi, resultado de um concurso público.

No início dos anos cinqüenta funda a Construtora Alfredo Mathias e continua atuando no Centro Novo, mas com sua visão empreendedora começa a lançar empreendimentos no vetor sudoeste da cidade, sendo um dos pioneiros na construção de edifícios nos bairros de Higienópolis, Avenida Paulista e Jardins.

\footnotetext{
22 Maria do Carmo Mathias Maffei, irmã caçula do arquiteto.

${ }^{23}$ Cesário se formaria físico, Simão, médico. Jorge Mathias trabalhou com o próprio Mathias na construtora e na empresa administração de imóveis: a Segurança Imobiliária S.A.
} 
Nos anos sessenta lança os empreendimentos das galerias no Centro Novo, vários edifícios em Higienópolis e o ousado empreendimento Shopping Center Iguatemi. Nos anos setenta lançou os não menos ousados empreendimentos do Portal do Morumbi e Centro Empresarial

Dono de uma personalidade marcante soube cerca-se dos melhores profissionais de sua época como os arquitetos Giancarlo Palanti, Lucjian Korngold, Siffredi \& Bardelli, Giancarlo Gasperini e nos últimos anos João Henrique da Rocha que viria a se tornar seu amigo e braço direito. Importante frisar que todos que trabalharam sobre sua liderança guardam profundo respeito e admiração por sua pessoa afirmando, não poucos, que ele foi o melhor patrão que já tiveram.

Procurou controlar toda a cadeia de produção tornando-se alem de construtor, incorporador, industrial (foi dono da Fábrica de Cerâmica Keralux e da Fábrica Peristal de beneficiamento de metais) e administrador de imóveis (a empresa Segurança Imobiliária S.A.). Estas empresas eram extremamente verticalizadas onde poder de decisão era divido com os diretores e engenheiros de obras.

Em 1973, Mathias adquiriu o terreno onde lançaria seu mais ousado empreendimento: O Portal do Morumbi, com 800 apartamentos de alto padrão. Para a execução das obras, Mathias importou da Alemanha um sistema inovador de formas deslizantes. O lançamento foi anunciado de forma bombástica nos jornais e televisão, porém na época, com a crise do petróleo e o fim do "milagre brasileiro", as vendas não tiveram o resultado esperado o que levou a empresa uma crise sem precedentes em sua historia. Procurou várias maneiras de resolver o problema, chegando a criar um sistema próprio de financiamento com o lançamento de títulos no mercado, que foi barrado pelo governo. Falece em 1979, com 73 anos de idade. 
4. A História da Construtora Alfredo Mathias S.A. 
"Não façam planos acanhados. Eles não têm magia para mover os homens e provavelmente nunca serão realizados. Façam planos grandiosos, almejem o alto na esperança e no trabalho, lembrando que um diagrama lógico uma vez registrado nunca morrerá mesmo depois de termos partido, permanecerá como um elemento vivo, afirmando-se sempre com crescente insistência... façam o seu lema a ordem e o seu guia a beleza." (Toledo, 1996)24

A trajetória profissional do arquiteto, engenheiro e empresário Alfredo Mathias confunde-se com a história recente da cidade de São Paulo. Formouse engenheiro-civil e arquiteto pela Escola Politécnica de São Paulo em 1929 e, portanto, foi testemunha (e um dos protagonistas) das profundas transformações que a cidade sofreu a partir dos anos trinta. Neste período seriam lançadas as bases da metrópole que emergiria após a Segunda Guerra Mundial, com a crise de 1929 o café perde espaço para a indústria e o Estado de São Paulo assumiu o papel de principal pólo industrial e econômico do país sendo a cidade de são Paulo o principal foco deste processo.

Depois de formar-se ingressou como engenheiro na Diretoria de Obras Públicas do Município onde foi o responsável pela fiscalização das obras do Palácio da Justiça (Figura 1) e do edifício da Faculdade de Direito do Largo de São Francisco (figura 2).

\footnotetext{
${ }^{24}$ Burnham, palestra proferida na "Town Planning Conference", Londres, 1910 - apud Toledo, Benedito Lima: Prestes Maia e as Origens do Urbanismo moderno em são Paulo. São Paulo, Empresa das Artes, 1996.
} 


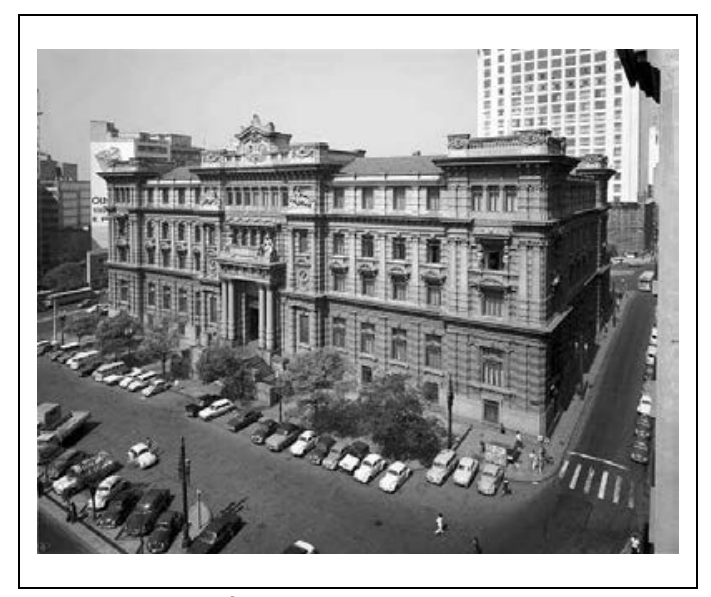

Figura 1: Palácio da Justiça ${ }^{25}$

O Palácio da Justiça, de autoria do arquiteto Ramos de Azevedo (1851-1928) teve sua pedra fundamental lançada em 1920, inspirado no Palácio da Justiça de Roma, foi uma das obras pioneiras no uso de estruturas metálicas com os acabamentos a cargo do Liceu de Artes e Ofícios. Já o edifício da Faculdade de Direito do Largo de São Francisco, de autoria do arquiteto português Ricardo Severo (1869-1940), foi iniciado em 1930, tem inspiração neocolonial e acabamentos também executados pelo do Liceu de Artes e Ofícios.

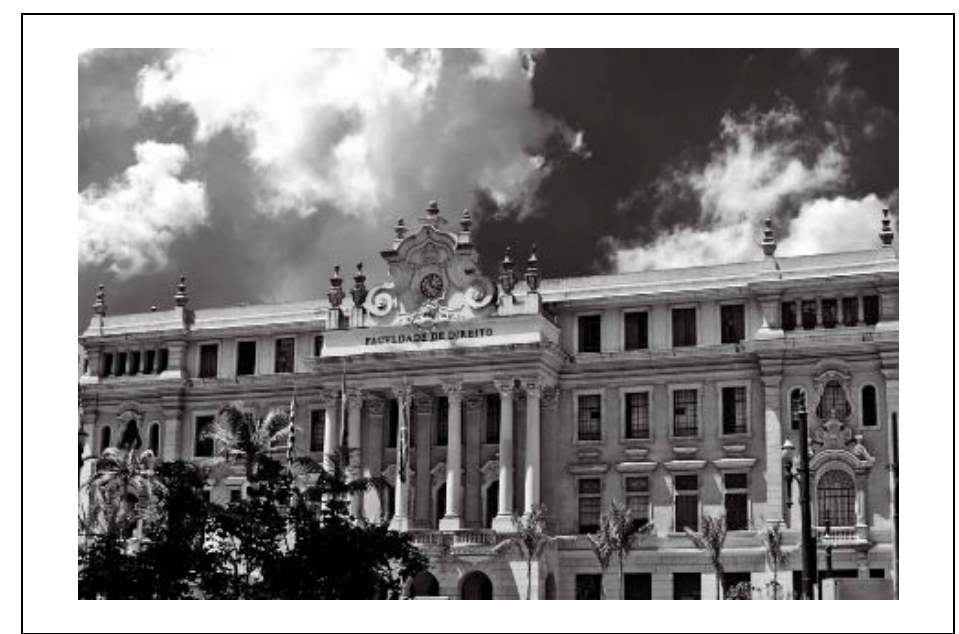

Figura 2: Faculdade de Direito do Largo São Francisco ${ }^{26}$

\footnotetext{
25 Fonte: http://imgs.obviousmag.org/archives/uploads/2006/2006032900_024.jpg 26 Fonte: http://edgblogs.s3.amazonaws.com/centroavante/files/201 1/02/Faculdade-de-Direitoda-USP.jpg
} 
Com a crise mundial de 1929 e a conseqüente queda dos preços do café, o sistema político brasileiro entra em colapso culminando na Revolução de 1930 que levaria Getúlio Vargas ao poder.

A Revolução de 1930, com seu caráter centralizador e a conseqüente perda da autonomia dos estados, a oligarquia paulista, que dominava o cenário político nacional, vê sua influência minada, fato que culminaria em São Paulo na Revolução de 1932. Vários engenheiros da Poli se alistam em favor da revolução, incluindo Mathias, que serve como major na Delegacia Técnica em Itatinga.

Na Era Vargas seriam lançadas as bases da metrópole que emergiria após a Segunda Guerra Mundial, os projetos visavam suceder a "etapa" agroexportadora, preparando os alicerces para o modelo industrial. Deste período destacam-se as obras do prefeito Francisco Prestes Maia (1938-1945), com seu Plano de Avenidas, seguindo sua filosofia expansionista, rodoviarista e verticalizadora (Campos, Candido Malta, pg. 396 - 2002).

Nos anos trinta, os grandes símbolos da cidade de São Paulo começaram a ser construídos (a maioria iniciada na gestão Fábio Prado): a abertura da Avenida Nove de Julho, a construção da Biblioteca Municipal Mário de Andrade, o novo Viaduto do Chá e o Estádio Municipal do Pacaembu.

Após a Revolução de 1932, Mathias se dedica à construção de casas de alto padrão para as famílias Bonfiglioli e Lunardelli, no jardim Bonfiglioli.

Em 1950 funda a Construtora Alfredo Mathias que desde seu início "dedicou-se à construção de grandes estruturas" (Entrevista de Fernando Mathias Mazzuquelli, sobrinho de Mathias, à Ricardo Pereira Leite). Na primeira fase executa obras adjacentes ao centro velho, em sua maioria por encomenda ou a preço de custo com projetos de diferentes arquitetos. De 1951 a 1956 os projetos são executados pelo arquiteto italiano Giancarlo Palanti. 
Giancarlo Palanti, 1906-1977(figura 3) nasceu em Milão onde forma-se arquiteto pelo Instituto Politécnico em 1929. Abre seu escritório em 1931 junto com Franco Albini e Renato Camus. Foi secretário de redação e redator da revista Domus entre 1932-1933, dirigida Gio Ponti; foi também redator da revista Casabella em 1934. Participa do grupo Ar de 1944-45, para o plano diretor para cidade de Milão, ligado ao CIAM.

Após o término da guerra o arquiteto vive um período de estagnação e desilusão. Diante deste quadro migra para o Brasil acompanhando sua noiva, Lily Maggi, que tinha parentes no país. Desembarca no porto de Santos em outubro de 1946 (Corato, 2008).

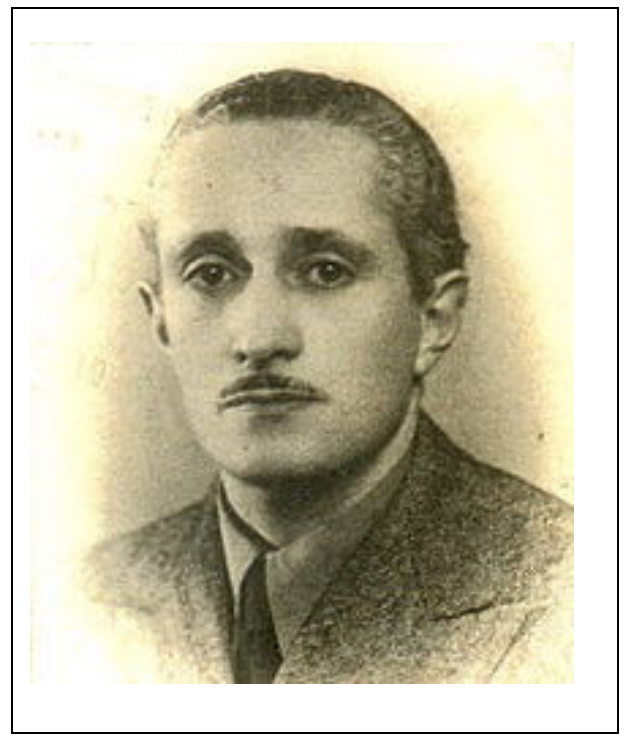

Figura 3: Giancarlo Palanti27

Em São Paulo trabalha junto à comunidade italiana e no início da década de 1950 desenvolve os projetos para a construtora Alfredo Mathias da qual foi diretor. São deste período a reforma do cine Jussara, os edifícios Chipre

27Fonte:http://†2.gstatic.com/images?q=tbn:ANd9GcQqw91in2XAA2X_011/YKI7hOiMSRfLX9ob63uw z61r6NPODeqi 
e Gibraltar e Cine Belas Artes (Avenida Paulista esquina com a Rua da Consolação) e o edifício Conde de Prates na Praça do Patriarca ${ }^{28}$.

Segundo Aline Coelho Sanchez Corato, o edifício Conde de Prates (figura 4) foi construído sob forma de incorporação e "seria o exemplo das novas táticas do mercado imobiliário da cidade", sua inauguração foi alardeada em vários anúncios publicitários e reportagens em revistas especializadas, tendo destaque o texto da revista Acrópole de agosto de 1956. São exaltadas as características do edifício e não foram poupados os adjetivos como "suntuoso e majestoso", destacando também o seu aspecto monumental.

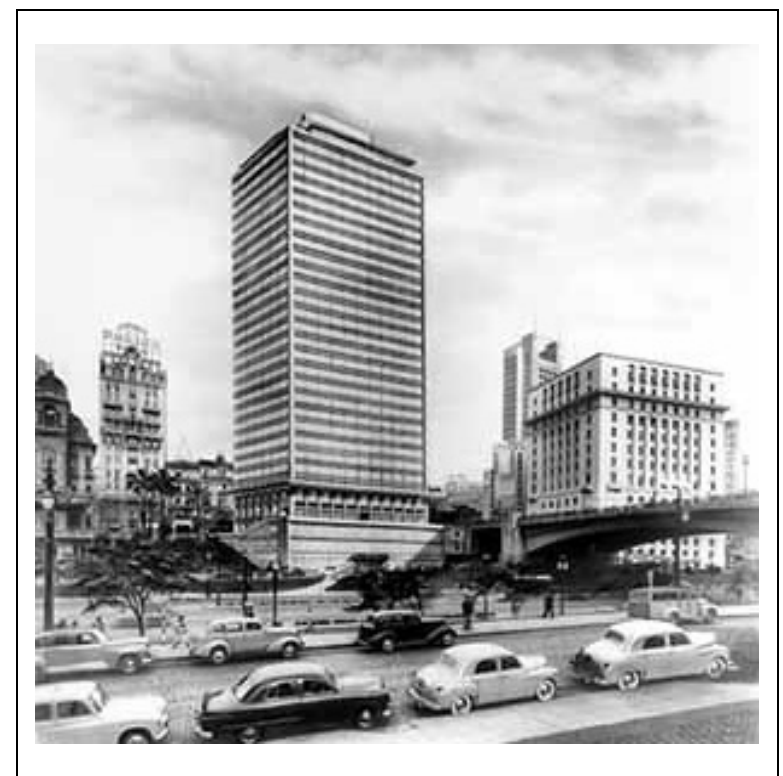

Figura 4: Edifício Conde de Prates ${ }^{29}$

Ainda sobre a autoria do edifício, segundo Manuel Rubio30, que fazia parte do corpo técnico da construtora na década de 1960 a concepção original do edifício é do próprio Mathias e posteriormente o projeto teve a colaboração de Palanti que executou o projeto das fachadas.

\footnotetext{
28 Mais adiante há uma lista de projetos executados por Palanti; a Biblioteca de Araras, os edifícios Chipre e Gibraltar, o Edifício Conde de Prates, entre outros.

29 Fonte: Arquivo GP / FAU - USP

30 Manuel Rubio foi projetista de arquitetura nas décadas de 1960 a 1970, sendo responsável pelo detalhamento do Portal do Morumbi, entre outros projetos.
} 
"Este edifício apresenta quatro fachadas envidraçadas e um núcleo central de circulação e serviços, capaz de liberar todo o perímetro do entorno para a divisão em salas comerciais. Destacase o desenvolvimento técnico mobilizado para a configuração da pele de vidro, com esquadrias sem parafusos ou rebites para os quais se usaram perfilados especiais com grande resistência à oxidação." (Corato, 2008)

Ainda, segundo Aline Corato:

"Ele coloca uma relação especial com a cidade ao acomodar-se ao desnível do sítio, estabelecendo um acesso pela parte baixa do Vale do Anhangabaú e outros dois interligados por uma galeria interna, que serve de hall ao edifício, abrindo-se para a Rua Líbero Badaró e para o Vale com acesso pelo viaduto do Chá; na altura destas entradas há uma esplanada que contorna todo o edifício..." (Corato, 2008)

À frente do departamento de projetos da construtora, Palanti desenvolve vários projetos cujos novos programas são impostos pela cidade como os grandes cinemas. Destaca-se o Cine Jussara, cujo detalhamento do forro resultou em um desenho especial; o Cine Jussara possuía 1400 lugares.

Outros projetos desenvolvidos para a construtora foram:

1) Edifício à Rua Barão de Tatuí, 351;

2) Edifício para a biblioteca de Araras (Biblioteca Martinico Prado);

3) Edifício à Rua Martiniano de Carvalho esquina com Rua Humaitá;

Deste período também merece destaque a construção do Hospital São Joaquim da Beneficência Portuguesa na Rua Maestro Cardin, 769, concluído em 1957, projeto dos arquitetos Hipolyto Pujol e Oscar Defilippi(Figura 5). 


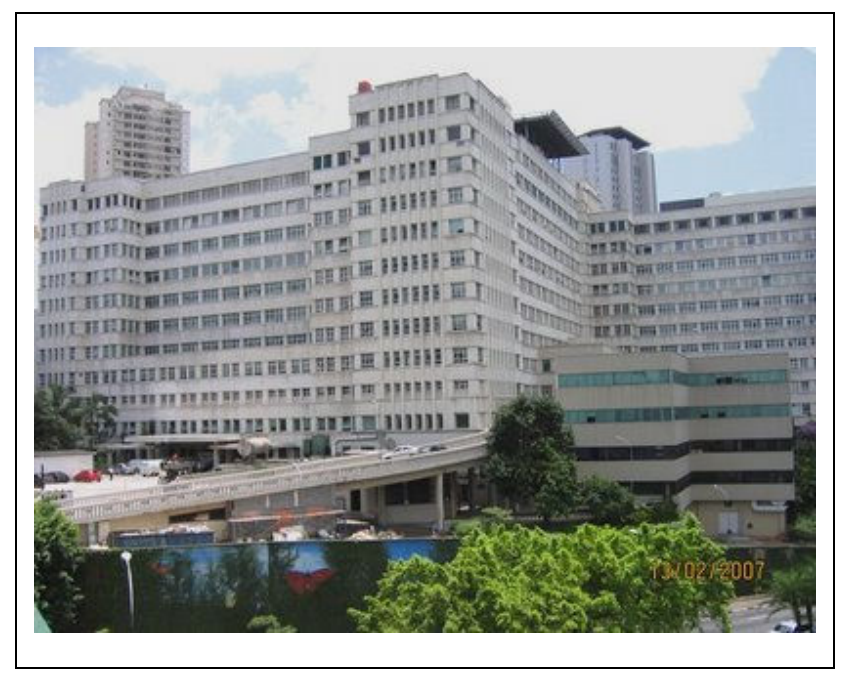

Figura 5: Hospital São Joaquim ${ }^{31}$

No final da década de 1950 a construtora inicia uma segunda fase onde se destacam os edifícios destinados a serviços e comércio, como é o caso das galerias do "Centro Novo" e os edifícios residenciais em bairros adjacentes, como Higienópolis e Avenida Paulista. A construtora se associa a membros das famílias Diederichsen, Dumont Villares, Citron, entre outras.

Desde o início da década de 1950 a cidade se reorganiza como uma cidade policêntrica, com subcentros estruturados em diferentes bairros como Pinheiros, Lapa, Santo Amaro e Brás. No mesmo período o Centro Novo era ocupado pelos cinemas, restaurantes e comercio de luxo (embora já demonstrassem sinais de se deslocar para a região da Avenida Paulista e Jardins). Com essa transferência, as elites dão um passo decisivo no processo de abandono do centro para o setor Sudoeste.

A produção imobiliária se intensifica com investimentos dos lucros da indústria, comércio e da exportação de produtos e o capital incorporador se consolidou como agente de produção do ambiente urbano. O número de plantas aprovadas na cidade cresce vertiginosamente: em 1940 a área

\footnotetext{
31 Fonte: http://2.bp.blogspot.com/UZXupTbP5oY/TWfaL6XS8j//AAAAAAAAAIs/8yLogMQP60U/s1600/HOSPITALBENEFICENCIA-PORTUGUESA-SP.jpg
} 
construída anual gira em torno de 1.600 m²; já na década de 1960 esse número sobe para $7.000 \mathrm{~m}^{2}$.

Os fundos previdenciários, as companhias de capitalização e as caixas econômicas expandem seus negócios e investem no empréstimo e financiamento de grandes edifícios, principalmente para a classe alta e em conjuntos populares e terrenos para as camadas populares. Nas zonas centrais há um aumento significativo de apartamentos tipo quitinete em edifícios que chegam a quase trinta pavimentos; estas construções tornaram-se um novo tipo de empreendimento que introduziram um novo tipo de programa e projeto: prédios residenciais com centenas de unidades, cujo térreo era destinado ao comércio ou serviços (Feldman, 2004 pg. 125)

Estes empreendimentos são marcados por múltiplas atividades: cinemas, comércio e restaurantes; que incorporaram galerias e ruas internas aos quarteirões. Localizavam-se principalmente no centro e em bairros adjacentes, embora também marcassem presença na Avenida Paulista.

De maneira geral se apropriaram da linguagem modernista, de grandes dimensões, implantados em terrenos liberados pelas demolições do Plano de Avenidas. É o caso do edifício Copan, na Avenida Ipiranga (figura 6); do Conjunto Metrópole, na Avenida São Luis; da Galeria Califórnia, na Rua Barão de Itapetininga (figura 7); dos edifícios São Vito e Mercúrio, juntos ao Mercado Municipal; do Edifício Paris-Roma-Rio, na bela Vista; do Edifício Radar, no Brás; do Edifício das Galerias Nações Unidas (figura 8) e do Conjunto Nacional (Figura 9), ambos na Avenida Paulista. 


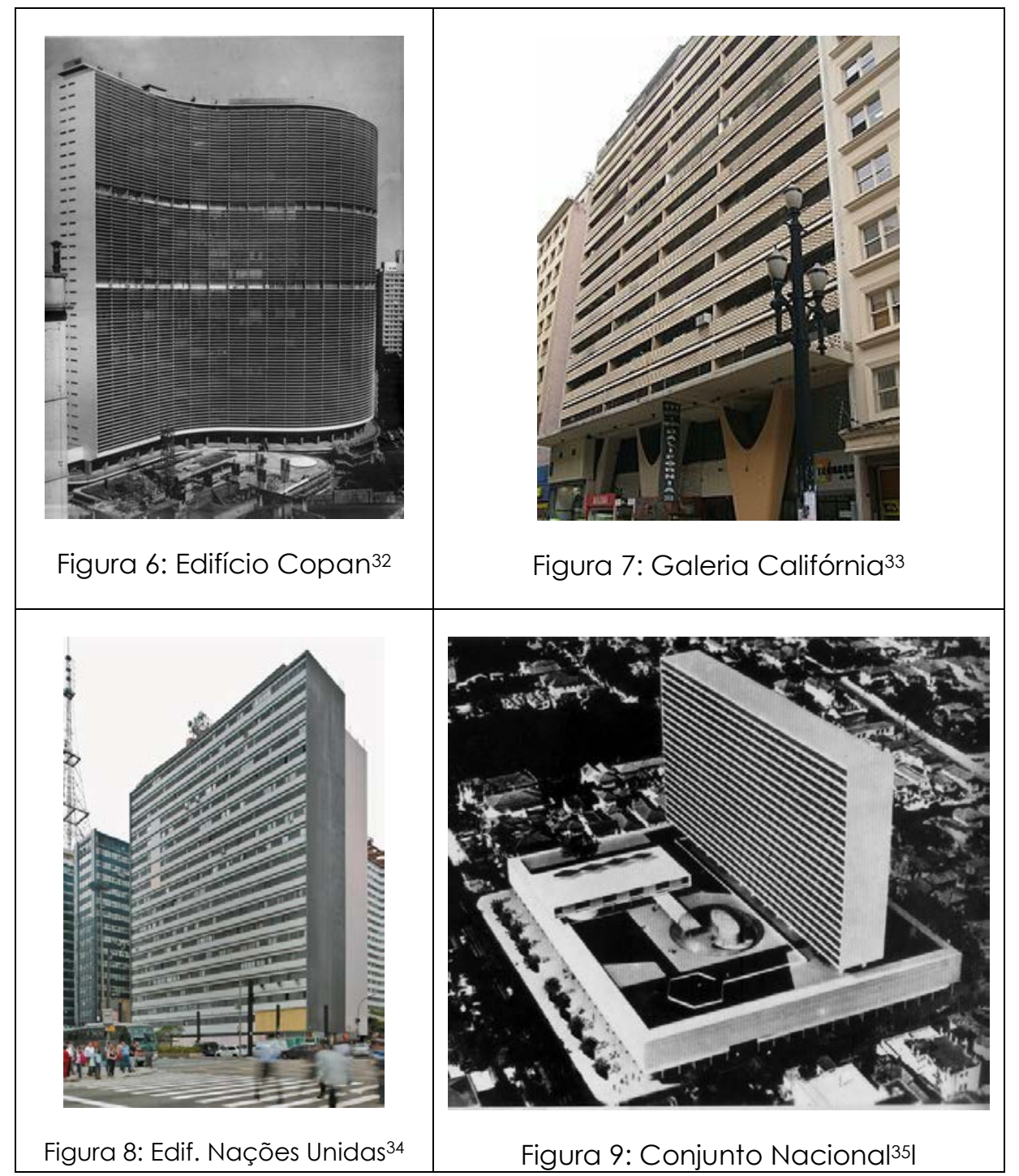

"A introdução da nova arquitetura no centro da cidade de São Paulo nem sempre tem dado aos arquitetos a oportunidade de um partido merecedor de registro (...). O preço dos terrenos e as condicionantes do código de Obras, interferem, impondo tanto o aproveitamento máximo, na área construída, quanto aos máximos de altura, recuos do corpo elevado, na frente e nas laterais, tudo informando e governando as possibilidades de concepção. Não se pode dizer que assim a arquitetura seja responsável única por um partido e pelos volumes que se exteriorizam, pela altura atingida". (Revista Habitat, pg. 17-22 - apud Corato, 2008)

\footnotetext{
32 Fonte: http://www.spmedica.com.br/copan.htm

${ }_{33}$ Fonte: http://pt.wikipedia.org/wiki/Edif\%C3\%ADcio_e_galeria_Calif\%C3\%B3rnia

34 Fonte: http://arquiteturaparalela.files.wordpress.com/2010/11/predio6.jpg

35 Fonte: http://culture-se.com/arquivos/News/images/Foto\%2002_\%
} 
Diante do novo panorama e da imposição dos novos programas a Construtora Alfredo Mathias inicia no último ano da década de 1950 a construção do Edifício e Galeria Sete de Abril - entre as ruas Sete de Abril 125 e Bráulio Gomes (figura 10).

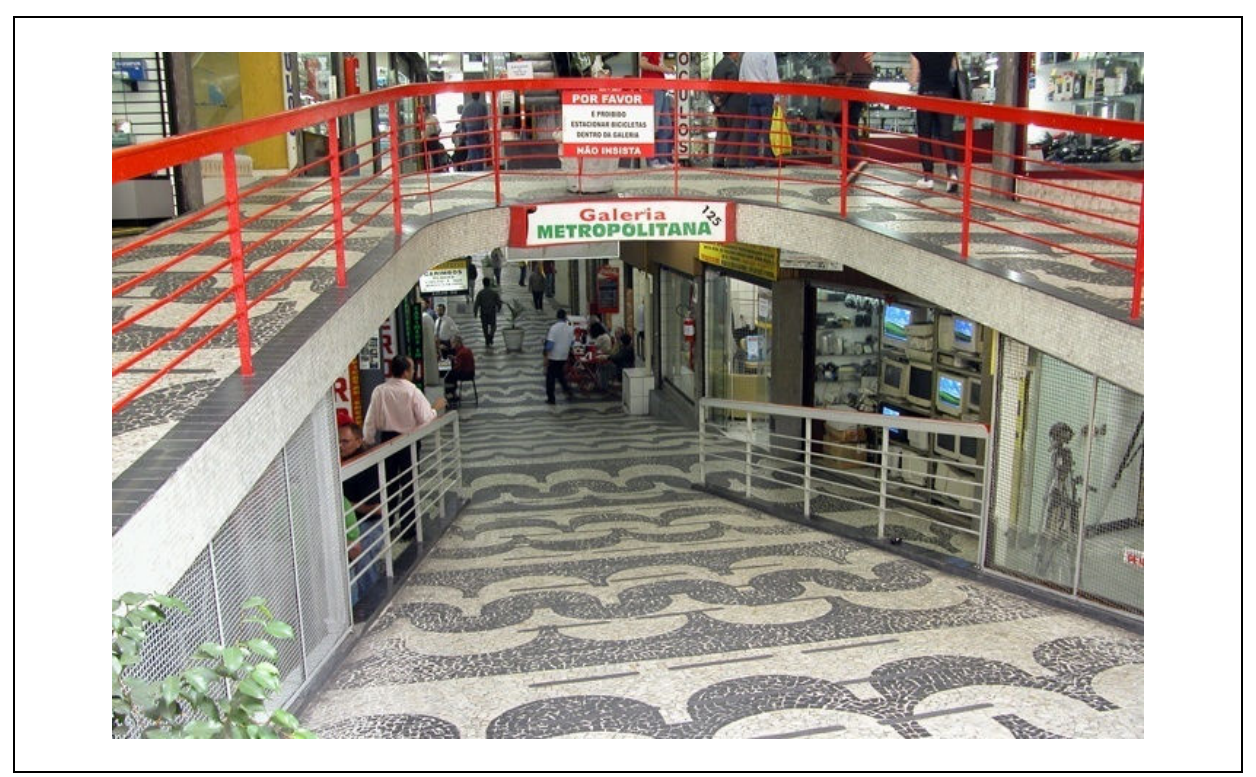

Figura 10: Galeria Sete de Abril - acesso pela Rua Bráulio Gomes ${ }^{36}$

Executado pelo Escritório de Arquitetura Siffredi \& Bardelli, o projeto é contemporâneo à Galeria Itapetinga ${ }^{37}$ e ao Edifício e Galeria Califórnia ${ }^{38}$ (1957 e 1955 respectivamente). Não se tratava de uma reforma dos térreos de edifícios existentes, como é o caso da Galeria Itapetininga e, embora utilizando elementos do tratamento dado por Niemeyer ao percurso da Galeria Califórnia, a Galeria Sete de Abril não dispunha de equipamentos voltados ao lazer (Aleixo, 2005).

\footnotetext{
36 Fonte: http://www.vitruvius.com.br/media/images/magazines/grid_12/4b65_07.galeria-7-de-abril.jpg

37 Rua Barão de Itapetininga, 267; projeto Escritório Severo Villares \& Cia

38 Rua Barão de Itapetininga, 255 com Rua Dom José de Barros; projeto Oscar Niemeyer
} 
A galeria foi concebida como elemento de ligação entre as ruas Sete de Abril e Bráulio Gomes o que evidencia sua vocação comercial. Seu espaço, como elemento de ligação é fluido, de fácil percepção, que nas palavras de Cynthia Aleixo:

"... a ligação entre as quadras permanece direta enquanto direção, mas cheia de variáveis em planta e em corte." (Aleixo, pg. 195, 2005).

O projeto tem uma planta simétrica com um eixo perpendicular às ruas Sete de Abril e Bráulio Gomes. Apresenta três níveis de galeria que somados ao mezanino correspondem em altura aos quatro pisos de escritórios. A circulação enfatiza a simetria da planta estando localizadas sobre este eixo as rampas e escadas rolantes que dão acesso aos diferentes níveis da galeria e aos corredores de circulação dos andares. O acesso à torre ocorre pelo meio do lote através de um bloco destinado aos elevadores/ caixa de escada (um em frente ao outro).

O bloco dos elevadores divide os andares de forma praticamente idêntica, as salas sofrem pequenas variações com relação às vias públicas. Cada andar possui dezesseis salas variando entre quinze e cinqüenta metros quadrados, a modulação dos pilares, embora visíveis nos andares, não aparecem nos pisos da galeria. A fachada apresenta uma estrutura coesa com os elementos côncavos da galeria, de onde a laje da sobreloja e as rampas do primeiro pavimento reforçam essa modulação.

Os pisos (Figura 11) receberam tratamento diferenciado: o primeiro, a 2,35 m abaixo do nível da calçada - galeria baixa - possui trinta e seis lojas com 15 metros quadrados e quatro maiores com 50 metros quadrados cada, localizadas nas extremidades junto às rampas. 


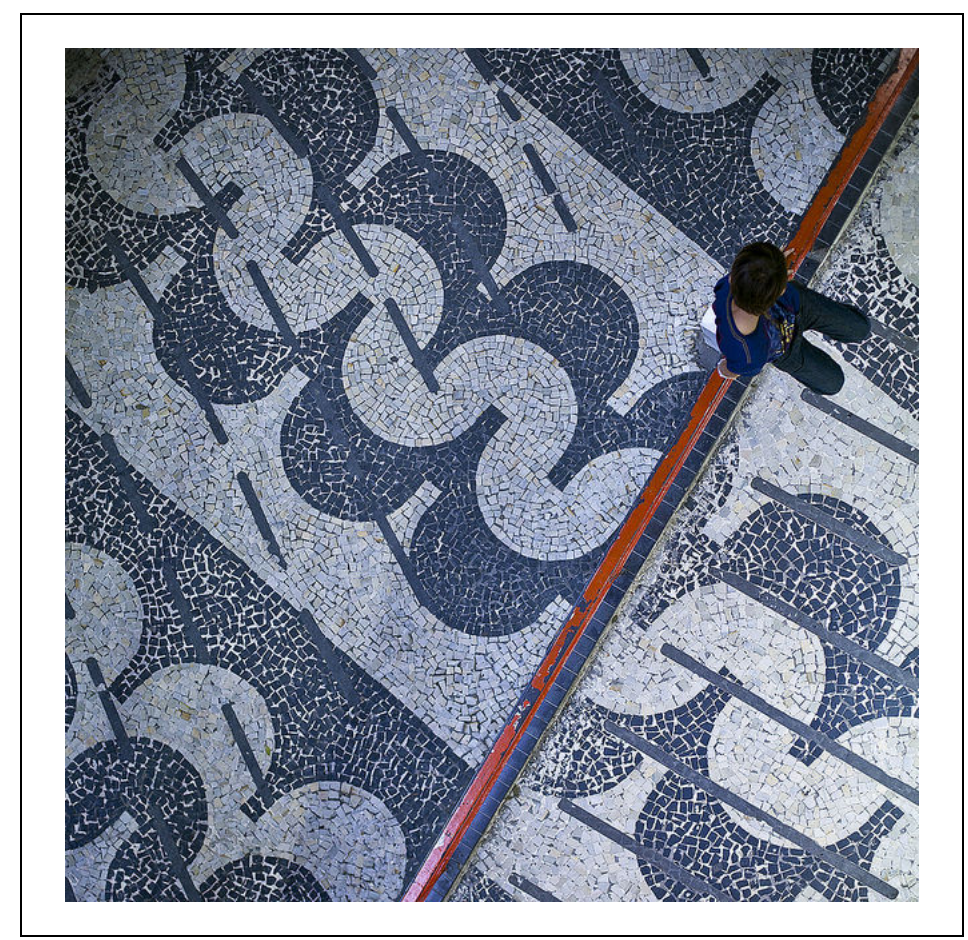

Figura 11: Galeria Sete de abril - pisos ${ }^{39}$

A galeria média, o segundo piso das lojas, acessível por meio das rampas laterais, ganhou mais quatro lojas resultando num total de quarenta lojas. As lojas deste pavimento, embora de dimensões modestas, ficaram com o espaço todo livre, pois os sanitários foram instalados no mezanino (as lojas que tiveram sua área reduzida devido ao alargamento necessário à implantação das rampas foram servidas por um conjunto de sanitários juntos à caixa da escada). A sobreloja mantém o desenho do piso inferior e são acessados por meio de escadas rolantes. Os recortes côncavos da laje avançando sobre as rampas, segundo Cynthia Aleixo:

"... construíram outro tipo de "espaços de estar", quase varandas para se apreciar a praça da biblioteca e suas árvores ou o movimentado vai e vem das pessoas pela sete de Abril (Aleixo, pg. 198, 2005)."

39 Fonte: http://farm6.staticflickr.com/5150/5596592455_fedf4088e6_z.jpg 
A simetria das plantas é evidenciada nas fachadas praticamente idênticas, não há diferenciação entre elas: o bloco compacto dos escritórios, com suas janelas contínuas, pairam sobre a área aberta da galeria. As lojas receberam fechamento com vidros e lambris de madeira e os pilares, quando visíveis foram revestidos com pastilhas cinza. O bloco dos escritórios foi revestido com pastilhas azuis claras e o forro, pintado de branco.

De se destacar os painéis cerâmicos produzidos pelo artista plástico italiano Buffoni, que retratam os elementos brasileiros e os desenhos do piso elaborados com mosaico português polido. Embora o projeto seja da autoria do Escritório de Arquitetura Siffredi \& Bardelli, é de se supor que o elemento de ligação entre a Construtora Alfredo Mathias e Buffoni tenha sido Palanti, que embora já afastado da construtora, mantinha contato com ambos.

A construção foi concluída em 1962 e marcou o inicio da parceria entre a construtora, o Escritório de Arquitetura Siffredi \& Bardelli e investidores como Jacob Lerner e Filip Citron. Parceria esta que rendeu os projetos de galerias: como o Centro Comercial Presidente, As Grandes Galerias e a Rua Nova Barão.

Lançados simultaneamente em 1962, o Centro Comercial Presidente e as Grandes Galerias tiveram todas as unidades vendidas em poucos dias, o que evidenciava a vivacidade da região. Ermanno Siffredi, responsável pelos projetos comenta em entrevista de 1992, sobre o sucesso deste tipo de empreendimento:

“... optou-se pela construção de prédios exclusivamente comerciais, pois o investimento era menor, o retorno mais rápido e face ao valor das lojas, o possivel ganho com outros espaços era desprezível. Soma-se a isso a perda de espaços de lojas que seriam necessárias para acesso e o maior volume da estrutura e o fato do encarecimento da própria estrutura." (Siffredi em entrevista a Fonseca, 1992 - apud Aleixo, pg. 2012, 2005). 
Nos anos 60 enfatiza-se a transferência das sedes dos bancos e grandes escritórios para a Avenida Paulista e região, o que diminuiu a procura de grandes escritórios no Centro Novo, diante desse quadro, afirma Aleixo:

"Os empreendedores voltaram-se para a produção de edifícios diferenciados, com a galeria não apenas interligando duas quadras como também ocupando diferentes andares. Dessa forma, a circulação vertical ganhou uma posição de destaque, interligando visualmente todo o conjunto - efeito proporcionado pelo recorte na laje que se repete em todos os andares. Os pátios internos de ventilação e iluminação foram substituídos por recuos na laje sem vedação e pelos rasgos entre os pisos permitindo a troca do ar com o interior e com o ambiente externo." (Aleixo, pg. 215, 2005)

O Centro Comercial Presidente (Figura 12), localiza-se na Rua Vinte e Quatro de Maio, 116 e faz interligação em "L" com a Rua Dom José de Barros. Diferente da Galeria Sete de Abril que possui uma estrutura bipartida em galeria e escritórios o centro comercial se apresenta de maneira diversa, não há mais divisão entre lojas e escritórios, o espaço se organiza através de diferentes níveis interligados por um grande vazio (porem a relação entre o térreo comercial e andares superiores para salas comerciais se manteve, embora não fosse mais refletido no tratamento arquitetônico diferenciado para esses espaços). 


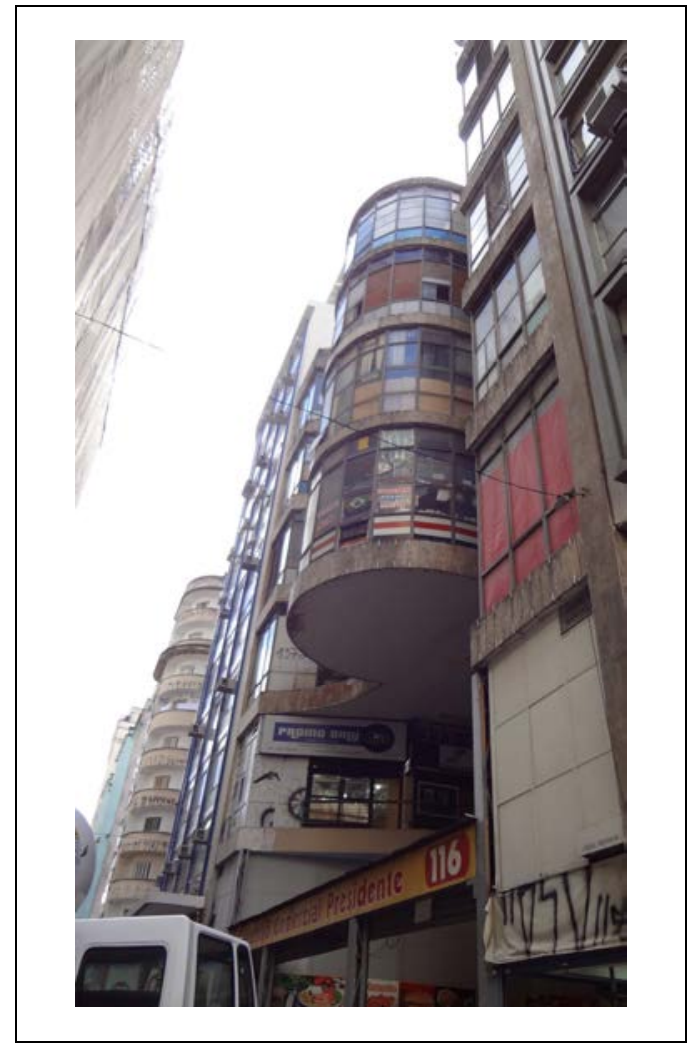

Figura 12: Centro Comercial Presidente 40

Semelhante ao Edifício da Galeria Sete de Abril, o edifício se desdobra em pisos a meio nível com o térreo e subsolo acessíveis pela Rua Vinte e Quatro de Maio através de rampas e os andares superiores através de escadas rolantes (os elevadores e escada estavam localizados no fundo do lote). A distribuição das lojas e salas comerciais seguiu o mesmo padrão de ocupação na parte periférica do lote, liberando o centro para a circulação. Nos últimos pavimentos foi criado um volume ovalado que avança em balanço sobre o passeio e cria um mirante para a paisagem.

Na face voltada a Rua Dom José de Barros abre-se um recorte em sua laje, onde novamente criam-se interessantes pontos vista e de estar revelando uma relação única entre o exterior e interior ressaltando pequenas frações da paisagem urbana;

40 Foto: Demósthenes Magno Santos - fev. - 2013 
"A delicadeza desses recortes anunciando fragmentos de luz, detalhes dos prédios vizinhos ou fatos cotidianos da vida das ruas centrais se contrapõe à rudeza da estrutura de concreto aparente, dramatizada ainda mais pelo pouco cuidado com os detalhes dos caixilhos, guarda-corpos ou com os acabamentos usados no edifício" (Aleixo, pg. 219, 2005).

Os pisos ficaram a cargo de Buffoni: no subsolo predomina uma cor clara e para o térreo uma cor mais escura sobre as quais o artista propõe a mesma solução de figuras geométricas desenhadas por peças negras.

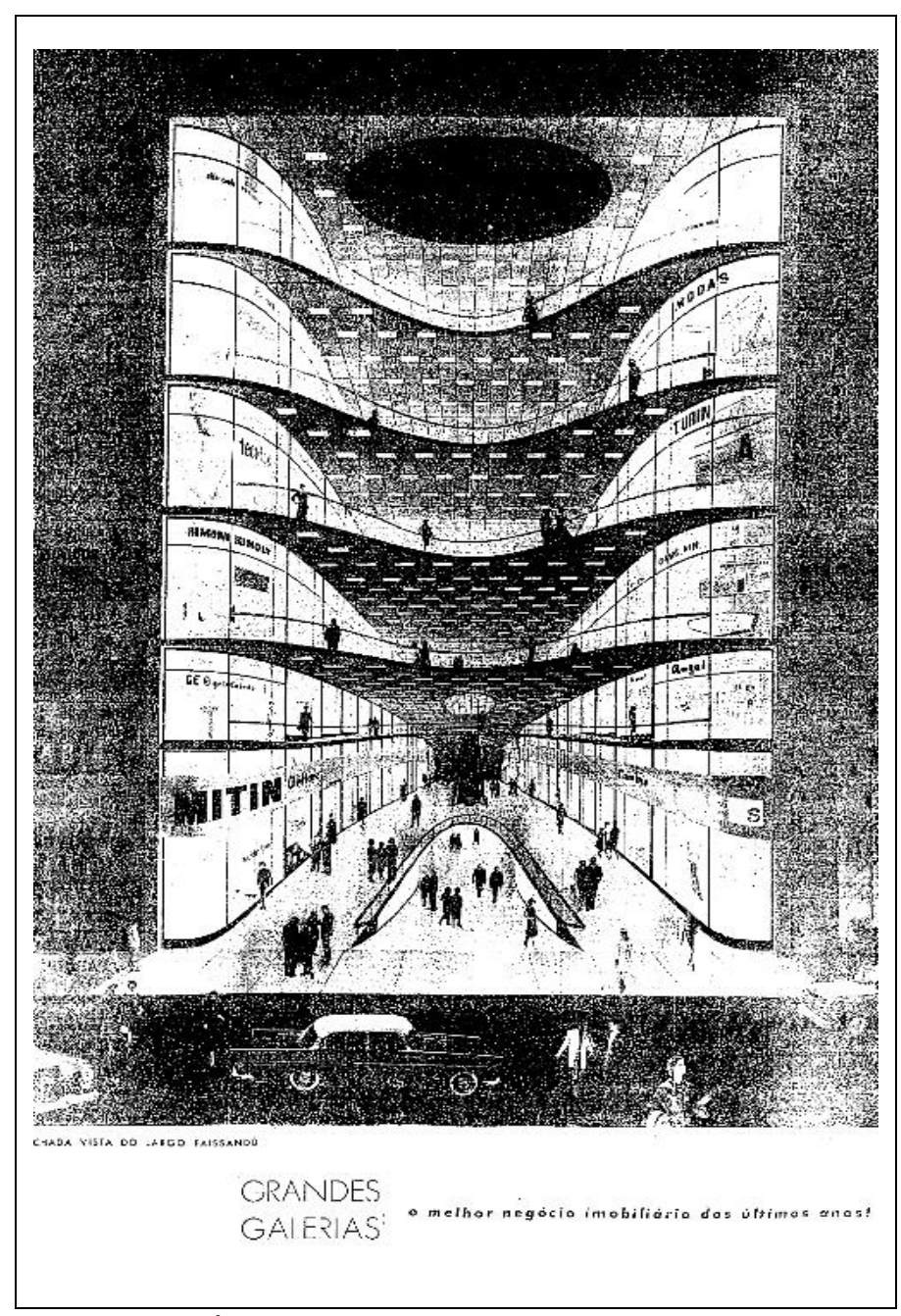

Figura 13: Edifício Grandes Galerias ${ }^{41}$ - perspectiva do lançamento

41 Fonte: http://blogs.estadao.com.br/reclames-do-estadao/files/201 1/06/1960.6.10-galeria-do-rock-paissandu2.jpg 
Lançada simultaneamente com o Centro Comercial Presidente, As Grandes Galerias (1962) - Rua Vinte e Quatro de Maio, 36 e Av. São João, 439 (Figura 13), difere substancialmente de sua "irmã" e vizinha que teve o seu tratamento arquitetônico simplificado.

De longe é o melhor projeto elaborado pela parceria da construtora e o Escritório de Arquitetura Siffredi \& Bardelli. Mais uma vez o partido adotado pelos arquitetos foi uma implantação linear, com as lojas e salas ocupando a periferia do lote e a área central destinada para circulação que organiza o espaço com um eixo na parte longitudinal do lote e espelha as lojas de forma quase simétrica. As fachadas são quase idênticas marcadas por solução homogênea com os andares reproduzindo a modulação dos espaços das lojas, porém a sensação espacial muda em cada andar devido à composição de cores e formatos dos pisos, vazios e mudança da posição das escadas rolantes que criam uma "atmosfera nova em cada andar".

A total ausência de marquises como elemento sinalizador de acesso é compensado pelo desenho sinuoso das lajes posicionadas sobre as entradas; na verdade, a delicadeza das curvas insinua e indica o caminho como um convite para visitar a galeria. Um olhar atento, segundo Cynthia Aleixo, evidencia que a laje do mezanino se diferencia dos demais pavimentos: os andares superiores possuem um desenho sinuoso com o fundo arredondado e o pavimento do mezanino é praticamente reto. A vedação das lojas e salas é em vidro com a parte superior em madeira que acompanha a sinuosidade das lajes:

"... Os tons da madeira e do vidro marcam a fachada e contrastam com a pintura alaranjada dos guarda-corpos. Completando sensação de movimento da fachada, as empenas das lajes receberam uma tina clara, quase branca, marcando definitivamente a sua sinuosidade na paisagem do Centro Novo." (Aleixo, 2005) 
O acesso à galeria pela Avenida São João (Figura 14) oferece duas opções: seguir pela rampa central para o piso do subsolo ou seguir pelas rampas laterais até a galeria térrea; no final das rampas, o recuo da laje do mezanino abre-se um pé direito duplo por onde se vê as escadas rolantes para o primeiro piso. O acesso pela Rua Vinte e Quatro de Maio vê-se as mesmas rampas e as mesmas soluções, os vão permanecem os mesmos e a solução do recuo da laje do mezanino, permite que desde a rua se visualize as escadas rolantes.

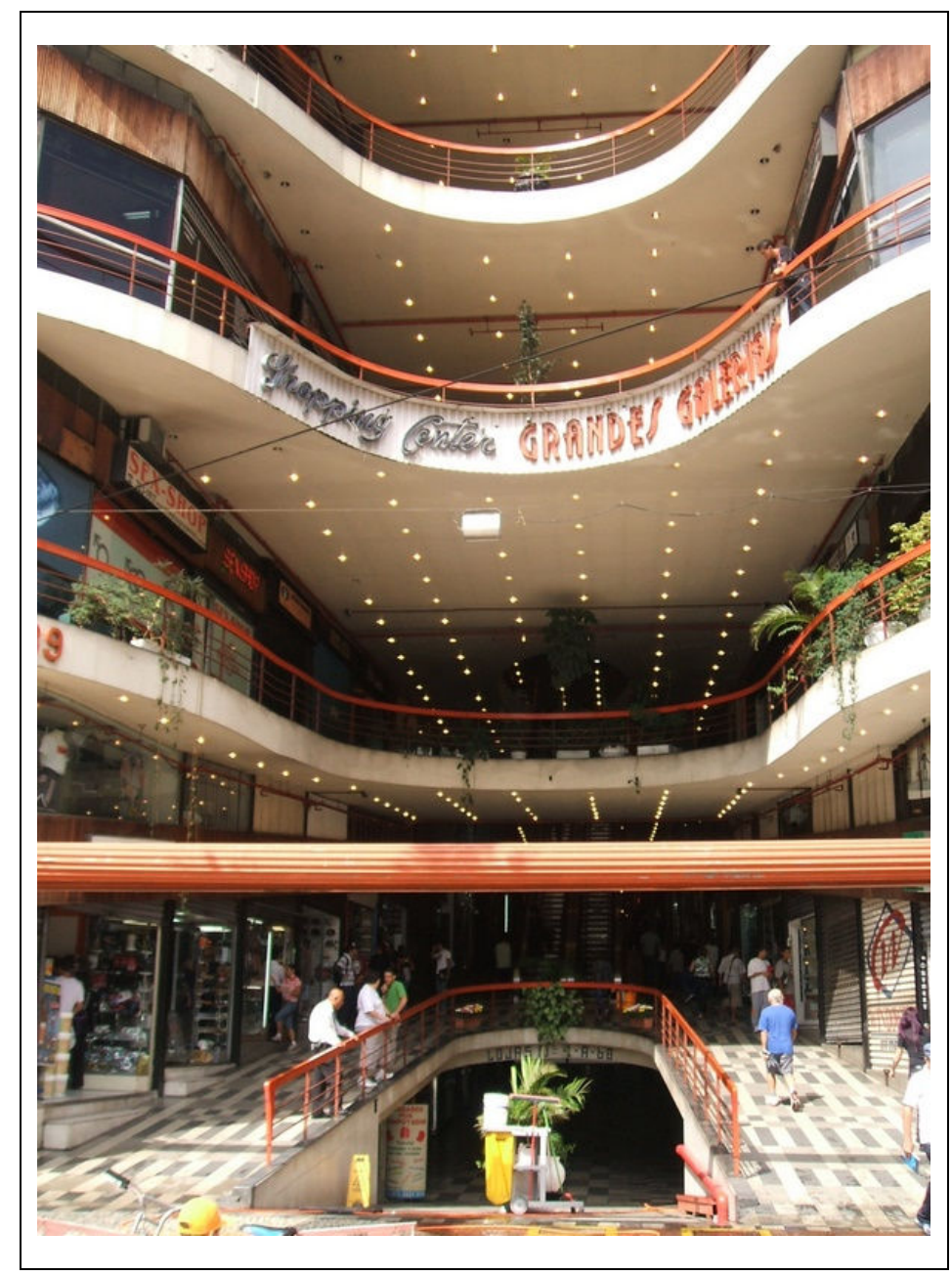

Figura 14: Rampas de acesso das Grandes Galerias ${ }^{42}$

42 Fonte: http://upload.wikimedia.org/wikipedia/commons/8/8f/Galeria_do_Rock _(Shopping_Center_Grandes_Galerias)_01.JPG 
Os pisos receberam aberturas ovais que ora recebem as escadas rolantes, ora permitem a integração visual entre os andares. Os desenhos dos pisos, elaborados por Bramante Buffoni, faz uso das pastilhas e peças cerâmicas nos tons cinza, marrom e róseo nas mais variadas paginações, que resultou em um efeito visual impressionante (Figura 15). Sobre os elevadores, Buffoni cria um painel cerâmico, onde retrata diferentes mulheres em tons negros em contraste com o colorido do fundo (na escada, os arquitetos criaram uma parada na altura do painel para sua visualização - Figura 16).

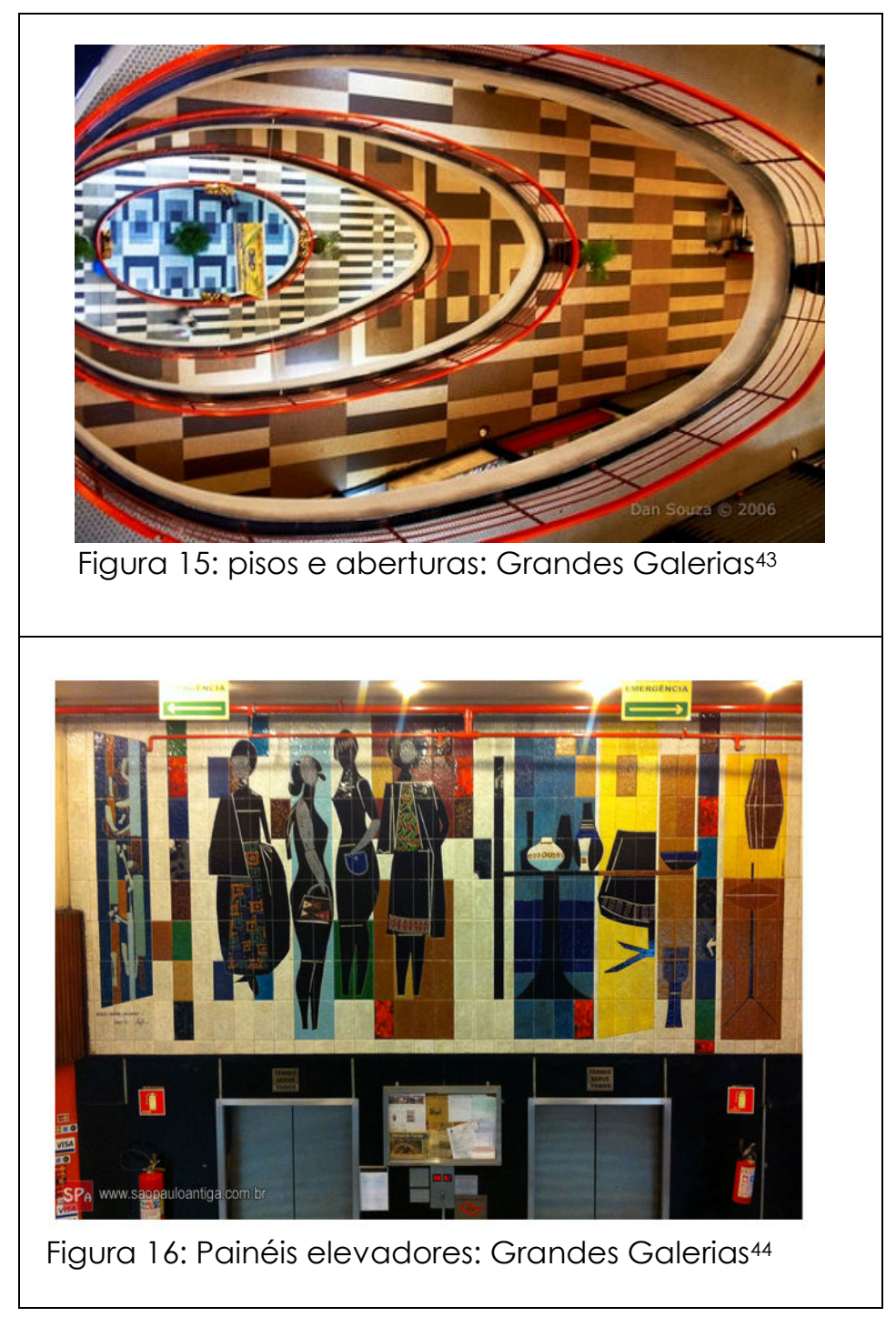

43 Fonte: $h t t p: / / o q u e v e m p o r a i . f i l e s . w o r d p r e s s . c o m / 2007 / 11 / g a l e r i a-d o-r o c k . j p g ? ~ w=474 \& h=310$ ${ }^{44}$ Fonte: http://www.saopauloantiga.com.br/wp-content/uploads/2011/1 1/outubro2k1 1.jpg 
Na cobertura, o terraço jardim, com os canteiros ao lado das coberturas zenitais recebem o último bloco onde funciona a parte administrativa do edifício.

No final de 1962 inicia-se a construção do último empreendimento com a parceria da construtora, do escritório Siffredi \& Bardelli e dos investidores (Benjamin Citron, Leon Leffer, Adolph Citron, Jacob Lerner entre outros) a Rua Nova Barão: projeto aprovado com oitenta lojas térreas, cinqüenta e quatro na sobreloja, três subsolos e mais de cem apartamentos de um e dois quatros e quitinetes (Figura 17). Os subsolos nunca foram executados, o que foi um prejuízo para o empreendimento, pois já se sentia a tendência do aumento dos veículos e a necessidade de espaço para estacionamento (Aleixo, pg. 220, 2005).

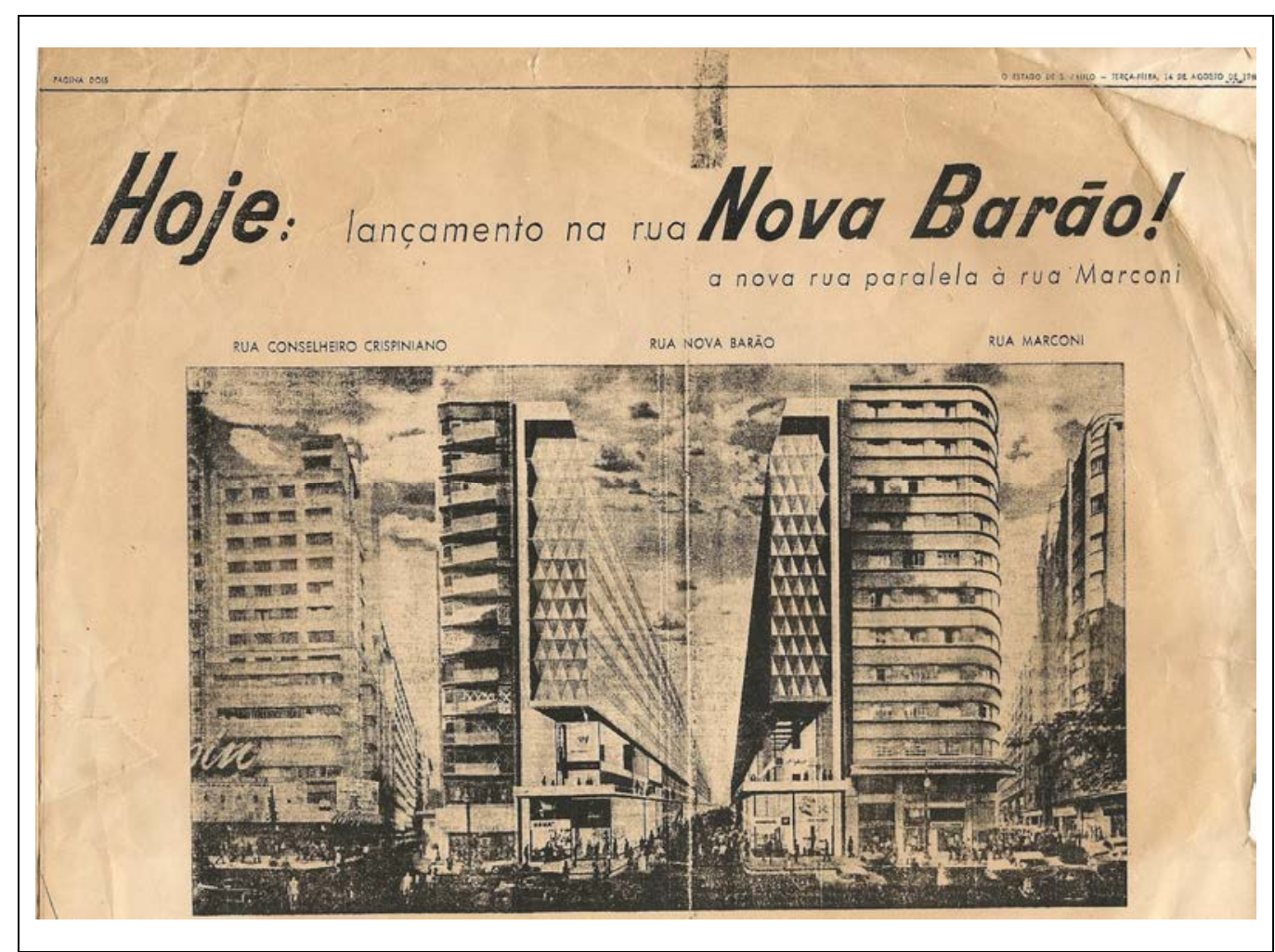

Figura 17: Lançamento da Galeria Rua Nova Barão45

45 Fonte: http://1.bp.blogspot.com/S6QXqzn_791/Tfungx0qHJI/AAAAAAAAAAY/XFWIreFtH7M/s1600/digitalizar0012.jpg 
Ainda na década de 1960 foram executados centros comerciais fora do Centro Novo, como o Centro Comercial Bom Retiro46 na Rua José Paulino com Rua Ribeiro de Lima, projeto de autoria do arquiteto polonês Lucjan Korngold e Gabriel Kauffnam, cuja particularidade foi a implantação no centro da quadra (Figura 18): as lojas ocupam a periferia do lote e na parte central uma torre de escritórios. O conjunto de maneira geral está em ótimo estado de conservação; sua linguagem é moderna com estrutura de concreto nervurado e as fachadas revestidas de cerâmica Gail (Figura 19). Outra galeria comercial do período, desta vez na região da Rua Vinte e Cinco de Março é a Galeria Pagé47.

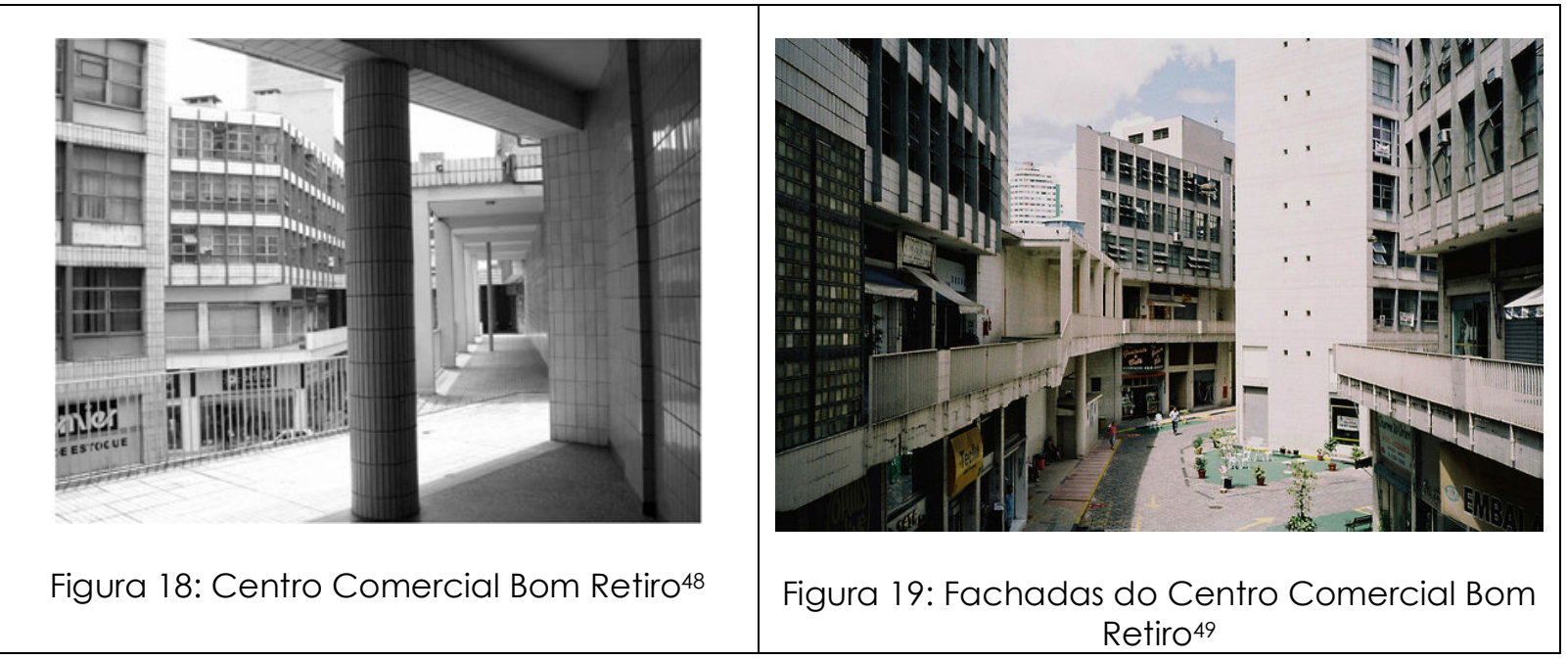

Em paralelo a construção das galerias a construtora lança vários edifícios residenciais como o edifício Princesa Isabel, Avenida São Luiz, 165; - Edifício Savoy, na Avenida Paulista, o Edifício Dória de Barros, na Avenida Angélica com Rua Dr. Veiga Filho; o edifício na Avenida Angélica com a Baronesa de Itu e o edifício após a Avenida Higienópolis com Angélica. Os edifícios com linguagem neoclássica foram elaborados pelo departamento

\footnotetext{
46 Quadra aberta:Uma tipologia urbana rara em São Paulo - texto de Abilio Guerra - Portal Vitruvius

47 Segundo Manuel Rubio, projetista da construtora nas décadas de 1960 a 1970

48 Fonte: http://media.timeout.com.br/contentFiles/image/saopaulo/01_AROUND_TOWN/events/2011/04 _oct_nov_dec/o-estrangeiro-na-cidade_ccjudaica/comercial-bom-retiro_arq-lucjan-korngold_gabriel-kaufman.jpg 49 Fonte: http://farm8.staticflickr.com/7055/6954060285_3b7ebb2741_z.jpg
} 
de projetos da própria construtora, sendo o autor das fachadas e áreas comuns o projetista Oswaldo Terreri.

Oswaldo Terreri (Figura 20) foi um profissional de carreira da construtora, que estudou no Liceu de Artes e Ofícios de São Paulo e era uma espécie de braço direito de Alfredo Mathias. Era responsável pela ponte entre estes projetos e os artesãos.

Os detalhes eram elaborados em papel Canson, geralmente na escala 1:1 ou com a ajuda de modelos. Terreri acompanhava também os processos de aprovação na prefeitura de São Paulo. Outra faceta deste profissional era o fato de se recusar a usar as "modernidades" para o desenho da época: escalímetros, gabaritos ou régua paralela. Desenhou a vida toda com régua "T", as medidas em qualquer escala eram feitas com uma régua escolar de trinta centímetros fazendo as conversões de cabeça. As fachadas neoclássicas eram elaboras com régua, escala e compasso, nunca usando algum tipo de gabarito. 


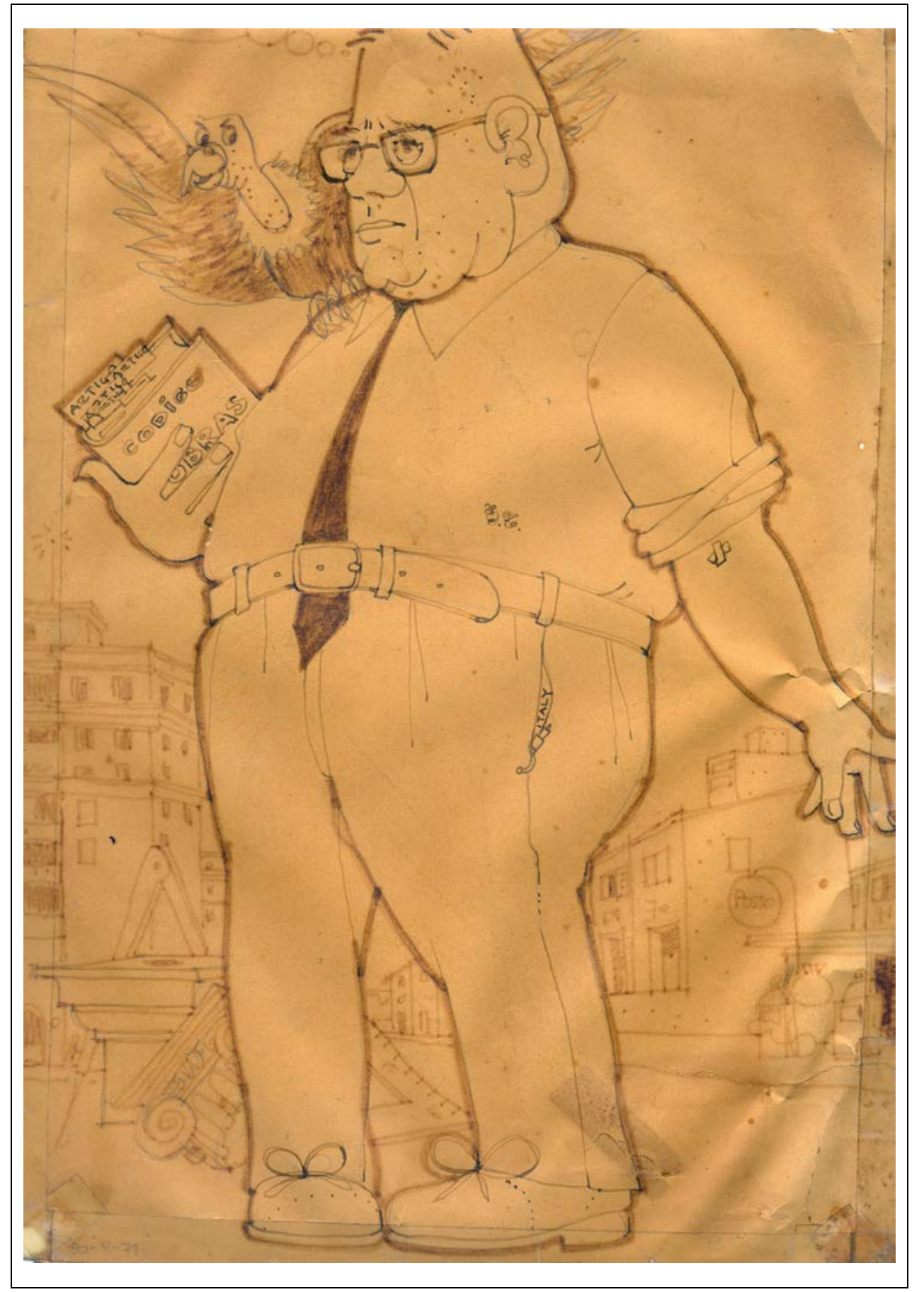

Figura 20: Osvaldo Terreri - caricatura elaborada por Juan Cabeza Sastre - 30-08-197150

50 Fonte: acervo Demósthenes Magno Santos 
De maneira geral, a opção da construtora era pela arquitetura moderna, seus térreos em pilotis com pé direito duplo, as empenas laterais cegas, as janelas corridas e o teto jardim. É caso dos edifícios Santa Odila e Santa Sofia (1962) na Avenida Higienópolis com Avenida Angélica (existe um terceiro edifício, o edifício Maria do Carmo51, na Avenida Angélica que completa o conjunto - Figuras 21 e 22).

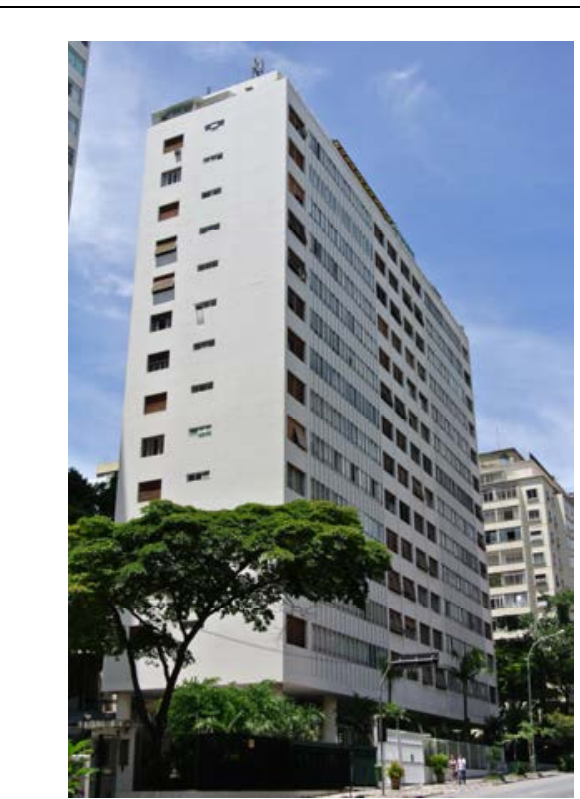

Figura 21: Ed. Sta Odila e Sta Sofia ${ }^{52}$

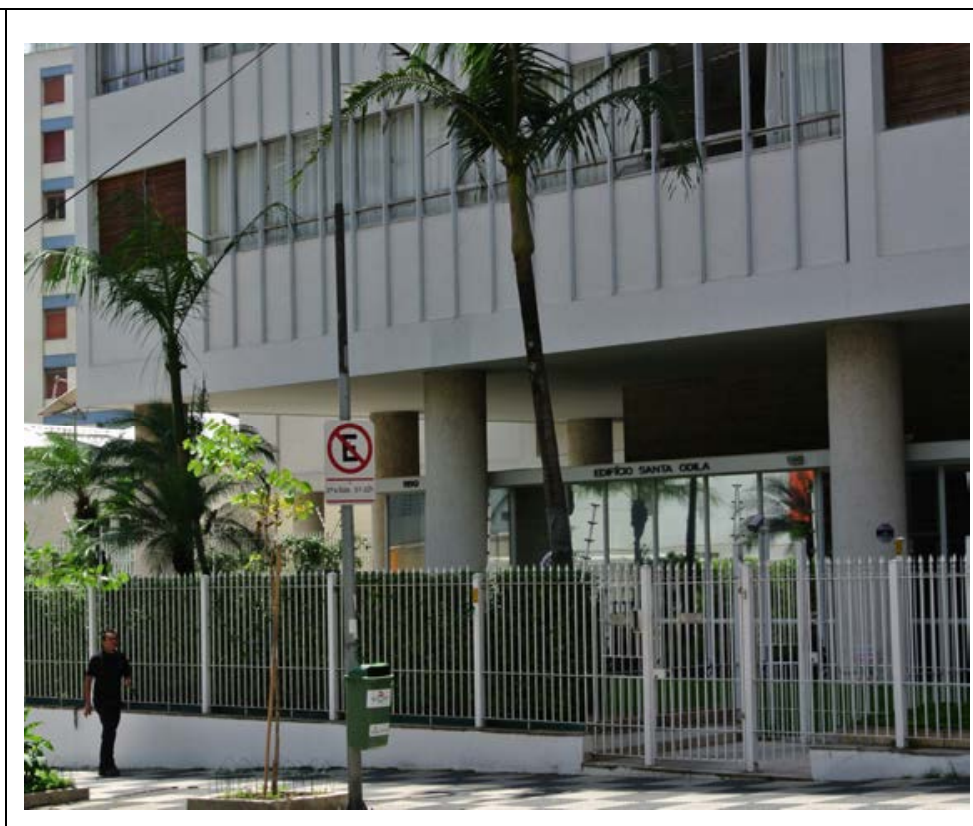

Figura 22: Ed. Sta Odila e Sta Sofia - detalhe ${ }^{53}$

No mesmo bairro, há edifícios em que ainda é necessária a confirmação de sua autoria, embora possuam a mesma linguagem dos citados Santa Odila e Santa Sofia: é o caso do edifício na Avenida Angélica com Rua Baronesa de Itu, o edifício na Avenida Angélica esquina com Rua Maranhão; o edifico na Rua Maranhão esquina com Rua Itacolomy.

\footnotetext{
${ }^{51}$ Estes edifícios receberam os nomes da mãe e irmãs de Alfredo Mathias: a mãe Sofia e das irmãs, Odila e Maria do Carmo

52 Fonte: Demósthenes Magno Santos - Fev. 2013

53 Fonte: Demósthenes Magno Santos - Fev. 2013
} 
Nos anos 60, Mathias fica sabendo de um empreendimento lançado no Rio de Janeiro que se titulava como o primeiro "Shopping Center do Brasil": o Shopping Center do Méier (1963), viabilizado pelo empreendedor Stanislaw Zaremba. Mathias entra em contato com Zaremba e o convidada para trabalhar na construtora.

Neste período, estava em desenvolvimento no terreno da Rua Iguatemi (futura Avenida Faria Lima) um conjunto de prédios residenciais cuja autoria era do escritório Crocce, Aflallo e Gasperini. Mathias resolve construir neste terreno o primeiro Shopping de São Paulo, o segundo do Brasil (mas definitivamente o primeiro naquelas dimensões): o Shopping-Center Iguatemi.

Zaremba convence Alfredo Mathias que arquiteto ideal para este empreendimento era o arquiteto carioca João Henrique da Rocha. Segundo Reinaldo Forner ${ }^{54}$ (que posteriormente viria a ser amigo do arquiteto João Henrique da Rocha), Mathias perguntou quem era este arquiteto e em resposta Zaremba afirma que era "simplesmente o arquiteto que ficou em segundo lugar no concurso de Brasilia". Mathias entra em contato com o arquiteto e solicita que este venha a uma reunião em São Paulo. Reunião esta que dura exatamente quatro horas, no final Mathias praticamente impõe que ele fique em São Paulo, deveria entrar em contato com a esposa no Rio de Janeiro e providenciasse a mudança imediata para São Paulo.

Nesse ínterim, solicitou o estudo de massas e implantação para o futuro shopping. Havia um impasse: o projeto em desenvolvimento pelo escritório Croce, Aflalo \& Gasperini, parceiro da construtora em outros empreendimentos. Tudo foi resolvido por um acordo de cavalheiros, onde o trabalho seria executado a quatro mãos, o que de fato foi feito, e assim nasceu o projeto do Shopping Center Iguatemi (Figura 23).

\footnotetext{
54 Reynaldo Forner fazia parte do corpo técnico da construtora, trabalhando junto com o arquiteto JoãoHenrique da Rocha no detalhamento do Centro Empresarial Lubeca
} 
"Inaugurado no final de 1966, o Iguatemi é o pioneiro entre os centros de compras de grande porte no Brasil. Em certo sentido, o sucesso comercial do empreendimento - considerado um dos metros quadrados mais caros do país - fortaleceu o vetor de crescimento urbano endinheirado em direção sudoeste da cidade" (Serapião, 2011)

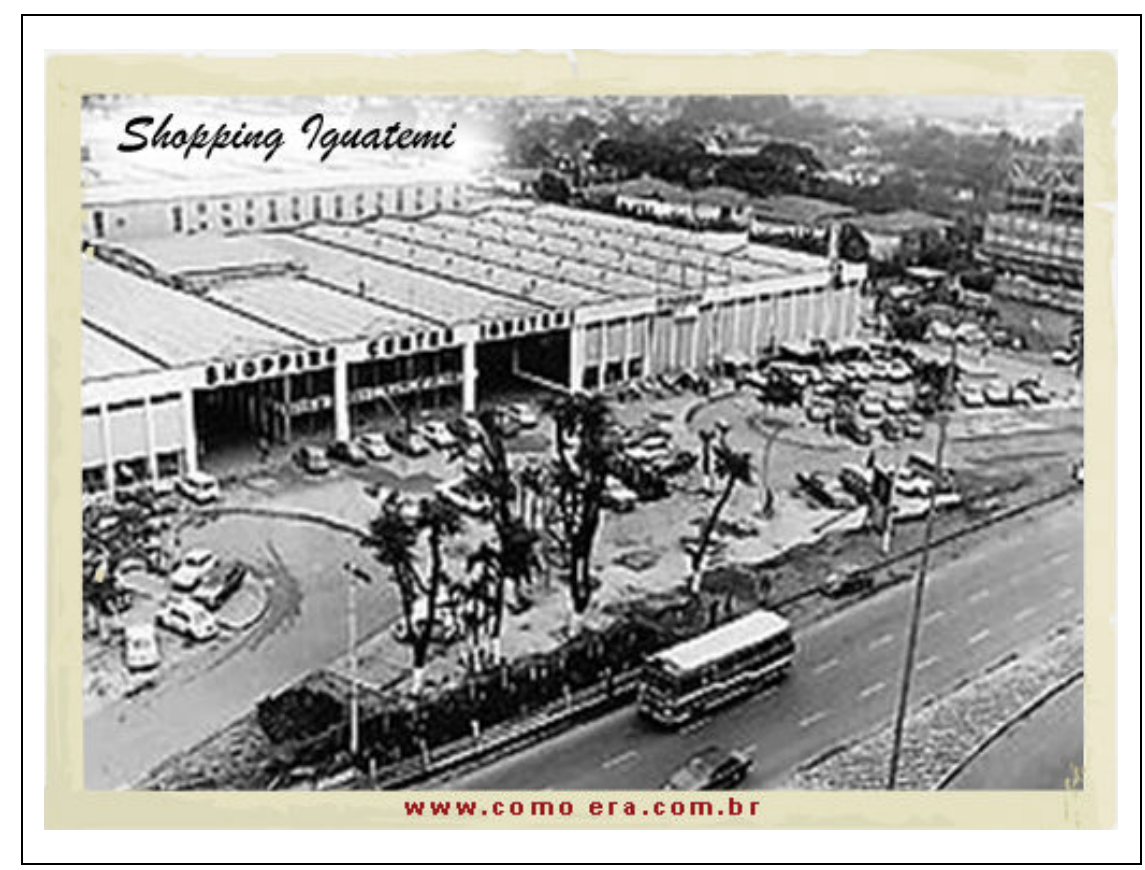

Figura 23: Shopping Iguatemi55

Mathias idealizou um novo sistema de financiamento para a obra por meio de cotas de participação. Citando Mazzuquelli, sobrinho de Mathias e funcionário da construtora, não foi fácil vender as 60.000 cotas e a construtora utilizou-as para pagar os fornecedores da obra, que se tornaram também proprietários da obra.

Reservou para si $10 \%$ do negócio, alem da taxa de administração da obra e, segundo Pereira Leite, o ativo mais valioso de todos: o direito de administrar o Shopping Center por um percentual nada desprezível das receitas

55 Fonte: http://www.comoera.com.br/wp-content/uploads/shopping-iguatemi-1966.jpg 
das lojas (direito esse que manteve por toda sua vida, após sua morte foi vendido pelo Espólio ao empresário Carlos Jereissati em 1980).

Inaugurado no final de 1966, com aproximadamente $35.000 \mathrm{~m}^{2}$, o projeto original surpreendeu pela originalidade, a fluidez das rampas que interligavam o shopping à rua, pelos grandes rasgos sobre o jardim central que permitiam a iluminação e ventilação fossem naturais criando uma atmosfera única. As fachadas propostas pelos arquitetos eram austeras, revestidas com pastilhas na cor creme e as bordas em pastilha branca. As fachadas foram totalmente descaracterizadas por inúmeras reformas e ampliações que fizeram o conjunto crescer dos $35.000 \mathrm{~m}^{2}$ para os atuais $130.000 \mathrm{~m}^{2}$ (Figura 24).

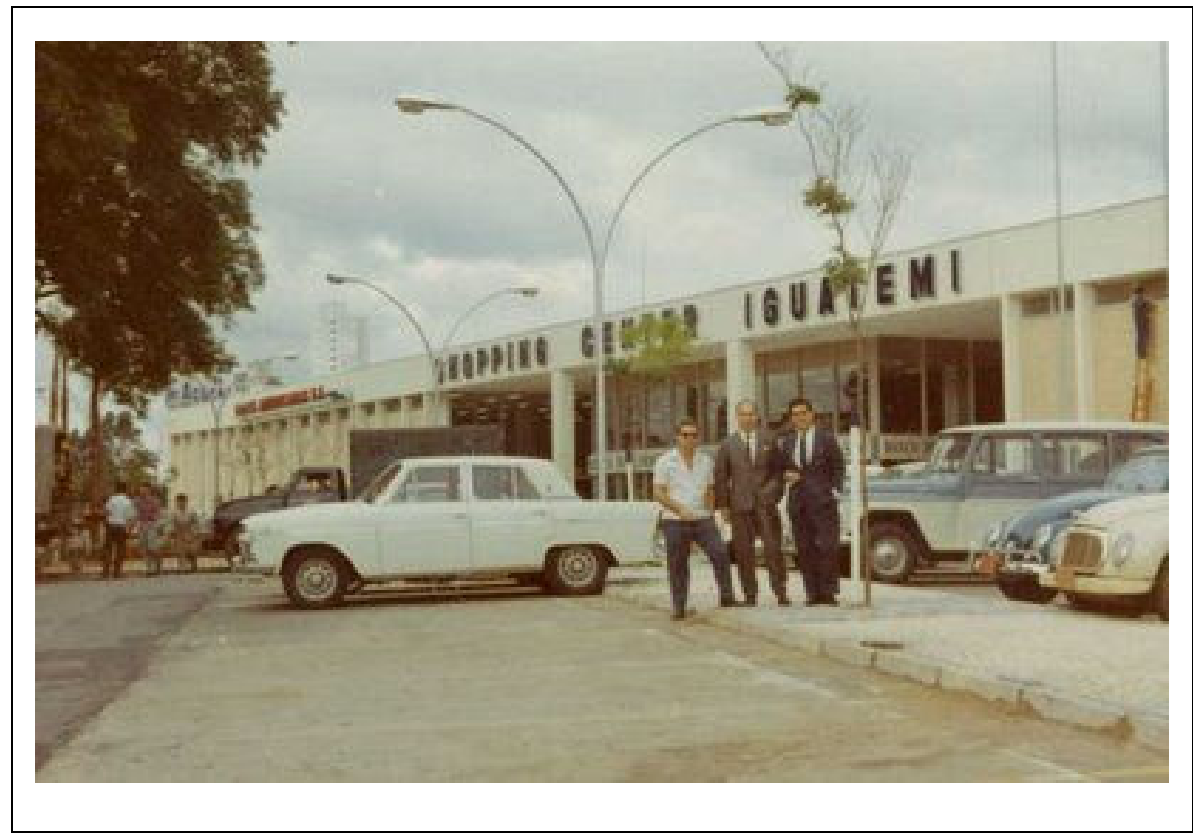

Figura 24: Fachada original do Shopping Iguatemi56

Junto ao shopping a construtora viabilizou a incorporação de quatro edifícios de alto padrão: os edifícios Monfort, Chatel, Avignon e Djon. Chama a atenção o pioneirismo do empreendimento: muitos apartamentos de alto padrão num único condomínio, como pela região, que na época era

56 Fonte: http://1.bp.blogspot.com/_AVRS4GKu2o/Sfn7a5a2EAl/AAAAAAAAB8E/7mMAxD8UBoY/ s400/Iguatemsaoplo.jpg 
predominantemente ocupada por casas, como também pela linguagem adotada, neoclássica, em contraste com as linhas modernas do shopping.

No bojo do sucesso do shopping a empresa realizou outros empreendimentos semelhantes: o Shopping Iguatemi de Salvador (1967), com 200 lojas e 37.000 m²; o Shopping Center da Lapa (1968) - inaugurado pelo prefeito Faria Lima, coml18 lojas; o Shopping Center Continental (1975) e o Shopping Center Iguatemi Campinas (1980), todos projetados pela parceria do arquiteto João Henrique da Rocha e a construtora.

Na década de 1960, a Construtora Alfredo Mathias também se dedicou a construção de obras públicas, das quais o maior destaque é o Palácio Anchieta para a Câmara dos Vereadores de São Paulo (Figura 25), construção de 1968, cujo estudo original era de Oscar Niemeyer( porem o projeto executado foi alterado pela construtora). Constrói várias escolas no interior do estado, tais como: EEPG Laurentina Silva em Santa Isabel; EEPG Água Vermelha em Poá; EEPG Vila Santa Tereza em Mogi das Cruzes.

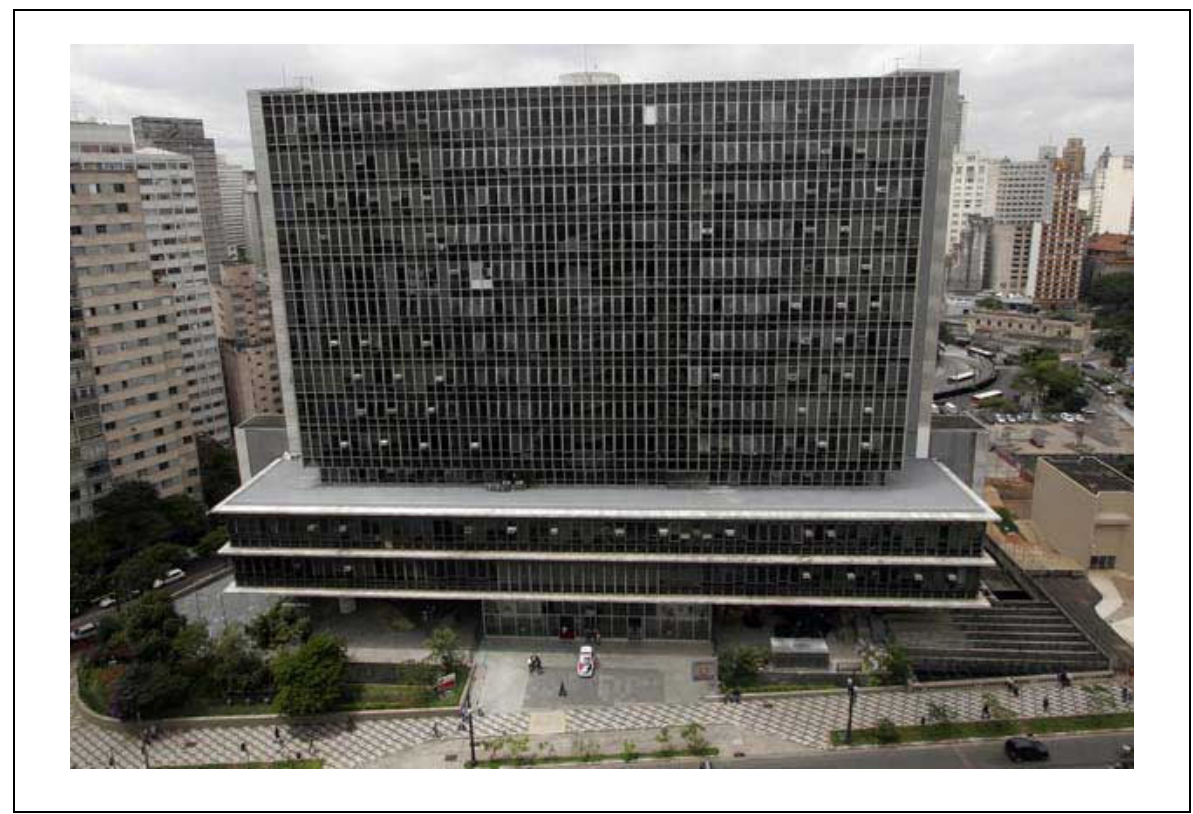

Figura 25: Palácio Anchieta - Câmara dos Vereadores de São Paulo57

57 Fonte: http://www.curiosando.com.br/wp-content/uploads/201 1/06/Camara-Municipal.jpg 
Constrói conjuntos habitacionais populares para o INOCOOP58 e CECAP59: - INOCOOP de Taboão da Serra, 372 unidades; O INOCOOP de Ermelino Matarazzo, 432 unidades; O INOCOOP Bandeirantes, em Mogi da Cruzes, 432 unidades; O CECAP Cruzeiro, 800 unidades e o CECAP Jacareí com 70 unidades.

No início da década de 1970, a construtora incorpora o sistema de vendas por financiamento pelo sistema de crédito para habitação popular, ou seja, o BNH. O primeiro empreendimento que utiliza o sistema de financiamento, somente para venda, foi o edifício na Avenida Enrique Schaumann, a partir deste empreendimento diversos edifícios foram lançados e financiados pelo $\mathrm{BNH}$ :

- O edifício Peixoto Gomide - Rua Peixoto Gomide, 1.689 - 48 unidades;

- O edifício Tietê - Alameda Tietê - 40 unidades;

- O edifício Toulouse - Rua Lisboa, 212 - unidades;

- O edifício Bordeaux - Rua Monte alegre, 892 - 32 unidades;

- O edifício Wimbledon Park - alto da Boa Vista - 68 unidades;

- Esplanada Granja Julieta - conjunto com quatro torres, $36.000 \mathrm{~m}^{2}-240$ unidades - Rua João Carlos da Silva Borges Granja Julieta;

- Edifícios na Rua da Mata, Itaim (1971 e 1972)

- Edifício Gaivota - Guarujá;

- Edifício Caravela - Guarujá 
Estes edifícios correspondentes a "fase BNH" da construtora foram executados em lotes urbanos convencionais pela equipe técnica da construtora onde, em períodos variados, passaram os arquitetos Sérgio Pillegi, Danilo Guido Bassani, o próprio João Henrique da Rocha e o arquiteto João Veiga. Também faziam parte do corpo técnico os seguintes profissionais: Juan Cabeza Sastre, gerente de projetos e responsável pelas perspectivas realizadas normalmente à guache ou à bico de pena. Juan era espanhol e começou muito cedo a trabalhar na construtora, porem antes foi aprendiz, aliás, o único aprendiz, do pintor Mik Carniccelli, que foi considerado nos anos quarenta e cinqüenta o Cézanne brasileiro. Também fizeram parte do corpo técnico os projetistas Reynaldo Forner, Manuel José Nicieza Rubio, que foram responsáveis pelos detalhamentos do Portal do Morumbi e Centro Empresarial Lubeca.

Nos anos setenta a construtora realizou obras de vulto para terceiros, mas sem dúvida, a de maior envergadura foi o Centro Empresarial Lubeca (Figura 26), hoje Centro Empresarial de São Paulo, projeto de João Henrique da Rocha.

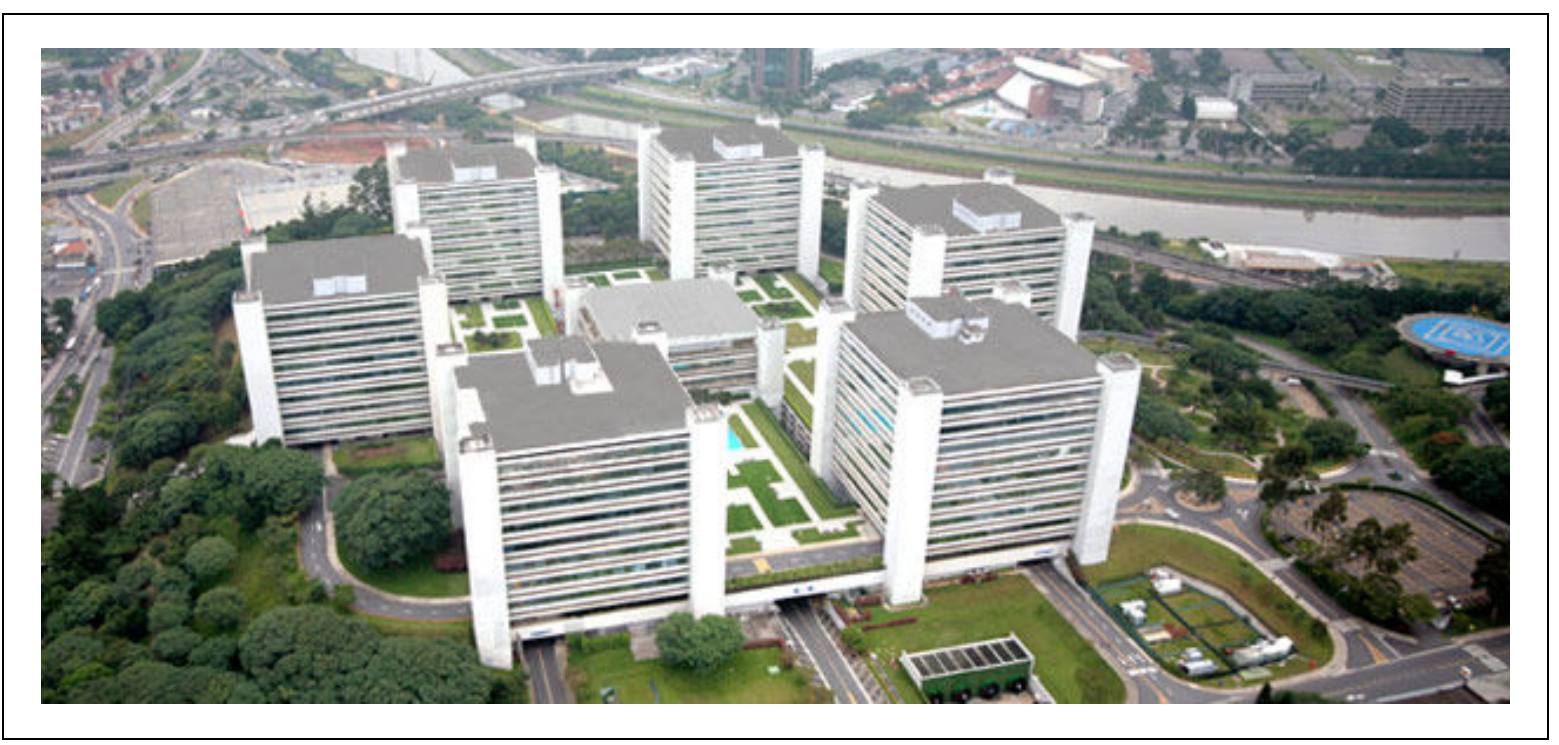

Figura 26: Centro Empresarial Lubeca60

60 Fonte: http://www.centroempresarial.com.br/imagens/secoes/como-chegar/localizacao.jpg 
Projeto de 1974, na época o maior complexo de escritórios da América Latina, localizado na Marginal do Rio Pinheiros. O projeto tem área construída de aproximadamente 410 mil metros quadrados implantados em um terreno de 23 hectares (a área útil dos andares de $2800 \mathrm{~m}^{2}$ ).

O projeto foi implantado sobre um morro que se debruça sobre a Marginal do Rio Pinheiros, possui seis torres de escritórios, um centro de eventos e um shopping com aproximadamente 110 lojas, centro médico, nove agências bancarias, oficina mecânica, heliponto e 4500 vagas para estacionamento. Para a construção deste empreendimento - e também do Portal do Morumbi, Mathias importou da Alemanha o sistema, então pioneiro, de formas metálicas deslizantes.

A implantação impressiona: sobre uma esplanada estão assentadas as seis torres de escritórios; o acesso, o shopping e os serviços foram posicionados no subsolo, liberando a praça para o paisagismo destacando as fachadas das torres (Figura 27) com suas janelas corridas e nas esquinas as prumadas dos sanitários.

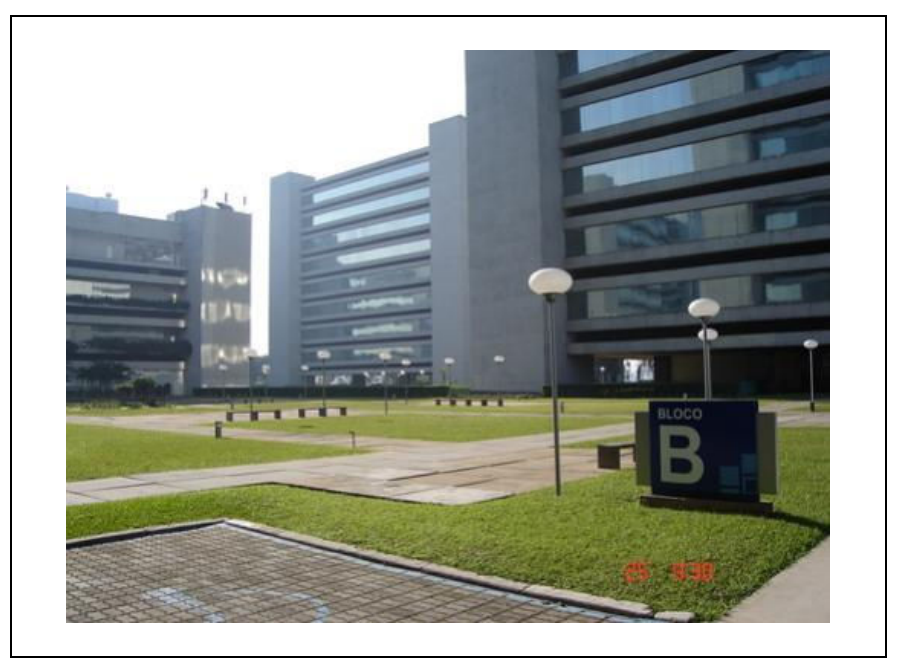

Figura 27: Centro Empresarial Lubeca - Esplanada61

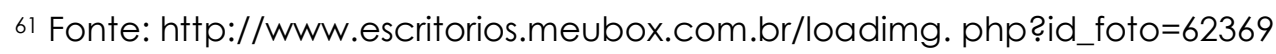


Outro edifício realizado por encomenda pela construtora foi o edifício para o Banco do Brasil em Santo André com 7500 m²; agências para a Caixa Econômica Federal e a torre-laboratório dos Elevadores Atlas-Villares, com 70 m de altura e $10.000 \mathrm{~m}^{2}$ de construção.

Em 1973, Mathias adquire o terreno que viria ser sua maior obra: o Portal do Morumbi (Figura 28). Projeto de João Henrique da Rocha, com 800 apartamentos de alto padrão variando de 180 a $250 \mathrm{~m}^{2}$, distribuídos em dezesseis torres de 25 andares, clube e shopping de apoio. $O$ projeto das torres tem os pilares expostos na fachada, o que liberou o programa do andar tipo com suas janelas corridas e peitoris baixos proporcionando a integração com mata existente.

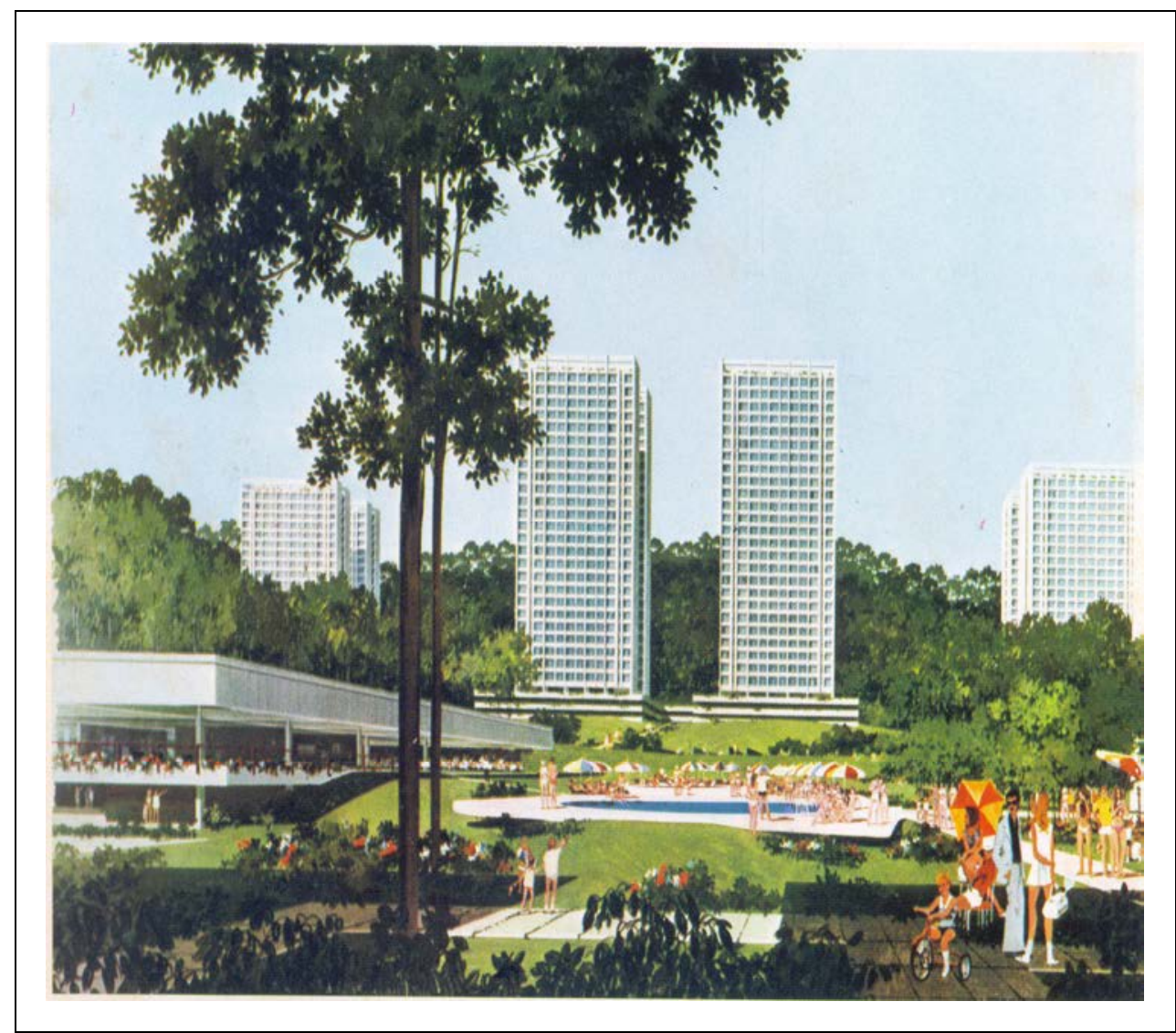

Figura 28: Perspectiva do Portal do Morumbi, Juan Cabeza Sastre, 197462

62 Fonte: prospecto de vendas: acervo Demósthenes Magno Santos 
A comercialização foi anunciada de forma bombástica a partir de $1^{\circ}$ de maio de 1974 com publicidade na Rede Globo de Televisão e em mais três postos de vendas- só o estande do Portal do Morumbi possuía 600 m².

Segundo Pereira Leite, as vendas começaram razoavelmente bem, mas ficaram mais difíceis depois do primeiro aumento de preços e pela suspensão dos financiamentos para imóveis novos (Figura 29).

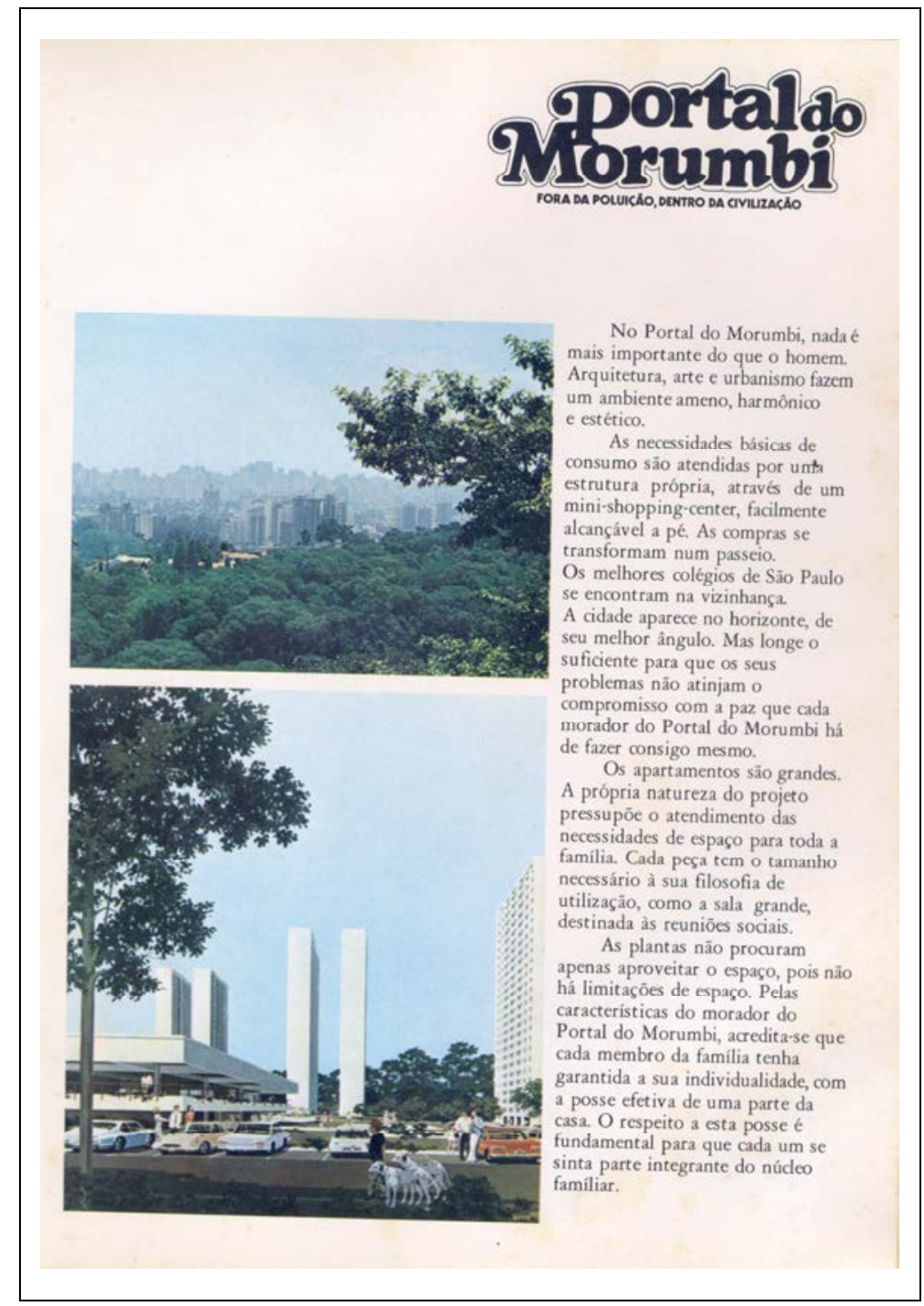

Figura 29: pagina 5 do prospecto de vendas do Portal do Morumbi63

63 Fonte: prospecto de vendas: acervo Demósthenes Magno Santos 
“... Para contornar o problema, Mathias entabulou um sistema em que os compradores poderiam dar seus apartamentos usados como entrada, pensando em revendê-los, oferecendo financiamento bancário e embolsando o dinheiro à vista. Ocorreu que em seguida, os agentes do crédito imobiliário também suspenderam para imóveis usados. (Pereira Leite, 2006).

Mais uma vez, Mathias propôs outro sistema, que foi denominado "Sistema Fácil" (Figura30), em que os compradores poderiam fazer "uma poupança" que poderia ser paga em três parcelas anuais e fixas. A idéia era que o sistema alavancasse as vendas, o que de fato ocorreu, permitindo a constituição de uma carteira de títulos que seriam descontados à vista no mercado financeiro que proporcionaria a criação do caixa necessário. Dada a situação econômica do país veio uma norma do Banco Central que proibia o desconto deste tipo de título.

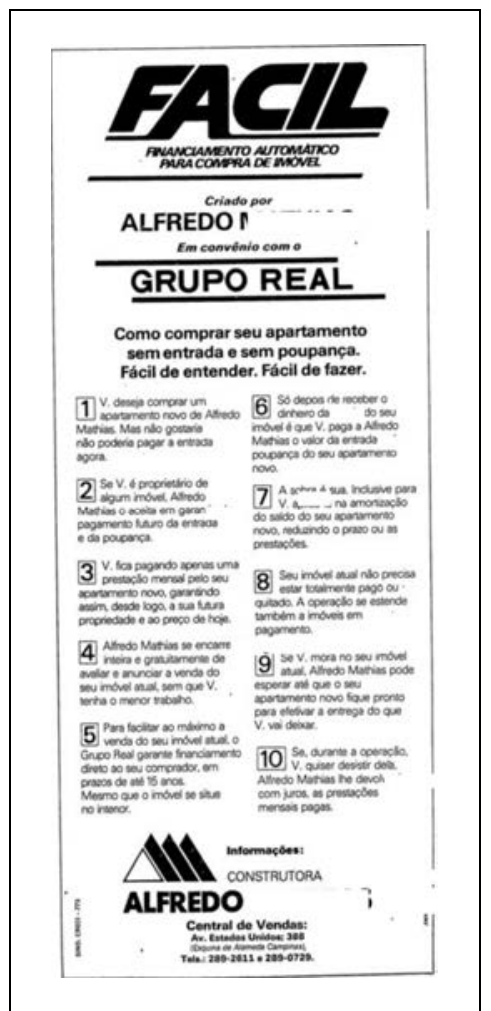

Figura 30: Anuncio Sistema Fácil64

${ }^{64}$ Anuncio veiculado no jornal Folha de São Paulo em 08 - 05 - 1975 
As dificuldades das vendas acarretaram à construtora altos encargos financeiros decorrentes do financiamento da obra. Em1977 elabora um dossiê onde expõem as grandes dificuldades que a empresa passava, não se esquecendo de mencionar o histórico da construtora, os representantes do governo oferecem os préstimos do Banco do Brasil para a captação de recursos em moeda estrangeira nos moldes da resolução número 63 e da lei 4131/62:

"a medida se mostrou ainda mais desastrosa para a empresa,
porque, e pouco tempo, houve as maxidesvalorizações,
provocadas pela instabilidade do cenário internacional
(Pereira Leite, 2006)."

Outra tentativa de salvar a empresa foi à participação em concorrências internacionais - a exportação de serviços de engenharia estava com bastante evidência na época e várias empresas buscavam contratos em países produtores de petróleo. A construtora participou de concorrências no Kuait (um complexo ministerial do porte do centro Empresarial São Paulo), no Iraque e na Venezuela, conseguindo vencer apenas dois pequenos hotéis da cadeia Novotel em Bagdá e Basra: acabaram se tornando um desastre, dado o alto custo de investimento em um país longínquo e a diversidade da cultura.

Diante desse quadro Mathias foi aconselhado pelo advogado Naum Rotemberg a pedir concordata, mas seu orgulho não permitia assumir algum tipo de fracasso. Faleceu em 1979 aos 75 anos e seus irmãos herdeiros acabaram pedindo a concordata e venderam a empresa a José Colagrossi.

Colagrossi passou a administrar e liquidar os ativos tendo a falência decretada judicialmente em vinte e sete de janeiro de 1984.

A empresa apresentava um modelo altamente verticalizado, desenvolvendo atividades comerciais, administrativas e de produção. O próprio 
Mathias era responsável pelas incorporações, vendas e serviços de construção ao setor público e privado. Os projetos ficavam à cargo do arquiteto João Henrique da rocha e do próprio Mathias; a produção ficava a cargo do engenheiro Celso Pinheiro Dória.

"Alfredo Mathias é um bom exemplo do modelo empreendedor da escola Empreendedora da Administração Estratégica: com boa formação técnica, era competente, disciplinado, exigente e, principalmente, autoconfiante. Confiança que valeram grandes saltos à frente, mas que também the causaram danos inesperados e irrecuperáveis. Nem mesmo sua determinação foi suficiente para superar as dificuldades de uma atividade de alto risco, com alto valor de investimento e um cenário turbulento" (Pereira Leite, 2006)

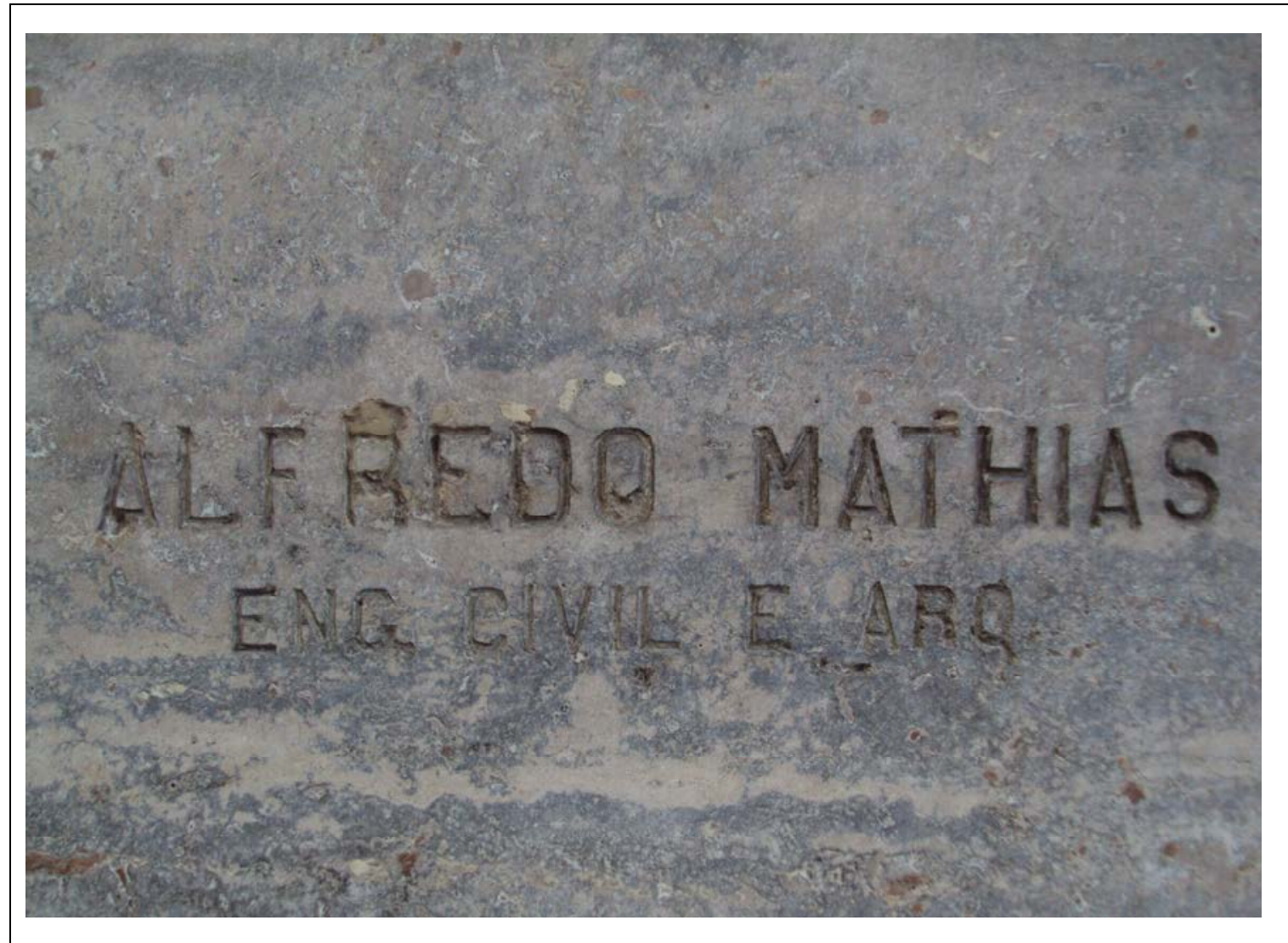

Figura 31: Planta com a assinatura do arquiteto no edifício na esquinas das avenidas São João com lpiranga. 65

65 Foto: Demósthenes Magno Santos - 2012 
5. Projetos Selecionados: Estudos de Caso 


\subsection{Giancarlo Palantib6}

Segundo Aline Sanchez Corato o arquiteto Giancarlo Palanti teria sido apresentado a Alfredo Mathias por uma carta de M. Argan, cunhado de seu irmão:

"Sem poder assinar os projetos e após tentativas de revalidação de seu diploma o trabalho com Alfredo Mathias parece ter sido uma proposta interessante para Giancarlo Palanti." (Corato, 2008)

\subsubsection{Cine Rivoli ou Jussara - 1951}

O primeiro trabalho desenvolvido pela parceria Alfredo Mathias/ Palanti foi o Cine Rivoli ou Jussara realizado em 1951, na Rua Dom José de Barros. Tratava-se de uma reforma e o cine foi encaixado dentro de um grande salão de um edifício existente. Os arquitetos resolveram o projeto acomodando acessos bilheterias e salas de espera ao lado de uma loja já existente. Com as circulações e banheiros colocados junto à divisa otimizou a circulação e a área de espera e rota de saída; neste projeto os arquitetos conseguiram acomodar cerca de 1400 lugares (figura 32).

Dentre os cuidados e apuros na execução do projeto é de se destacar o rigor técnico em relação à acústica e iluminação, para tanto desenvolveram o desenho do forro com elementos sobrepostos para melhorar as condições de acústica, iluminação e condicionamento de ar (figura 33). Em texto assinado na revista Habitat $n^{\circ} 6$ (1952) pelos arquitetos a arquitetura interna teria sido concebida na máxima simplicidade e a decoração apresentava:

"acordos e contrastes dos elementos arquitetônicos e funcionais e pelas cores dos mesmos" (Alfredo Mathias / Palanti - Revista Habitat n6).

66 Em 1989 a família de Giancarlo Palanti doou à Biblioteca da FAU-USP o acervo de projetos do arquiteto, num total de 120 obras. 
Com os recursos de pintura e do detalhamento da tela fez a mesma parecesse flutuar, suspensa no espaço (figura33).

Por se tratar de uma reforma os arquitetos resolveram pelo destaque da nova construção em relação à antiga através de uma grande marquise com iluminação indireta na fachada (figuras 34 a 38).

“... entre outras, a função de criar clara separação entre a nova arquitetura do cinema e a antiga arquitetura do resto da fachada". (Alfredo Mathias / Palanti - Revista Habitat n 6)

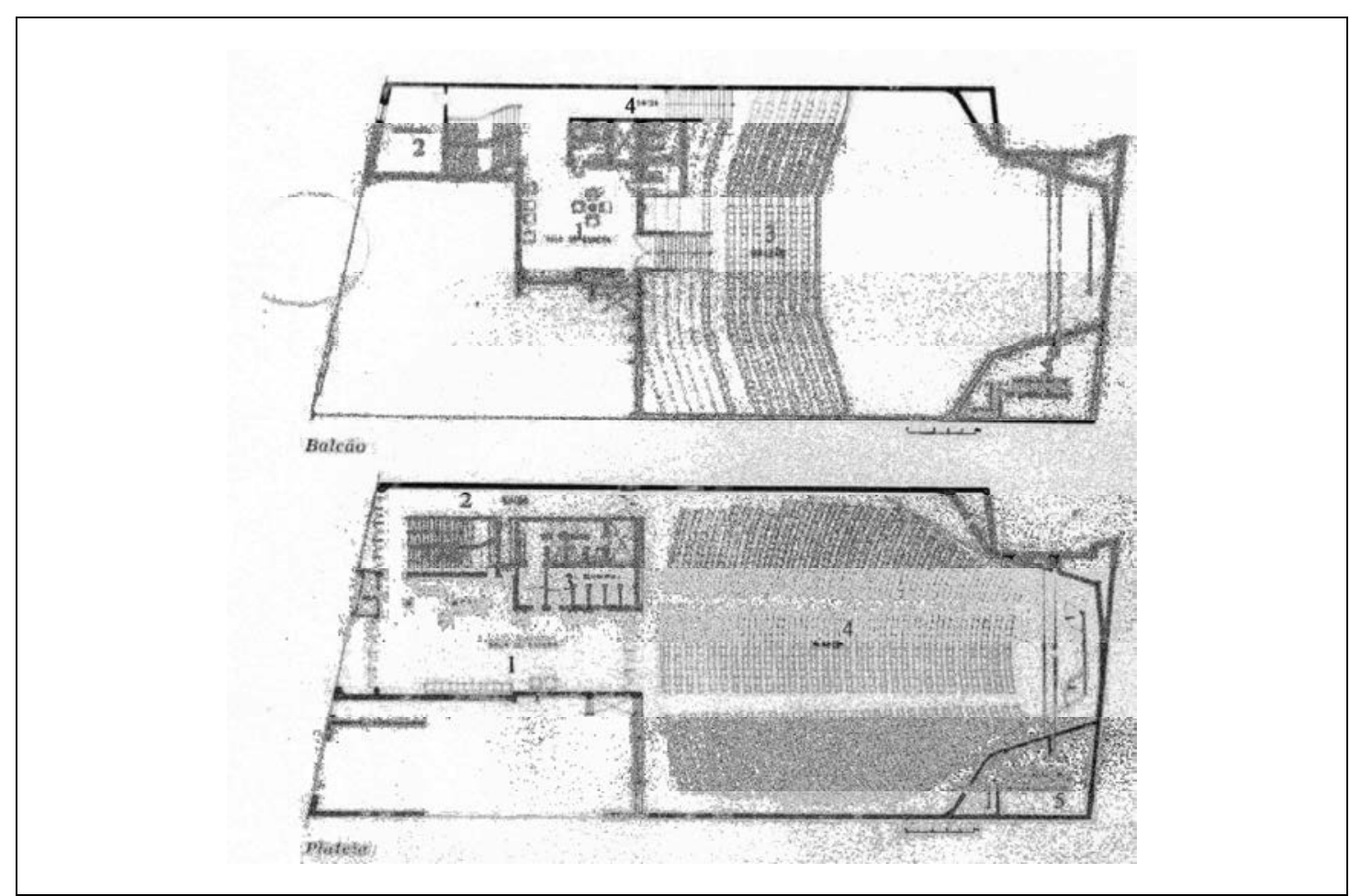

Figura 32: Cine Rivoli ou Jussara

Balcão: 1) Sala de espera; 2)Gerência; 3) Balcão; 4)Saída; 5)Ar condicionado. Platéia: 1) Sala de Espera 2) Saída; 3)Banheiros; 4)Platéia; 5) Ar condicionado. ${ }^{67}$

${ }^{67}$ Fonte: REVISTA HABITAT, N 6 - 1952 


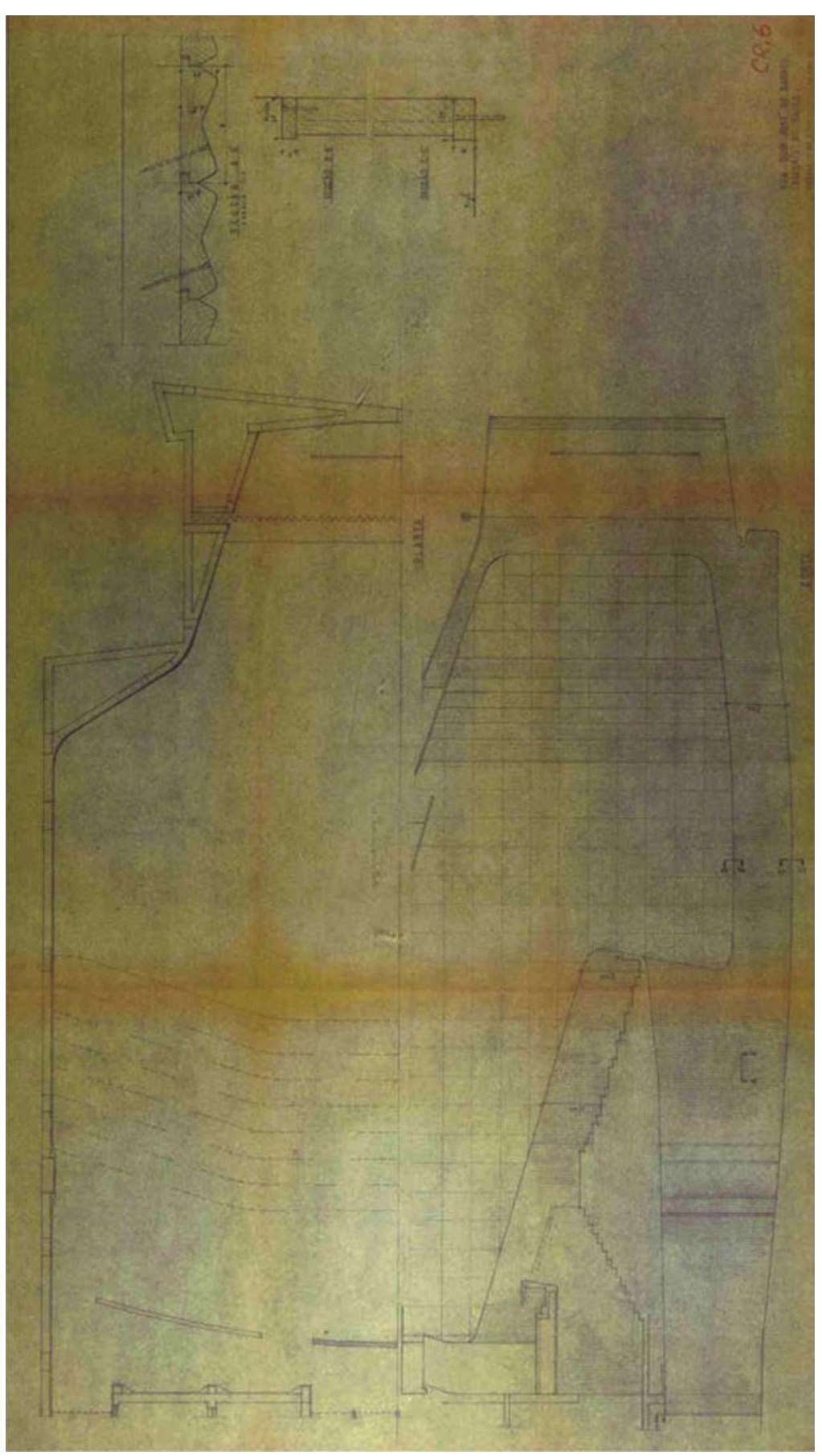

Figura 33: Cine Rivoli ou Jussara

Corte Longitudinal detalhamento - 195168

${ }^{68}$ Fonte: Arquivo GP / FAU - USP 


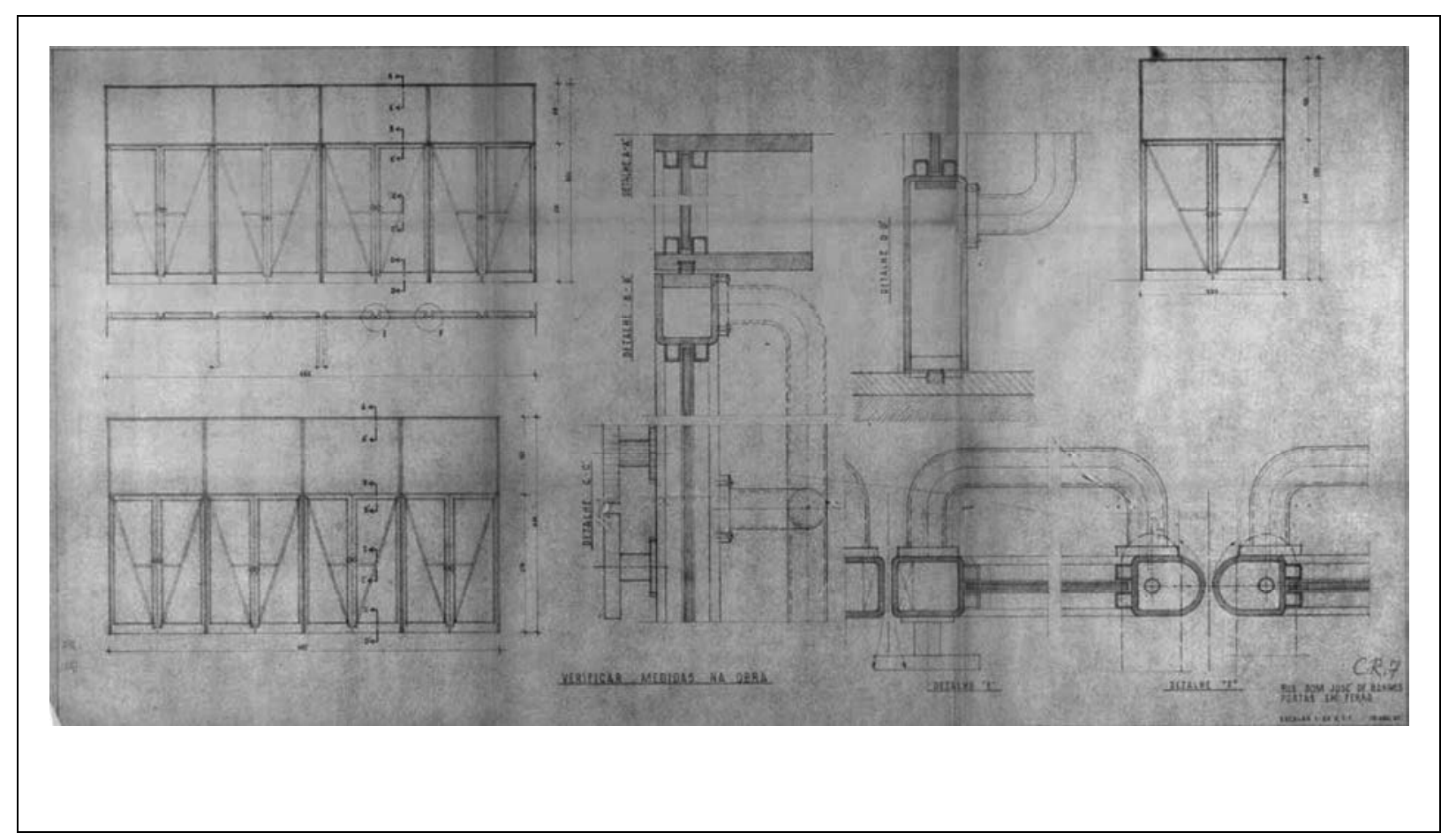

Figura 34: Cine Rivoli ou Jussara

Detalhamento - 195169

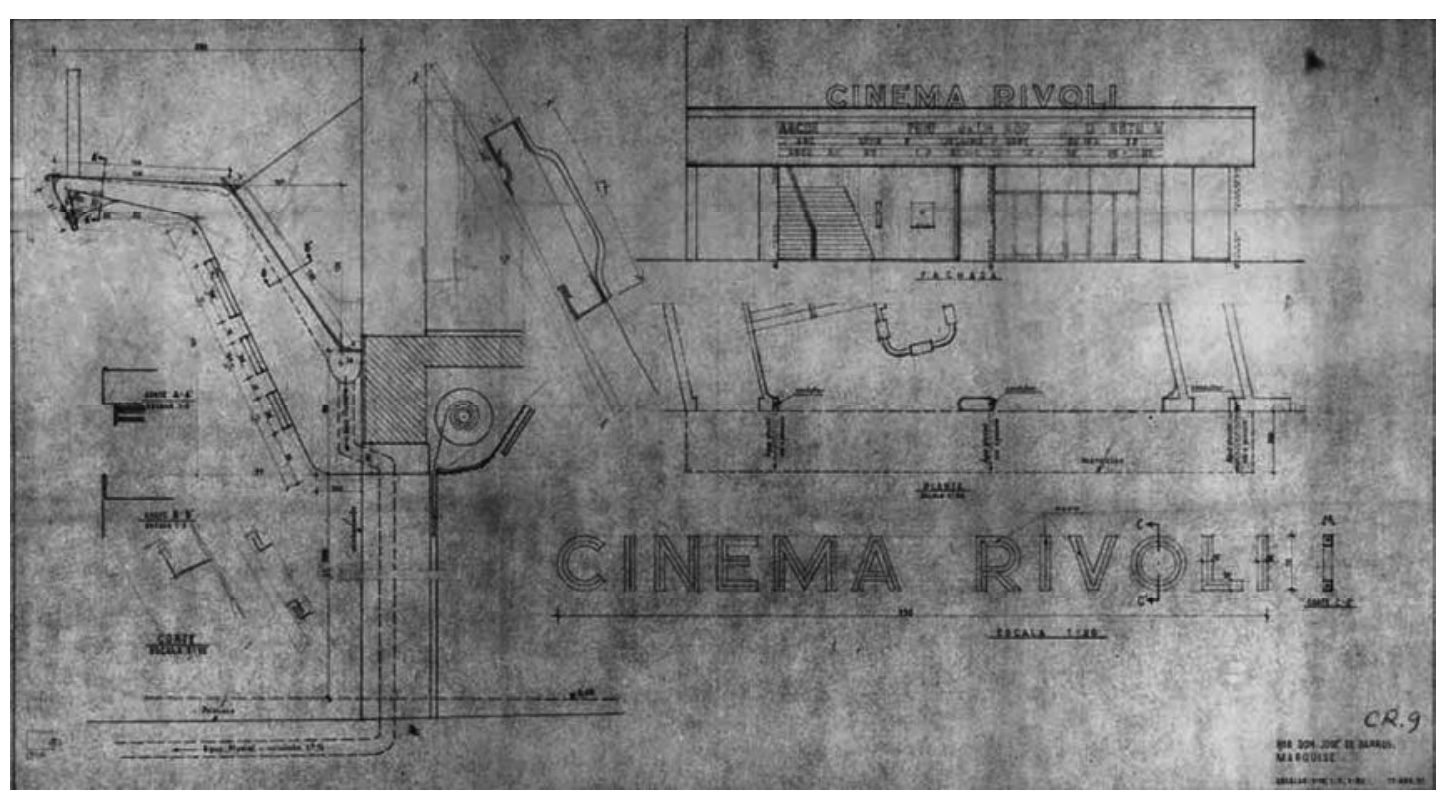

Figura 35: Cine Rivoli ou Jussara Detalhamento - 195170

\footnotetext{
${ }^{69}$ Fonte: Arquivo GP / FAU - USP

${ }^{70}$ Fonte: Arquivo GP / FAU - USP
} 


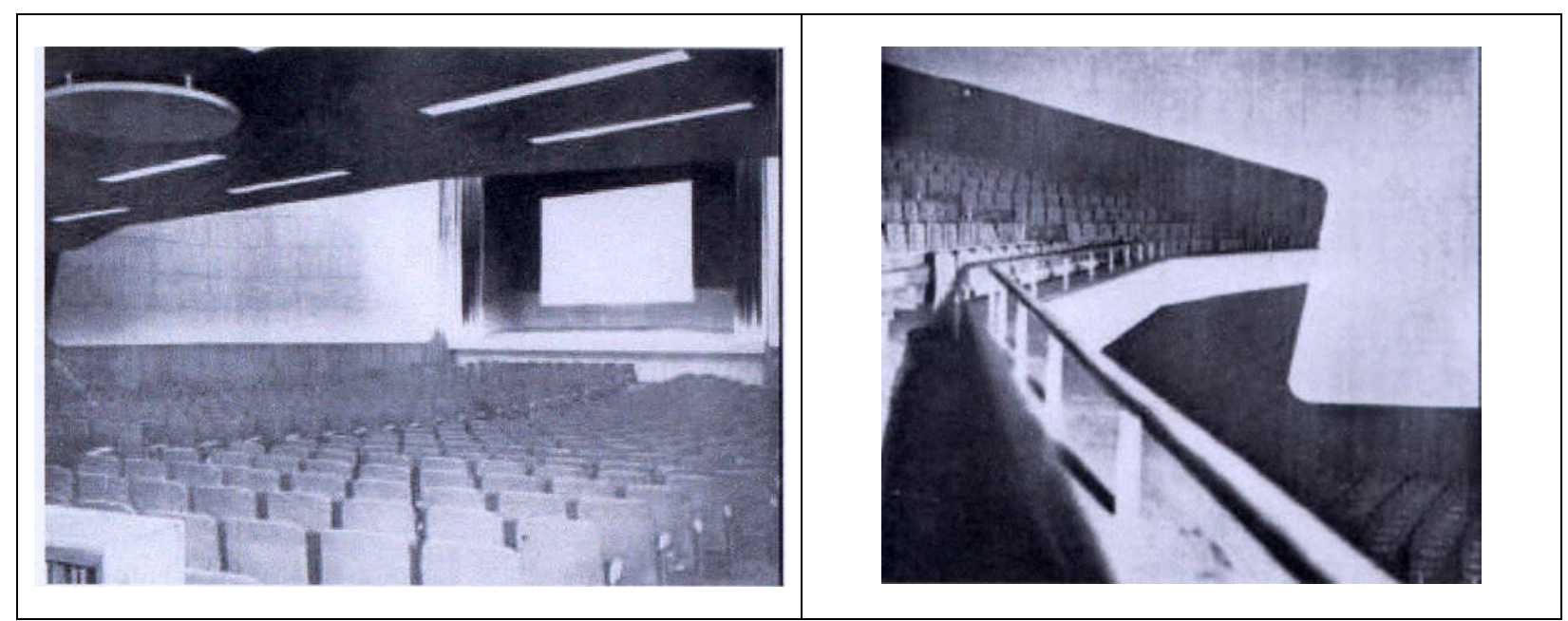

Figura 36: Cine Rivoli ou Jussara

Esquerda: vista da platéia vista para a tela de projeção;

Direita: detalhe do balcão71

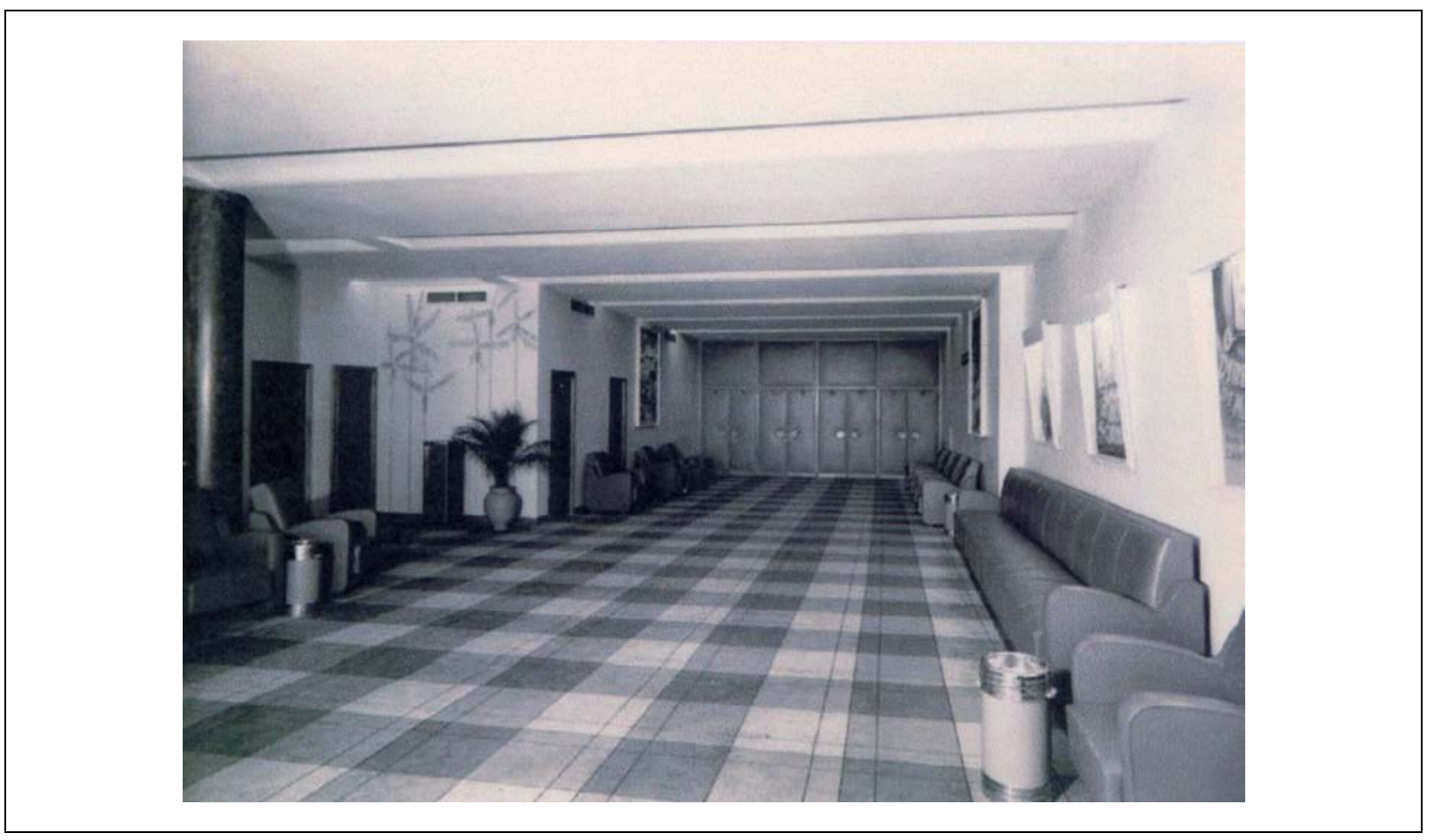

Figura 37: Cine Rivoli ou Jussara

Vista da Sala de espera do andar térreo ${ }^{72}$

\footnotetext{
${ }^{71}$ Fonte: REVISTA HABITAT, N N 6 - 1952

${ }^{72}$ Fonte: REVISTA HABITAT, N ${ }^{\circ} 6-1952$
} 


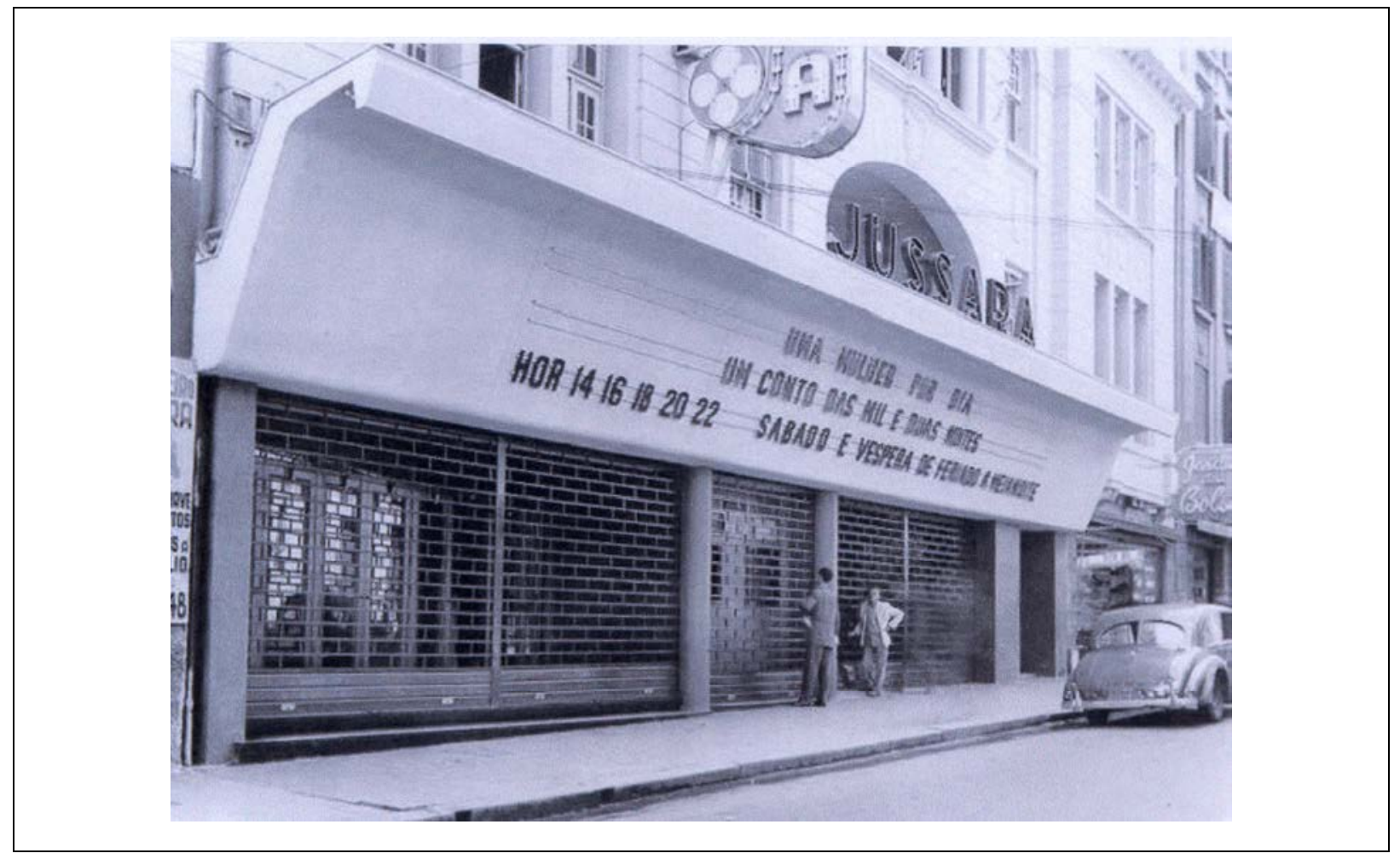

Figura 38: Cine Rivoli ou Jussara

Fachada - vista da marquise - 195173

5.1.2. Edifício Conde de Prates - 1952

De 1952 a 1954, Palanti trabalha para a construtora com Diretor da Seção de Projetos; segundo o currículo do arquiteto realizou vários projetos, dentre os quais se destacam 29 edifícios de três pavimentos; dois projetos para o concurso da Câmara Municipal de São Paulo; as reformas nos projetos dos edifícios Conde de Prates, Gibraltar e Chipre; do cine Trianon (o extinto Belas Artes);o projeto do Edifício Itororó, na Rua Martiniano de Carvalho); vários edifícios de escritórios e para residências, dentre os quais o edifício da Rua barão de Tatuí, 352; o projeto para a Biblioteca Municipal de Araras e um edifício de apartamentos no Guarujá, o edifício Gaivota.

Nesse período Palanti desenha vários edifícios que seriam pontos de referência na cidade, como é o caso do Edifício Conde de Prates.

\footnotetext{
${ }^{73}$ Fonte: Arquivo GP / FAU - USP
} 
"O edifício foi construído em terras onde antes eram localizadas as propriedades do Conde de Prates, maior proprietário da região do Vale do Anhangabaú na ocasião da edificação do Plano Bouvear. A construção do viaduto do Chá e a conclusão das obras do Parque do Anhangabaú e imediações da década de 1910 consolidam naquele momento uma nova centralidade em São Paulo para alem do Anhangabaú. A expansão da cidade para além do viaduto, no chamado "Centro Novo", começaria nos anos 20 e efitivar-se-ia nos anos 30 após a construção do novo viaduto do Chá, mais largo que o anterior. O caminho do centro da cidade rumo a oeste, atravessaria então este viaduto em direção à Praça da República, consolidando entre 1910 e 1940 o "Centro-Novo" nessa região. "(Simões, 1995, apud Corato, 2008)

O Edifício Conde Prates foi construído sob forma de incorporação através da Segurança Imobiliária S.A. ${ }^{74}$ e apresentaria novas táticas no mercado imobiliário da cidade. Sua inauguração foi alardeada em vários anúncios publicitários e em publicações especializadas em destaque o da Revista Acrópole de agosto de 1956 que exaltava as características e qualidades do projeto.

Segundo Aline Sanchez Corato, Lucjan Korngold pretendia construir um edifício com um volume puro sem os escalonamentos nos últimos andares (como era exigido no Código de Obras vigente), na esquina da Rua 24 de maio com a Rua Conselheiro Crispiniano, a municipalidade acabou por acatar as reivindicações do arquiteto em troca da exclusão de um pavimento. Nos estudos do projeto do Edifício Conde de Prates, Mathias ainda em 1950 usa do mesmo artifício e passa de um volume escalonado para um volume puro colocado sobre uma esplanada a altura do viaduto do Chá "constituída por uma espécie de loggia, com os pilares constituindo uma membrana entre a rua e o edifício "(figuras 40 e 42).

${ }^{74}$ A empresa de administração de imóveis, Segurança Imobiliária S.A pertencia também a Alfredo Mathias e era dirigida por seu irmão, o Sr. Jorge Mathias. 
"O parcerista lembra que outros edifícios construídos em locais de grande importância, do ponto de vista urbanístico e arquitetônico, como o edifício CBI, na Rua Formosa, os Diários Associados, na Rua 7 de Abril, o Conde de Prates, na Praça do Patriarca...não se enquadram nos rígidos preceitos da legislação de sua época, porém mereceram.. .estudos específicos e cuidadosos por parte de Prefeitura, exemplificando a orientação dos técnicos no sentido de privilegiar a analise dos edifícios considerados como pontos focais." (Anat Falbel, apud Corato, 2008)

O Conde Prates foi o segundo arranha-céu construído no vale do Anhangabaú e, junto com o Edifício $C B$ r romperam as relações espaciais pensadas por Bouvard para o vale. Implantado nas divisas do vale na altura do Viaduto do Chá, apresenta uma esplanada que contorna o edifício, este se acomoda ao desnível do terreno estabelecendo um acesso pelo Vale do Anhangabaú e outros dois, interligados por uma galeria, que serve de hall do edifício, entre a Rua Líbero Badaró e a esplanada/mirante para o Vale do Anhangabaú. Há uma relação de visibilidade entre a cidade e o edifício: do hall do edifício ou dos escritórios envidraçados há uma troca: a cidade é parte integrante do edifício, no entanto o edifício é parte integrante da paisagem da cidade (figura 43).

O edifício foi concebido com as quatro fachadas envidraçadas com um núcleo central onde estão o core e os serviços, esta configuração já era prevista desde 1951, antes da participação de Palanti, embora este já tivesse parceria com Mathias (Figura 41). A intervenção de Palanti se deu a partir de 1952 no desenho da fachada o qual contribui com a pureza do volume sobre a esplanada (figura 42). O pavimento térreo no nível da Rua Libero Badaró, apresenta pé direito duplo com os pilares revestidos em granito escuro junto a corpo do edifício e a esplanada é evidenciada pelo desenho horizontal da marquise e sob a qual abriga as lojas no alinhamento do lote (figura 43). 
As fachadas são marcadas por linhas horizontais em cinza claros com elementos em pequenos balanços que enfatizam essa horizontalidade e pelos pilares escuros que aparecem atrás da caixilharia. O prisma é enfatizado por grossas faixas em cinza claros nas esquinas. Aline Sanchez enfatiza 0 rigor técnico na configuração da pele de vidro desenvolvido por Palanti: as esquadrias foram executadas sem parafusos ou rebites visíveis com perfilados resistentes à oxidação, um grande avanço tecnológico para a época (figuras 45 e 46).

O esquema das fachadas, mesmo antes da participação de Palanti, segue uma composição clássica, ou seja, foi definida em três partes (figuras 41 e 42):

"1) um embasamento, constituído pelos andares inferiores ao nível do viaduto do Chá, nos limites do lote, pela esplanada e sua cobertura; 2) o corpo do edifício, recuado em relação ao contorno da base; 3) um pequeno coroamento na cobertura, onde se localiza o terraço jardim. As alterações propostas por Palanti não rejeitam este esquema de uma composição clássica" (Corato, 2008)

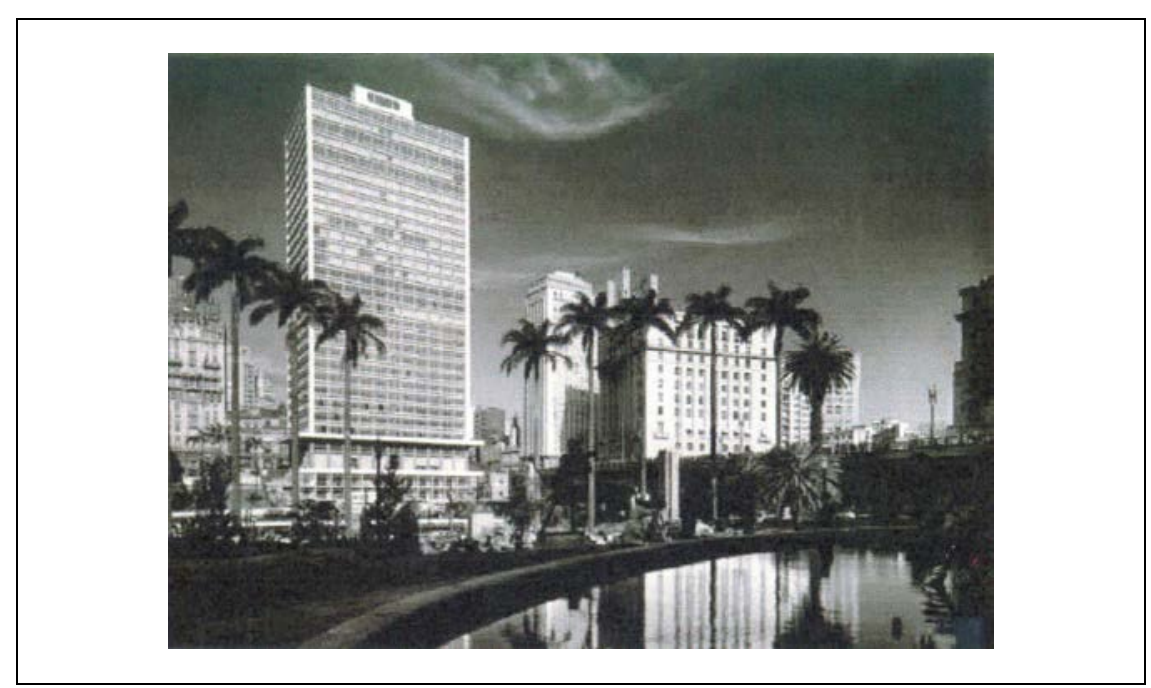

Figura 39: Edifício Conde Prates - 1952 Alfredo Mathias e Giancarlo Palanti75

\footnotetext{
${ }^{75}$ Fonte: Arquivo GP / FAU - USP
} 


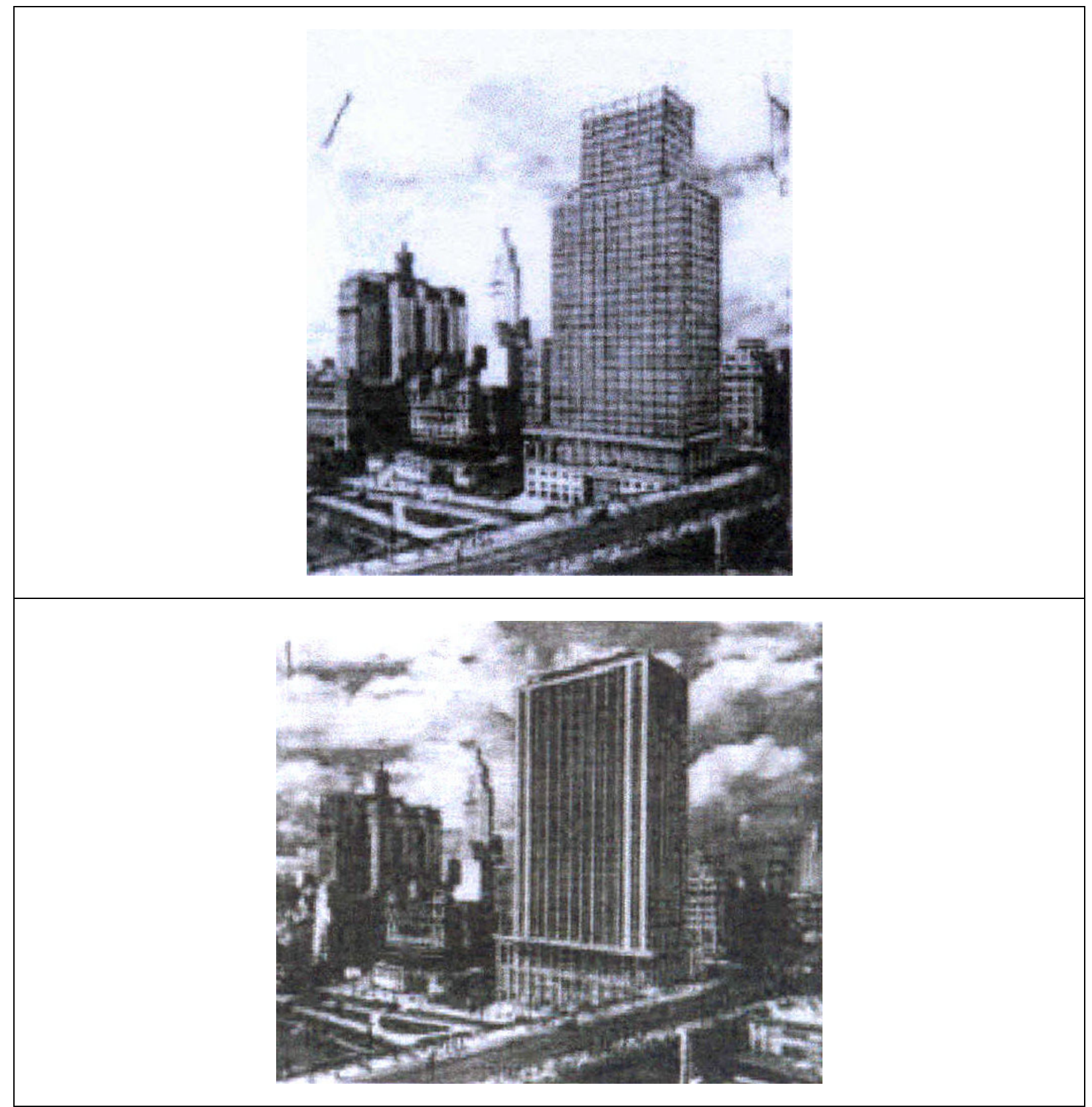

Figura 40: Edifício Conde Prates - 1952

Acima: perspectiva do prédio com o volume escalonado;

Abaixo: perspectiva do projeto substitutivo de $1950^{76}$

${ }^{76}$ Fonte FALBEL, 2003, PG. 271 


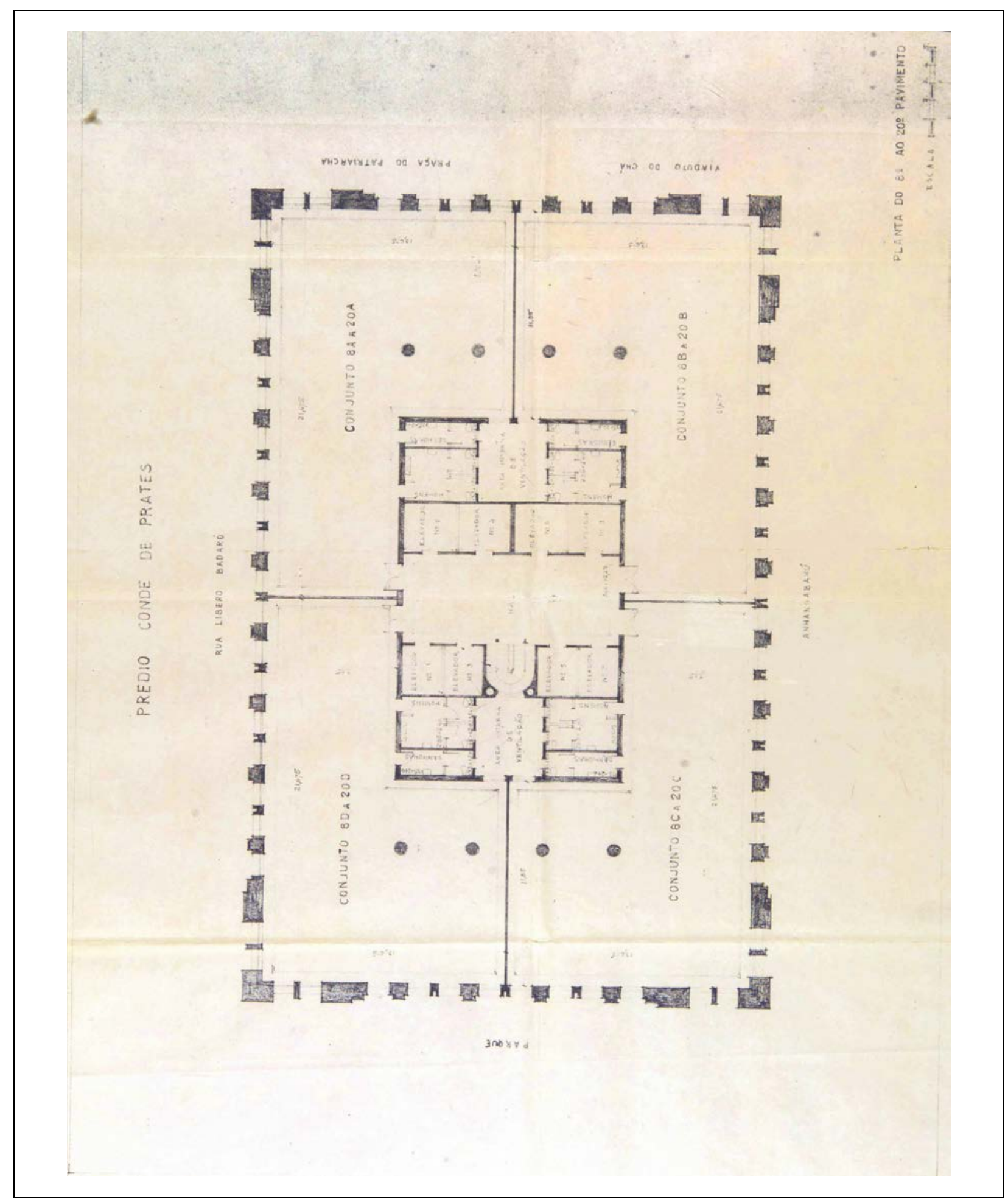

Figura 41: Edifício Conde Prates - 1952

Planta do Andar Tipo - anterior a proposta final das fachadas - $1952^{77}$

${ }^{77}$ Fonte: Arquivo GP / FAU - USP 


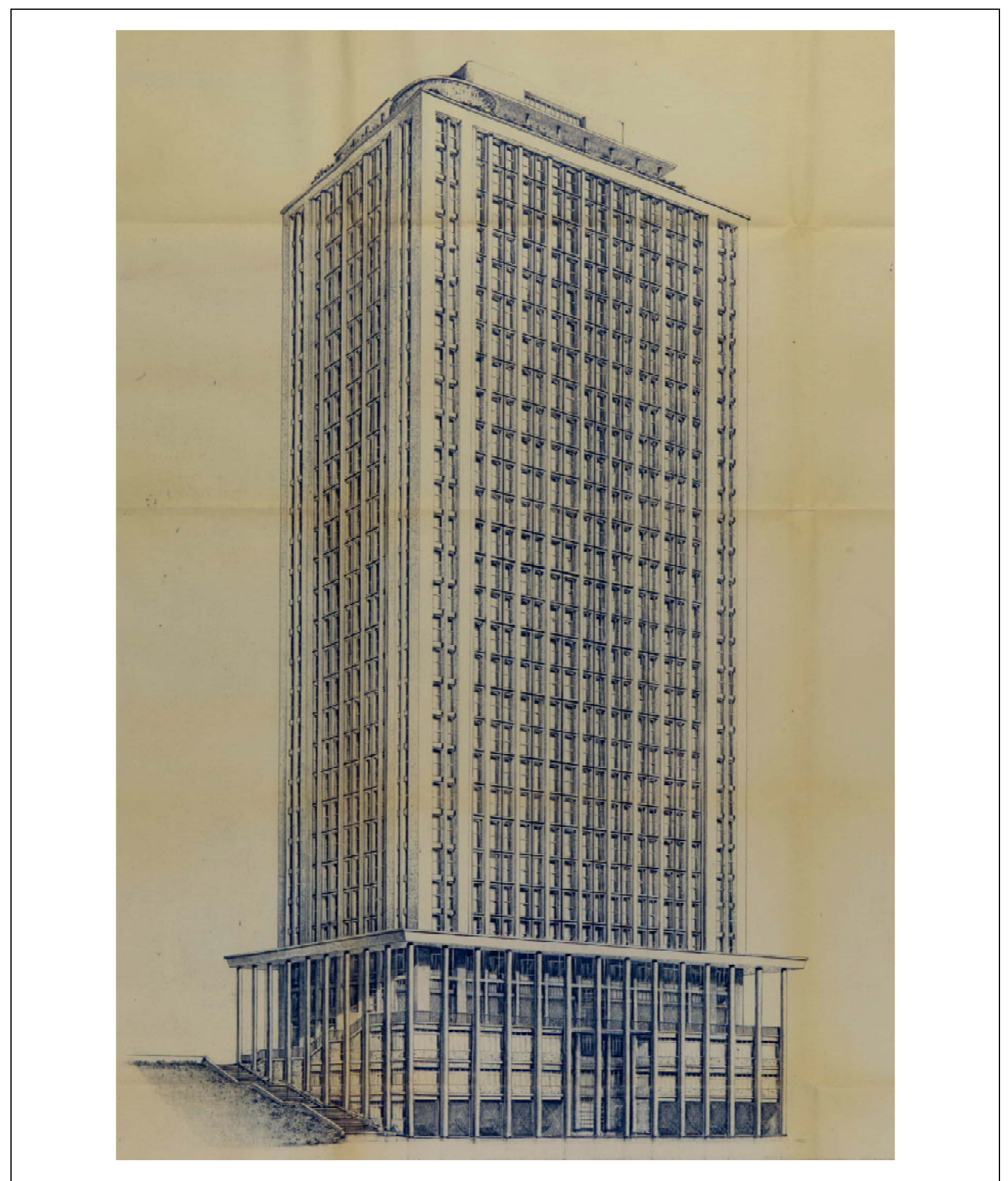

Figura 42: Edifício Conde Prates - 1952

Perspectiva dos primeiros estudos da fachada: já apresenta a definição do volume prismático e a esplanada envolta em pilares - $1952^{78}$

\footnotetext{
${ }^{78}$ Fonte: Arquivo GP / FAU - USP
} 


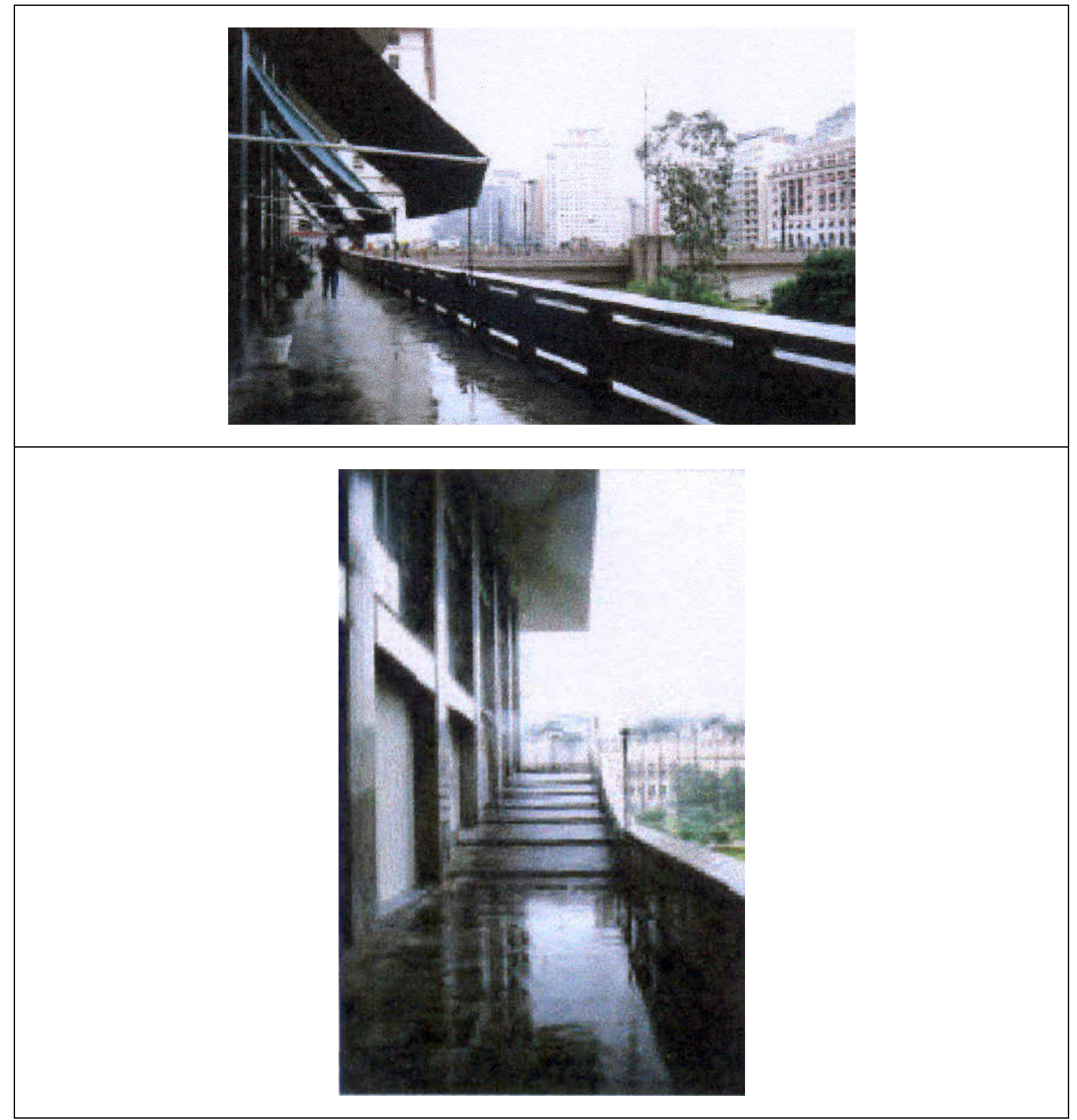

Figura 43: Edifício Conde Prates - 1952

Vistas da esplanada ${ }^{79}$

79 Fonte: Arquivo GP / FAU - USP 

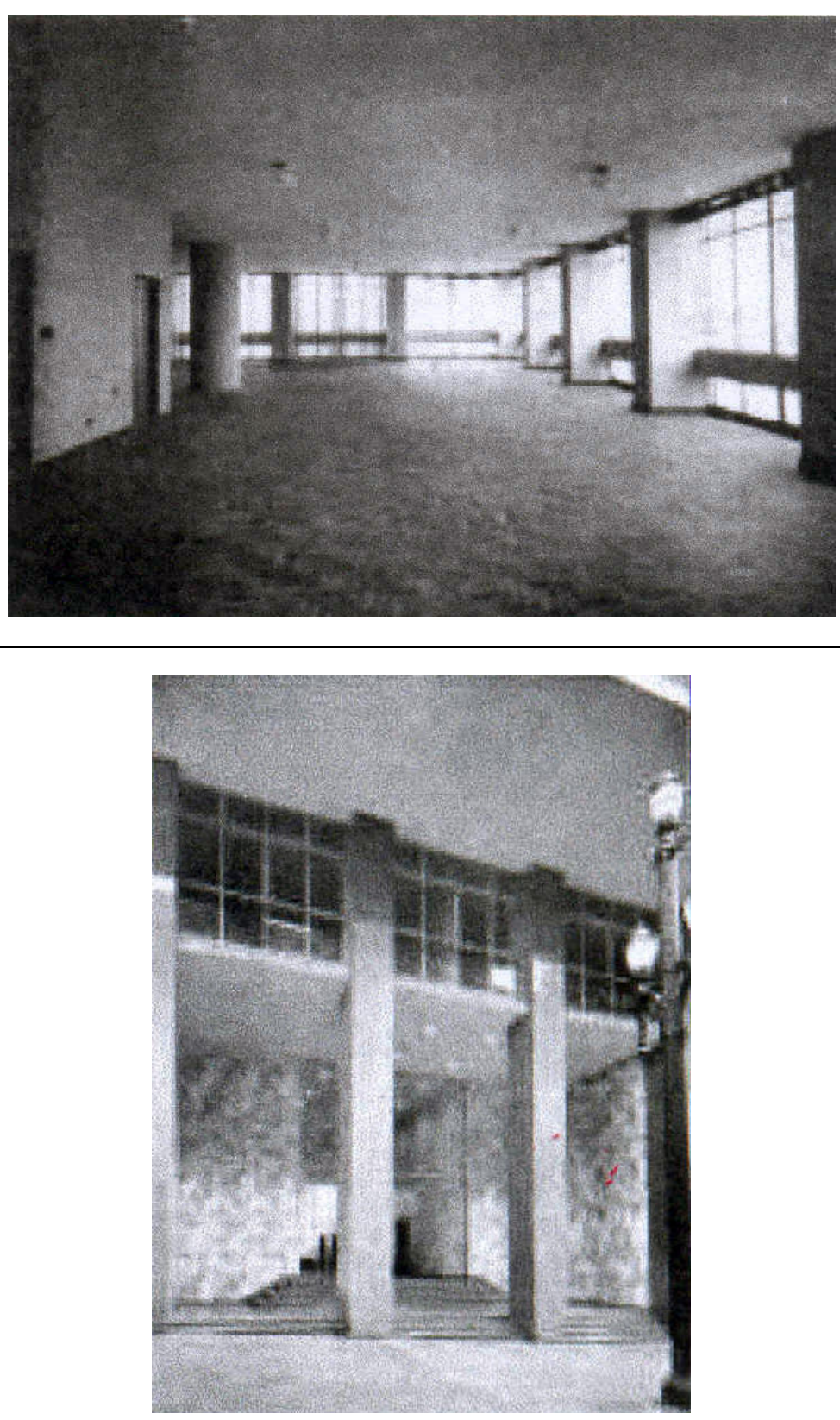

Figura 44: Edifício Conde Prates - 1952

Acima: vista do interior dos escritórios,

Abaixo: acesso para a Rua Líbero Badaró. 80

80 Fonte: Revista Acrópole, $n^{\circ} 214$ 


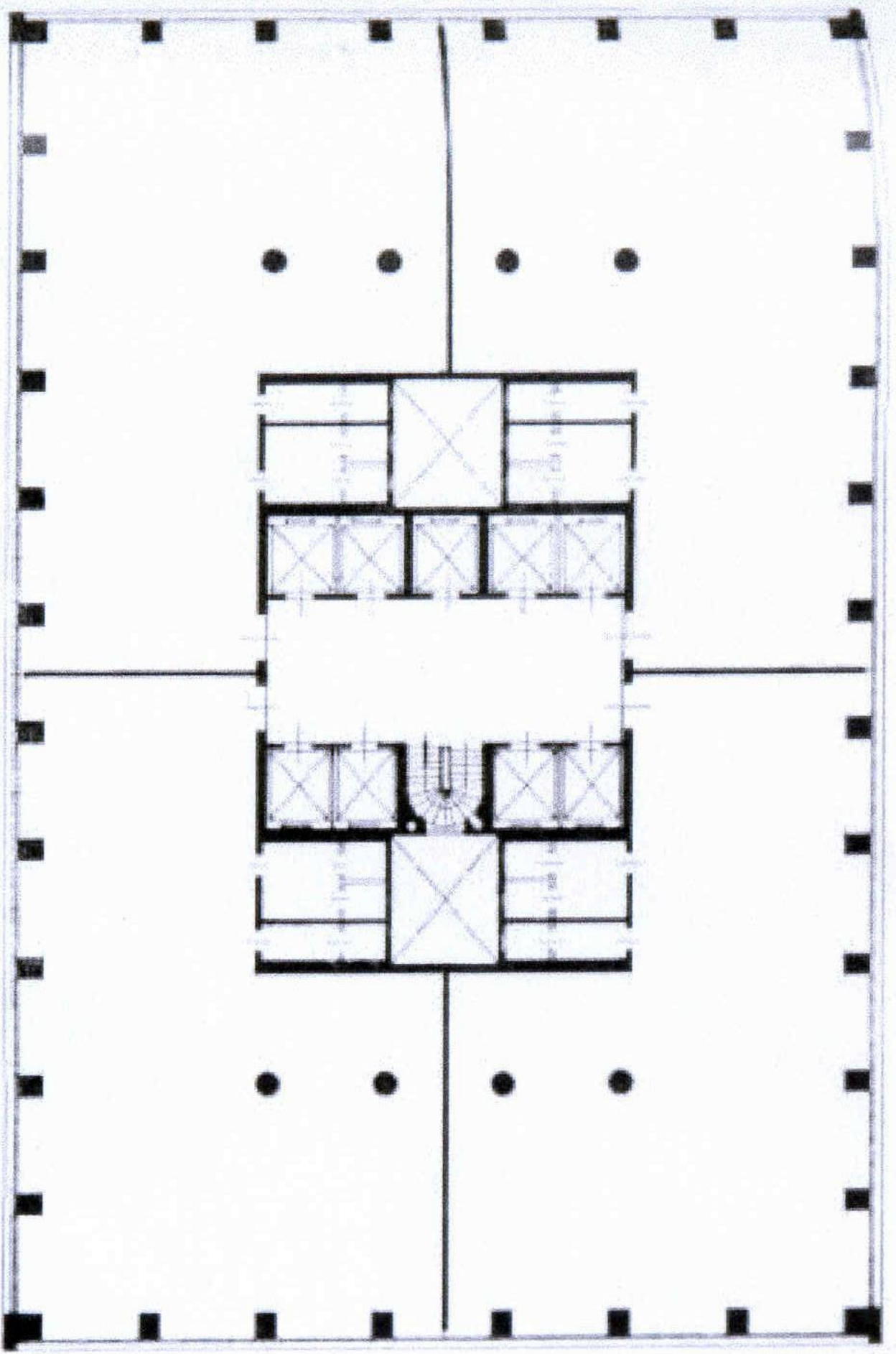

Figura 45: Edifício Conde Prates - 1952

Planta do Andar Tipo reformulado por Palanti 81

${ }^{81}$ Fonte: Arquivo GP / FAU - USP 


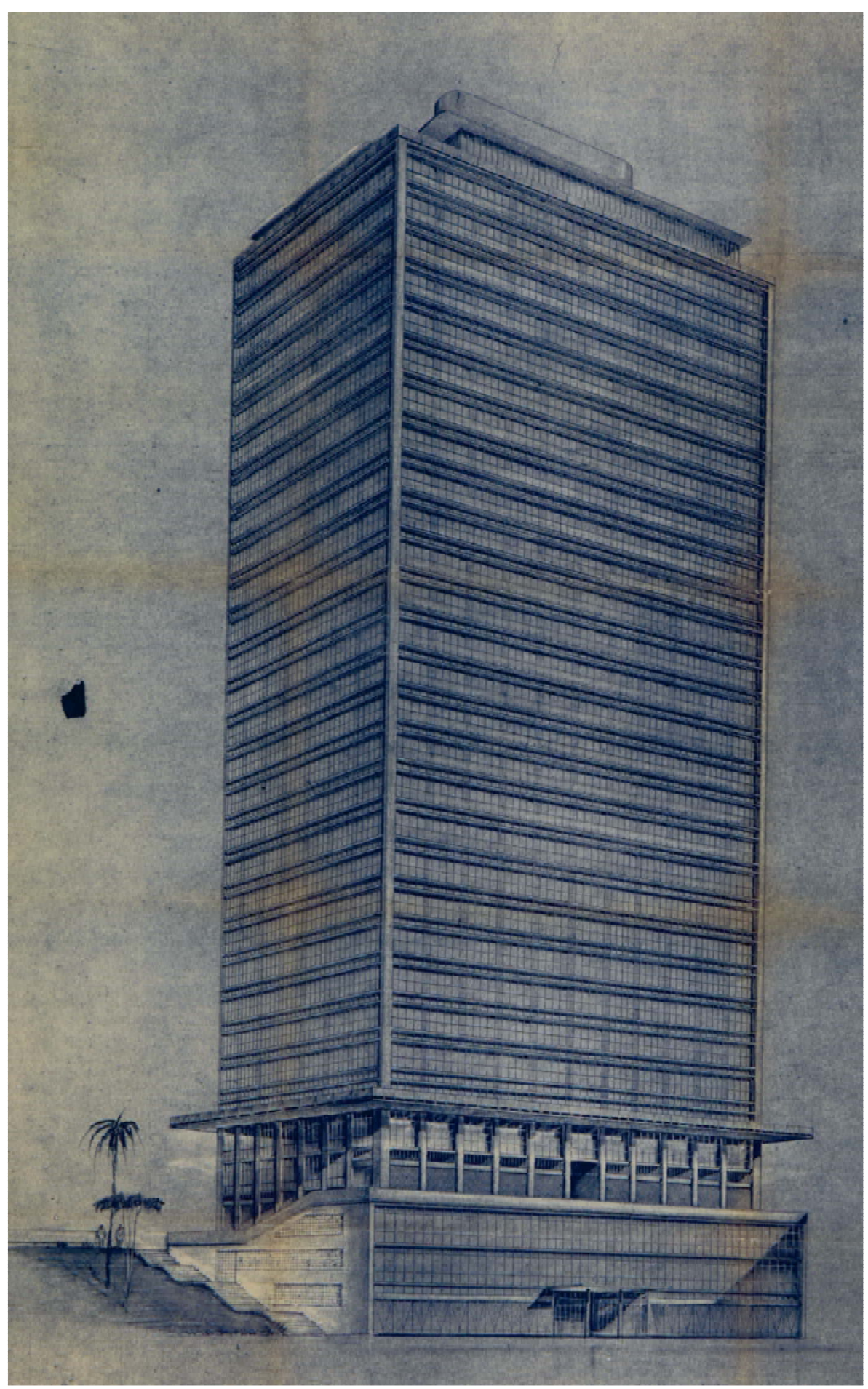

Figura 46: Edifício Conde Prates - 1952

Perspectiva do edifício reformulada por Palanti.82

\footnotetext{
${ }^{82}$ Fonte: Arquivo GP / FAU - USP
} 


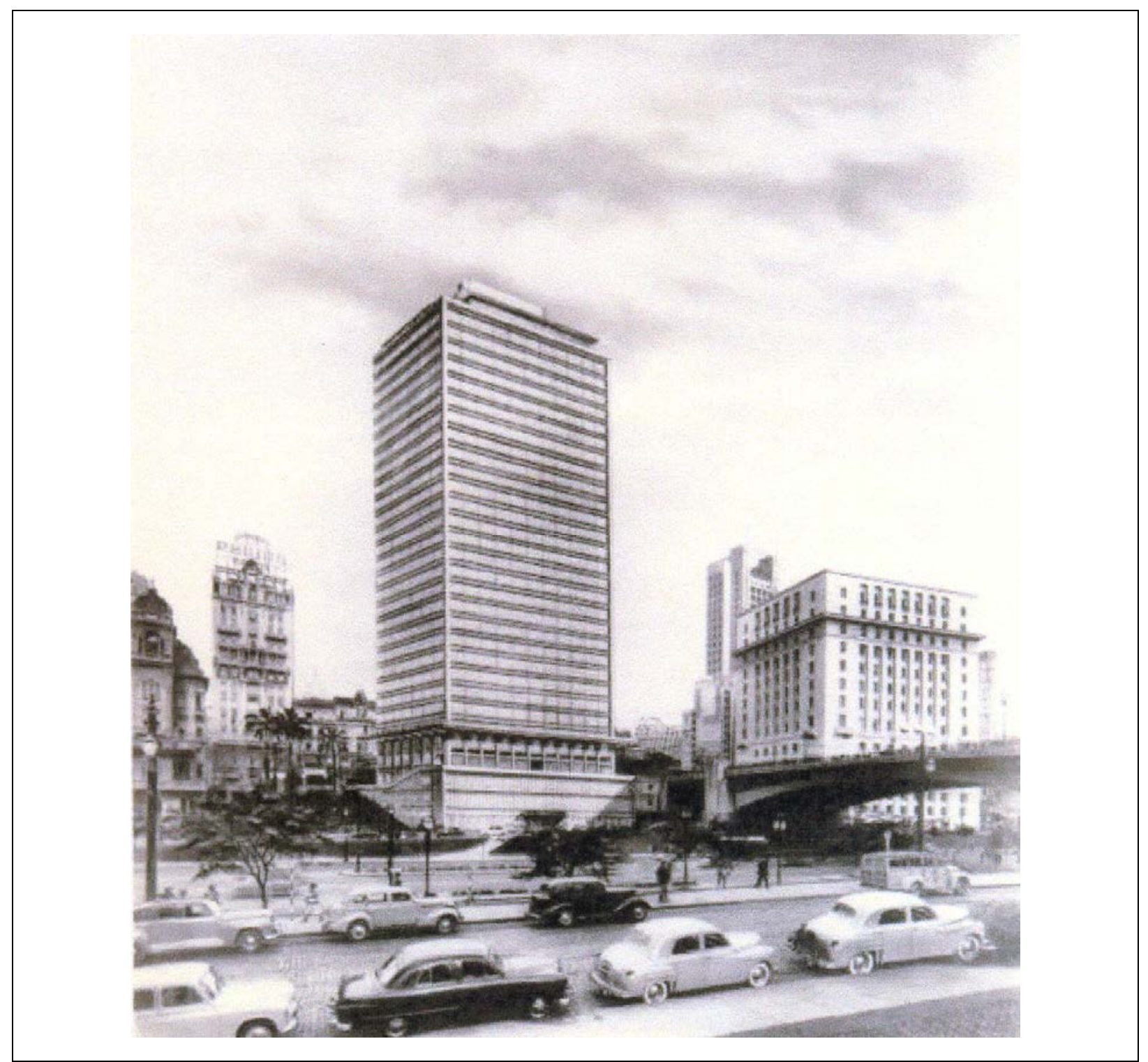

Figura 47: Edifício Conde Prates - 1952

Fotomontagem com a perspectiva do edifício reformulada por Palanti.83

${ }^{83}$ Fonte: Arquivo GP / FAU - USP 


\subsubsection{Edifício Chipre / Gibraltar e Cine Trianon - 1952}

Este conjunto assim como o Edifício Conde de Prates está localizado em importante esquina da cidade. A Avenida Paulista nos anos 60 e 70 seria o palco da expansão após a ocupação do Centro Novo e já enfatizava a eleição do vetor sudoeste da cidade como ponto focal para os empreendimentos para a classe média e alta.

O período não só coincide com a reforma das fachadas do Edifício Conde Prates como o trabalho é o mesmo, ou seja, a reforma das fachadas dos edifícios como do cinema.

Para os edifícios Palanti resolve a fachada colocando o fuste do prédio sobre um embasamento revestido de arenito (tipo canjica) junto à divisa do lote. Sobre este embasamento, correspondente ao pavimento térreo e primeiro pavimento sobe o bloco de apartamentos em balanço com vista privilegiada para a Avenida Paulista (Figura 48). Os recortes dos terraços, os tons esverdeados dos vidros e os caixilhos do chão ao teto conferem grande leveza ao conjunto onde de maneira geral as finas lajes conferem a horizontalidade do conjunto: a composição das fachadas segue a mesma solução do Edifício Conde de Prates; o esquema tri-partido com a base, fuste e coroamento (figura 52).

Já o Cine Belas Artes (antigo Trianon), embora pertencente ao conjunto, com frente para a Rua da Consolação, teve sua composição diferenciada em relação aos prédios: a fachada possuía uma grande empena revestida de elementos horizontais dava movimento à empena cega da sala de projeção, possuía, também, uma marquise aos moldes da marquise do cine Jussara (figuras 49 e 51 ). 
Em 1982 ocorreu um incêndio que destruiu suas instalações, foi reformado tendo sua fachada alterada e ampliaram o número de salas: uma pequena sala no subsolo (que já constava no projeto original) e a grande sala divida em várias salas.

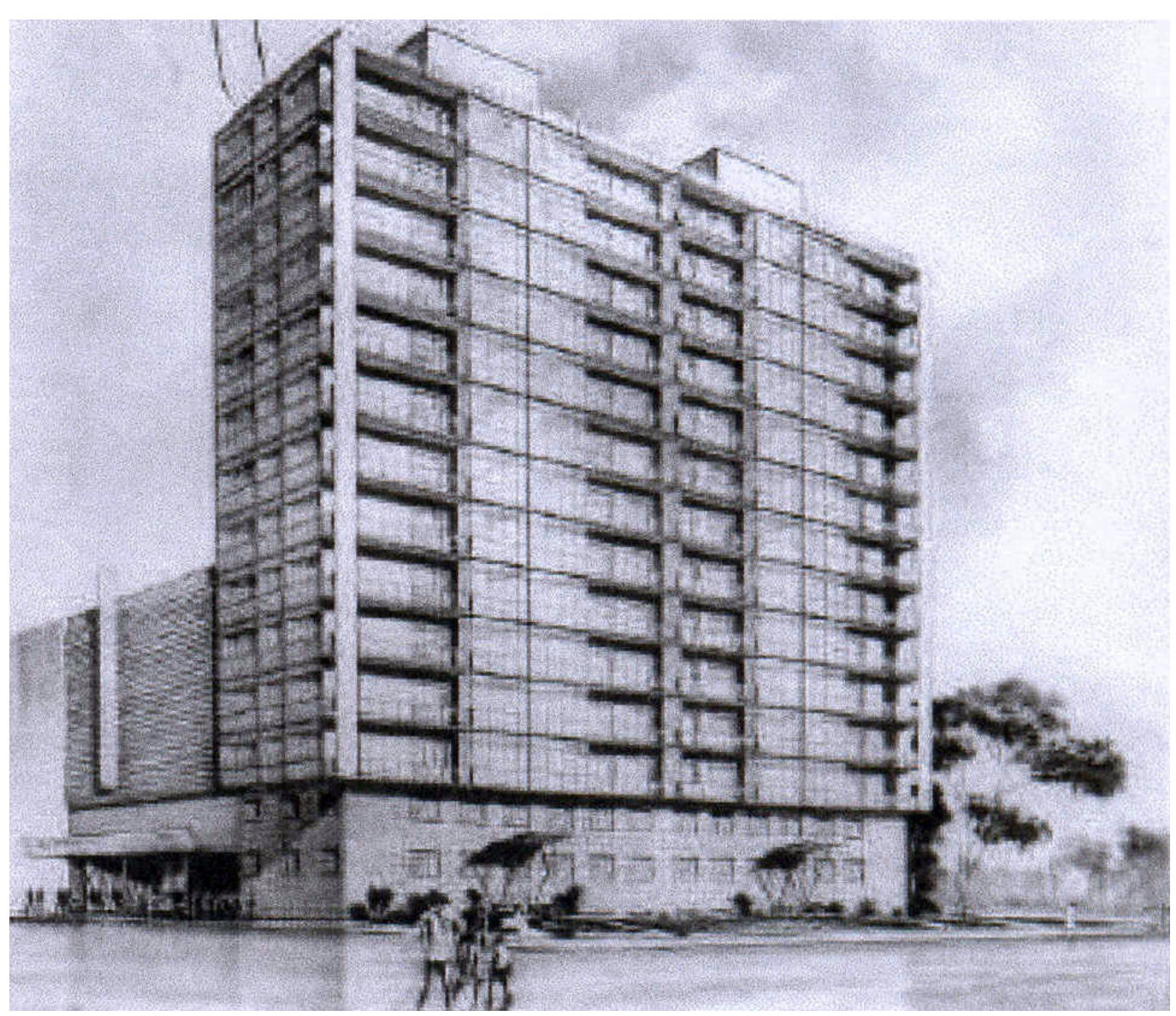

Figura 48: Perspectiva dos Edifícios Chipre e Gibraltar e Cine Trianon - 1952 Alfredo Mathias e Giancarlo Palanti. 84

${ }^{84}$ Fonte: Arquivo GP / FAU - USP 


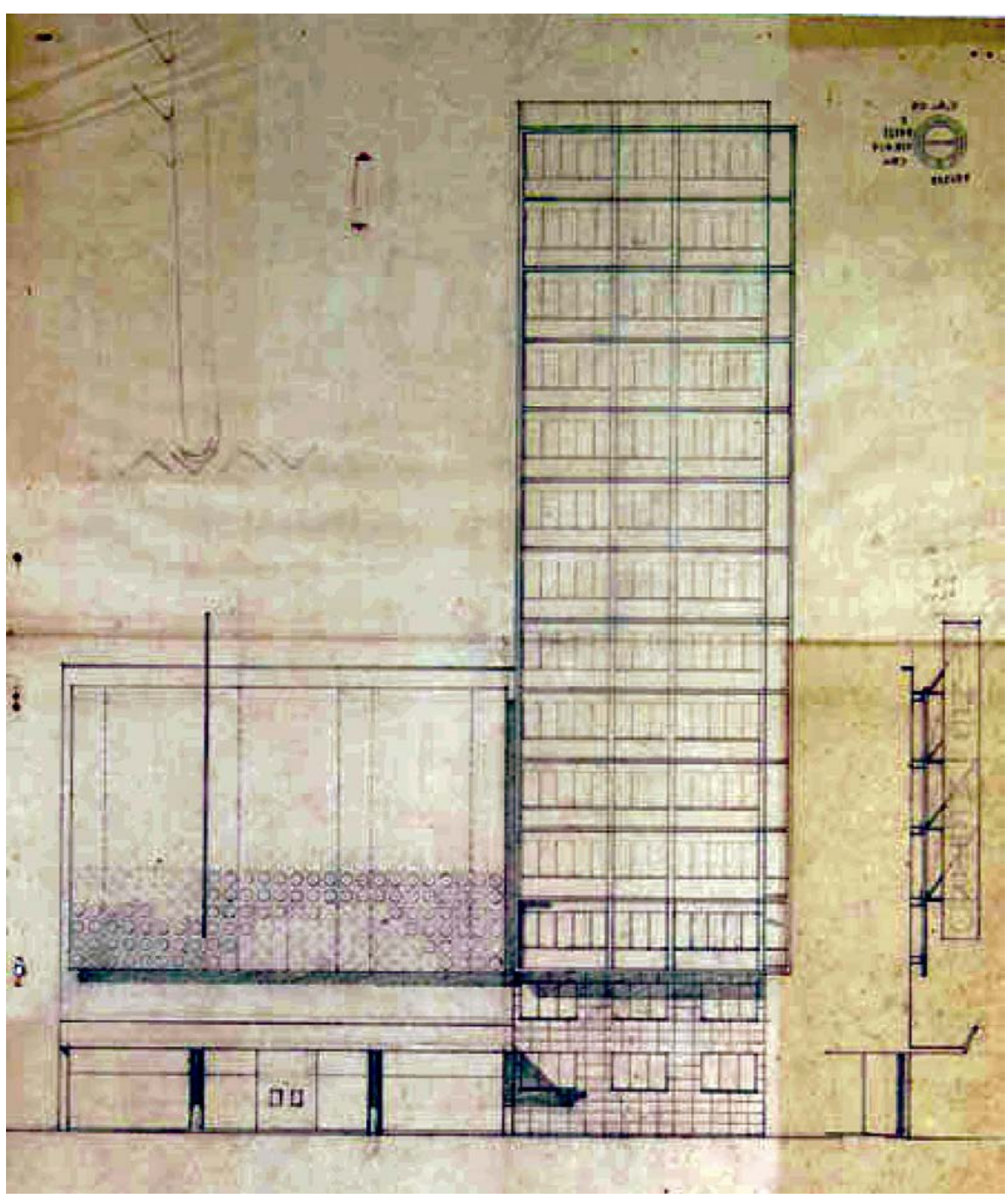

Figura 49: Edifícios Chipre e Gibraltar e Cine Trianon - 1952

Estudo das fachadas para a Rua da Consolação, posteriormente na base do edifício seria inserida a saída da passagem subterrânea sob a Rua da Consolação. ${ }^{85}$

${ }^{85}$ Fonte: Arquivo GP / FAU - USP 


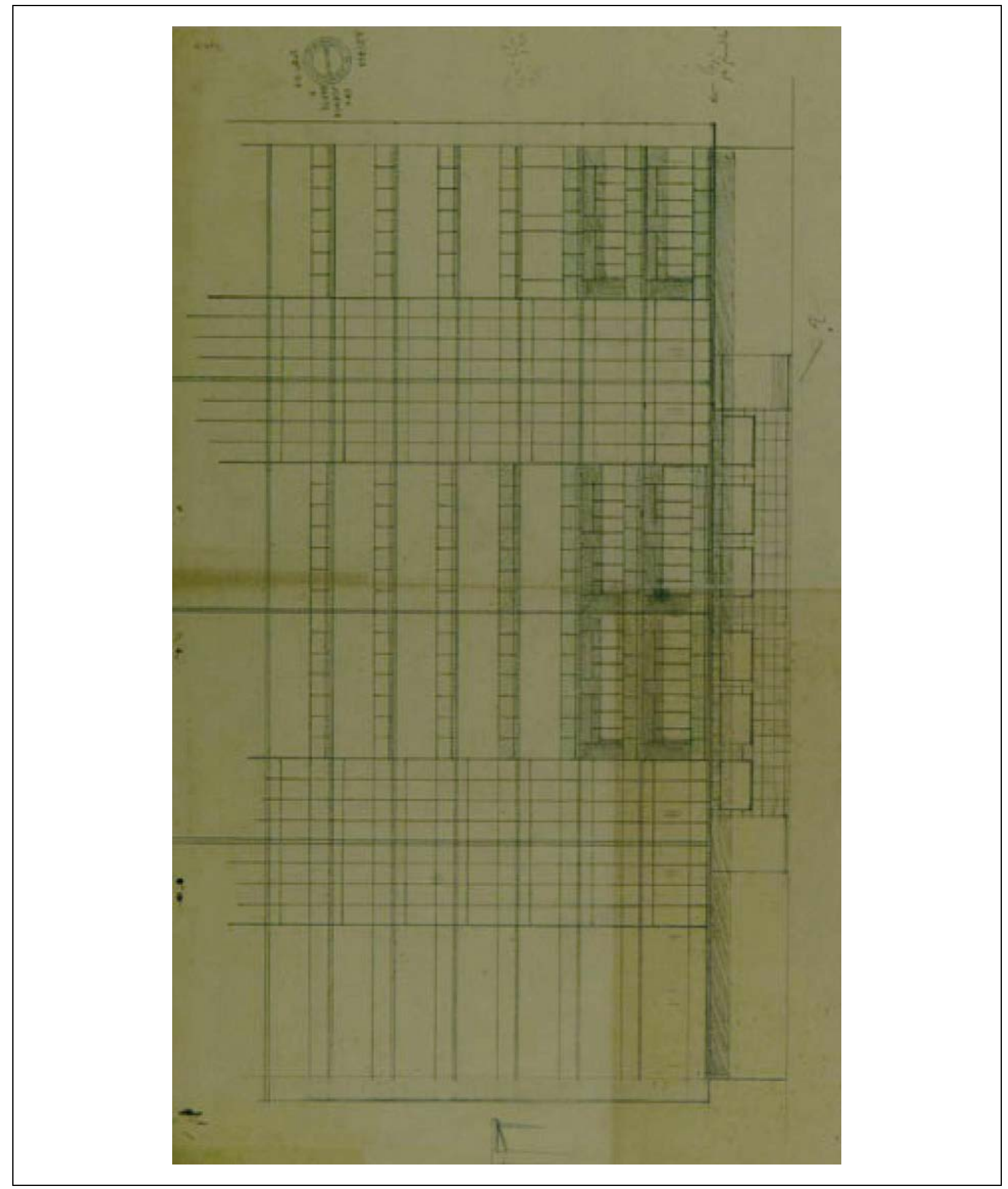

Figura 50: Edifícios Chipre e Gibraltar e Cine Trianon - 1952

Estudo das fachadas para a Avenida Paulista. 86

\footnotetext{
${ }^{86}$ Fonte: Arquivo GP / FAU - USP
} 


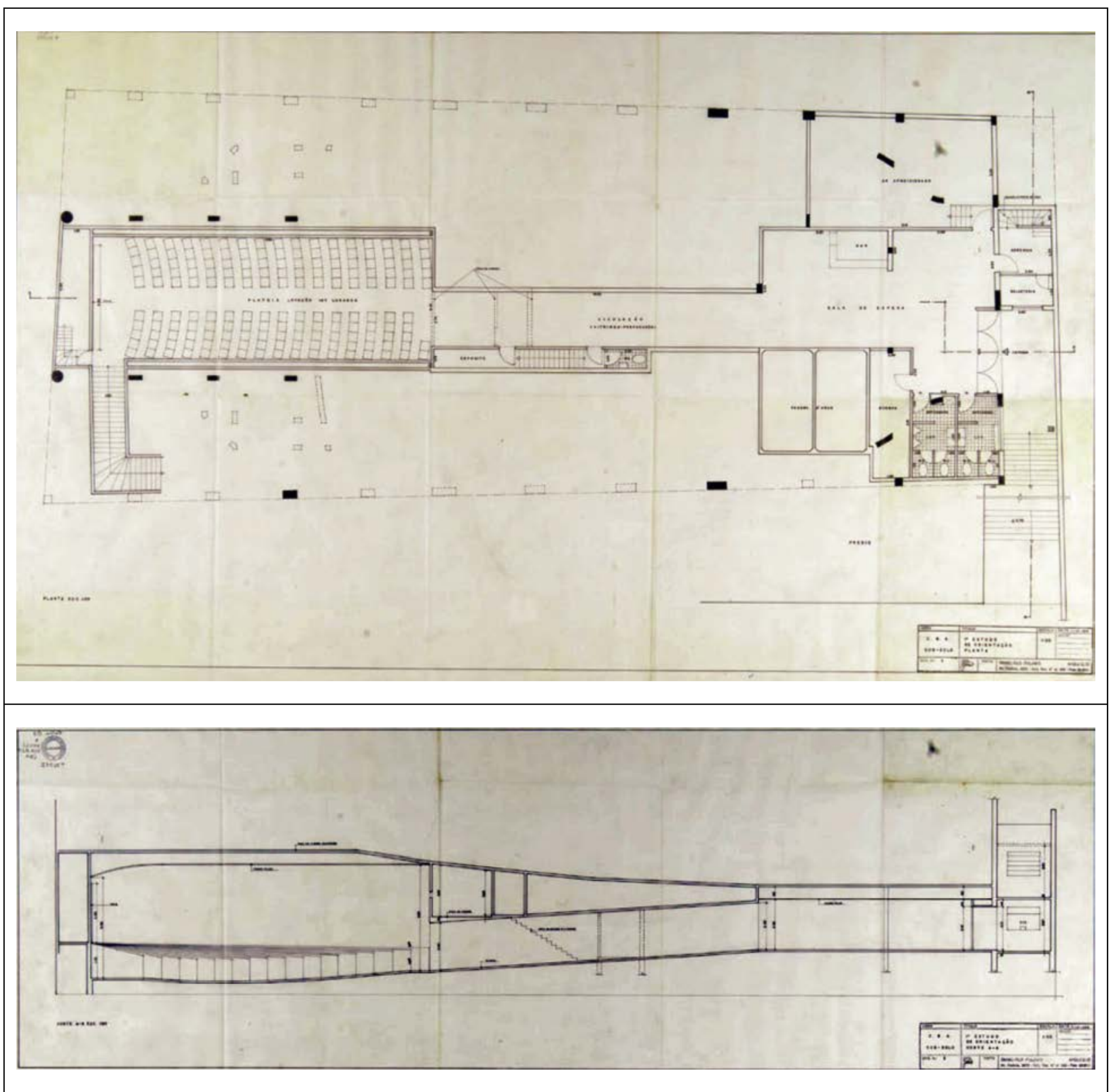

Figura 51: Cine Trianon - 1952

Acima: Planta da sala de projeção localizada no subsolo

Abaixo: corte longitudinal da sala do subsolo, notar que a tela de projeção está no sentido oposto à grande sala do pavimento térreo. ${ }^{87}$

\footnotetext{
${ }^{87}$ Fonte: Arquivo GP / FAU - USP
} 


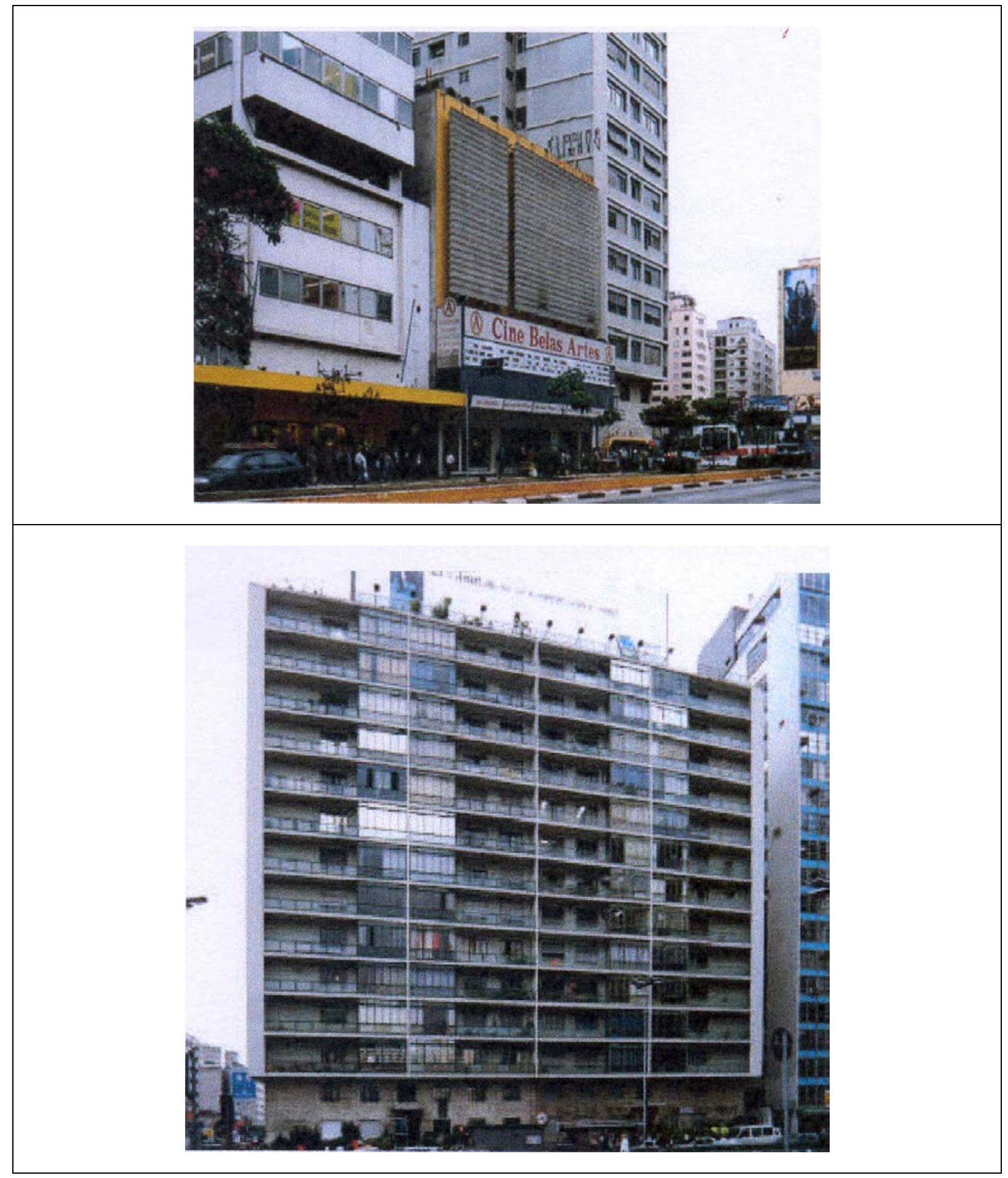

Figura 52: Edifícios Chipre e Gibraltar e Cine Trianon - 1952 Fotos do conjunto em 2003.88

${ }^{88}$ Fonte: Arquivo GP / FAU - USP 


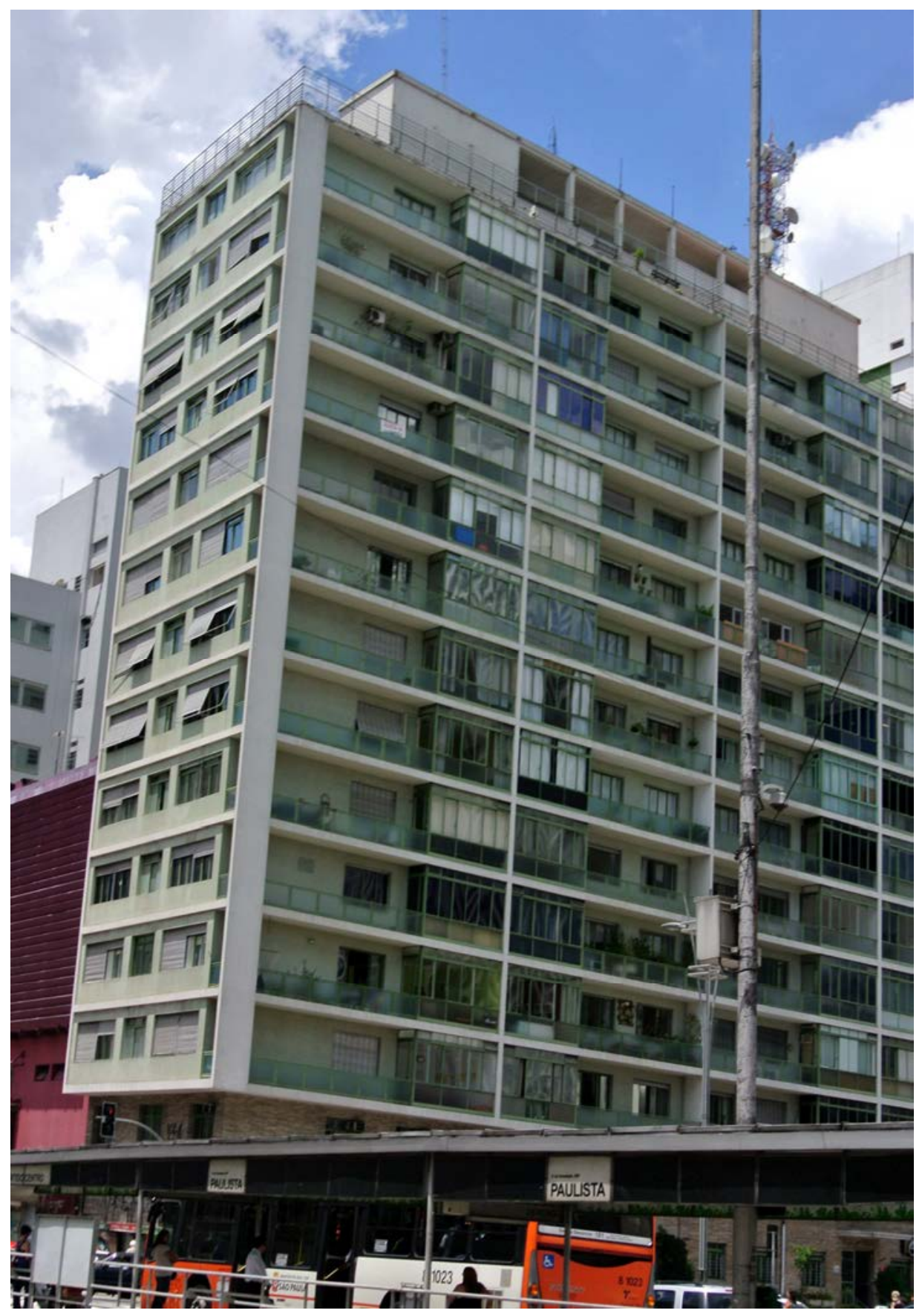

Figura 53: Edifícios Chipre e Gibraltar e Cine Trianon - 1952 . Foto do conjunto em $2013^{89}$

\footnotetext{
${ }^{89}$ Foto: Demósthenes Magno Santos - fevereiro/ 2013
} 


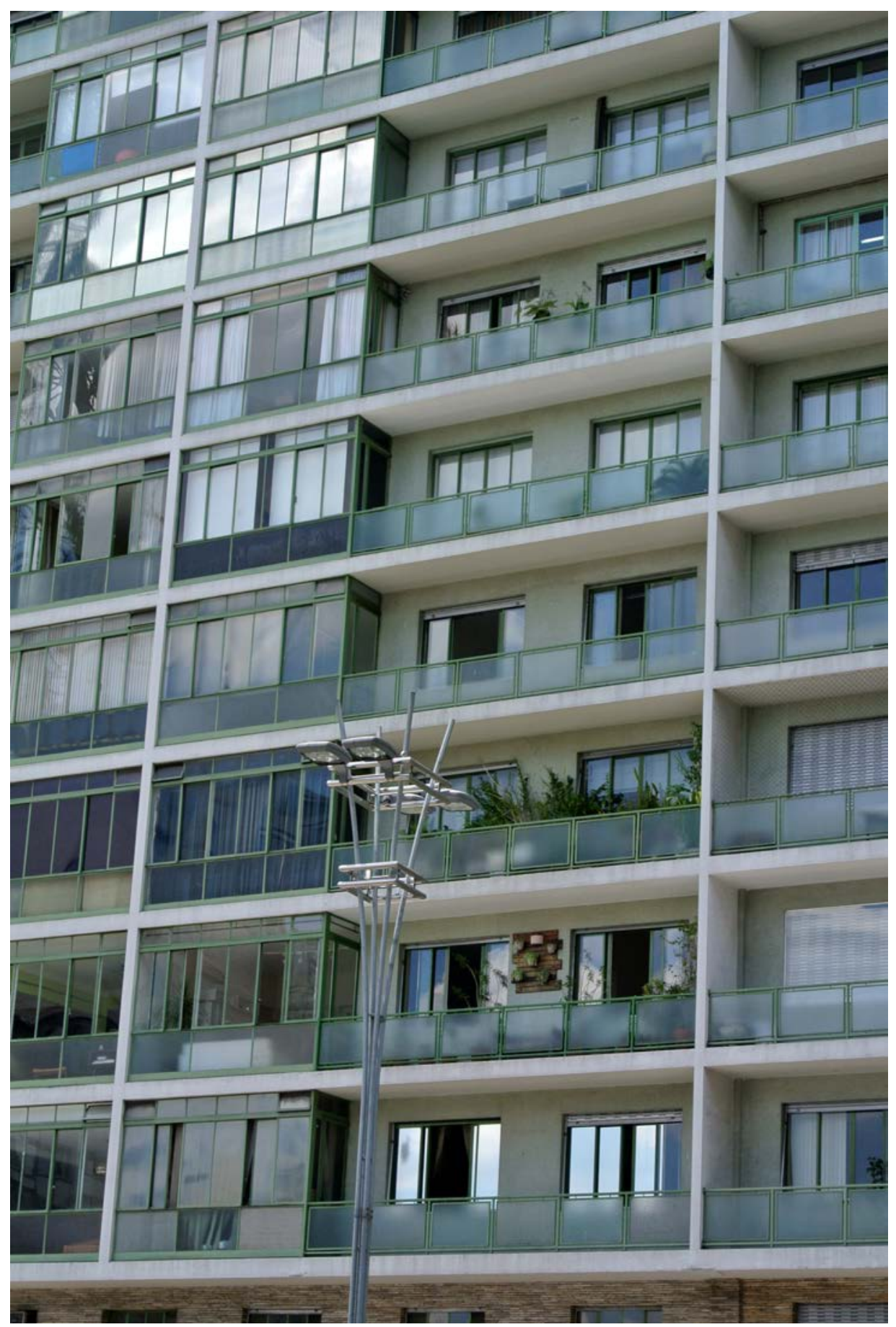

Figura 54: Edifícios Chipre e Gibraltar e Cine Trianon - 1952 Foto do conjunto em 201390

\footnotetext{
${ }^{90}$ Foto: Demósthenes Magno Santos - fevereiro/ 2013
} 


\subsubsection{Edifício na Rua Barão de Tatuí, 351 - 1953}

Este prédio de apartamentos de aluguel91, segundo Aline Sanchez, foi projetado por Palanti para sua noiva Lívia Maria Maggi, embora não faça referência da empresa construtora Sylvia Ficher em seu livro "Os Arquitetos da Poli" 92 afirma que a construção foi da Construtora Alfredo Mathias sendo a autoria do arquiteto Italiano. Recebeu o nome de Edifício Lili (Lili era o apelido de Lívia Maggi).

O projeto foi implantado em um terreno de quinze metros de frente o que resultou na configuração de dois apartamentos por andar, de dois quartos, com sala, cozinha, banheiro, quarto de empregada, WC e área de serviços. A organização dos espaços, a colocação das circulações no centro do projeto resultou numa distribuição onde praticamente não existem corredores. Nota-se nesta planta a preocupação na compartimentação de atividades e principalmente a diferenciação de acessos social e de serviços.

O edifício foi implantado no centro do lote, com recuos na frente e nos fundos, sem recuos laterais, onde manteve as empenas cegas; aproveitou o declive do terreno, da rua para os fundos, para implantar o estacionamento e um depósito para cada apartamento. Nas palavras de Aline Sanchez:

\footnotetext{
"A relação entre o edifício e a rua é amistosa, mediada por um jardim, um muro e gradil baixo, que assim permanecem até hoje, e por uma marquise e escada que juntas formam um desenho que parece conduzir à entrada, a primeira ascendente e a segunda descendente em relação ao acesso, como uma espécie de convite." (Corato, 2008)
}

\footnotetext{
91 O bairro de Santa Cecília próximo ao bairro de Higienópolis foi alvo deste tipo de empreendimento naqueles anos.

92 EDUSP - Editora da Universidade de São Paulo, São Paulo, 2005
} 
As fachadas em tons de ocre tiveram os parapeitos delimitados por floreiras e podem ser completamente abertos ou fechados por venezianas embutidas nas paredes (a fachada principal está diretamente posicionada para o poente), o desalinho entre os terraços e a linha das janelas foi recebido com estranheza pela imprensa especializada exceto pela revista Habitat dirigida pelo casal Bardi que elogia a atuação do arquiteto (figuras de 55 a 69). 93

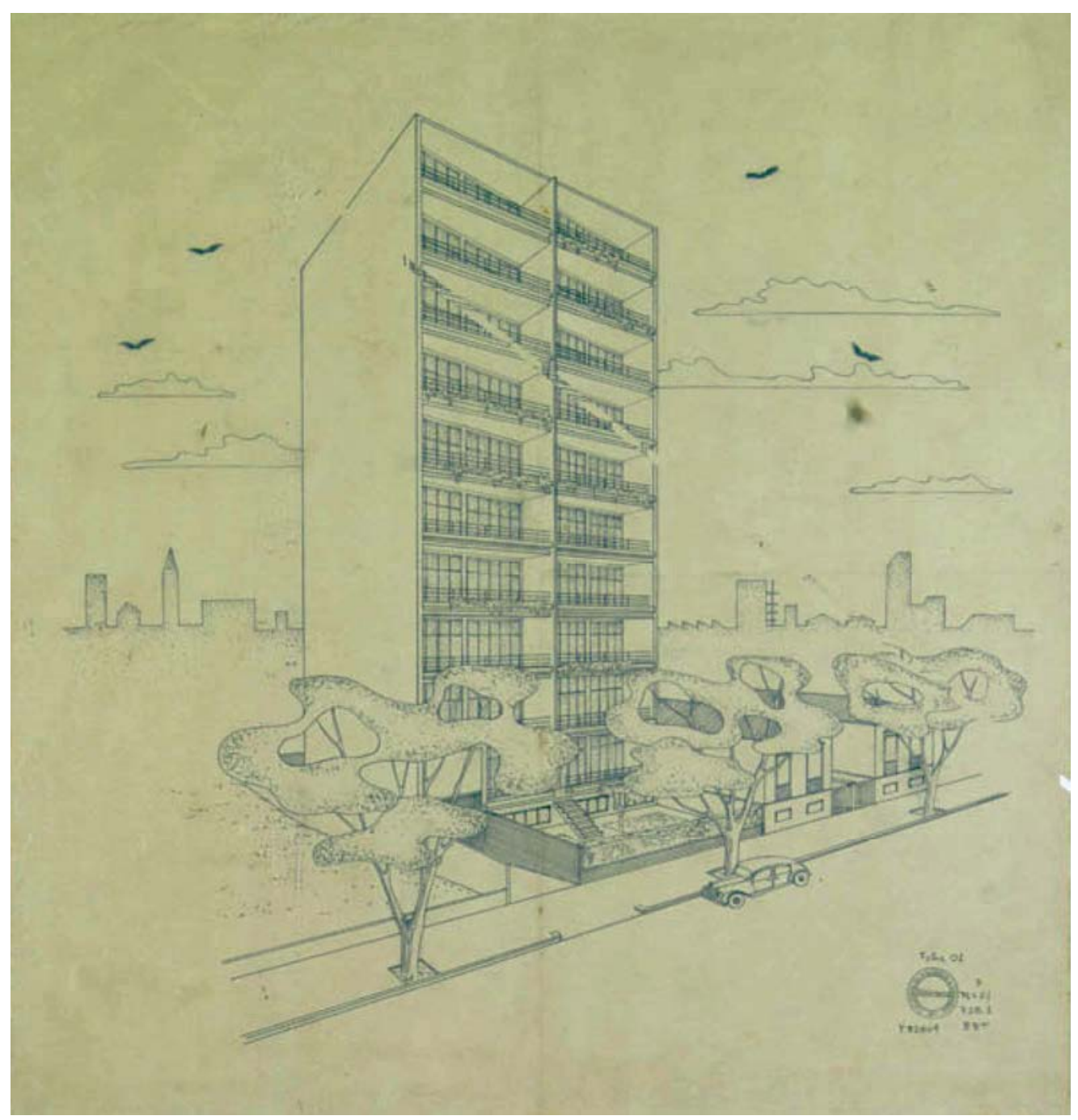

Figura 55: Edifício Lili, Rua Barão de Tatuí, 351 - 1953

93 Revista Habitat, 1953 apud Aline Sanchez, pg. 108 - 2004 
Estudos iniciais - perspectiva ${ }^{94}$

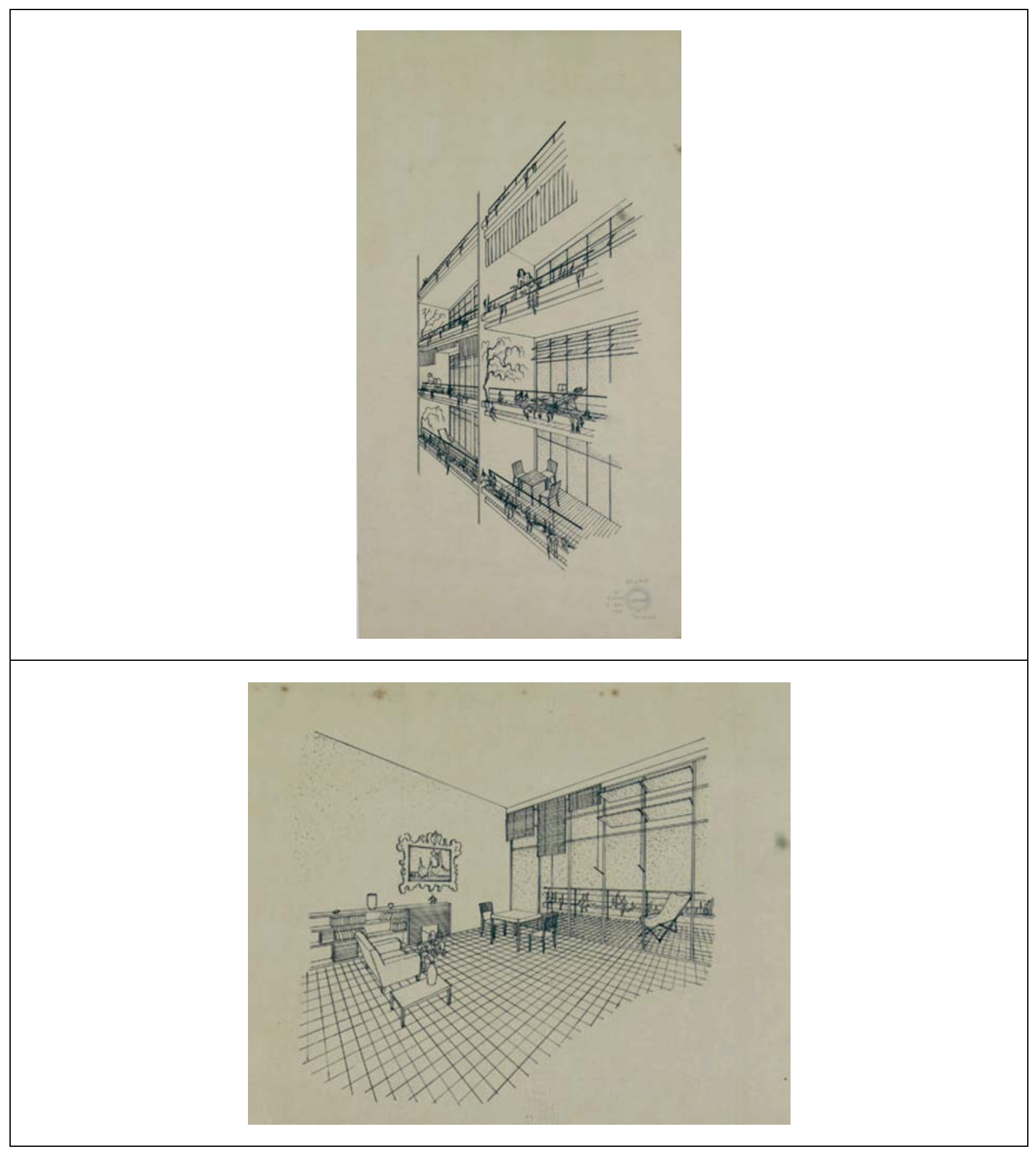

Figura56: Edifício Lili, Rua Barão de Tatuí, 351 - 1953

Estudos iniciais - perspectivas internas 95

\footnotetext{
${ }^{94}$ Fonte: Arquivo GP / FAU - USP

${ }^{95}$ Fonte: Arquivo GP / FAU - USP
} 


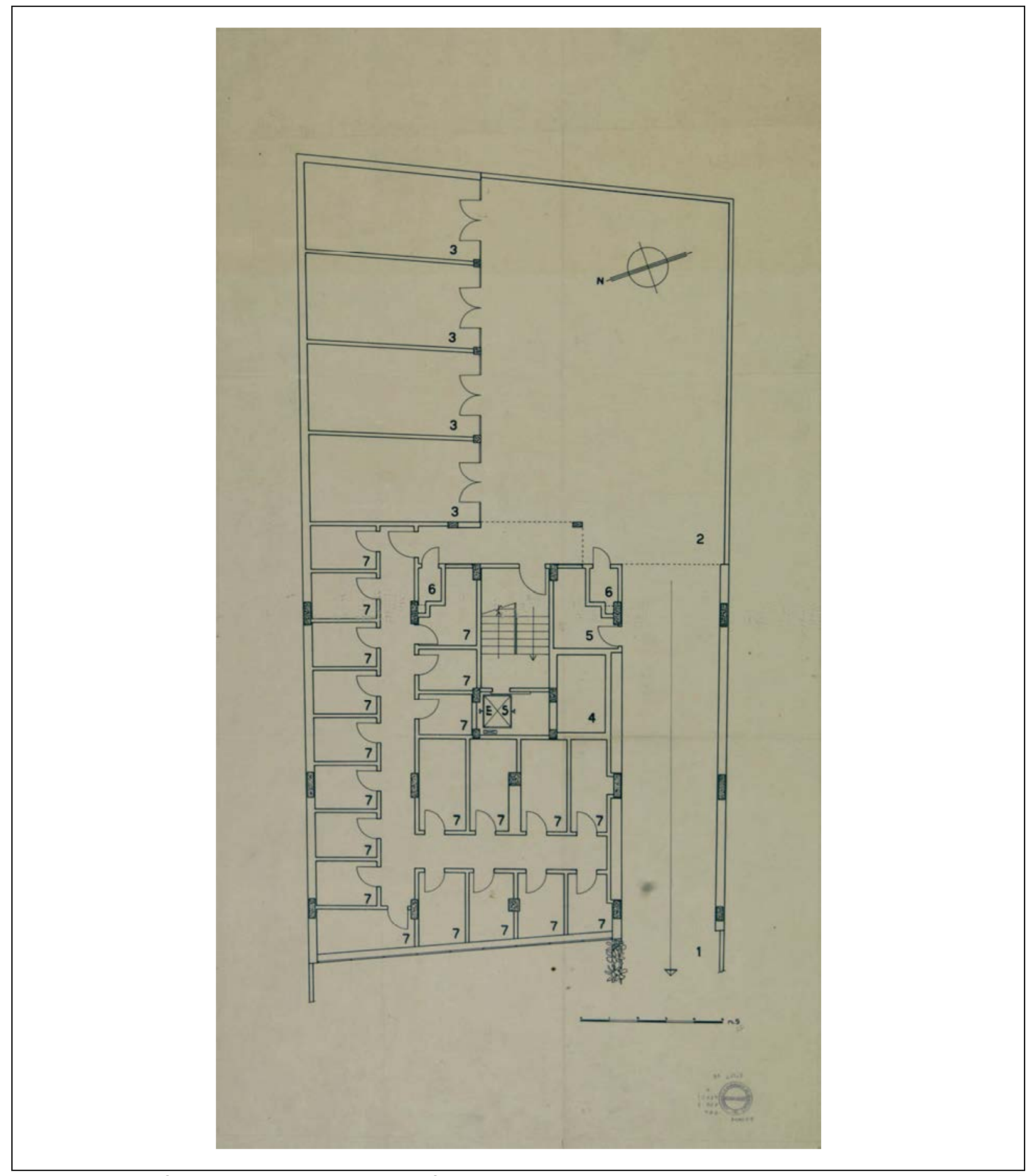

Figura 57: Edifício Lili, Rua Barão de Tatúi, 351 - 1953

Planta do Subsolo:96

\footnotetext{
${ }^{96}$ Fonte: Arquivo GP / FAU - USP
} 


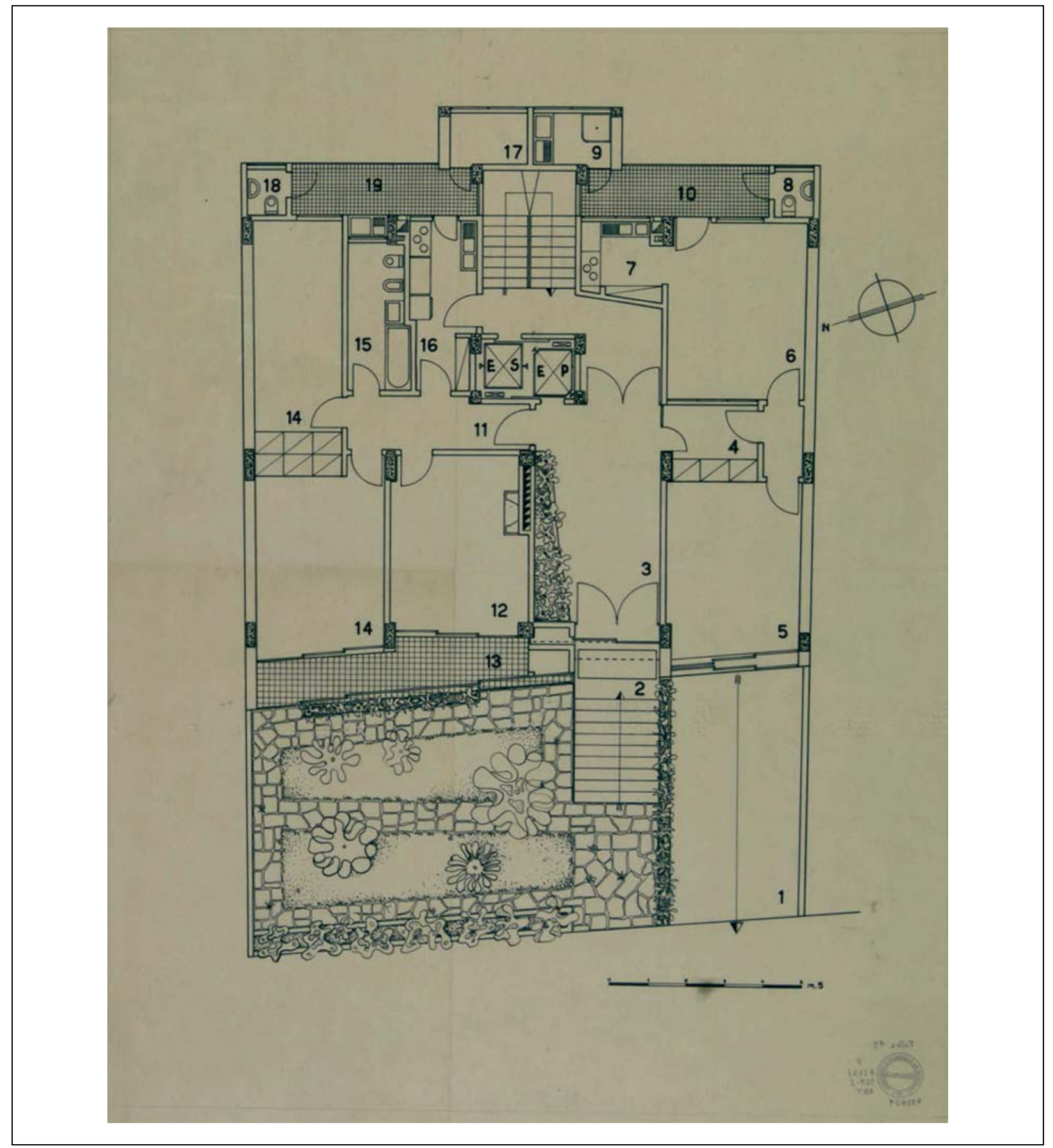

Figura 58: Edifício Lili, Rua Barão de Tatuí, 351 - 1953

Planta do Pavimento Térreo:97

\footnotetext{
${ }^{97}$ Fonte: Arquivo GP / FAU - USP
} 


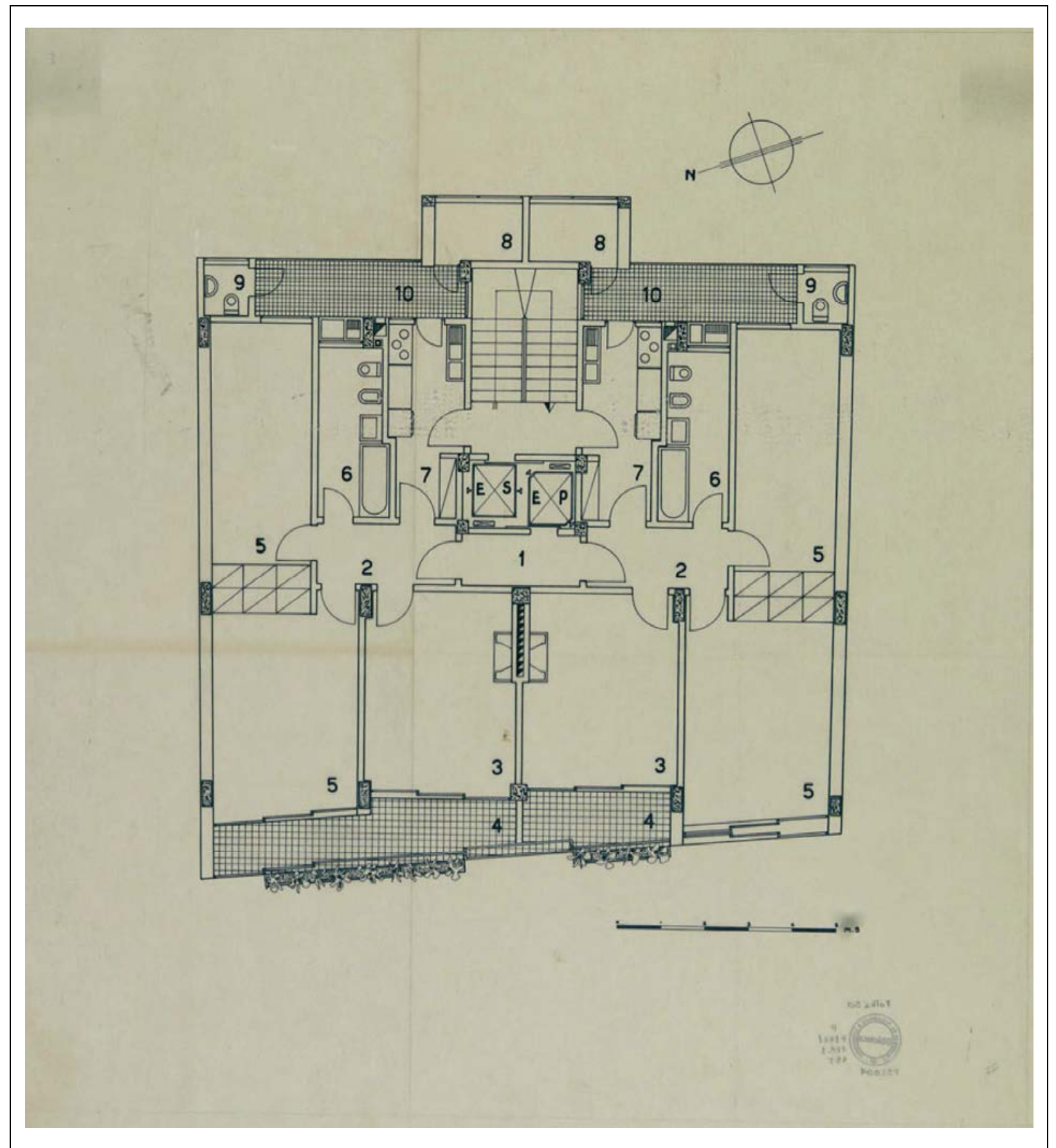

Figura 59: Edifício Lili, Rua Barão de Tatuí, 351 - 1953

Planta do Pavimento Tipo:98

\footnotetext{
${ }^{98}$ Fonte: Arquivo GP / FAU - USP
} 


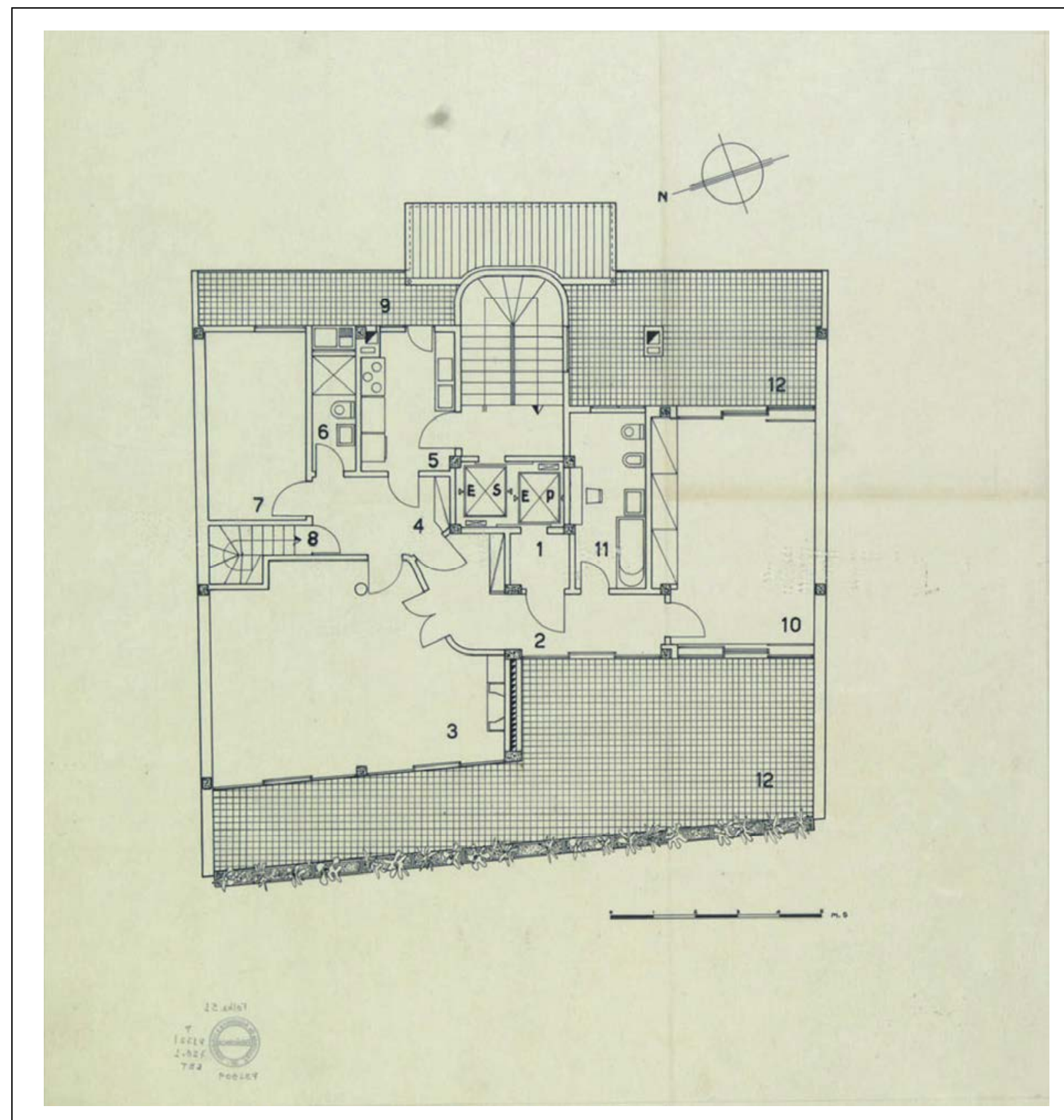

Figura 60: Edifício Lili, Rua Barão de Tatuí, 351 - 1953

Planta do Pavimento de Cobertura: 99

${ }^{99}$ Fonte: Arquivo GP / FAU - USP 


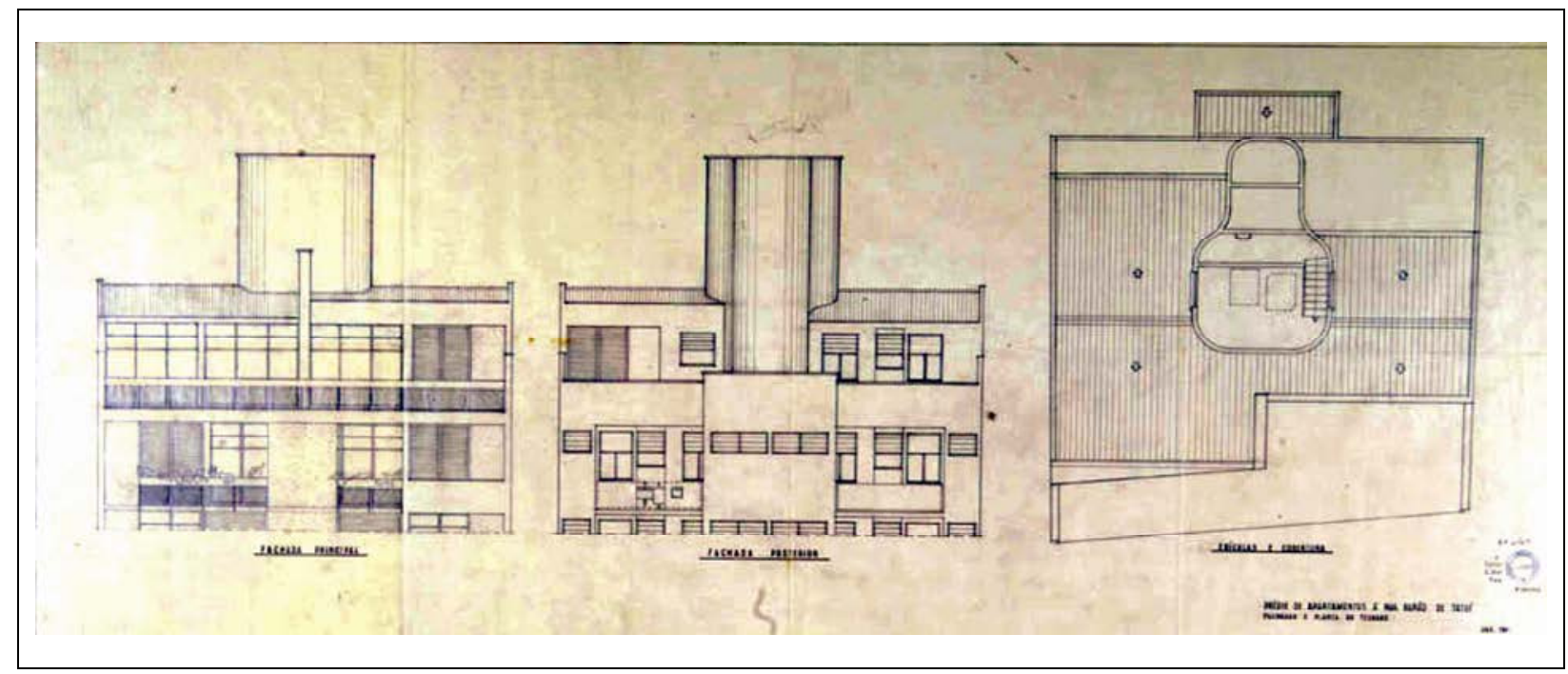

Figura 61: Edifício Lili, Rua Barão de Tatuí, 351 - 1953

Planta do Ático:100

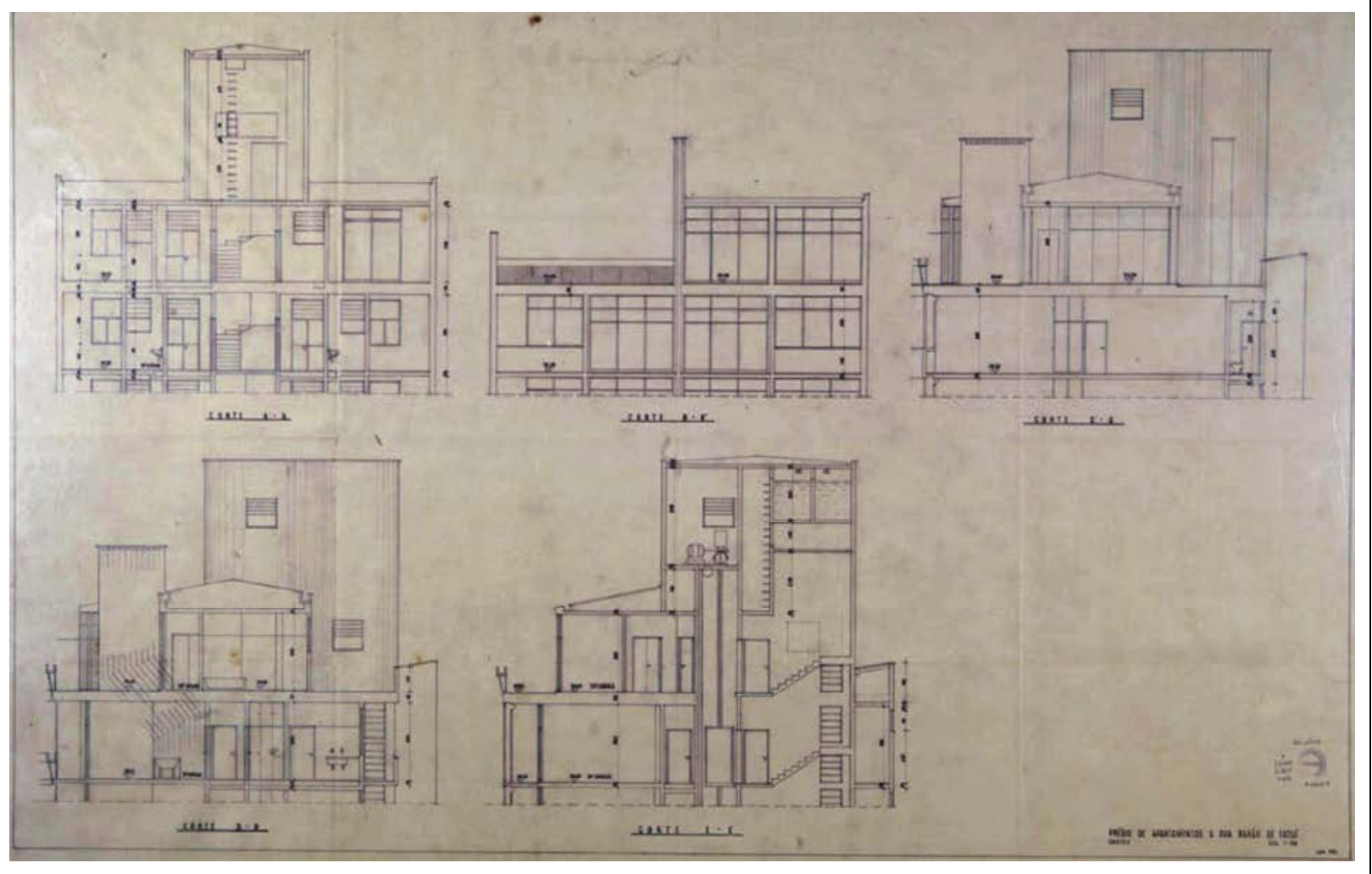

Figura 62: Edifício Lili, Rua Barão de Tatuí, 351 - 1953 Cortes:101

\footnotetext{
${ }^{100}$ Fonte: Arquivo GP / FAU - USP

${ }^{101}$ Fonte: Arquivo GP / FAU - USP
} 


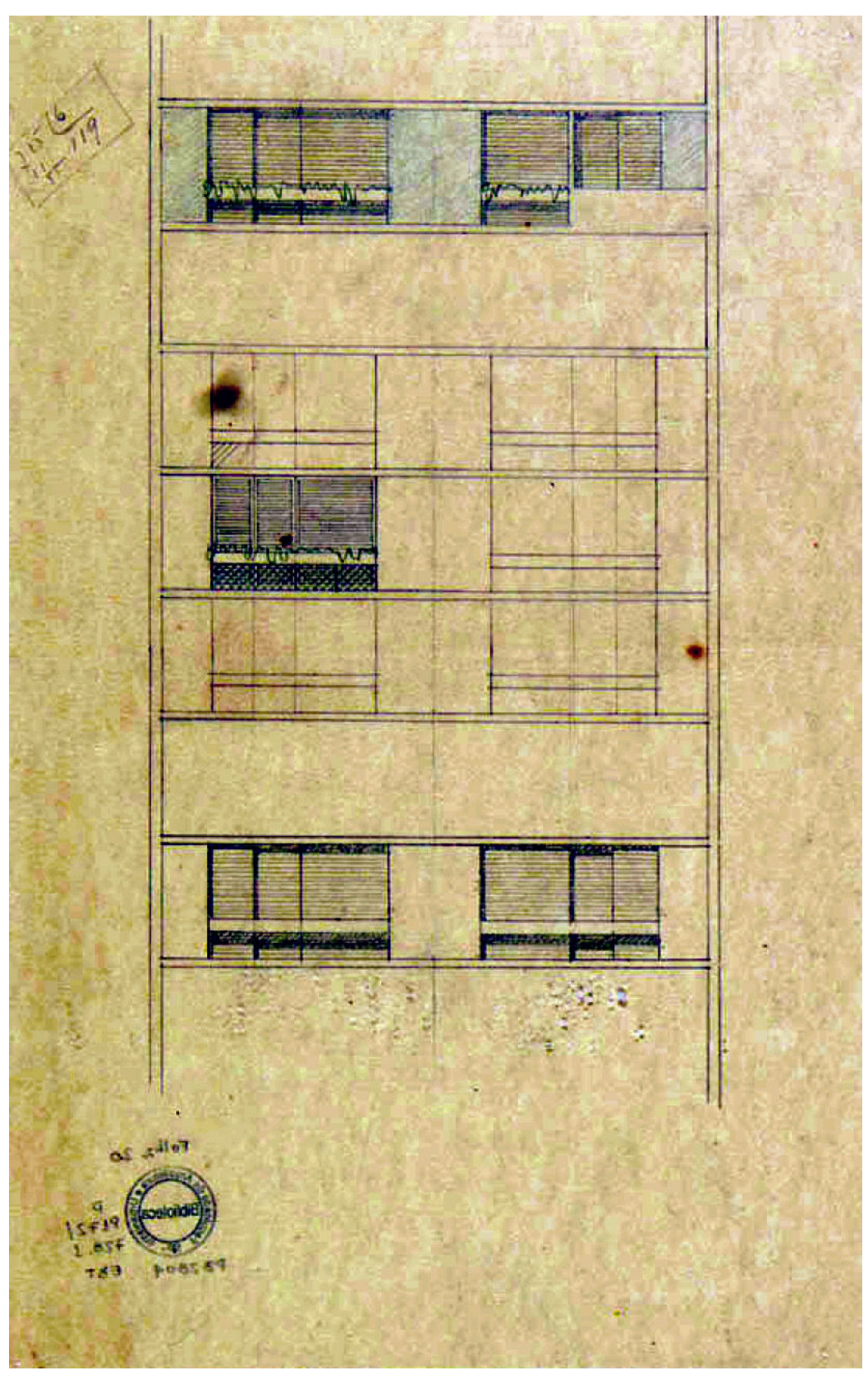

Figura 63: Edifício Lili, Rua Barão de Tatuí, 351 - 1953 Estudos de Fachada 102

${ }^{102}$ Fonte: Arquivo GP / FAU - USP 


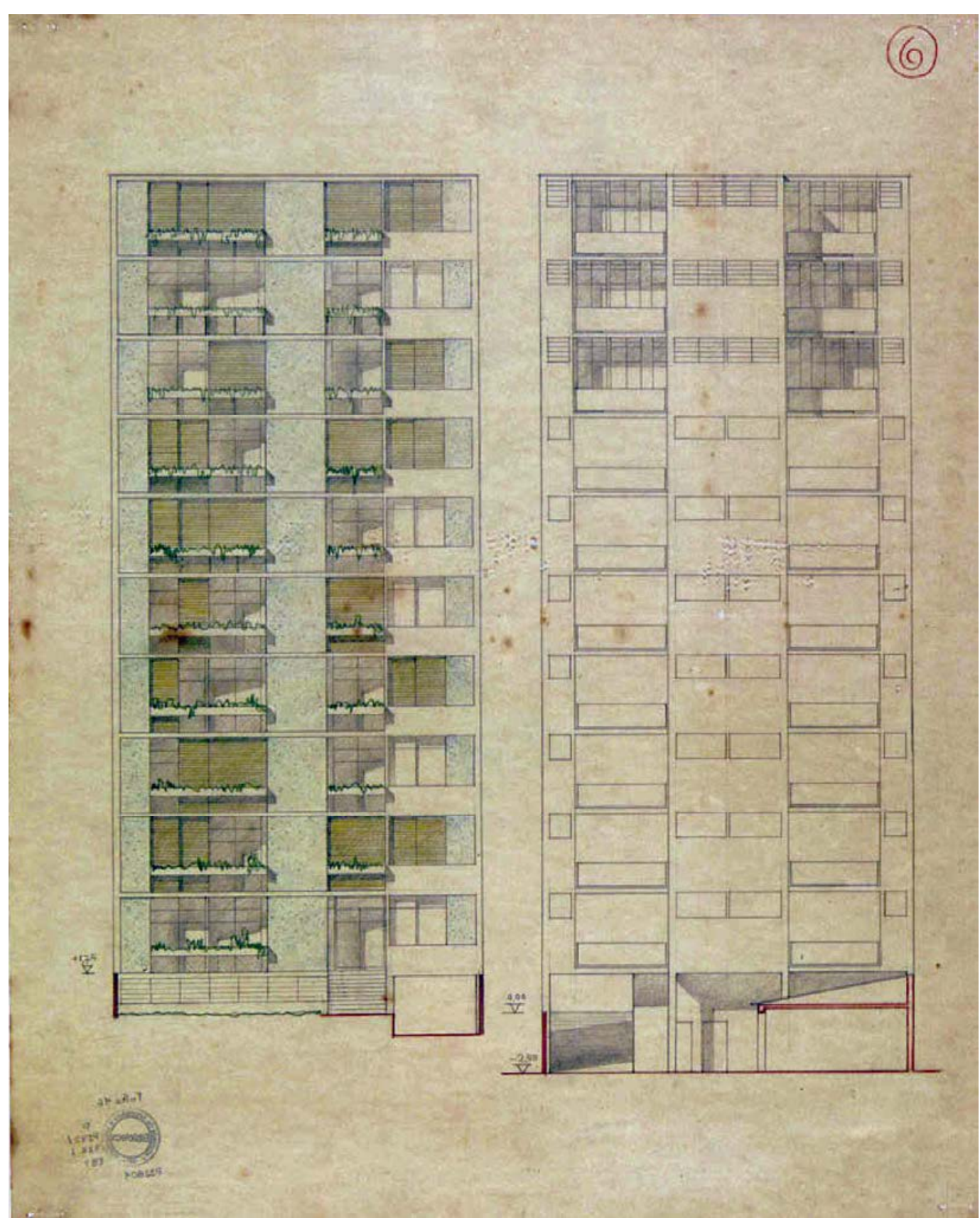

Figura 64: Edifício Lili, Rua Barão de Tatuí, 351 - 1953 Fachadas 103

${ }^{103}$ Fonte: Arquivo GP / FAU - USP 


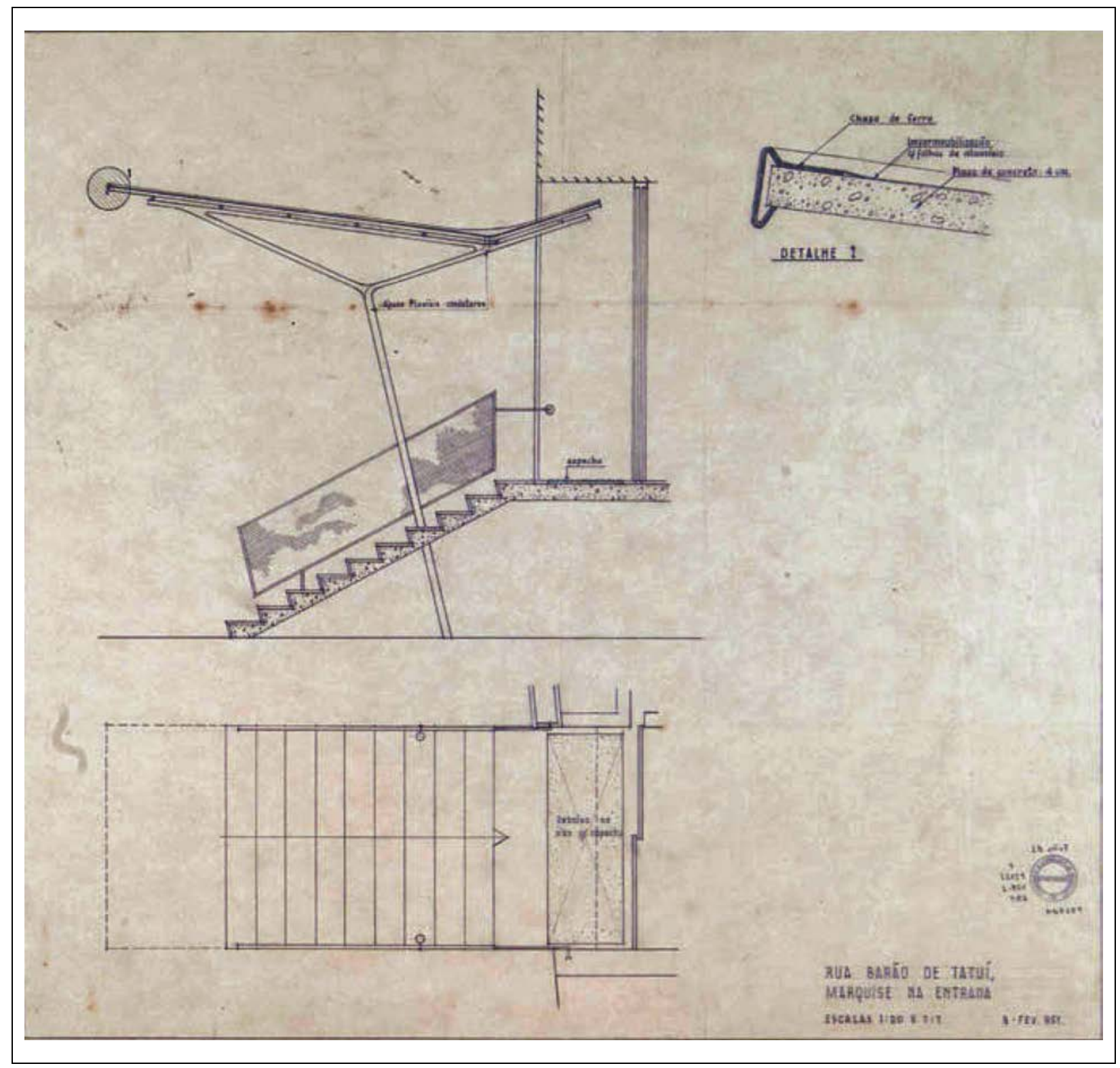

Figura 65: Edifício Lili, Rua Barão de Tatuí, 351 - 1953

Detalhe da Escada e Marquise ${ }^{104}$

${ }^{104}$ Fonte: Arquivo GP / FAU - USP 


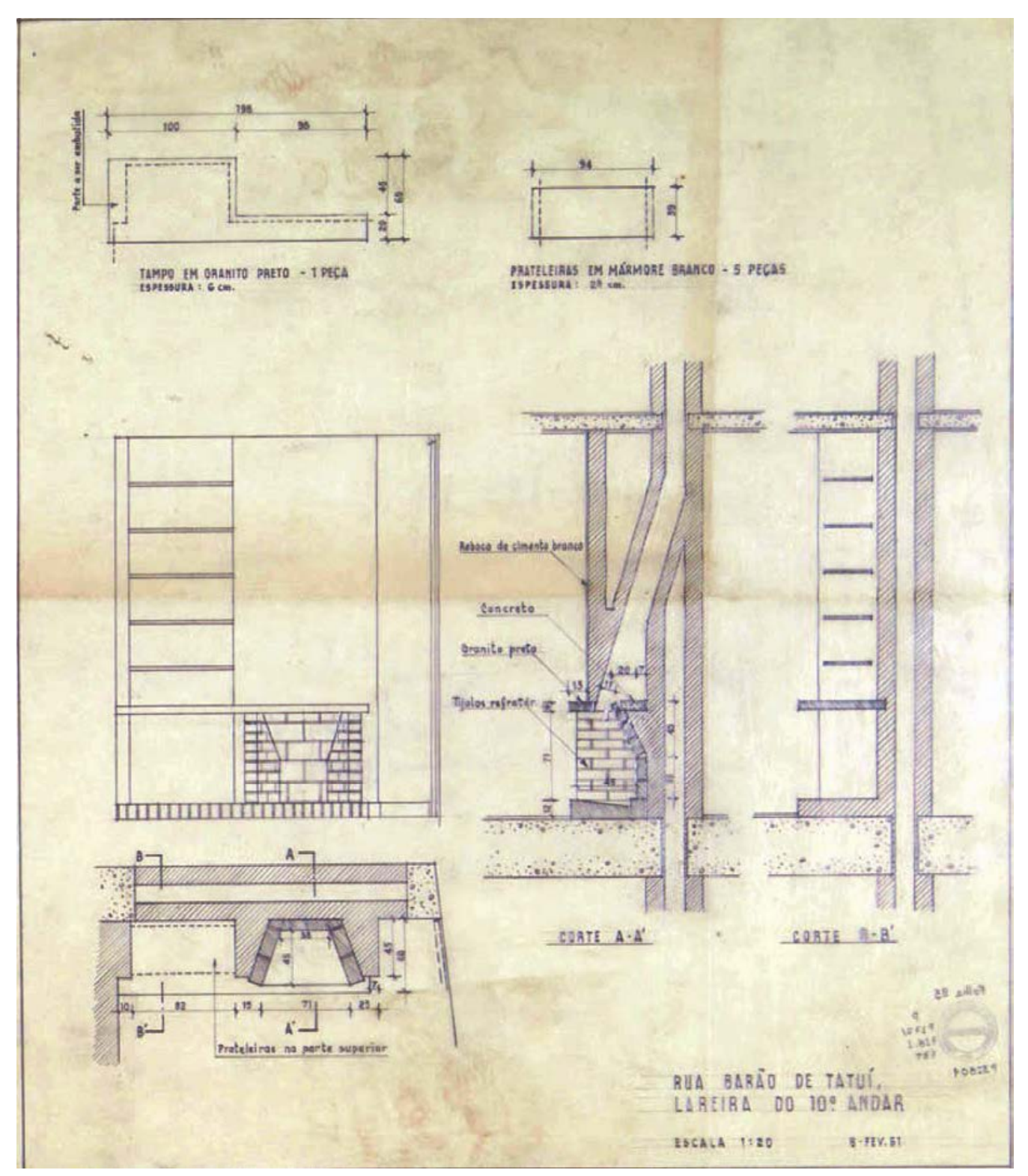

Figura 66: Edifício Lili, Rua Barão de Tatuí, 351 - 1953

Detalhe da Lareira ${ }^{105}$

${ }^{105}$ Fonte: Arquivo GP / FAU - USP 


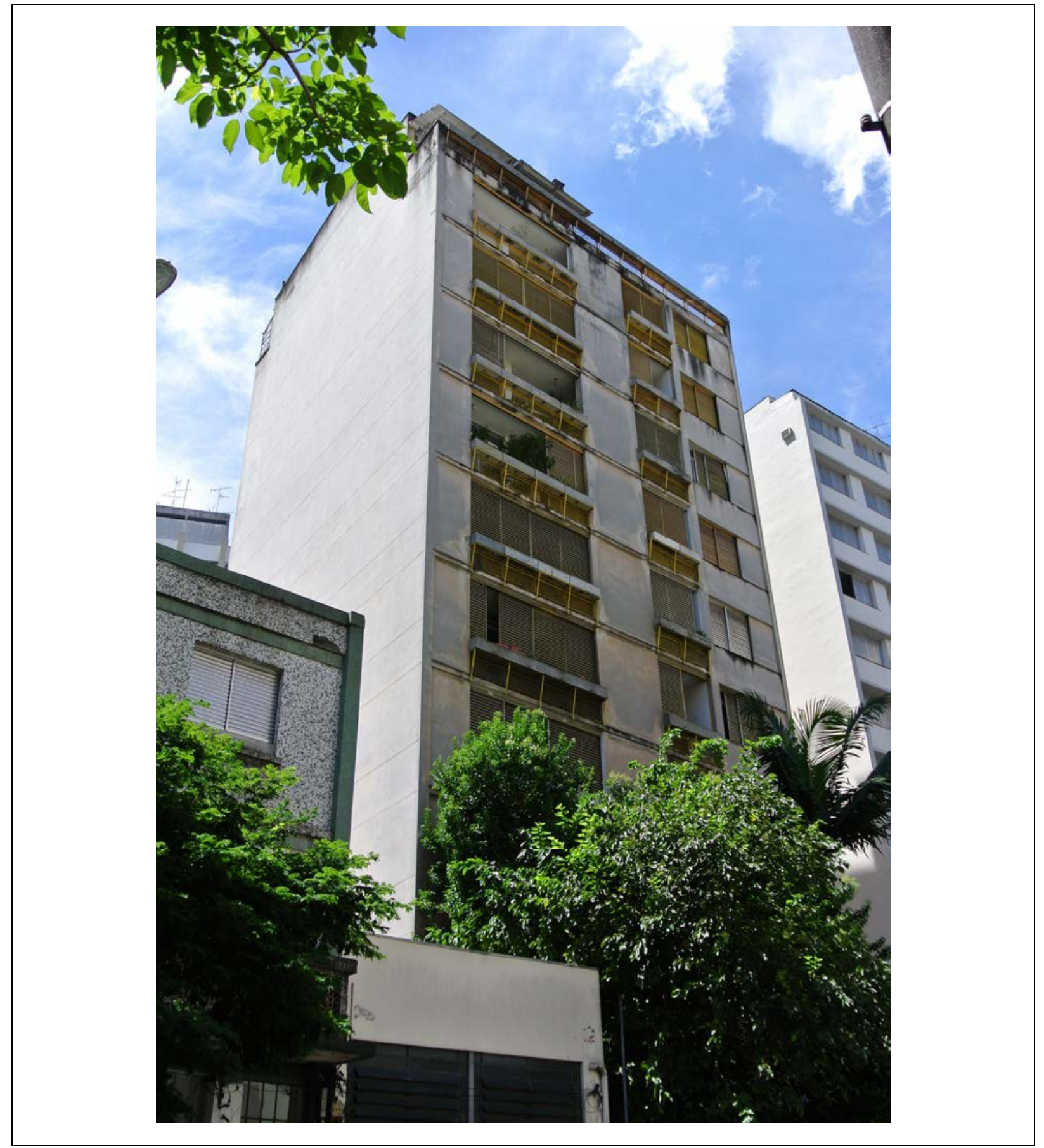

Figura 67: Edifício Lili, Rua Barão de Tatuí, 351 - 1953 Fachada Principal - estado atual 106

${ }^{106}$ Foto: Demósthenes Magno Santos - fev. 2013 


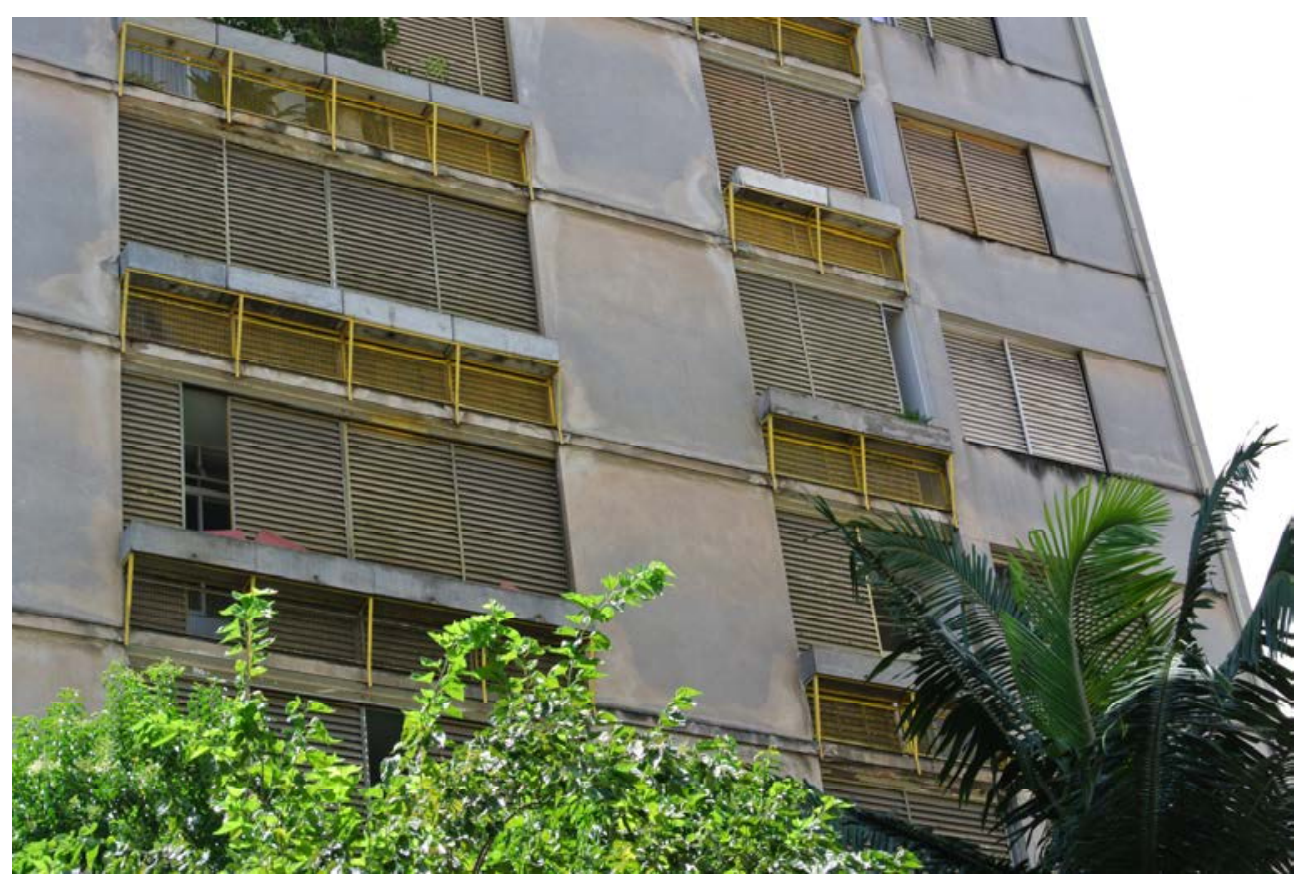

Figura 68: Edifício Lili, Rua Barão de Tatuí, 351 - 1953 Fachada Principal - detalhe 107

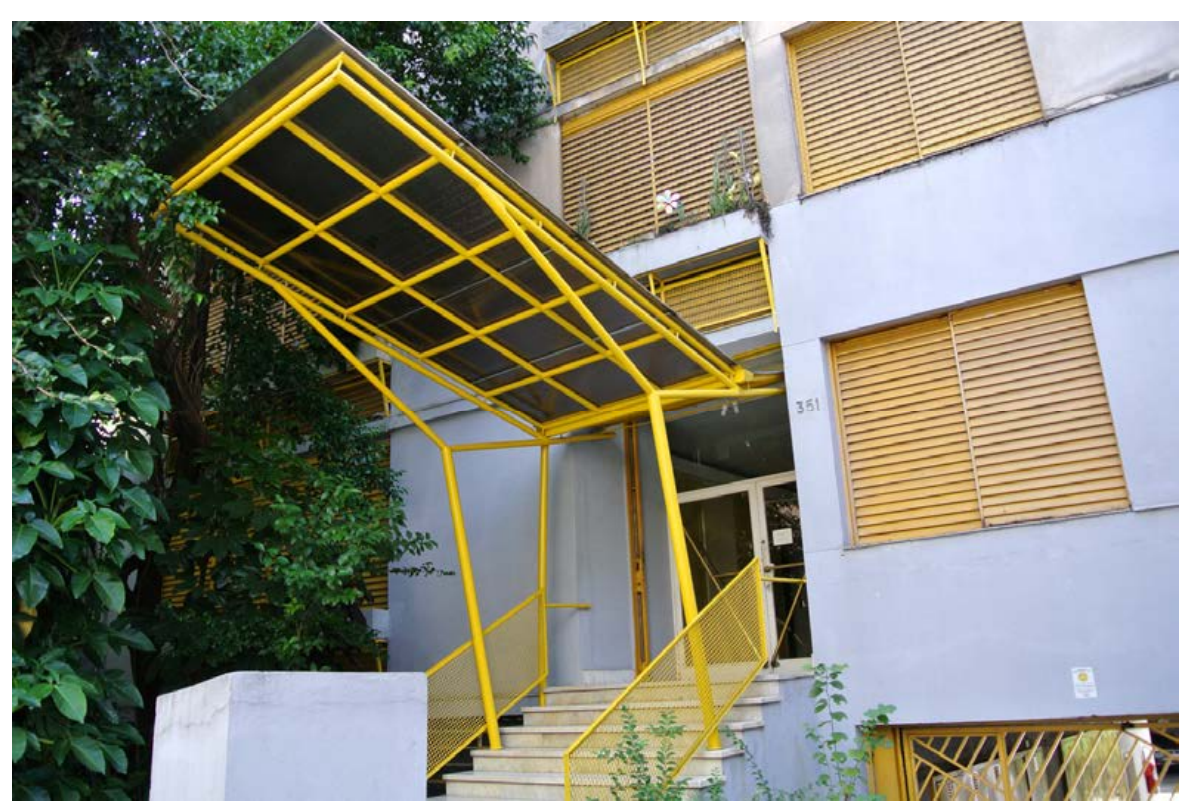

Figura 69: Edifício Lili, Rua Barão de Tatuí, 351 - 1953

Fachada Principal - detalhe da marquise 108

${ }^{107}$ Foto: Demósthenes Magno Santos - fev. 2013

${ }^{108}$ Foto: Demósthenes Magno Santos - fev. 2013 
Mais um exemplar da parceria Palanti e Alfredo Mathias, a biblioteca foi um presente do casal Renata Crespi da Silva Prado e Fábio da Silva Prado ao município de Araras no interior de São Paulo, recebeu o nome do pai de Fábio Prado Martinico Prado, importante cafeicultor e expoente político do estado durante a Primeira República.

O edifício está implantado no centro de uma praça e apresenta um hall de distribuição aberto para duas ruas que permite ao transeunte atravesse a praça passando dentro da biblioteca. Nesta galeria estão conectados os principais volumes que constituem a biblioteca: um volume mais alto, prismático, recebe o acervo e outro, mais baixo e horizontal contém um auditório para 120 pessoas, a sala de leitura, a administração e dependências de apoio. A distribuição dos volumes a partir de um eixo axial permitiu que a edificação não tivesse uma fachada que fosse considerada de fundos em relação à praça; no entanto, o tratamento semelhante em ambas as fachadas provocou problemas de insolação embora existam pequenas abas sobre as janelas na tentativa de minimizar a incidência solar. As cadências de linhas horizontais e verticais na fachada evidenciam o traço de Palanti e faz com que o edifício ganhe certa imponência.

Como havia o problema do reconhecimento do diploma dos arquitetos estrangeiros mais uma vez a autoria fica registrada apenas no nome de Alfredo Mathias conforme a placa comemorativa encontrada no interior da biblioteca (figuras 70 a 72 ). 


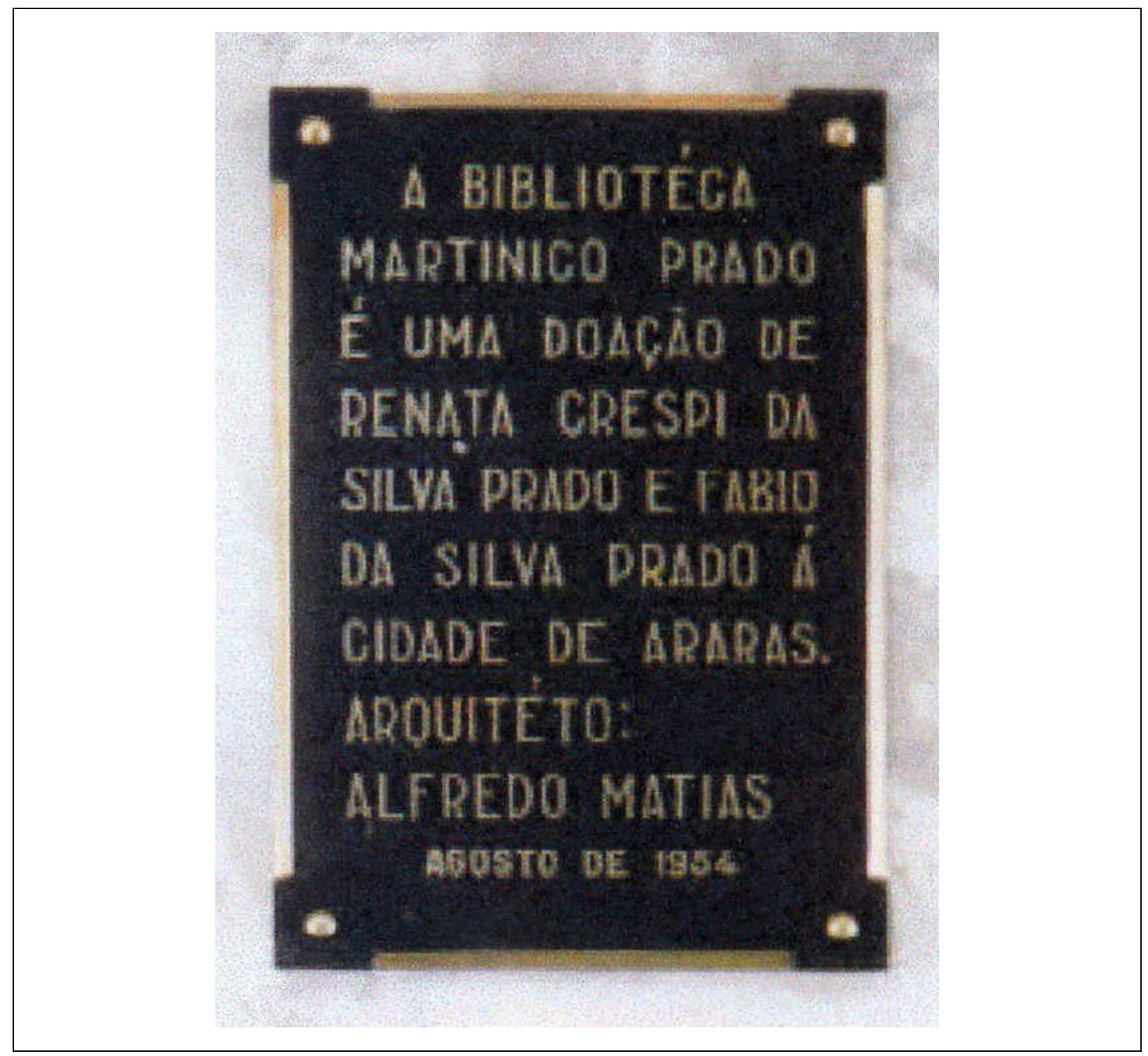

Figura 70: Biblioteca Pública Martinico da Silva Prado - Araras - S.P. - 1954 Placa Comemorativa109

${ }^{109}$ Fonte: Aline Sanchez, pg. 182 - 2004 

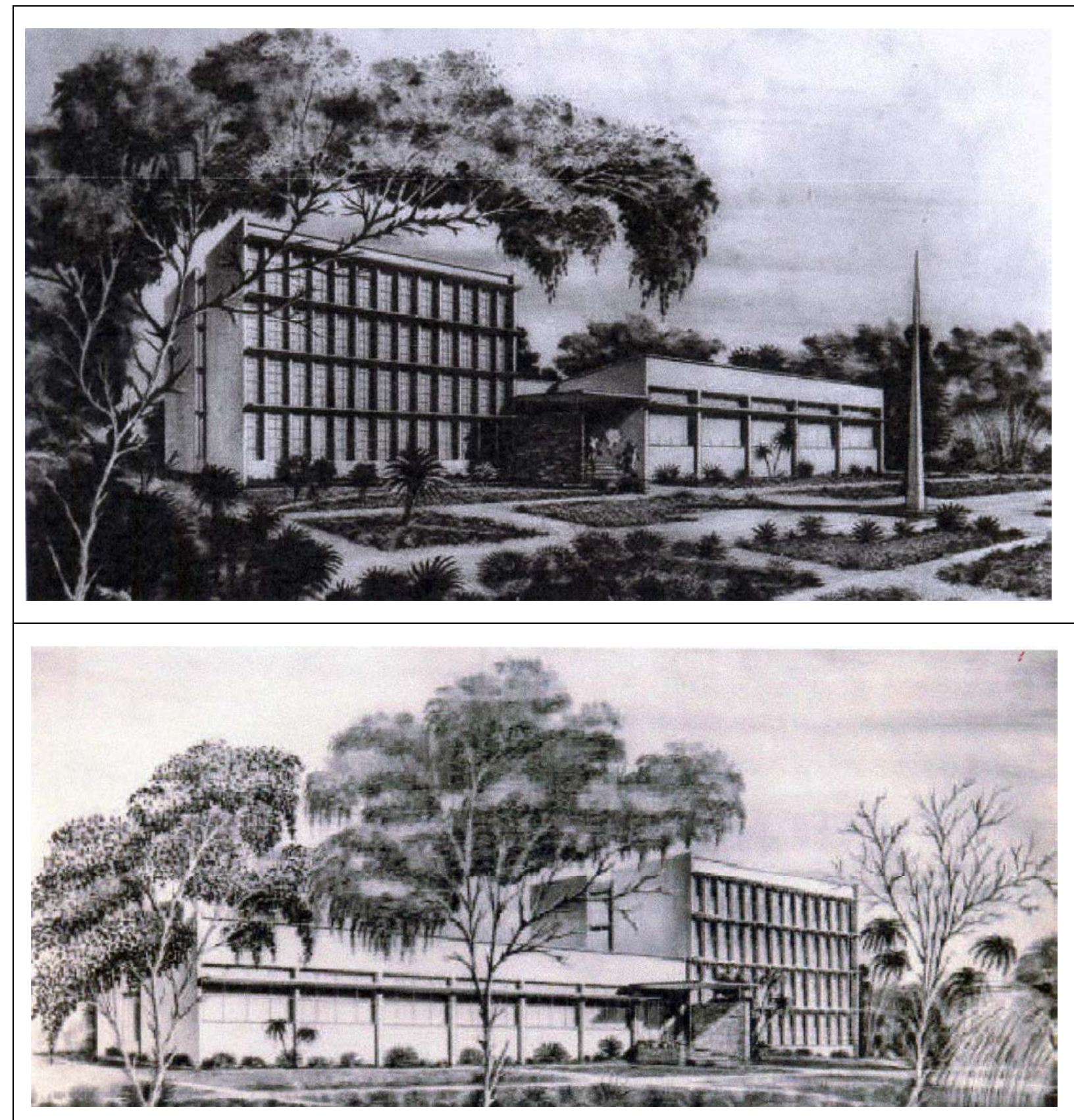

Figura 71: Biblioteca Pública Martinico da Silva Prado - Araras - SP - 1954 Estudos das Fachadas - Perspectiva - Giancarlo Palanti 10

${ }^{110}$ Fonte: Arquivo GP / FAU - USP 


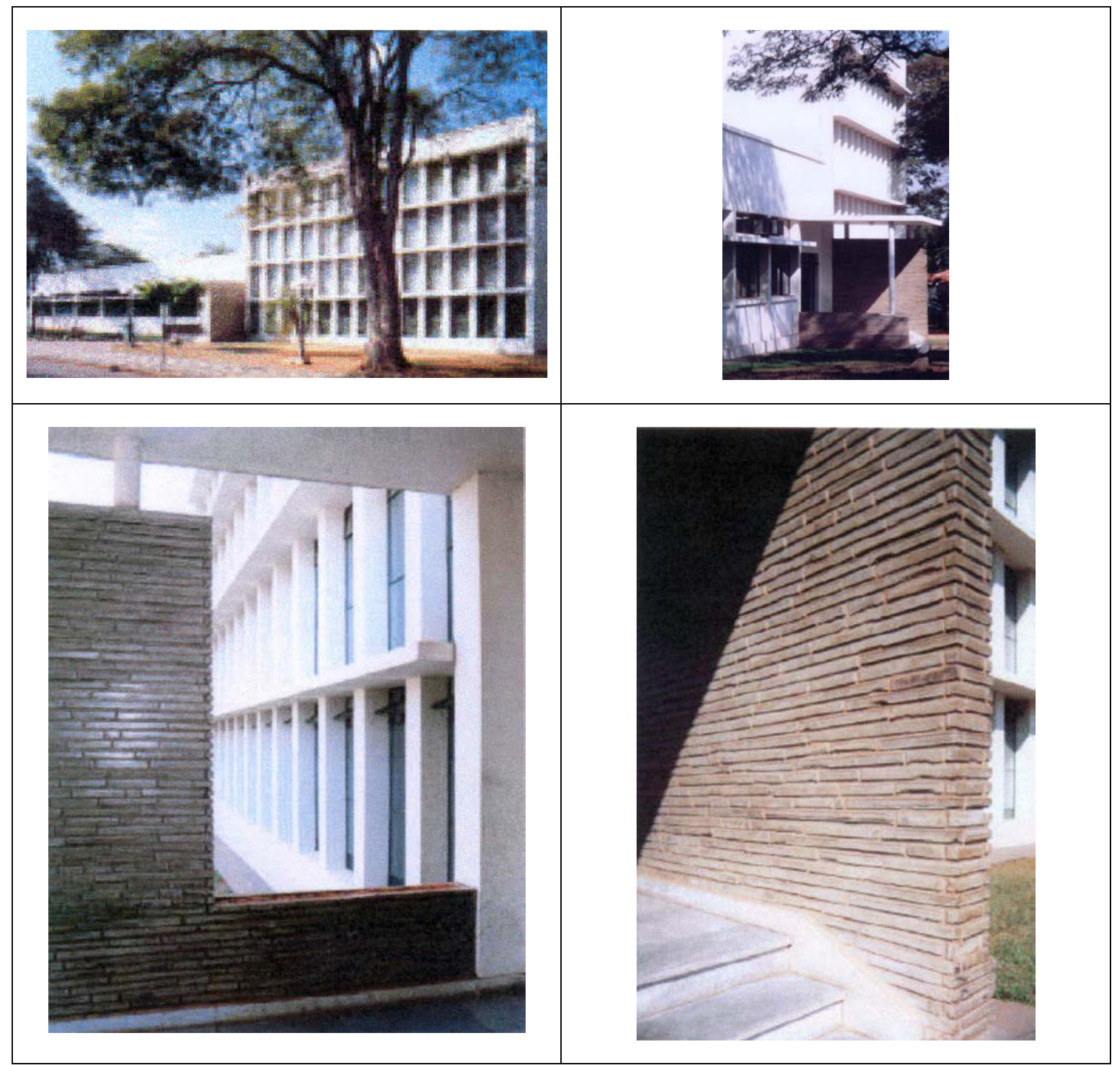

Figura 72: Biblioteca Pública Martinico da Silva Prado - Araras - SP - 1954 Fotos do local ${ }^{111}$

${ }^{111}$ Fonte: Aline Sanchez, pg. 182 - 2004 


\subsubsection{Propostas para o Paço Municipal de São Paulo - 1952}

Em 1952 foi realizado um concurso para a construção do Paço Municipal de São Paulo, no terreno ente a Praça da Bandeira, Rua Santo Antonio, Viaduto Jacareí e Rua Santo Amaro - local previsto desde a apresentação do Plano de Avenidas de Prestes Maia. Segundo Luiz Saia não houve nenhum projeto classificado em primeiro lugar e o prefeito Armando de Arruda Pereira nomeia o arquiteto Oscar Niemeyer para a elaboração do projeto, na administração seguinte, de Jânio Quadros, o projeto não foi considerado prioritário nem pela prefeitura ou pelo governo do Estado.

No concurso a Construtora Alfredo Mathias recebeu duas menções honrosas por dois projetos apresentados que foram projetados por Palanti. Os projetos apresentados partem de esplanadas ajardinadas onde os edifícios sobre pilotis liberariam a passagem de pedestres e permitissem uma visão panorâmica do Vale do Anhangabaú, o prédio do executivo seria uma lâmina de 114 metros de comprimento e 75 metros de altura no sentido perpendicular ao eixo do vale.

Para as fachadas, o arquiteto utilizou o sistema modular na divisão dos caixilhos a fim de facilitar a colocação de divisórias pré-fabricadas; mais uma vez o conceito da composição das fachadas parte do conceito empregado no Edifício Conde Prates na composição das paredes envidraçadas marcando mais um dos pontos chaves da paisagem paulistana (Figura 73) 


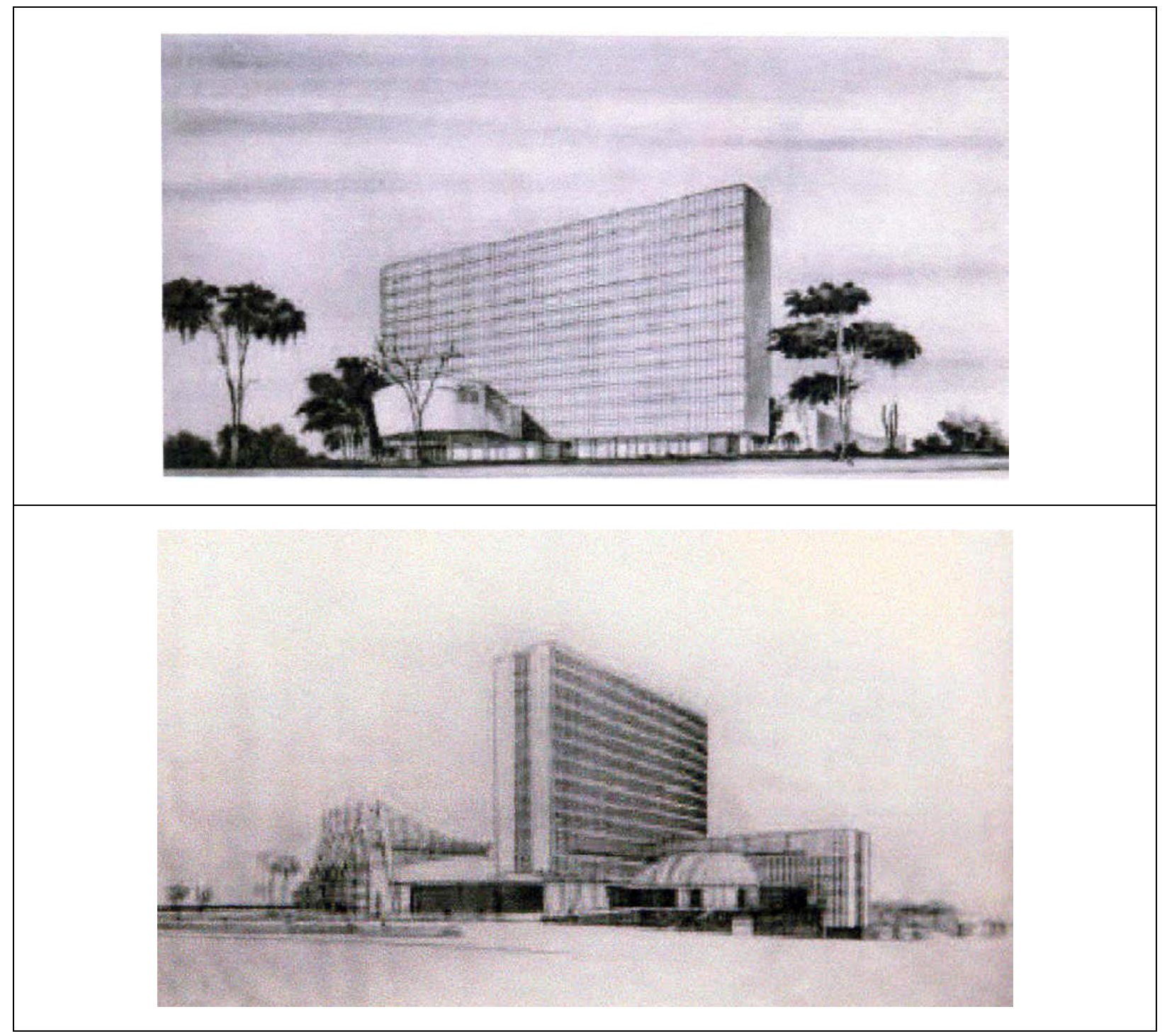

Figura 73: Concurso para o Paço Municipal de São Paulo - 1952

Estudos das Fachadas - Perspectiva - Giancarlo Palanti 12

5.2.1. Hospital São Joaquim da Beneficência Portuguesa - 1957

O projeto para o edifício São Joaquim da Beneficência Portuguesa data de 1944 e foi o resultado de concurso público do qual saíram os vencedores os arquitetos Hypólito Gustavo Pujol Jr. e Nico Oscar Lino Defilippi, ficando a construção a cargo da Construtora Alfredo Mathias,i finalizada em 1957.

\footnotetext{
${ }^{112}$ Fonte: Arquivo GP / FAU - USP
} 
Com aproximadamente 120 mil metros quadrados de construção, foi implantado na diagonal do terreno e hoje boa parte de sua fachada pode ser vista a partir da Avenida vinte e Três de maio. Além dos subsolos, possui um pavimento térreo e mais oito pavimentos. O prédio tem forma de "Z" aberto e apresenta uma composição horizontal tendo elementos verticais em suas extremidades que dão ritmo e equilíbrio à construção. Construído com estrutura de concreto e alvenaria foi revestido com pastilhas claras com extremo requinte na execução dos detalhes dos peitoris e abas no fundo da viga que enfatizam a horizontalidade do partido arquitetônico.

Atualmente, segundo o site institucional do hospital $60 \%$ da área construída do hospital é reservada ao atendimento ao SUS (sistema único de Saúde).

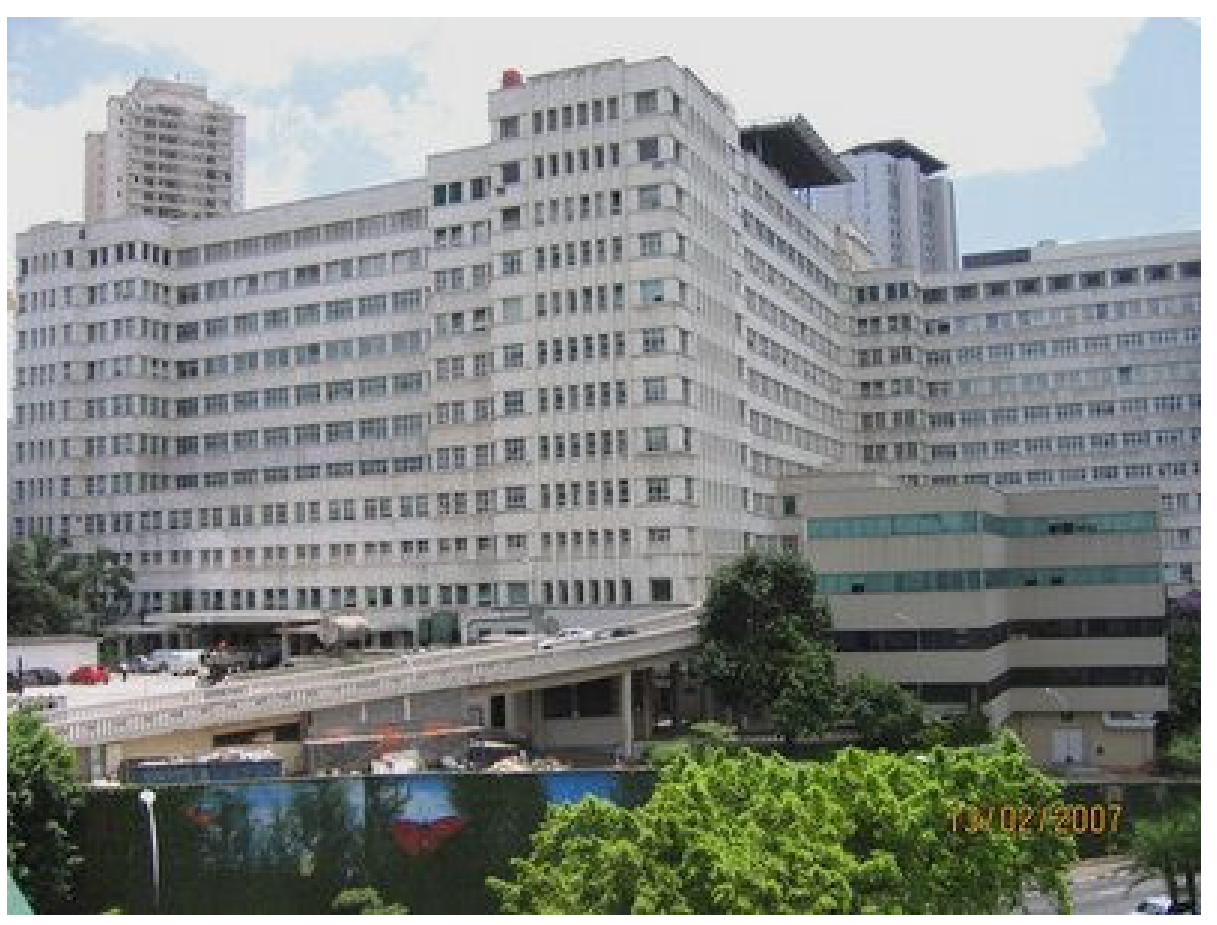

Figura 74: Hospital são Joaquim da beneficência Portuguesa - 1957

Fachada Hypólito Gustavo Pujol Jr. e Nico Oscar Lino Defilippi 113

${ }^{113}$ Fonte: http://2.bp.blogspot.com/-UZXupTbP5oY/TWfaL6xS8jl

/AAAAAAAAAIS/8yLOgMQP60U/s1600/HOSPITAL-BENEFICENCIA-PORTUGUESA-SP.jpg 


\subsubsection{Centro Comercial Presidente - 1962}

Segundo empreendimento da Construtora Alfredo Mathias em consórcio com as famílias Citron e Jacob Lerner como incorporadores e o projeto à cargo do Escritório de Arquitetura Siffredi \& Baderlli, foi lançado no mercado no início da década de 1960 e demonstrou ser um sucesso de vendas, tendo suas unidades vendidas em quinze dias, sendo entregue em 1962.

Segundo Ermano Siffredi, em entrevista a Nuno de Azevedo Fonseca114, o investimento na construção de edifícios comerciais era menor e o retorno mais rápido.

O edifico foi implantado ocupando as laterais em toda a extensão do lote onde estão localizadas as lojas e os escritórios nos andares superiores, e foi mantido um grande vazio, em todos os andares que se abre para a cidade e nele estão contidas as circulações verticais por escadas rolantes que se debruçam sobre o vazio.

Um aspecto importante das galerias comerciais projetadas neste período era o fato de permanecerem abertas vinte e quatro horas por dia, pois não possuíam portões e a circulação dos pedestres não era coibida mesmo que as lojas estivessem fechadas.

O projeto apresenta a mesma tipologia empregada na Galeria sete de Abril (primeiro empreendimento do grupo de investidores em parceria com a construtora): mais elaborada que o primeiro empreendimento é, no entanto, mais simples que sua irmã e vizinha as Grandes Galerias (atual Galeria do Rock) que tem sua concepção mais luxuosa em comparação com a Galeria Presidente.

\footnotetext{
114 Estudo comparativo das propostas de cidades contidas em edifícios dos anos 19451965/1965-1985, dissertação de mestrado apresentada à Faculdade de Engenharia de São Carlos, 1982.
} 
Embora mais simples as soluções formais das circulações em balanço junto com as escadas rolantes sobre o vazio causam estranheza e surpresa pela solução de seu desenho, pelos efeitos de luz o sombra e pela grande clarabóía que fecha este vazio.

Localizada na Rua Vinte e Quatro de Maio, 116 dá acesso à Rua Dom José de Barros pelo subsolo a meio piso com acesso por meio de uma rampa no meio do conjunto; já o acesso à galeria propriamente dito é feito também por meio de rampas, mas desta vez laterais à rampa que vai ao subsolo. O pavimento térreo também está a meio piso em relação à rua e possui desenhos elaborados por Bramanti Buffoni (figuras 75 a 78).

Ficha técnica: Centro Comercial Presidente

Localização: $\quad$ Rua Vinte e quatro de Maio, 116 - Rua Dom José de Barros

Construtor: $\quad$ Construtora Alfredo Mathias S.A.

Incorporadores: Família Citron, Construtora Alfredo Mathias e Escritório de Arquitetura Siffredi \& Bardelli

Autor do Projeto: Escritório de Arquitetura Siffredi \& Bardelli

$N^{\circ}$ de pavimentos: Subsolo, Térreo, pav. Tipo (5x), terraço-jardim

Uso: Comércio e Serviços

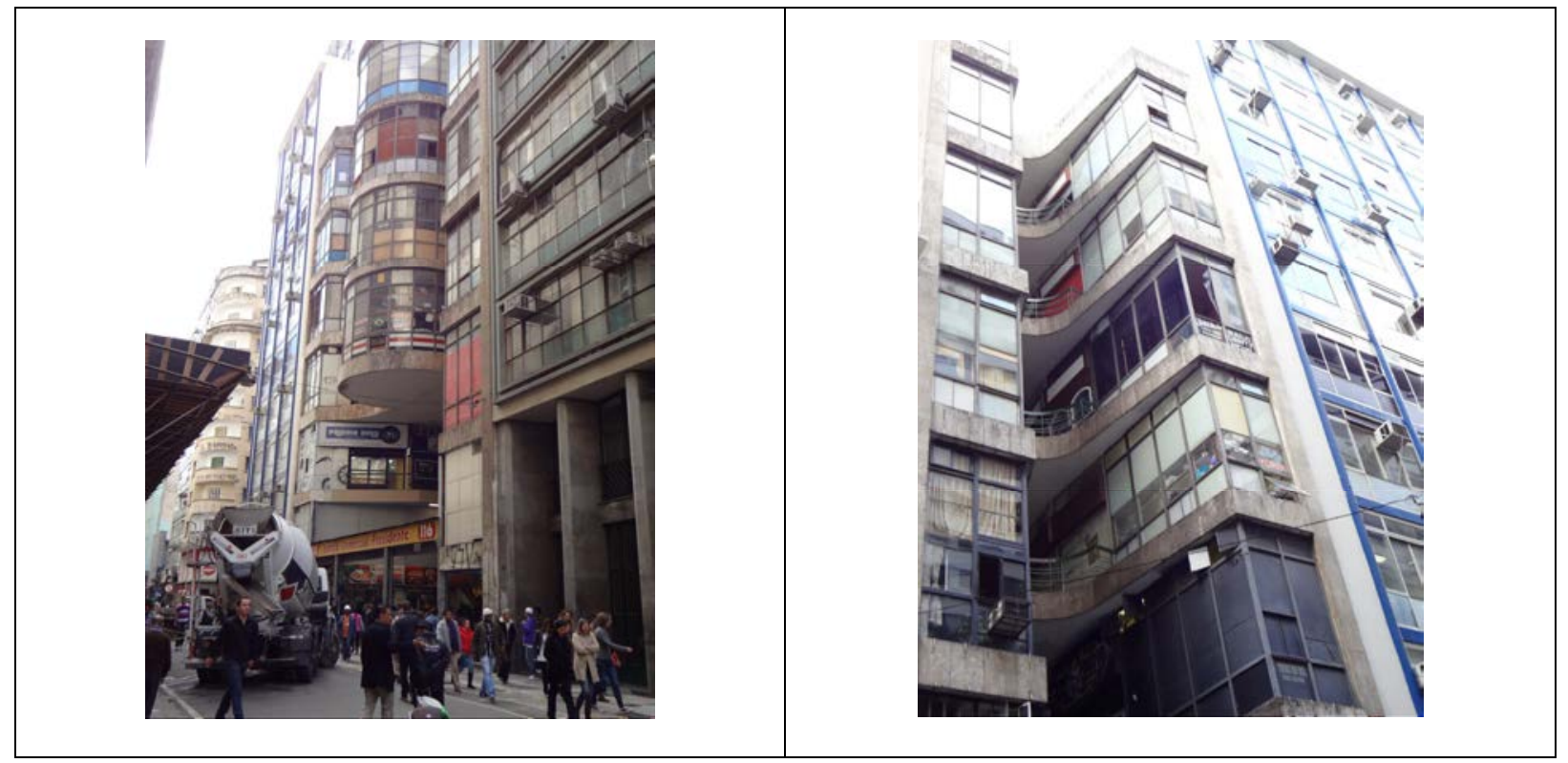

Figura 75: Centro comercial Presidente- Escritório de Arquitetura Siffredi \& Bardelli - 1962 Esquerda: acesso pela Rua Vinte e Quatro de Maio, 116

Direita: fachada para a Rua Dom José de Barros ${ }^{115}$

${ }^{115}$ Fotos: Demósthenes Magno Santos - Maio 2012 

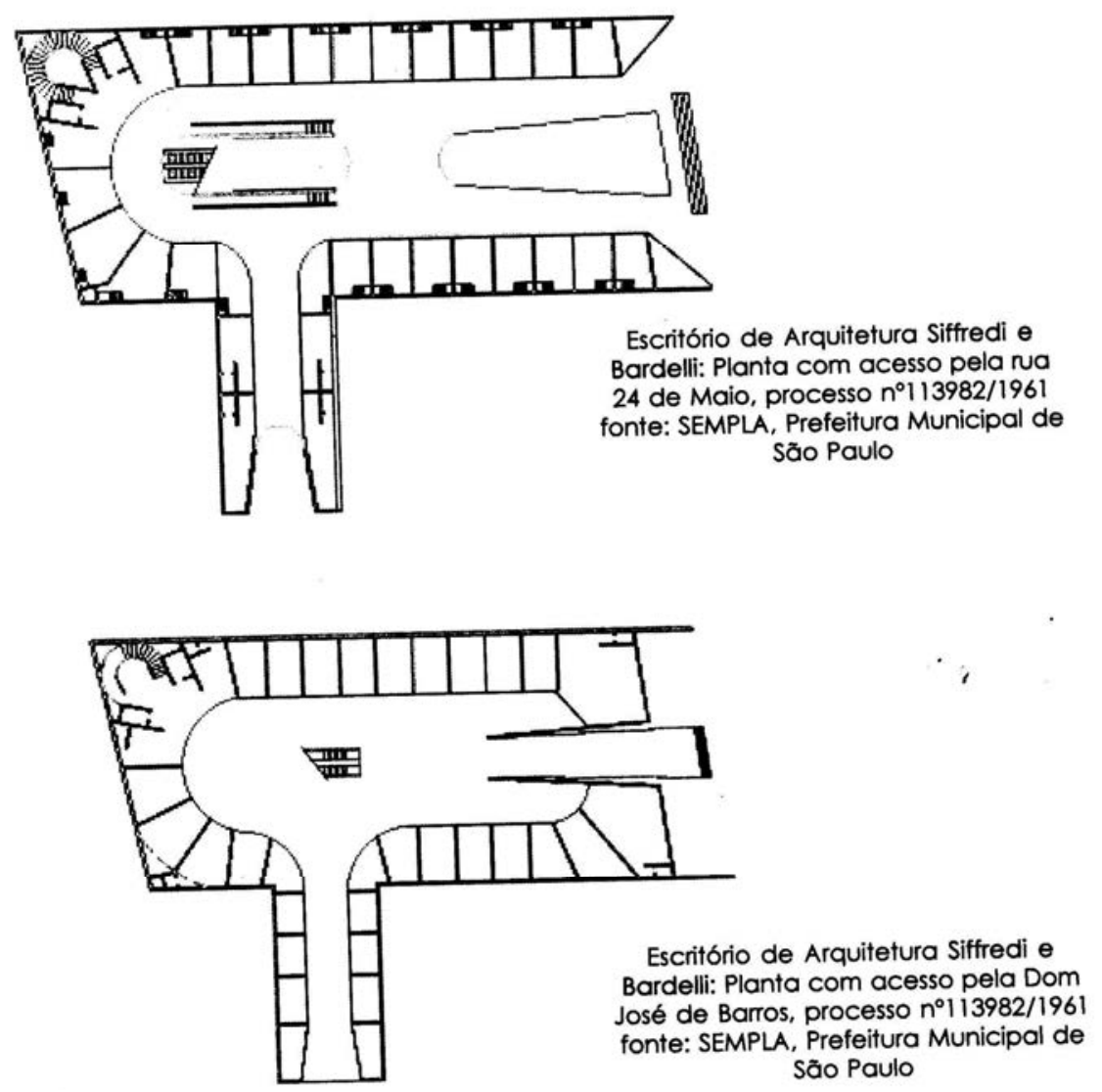

、
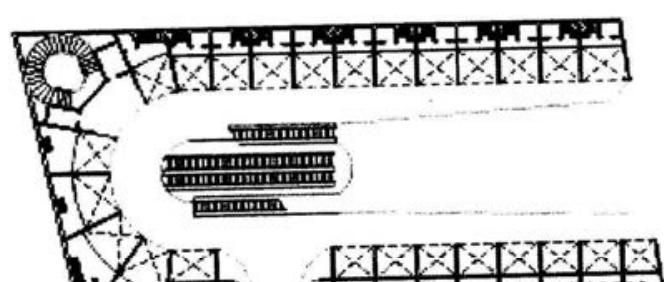

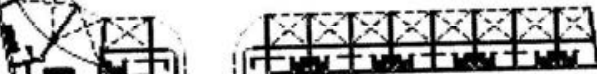

的

Escritório de Arquitetura Siffredi e Bardelli: Planta distribuição das salas nos andares, processo n०113982/1961 fonte: SEMPLA, Prefeitura Municipal de São Paulo

Figura 76: Centro comercial Presidente- Escritório de Arquitetura Siffredi \& Bardelli - 1962 Plantas de baixo para cima: subsolo, pavimento térreo e pavimento tipo'116

${ }^{116}$ Fonte: SEMPLA, Prefeitura do Município de São Paulo 

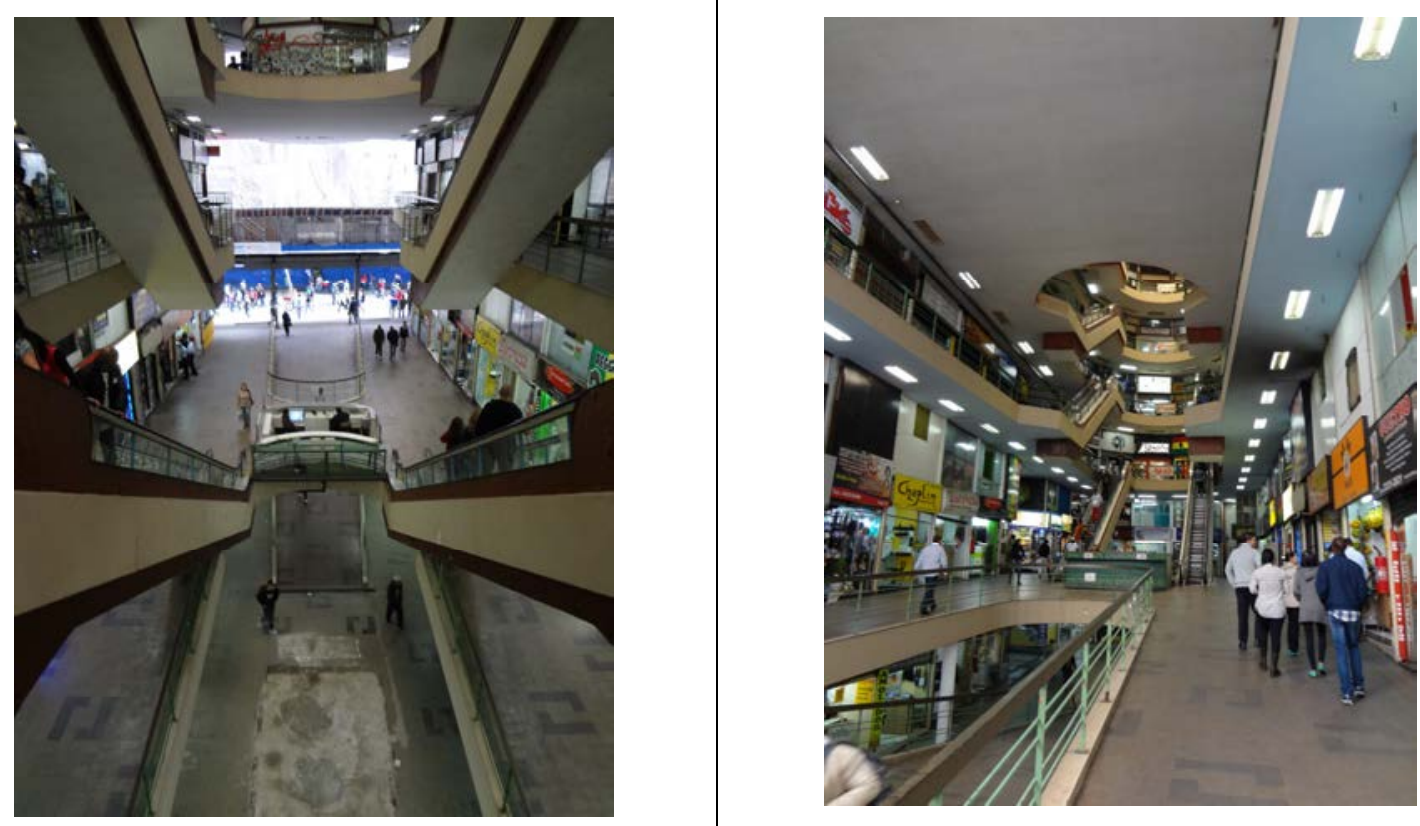

Figura 77: Centro comercial Presidente- Escritório de Arquitetura Siffredi \& Bardelli - 1962 Esquerda: escadas rolantes sobre o vazio;

Direita: rampa de acesso ao pav. Térreo e demais andares da galeria ${ }^{117}$
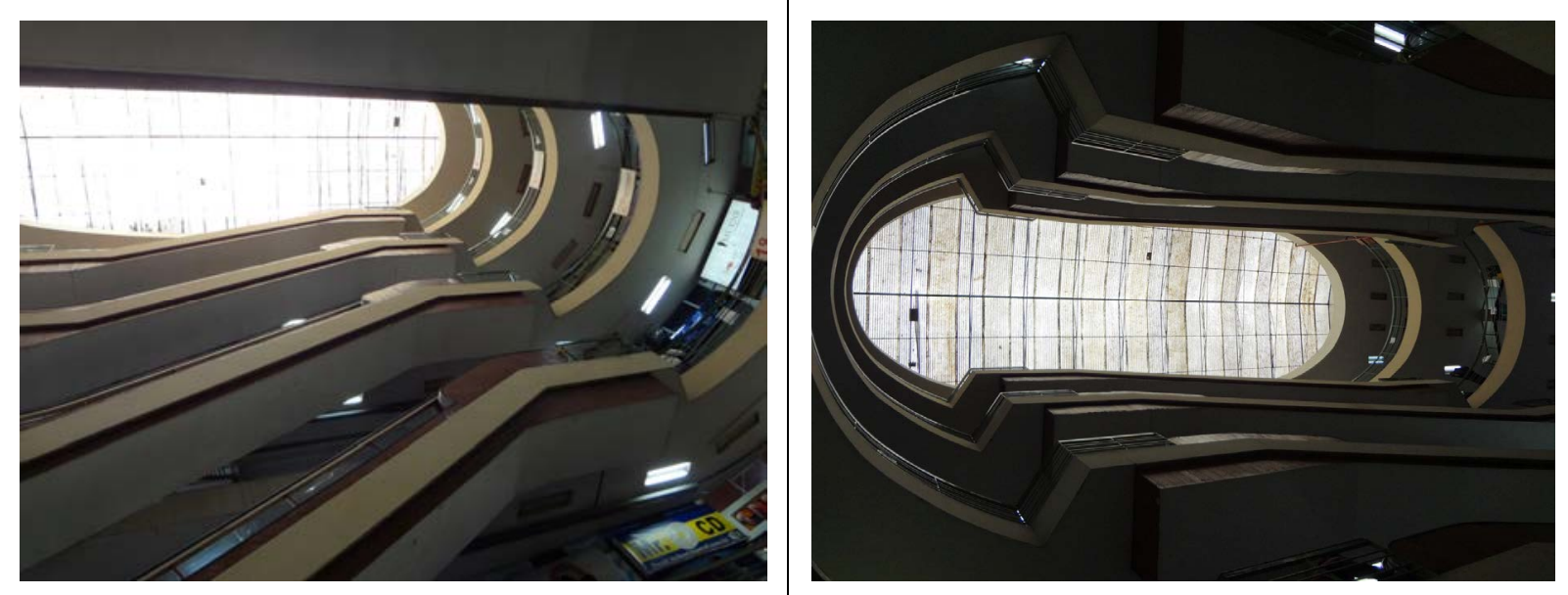

Figura 78: Centro comercial Presidente- Escritório de Arquitetura Siffredi \& Bardelli - 1962 Esquerda: escadas rolantes sobre o vazio;

Direita: vista da clarabóia. ${ }^{118}$

\footnotetext{
${ }^{117}$ Fotos: Demósthenes Magno Santos - Maio 2012

${ }^{118}$ Fotos: Demósthenes Magno Santos - Maio 2012
} 


\subsubsection{Grandes Galerias - atual Galeria do Rock - 1962}

Projeto rico em detalhes que vão desde a análise elaborada da iluminção até a elaboração dos painéis em madeira que fecham as lojas. Implantado em lote com frente para a Rua Vinte e Quatro de Maio e Avenida São João, está localizado em local nobre do Centro Novo e fica próximo aos grandes cinemas da região.

"A própria situação do lote favoreceu a implantação de um projeto linear... o edifício foi organizado por um eixo transversal a maior face do lote, que espelha duas metades simétricas, mas bem diferentes espacialmente. Apesar das fachadas serem quase idênticas... é de uma atmosfera nova em cada andar." (Aleixo, 2005)

O partido adotado pelos arquitetos mais vez repete o adotado nos projetos precedentes 119 utilizando rampas de acesso e desníveis para organizarem a entrada pela calçada em dois níveis distintos: o subsolo e o pav. Térreo. O projeto não possui marquises que acentuem suas entradas e os arquitetos adoram uma solução simples para marcá-las: as lajes do conjunto possuem delicada curva que induzem os caminhantes do sentido das rampas e o caminho a ser percorrido. O acesso, semelhante aos adotados nos projetos anteriores oferecem duas opções ao pedestre, seguir pela rampa central em direção ao subsolo ou seguir pelas rampas laterais para o pavimento térreo. $\bigcirc$ desenho sinuoso do primeiro pavimento difere dos demais pavimentos, pois a laje recua até o final das rampas de acesso criando um pé-direito duplo, dando imponência as entradas.

A solução adotada para a implantação das lojas também foi o mesma: as lojas estão localizadas nas laterais do lote liberando a parte central para a circulação e entre os andares, por meio de escadas rolantes. A circulação é

119 Galeria sete de Abril, 1959 e Centro Comercial Presidente, 1962 
completada por uma caixa de escada e elevadores localizados no meio do lote um em frente ao outro. Os pisos possuem aberturas em formas ovais em posições diferentes em cada piso, assim como a posição das escadas rolantes variam de piso a piso. Estas soluções criam movimentação e surpresa para os usuários da galeria. As delicadas curvas das fachadas oferecem uma visão panorâmica para cidade, as lojas possuem fechamento de vidro e painéis de madeira na parte superior e $\mathrm{o}$ forro recebeu acabamento em pintura clara (mesma solução adotada na Galeria Sete de Abril), é marcante nas fachadas a cor laranja dos guarda-corpos que acompanhando a sinuosidade das lajes causa movimento à fachada.

Os desenhos dos pisos e os painéis sobre as portas dos elevadores do pavimento térreo ficaram a cargo do artista italiano Bramante Buffoni. Para os pisos Buffoni fez uso de composições a partir de peças cerâmicas em tons de cinza, marrom e um rosa fechado. As peças são as mesmas, mas em cada andar propôs variadas composições geométricas de inspiração construtivista:

\footnotetext{
"Buffoni trabalhou com composições idênticas no subsolo e primeiro pavimento, bem como no térreo e segundo pavimento, variando as suas cores e tonalidades." (Aleixo - 2005)
}

O efeito visual impressiona; a integração através dos vazios dos andares e os desenhos dos pisos criam movimento a cada ângulo e a galeria se transforma; na cobertura o do terraço jardim: neste piso estão os fechamentos das clarabóias que dão luz ao interior da galeria e canteiros de plantas, é usado pela administração e o terraço propriamente dito destinado a apresentações e encontros musicais.

A galeria esta em geral em ótimo estado, estando à frente seu síndico, Toninho, que defende a integridade do conjunto e demonstrou ser um entusiasta com a obra da construtora (Figuras 79 a.87) 
Ficha técnica: Edifício Grandes Galerias

Localização: $\quad$ Rua Vinte e quatro de Maio, 36 - Avenida São João, 439

Construtor: $\quad$ Construtora Alfredo Mathias S.A.

Incorporadores: Família Citron, Jacob Lerner, Construtora Alfredo Mathias e Escritório de Arquitetura Siffredi \& Bardelli

Autor do Projeto: Escritório de Arquitetura Siffredi \& Bardelli

$\mathrm{N}^{\circ}$ de pavimentos: Subsolo, Térreo, pav. Tipo (5x), terraço-jardim

Uso: Comércio e Serviços

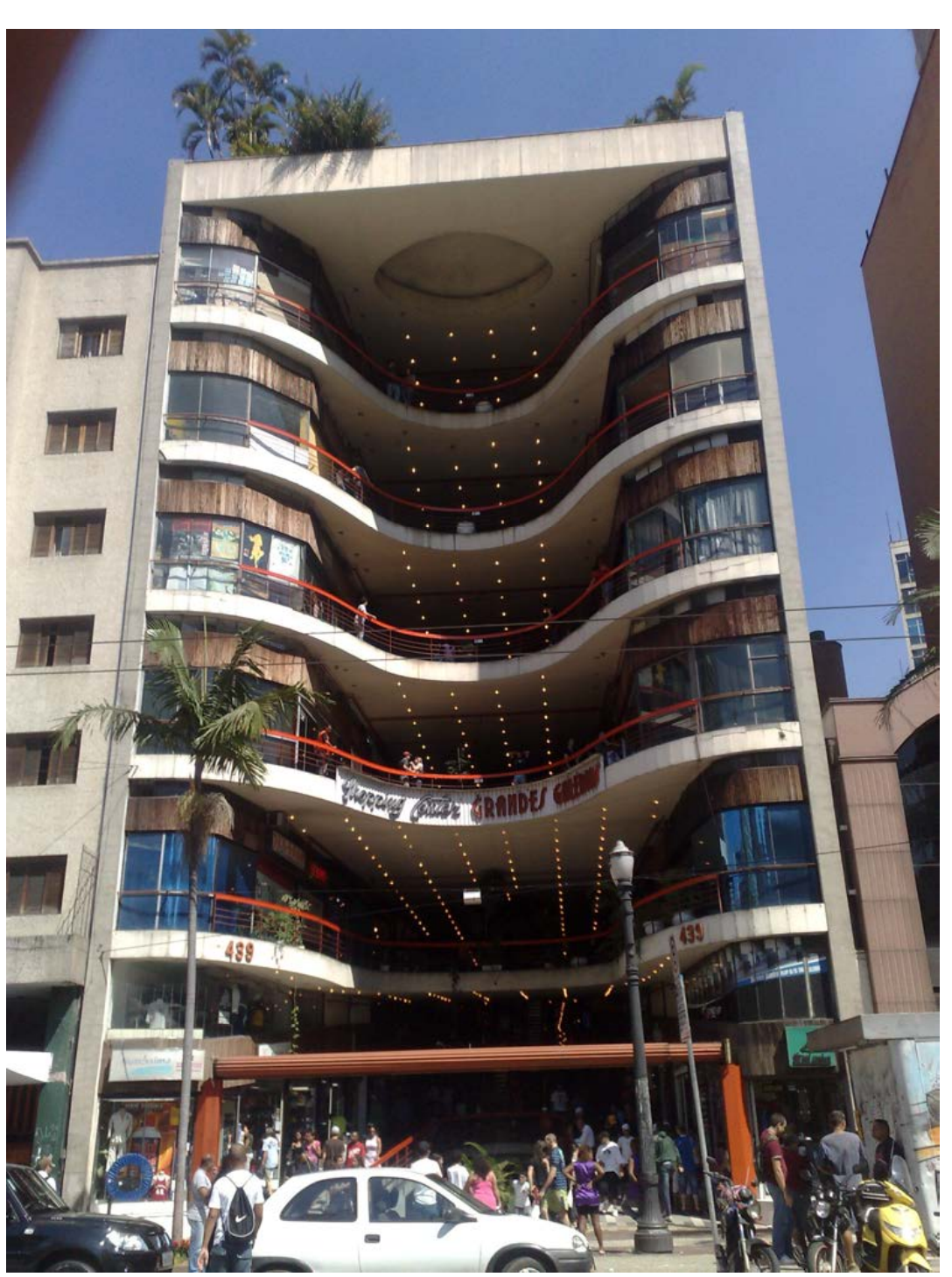

Figura 79: Grandes Galerias- Escritório de Arquitetura Siffredi \& Bardelli - 1962 Fachada para a Avenida São João, 439.120

${ }^{120}$ Fotos: Demósthenes Magno Santos - Maio 2012 


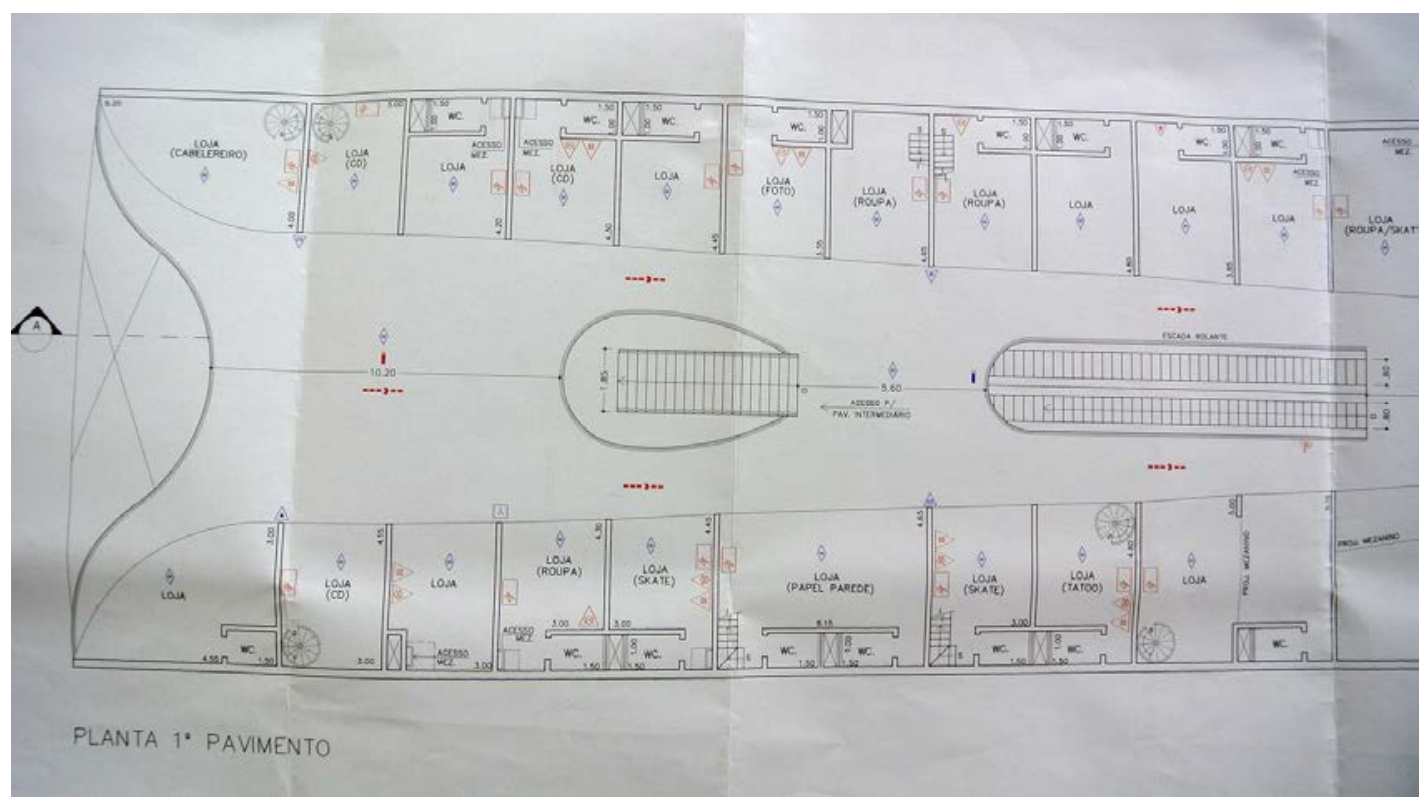

Figura 80: Grandes Galerias- Escritório de Arquitetura Siffredi \& Bardelli - 1962 Planta parcial do $1^{\circ}$ pavimento com frente para a Avenida São João. ${ }^{121}$

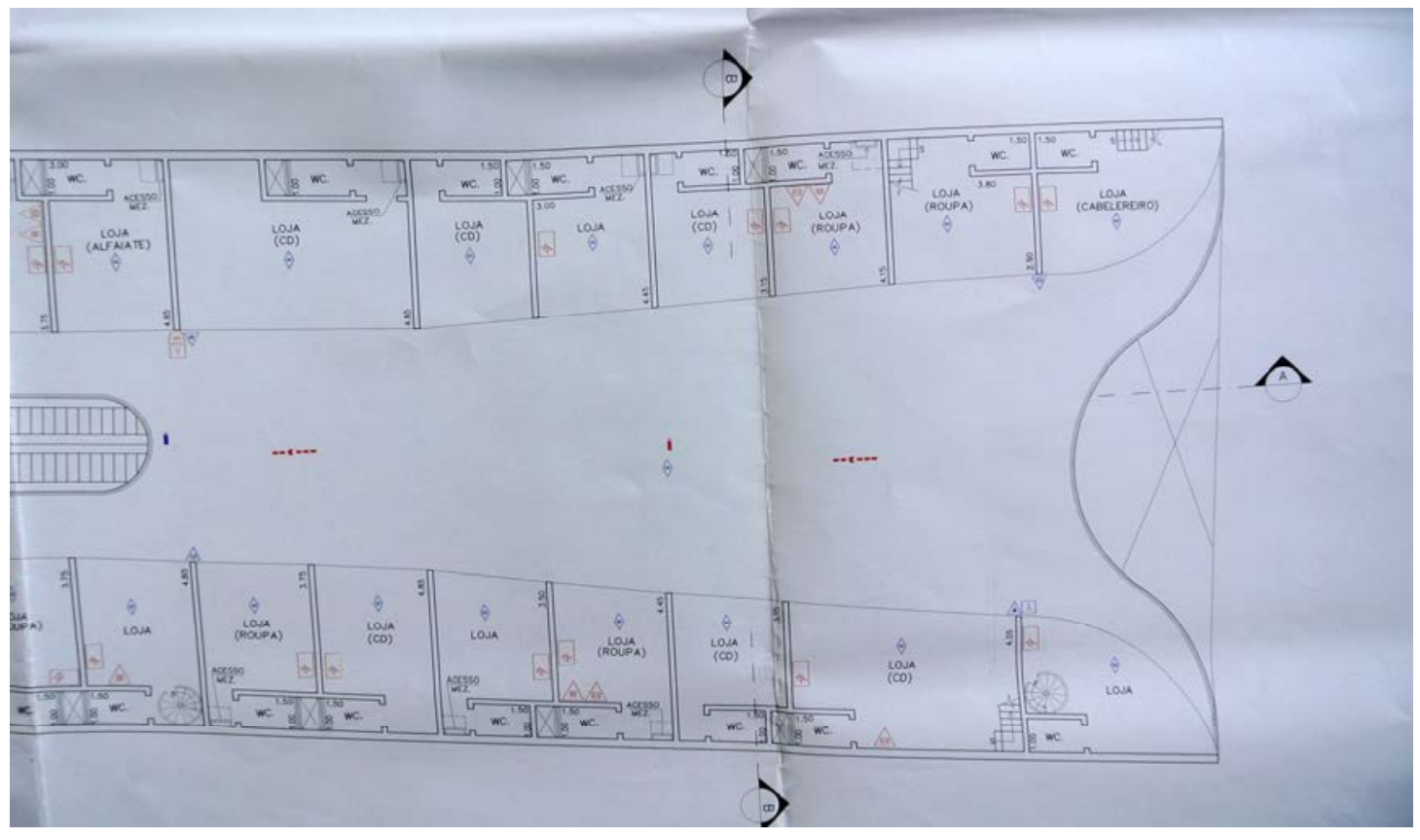

Figura 81: Grandes Galerias- Escritório de Arquitetura Siffredi \& Bardelli - 1962 Planta parcial do $1^{\circ}$ pavimento com frente para a Rua 24 de maio. ${ }^{122}$

${ }^{121}$ Fonte: arquivo da Galeria do Rock, gentilmente cedido pelo sindico "Toninho";

${ }^{122}$ Fonte: arquivo da Galeria do Rock, gentilmente cedido pelo sindico "Toninho". 


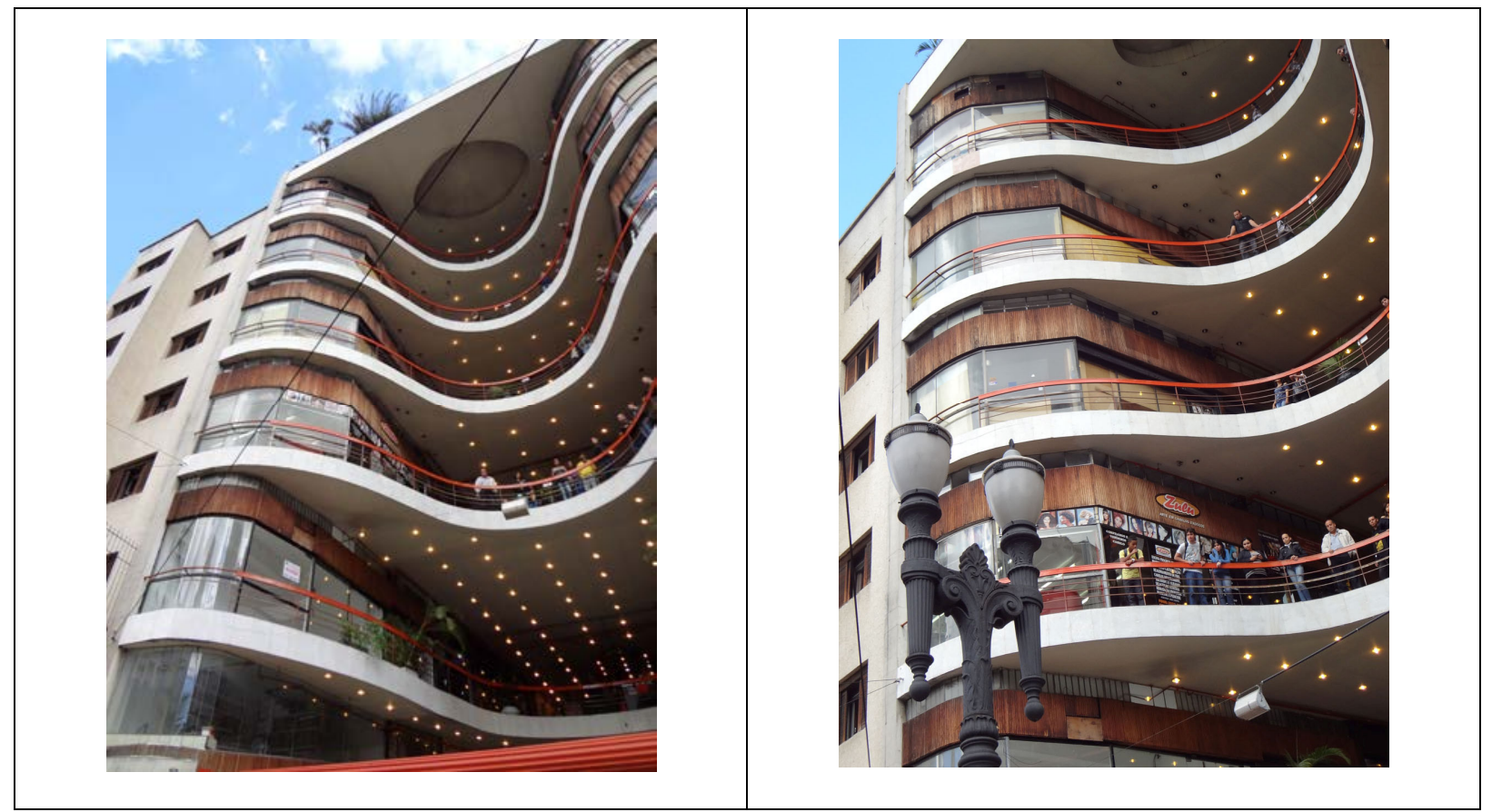

Figura 82: Grandes Galerias- Escritório de Arquitetura Siffredi \& Bardelli - 1962 Fachada para a Avenida São João, 439 Detalhes da Fachada. ${ }^{123}$

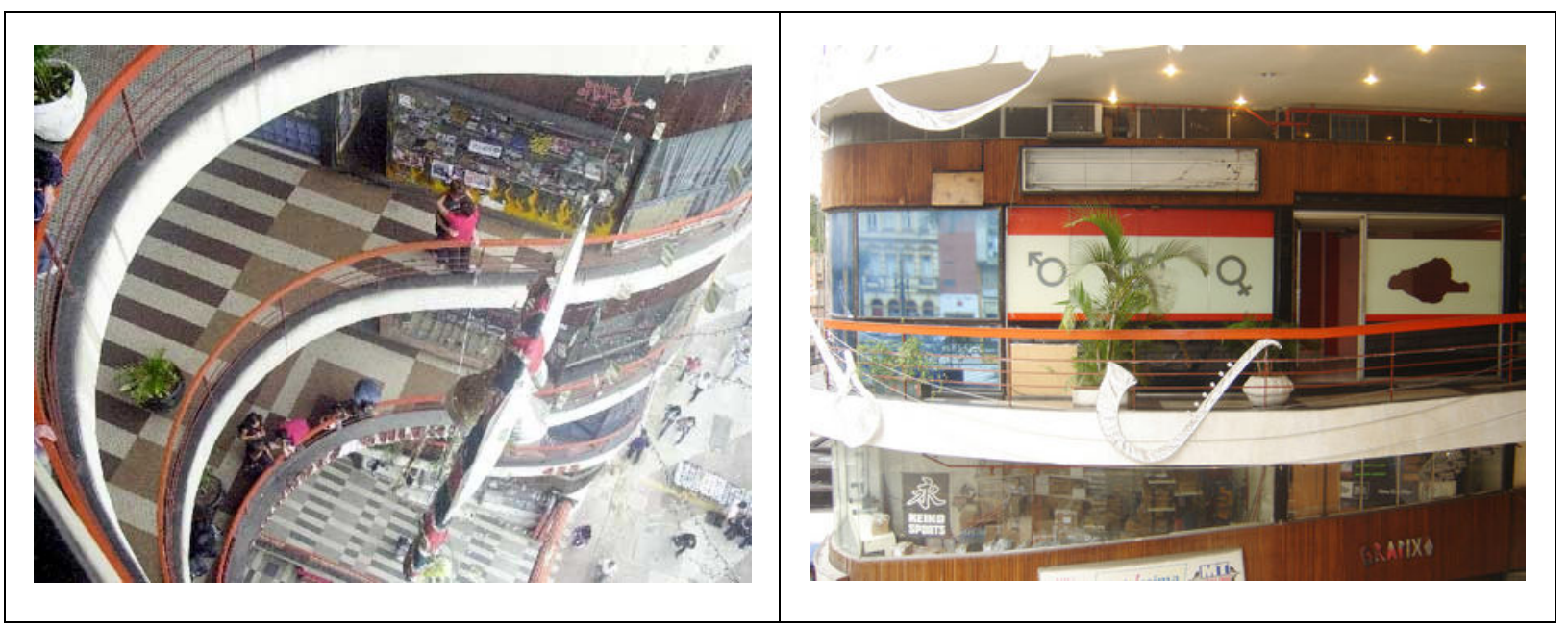

Figura 83: Grandes Galerias- Escritório de Arquitetura Siffredi \& Bardelli - 1962 Fachada para a Avenida São João, 439

Esquerda: detalhe da laje e pisos - Direita: detalhe do guarda-corpo.124

\footnotetext{
${ }^{123}$ Fotos: Demósthenes Magno Santos - Maio 2012

${ }^{124}$ Fotos: Demósthenes Magno Santos - Maio 2012
} 

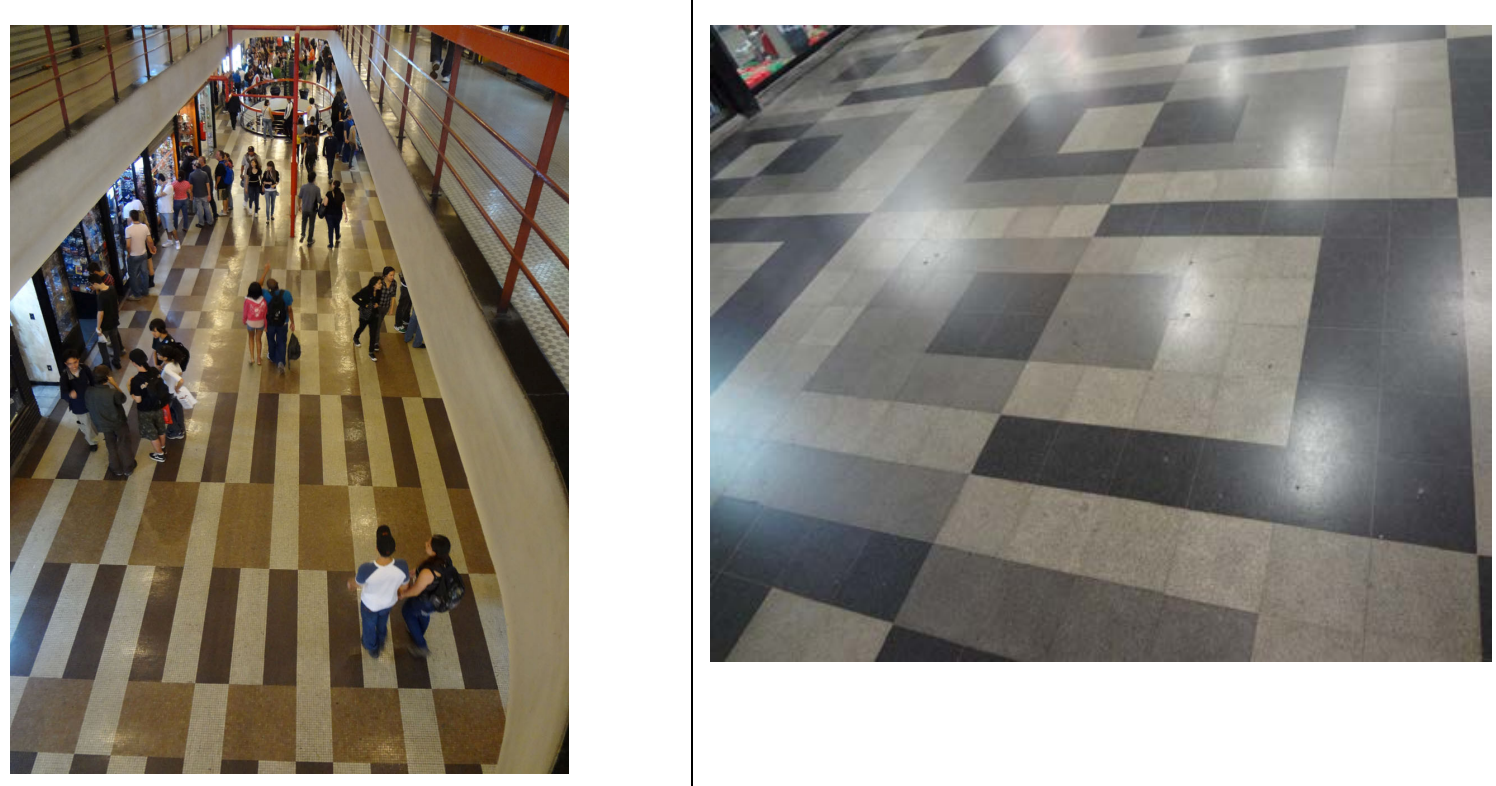

Figura 84: Grandes Galerias- Escritório de Arquitetura Siffredi \& Bardelli - 1962 Detalhes dos pisos. ${ }^{125}$
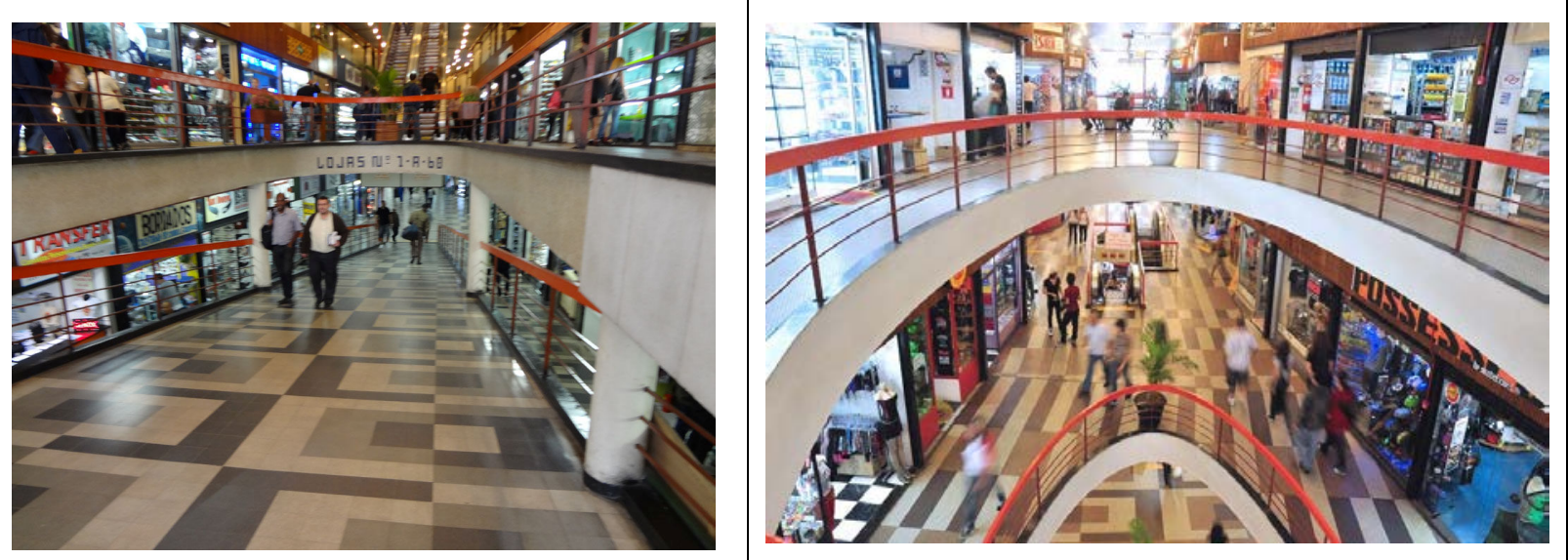

Figura 85: Grandes Galerias- Escritório de Arquitetura Siffredi \& Bardelli - 1962 Detalhes dos pisos. ${ }^{26}$

\footnotetext{
${ }^{125}$ Fotos: Demósthenes Magno Santos - Maio 2012

${ }^{126}$ Fotos: Demósthenes Magno Santos - Maio 2012
} 


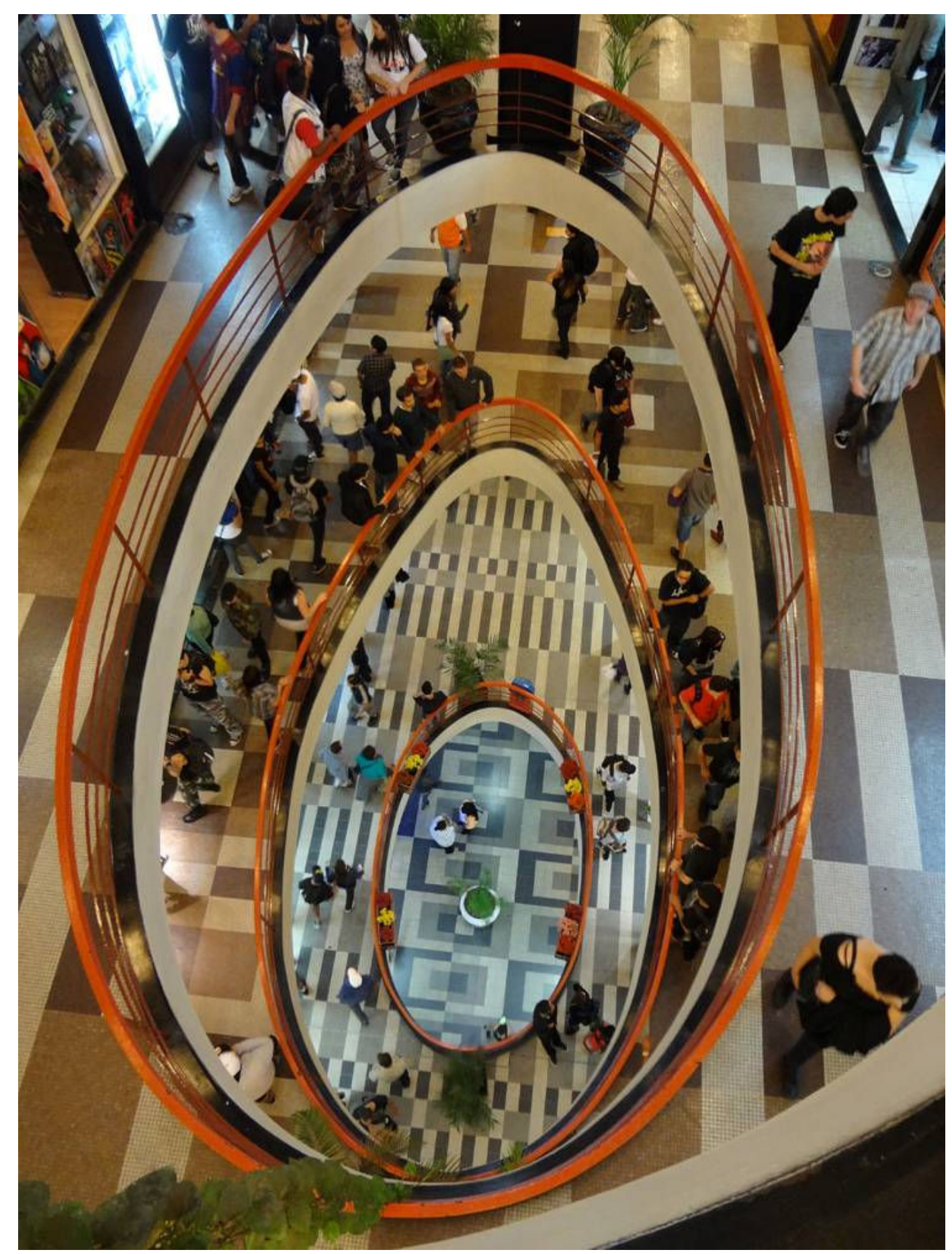

Figura 86: Grandes Galerias- Escritório de Arquitetura Siffredi \& Bardelli - 1962 Detalhes dos pisos, vistos através dos vazios. ${ }^{127}$

${ }^{127}$ Fotos: Demósthenes Magno Santos - Maio 2012 


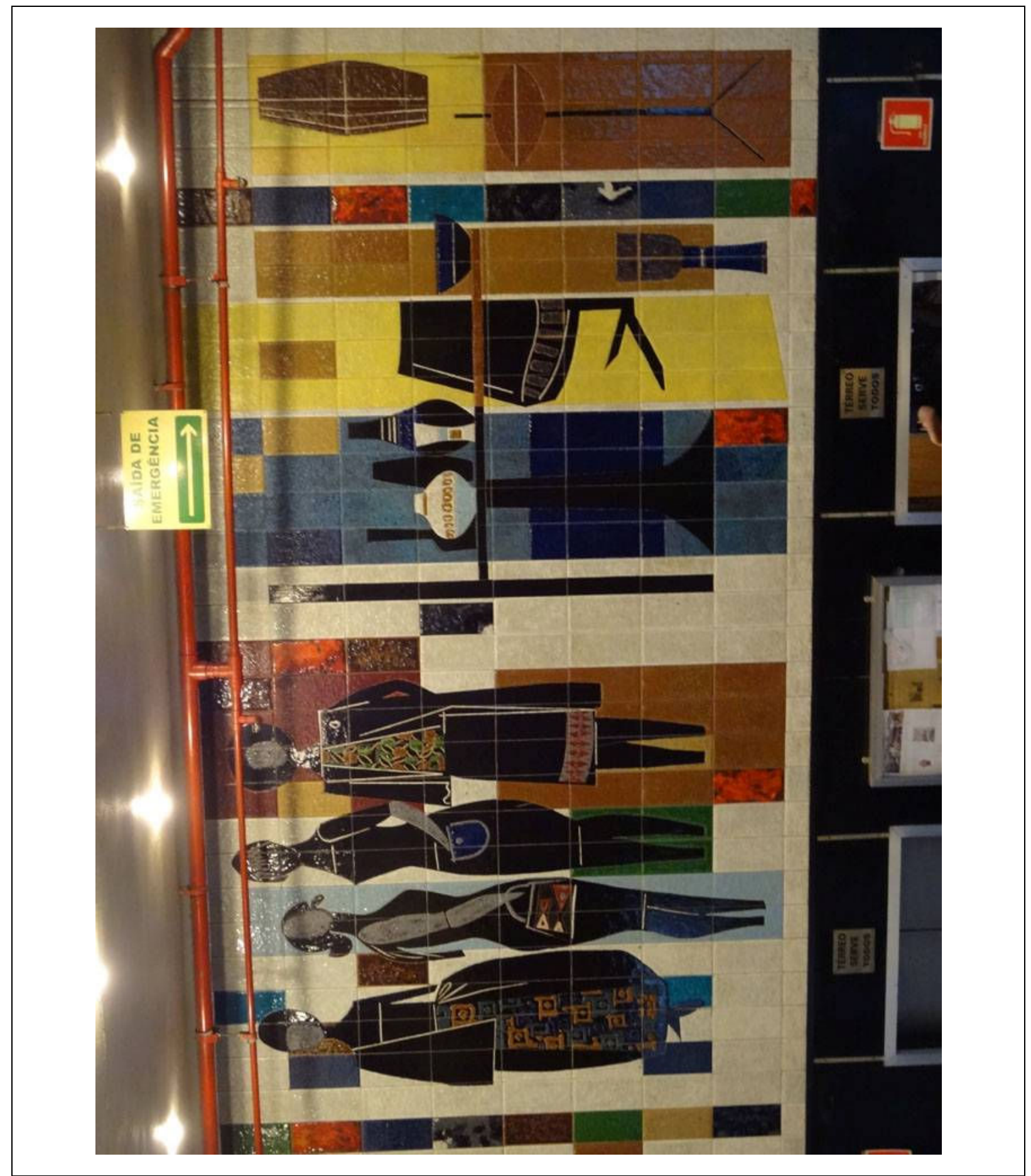

Figura 87: Grandes Galerias- Escritório de Arquitetura Siffredi \& Bardelli - 1962

Painel em cerâmica de Bramante Buffoni sobre as portas dos elevadores do pavimento térreo. ${ }^{128}$

${ }^{128}$ Fotos: Demósthenes Magno Santos - Maio 2012 


\subsection{Condomínio Portal do Morumbi - 1973}

Este grande e emblemático empreendimento foi idealizado por Mathias em 1973 e finalizado em 1976. O projeto foi inteiramente realizado dentro da própria construtora, sendo a implantação e projeto de realizado pelo arquiteto João Henrique da Rocha e a construção sob a responsabilidade do engenheiro Rubens Russo. O projeto de paisagismo foi desenvolvido em duas etapas, na primeira fase optou-se pela preservação dos bosques existentes e ficou à cargo do arquiteto-paisagista Victor del Mazo e a segunda fase, em 1982, sobre a responsabilidade do escritório Geizer Paisagismo e Meio Ambiente, encarregado de desenvolver um projeto de manejo e preservação das espécies existentes, alem de promover o plantio de espécies nativas e a criação de novos bosques. ${ }^{129}$

Com o objetivo de aperfeiçoar e propor uma construção o mais industrializada possível, foi executado como protótipo dois edifícios na Alameda Lorena $\mathrm{n}^{\circ} 1041$, com a planta do apartamento médio do Portal $\left(200 \mathrm{~m}^{2}\right)$, onde se fizeram os ensaios das formas deslizantes e otimização dos componentes ( Figuras 89 a 90).

O Portal do Morumbi está localizado no bairro que leva o mesmo nome e foi concebido como um parque exclusivo aos moradores além de um clube em seu interior. O terreno possui 165 mil $\mathrm{m}^{2}$ dos quais apenas 15\% são ocupados por construções e o restante destinado a espaços de uso comum. Segundo o material promocional da época:

"O objetivo era proporcionar um ambiente saudável para quem quisesse criar seus filhos com muito verde e espaço dentro da cidade de São Paulo" (Nagy, 1989, apud Aragão, 2007)

\footnotetext{
129 O escritório Rodolfo Geiser foi contratado por uma comissão de moradores já preocupados
} com a preservação do conjunto. 
Nestes espaços foram distribuídos extensos gramados, bosques e jardins, viveiros de aves, mini cascata (embora haja uma nascente dentro do condomínio a cascata é artificial), piscinas, quadras poli-esportivas e de tênis e quatro playgrounds.

Os 800 apartamentos possuem áreas que variam de $180 \mathrm{~m}^{2}$ a $250 \mathrm{~m}^{2}$, distribuídos em 16 torres de 25 pavimentos cada, construídos inteiramente em concreto aparente, tem os pilares extremamente delgados, considerando-se a altura das torres com requintes nos cuidados dos prumos e colocação das esquadrias. O arquiteto João Henrique da Rocha exigiu que as esquadrias fossem colocadas em o uso de "espaletas" de alvenaria que facilitaria sua colocação, mas na visão do arquiteto retiraria a leveza almejada dos pilares. Para a construção do conjunto Mathias trouxe da Alemanha o sistema de formas deslizantes, na época recém desenvolvida, para agilizar o processo de construção.

Os apartamentos possuem ambientes com dimensões generosas (a sala do apartamento de quatro dormitórios possui 5,00 metros de largura por 12,50 metros de comprimento), distribuídos por um esquema extremante racional de circulação onde os pilares e shafts foram colocados na parte externa das fachadas criando timo à construção. Nos pavimentos térreos foram implantados os halls e salões de festas fechados exclusivamente com vidros mantendo total integração com a paisagem exuberante.

As torres são implantadas sobre as garagens, mas com a preocupação de ter o menor movimento de terra possível resultando em garagens "semienterradas" cujas fachadas expostas têm o fechamento com elementos prémoldados de concreto atrás de jardineiras corridas por toda a fachada (após 37 anos da construção a vegetação, na maioria dos casos Costelas de Adão, estão exuberantes e em completa integração com a paisagem obstruindo completamente o impacto da construção no ambiente). 
O conjunto possui duas portarias, um mini Shopping, projetado na área externa para apoio do condomínio além de um departamento de manutenção e apoio aos condôminos. Possuem, entre o pessoal da administração, seguranças, jardineiros e manutenção um total de 300 funcionários, só de jardineiros são 25 funcionários. Dentro do condomínio existem nove poços artesianos que ainda são utilizados sob a acessória da Sabesp para o controle da qualidade da água.

O condomínio apresenta-se em excelente estado de conservação, suas fachadas estão sendo restauradas pela terceira vez sob os cuidados de técnicos do IPT e, de maneira geral, a preocupação dos moradores é manter o condomínio com as características originais do empreendimento, principalmente ao acabamento e manutenção do concreto parente das construções. Atualmente o condomínio negocia com a Prefeitura do Município de São Paulo o tombamento da área verde, transformando-a em uma "APA" (área de preservação ambiental). (figuras 88 a 104) 


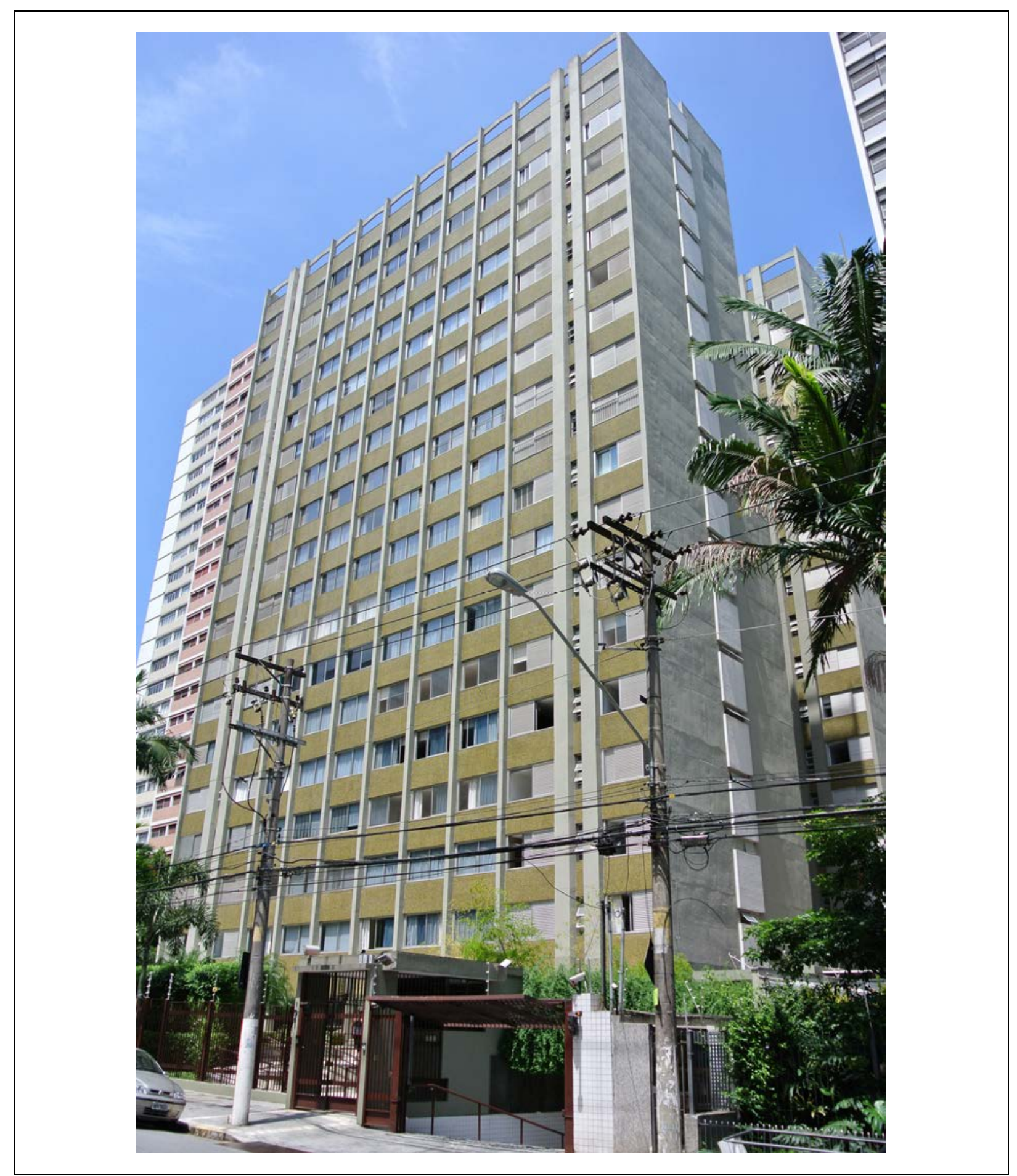

Figura 88: Conjunto de dois edifícios á Alameda Lorena 1041 Protótipos para a execução do Portal do Morumbi Projeto João Henrique da Rocha. ${ }^{130}$

${ }^{130}$ Foto: Demósthenes Magno Santos - Fev. 2013 


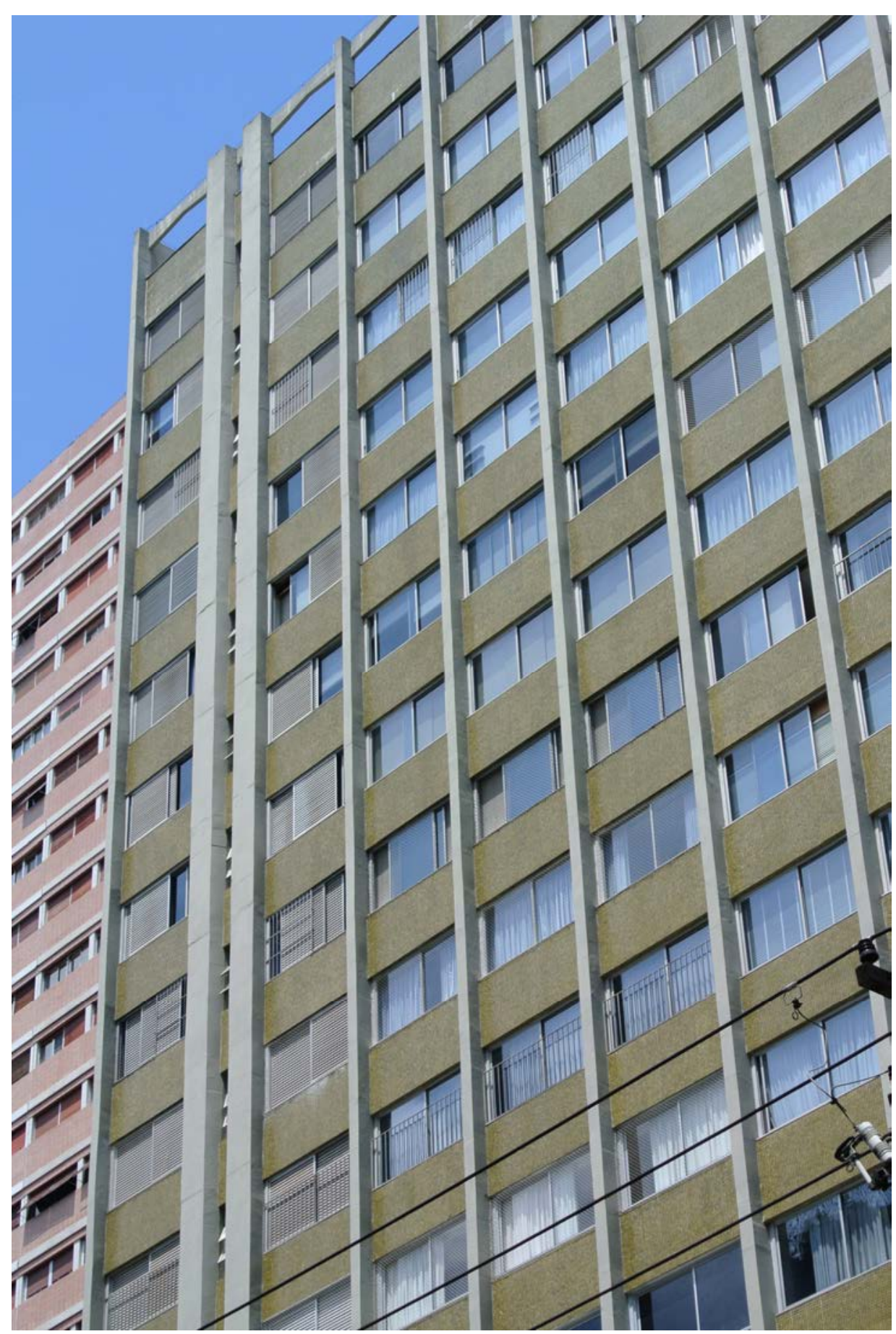

Figura 89: Conjunto de dois edifícios á Alameda Lorena 1041 Protótipos para a execução do Portal do Morumbi Projeto João Henrique da Rocha. ${ }^{131}$

${ }^{131}$ Foto: Demósthenes Magno Santos - Fev. 2013 


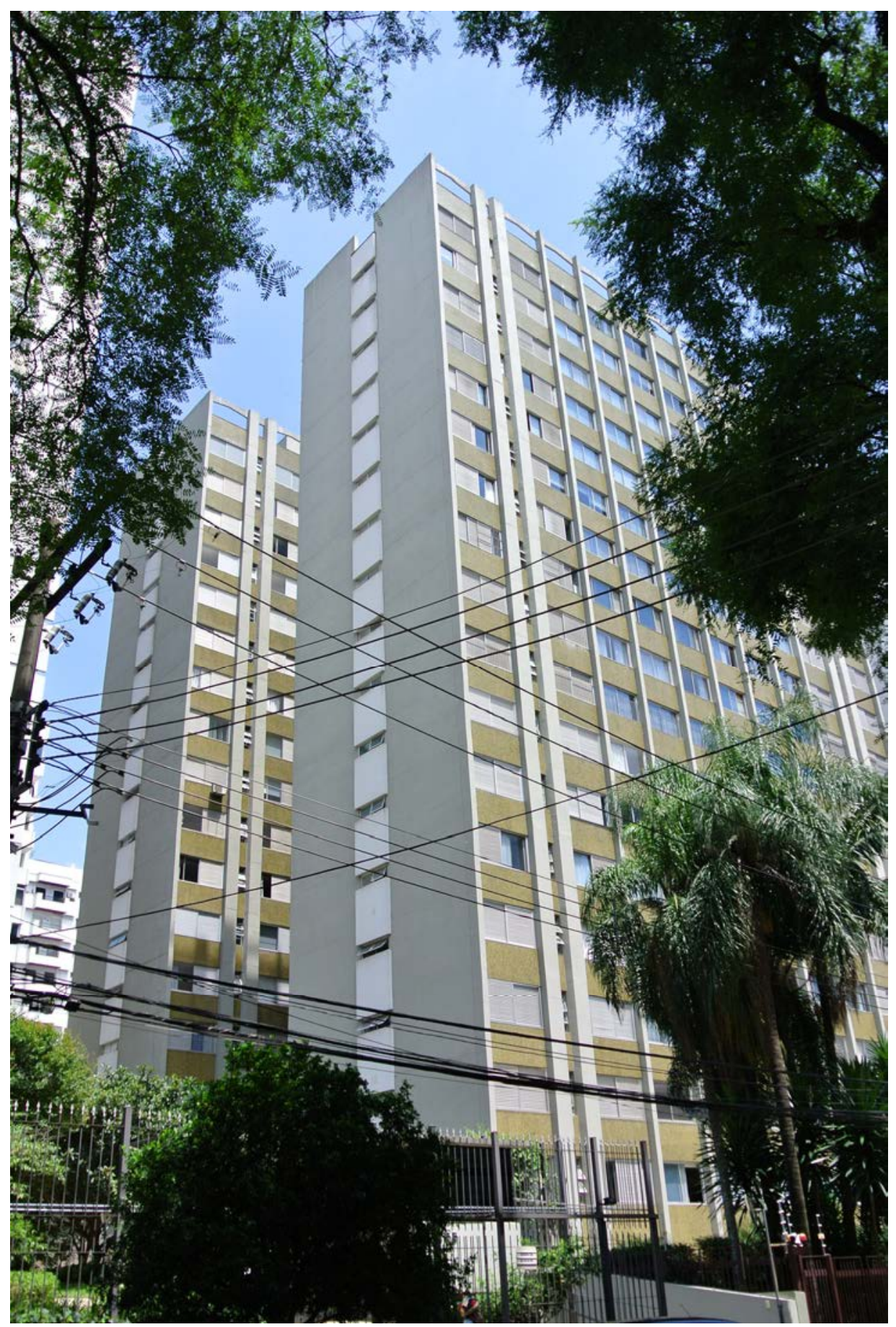

Figura 90: Conjunto de dois edifícios á Alameda Lorena 1041 Protótipos para a execução do Portal do Morumbi Projeto João Henrique da Rocha. ${ }^{132}$

${ }^{132}$ Foto: Demósthenes Magno Santos - Fev. 2013 


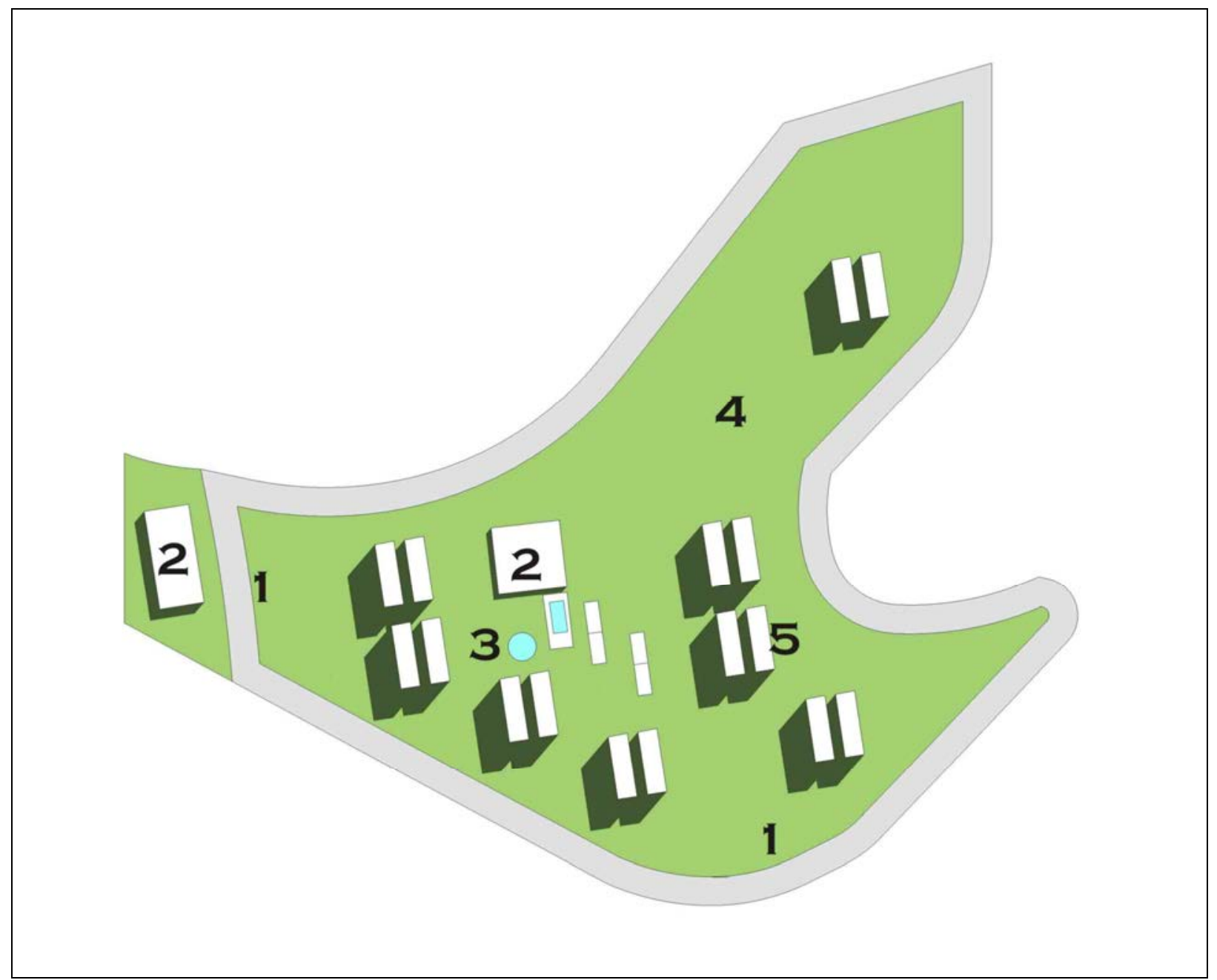

Figura 91: Condomínio Portal do Morumbi- Projeto João Henrique da Rocha - 1973 Implantação: 1)Portarias; 2)Shopping; 3)Piscinas e quadras externas; 4)bosque; 5)blocos de apartamentos. ${ }^{133}$

${ }^{133}$ Fonte: Desenho do autor, 2013 


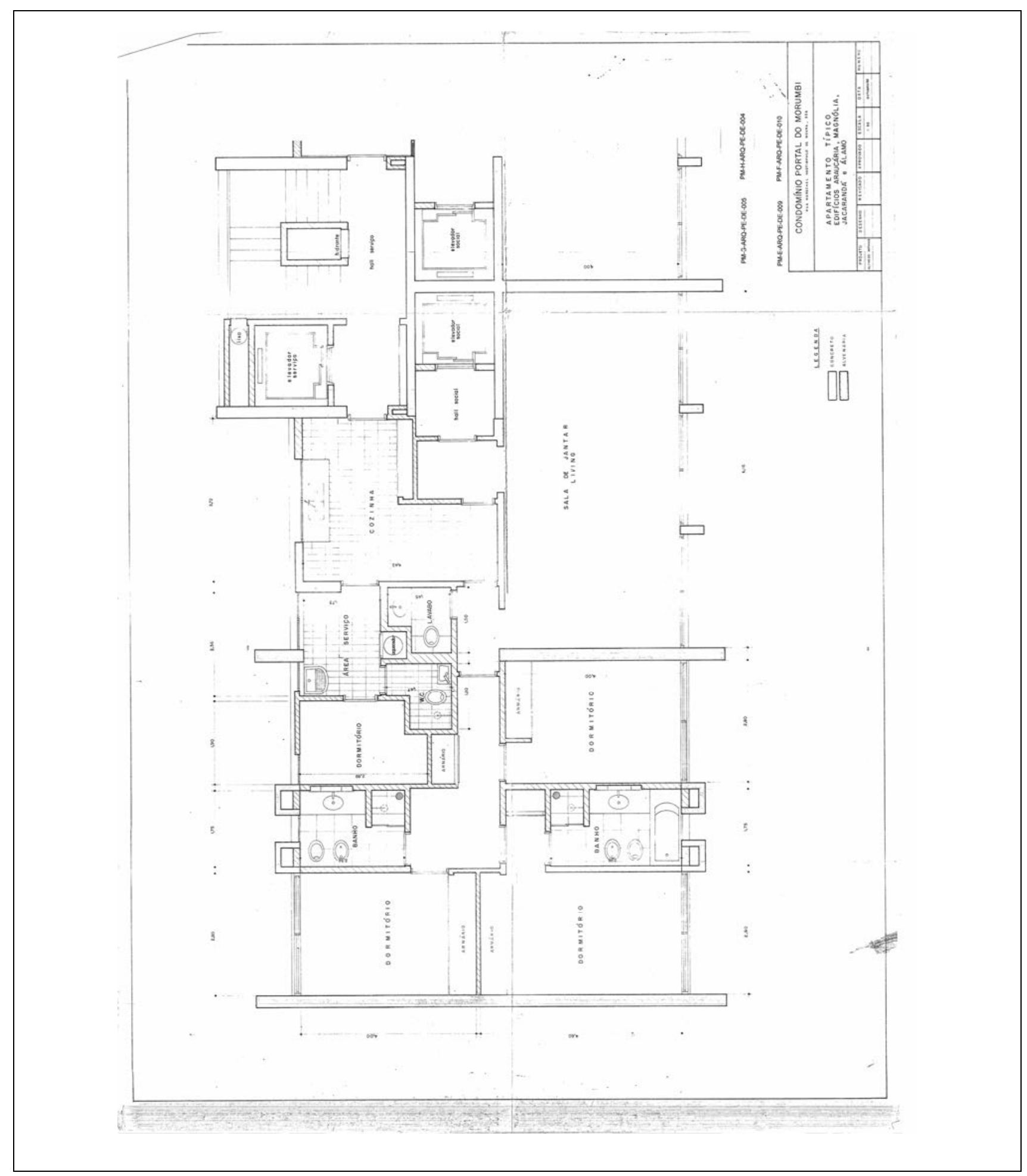

Figura 92: Condomínio Portal do Morumbi- Projeto João Henrique da Rocha - 1973 Projeto executivo: planta do andar tipo com três dormitórios. ${ }^{134}$

${ }^{134}$ Fonte: Arquivo do Condomínio Portal do Morumbi 


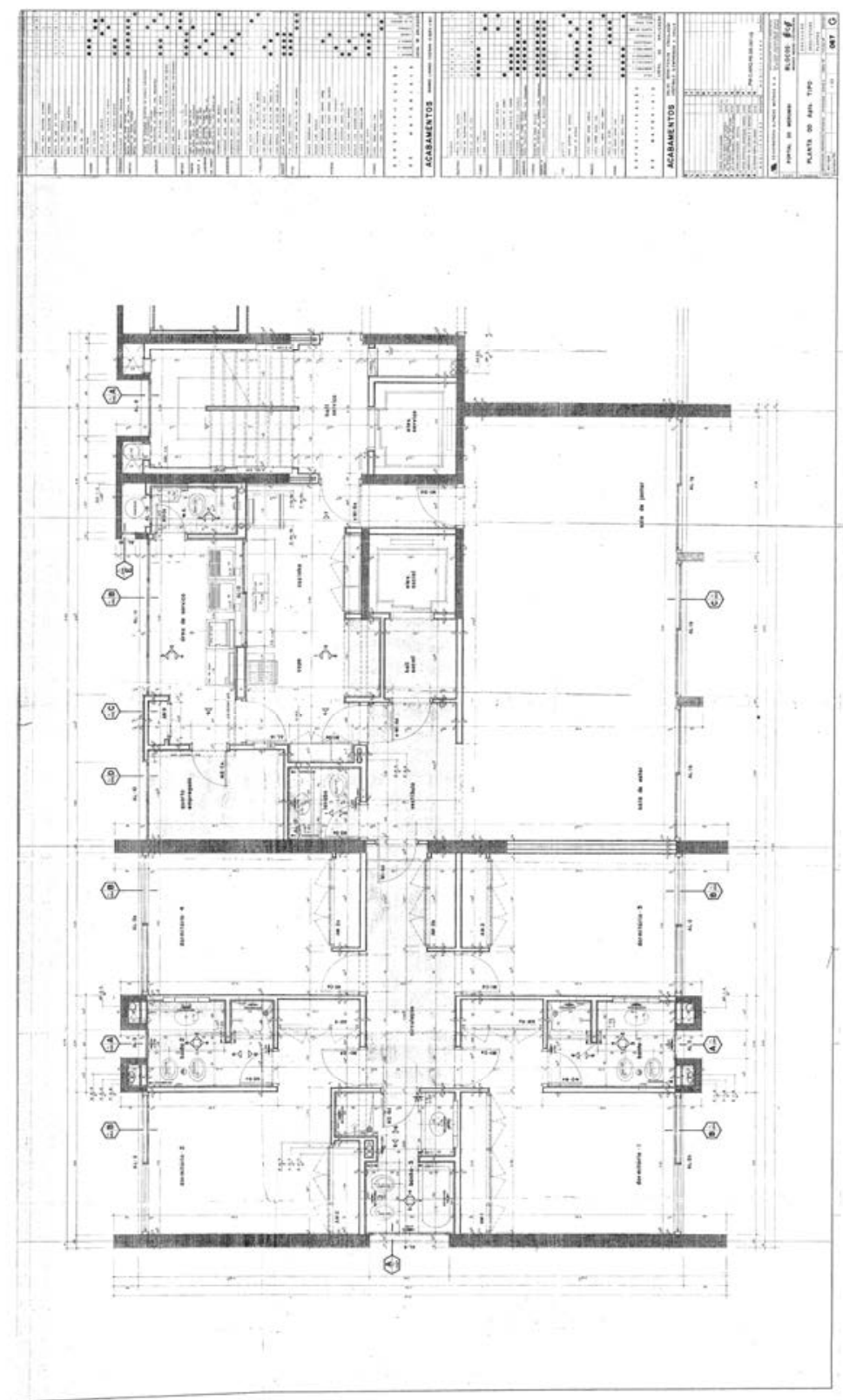

Figura 93: Condomínio Portal do Morumbi- Projeto João Henrique da Rocha - 1973 Projeto executivo: planta do andar tipo com quatro dormitórios. ${ }^{135}$

${ }^{135}$ Fonte: Arquivo do Condomínio Portal do Morumbi 


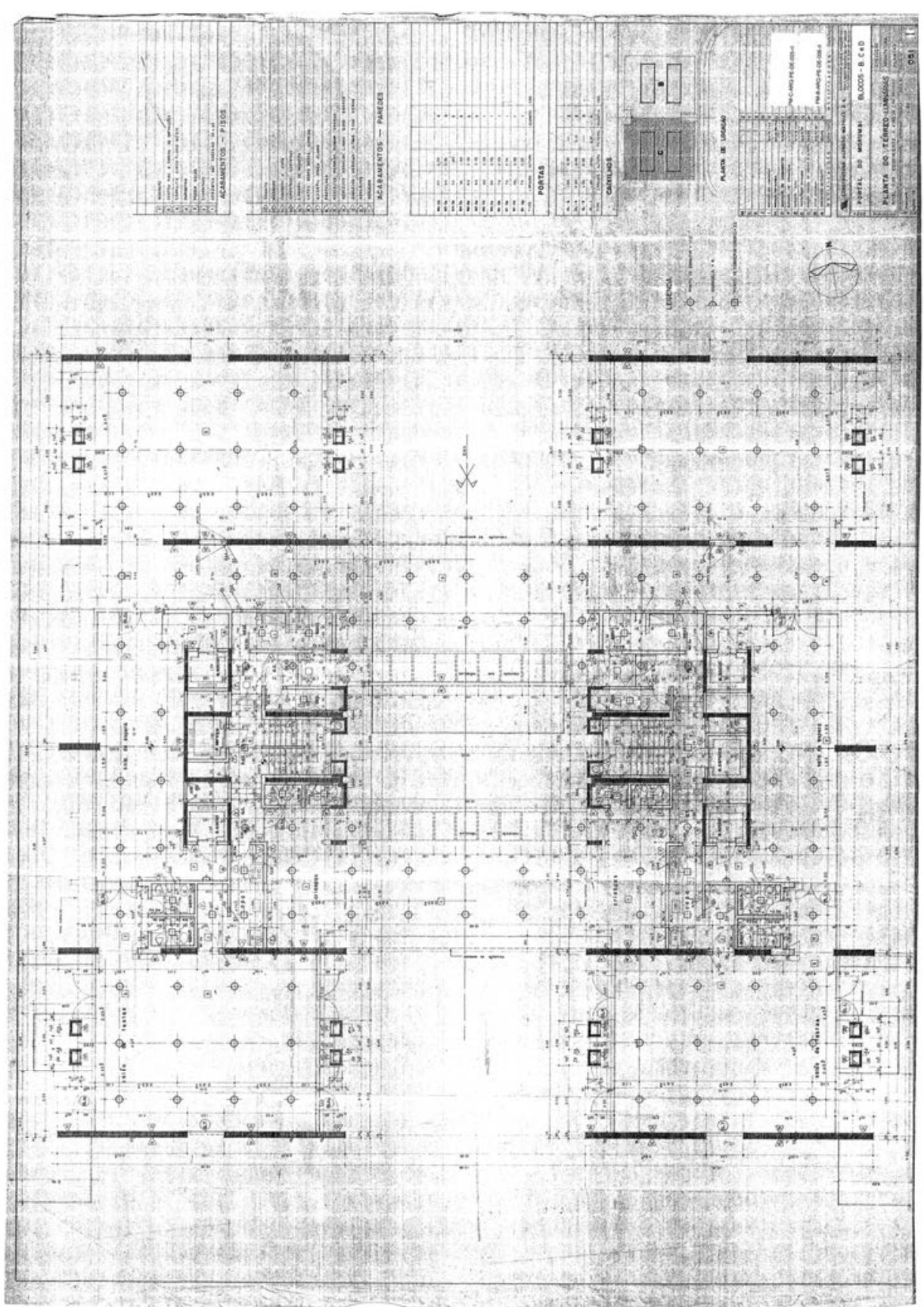

Figura 94: Condomínio Portal do Morumbi- Projeto João Henrique da Rocha - 1973 Projeto executivo: planta do andar tipo com quatro dormitórios. 136

${ }^{136}$ Fonte: Arquivo do Condomínio Portal do Morumbi 


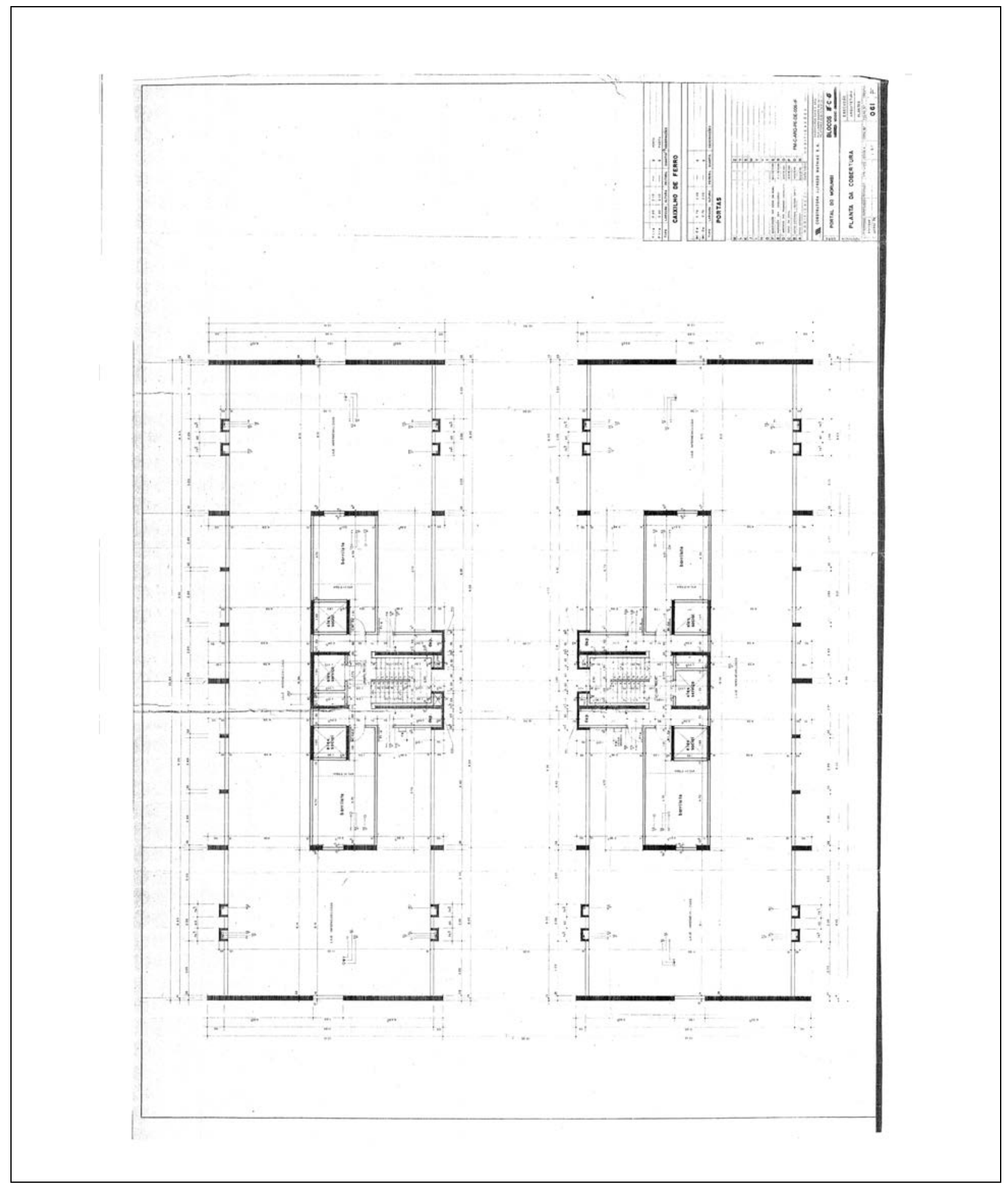

Figura 95: Condomínio Portal do Morumbi- Projeto João Henrique da Rocha - 1973 Projeto executivo: planta da cobertura. ${ }^{137}$

${ }^{137}$ Fonte: Arquivo do Condomínio Portal do Morumbi 


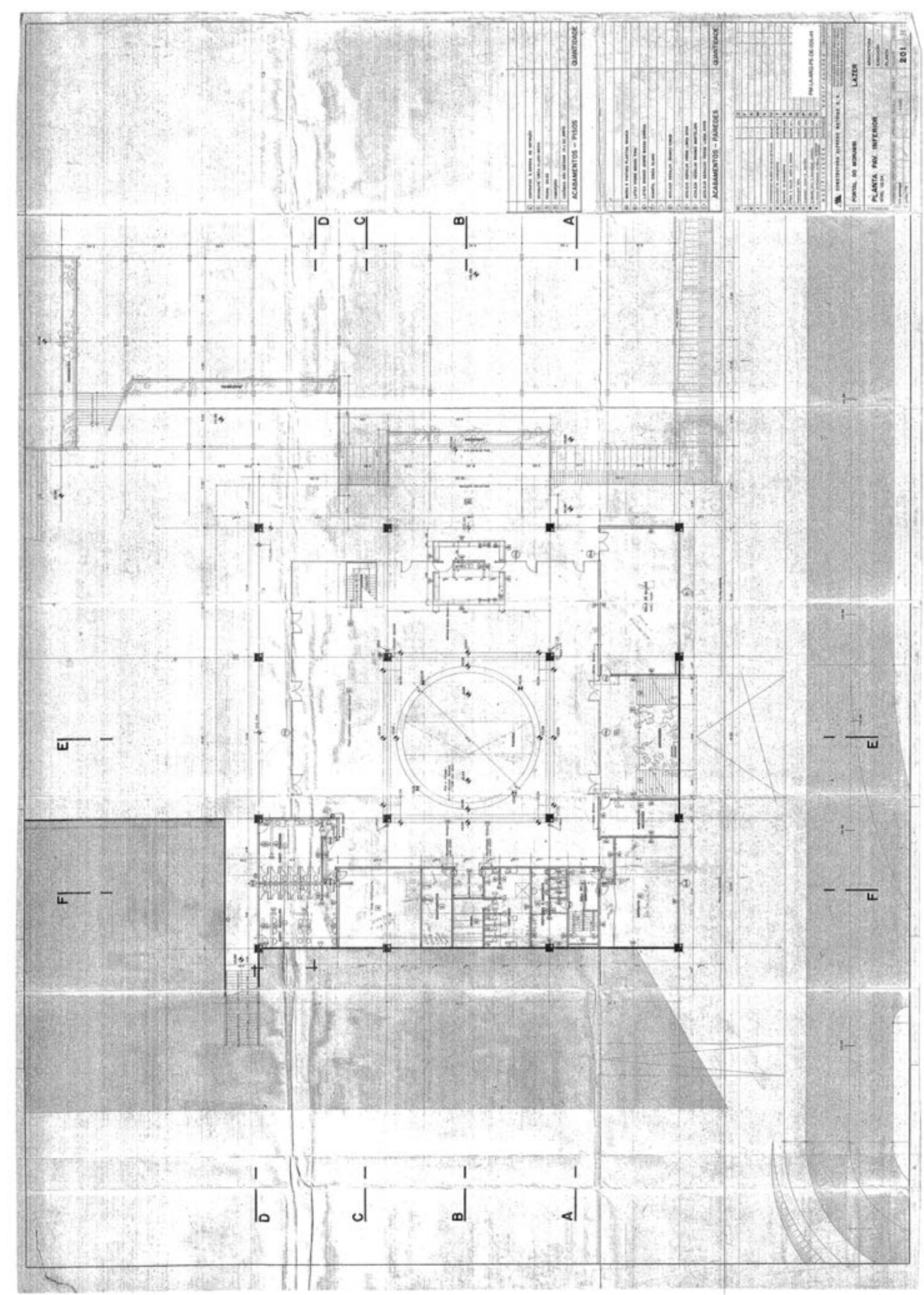

Figura 96: Condomínio Portal do Morumbi- Projeto João Henrique da Rocha - 1973 Projeto executivo: Clube - planta do andar inferior. ${ }^{138}$

${ }^{138}$ Fonte: Arquivo do Condomínio Portal do Morumbi 


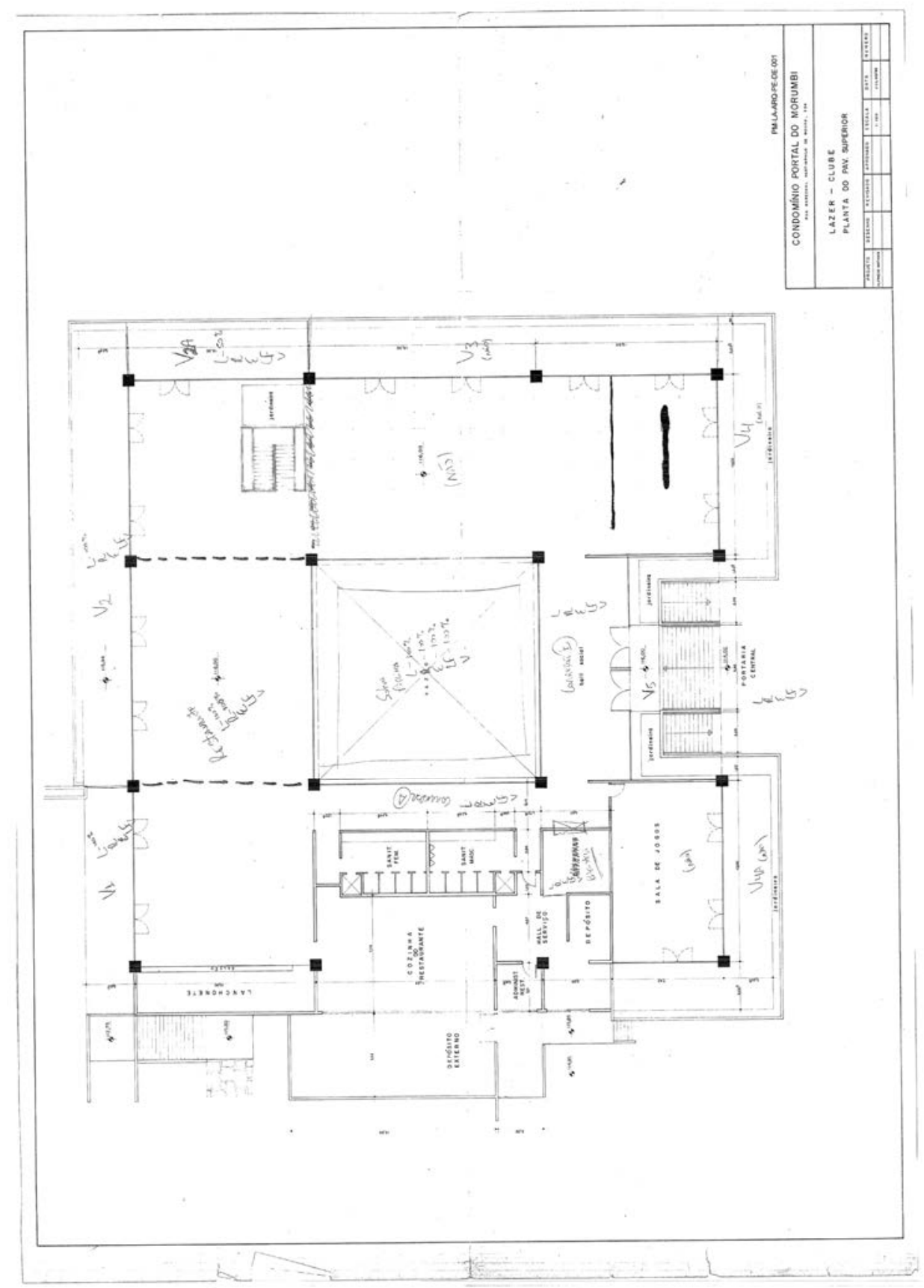

Figura 97: Condomínio Portal do Morumbi- Projeto João Henrique da Rocha - 1973 Projeto executivo: Clube - planta do andar superior. ${ }^{139}$

${ }^{139}$ Fonte: Arquivo do Condomínio Portal do Morumbi 


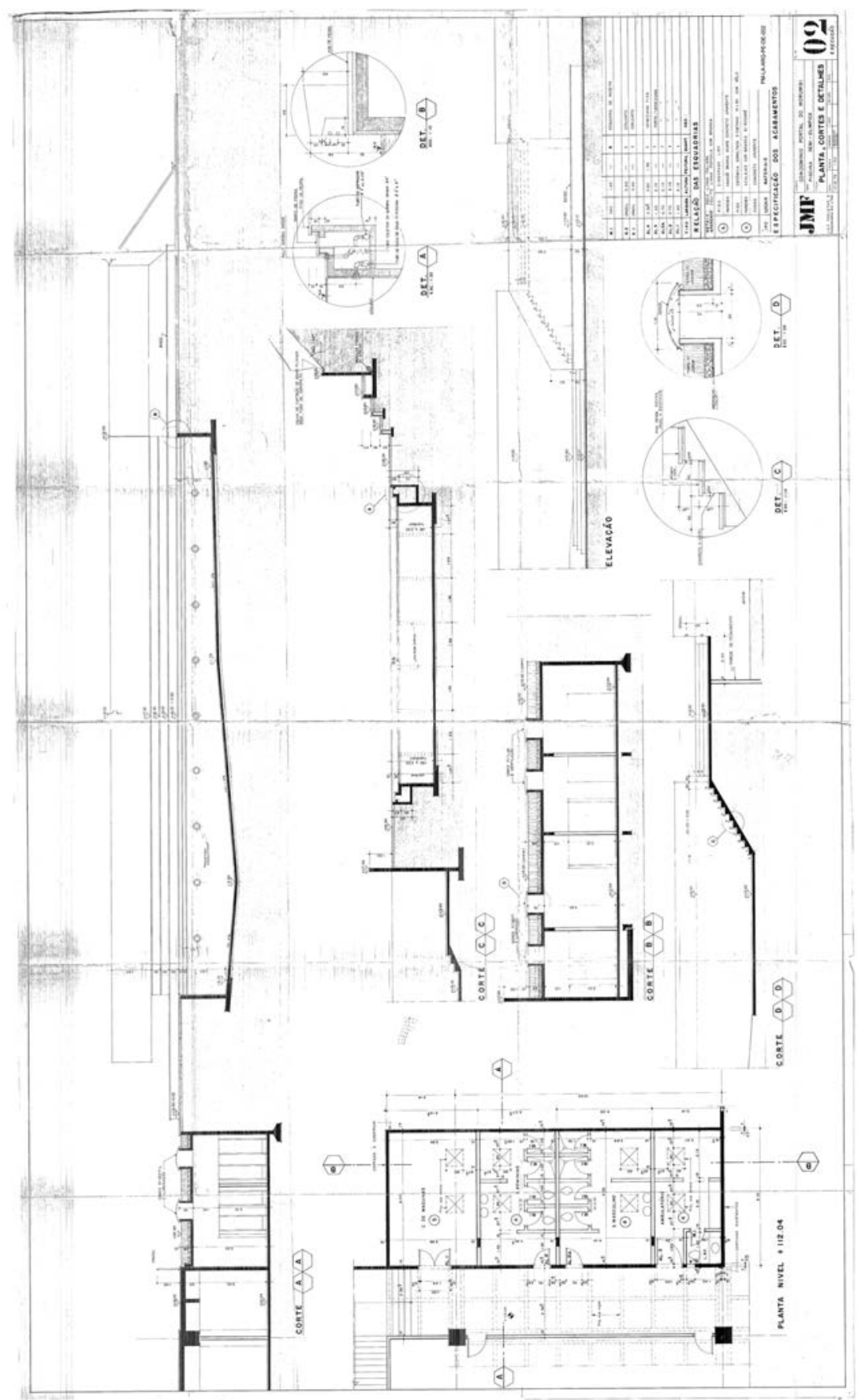

Figura 98: Condomínio Portal do Morumbi- Projeto João Henrique da Rocha - 1973 Projeto executivo: Clube - corte da piscina externa semi-olimpica. ${ }^{140}$

${ }^{140}$ Fonte: Arquivo do Condomínio Portal do Morumbi 


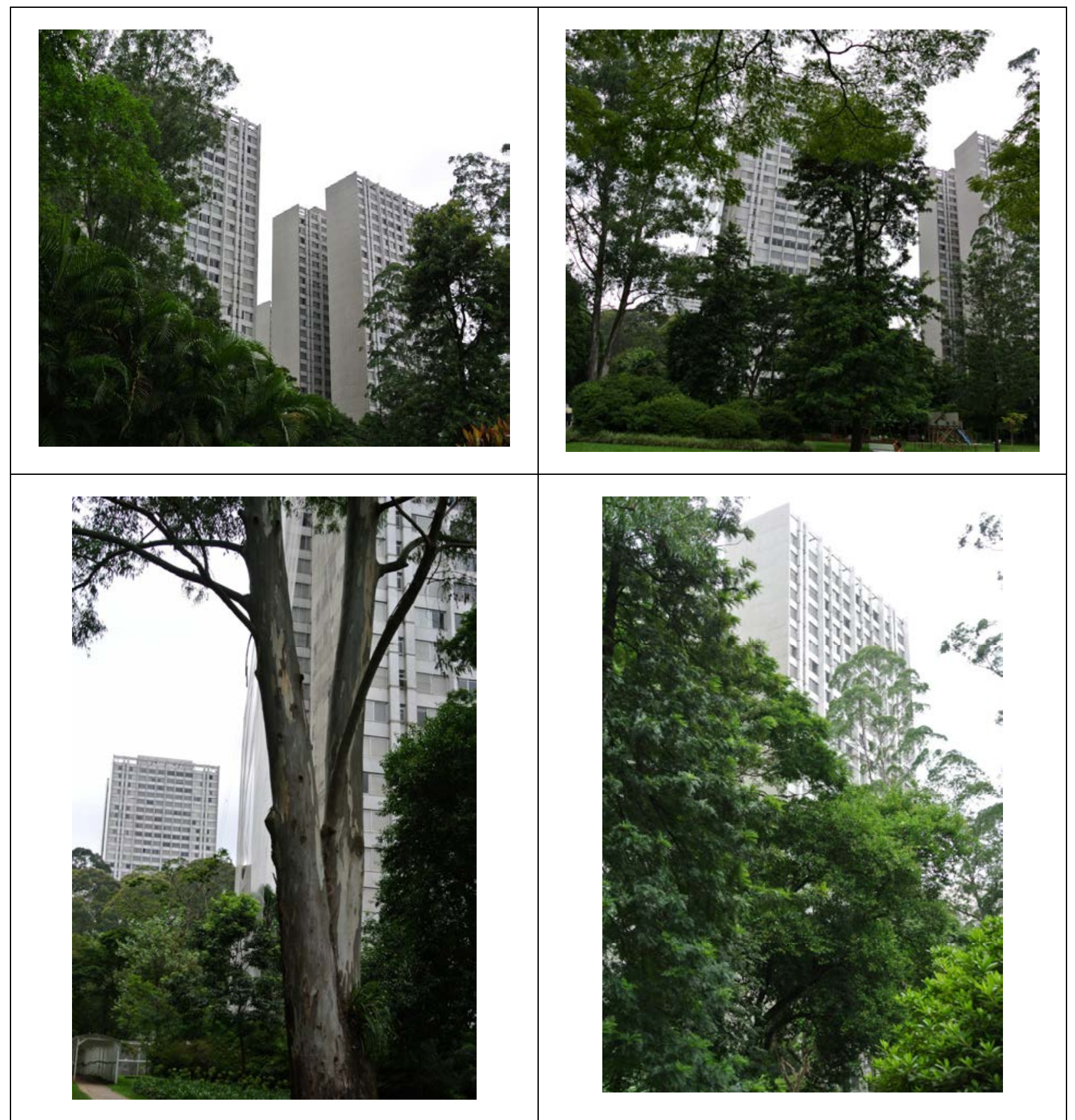

Figura 99: Condomínio Portal do Morumbi- Projeto João Henrique da Rocha - 1973

Fotos atuais do Portão do Morumbi, partindo do portão em frente ao Shopping, dando a volta no sentido anti-horário. ${ }^{141}$

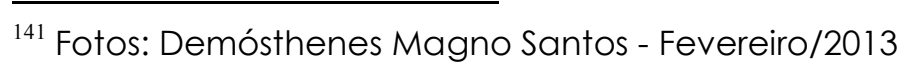




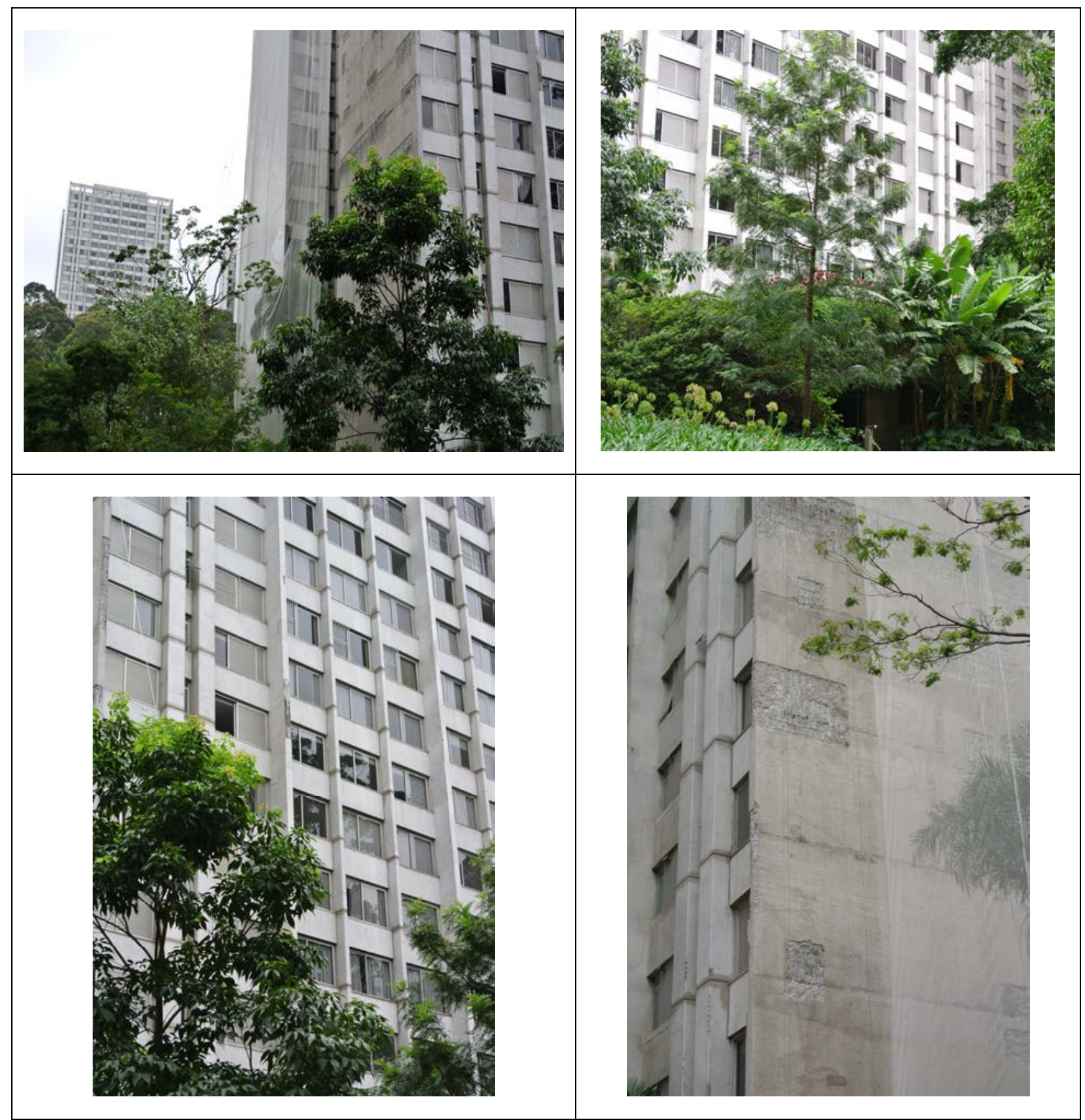

Figura 100: Condomínio Portal do Morumbi- Projeto João Henrique da Rocha - 1973

Fotos atuais do Portão do Morumbi, partindo do portão em frente ao Shopping, dando a volta no sentido anti-horário. ${ }^{142}$

${ }^{142}$ Fotos: Demósthenes Magno Santos - Fevereiro/2013 


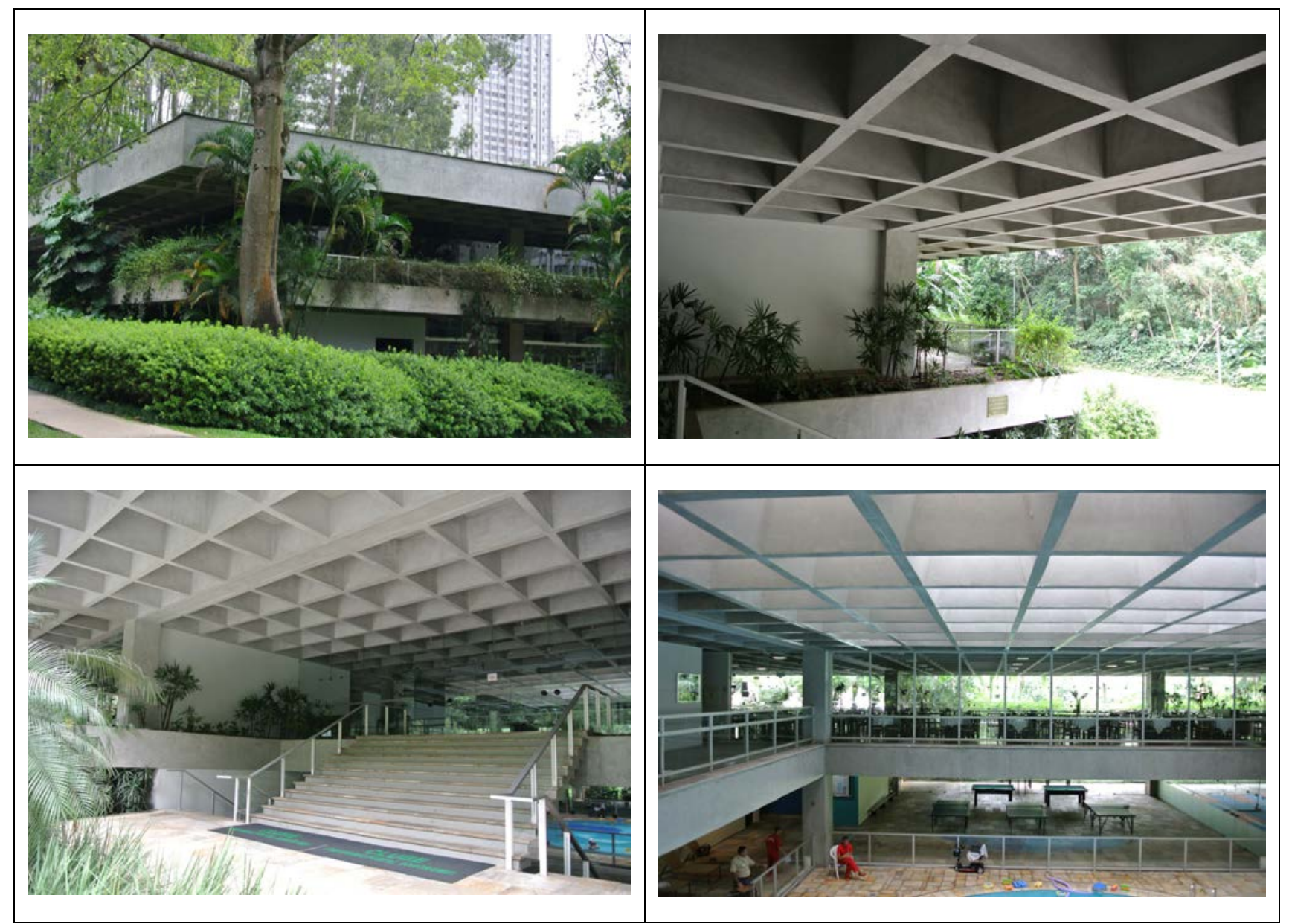

Figura 101: Condomínio Portal do Morumbi- Projeto João Henrique da Rocha - 1973

Fotos atuais do Portão do Morumbi, partindo do portão em frente ao Shopping, dando a volta no sentido anti-horário. ${ }^{143}$

${ }^{143}$ Fotos: Demósthenes Magno Santos - Fevereiro/2013 


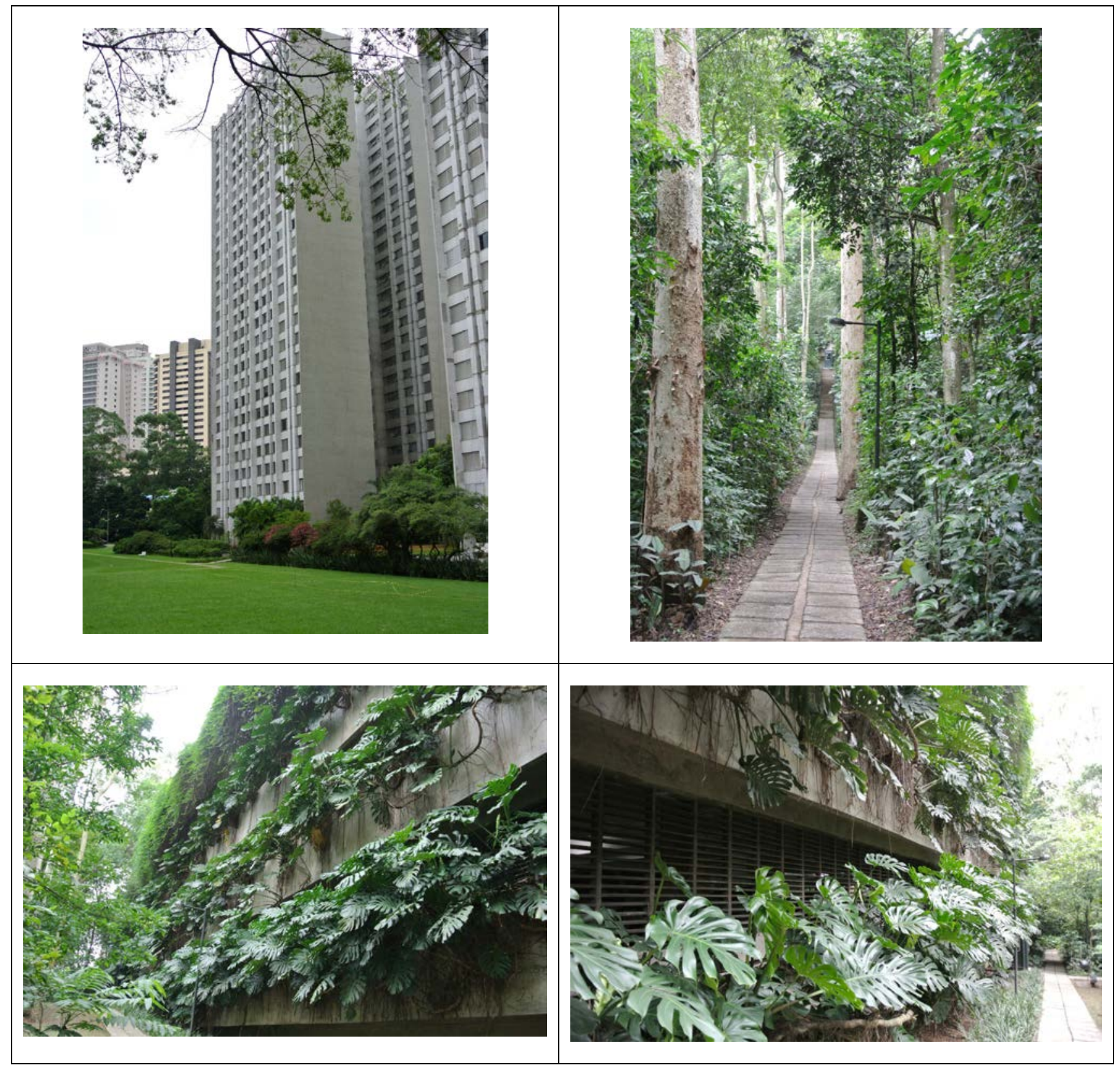

Figura 102: Condomínio Portal do Morumbi- Projeto João Henrique da Rocha - 1973

Fotos atuais do Portão do Morumbi, partindo do portão em frente ao Shopping, dando a volta no sentido anti-horário. ${ }^{144}$

\footnotetext{
${ }^{144}$ Fotos: Demósthenes Magno Santos - Fevereiro/2013
} 


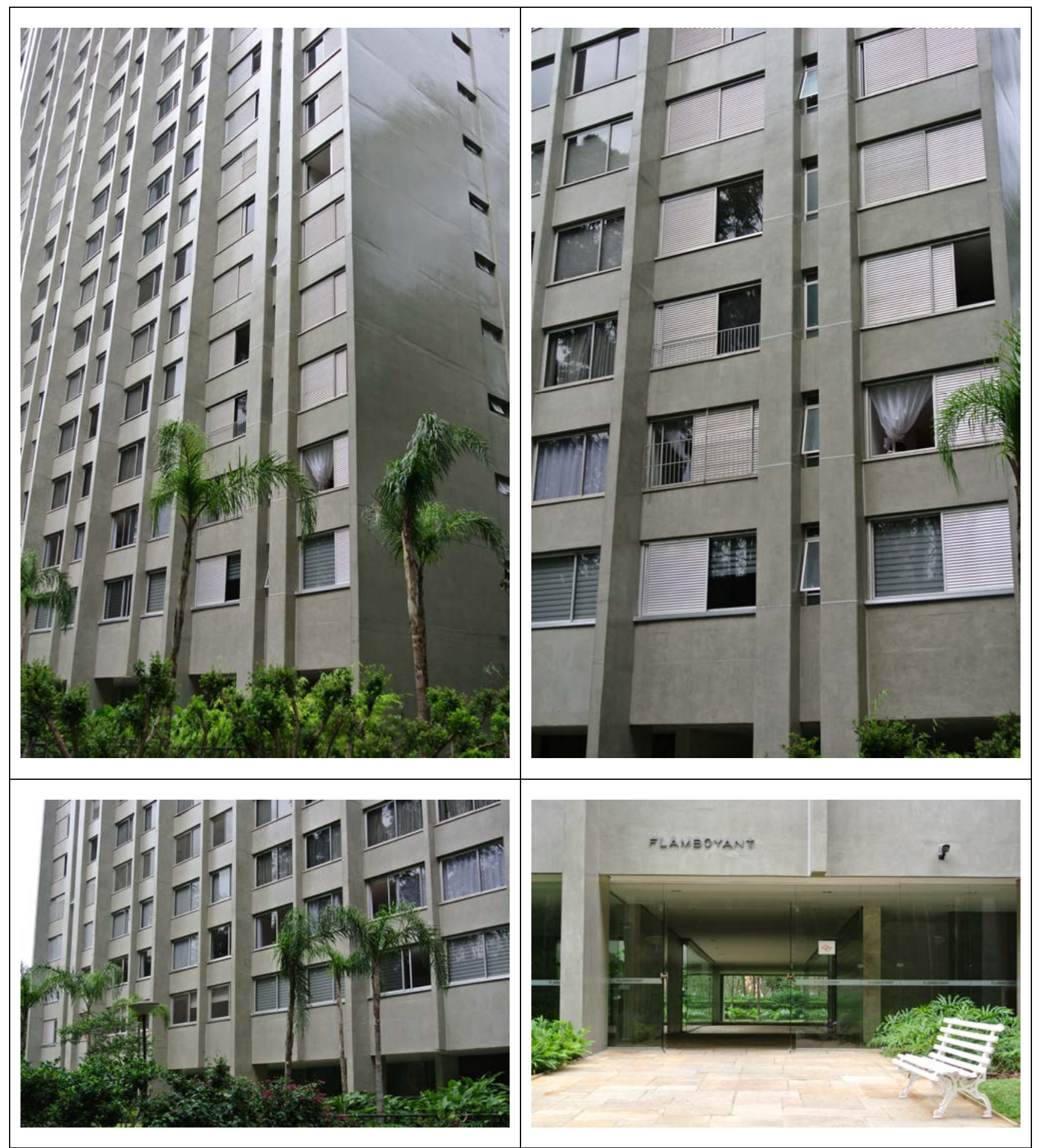

Figura 103: Condomínio Portal do Morumbi- Projeto João Henrique da Rocha - 1973

Fotos atuais do Portão do Morumbi, partindo do portão em frente ao Shopping, dando a volta no sentido anti-horário. ${ }^{145}$

${ }^{145}$ Fotos: Demósthenes Magno Santos - Fevereiro/2013 


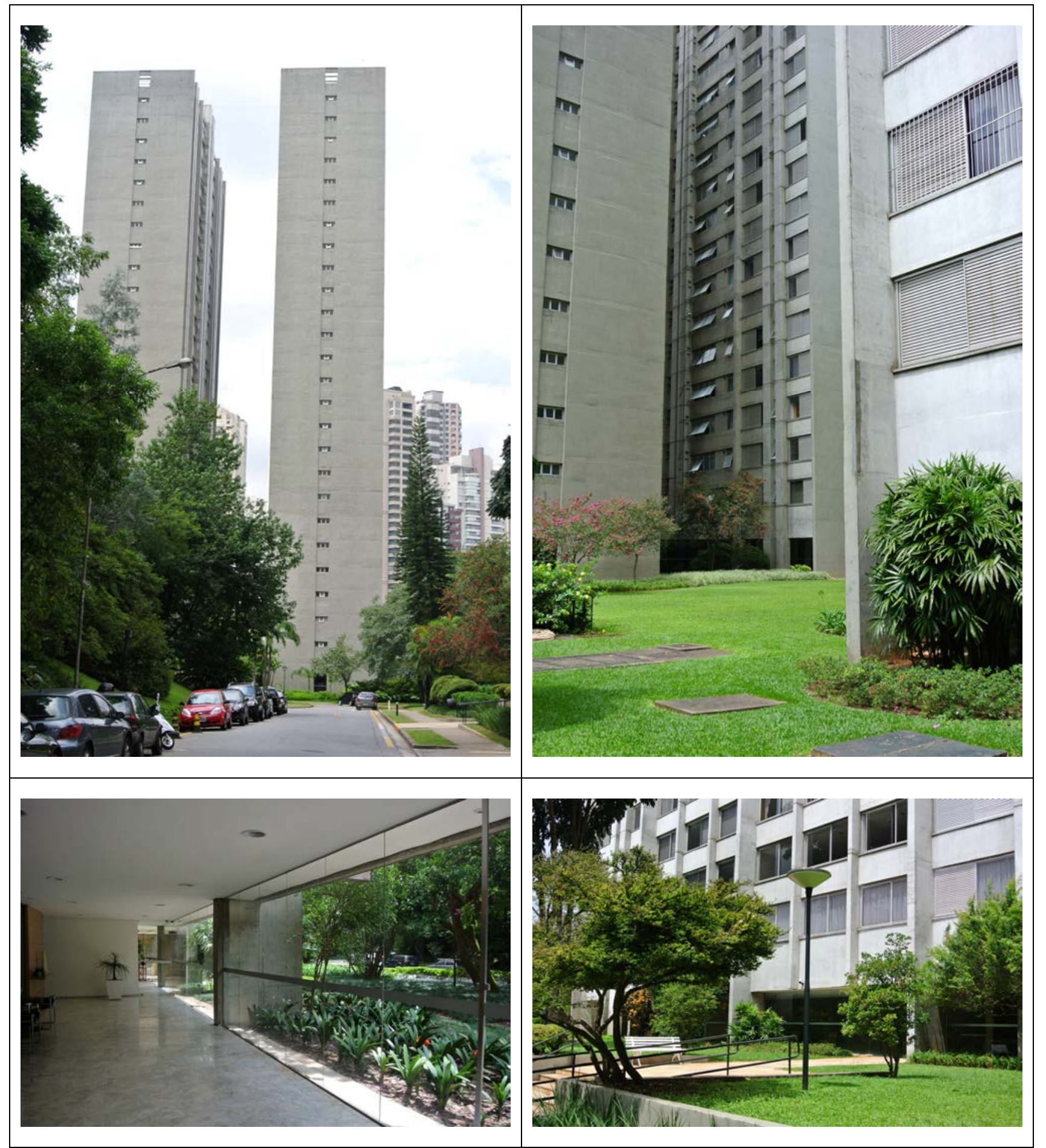

Figura 104: Condomínio Portal do Morumbi- Projeto João Henrique da Rocha - 1973

Fotos atuais do Portão do Morumbi, partindo do portão em frente ao Shopping, dando a volta no sentido anti-horário. ${ }^{146}$

${ }^{146}$ Fotos: Demósthenes Magno Santos - Fevereiro/2013 


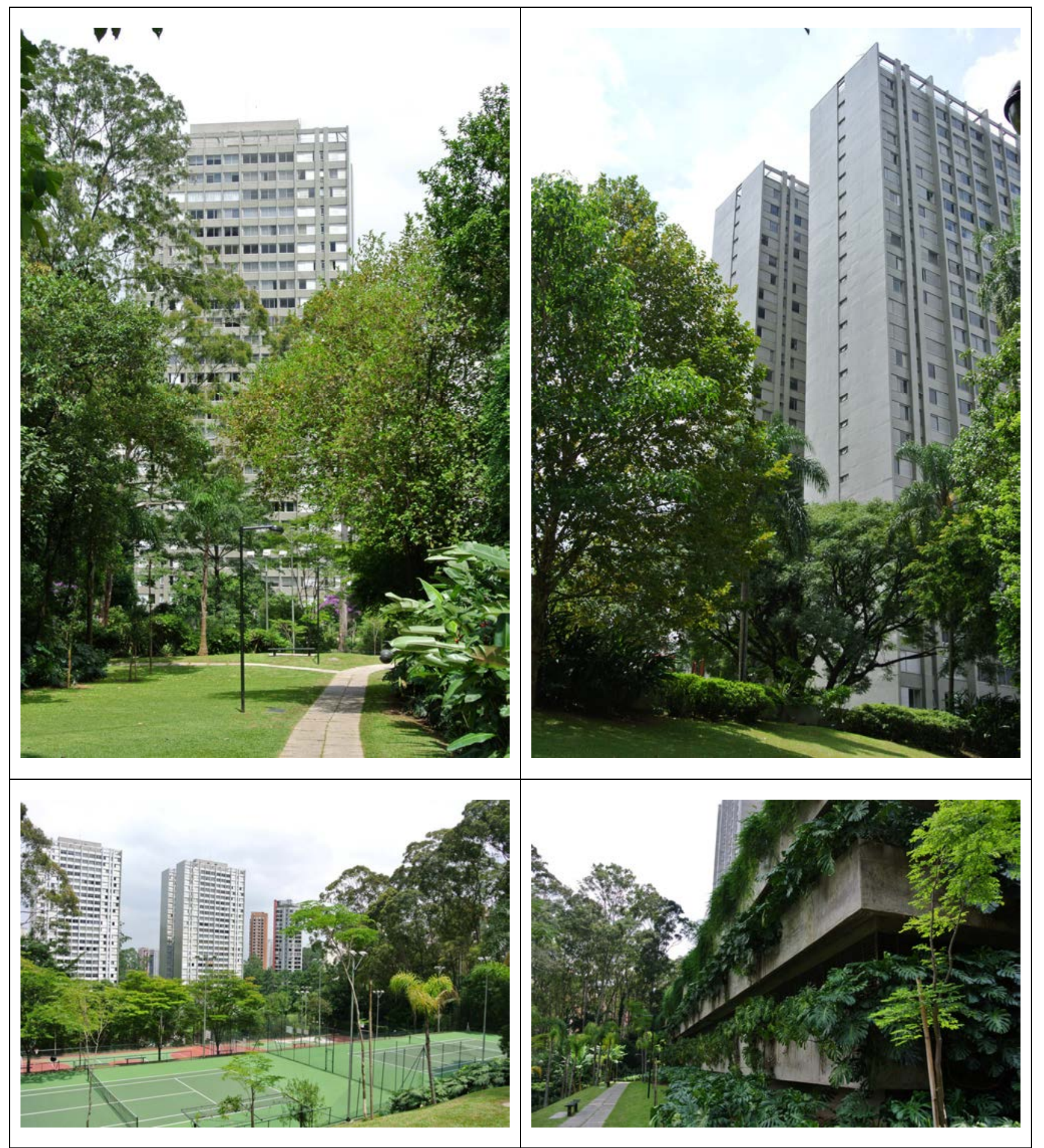

Figura 105: Condomínio Portal do Morumbi- Projeto João Henrique da Rocha - 1973

Fotos atuais do Portão do Morumbi, partindo do portão em frente ao Shopping, dando a volta no sentido anti-horário. ${ }^{147}$

${ }^{147}$ Fotos: Demósthenes Magno Santos - Fevereiro/2013 


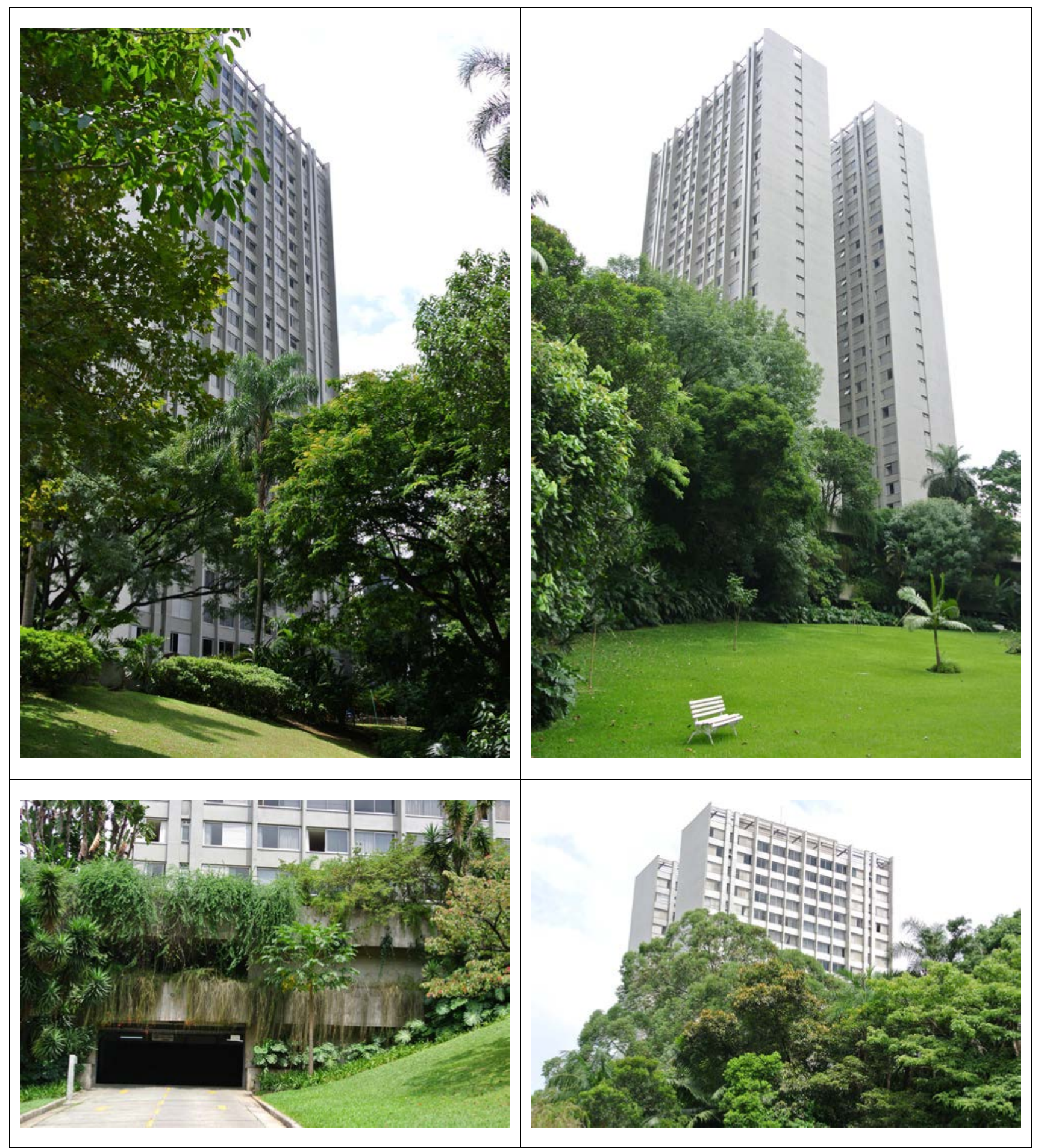

Figura 106: Condomínio Portal do Morumbi- Projeto João Henrique da Rocha - 1973

Fotos atuais do Portão do Morumbi, partindo do portão em frente ao Shopping, dando a volta no sentido anti-horário. ${ }^{148}$

${ }^{148}$ Fotos: Demósthenes Magno Santos - Fevereiro/2013 


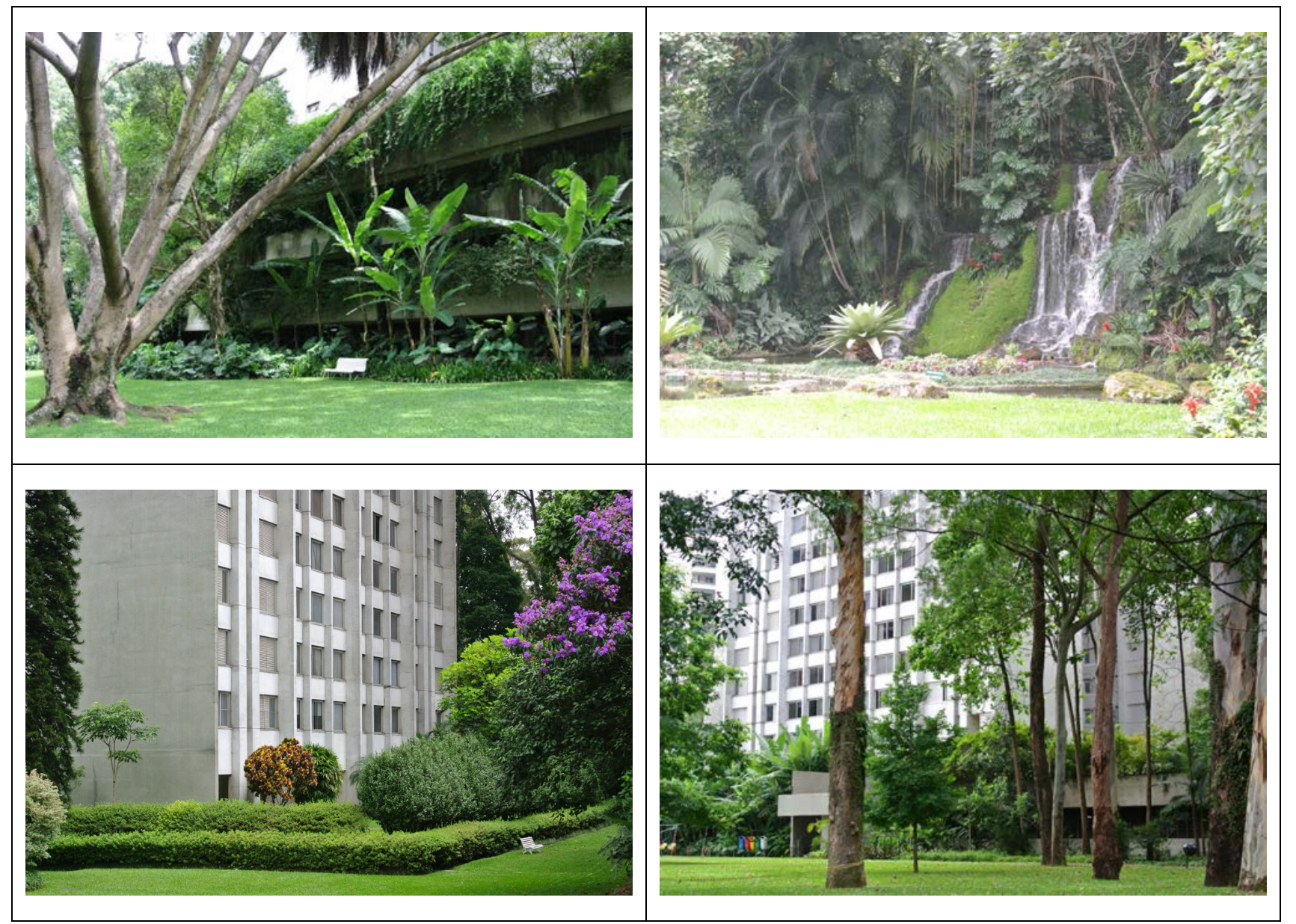

Figura 107: Condomínio Portal do Morumbi- Projeto João Henrique da Rocha - 1973

Fotos atuais do Portão do Morumbi, partindo do portão em frente ao Shopping, dando a volta no sentido anti-horário. ${ }^{149}$

${ }^{149}$ Fotos: Demósthenes Magno Santos - Fevereiro/2013 


\section{Considerações Finais}

Este trabalho teve como objetivo estudar a atuação do incorporador, empresário e construtor Alfredo Mathias diante da realidade construída dos anos de 1950 a 1985. Buscamos o conhecimento da evolução urbana da cidade e as condições que propiciaram sua atuação, desde as intervenções do Plano de Avenidas até as interpretações dos códigos legislativos que permitiram essa atuação. Acreditamos ser de interesse público o registro de suas obras que marcam profundamente a paisagem da cidade. Alfredo Mathias foi empresário, construtor, arquiteto e capitalista, sua obra é um registro que mesmo atuando no mercado imobiliário é possível fazer uma arquitetura de qualidade. 
Os fatos tornam-se historia, a história torna-se lenda e lenda torna-se mito. Procuramos resgatar a historia do mito Alfredo Mathias. Descobrimos um gigante: dono de um grande carisma, um visionário e empreendedor com uma produção vastíssima, do qual este trabalho é apenas um pequeno registro. Nossa intenção é dar prosseguimento a esta pesquisa em um futuro doutorado onde pesquisaremos a fundo sua biografia, seus parceiros comerciais e principalmente a atuação da construtora nos anos após sua morte. Sua vida pode assim ser definida, parafraseando Jean Cocteau: "Não sabendo que era impossível, foi lá e fez".

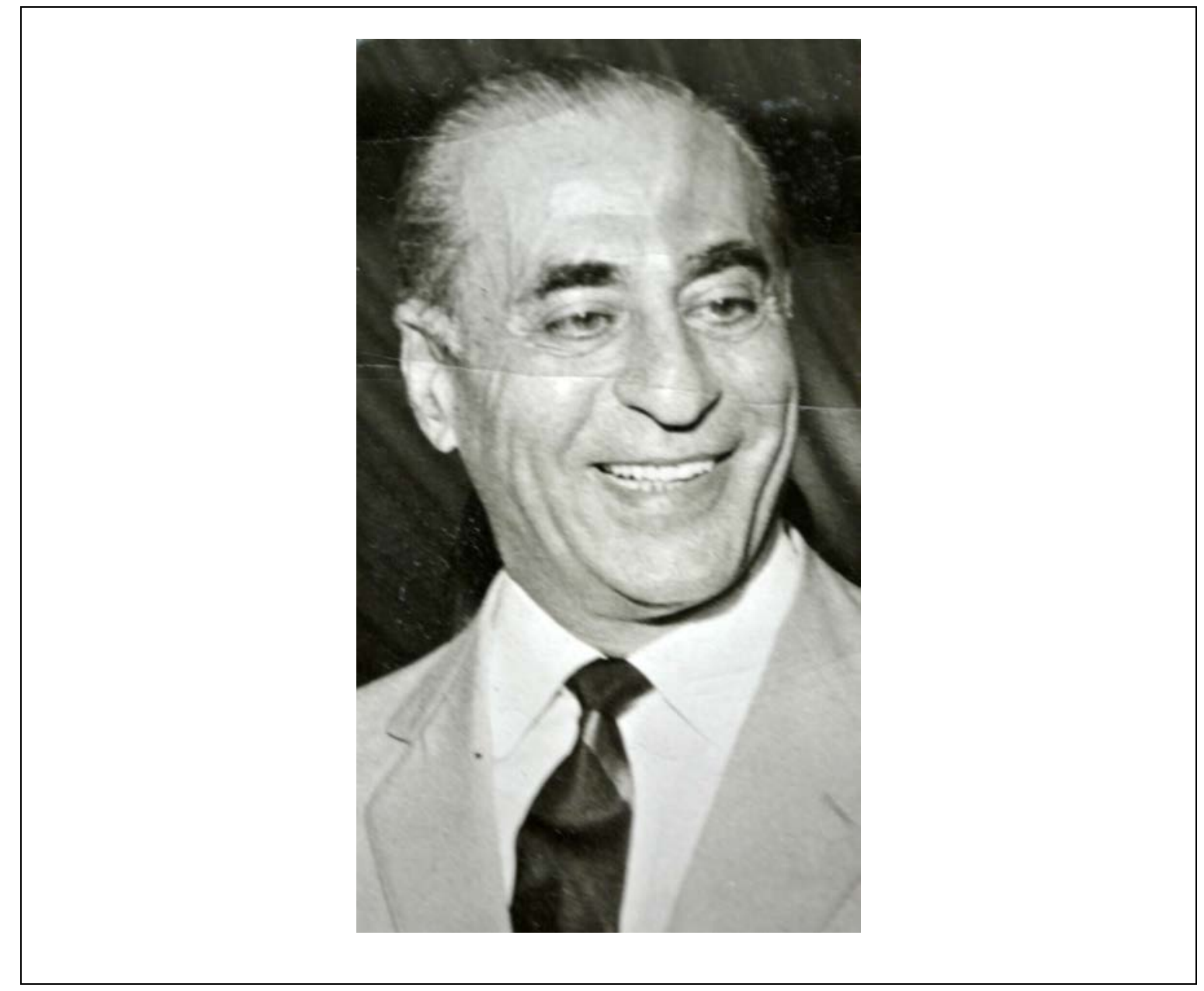

Figura 108: Alfredo Mathias (1906 - 1979). ${ }^{150}$

\footnotetext{
${ }^{150}$ Foto gentilmente cedida pela $S r^{a}$ Maria do Carmo Mathias Maffei, sem data
} 


\section{Referências Bibliográficas}

ALEIXO, Cyntia Augusta Poleto. Edifícios e galerias comerciais: arquitetura e comércio na cidade de São Paulo, anos 50 e 60. Dissertação de Mestrado apresentada a Escola de Engenharia de São Carlos - Universidade de São Paulo. São Carlo, São Paulo, 2005

Antonucci, Denise. SAGMACS: o estudo que fez escola, in

Ato Municipal $n^{\circ} 611$ - A Cidade que não pode parar 2002. Editora Mackenzie, São Paulo.

Ato Municipal $n^{\circ} 769$ - A cidade que não pode parar 2002. Editora Mackenzie, São Paulo.

Ato Municipal n 834 - A cidade que não pode parar 2002. Editora Mackenzie, São Paulo.

Ato Municipal no 861 - A cidade que não pode parar 2002. Editora Mackenzie São Paulo.

CAMPOS, Candido Malta. Os Rumos da Cidade, Urbanismo e Modernização em São Paulo. Editora SENAC, São Paulo, 2002.

CAMPOS, Candido Malta e SMOEKH, Nádia. A cidade que não pode parar. Editora Mackenzie, São Paulo, 2002.

CAMPOS, Candido Malta e SOMEKH, Nádia. O Super-plano: PUB - Plano Urbanístico Básico in A cidade que não pode parar. Editora Mackenzie, São Paulo, 2002

COHEN, Jean-Louis. Scènes de La vie future: l'architecture europèenne et la tentation de l'amérique, 1893-1960, 1995. Flammarion 
CORATO, Aline Coelho Sanches. A obra e trajetória do arquiteto Giancarlo Palanti: Itália e Brasil. Dissertação de Mestrado apresentada a Escola de Engenharia de São Carlos da Universidade de São Paulo. São Carlos, São Paulo, 2008.

DA SILVA, Luís Octavio. A Constituição das bases para a verticalização na cidade de São Paulo. São Paulo, 07.080, Vitruvius, jan 2007 , www.vitruvius.com.br/arquitestos/07.080/280

FEDELMAN, Sarah. Planejamento e zoneamento: São Paulo 1947-1962, tese de Doutorado apresentada a Faculdade de Arquitetura e urbanismo da Universidade de São Paulo, São Paulo, 1996.

FEDELMAN, Sarah. A configuração espacial da cidade, in São Paulo Metrópole em Trânsito, org. Candido Malta Campos, Lúcia Helena Gama, Vladimir Scchetta, Ed. SENAC 2004.

FICHER, Sylvia. Edifícios Altos no Brasil, in: Revista Espaços e Debates - Cidades Brasileiras Século XX, n. 37, São Paulo, 1994.

FICHER, Sylvia. Os Arquitetos da Poli: Ensino e Profissão em São Paulo. FAPESP Editora da Universidade de São Paulo, São Paulo, 2005.

FRANCO, RuY Eduardo Debs. Artacho Jurado: arquitetura proibida. Editora SENAC, São Paulo, 2008.

GOHN, Maria da Glória. Movimentos e lutas sociais, in São Paulo Metrópole em Trânsito, org. Candido Malta Campos, Lúcia Helena Gama, Vladimir Scchetta, Editora SENAC, São Paulo, 2004.

GROSTEIN, Maria Dora. Periferias: loteamentos ilegais e formas de crescimento urbano, in São Paulo Metrópole em Trânsito, org. Candido Malta Campos, Lúcia Helena Gama, Vladimir Scchetta, Editora SENAC, São Paulo, 2004. 
GUNN, Philip, CORREIA, Telma de Barros. A industrialização brasileira e a dimensão geográfica dos estabelecimentos industriais. Revista Brasileira de Estudos urbanos e Regionais - ANPUR, volume sete, número 1 - maio de 2005.

MARTINS, Egídio. O papel do engenheiro na sociedade moderna. Boletim do Instituto de Engenharia, n 142, vol. XXVIII, São Paulo, fevereiro de 1939, pg. 95.

MAIA, Francisco Prestes. Introdução ao Estudo de um Plano de avenidas para a cidade de São Paulo. Ed. Melhoramentos, São Paulo, 1930.

MELO, Luiz Inácio de Anhaia. O recreio ativo das cidades modernas, Escolas Salesianas, São Paulo, 1929.

MELO, Luiz Inácio de Anhaia. Programa da cadeira de estética, composição geral e urbanismo, em anuário da Escola politécnica para o ano de 1932.

MELO, Luis Inácio de Anhaia. "O problema legal: regulamentação e expropriação", em Problemas de Urbanismo: bases para a resolução do problema técnico, in CAMPOS, Candido Malta. Os rumos da Cidade, Urbanismo e Modernização em São Paulo. Editora SENAC, São Paulo, 2002.

LEFÈVRE, J. E. de A. Entre o Discurso e a Realidade. A quem interessa o centro de são Paulo? A Avenida São Luiz e sua evolução. Tese de Doutorado, FAU/USP. São Paulo 1999.

LEME, Maria Cristina da Silva. Revisão do plano de avenidas: um estudo sobre o planejamento urbano. Tese de Doutorado apresentada a Faculdade de Arquitetura e urbanismo da Universidade de São Paulo, São Paulo, 1990.

LEMOS, Carlos Alberto Cerqueira. Edifícios Residenciais em São Paulo: da sobriedade à personificação. Revista Projeto, n. 133. São Paulo, 1990. Pg. 57-58. 
LIMA, Sionara Barbosa S. de. O Sistema de Áreas Verdes e a formação da idéia de Recreio Ativo em São Paulo na primeira metade do século XX. Anais do XVII Encontro Regional de História - O lugar da História. ANPUH/SP UNICAMP, 2004

MENDES, Zilda. A industrialização de São Paulo pela visão de Warren Dean. 2011, $248 \mathrm{pg}$.

MÜLLER, Nicia Lecocp. A Área central da cidade. In Azevedo, A. - A cidade de São Paulo - estudos de geografia urbana. São Paulo. Companhia Editora nacional, São Paulo, vol. III 1958.

MORSE, Richard M. Formação histórica de São Paulo (Dief, 1970) pg. 373. Gainesville: University of Florida Press, 1958, in CAMPOS, Candido Malta. Os rumos da Cidade, Urbanismo e Modernização em São Paulo. Editora SENAC, São Paulo, 2002.

OLIVEIRA, Marcel Steiner Giglio de. Arquitetura em São Paulo na Era Vargas, o Art Déco e ao Arquitetura Fascista nos edifícios públicos (1930-1945). Dissertação de Mestrado apresentado à Faculdade de Arquitetura e Urbanismo da Universidade de São Paulo, São Paulo, 2008.

PEREIRA LEITE, LUiz Ricardo - Estudo das Estratégias das Empresas Incorporadoras do Município de são Paulo no segmento residencial no Período 1960-1980. Dissertação de Mestrado apresentada à Faculdade De Arquitetura e Urbanismo da Universidade de São Paulo, São Paulo, 2006

PORTA, Paula, organização, História da Cidade de São Paulo, VOL.III, editora Paz e Terra - São Paulo. 
QUEIROZ, Fábio Abreu de. Apartamento modelo: arquitetura, modos de morar e produção imobiliária na cidade de São Paulo. Dissertação de Mestrado apresentada à Escola de Engenharia de São Calos da Universidade de São Paulo, São Carlos, 2008.

SEGAWA, Hugo. Prelúdio da Metrópole, arquitetura e Urbanismo em São Paulo na passagem do século XIX ao XX, $2^{a}$ edição 2004, editora Ateliê, São Paulo.

SERAPIÃO, Fernando. A arquitetura de Croce, Aflalo \& Gasperini: forma, técnica e método. Editora Paralaxe, São Paulo, 2011.

SILVA, Joana Mello de Carvalho e. O Arquiteto e a produção da cidade - a experiência de Jacques Pilon em perspectiva (1930-1960) - Tese de Doutorado apresentado à Faculdade de Arquitetura e Urbanismo da Universidade de São Paulo, São Paulo, 2010.

SIMÕES JR., José Geraldo. Anhangabaú, história e urbanismo, Imprensa Oficial do Estado de São Paulo, São Paulo, 2004.

SINGER, Paul. Desenvolvimento econômico e evolução urbana. SP in Metrópole em Trânsito. Editora SENAC, São Paulo, SP - pg. 124.

SOMEKH, Nádia. A Cidade Vertical e o Urbanismo Modernizador: São Paulo 1920 -1938. Studio Nobel/EDUSP/FAPESP, São Paulo, 1997.

SOUZA, Maria Adélia de, A Identidade da Metrópole: A verticalização em São Paulo. Editora HUCITEC - EDUSP, 20ª edição, 1994 - São Paulo

REIS, Nestor Goulart. Dois Séculos de Projetos no Estado de São Paulo, VOL III, Imprensa Oficial do Estado de São Paulo \EDUSP, São Paulo 2010.

TOLEDO, Benedito Lima. Prestes Maia e as Origens do Urbanismo moderno em São Paulo. Empresa das Artes Editora, São Paulo, 1996. 
TOPALOV, Cristian, Les prometeurs immobilièrs. Contribution à L'analyse de La production capitaliste. La recherche urbaine 4. Paris, Mouton, 1974. pg. 416

VILLA, Simone Barbosa. Mercado Imobiliário e Edifícios de Apartamentos: produção do espaço habitável no século XX. Portal VITRUVIUS - 2006 - pg. 3

VILLAÇA, Flávio. Elites, desigualdade e poder Municipal, in São Paulo Metrópole em Trânsito, org. Candido Malta Campos, Lúcia Helena Gama, Vladimir Sacchetta (org.), Editora SENAC, São Paulo, 2004. 
APÊNDICES: Localização e Fotos dos Edifícios Relacionados 


\section{APÊNDICE A - Palácio da Justiça Clovis Beliváqua}

Projeto: Francisco de Paula Ramos de Azevedo - ano 1920

Após formar-se em 1929, Alfredo Mathias trabalha como engenheiro para a Diretoria de Obras Públicas do Município como fiscal de obras

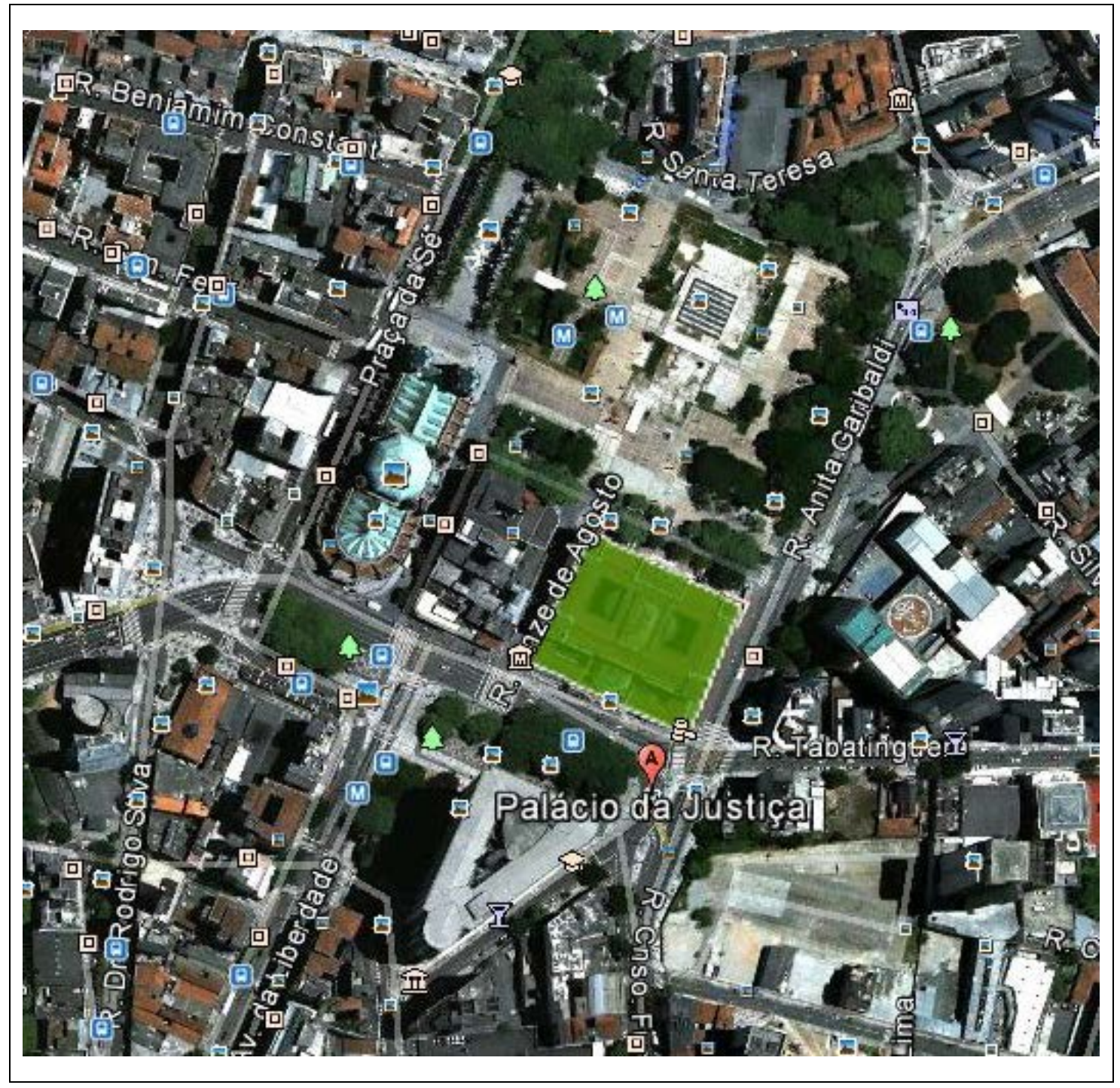

Localização'151

${ }^{151}$ Fonte: Foto Google Earth - 2011 


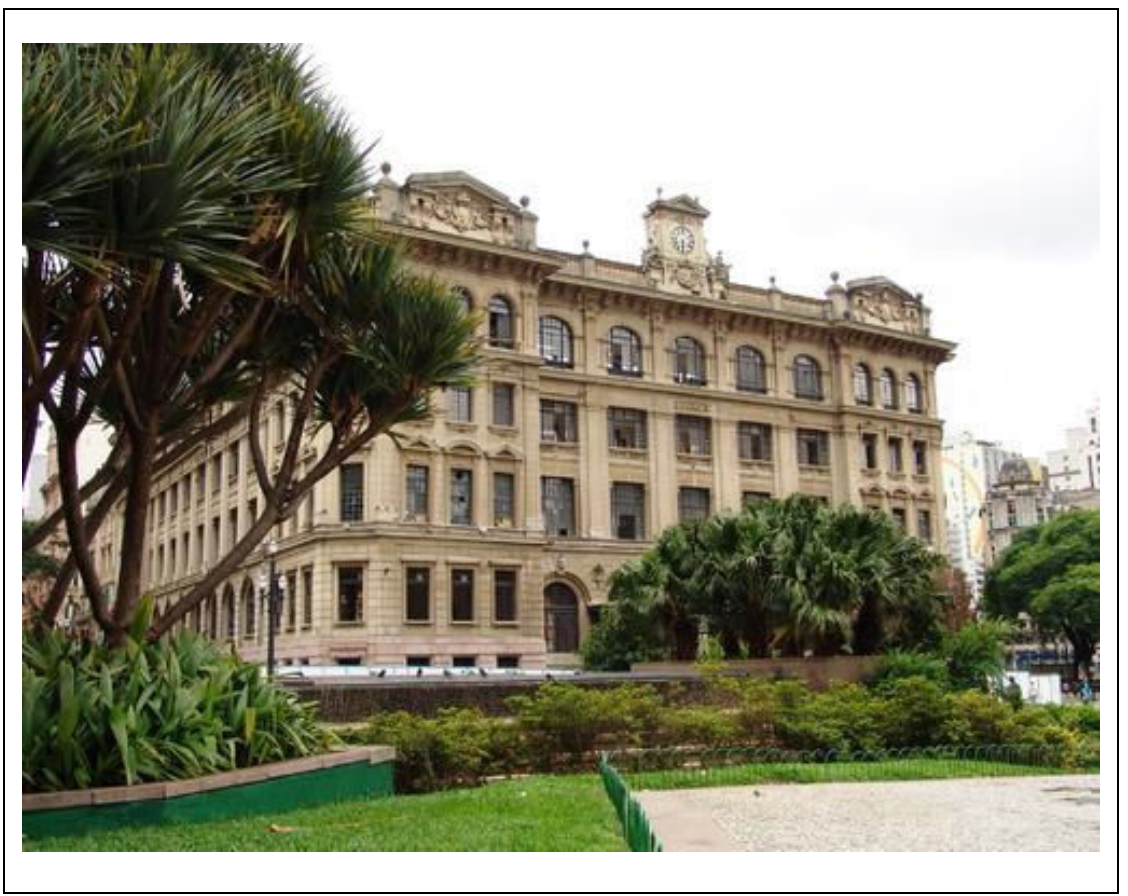

Fachada par a Praça Clovis Belivaqua ${ }^{152}$

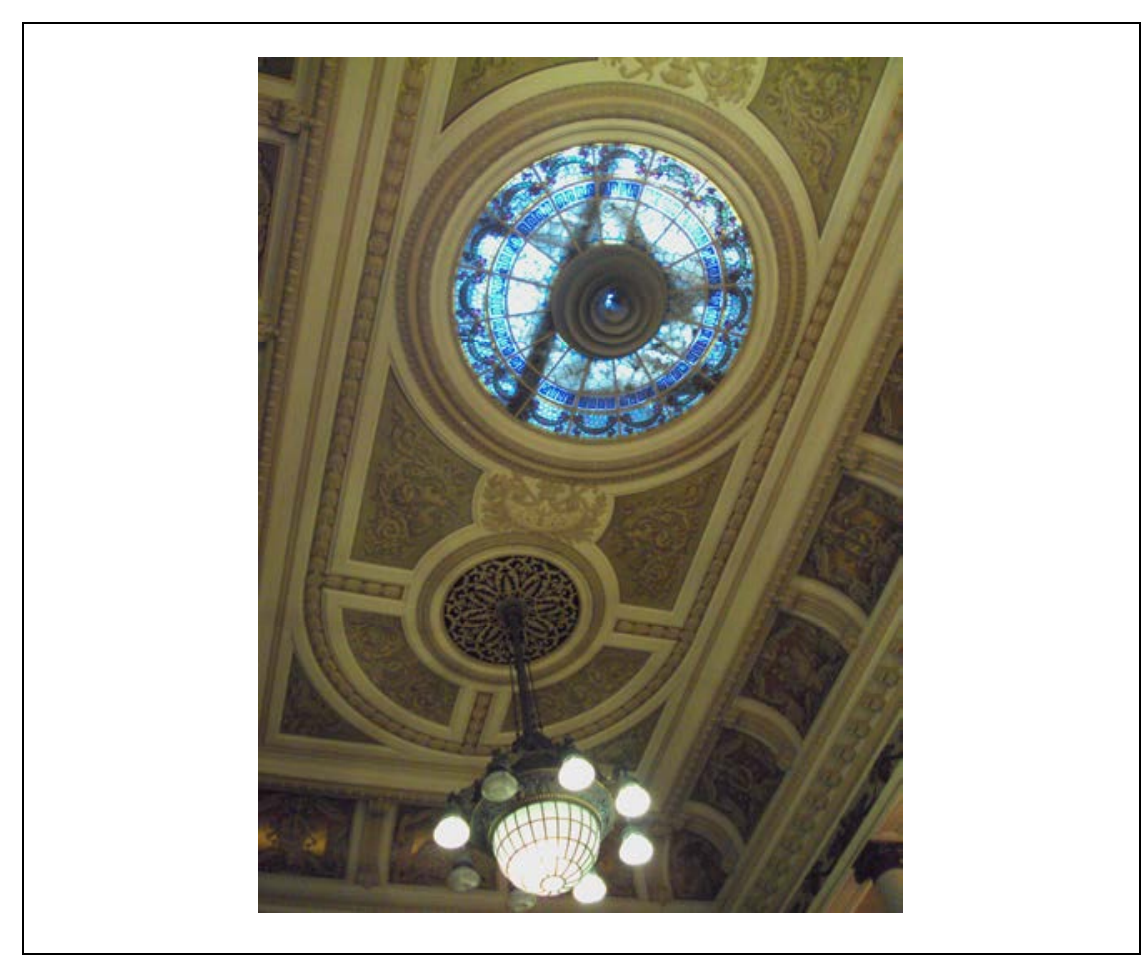

Forro do Tribunal do Juri153

152 Foto: Demósthenes Magno Santos - abril/2012

153 Foto: Demósthenes Magno Santos - abril/2012 


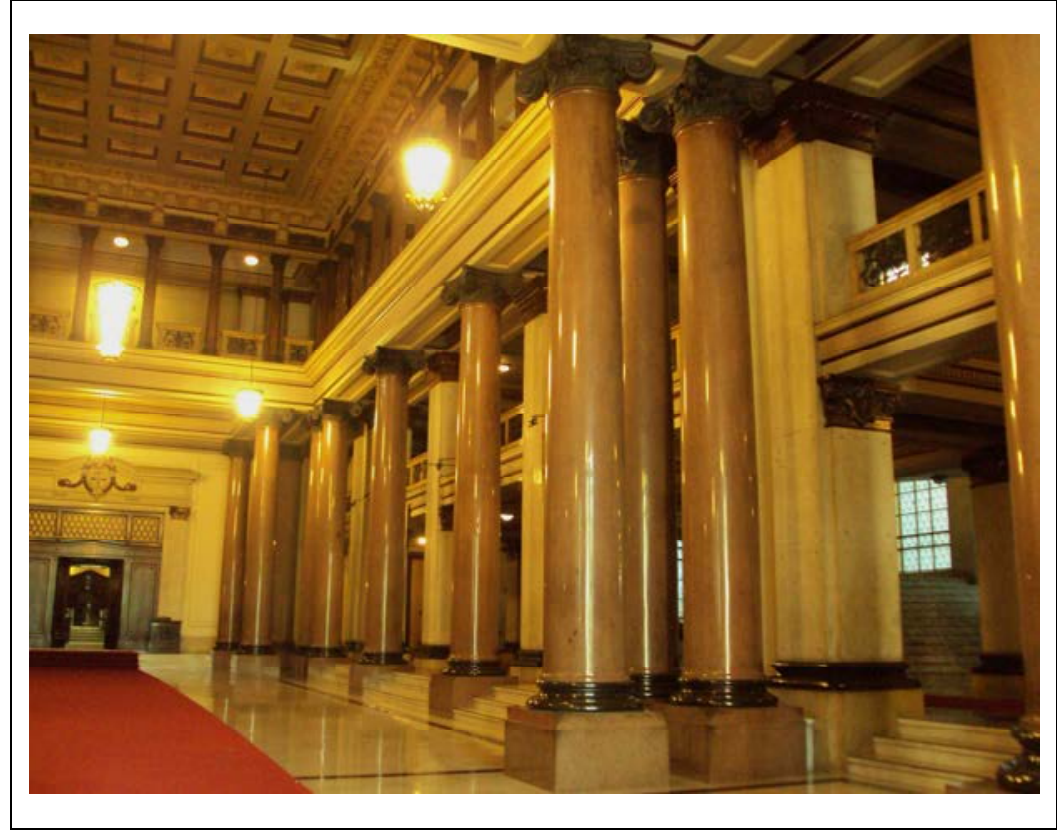

Sala dos Passos Perdidos 154

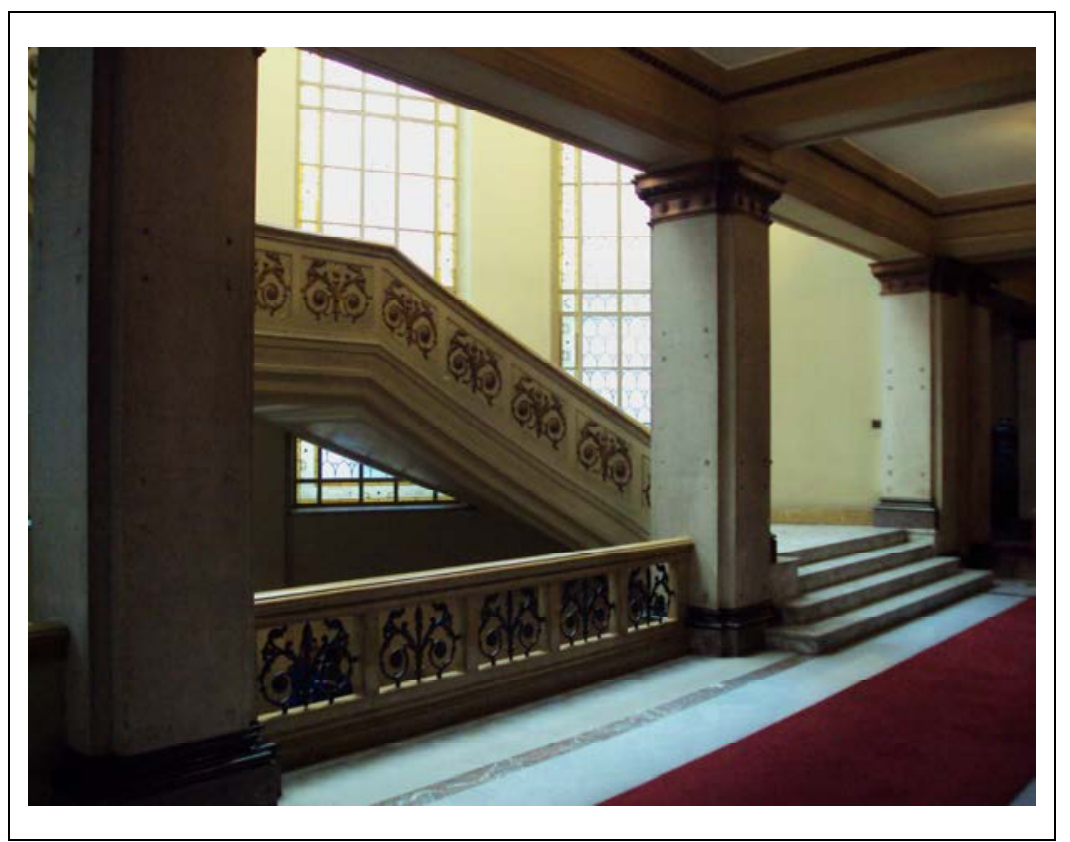

Escadarias 155

154 Foto: Demósthenes Magno Santos - abril/2012

155 Foto: Demósthenes Magno Santos - abril/2012 


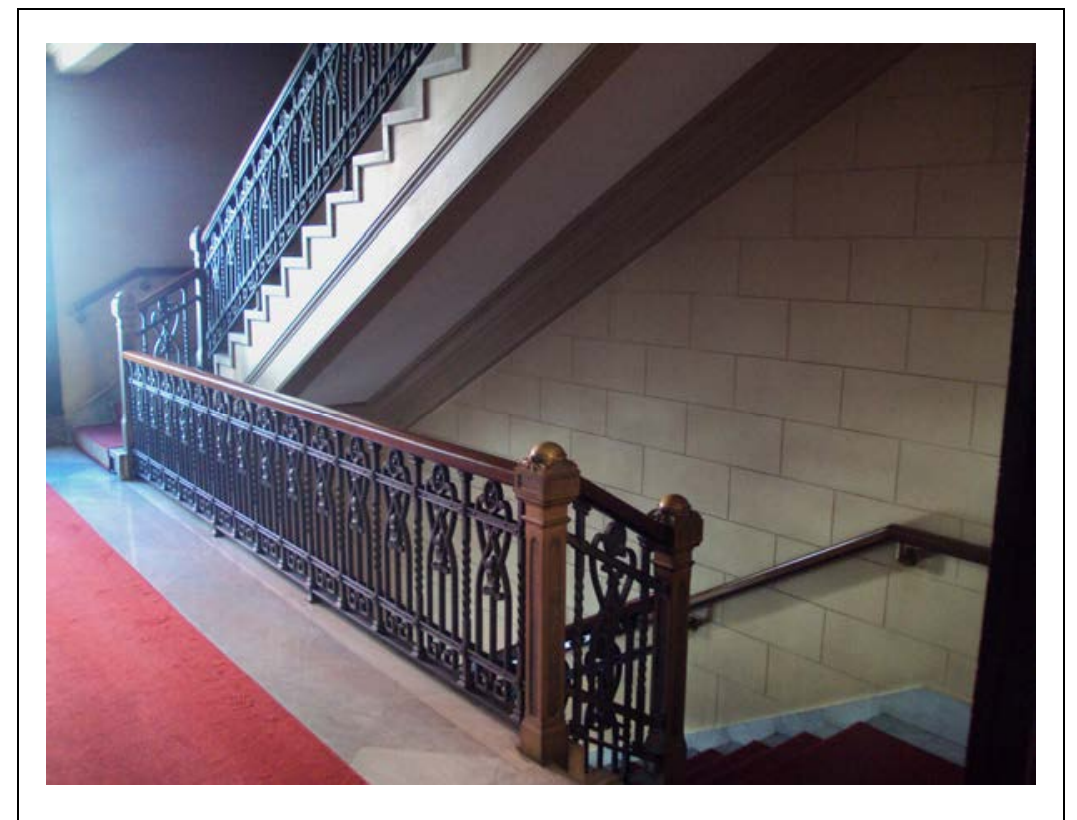

Escadarias ${ }^{156}$

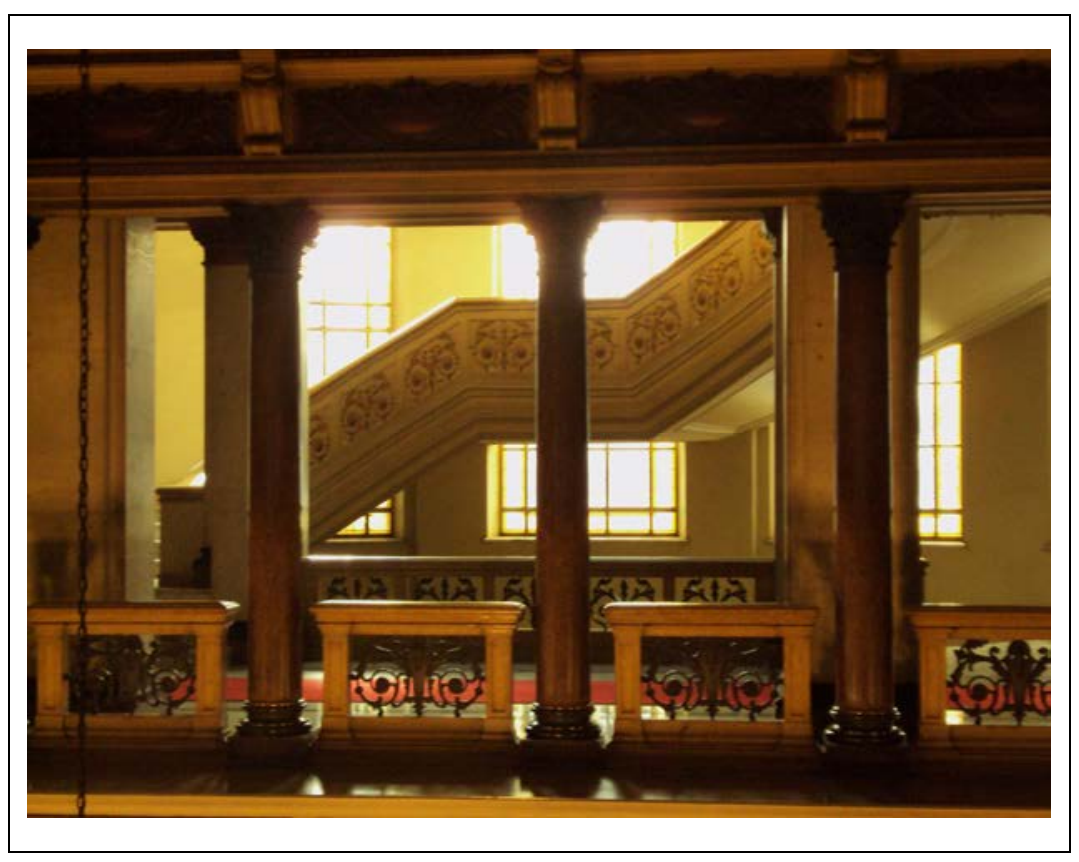

Loggia da Sala dos Passos Perdidos ${ }^{157}$

156 Foto: Demósthenes Magno Santos - abril/2012

157 Foto: Demósthenes Magno Santos - abril/2012 
APÊNDICE B - Edifício da Faculdade de Direto do Largo São Francisco

Projeto: Ricardo Severo - ano 1930

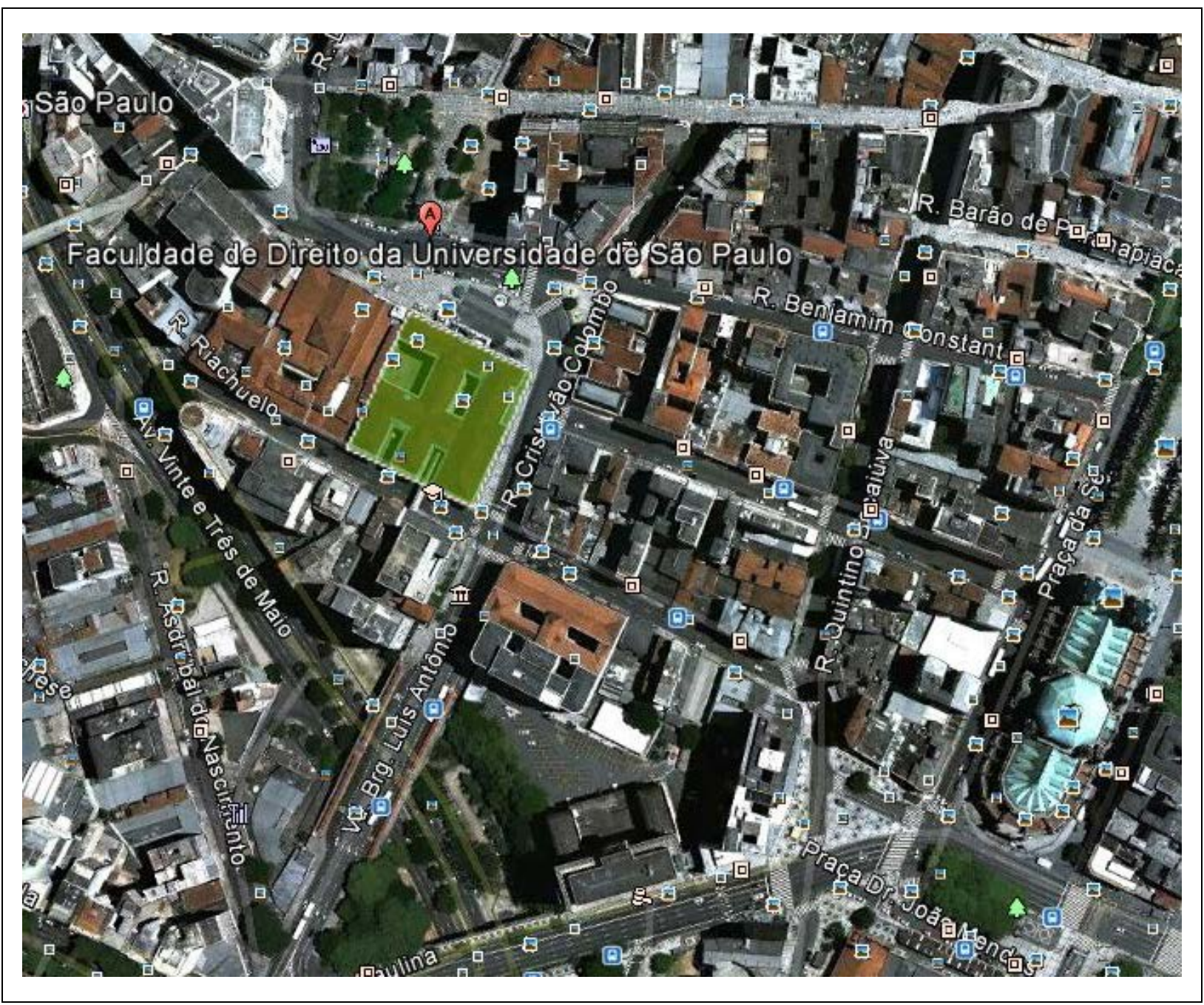

Localização ${ }^{158}$

158 Fonte: Foto Google Earth - 2011 


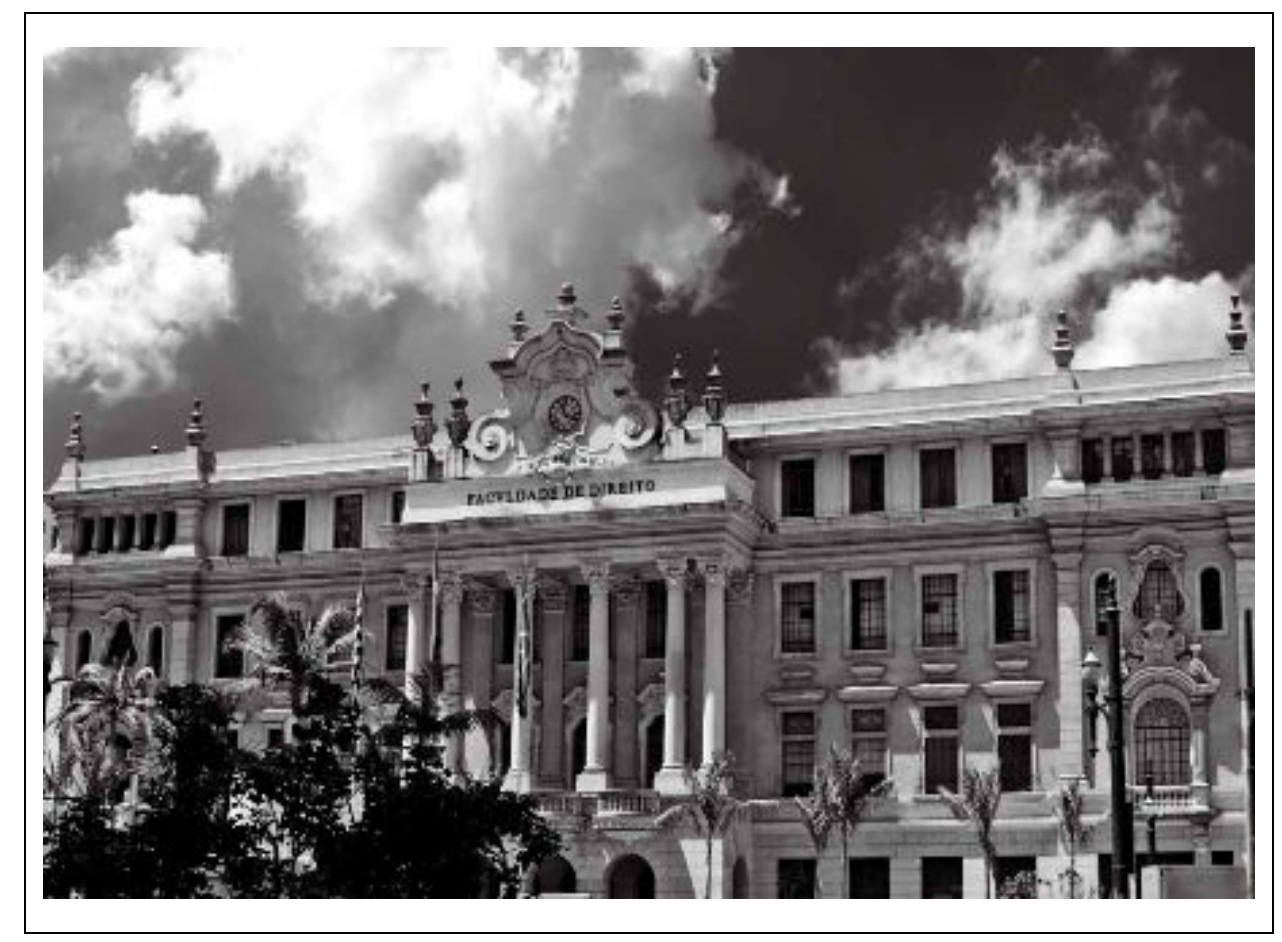

Fachada ${ }^{159}$

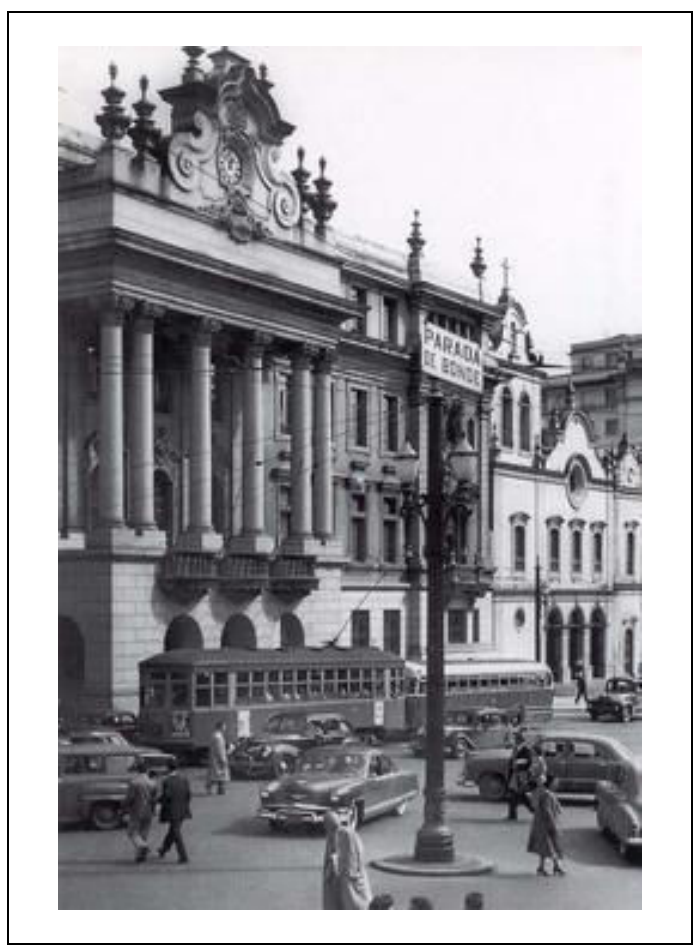

Fachada 160

159 Fonte: http://edgblogs.s3.amazonaws.com/centroavante/files/201 1/02/Faculdade-de-Direito-da-USP.jpg
160 Fonte: http://edgblogs.s3.amazonaws.com/centroavante/files/201 1/02/Faculdade-de-Direito-da-USP.jpg 


\section{APÊNDICE C - Edifício Conde de Prates}

Projeto: Alfredo Mathias e Giancarlo Palanti - ano 1956

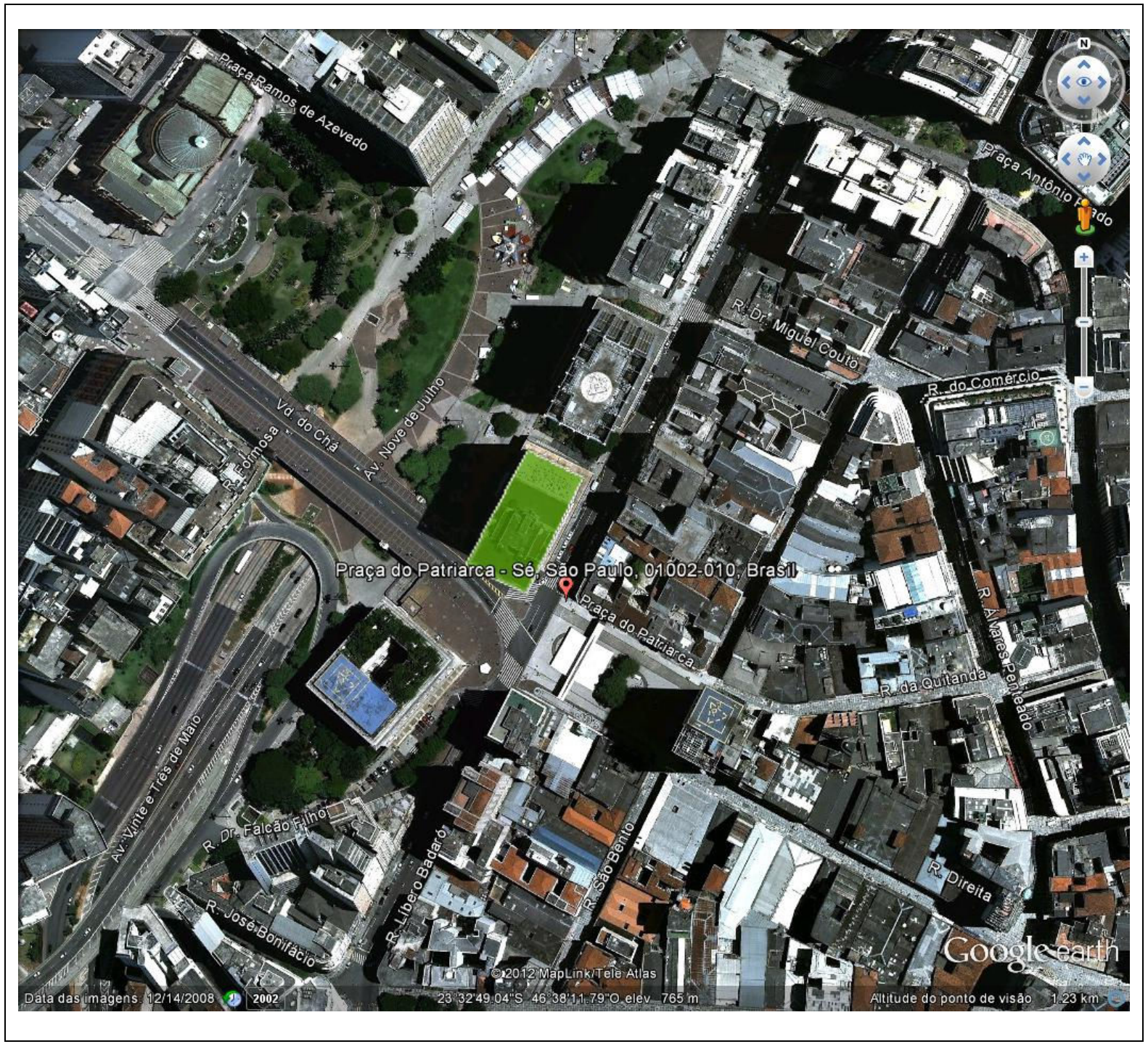

Localização ${ }^{161}$

161 Fonte: Foto Google Earth - 2011 


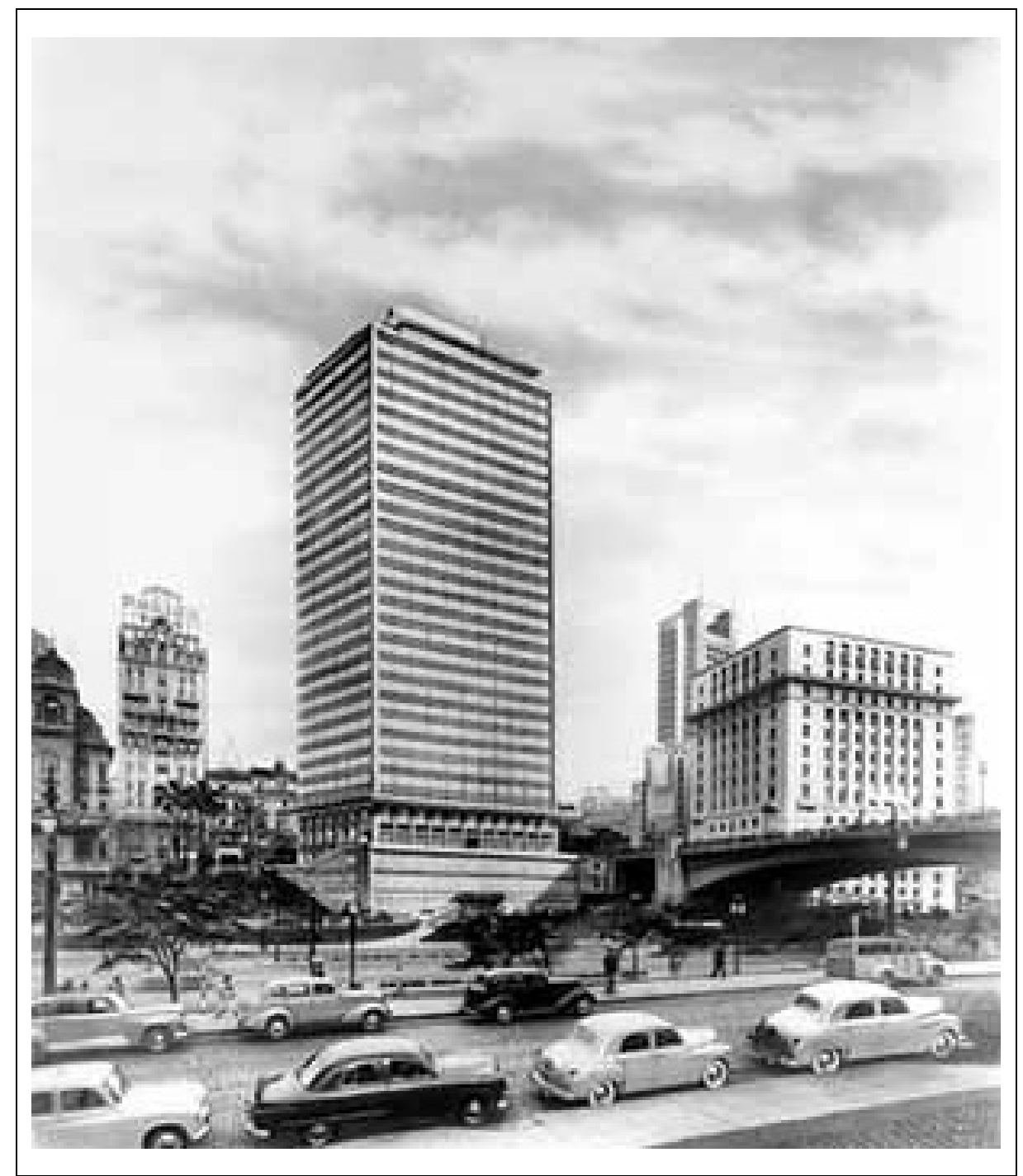

Edifício Conde de Prates visto da Rua Formosa ${ }^{162}$

162 Fonte: Arquivo GP / FAU - USP 


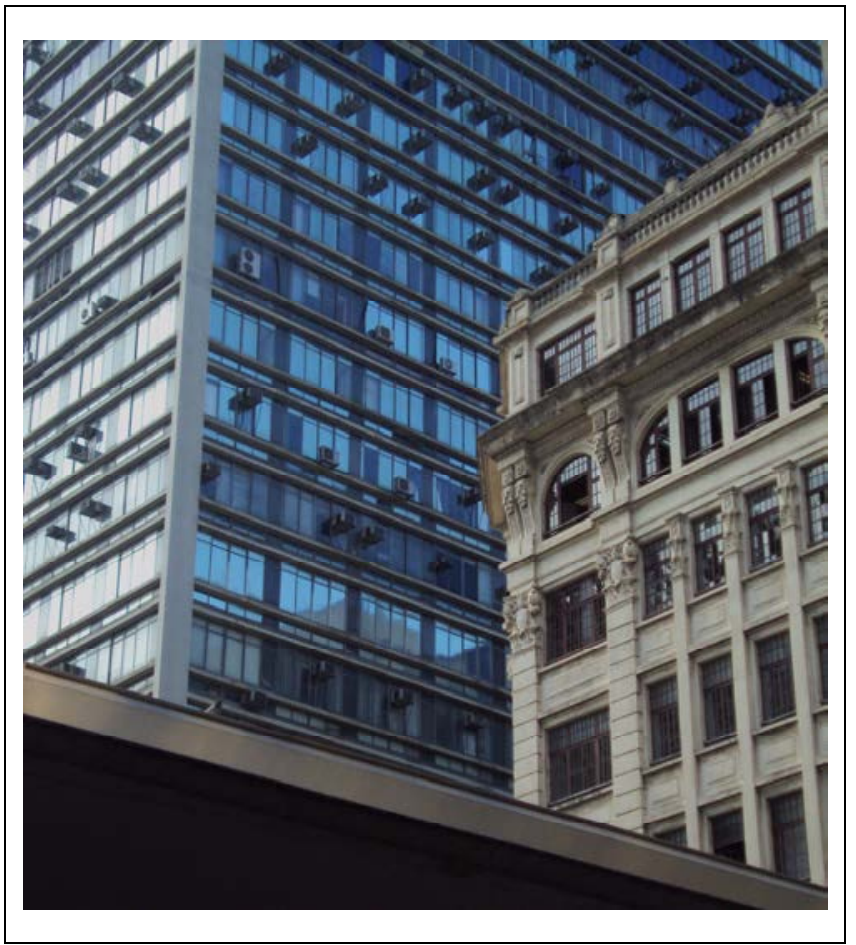

Edifício Conde de Prates visto da Praça do Patriarcal63

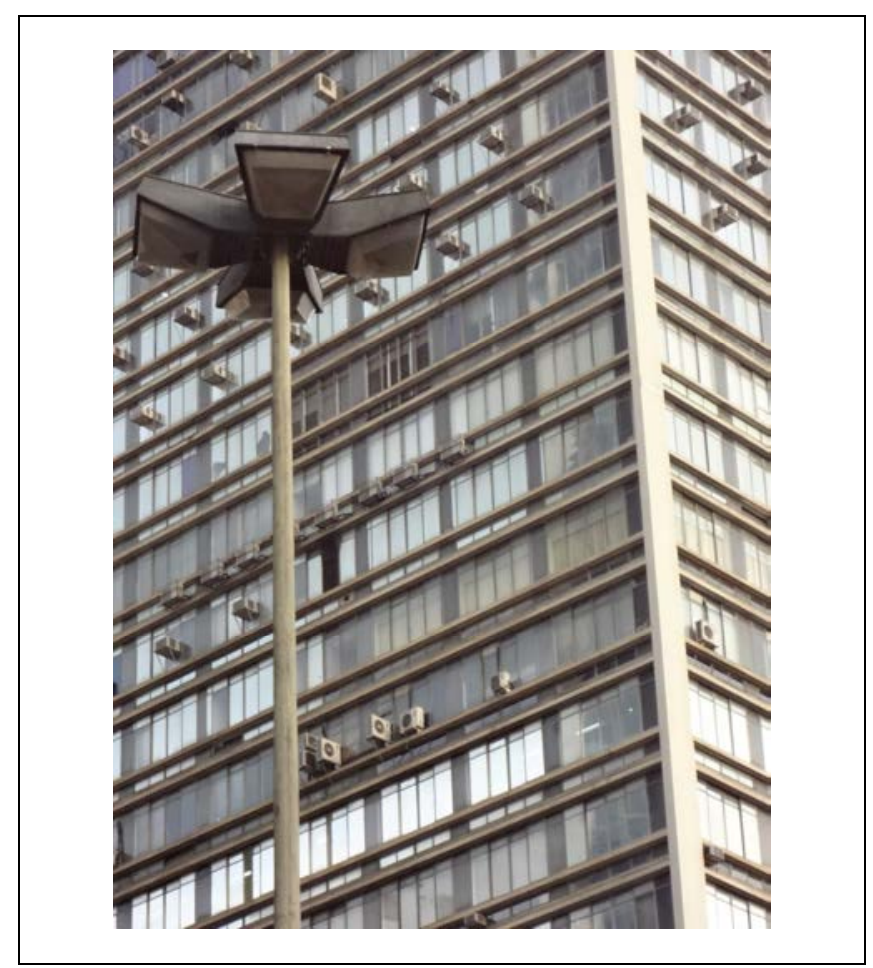

Edifício Conde de Prates - detalhe dos caixilhos 164

163 Foto: Demósthenes Magno Santos - maio/2012

164 Foto: Demósthenes Magno Santos - maio/2012 


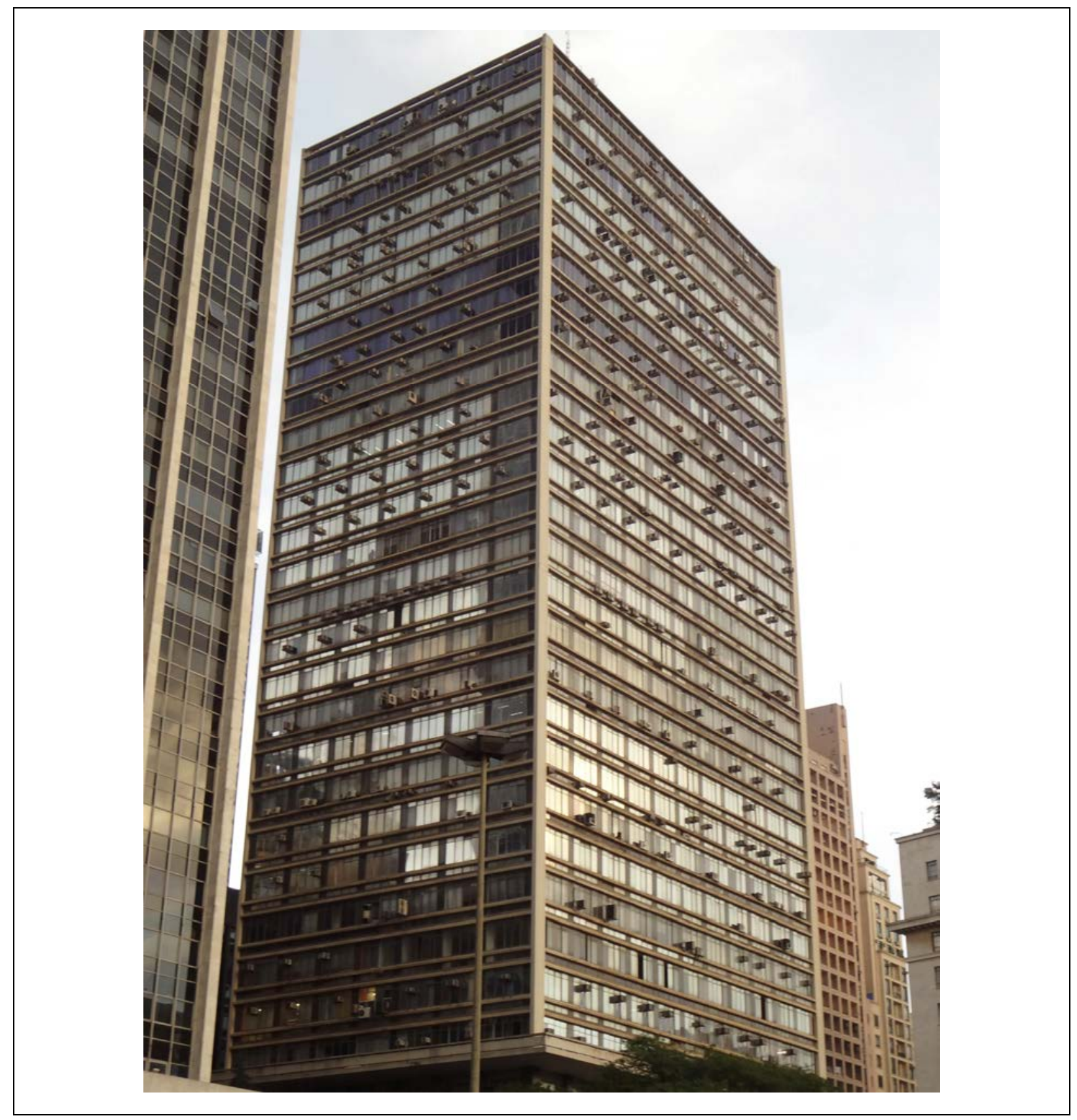

Edifício Conde de Prates visto do Vale do Anhangabaú 165

165 Foto: Demósthenes Magno Santos - maio/2012 


\section{APÊNDICE D - Biblioteca Municipal Martinico Prado - Araras}

Projeto: Giancarlo Palanti para a Construtora Alfredo Mathias, 1953

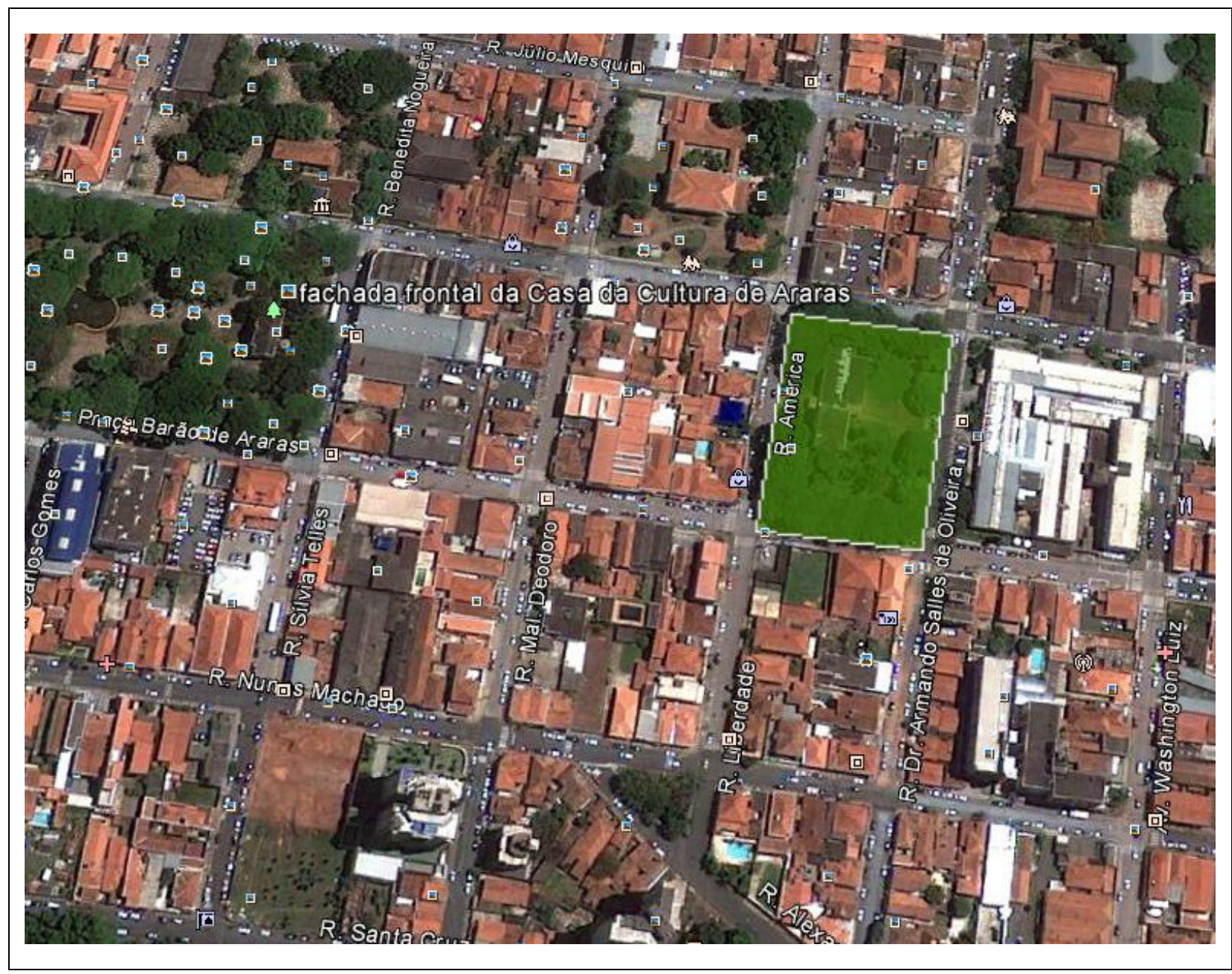

Localização ${ }^{166}$

166 Fonte: Foto Google Earth - 2011 


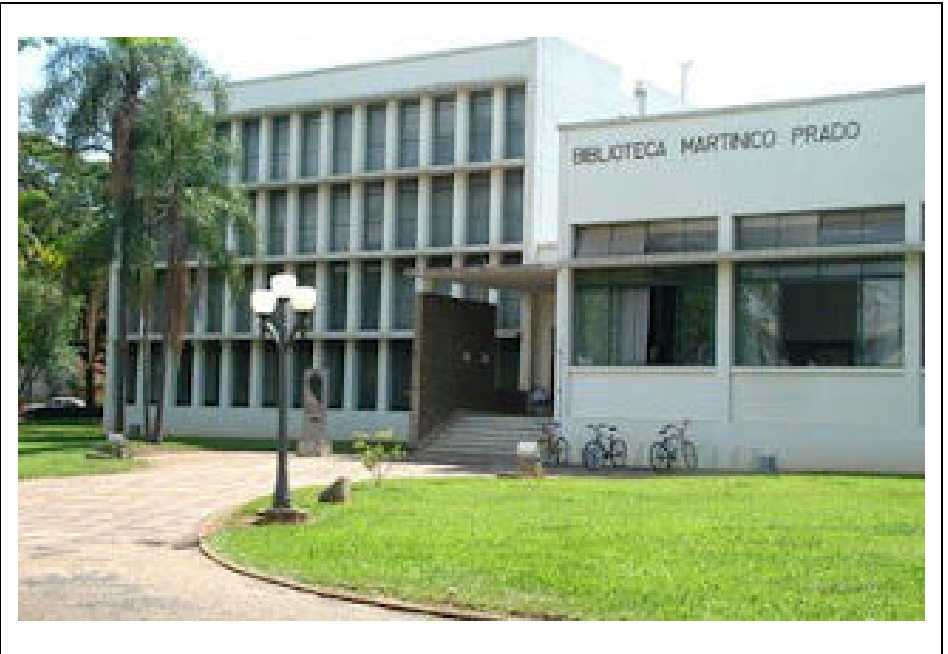

Fachada 167

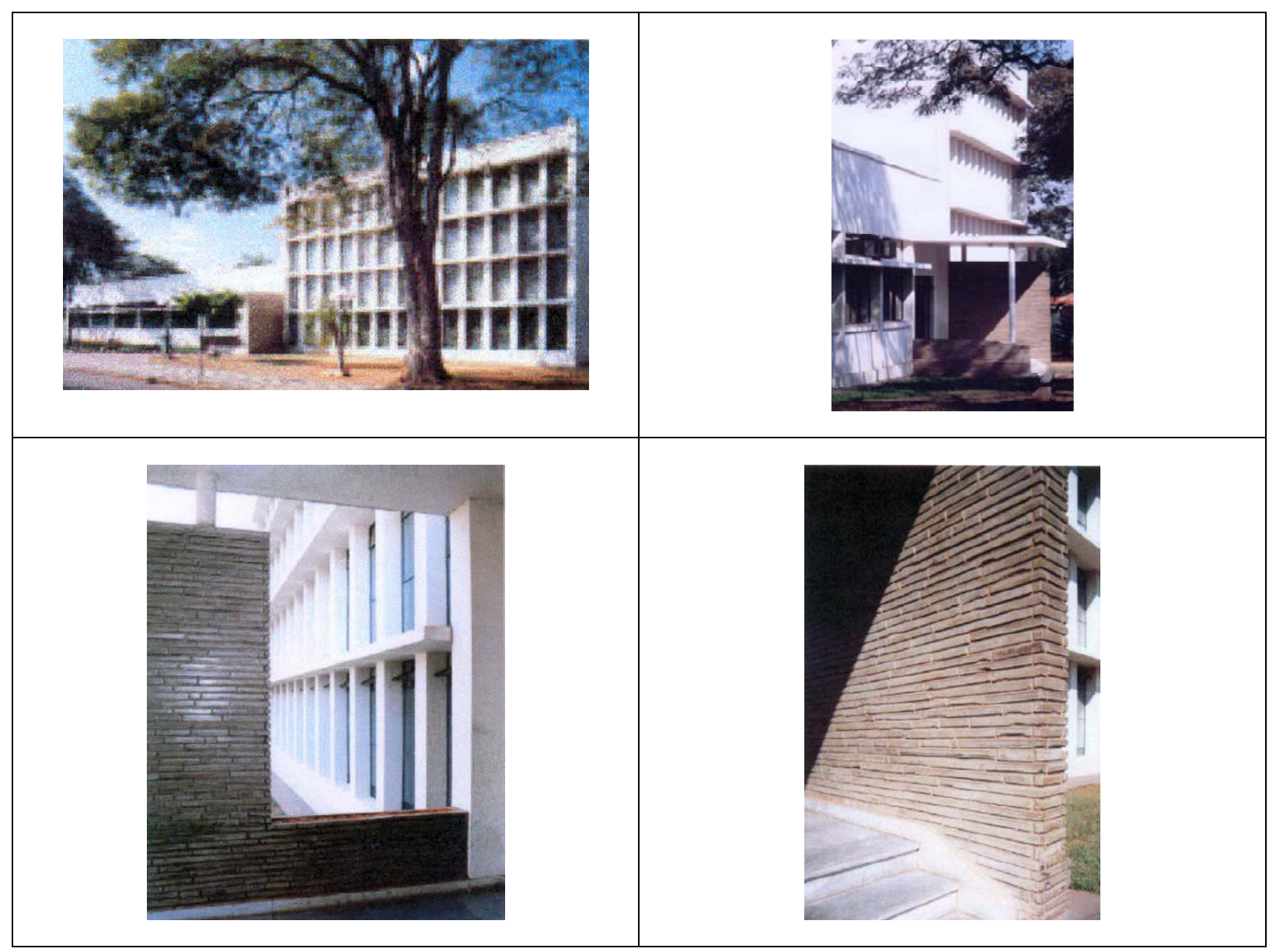

Biblioteca Pública Martinico da Silva Prado - Araras - SP - 1954 Fotos do locall68

167 Fonte: Arquivo GP / FAU - USP 
APÊNDICE E - Edifício Rua Barão de Tatuí, 351

Projeto: Giancarlo Palanti para a Construtora Alfredo Mathias - 1953

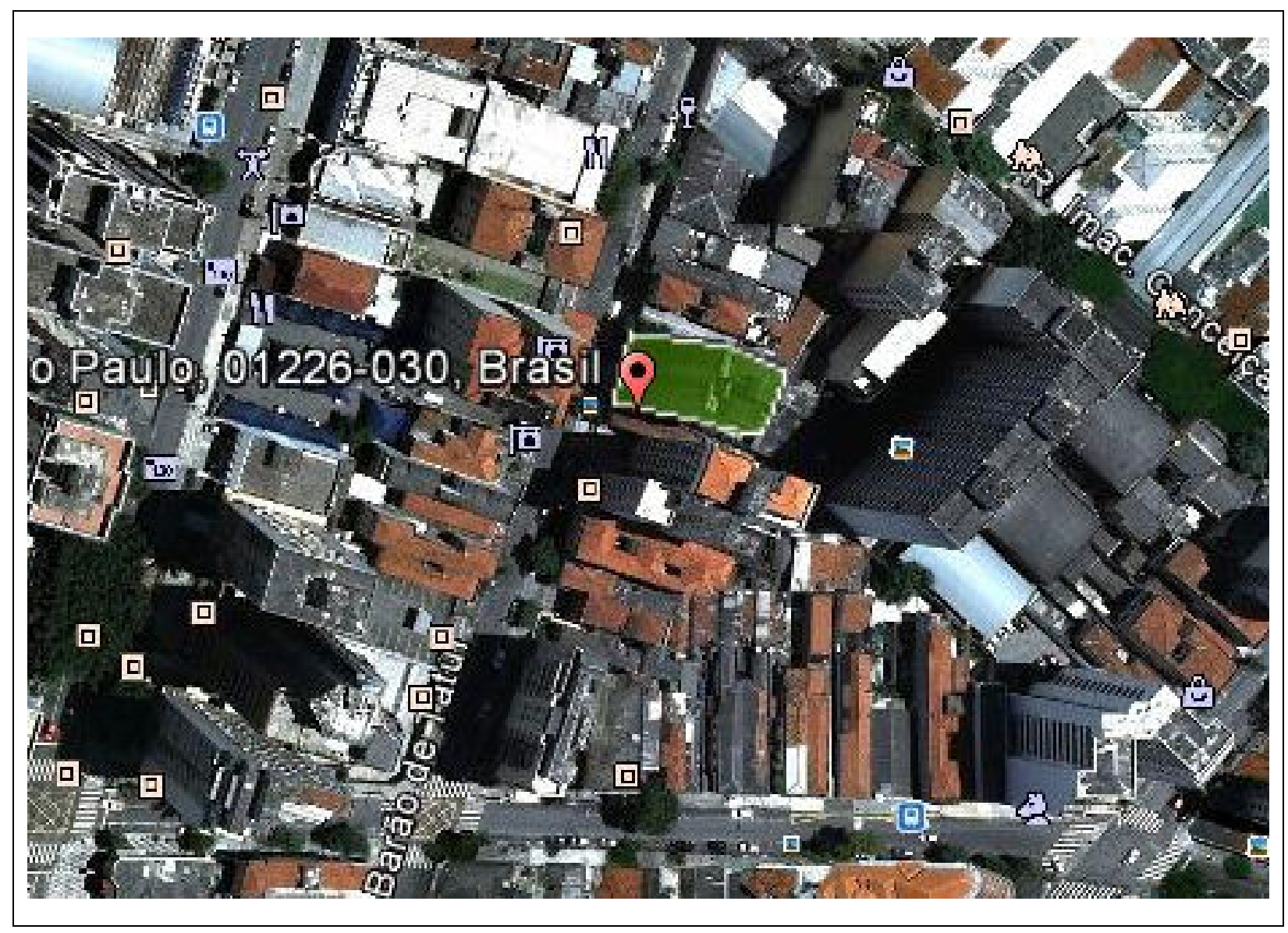

Localização ${ }^{169}$

168 Fonte: Aline Sanchez, pg. 182 - 2004

169 Fonte: Foto Google Earth - 2011 


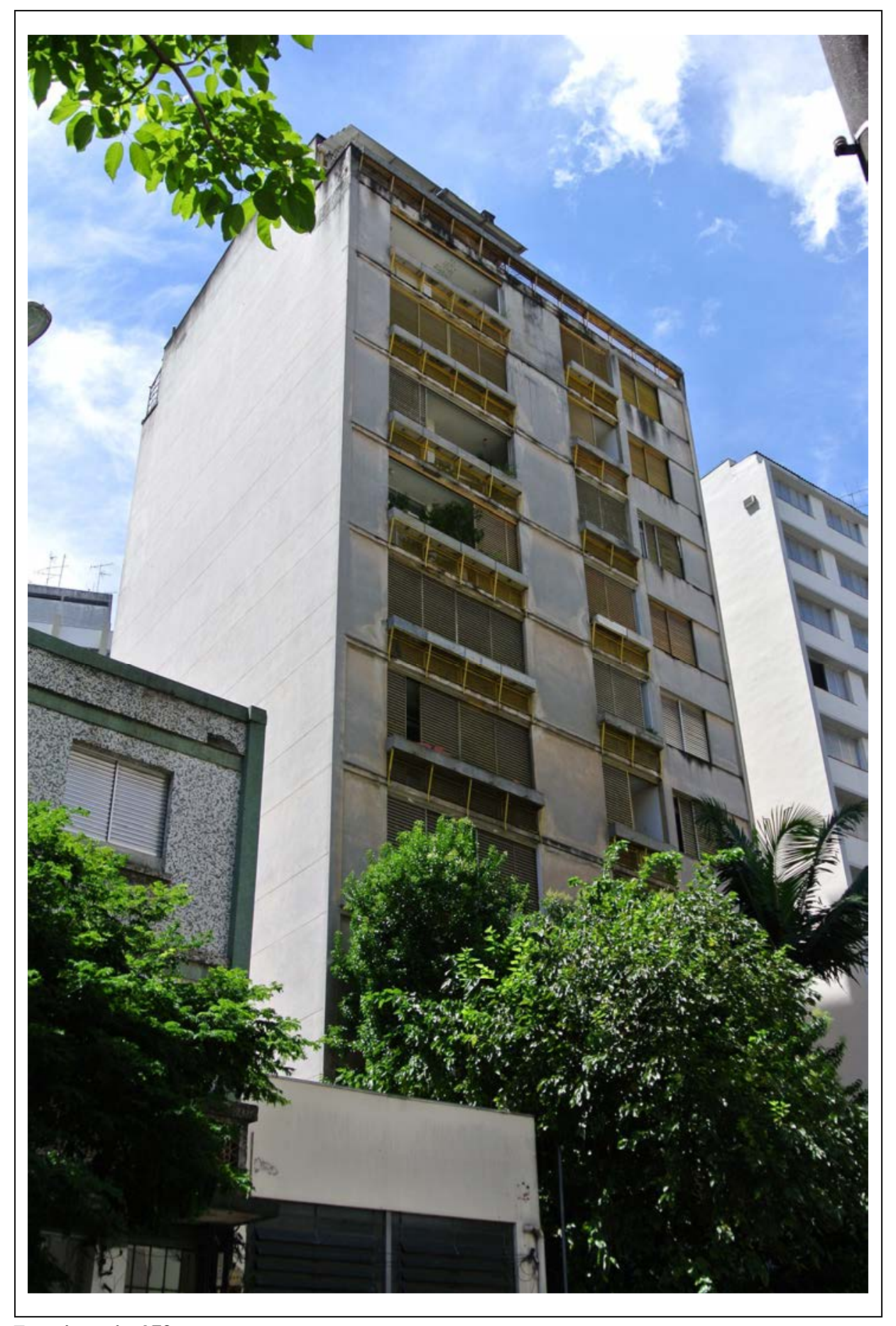

Fachada 170

170 Foto: Demósthenes Magno Santos - fev. 2013 


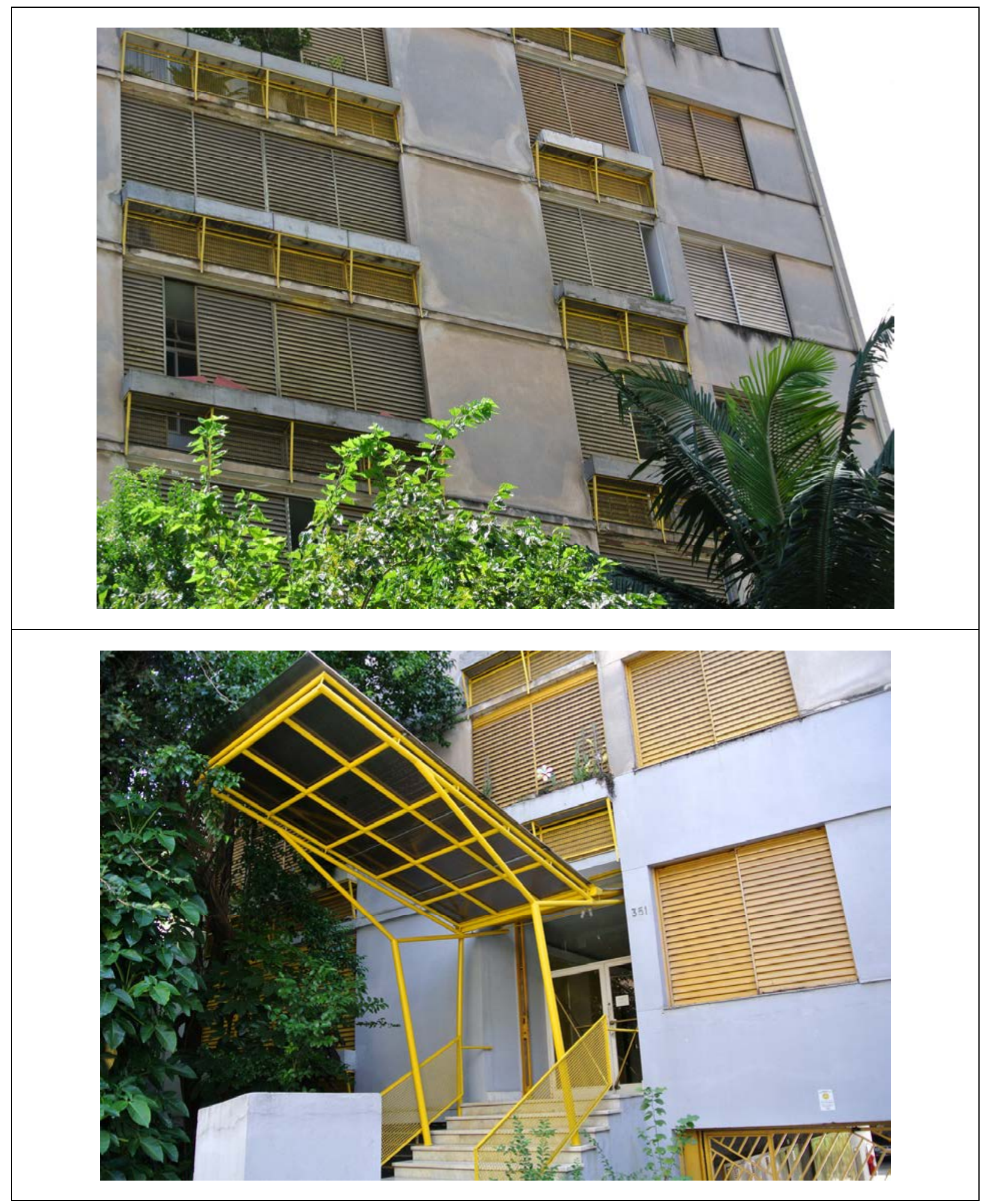

Detalhe da fachada e detalhe da marquise ${ }^{171}$

171 Foto: Demósthenes Magno Santos - fev. 2013 


\section{APÊNDICE F - Edifícios Gibraltar e Chipre}

Projeto: Giancarlo Palanti - entre 1952

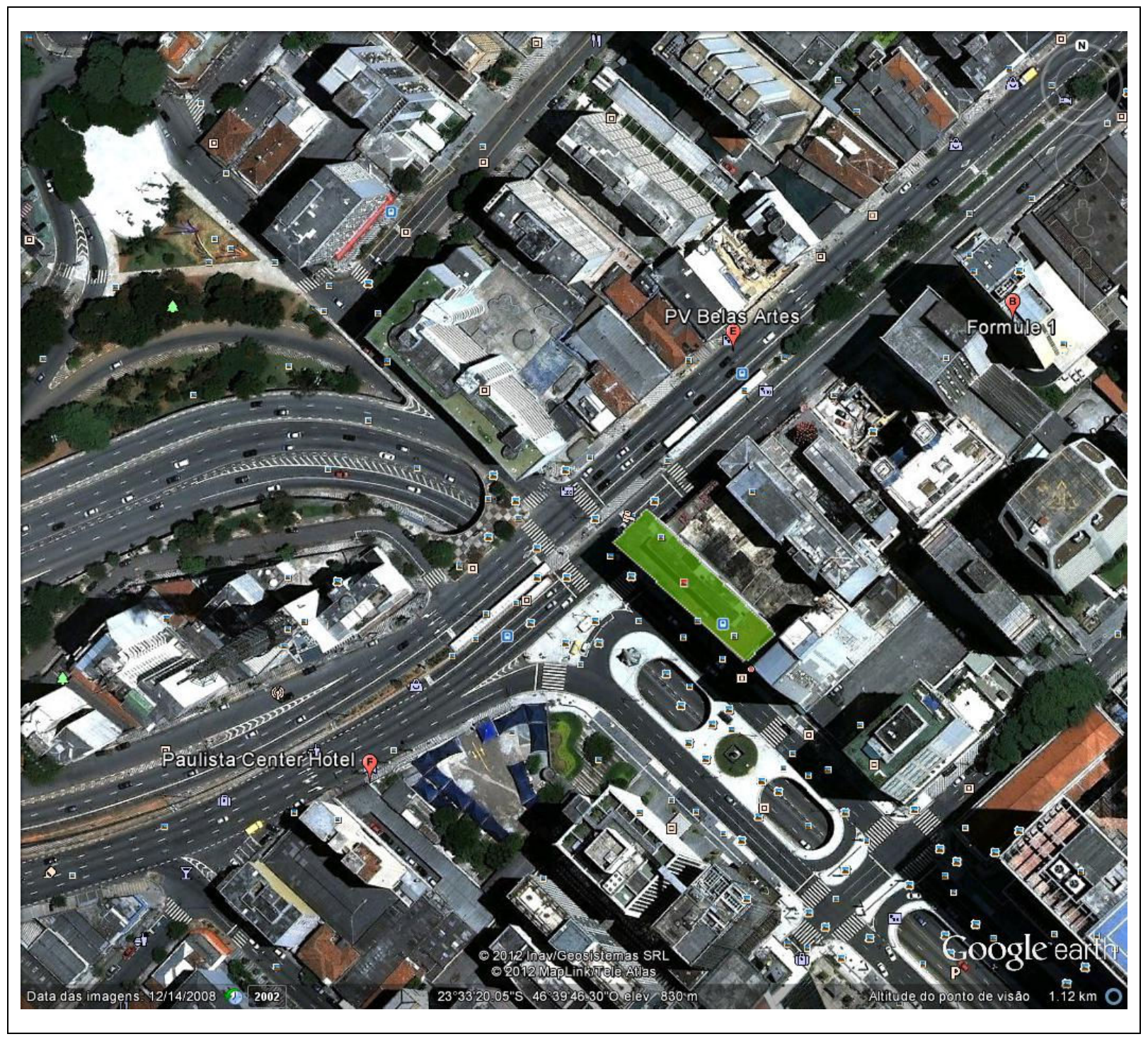

Localização $^{172}$

172 Fonte: Foto Google Earth - 2011 


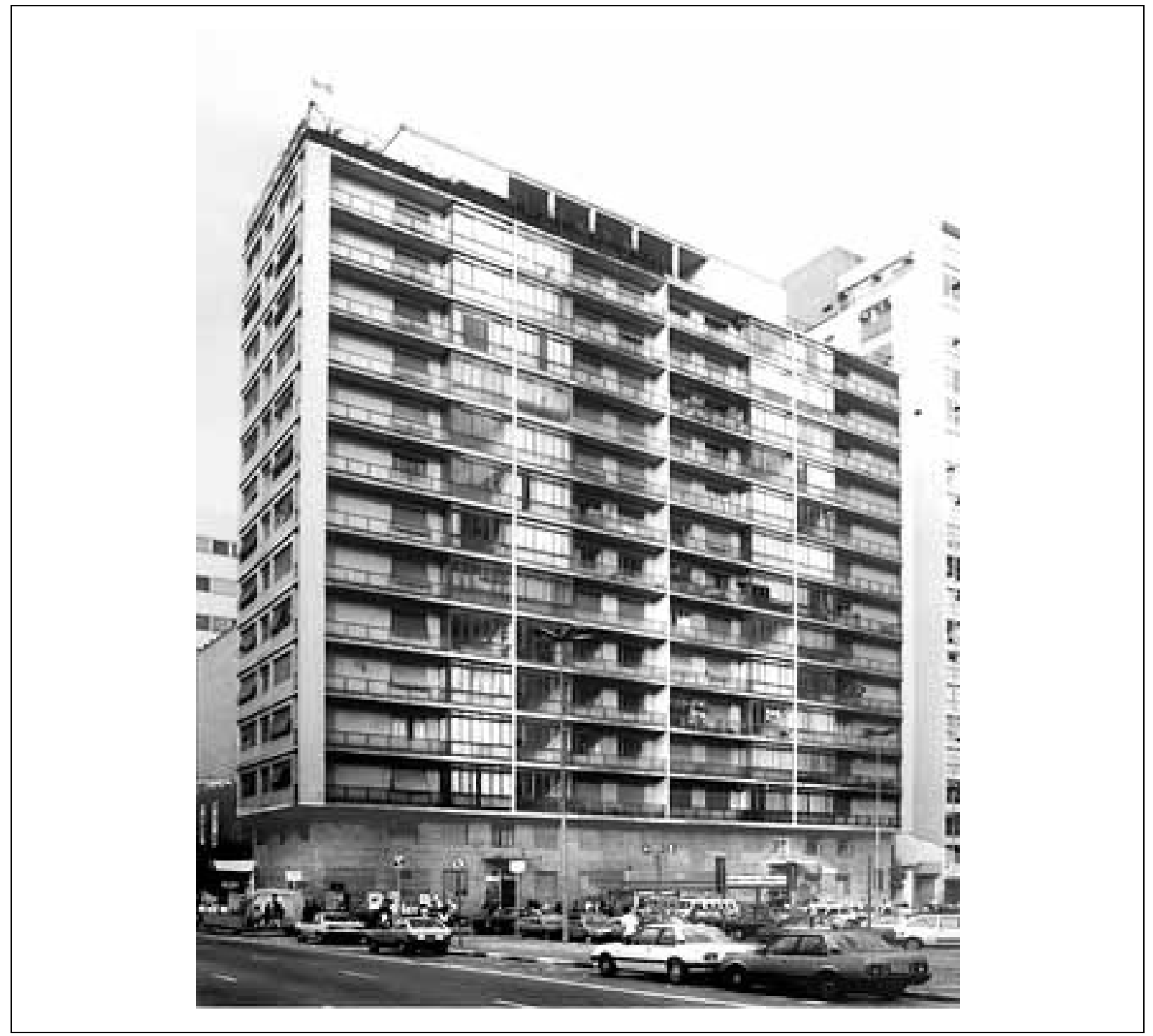

Fachada 173

173 Fonte: http://www.vitruvius.com.br/media/images/magazines/grid_9/28e4_031-01-06.jpg 


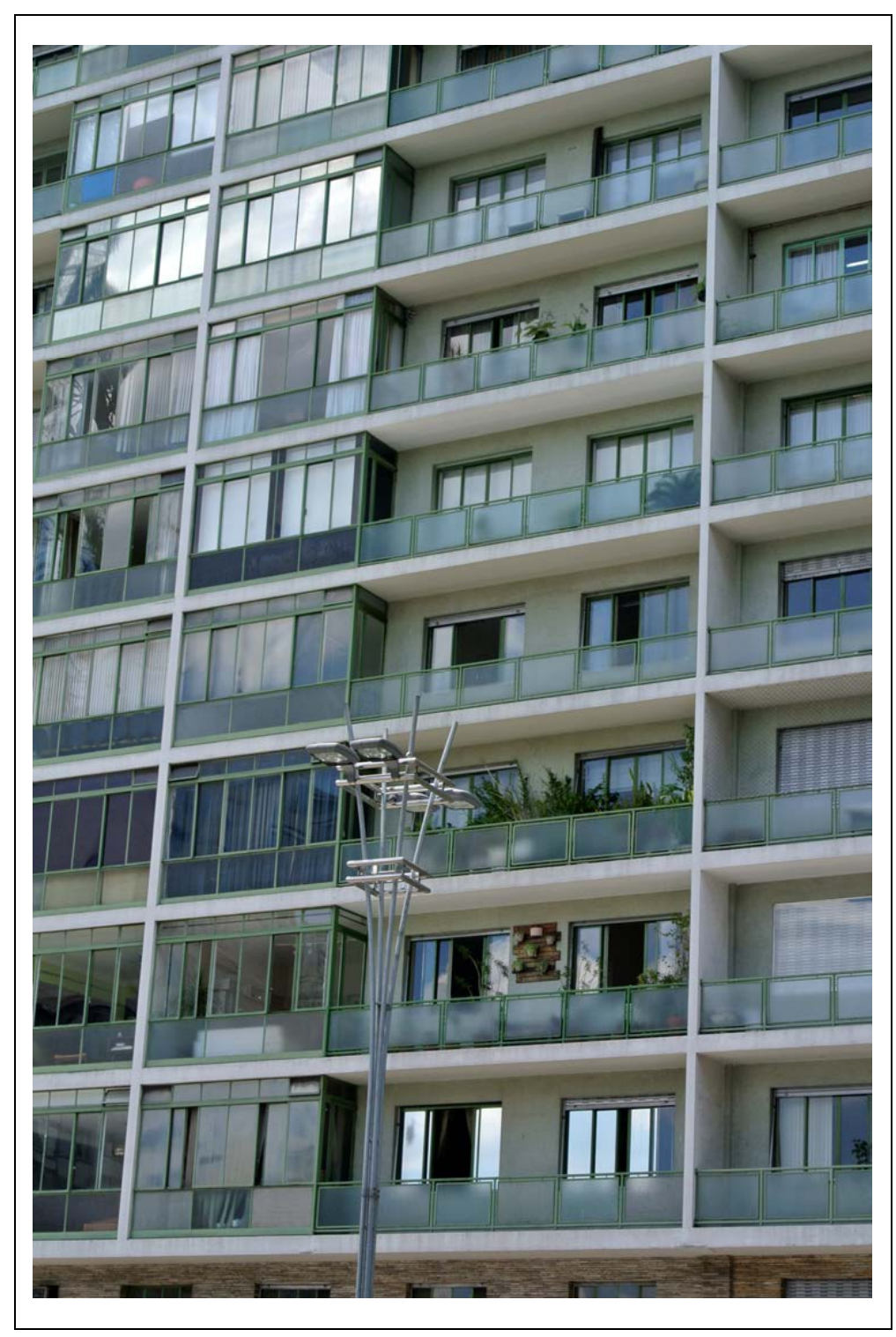

Detalhe da Fachada - 2013174

174 Foto: Demósthenes Magno Santos - fevereiro 2013 


\section{APÊNDICE G - Cine Belas Artes (antigo Cine Trianon)}

Projeto: Giancarlo Palanti - entre 1952

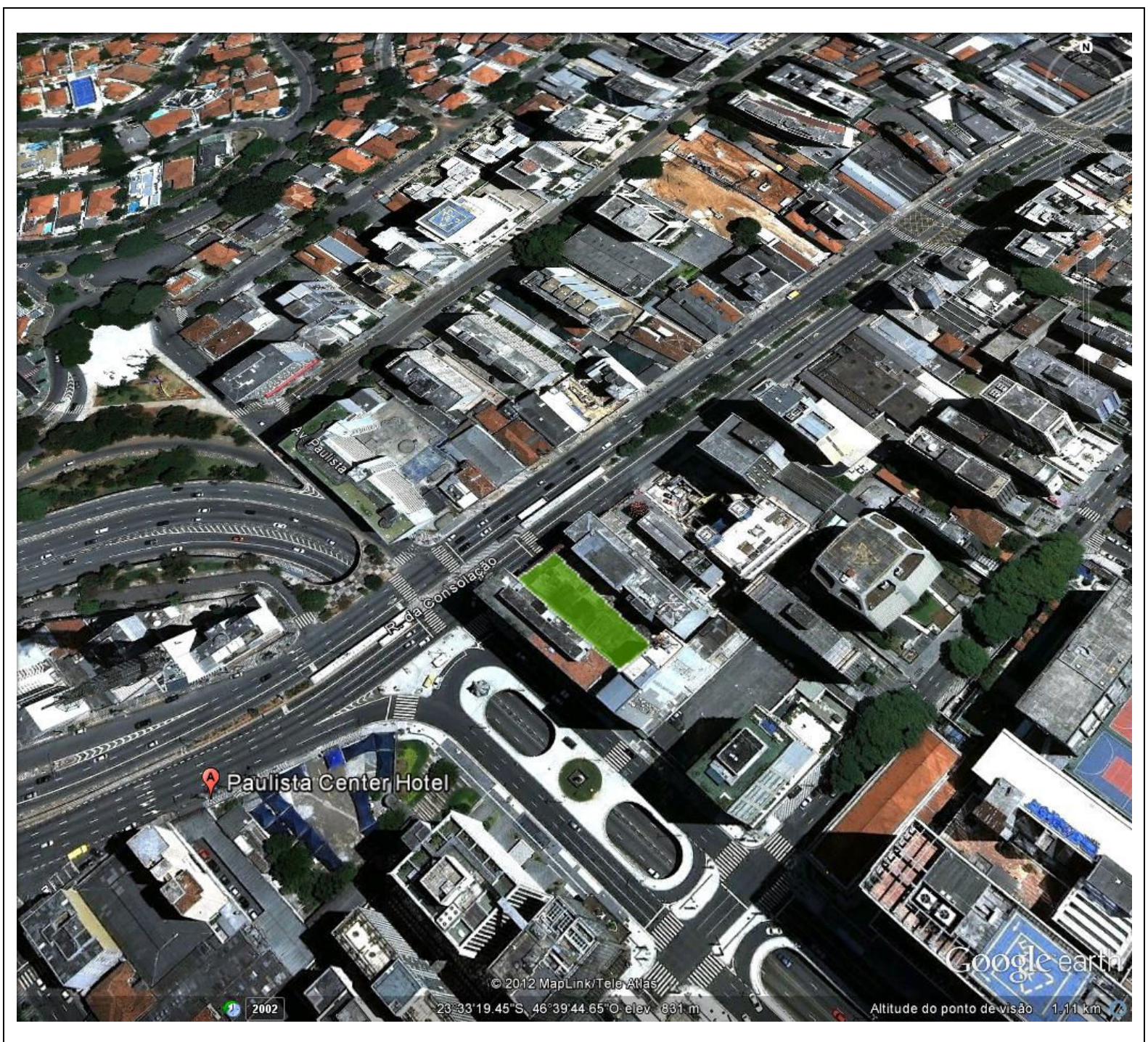

Figura 47: Localização175

175 Foto Google Earth - 2011 


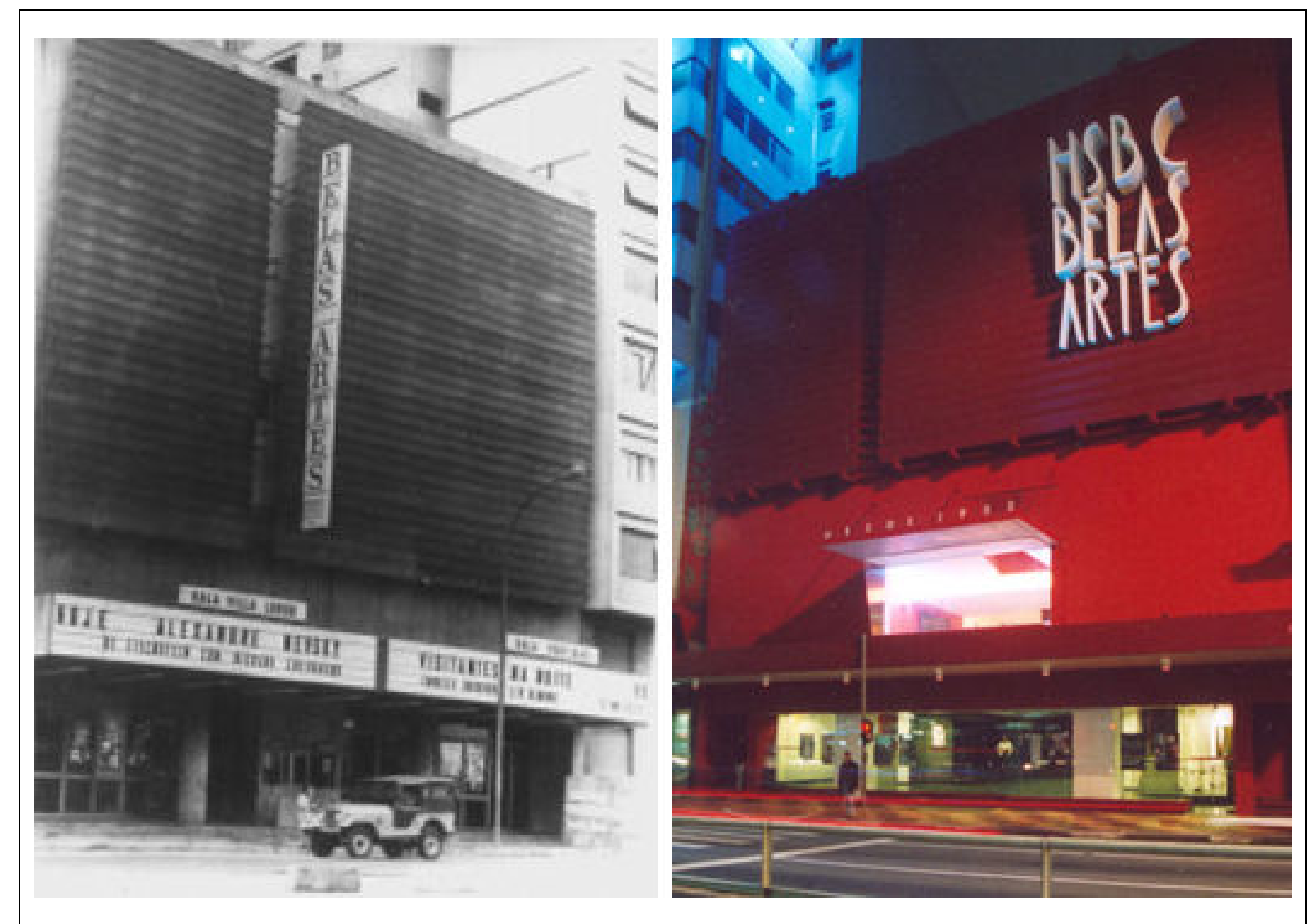

Fachada: 1971 e em 2011176

176 Fonte: http://manequim.abril.com.br/blogs/mesa-de-luz/files/201 1/01/Cine-Belas-Artes.jpg 
APÊNDICE H - Edifício à Rua Martiniano de Carvalho esquina com Rua Humaitá

Projeto: Giancarlo Palanti - entre 1954 / 1956

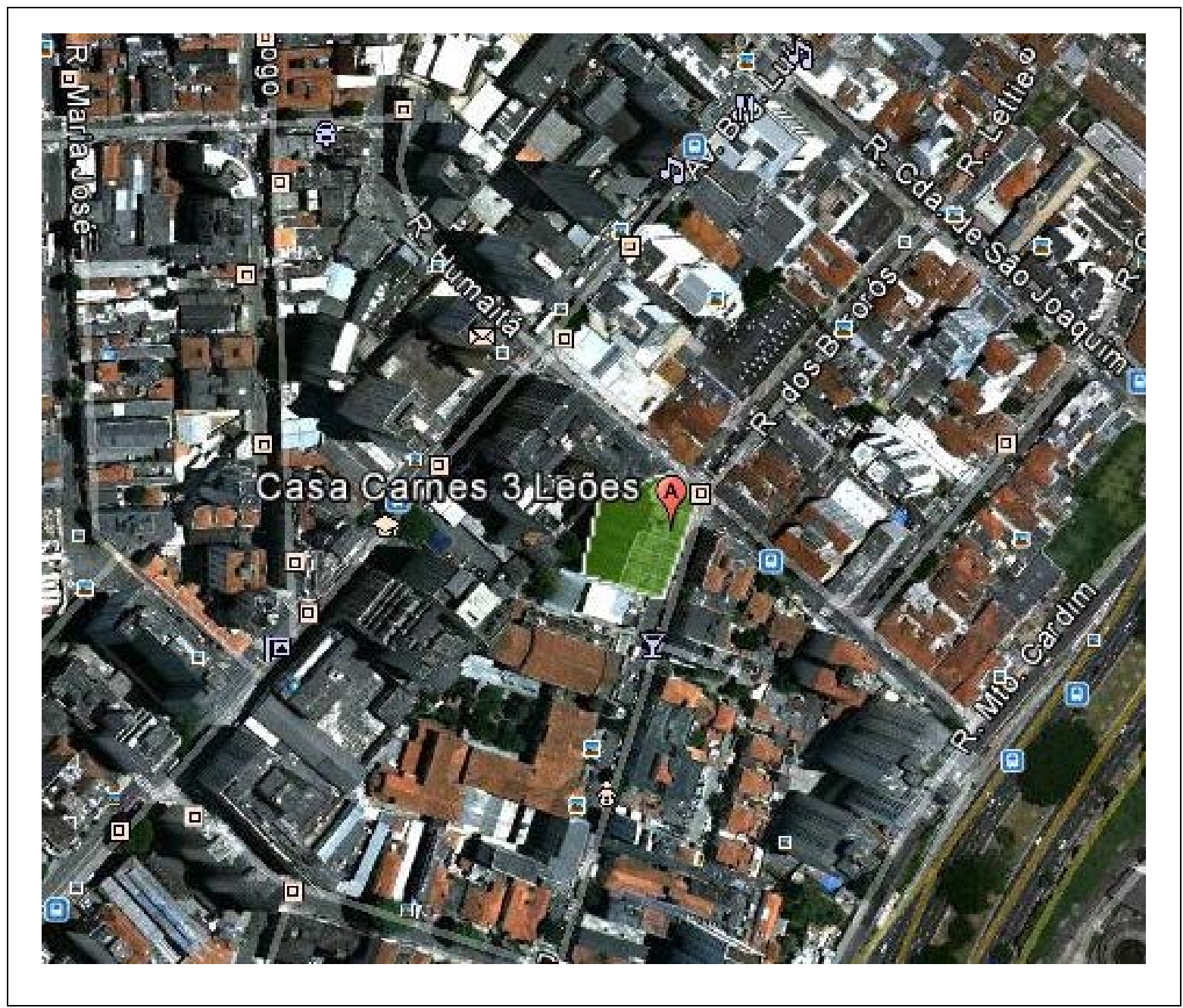

Localização ${ }^{177}$

177 Foto Google Earth - 2011 


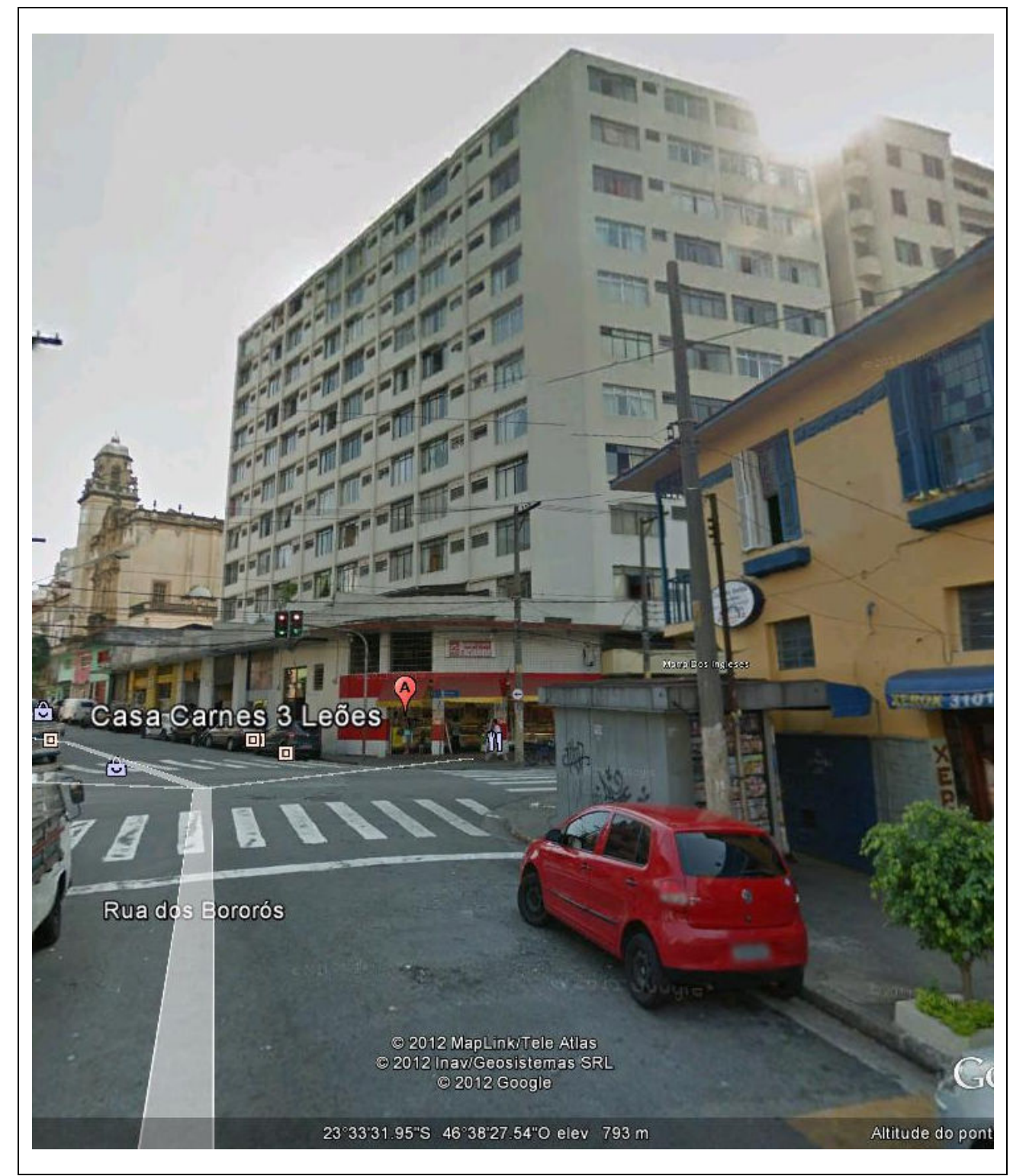

Fachada ${ }^{178}$

178 Foto Google Earth - 2011 


\section{APÊNDICE I - Hospital São Joaquim da Beneficência Portuguesa Rua Maestro Cardin, 769}

Projeto: Hipolyto Pujol e Oscar Defilippi - ano 1957

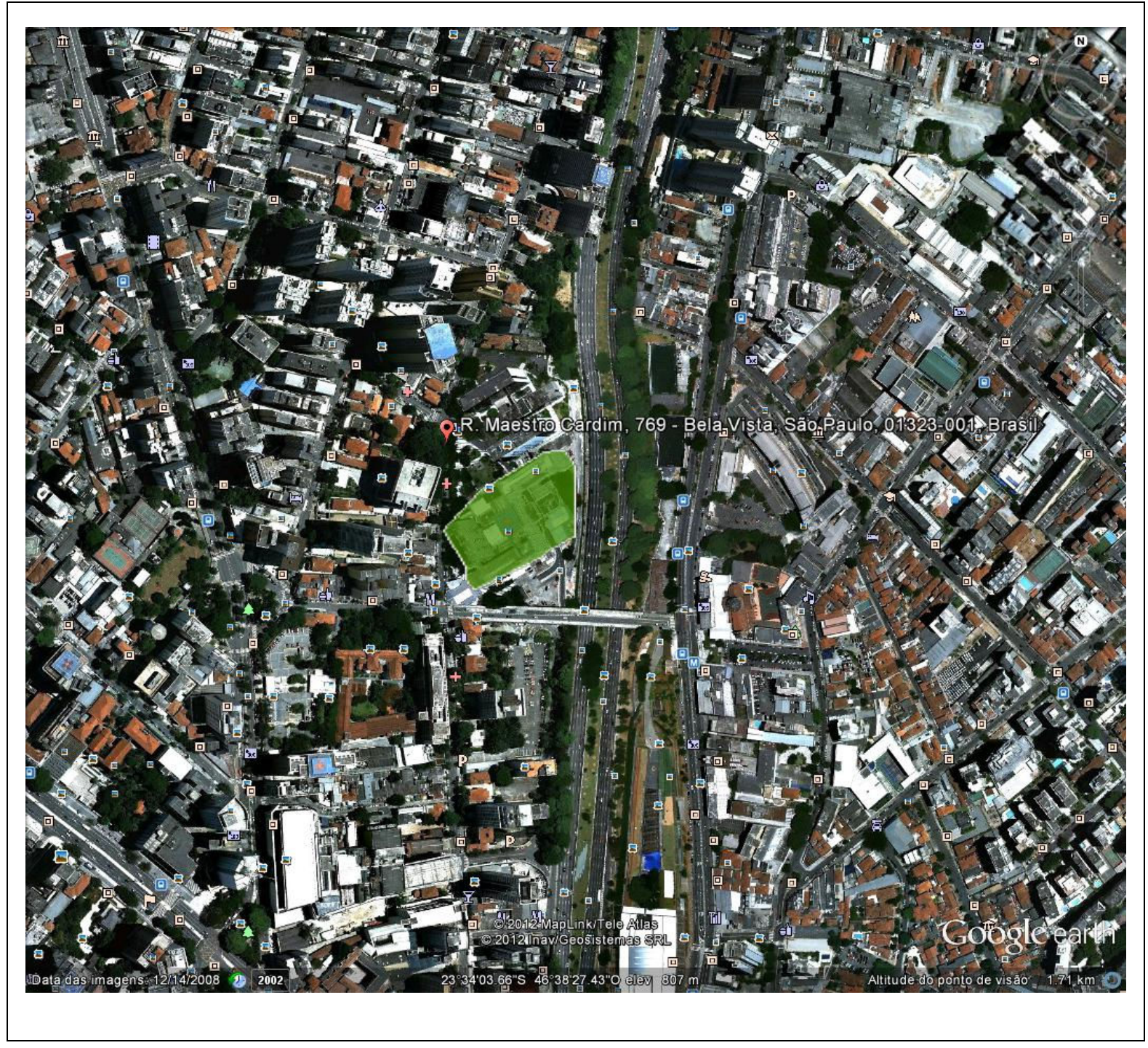

Figura 51: Localização179

179 Foto Google Earth - 2011 


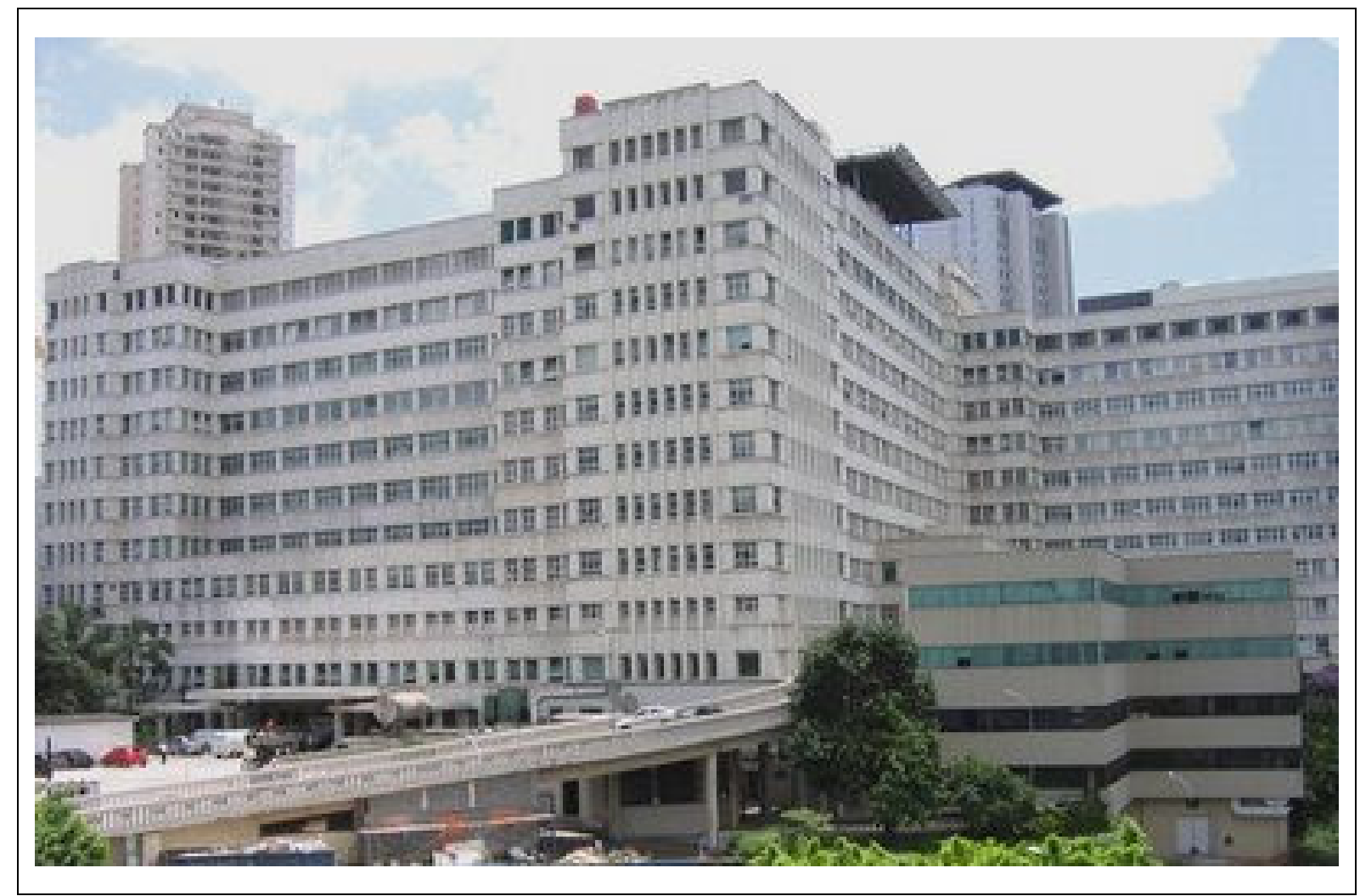

Fachada ${ }^{180}$ 
APÊNDICE J - Edifício e Galeria Sete de Abril Rua Sete de Abril 125 com Rua Bráulio Gomes

Projeto: Escritório de Arquitetura Siffredi e Bardelli - ano 1959

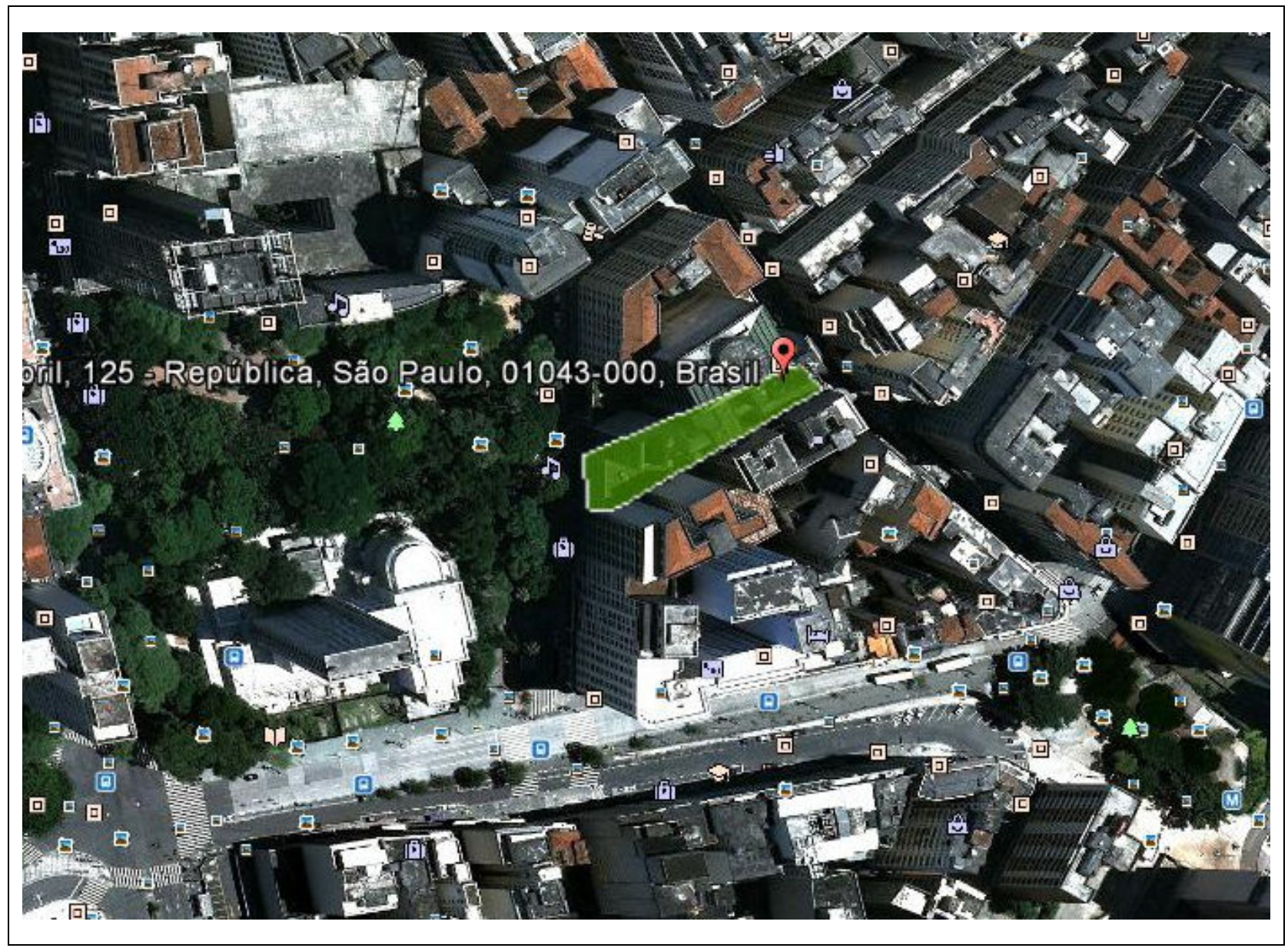

Localização'181

181 Foto Google Earth - 2011 


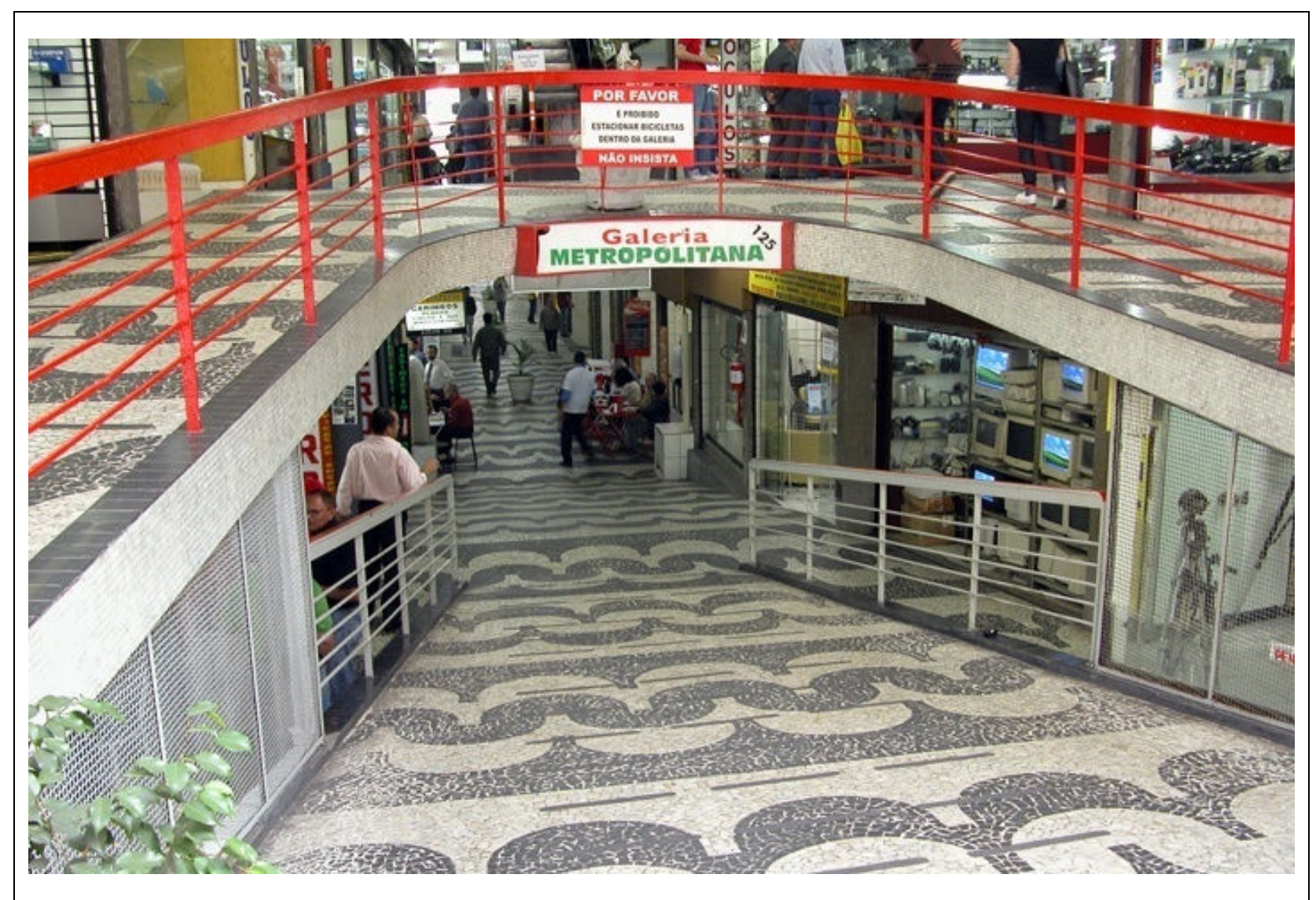

Acesso à galeria ${ }^{182}$

182 Foto: Demósthenes Magno Santos - maio 2012 


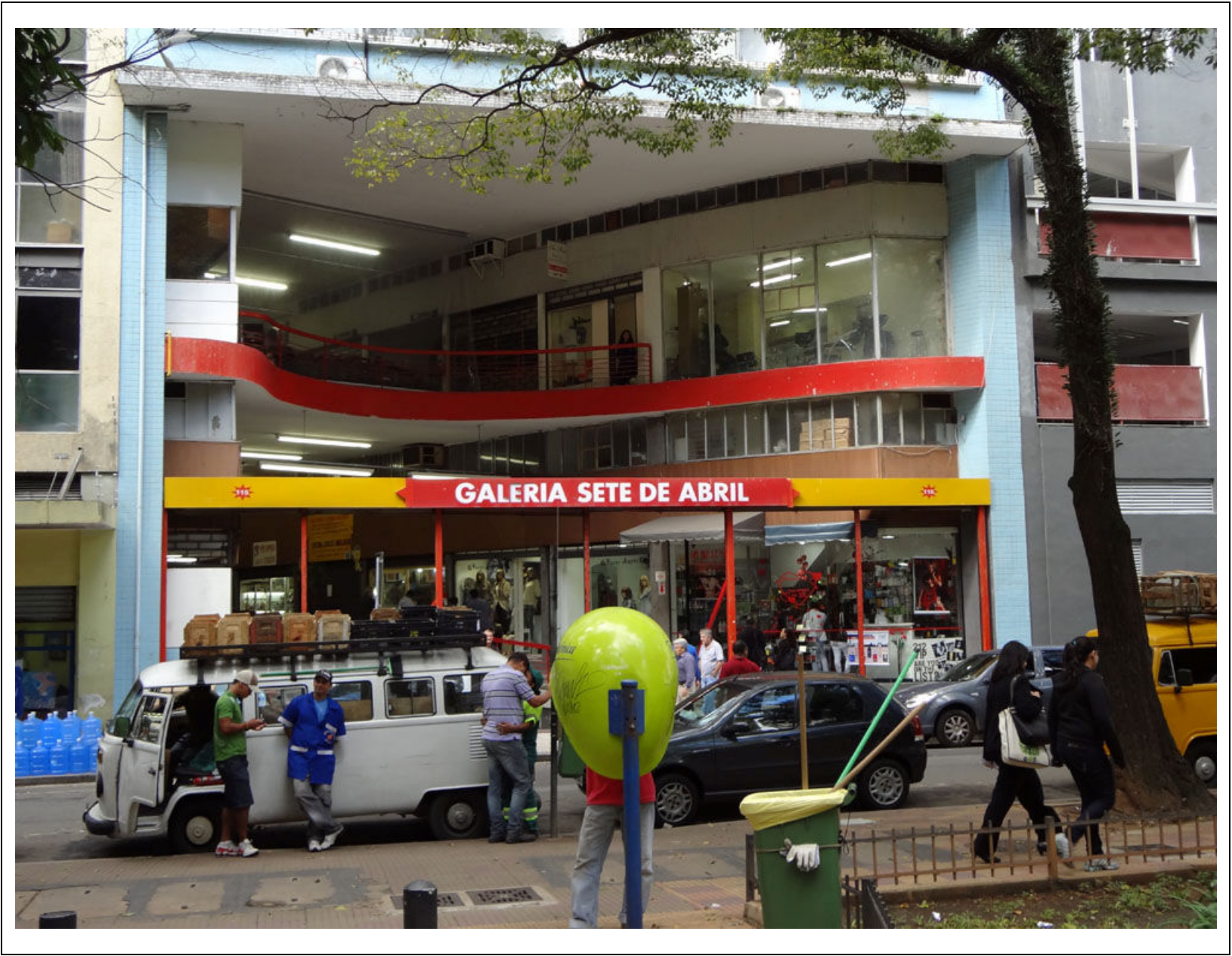

Fachada para a Praça Dom José Gaspar183

183 Foto: Demósthenes Magno Santos - maio 2012 


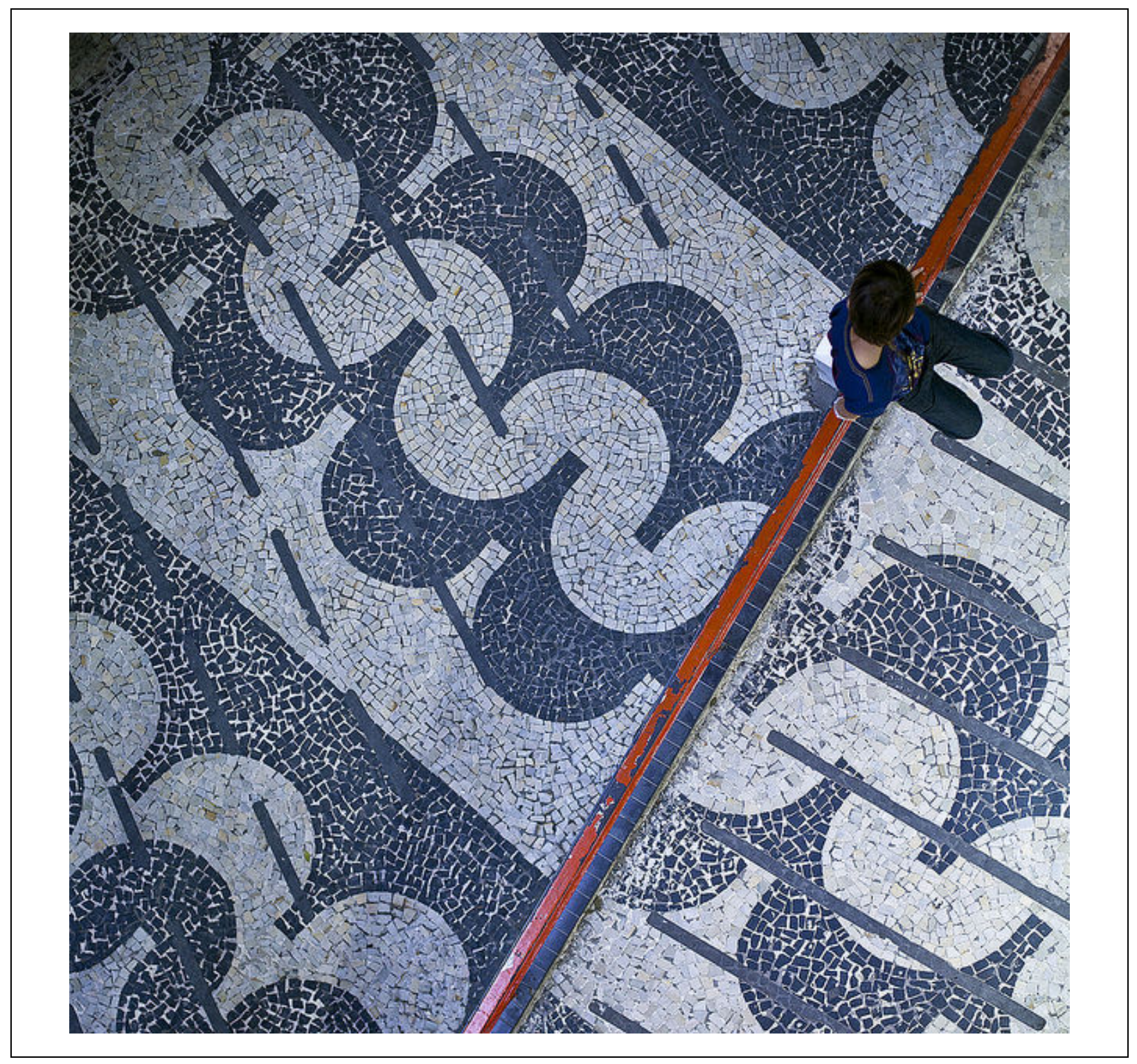

Detalhe do piso elaborado por Bramante Buffoni ${ }^{184}$

184 Foto: Demósthenes Magno Santos - maio 2012 


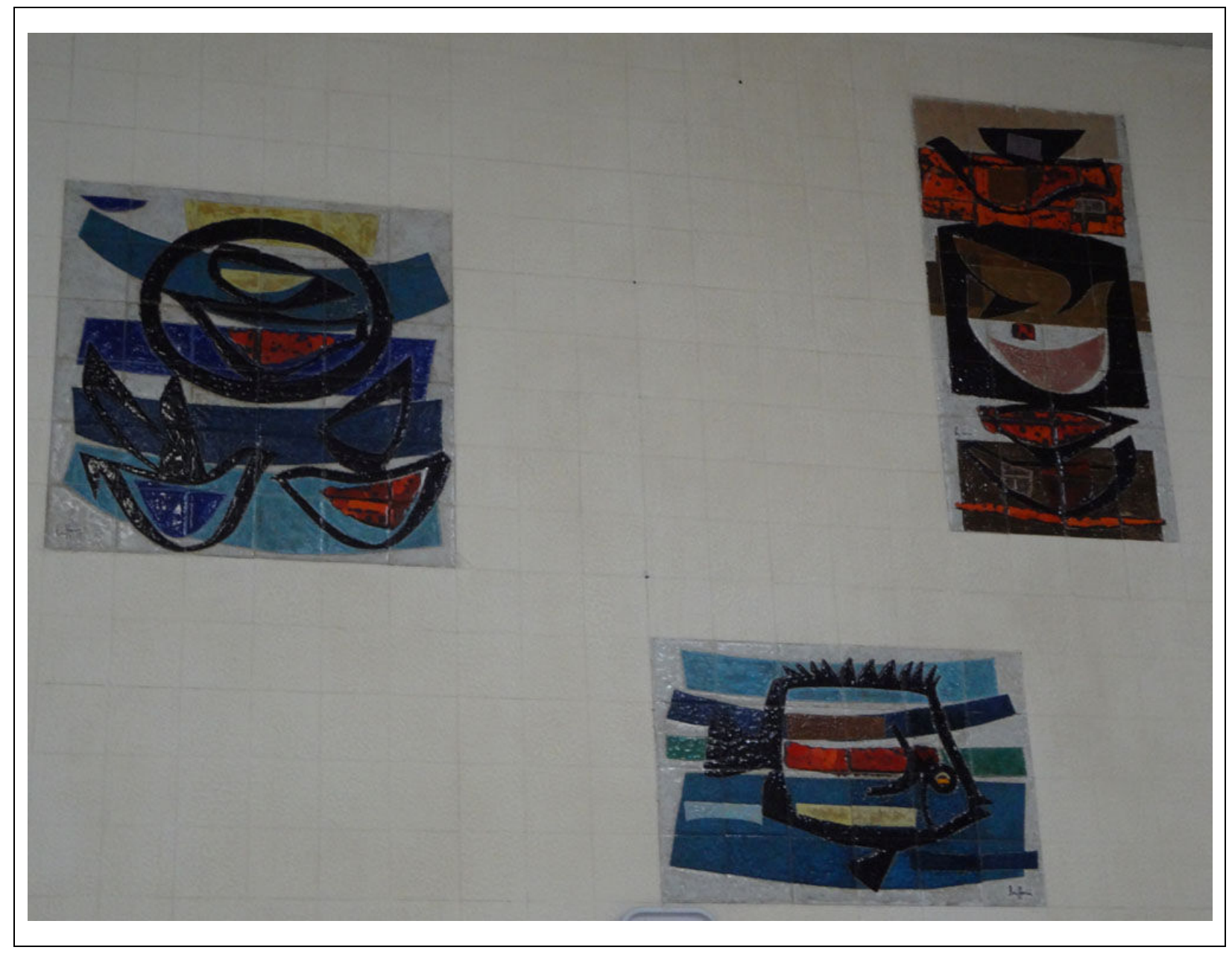

Detalhe dos painéis em cerâmica elaborados por Bramante Buffoni185

185 Foto: Demósthenes Magno Santos - maio 2012 


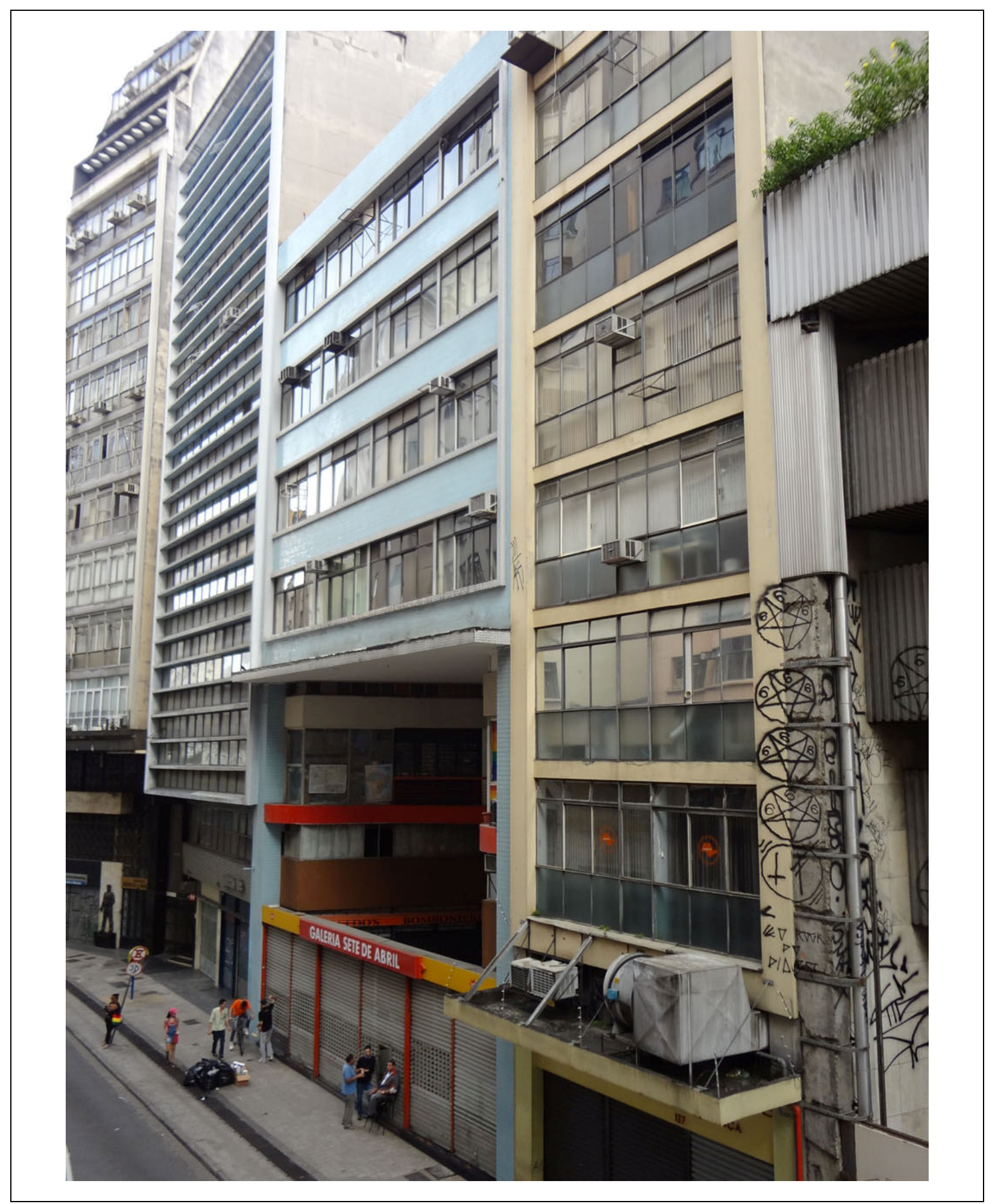

Fachada para a Rua Sete de Abrill ${ }^{186}$

186 Foto: Demósthenes Magno Santos - maio 2012 


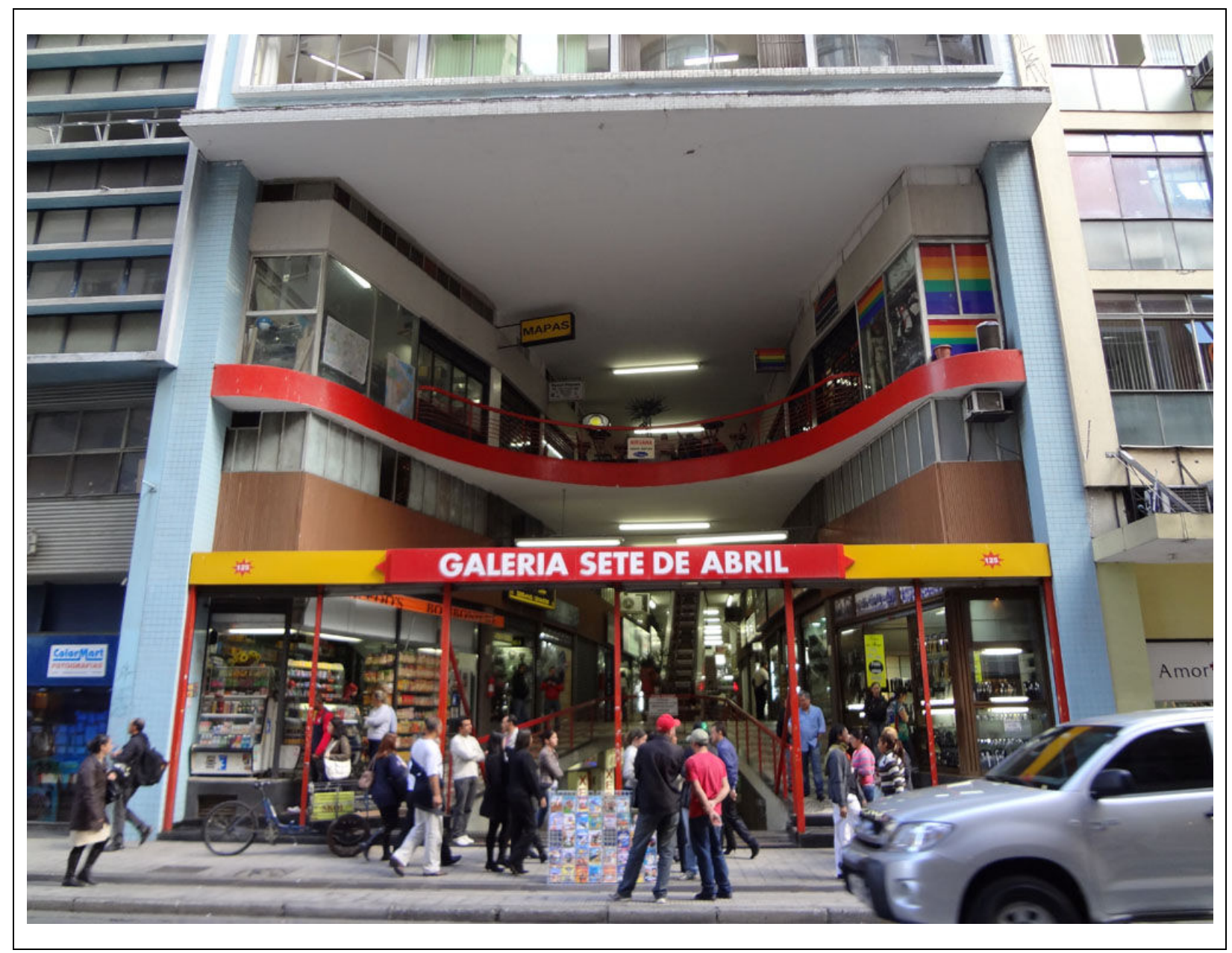

Fachada para a Rua Sete de Abril - acesso 187

187 Foto: Demósthenes Magno Santos - maio 2012 


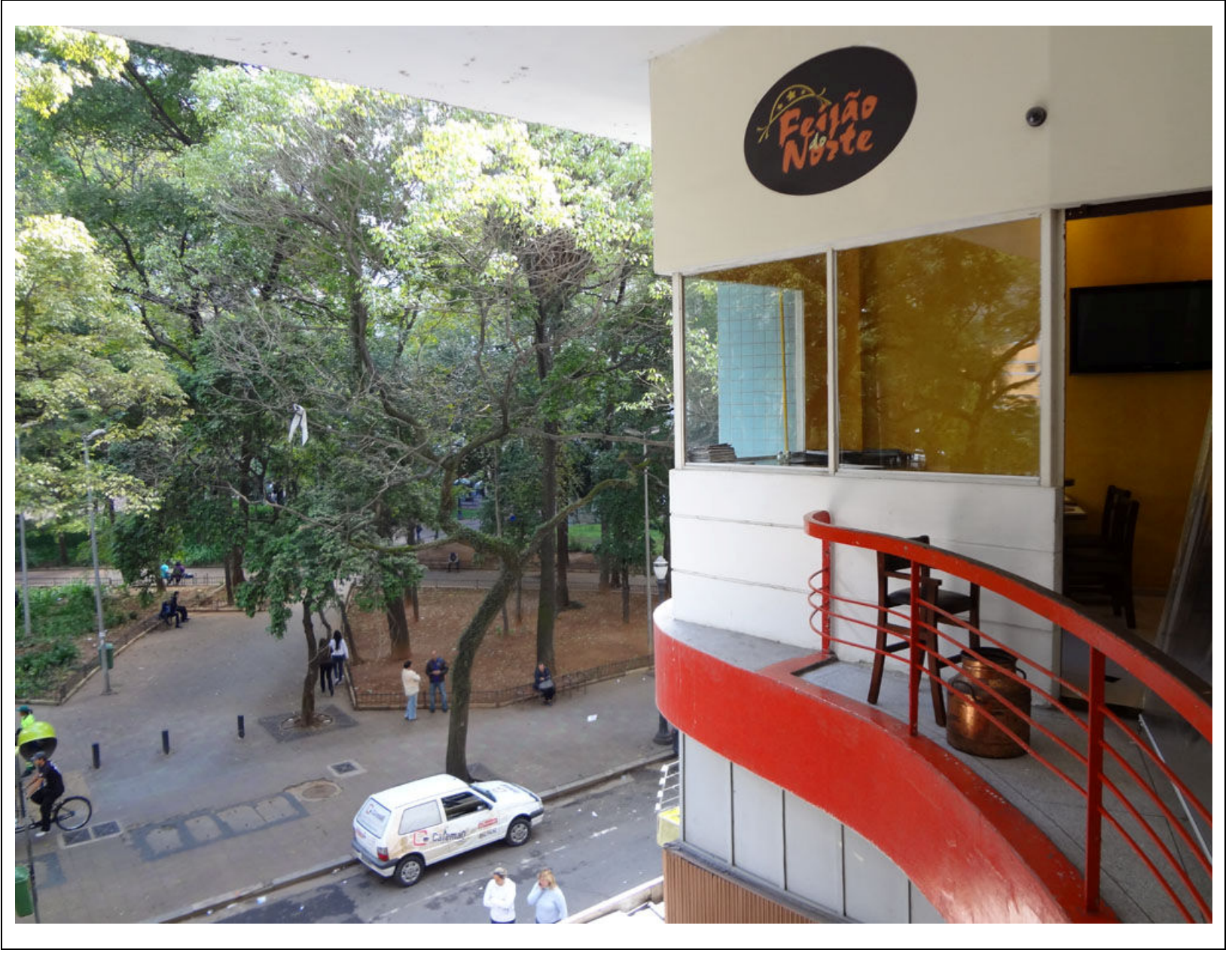

Praça Dom José Gaspar vista do primeiro pavimento ${ }^{188}$

188 Foto: Demósthenes Magno Santos - maio 2012 


\section{APÊNDICE K - Centro Comercial Presidente Rua Vinte e Quatro de Maio, 116}

Projeto: Escritório de Arquitetura Siffredi e Bardelli - ano 1962

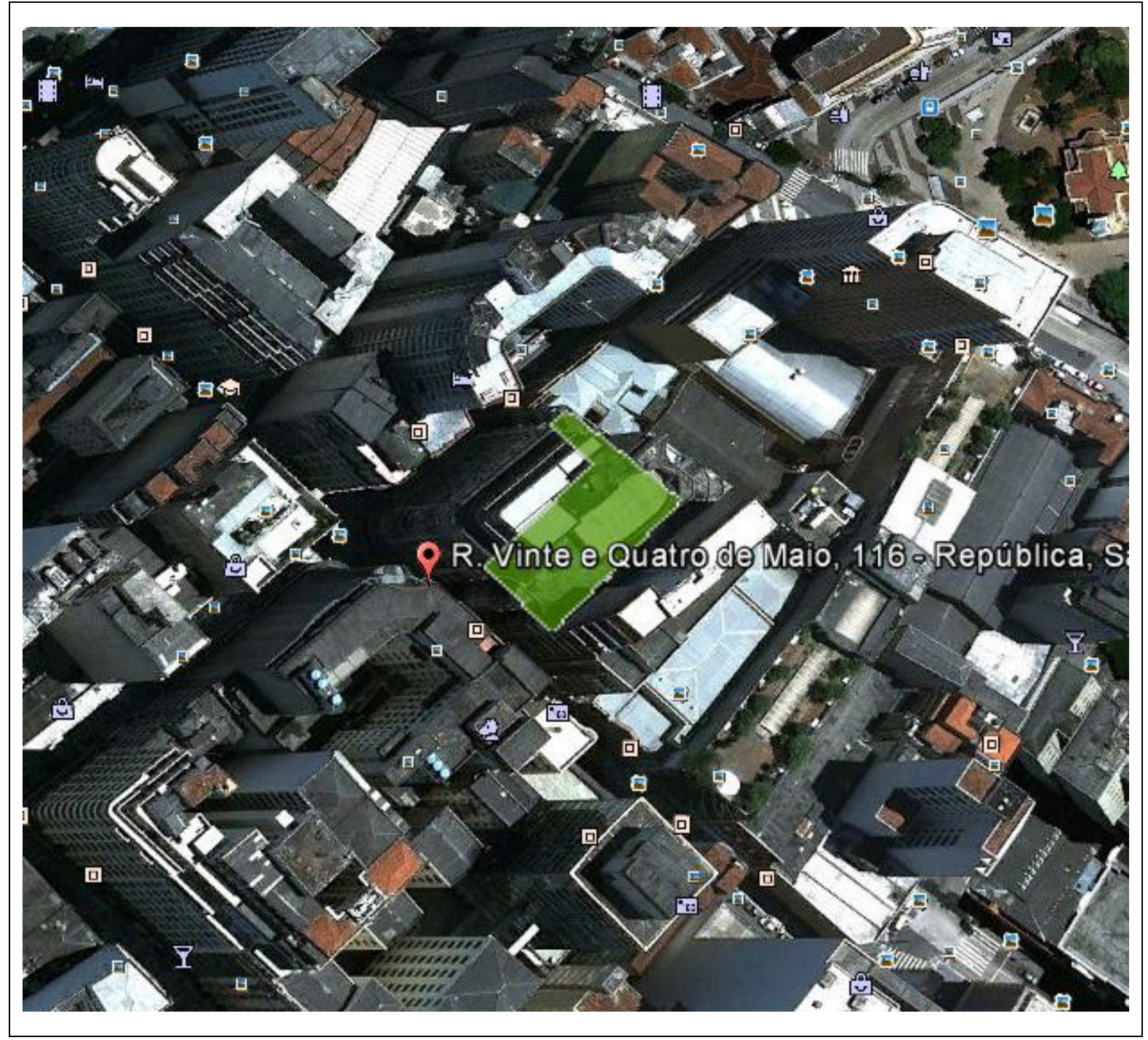

Localização ${ }^{189}$

189 Foto Google Earth - 2011 


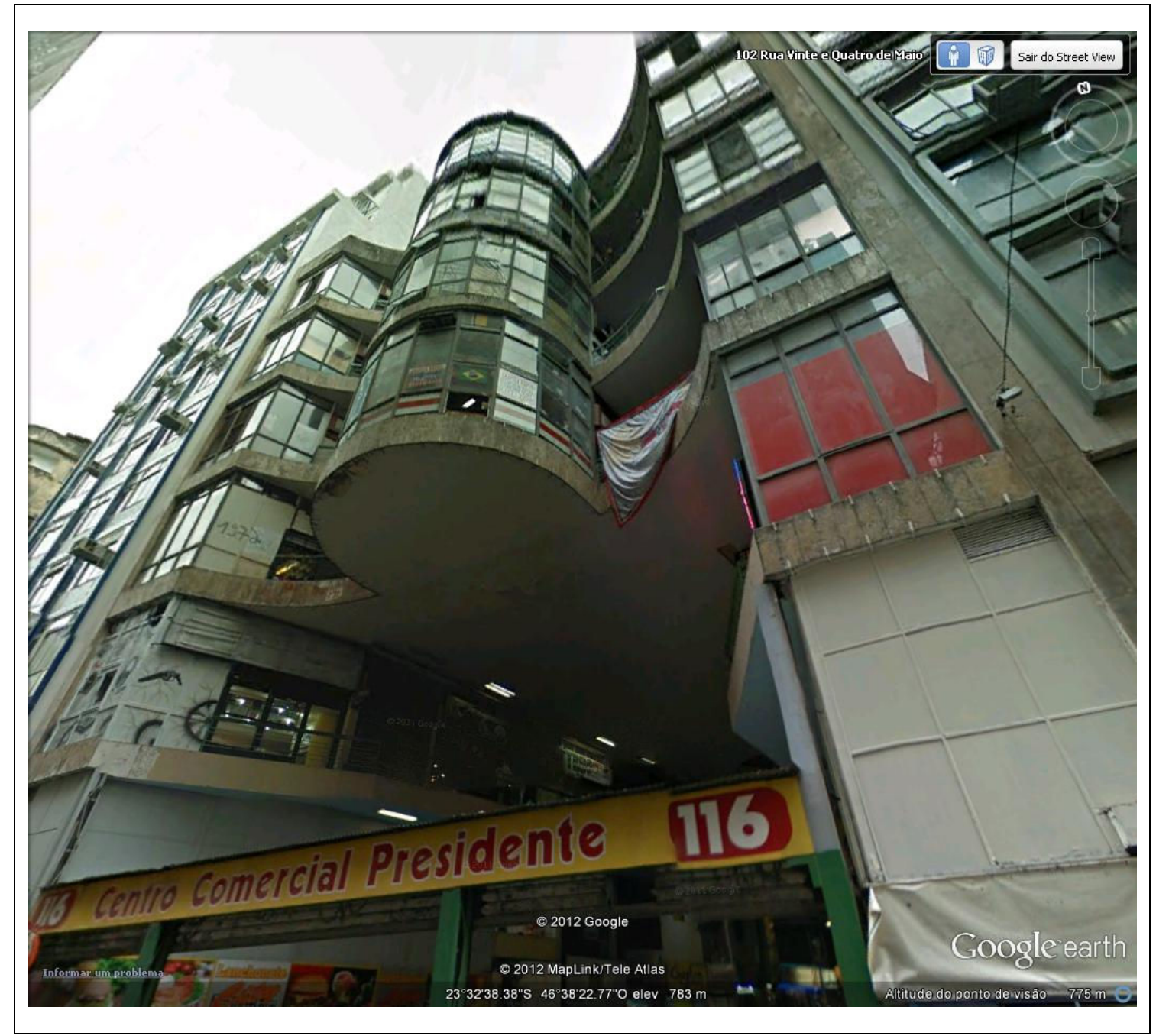

Fachada para a Rua Vinte e Quatro de Maio ${ }^{190}$

190 Foto Google Earth - 2011 


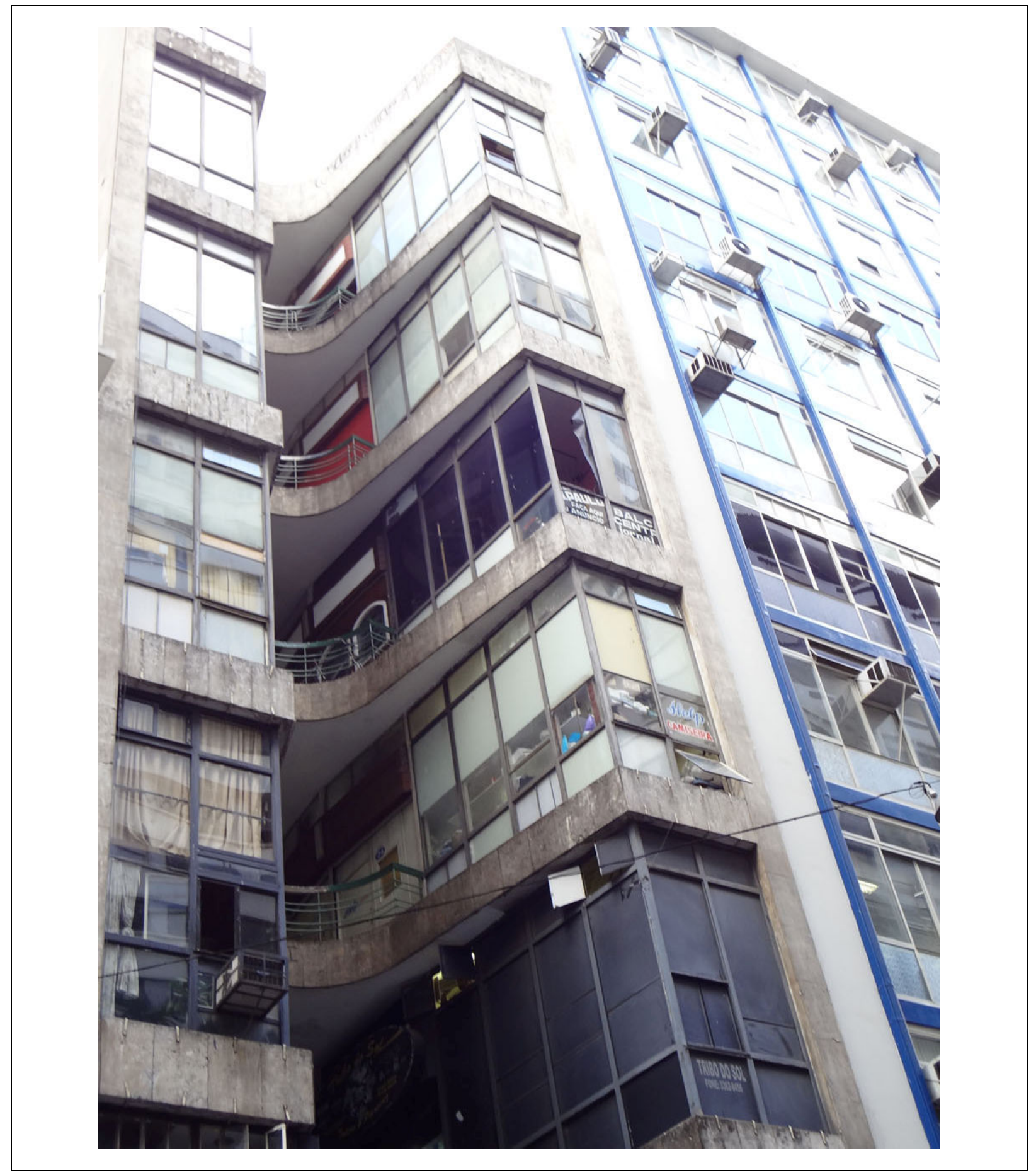

Fachada para a Rua Dom José de Barros ${ }^{191}$

191 Foto: Demósthenes Magno Santos - maio 2012 


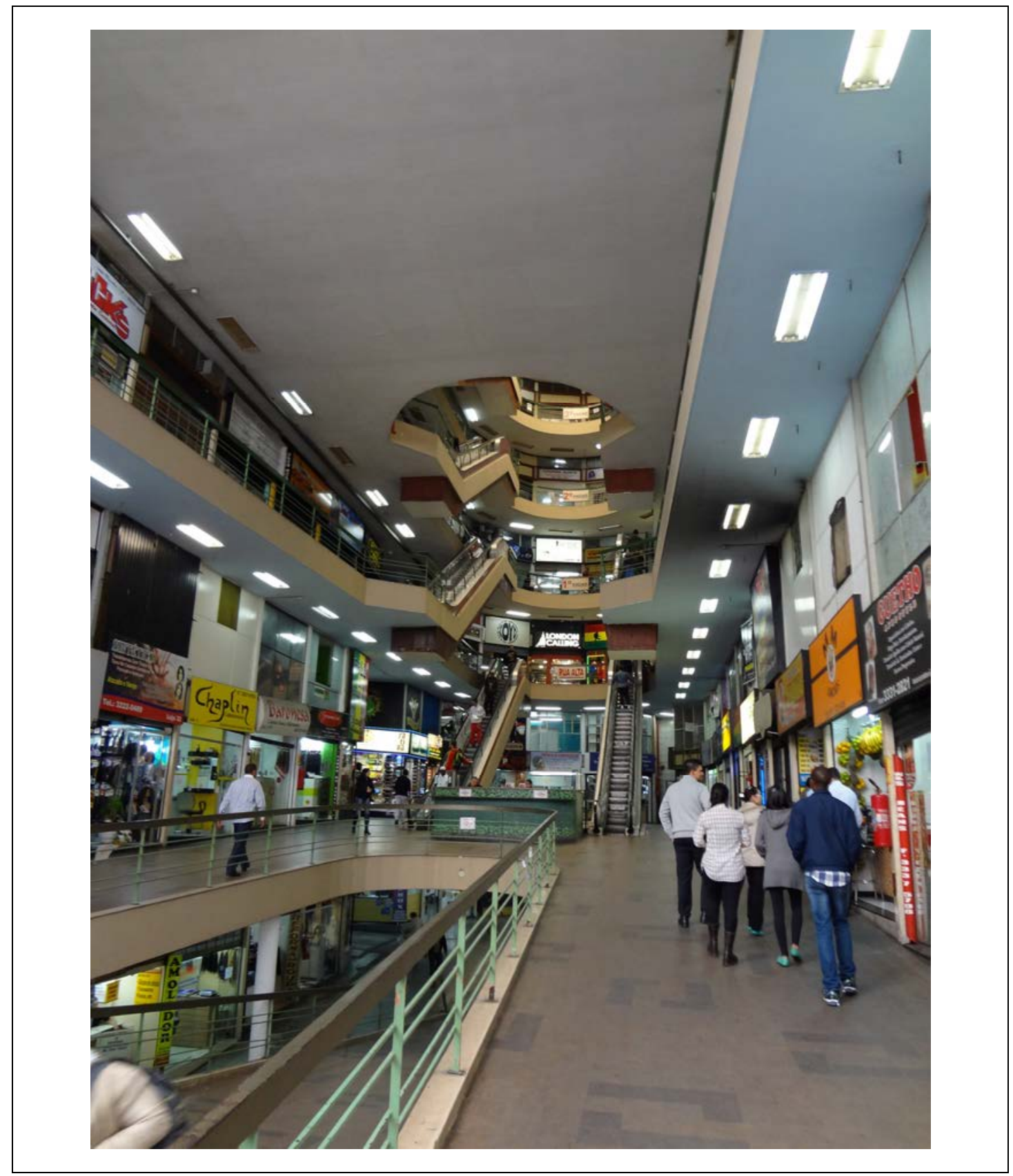

Acesso à galeria pela Rua Vinte e Quatro de Maio ${ }^{192}$

192 Foto: Demósthenes Magno Santos - maio 2012 


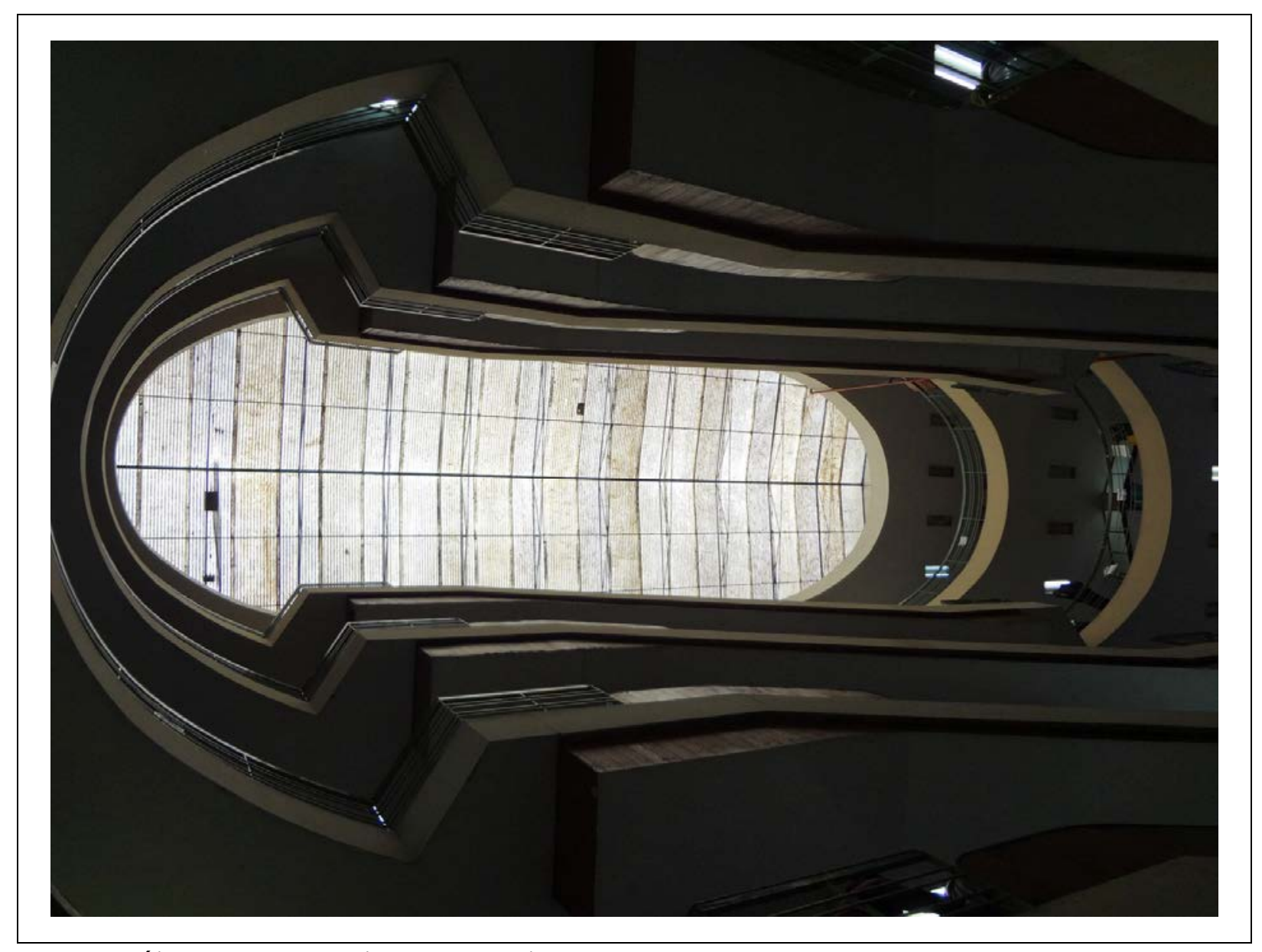

Clarabóia sobre o vazio da galeria ${ }^{193}$

193 Foto: Demósthenes Magno Santos - maio 2012 


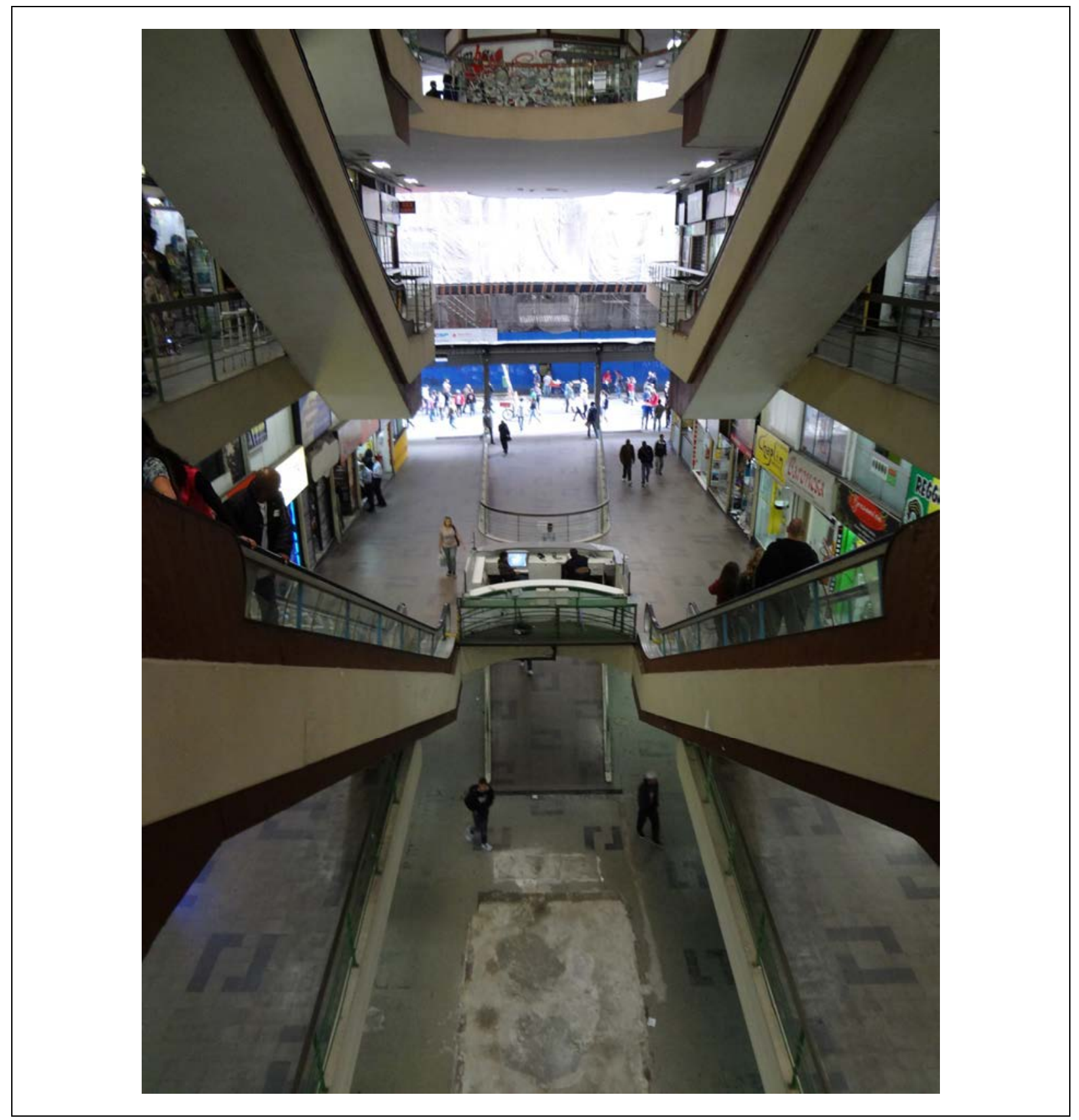

Escadas rolantes sobre o vazio 194

194 Foto: Demósthenes Magno Santos - maio 2012 


\section{APÊNDICE L - Grandes Galerias \\ Rua Vinte e Quatro de Maio, 36 e Avenida São João, 439}

Projeto: Escritório de Arquitetura Siffredi e Bardelli - ano 1962

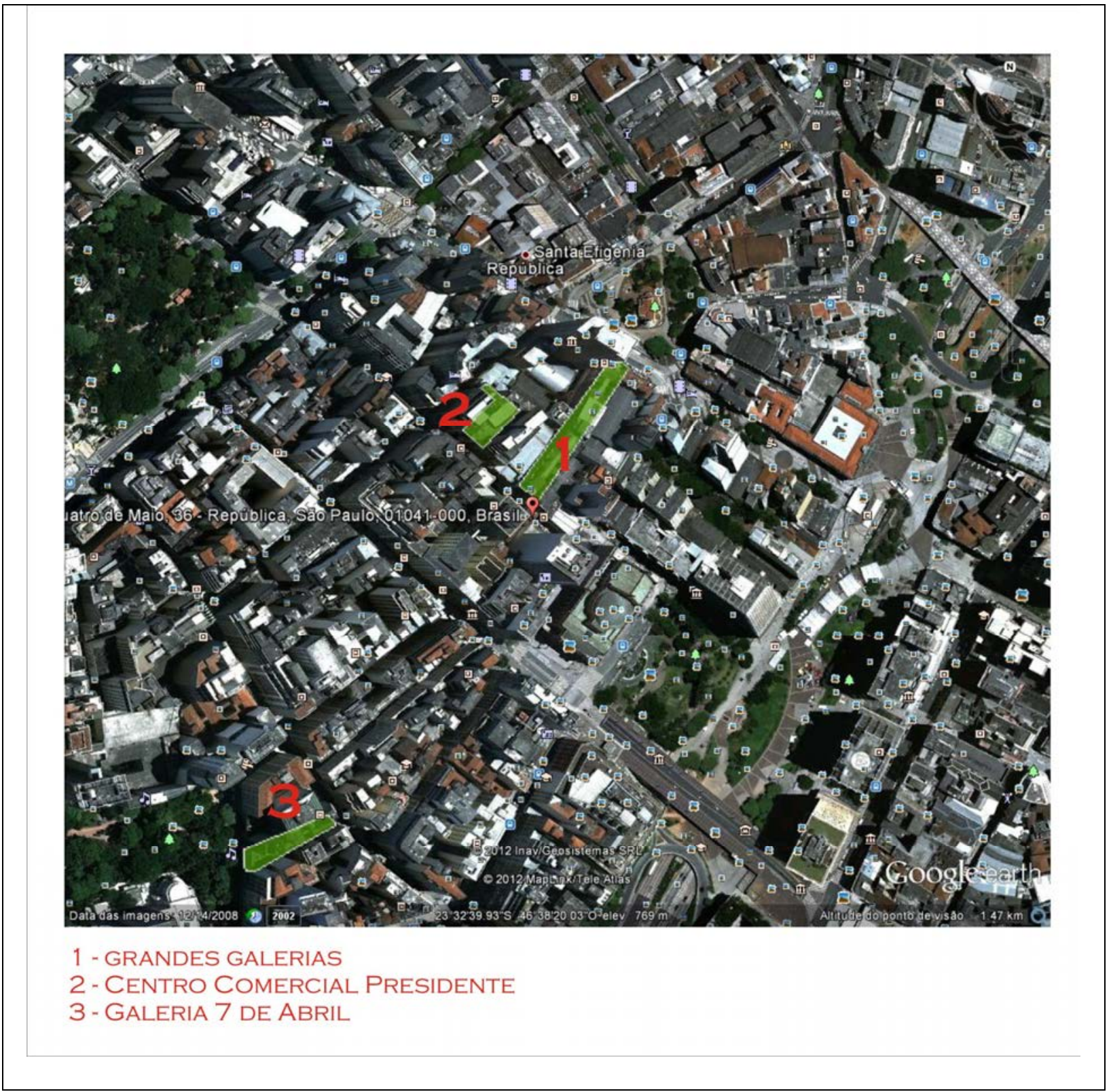

Figura 58: Localização ${ }^{195}$

195 Foto Google Earth - 2011 


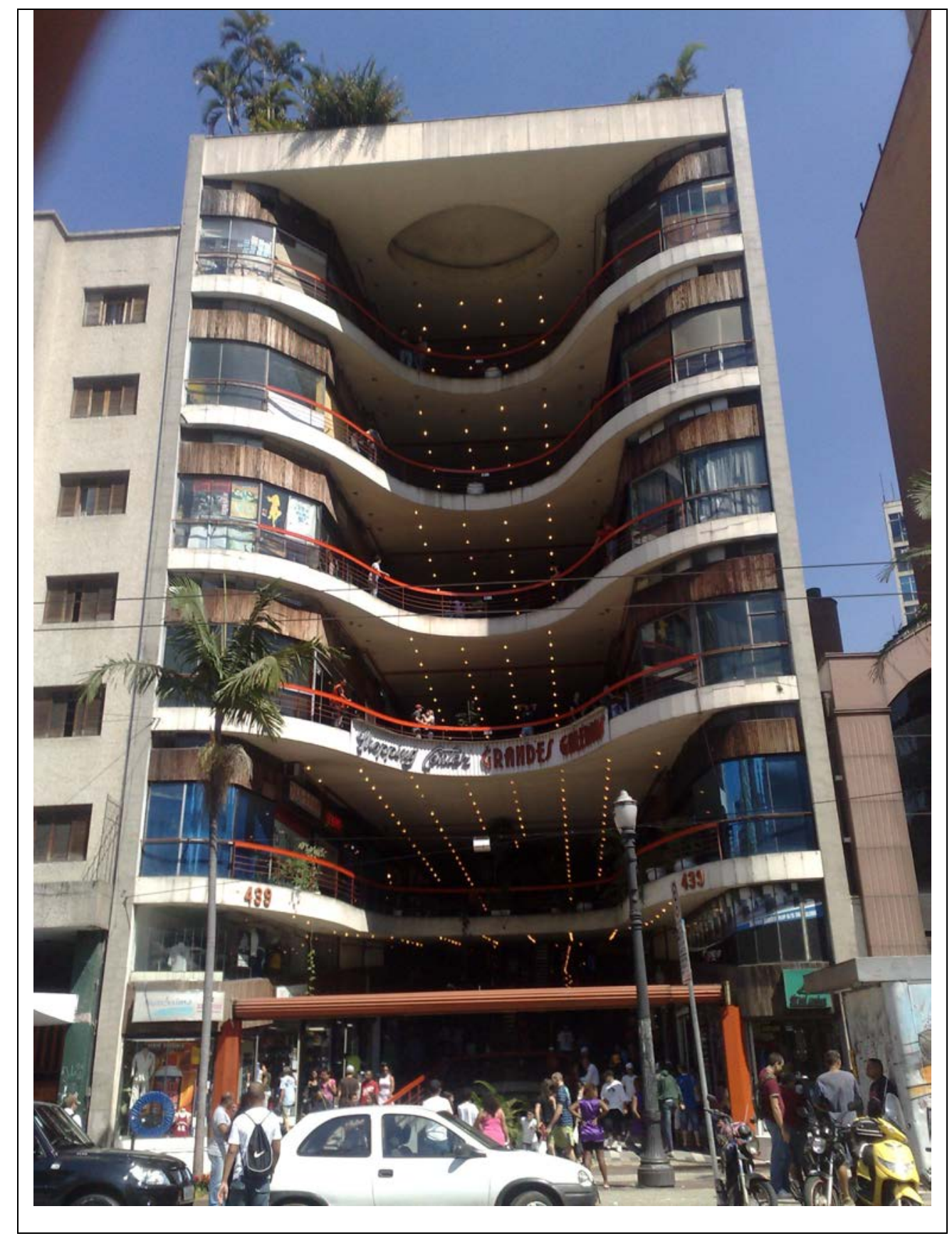

Fachada para a Avenida São João'196

196 http://spcentro.files.wordpress.com/2010/06/17042010355.jpg 


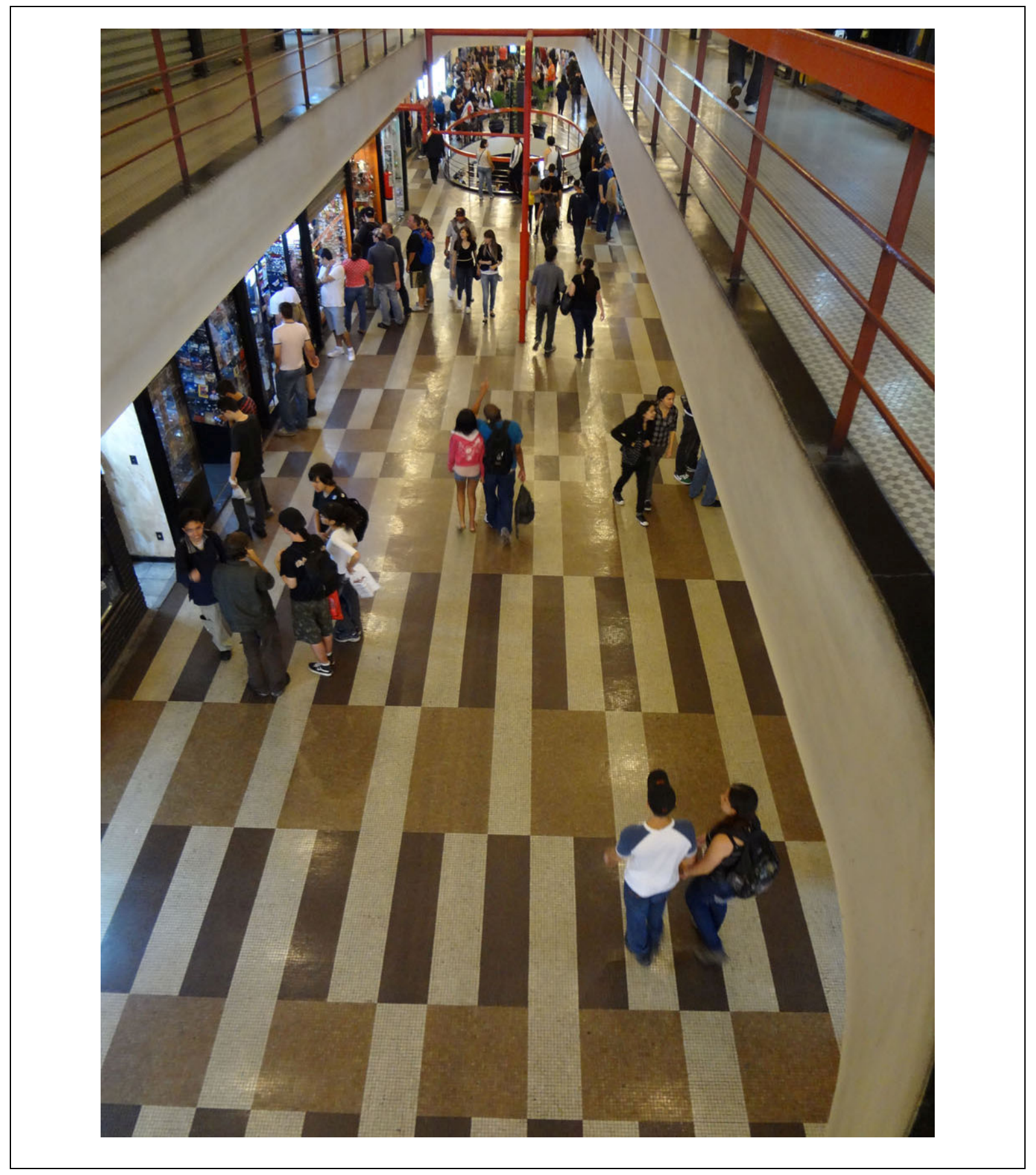

Detalhe do piso do pavimento térreo ${ }^{197}$

197 Foto: Demósthenes Magno Santos - maio 2012 


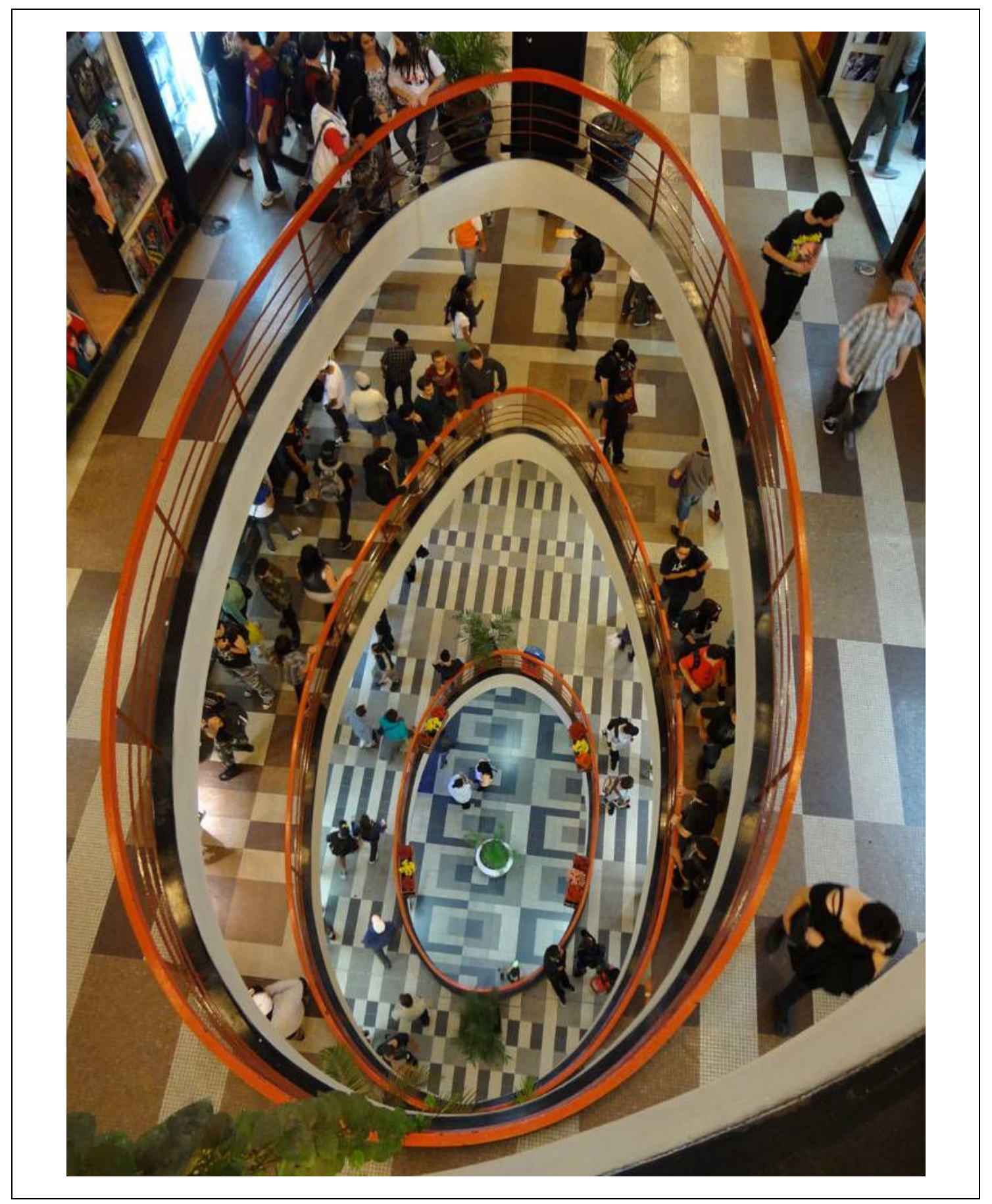

Detalhe dos vazios e pisos ${ }^{198}$

198 Foto: Demósthenes Magno Santos - maio 2012 


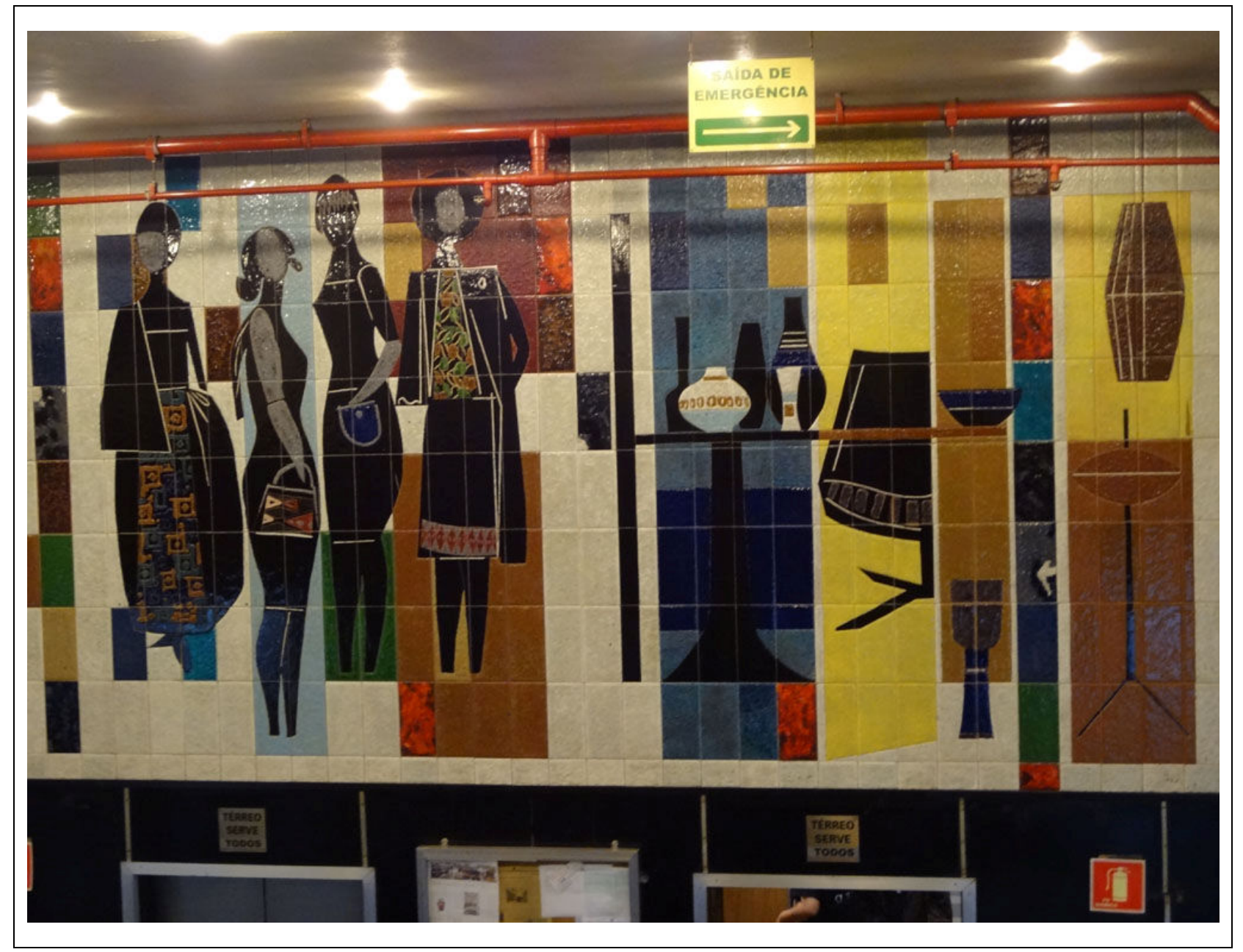

Detalhe do painel cerâmico sobre os elevadores no pav. Térreo (Bramante Buffoni) 199

199 Foto: Demósthenes Magno Santos - maio 2012 


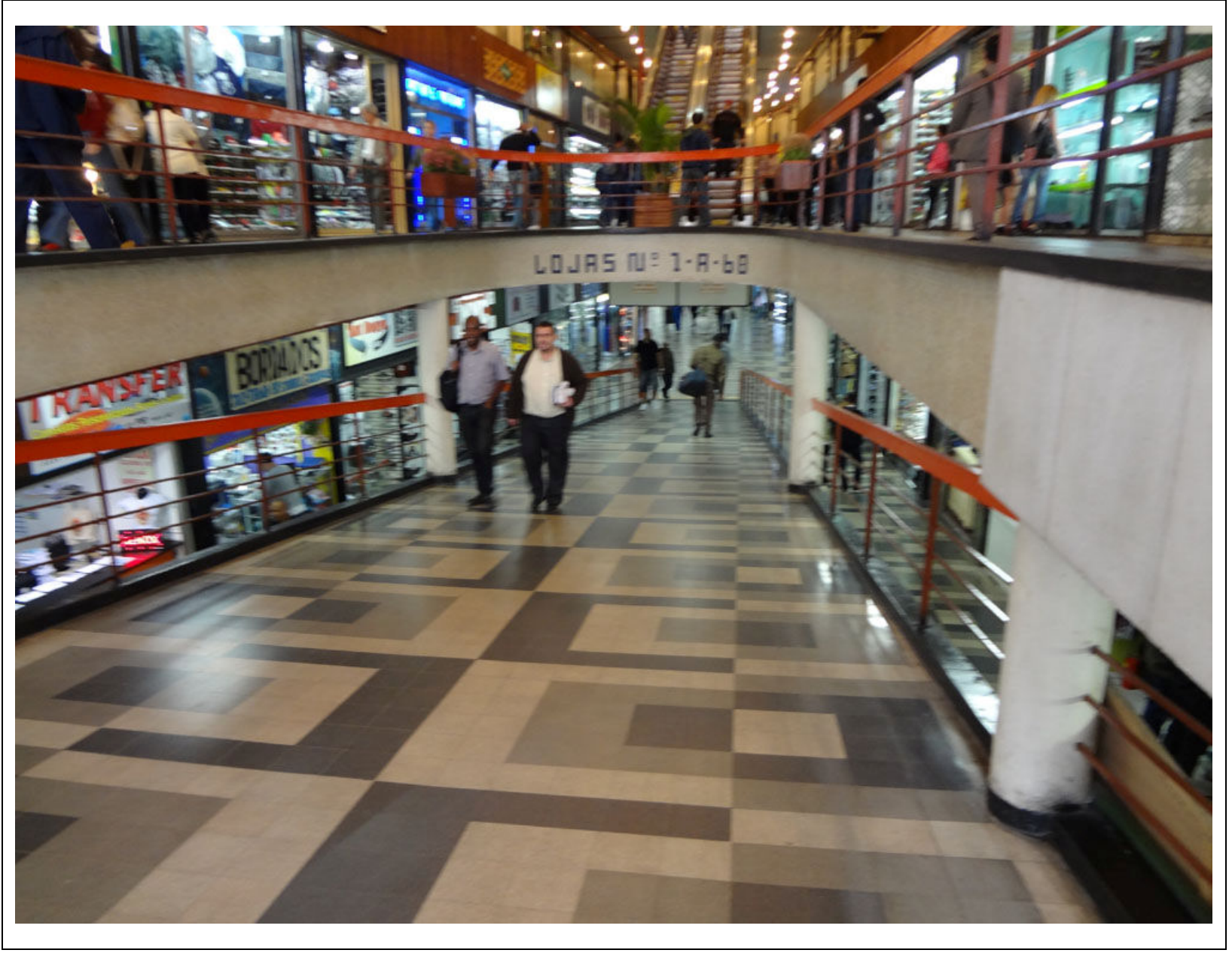

Rampa de acesso ao subsolo200

200 Foto: Demósthenes Magno Santos - maio 2012 


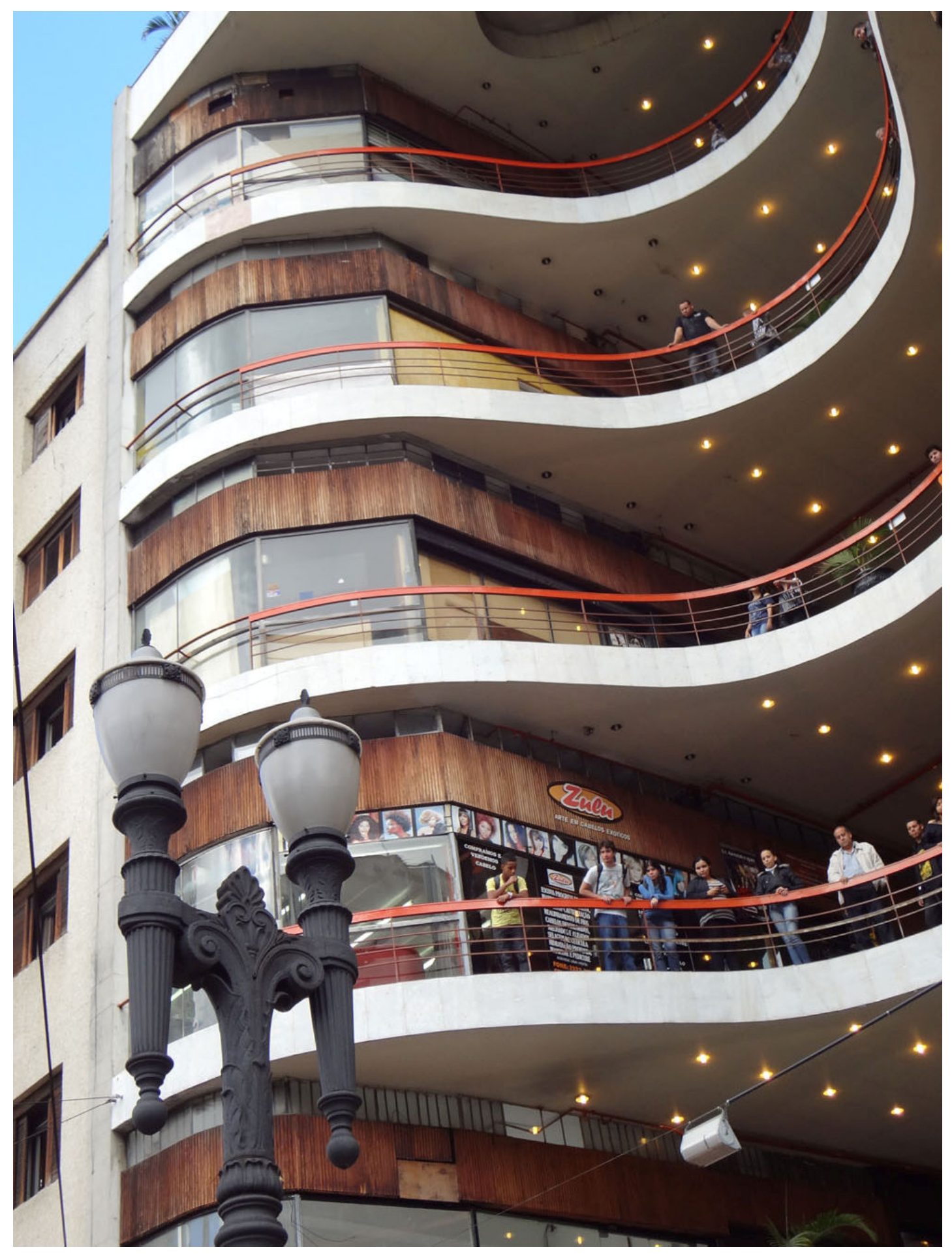

Detalhe da fachada para a Avenida São João201

201 Foto: Demósthenes Magno Santos - maio 2012 
APÊNDICE M - Rua Nova Barão

Interligação das Ruas Sete de Abril e Rua Barão de Itapetininga

Projeto: Escritório de Arquitetura Siffredi e Bardelli - ano 1962

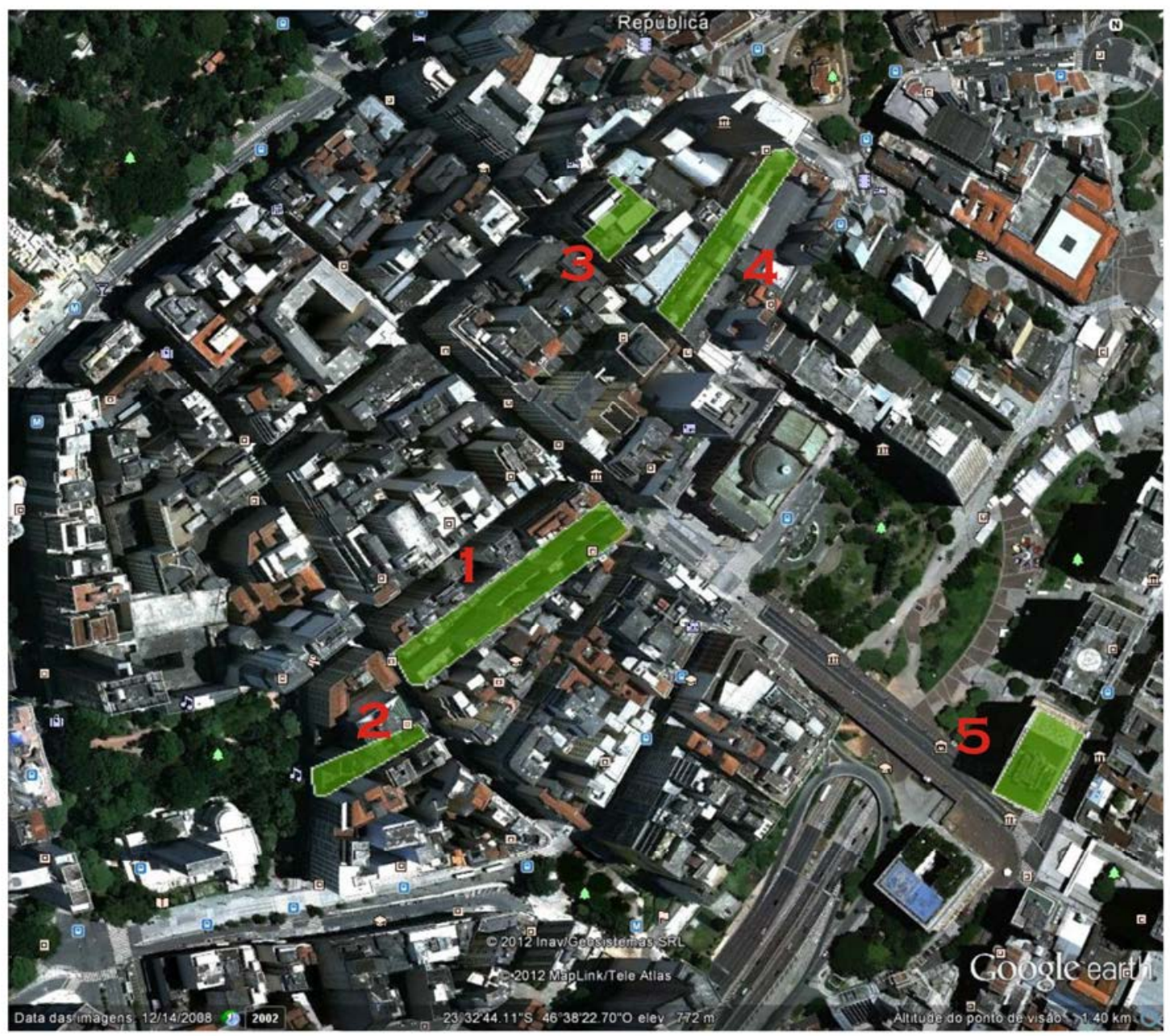

1 - RUA NOVA BARÃO

2 - GALERIA SETE DE ABRIL

3 - CENTRO COMERCIAL PRESIDENE

4 - GRANDES GALERIAS

5 - EDIFICIO CONDE DE PRATES

Localização202

202 Foto Google Earth - 2011 


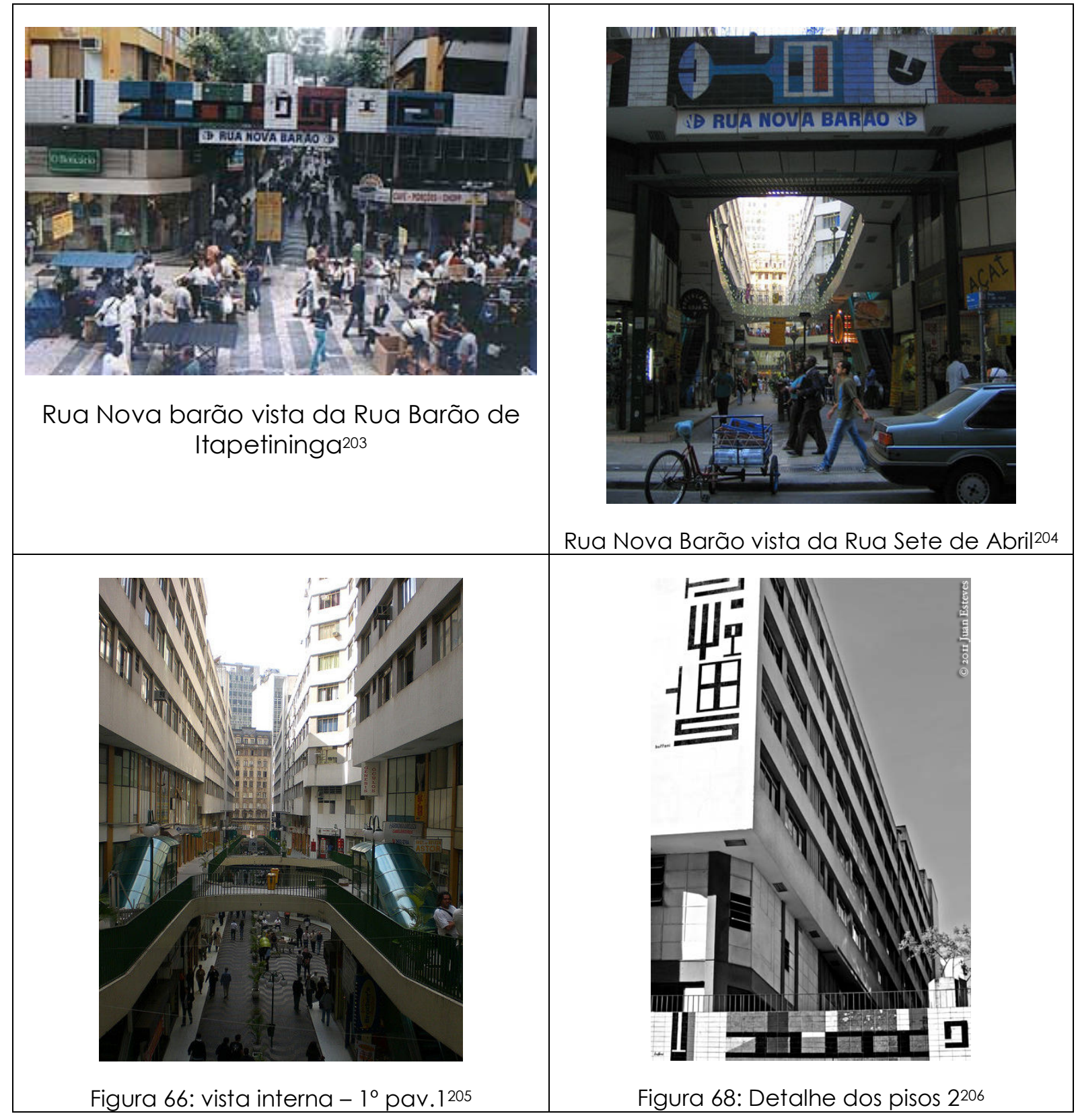

203 Fonte: http://www.estrelaonze.com.br/003_eventos/2001_nova-barao/nova-barao_01.JPG

204 Fonte: http://www.atitudebrasil.com/capital/wp-content/uploads/201 1/01/GALERIA-nova-barao-7-

205 Fonte: $\mathrm{http}: / /$ farm 1. static.flickr.com/95/243468990_5f022e81bd.jpg

206 Fonte: http://farm4.staticflickr.com/3058/2625601199_759ffbd219_z.jpg 


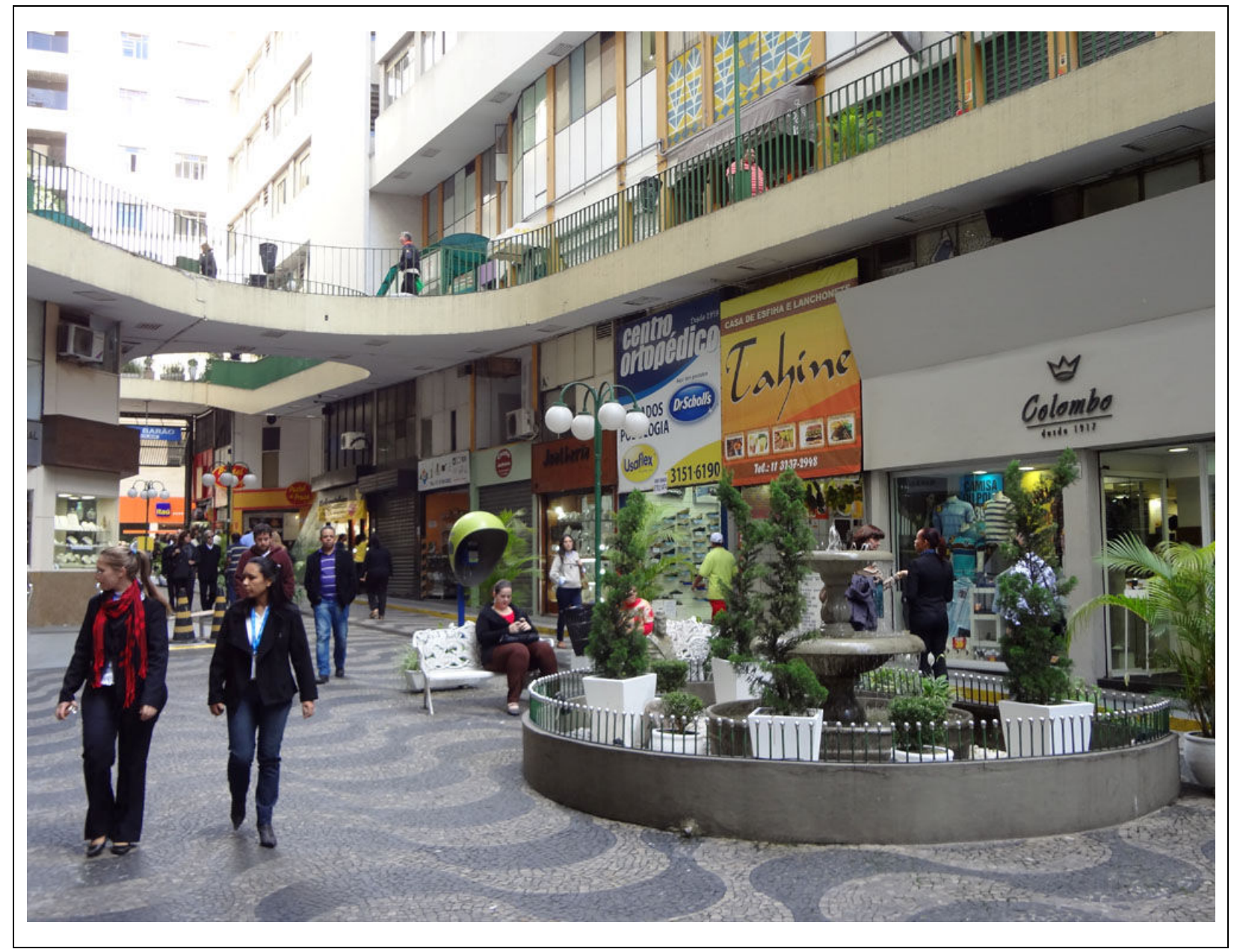

Detalhe da rua interna, em destaque o acréscimo da fonte em desarmonia com conjunto207

207 Foto: Demósthenes Magno Santos - maio 2012 


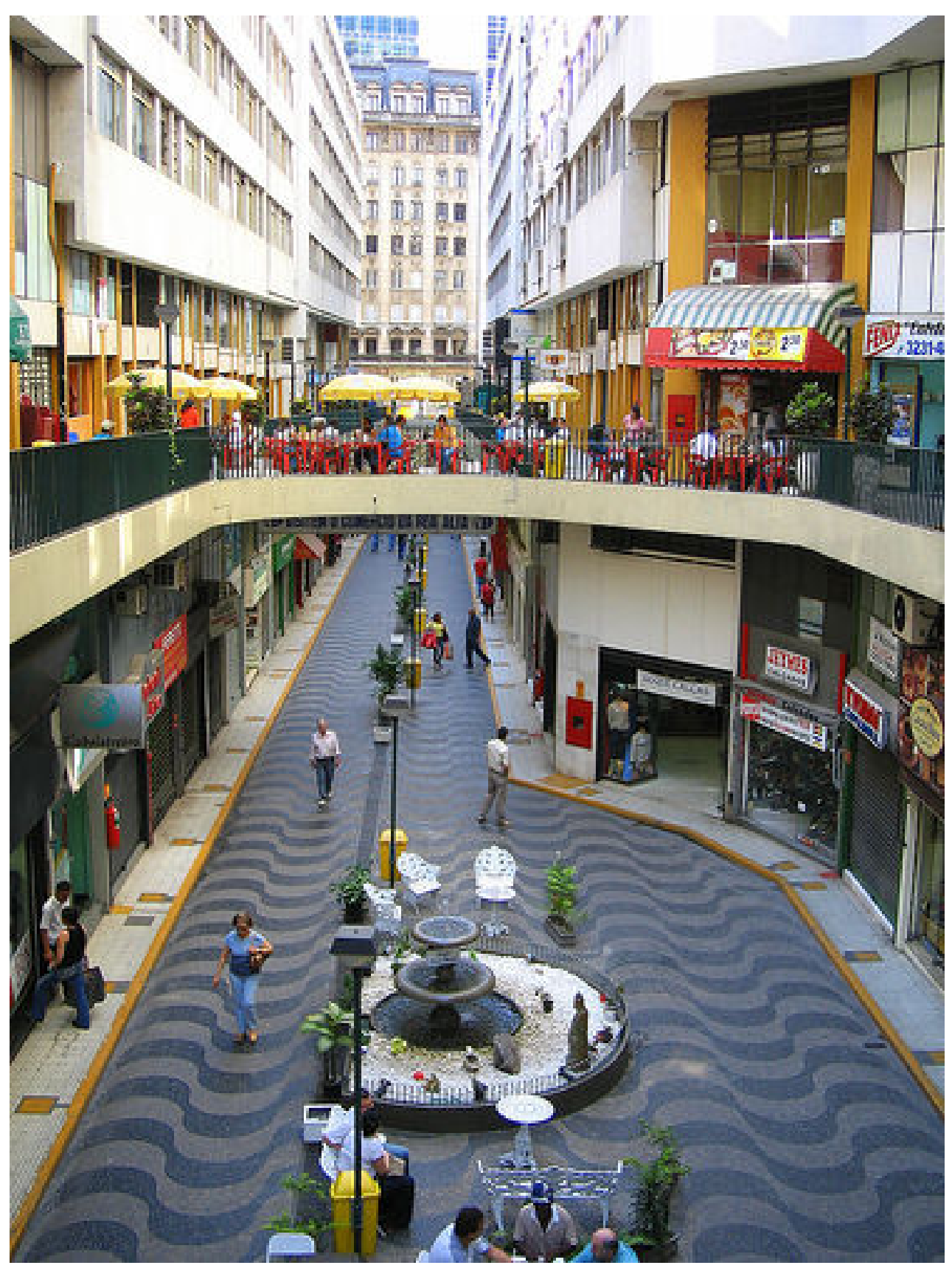

Detalhe: vistas das ruas inferior e superior 208

208 Foto: Demósthenes Magno Santos - maio 2012 


\section{APÊNDICE N - Centro Comercial Bom Retiro Rua José paulino com Rua Ribeiro de Lima}

Projeto: Lucjan Korngold e Gabriel Kauffnam - década 1960

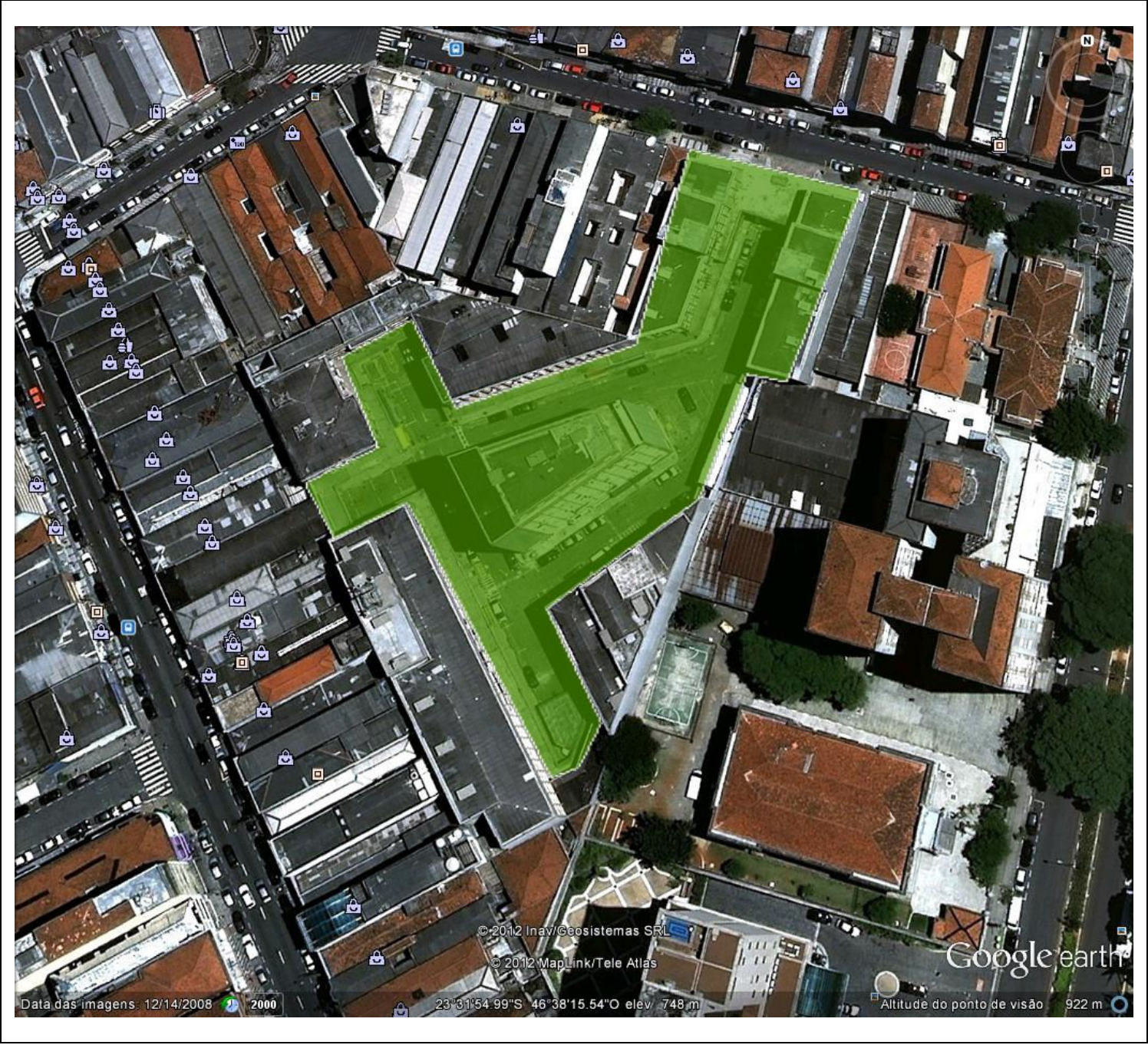

Localização209

209 Foto Google Earth - 2011 


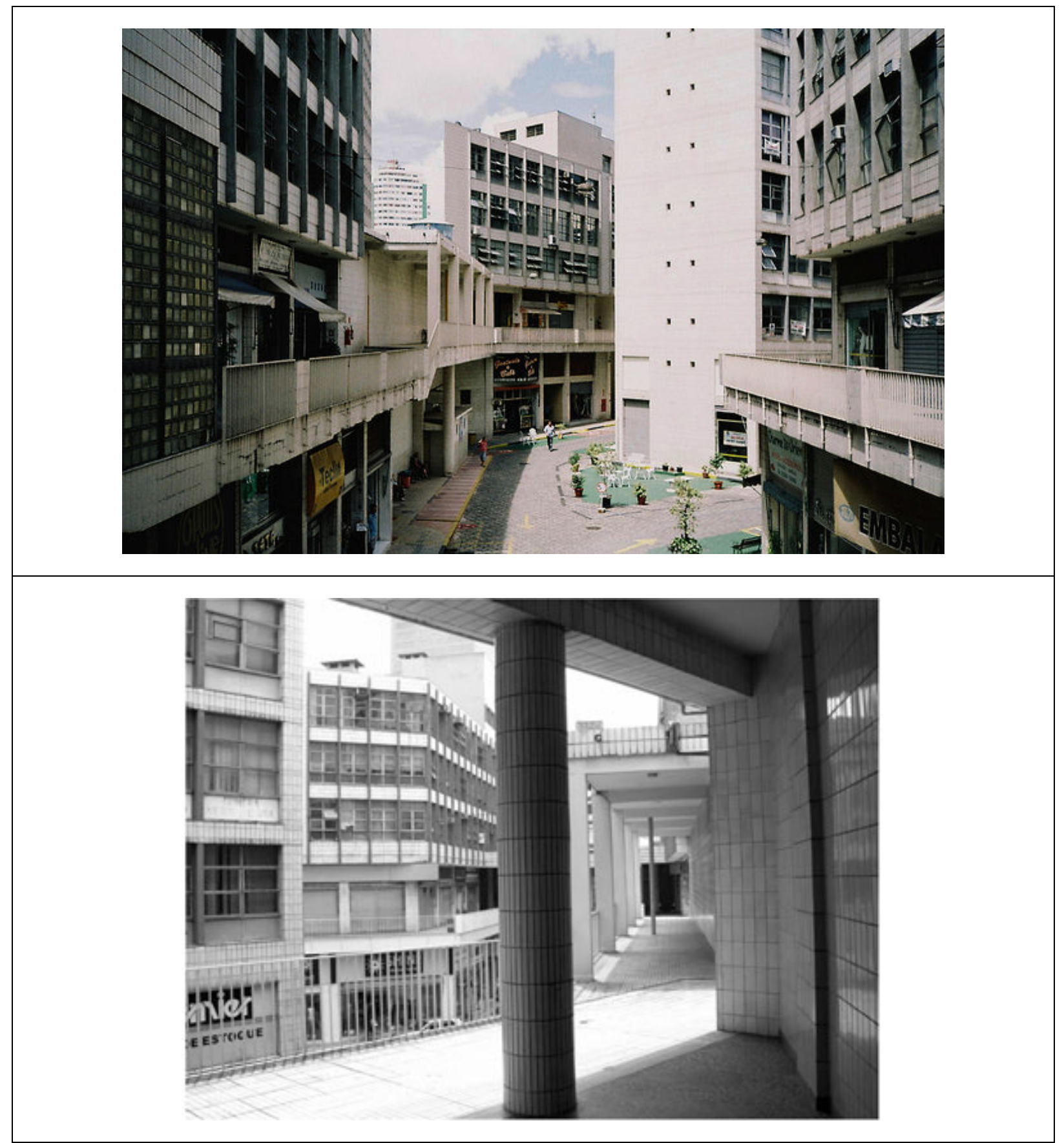

Superior: vista da rua interna ${ }^{210}$

Inferior: vista interna do acesso da Rua Ribeiro de Lima211

210 Fonte: http://farm8.staticflickr.com/7055/6954060285_3b7ebb2741_z.jpg

211 Fonte: http://media.timeout.com.br/contentFiles/image/saopaulo/01_AROUND_TOWN/events/2011/04_oct_nov 


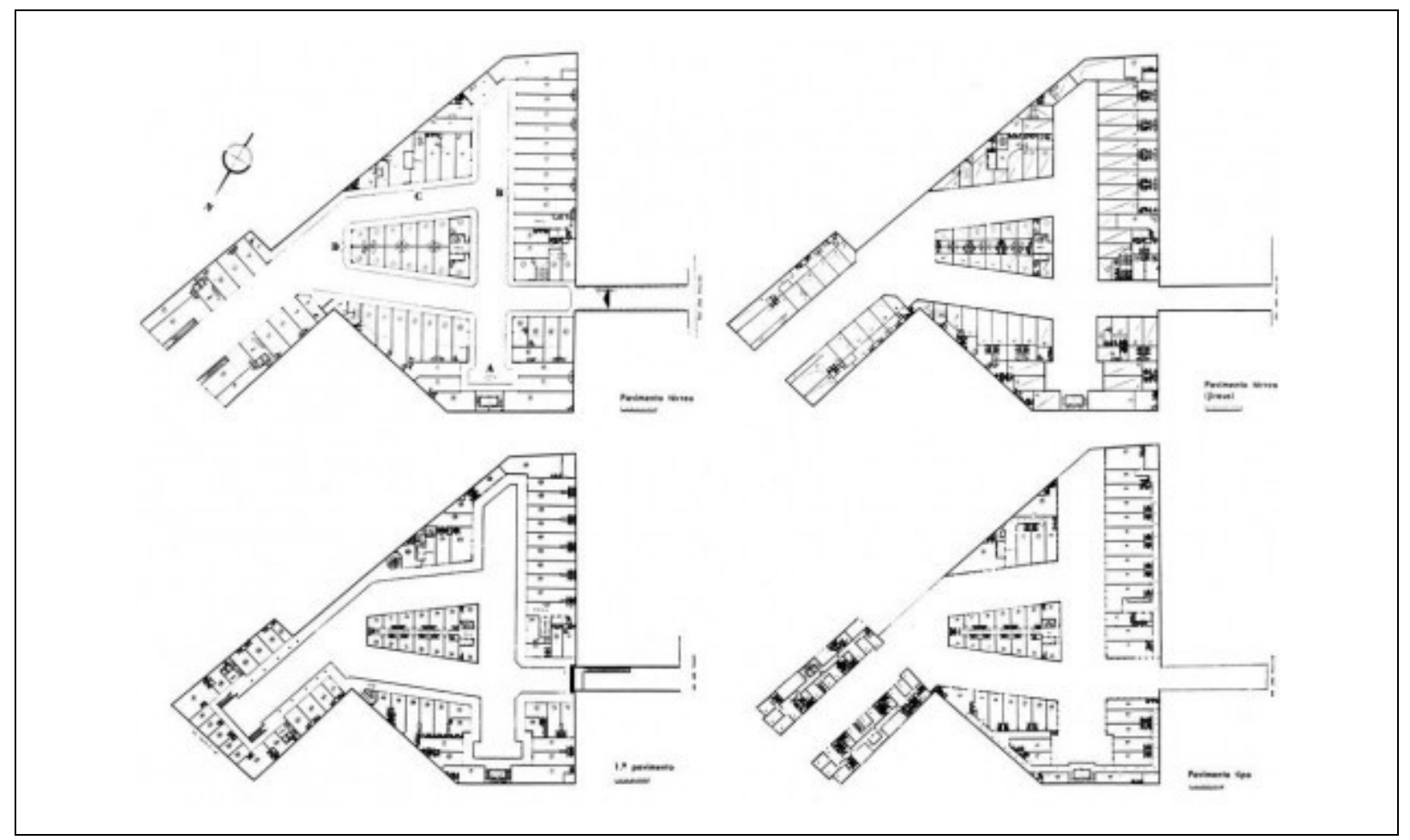

Plantas 212

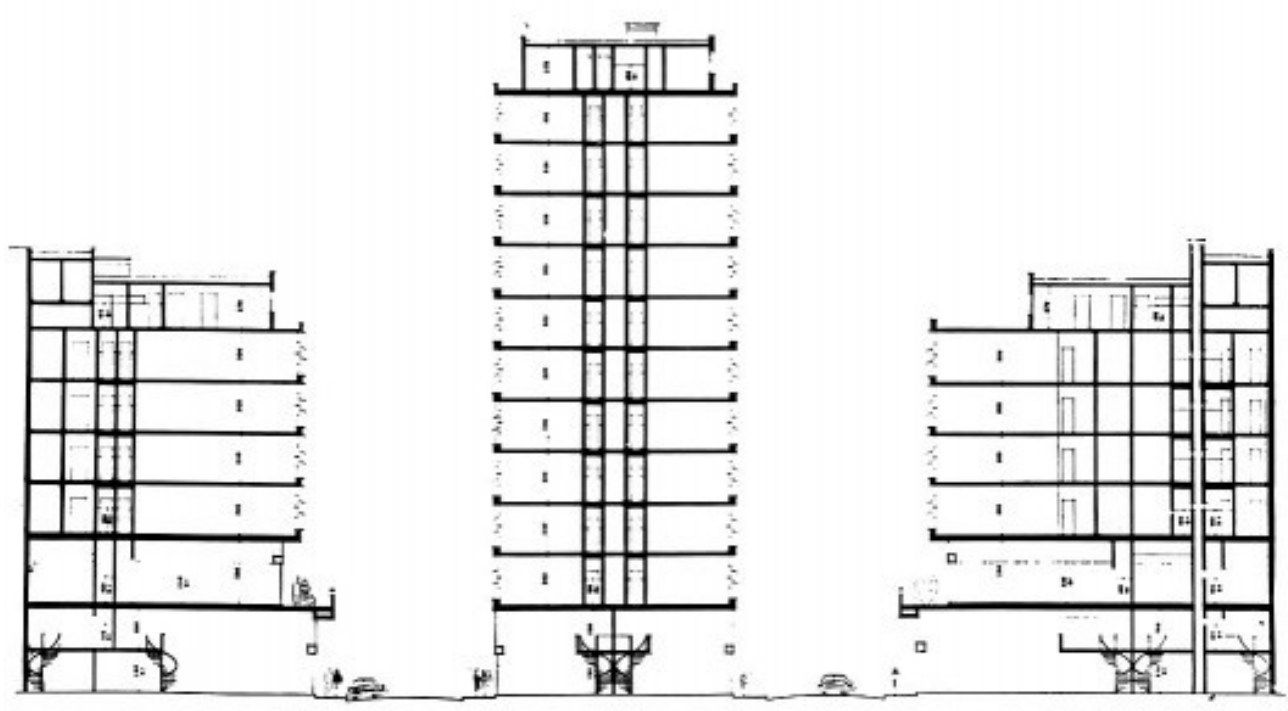

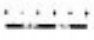

Cortes $^{213}$

212 Fonte: $\mathrm{http}: / /$ www.vitruvius.com.br/media/images/magazines/grid_9/78e88499cfea_korngold_bomretiro03.jpg 213 Fonte: http://www.vitruvius.com.br/media/images/magazines/grid_9/a6a34aafacb9_korngold_bomretiro04.jpg 


\section{APÊNDICE O - Edifício Princesa Isabel Avenida São Luiz, 165}

Projeto e Construção: Alfredo Mathias -1944

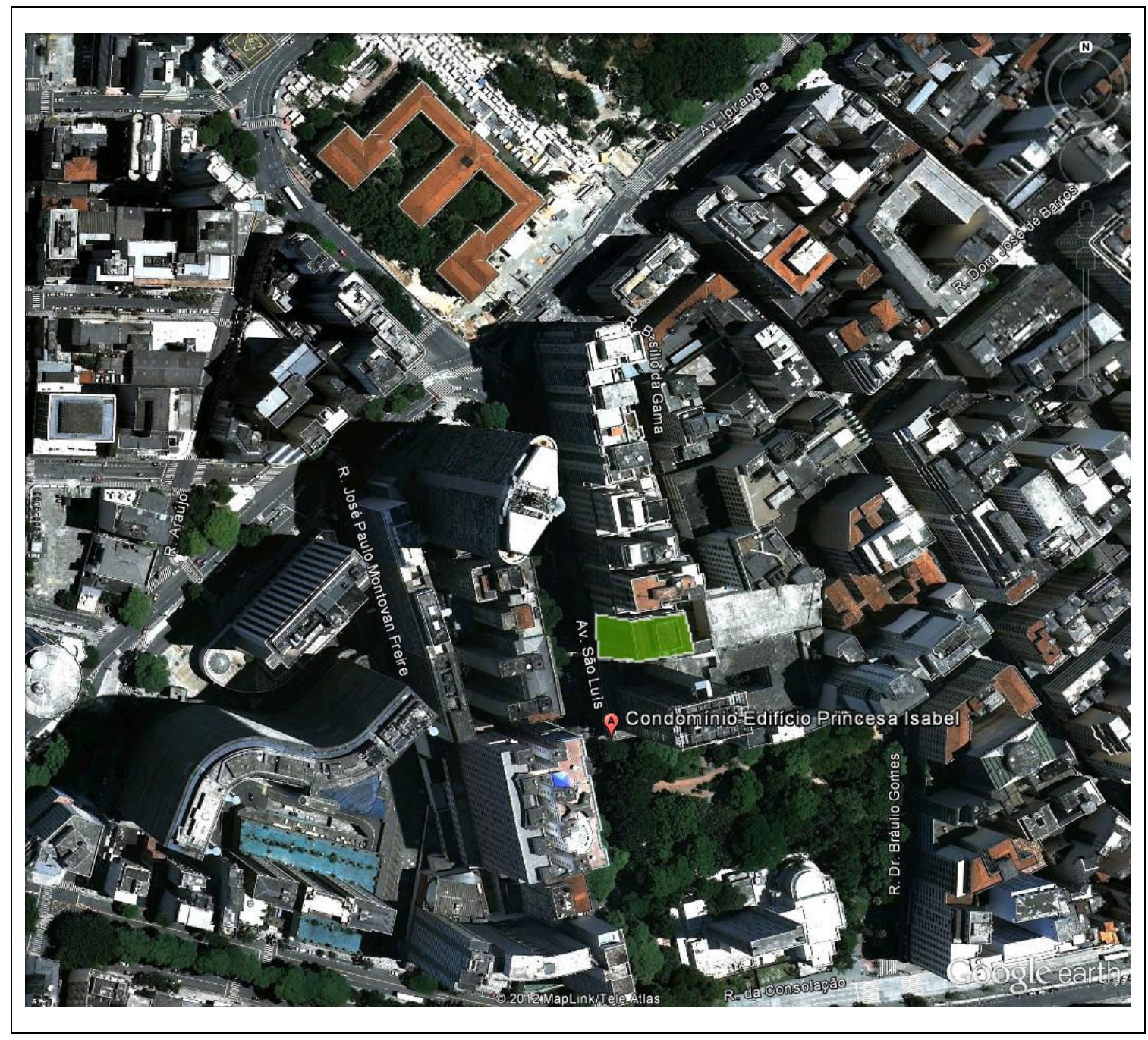

Localização ${ }^{214}$ 


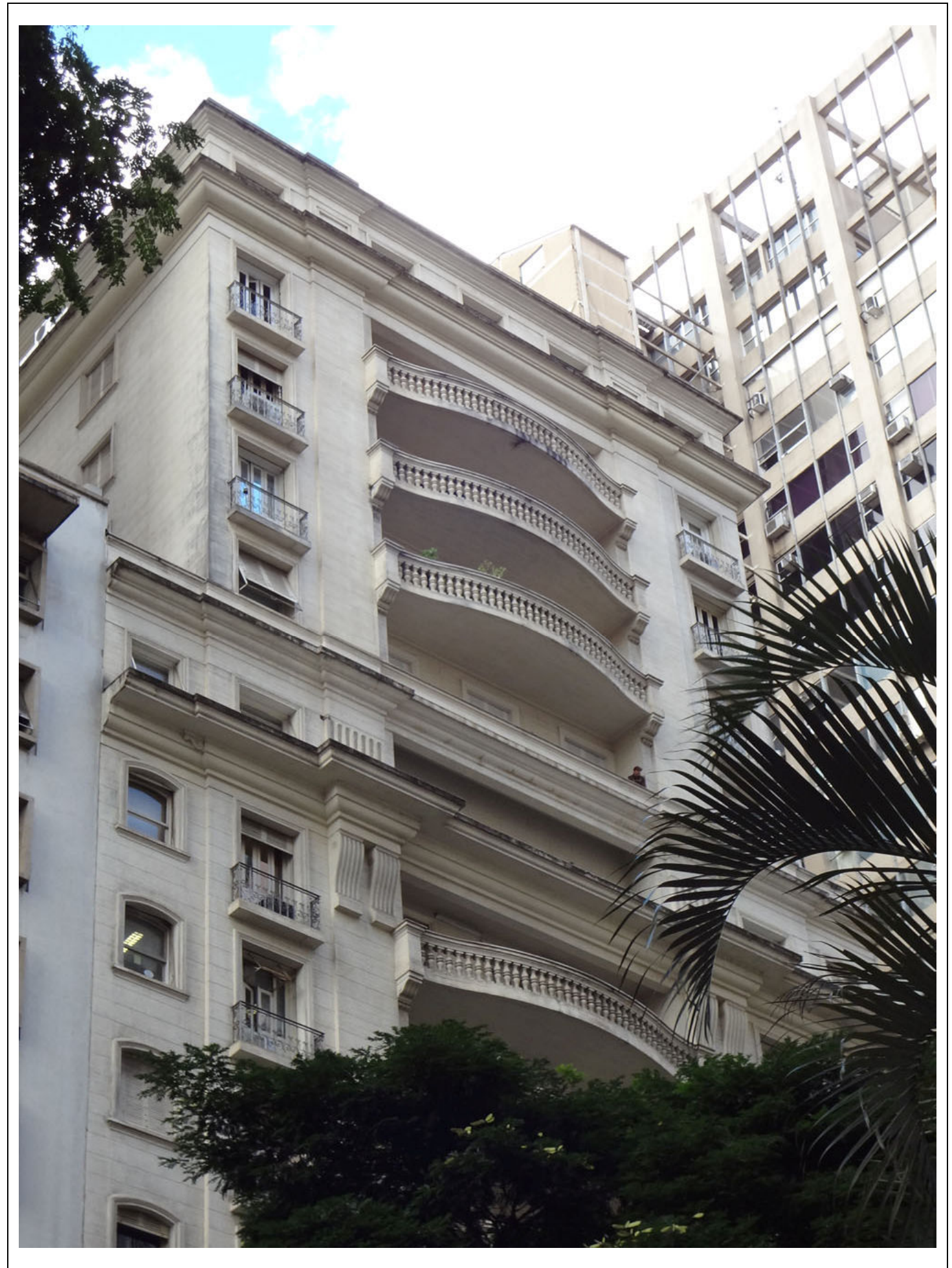

Detalhe da fachada 215

215 Foto: Demósthenes Magno Santos - maio 2012 


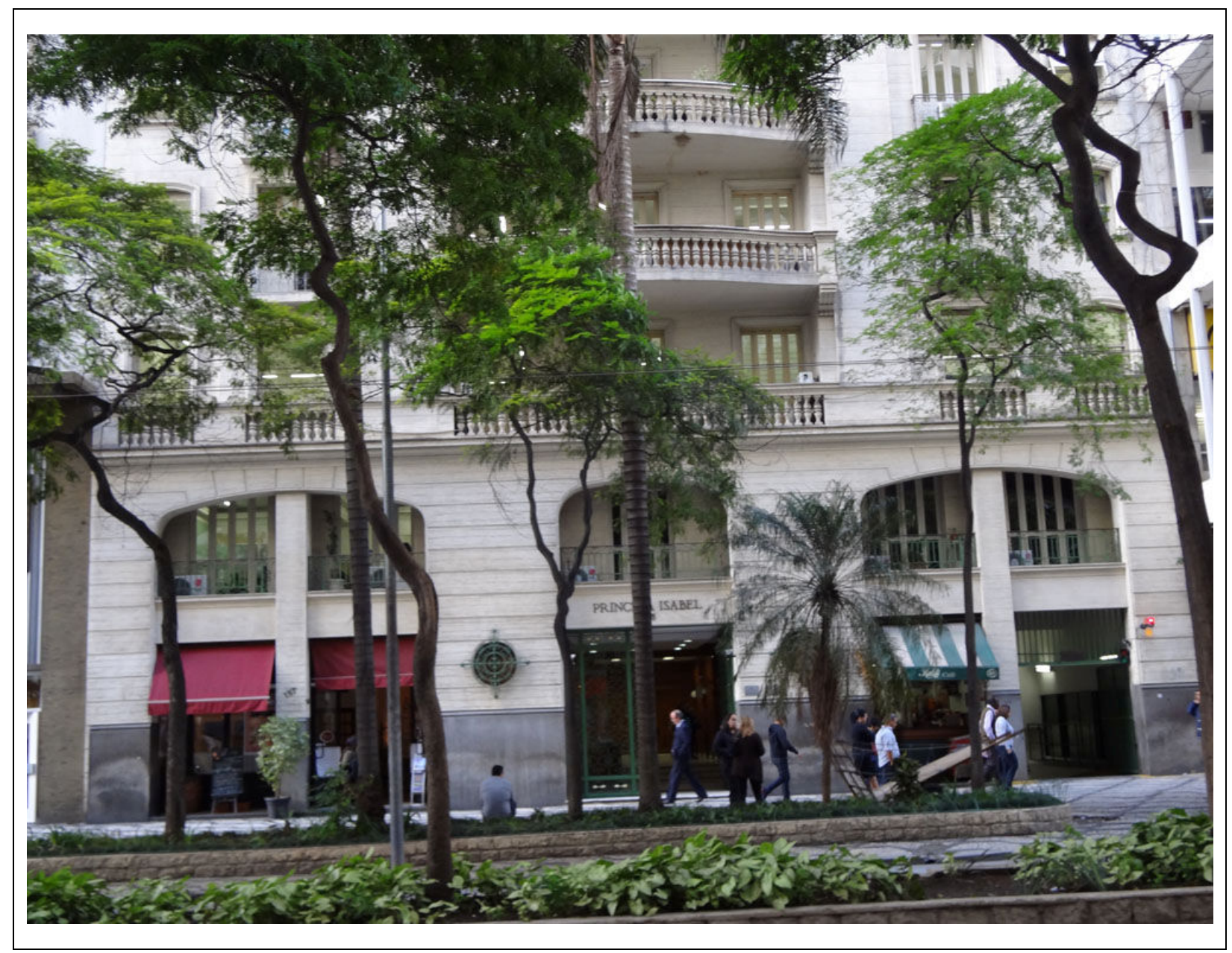

Detalhe da fachada 216

216 Foto: Demósthenes Magno Santos - maio 2012 


\section{APÊNDICE P - Edifício Savoy \\ Avenida Paulista esq. Rua Joaquim Eugênio de Lima}

Projeto (estudo original) Giancarlo Palanti

Construção: Alfredo Mathias - 1960

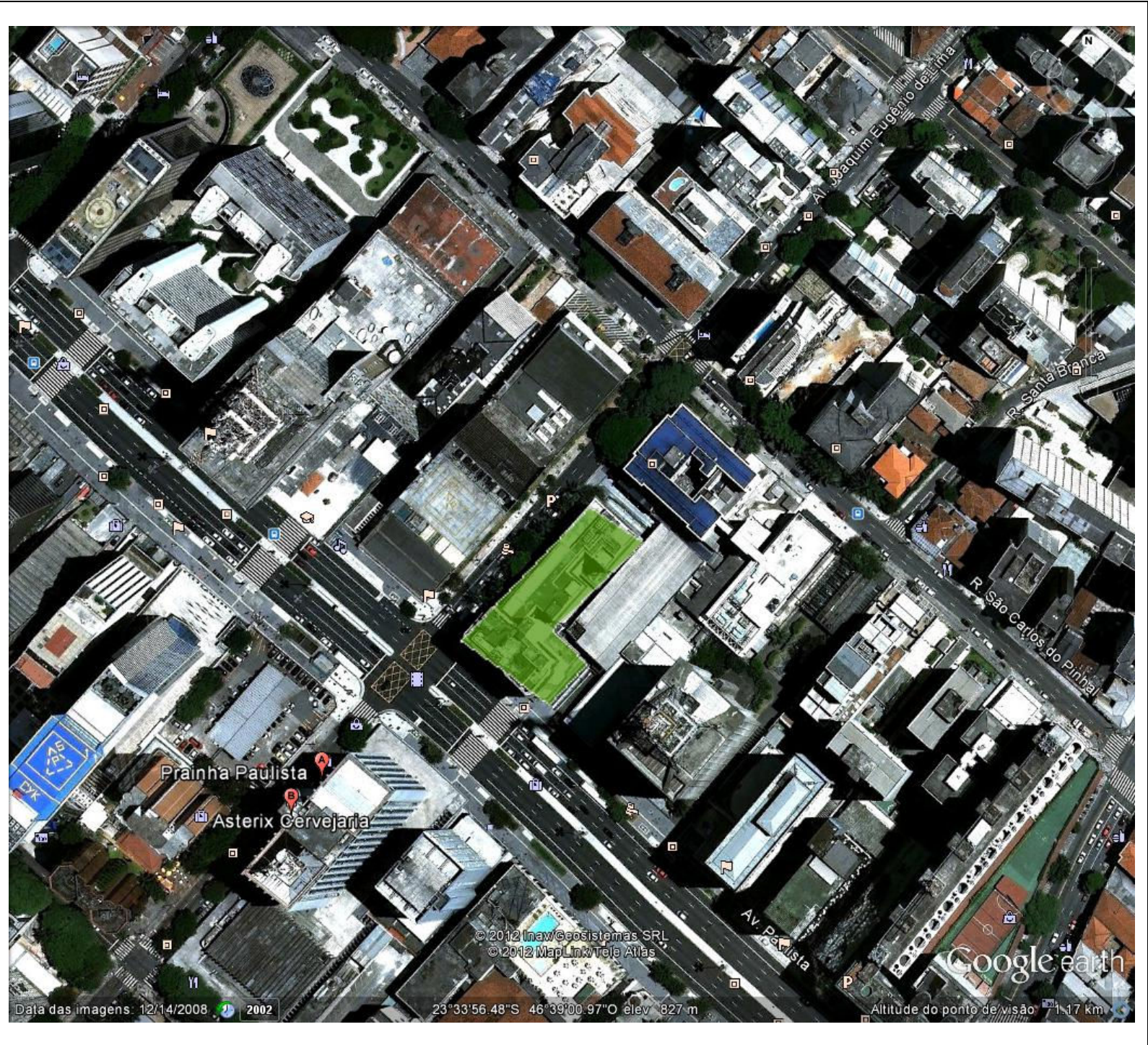

Localização217

217 Foto Google Earth - 2011 


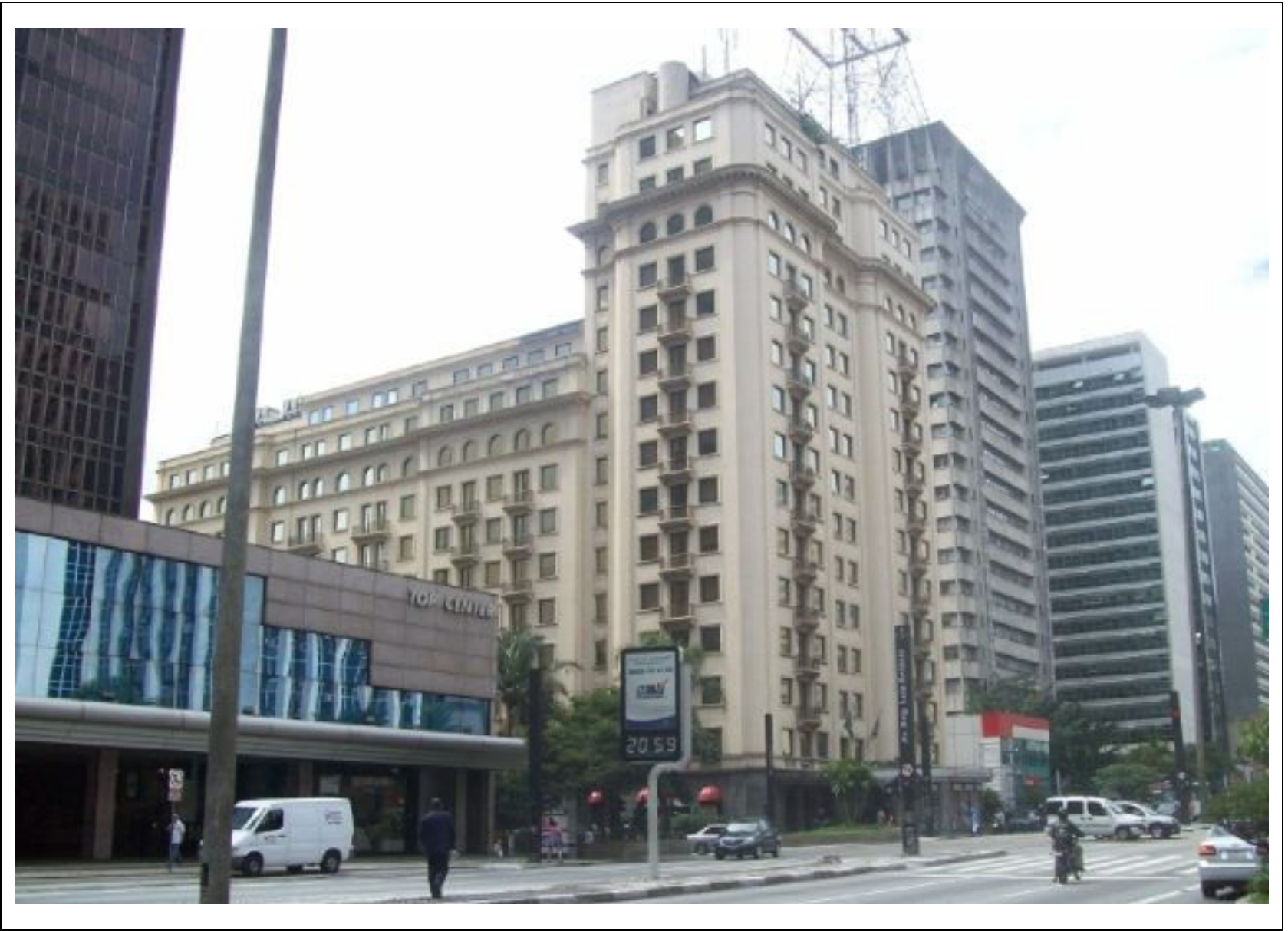

Fachada 218

218 Foto Google Earth - 2011 


\section{APÊNDICE Q - Edifício Veiga Filho Angélica esq. Rua Dr. Veiga Filho}

Projeto e Construção: Alfredo Mathias

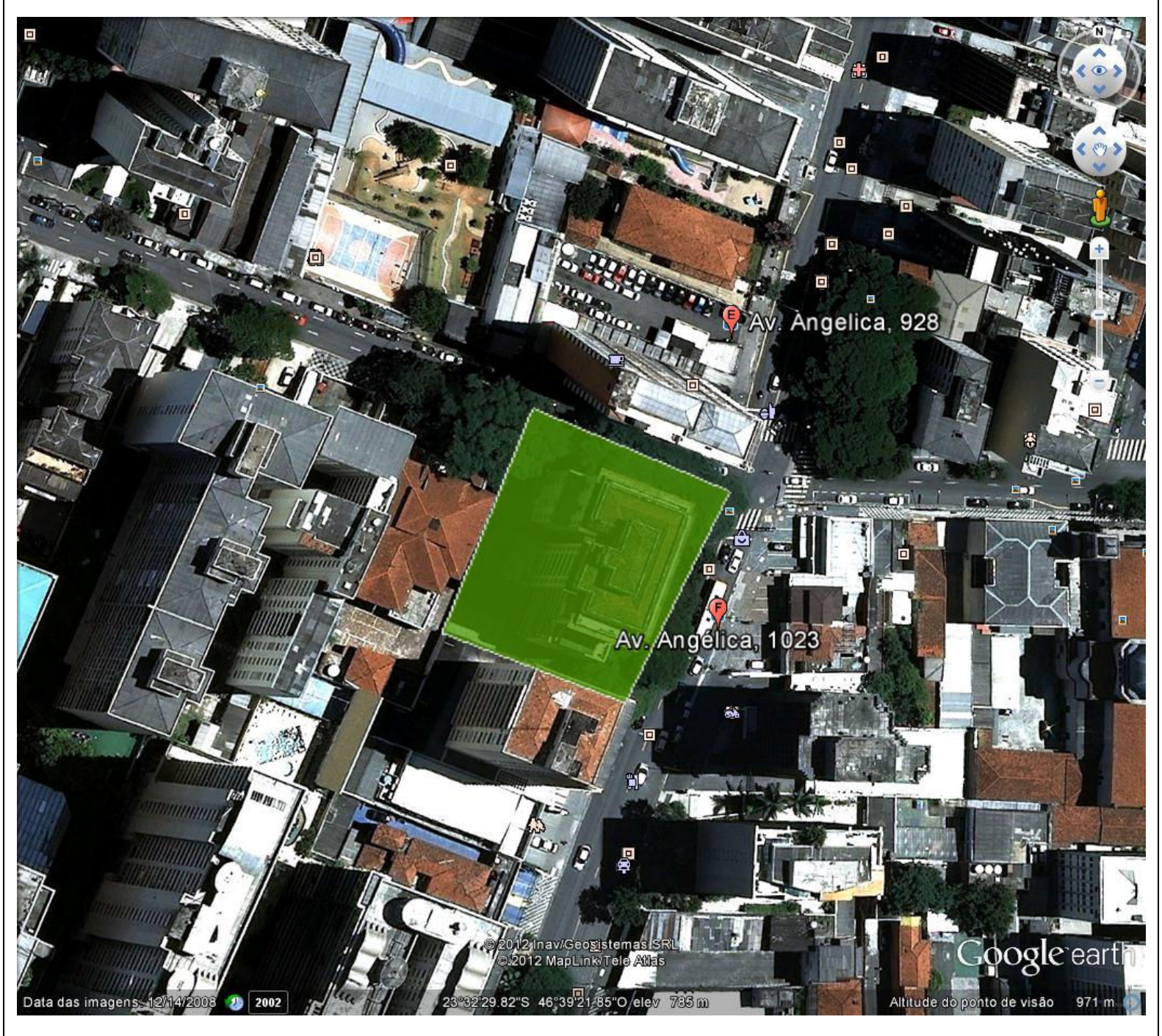

Localização219

219 Foto Google Earth - 2011 


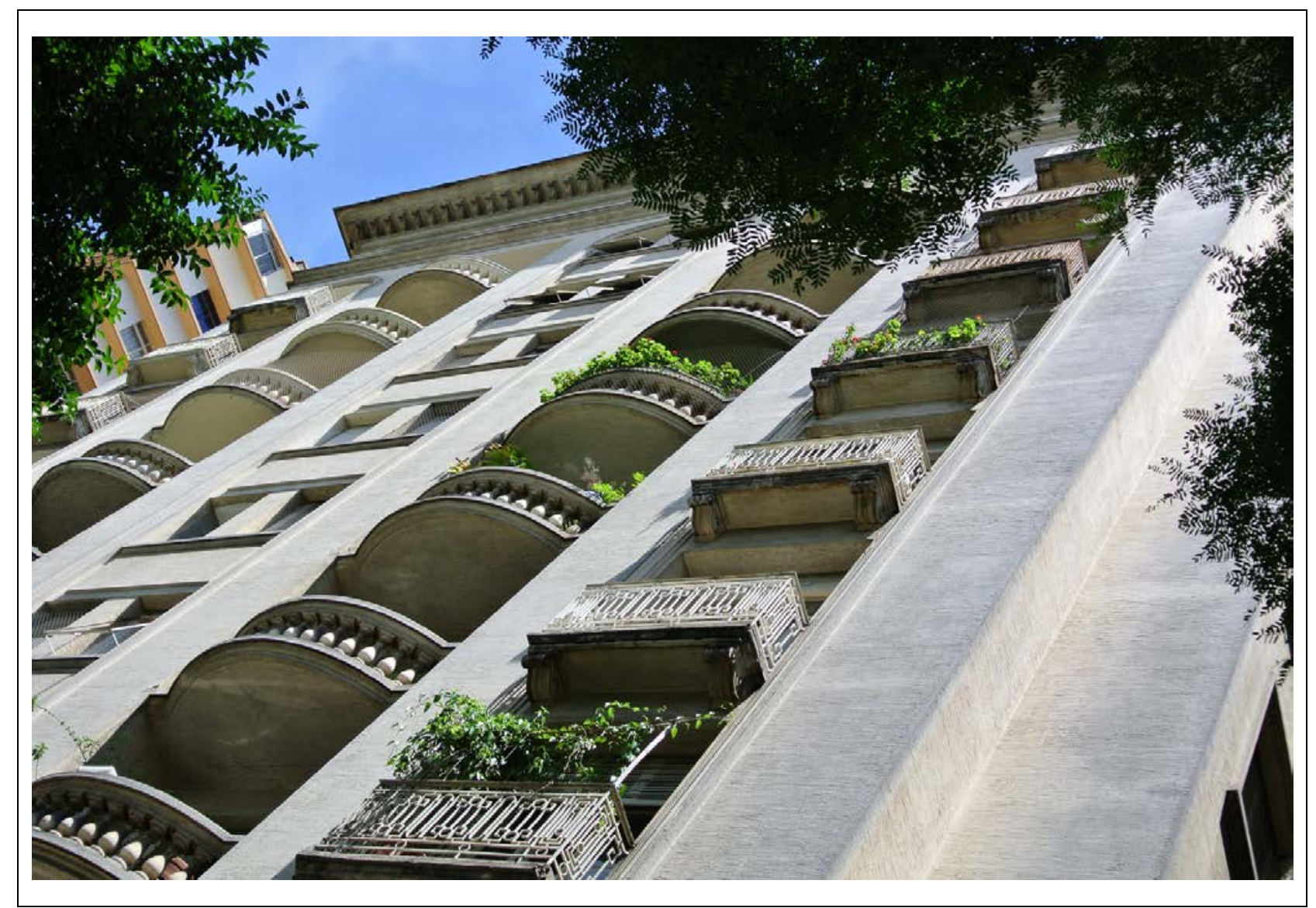

Detalhe da fachada para a Avenida Angélica ${ }^{220}$

220 Foto: Demósthenes Magno Santos - fevereiro 2013 


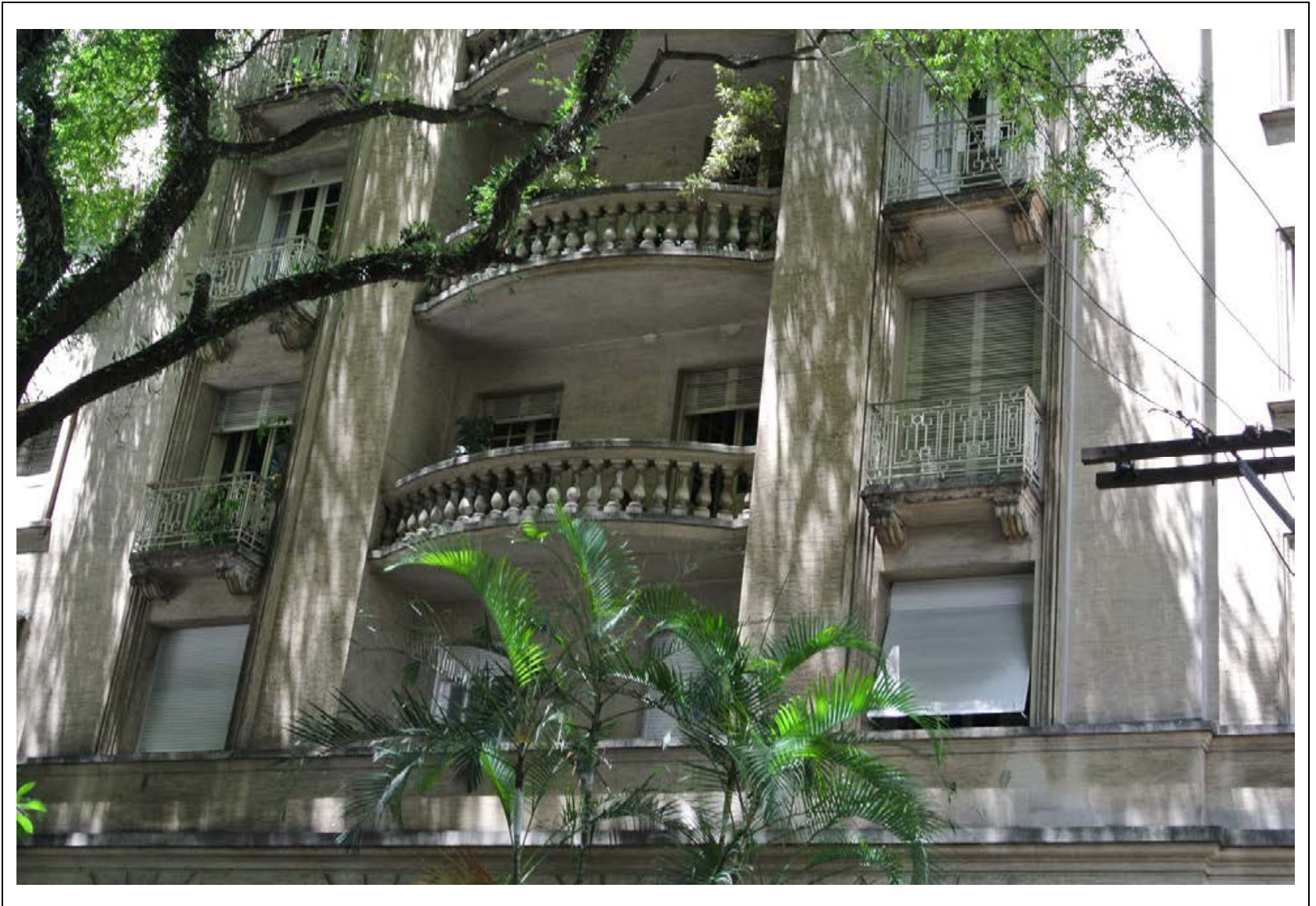

Detalhe da fachada para Rua Dr. Veiga Filho221

221 Foto: Demósthenes Magno Santos - fevereiro 2013 


\section{APÊNDICE R - Edifício na Avenida angélica}

Projeto e Construção: Alfredo Mathias

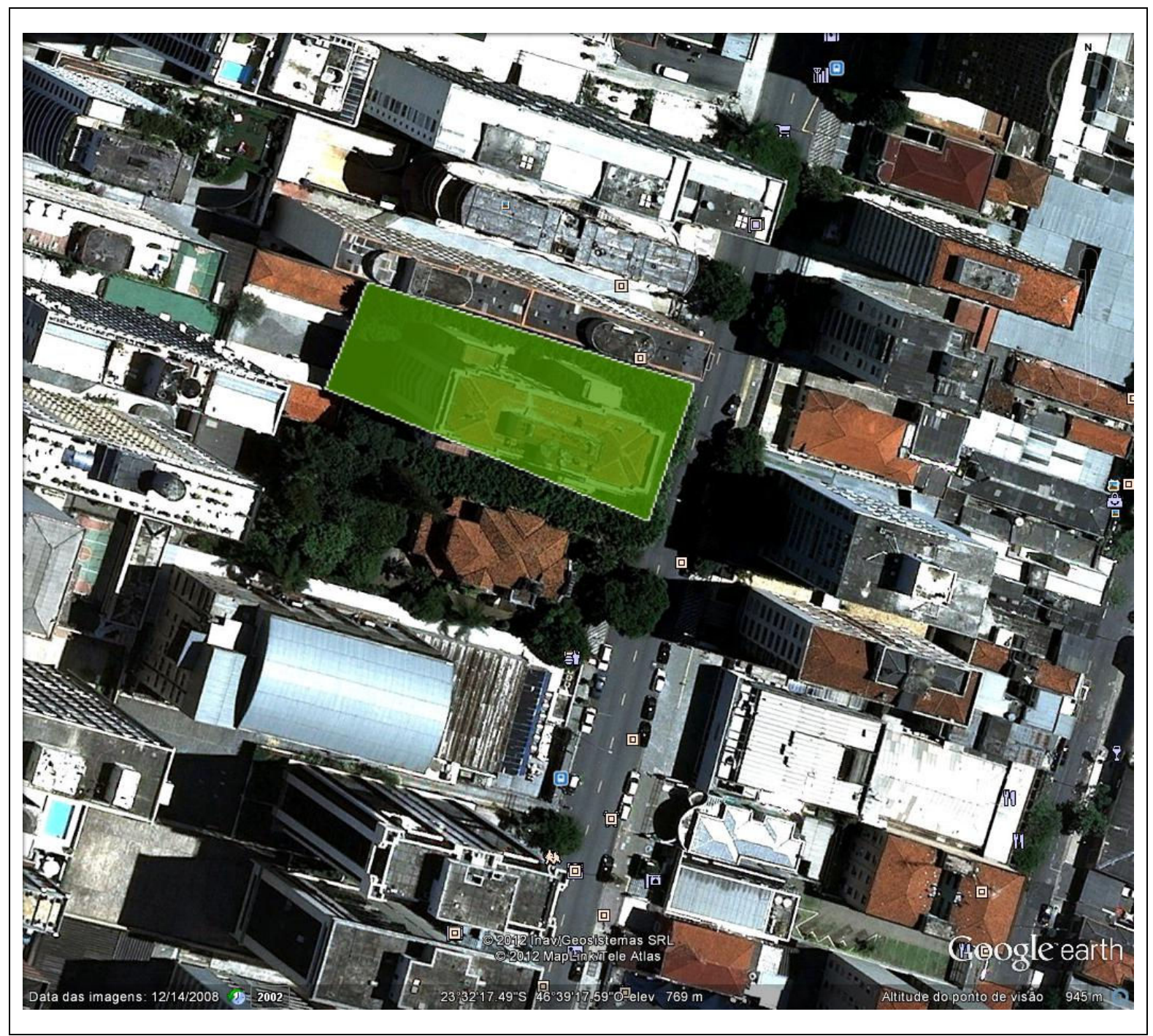

Figura 80: Localização222

222 Foto Google Earth - 2011 


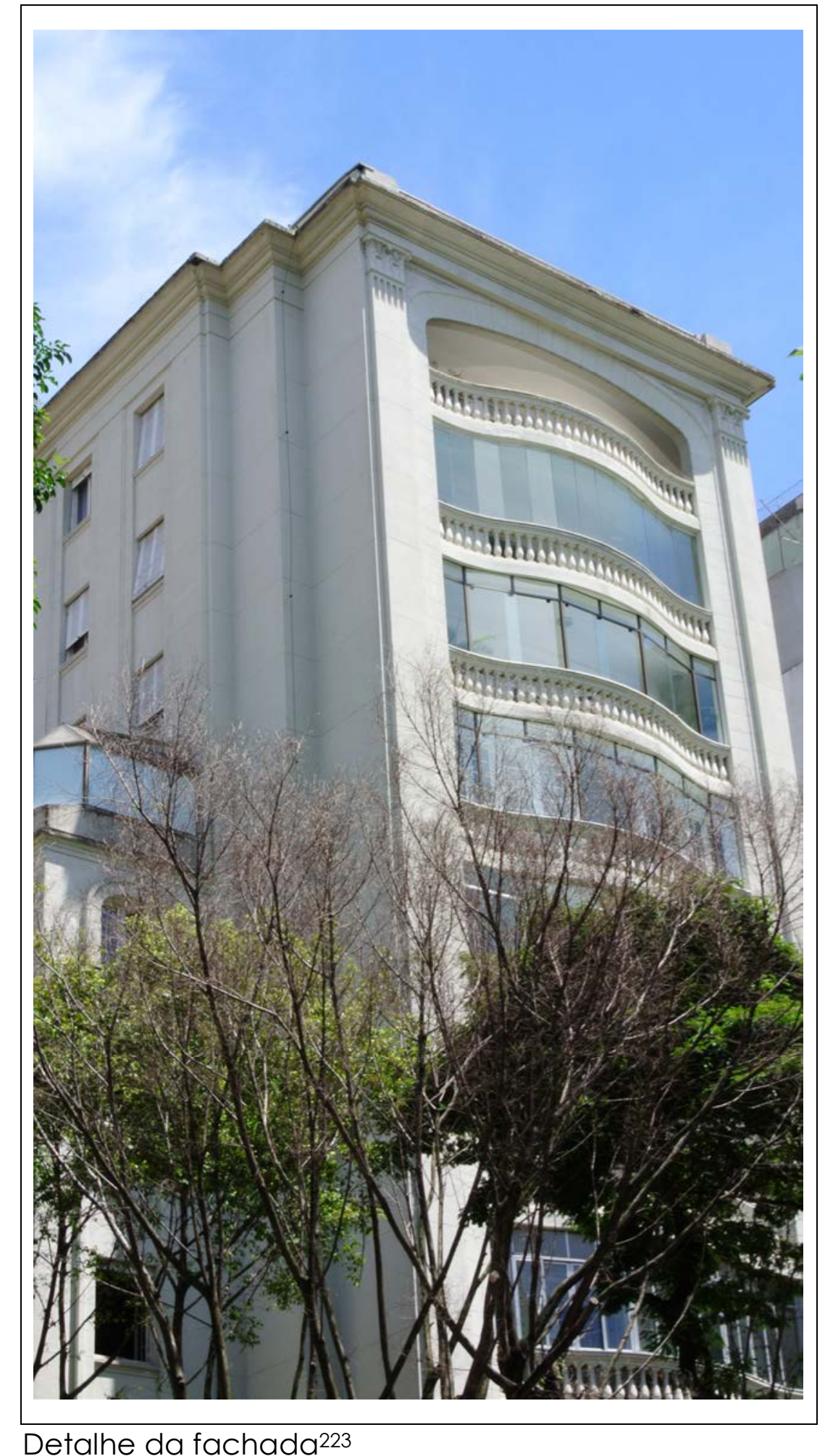

223 Foto: Demósthenes Magno Santos - fevereiro 2013 


\section{APÊNDICE S - Edifícios Santa Odila e Santa Sofia Avenida Angélica esq. Avenida Higienópolis}

Projeto e Construção: Alfredo Mathias - 1962

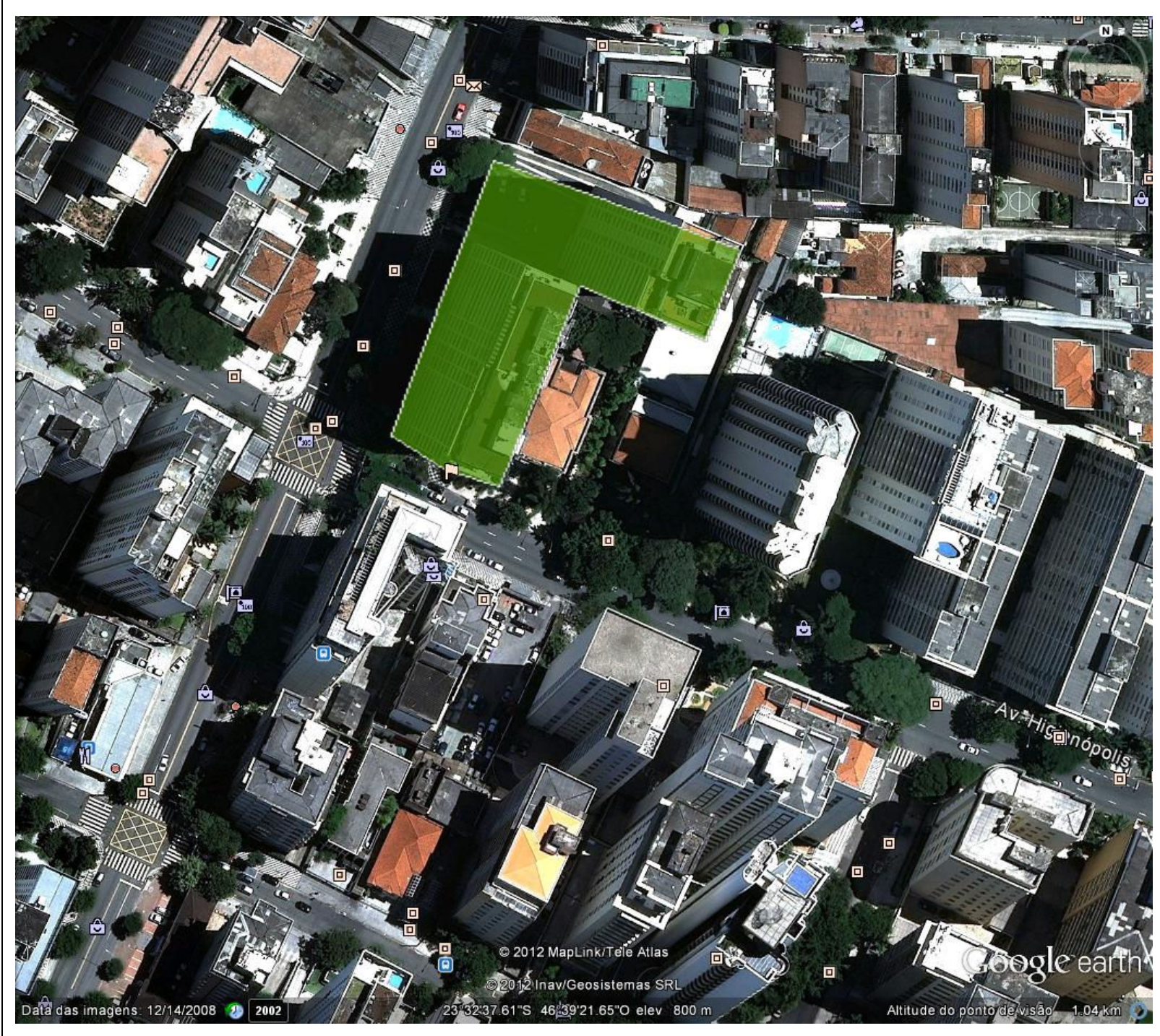

Localização224

224 Foto Google Earth - 2011 


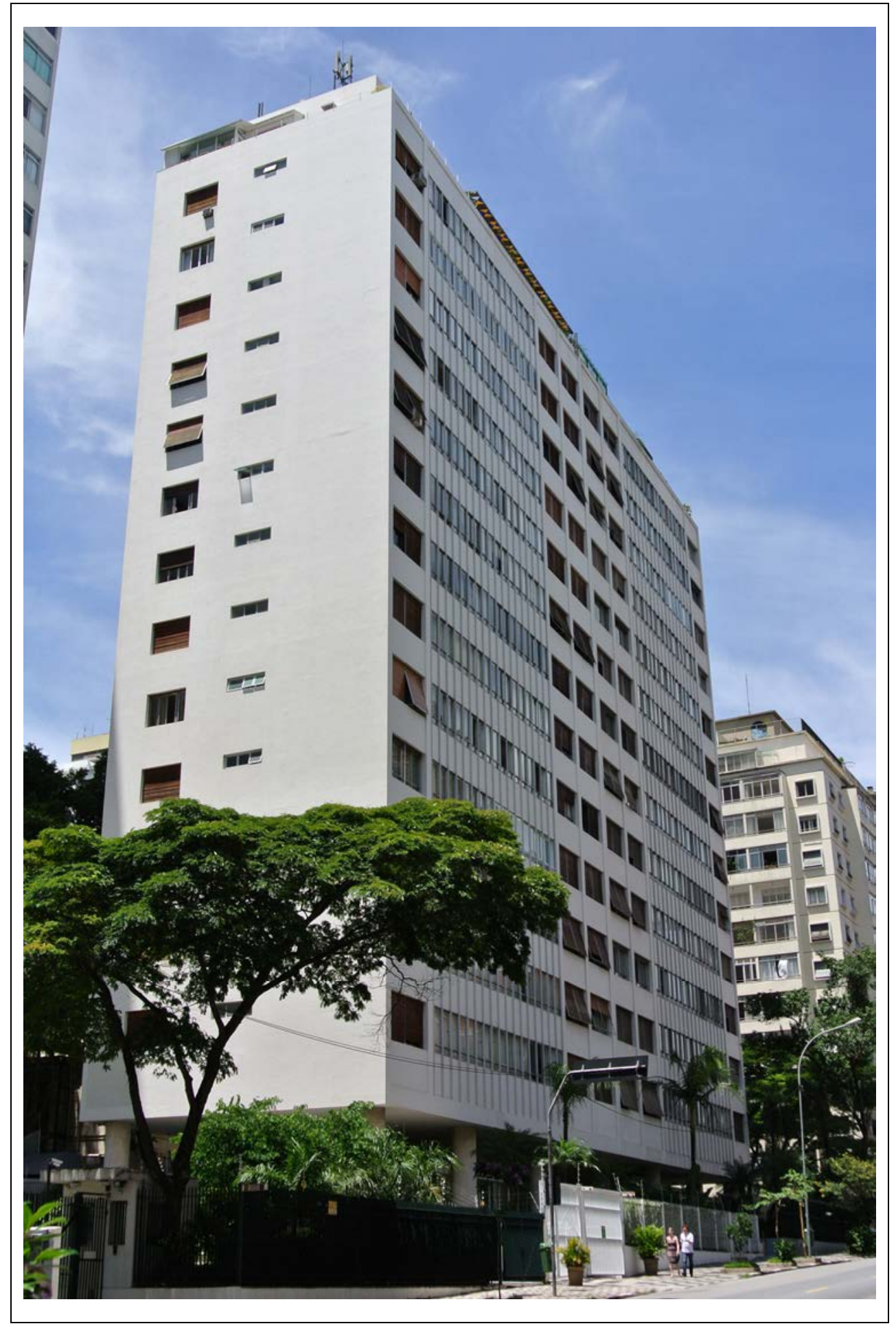

Fachada 225

225 Foto: Demósthenes Magno Santos - fevereiro 2013 


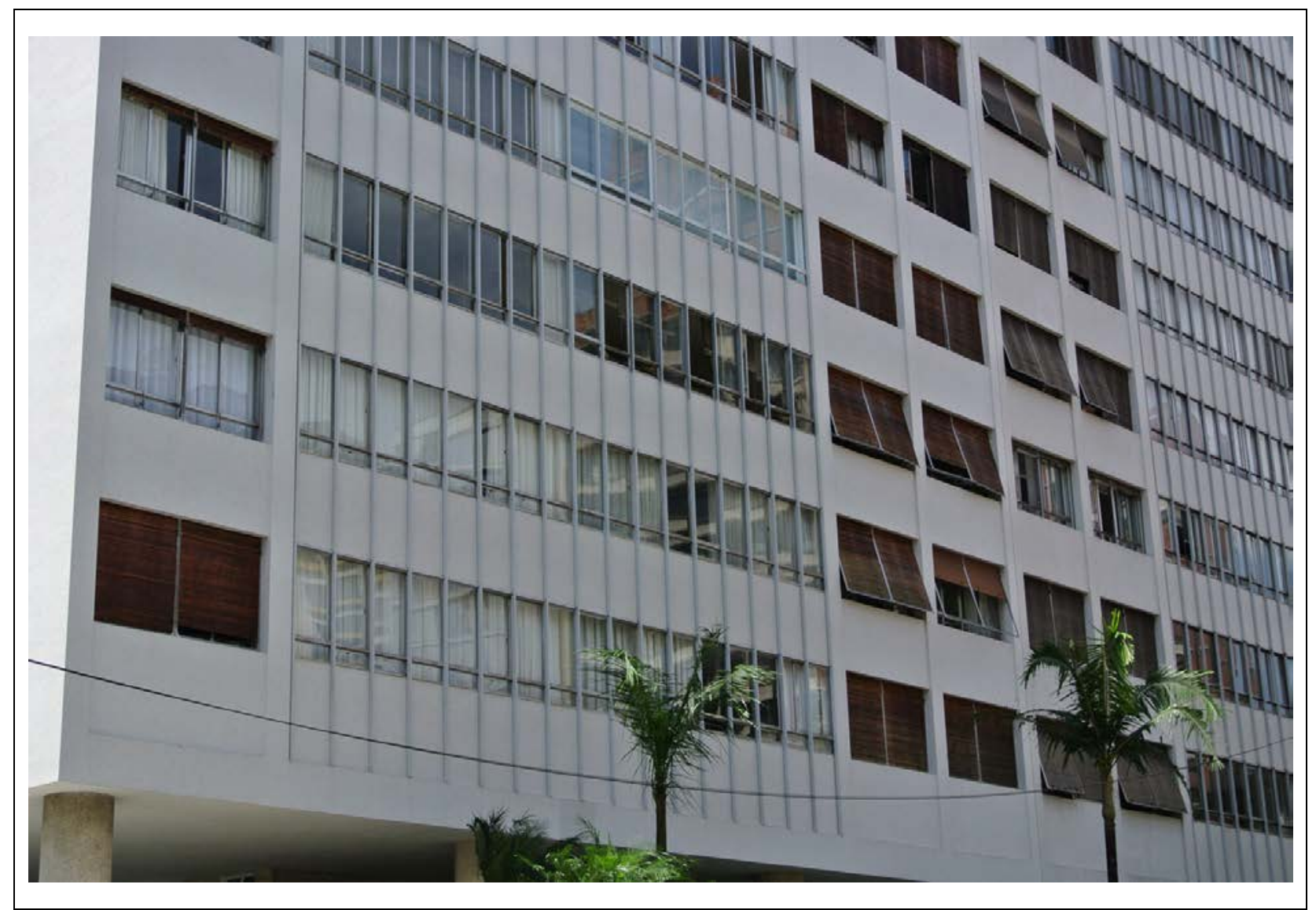

Detalhe da fachada226

226 Foto: Demósthenes Magno Santos - fevereiro 2013 


\section{APÊNDICE T - Edifício Avenida Angélica com Rua Baronesa de Itu}

Projeto: Giancarlo Palanti

Construção: Alfredo Mathias

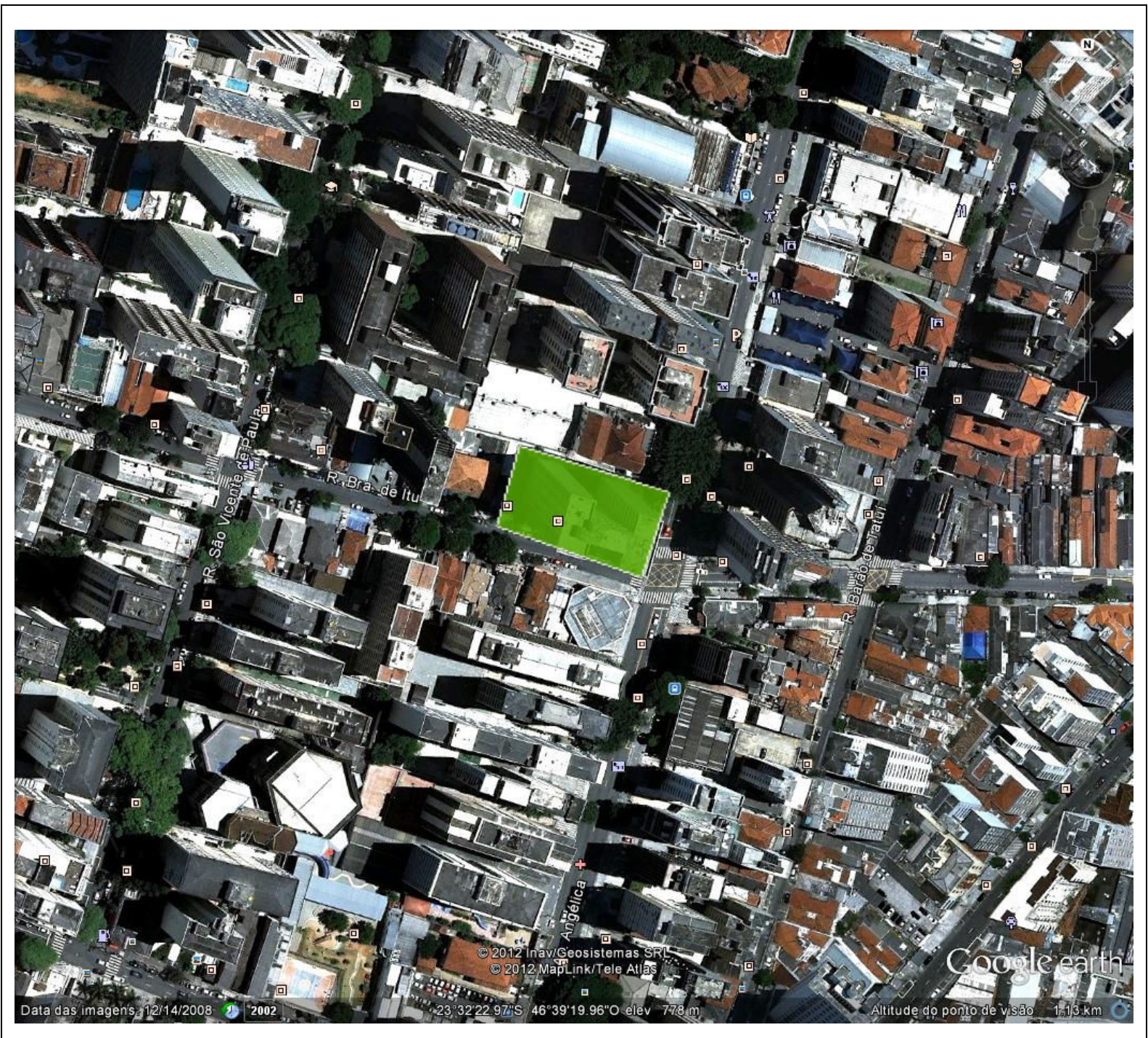

Localização227

227 Foto: Demósthenes Magno Santos - fevereiro 2013 


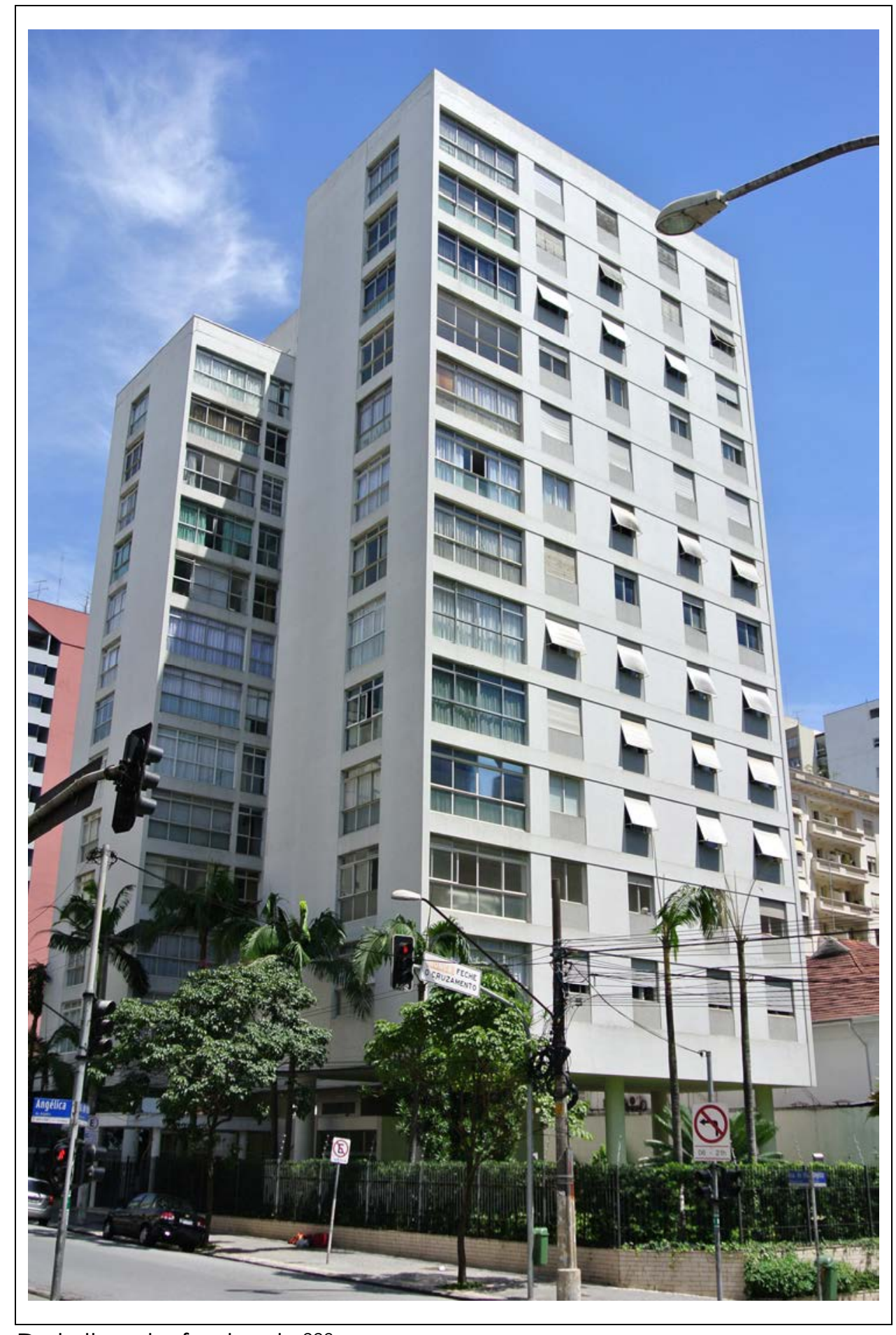

Detalhe da fachada 228

228 Foto: Demósthenes Magno Santos - fevereiro 2013 


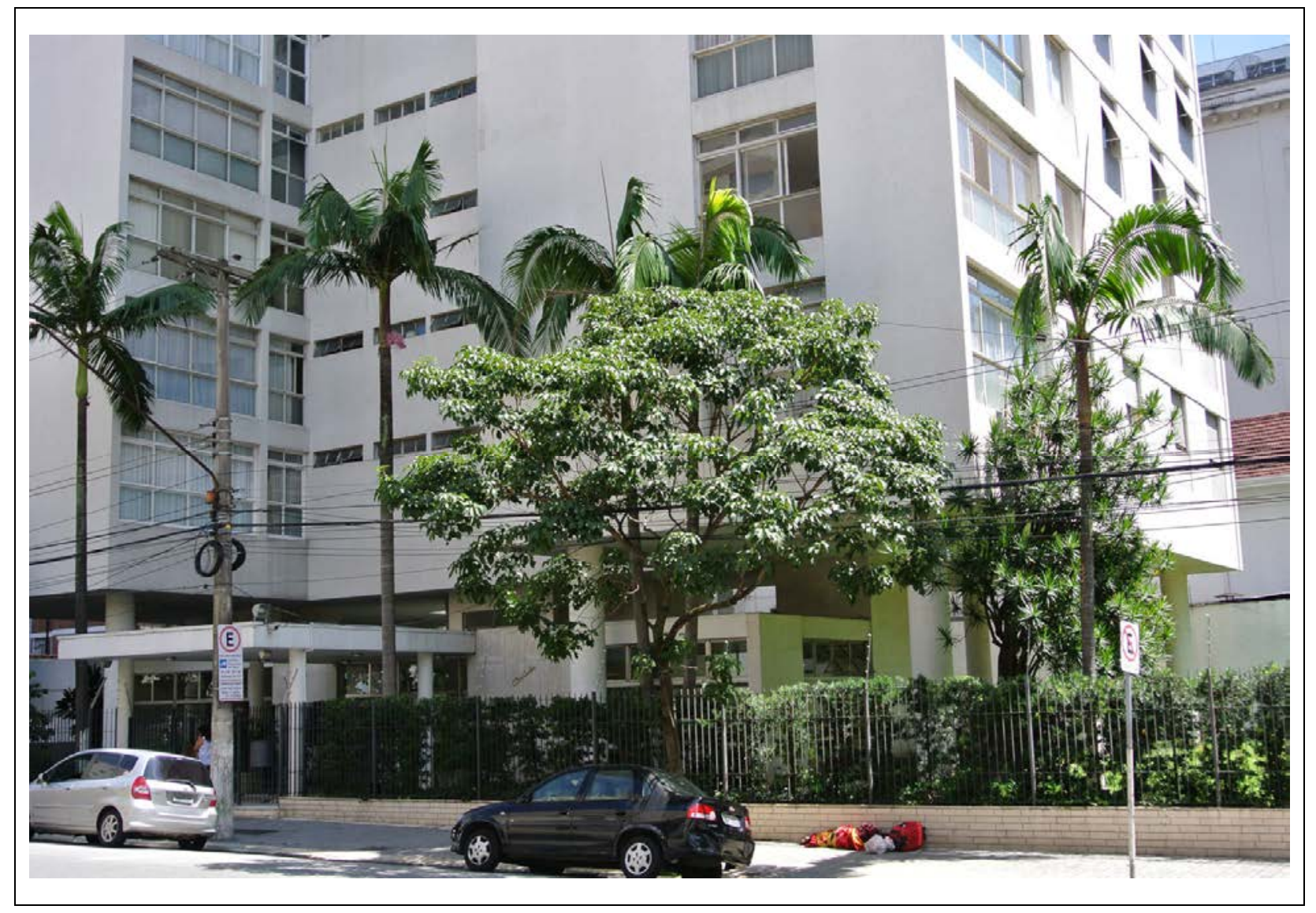

Detalhe da fachada 229

229 Foto: Demósthenes Magno Santos - fevereiro 2013 


\section{APÊNDICE U - Edifício Avenida Higienópolis esquina Rua Itacolomy}

Projeto e Construção: Alfredo Mathias a confirmar

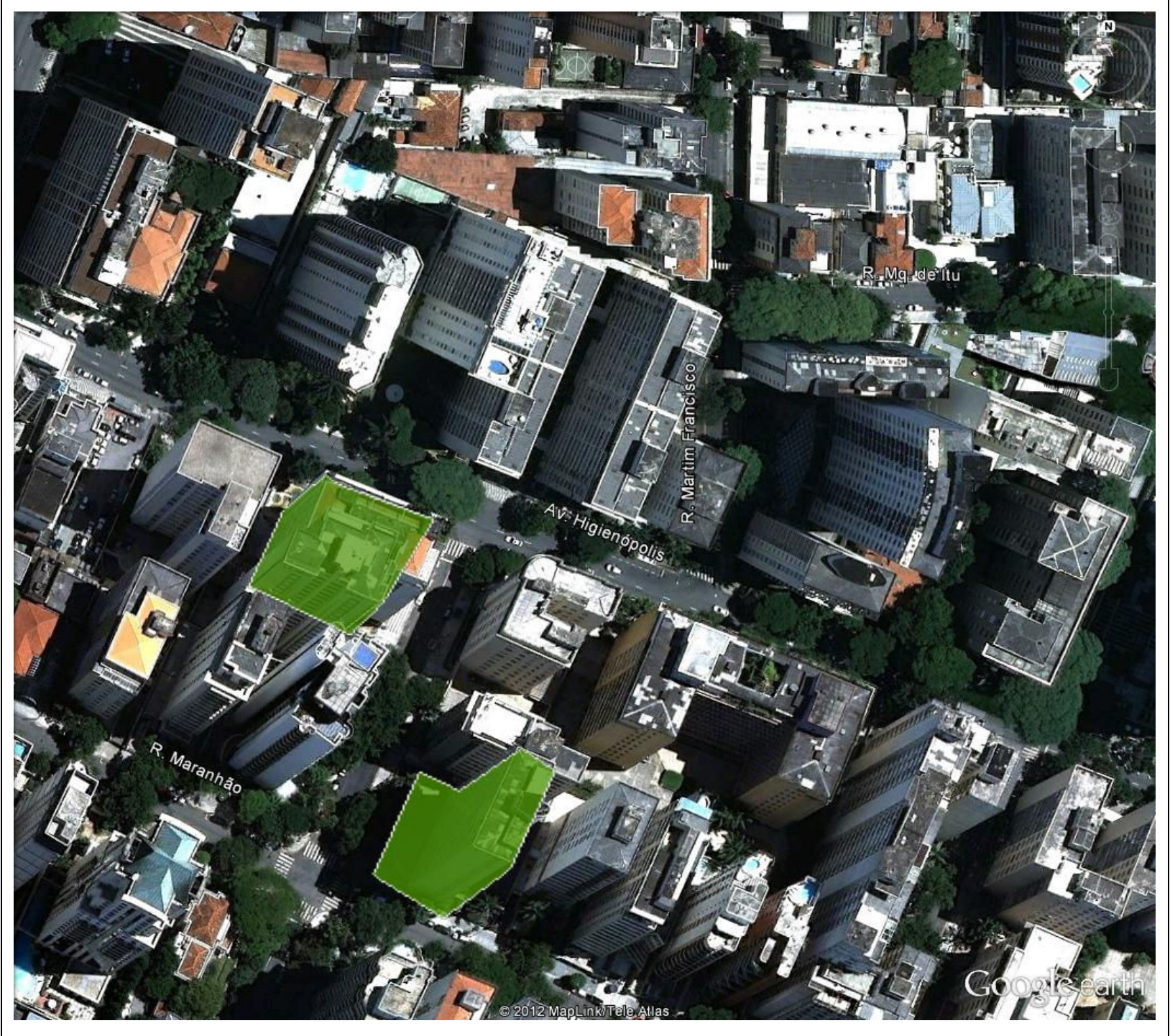

Localização230

230 Foto Google Earth - 2011 


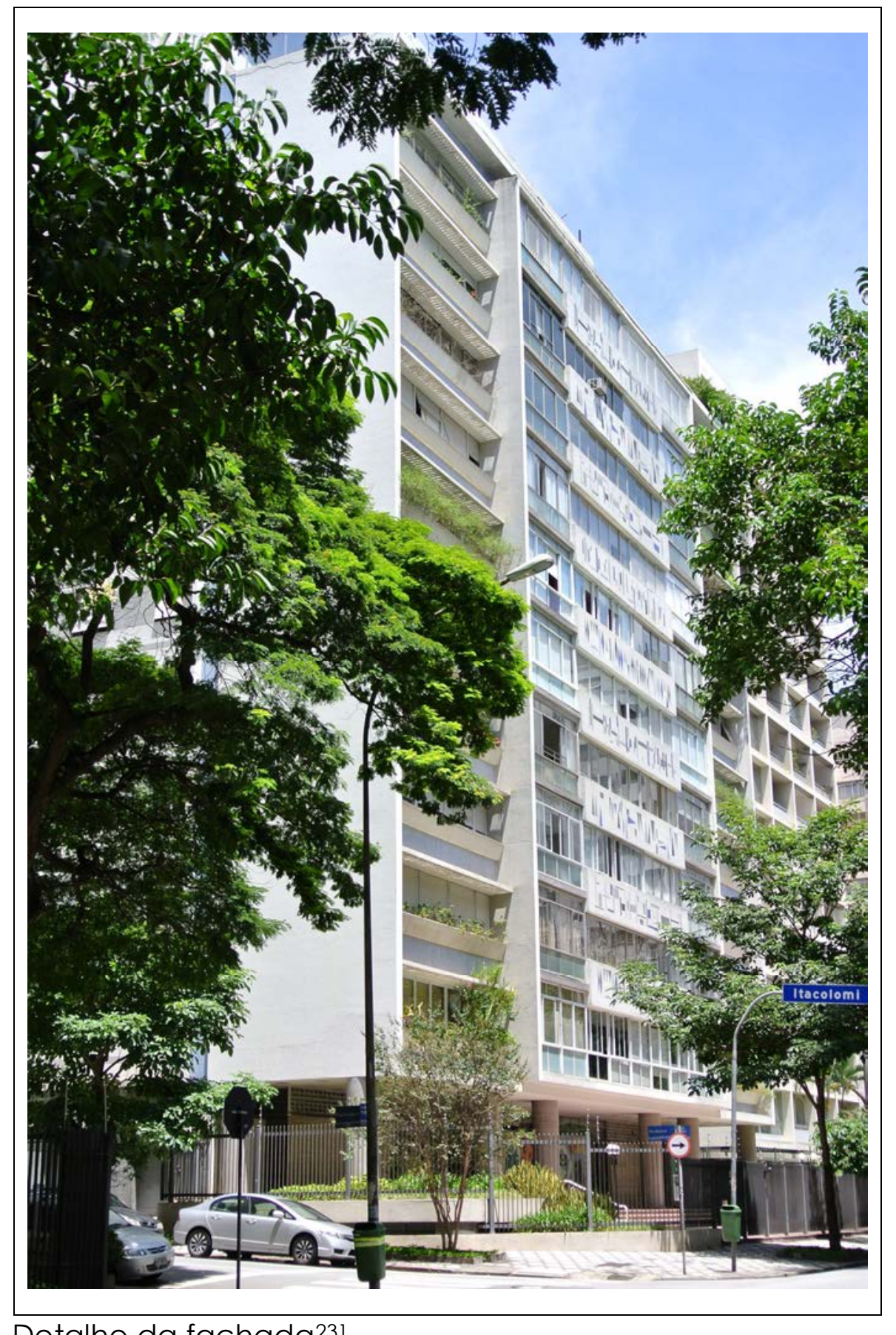

Detalhe da fachada 231

231 Foto: Demósthenes Magno Santos - fevereiro 2013 


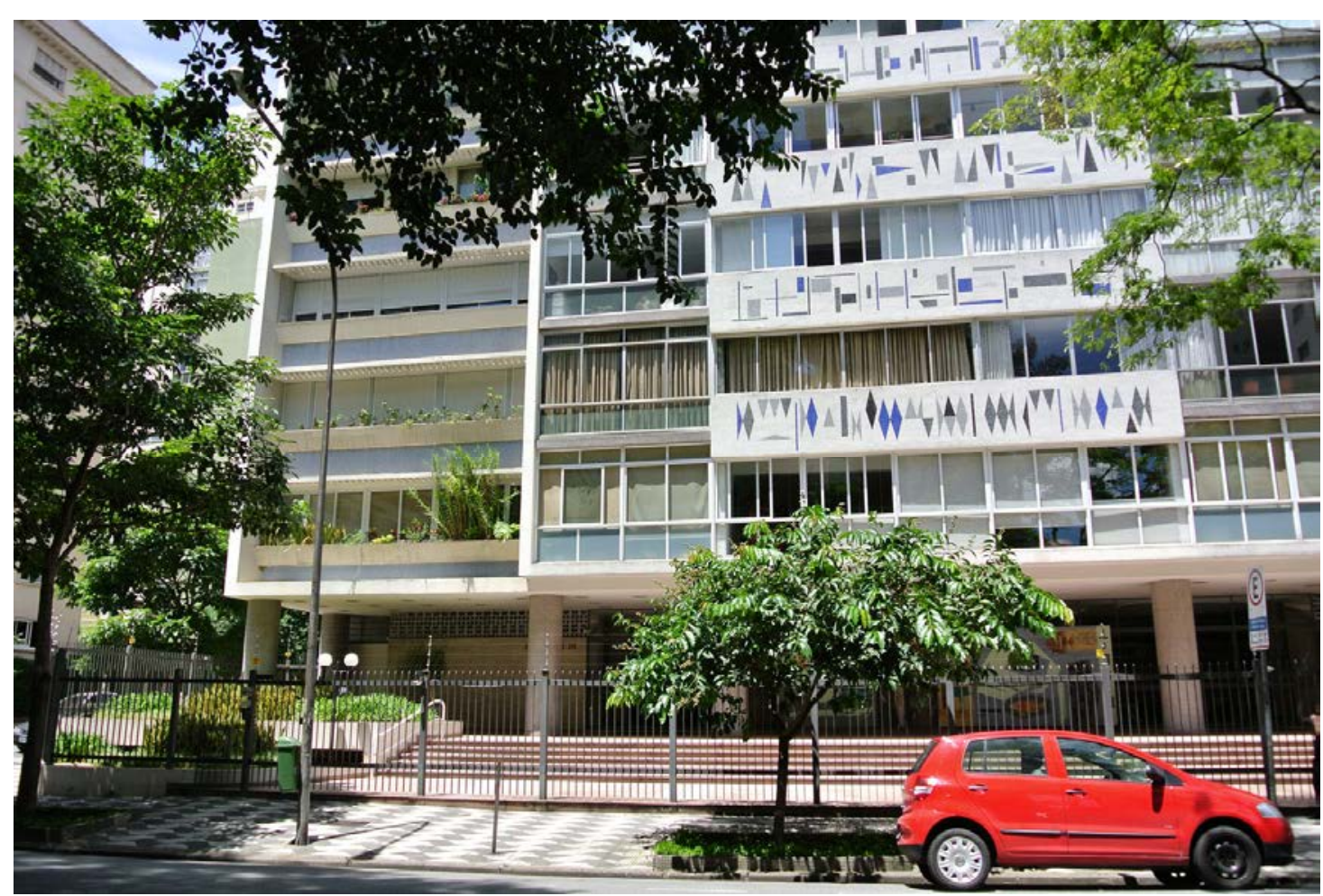

Detalhe da fachada 232

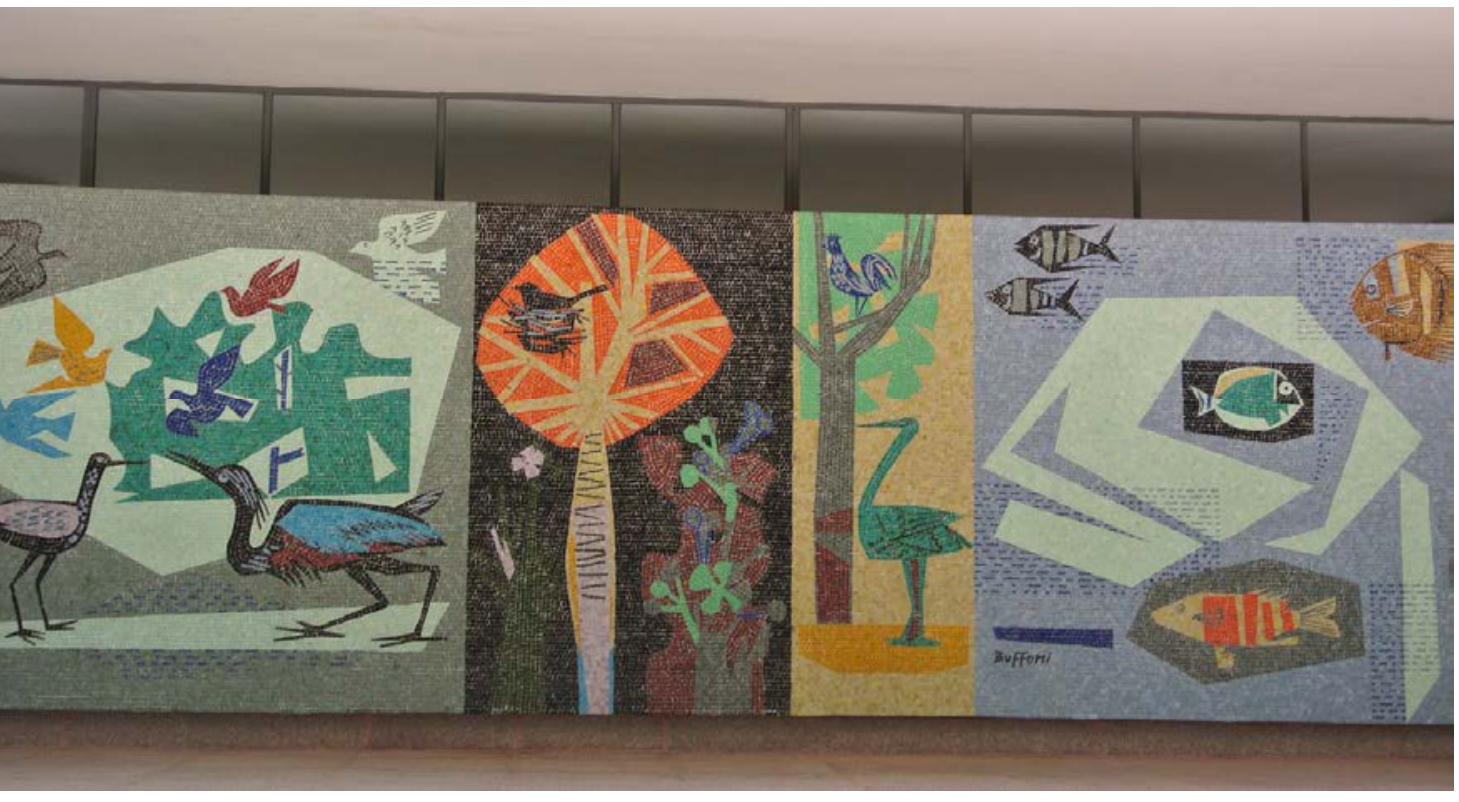

Detalhe Do Painel cerâmico - autor Bramante Buffoni

232 Foto: Demósthenes Magno Santos - fevereiro 2013 


\section{APÊNDICE V- Shopping Center Iguatemi}

Projeto: João Henrique da Rocha e Crocce Aflallo Gasperini - ano 1966

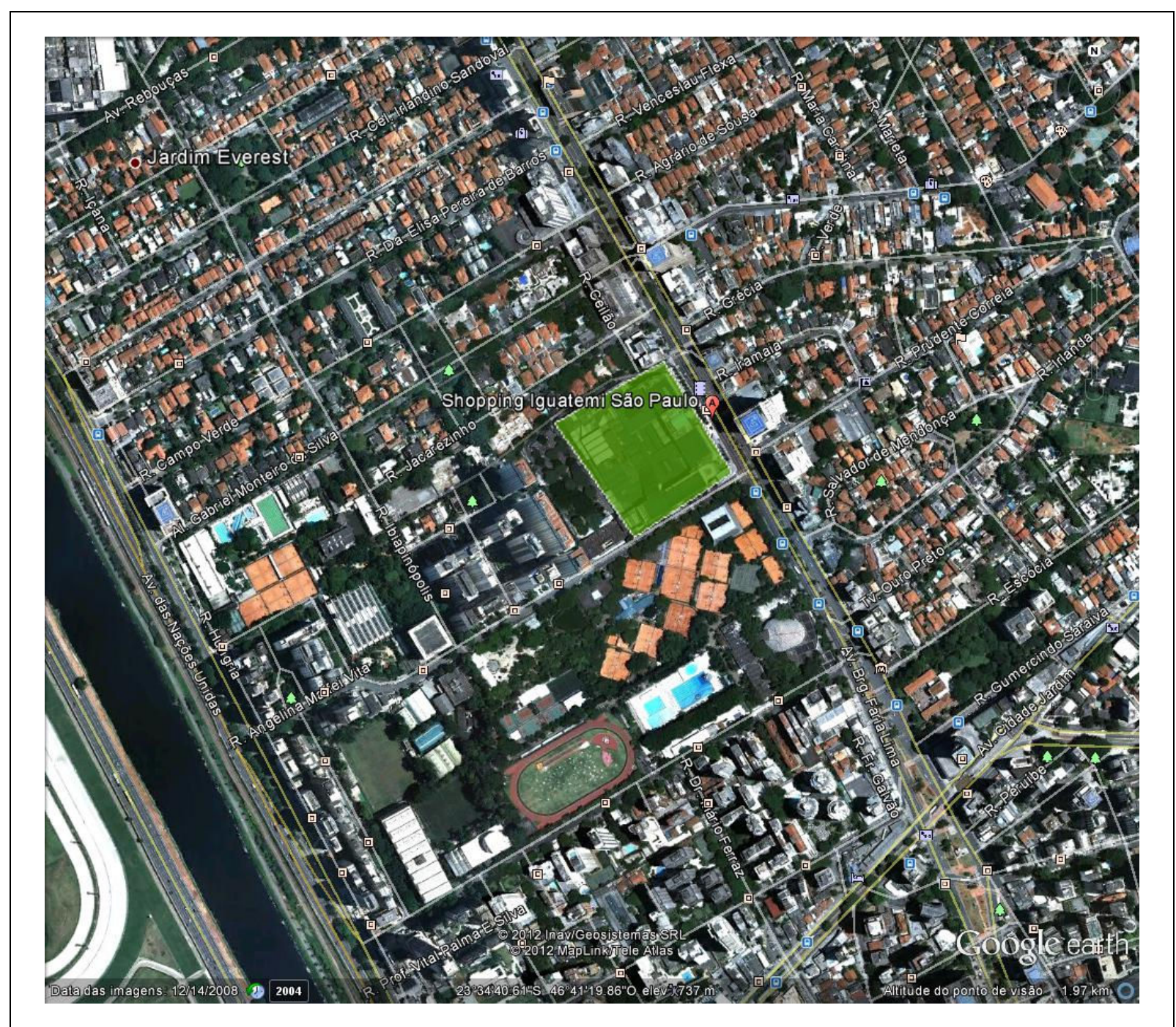

Localização233

233 Foto Google Earth - 2011 


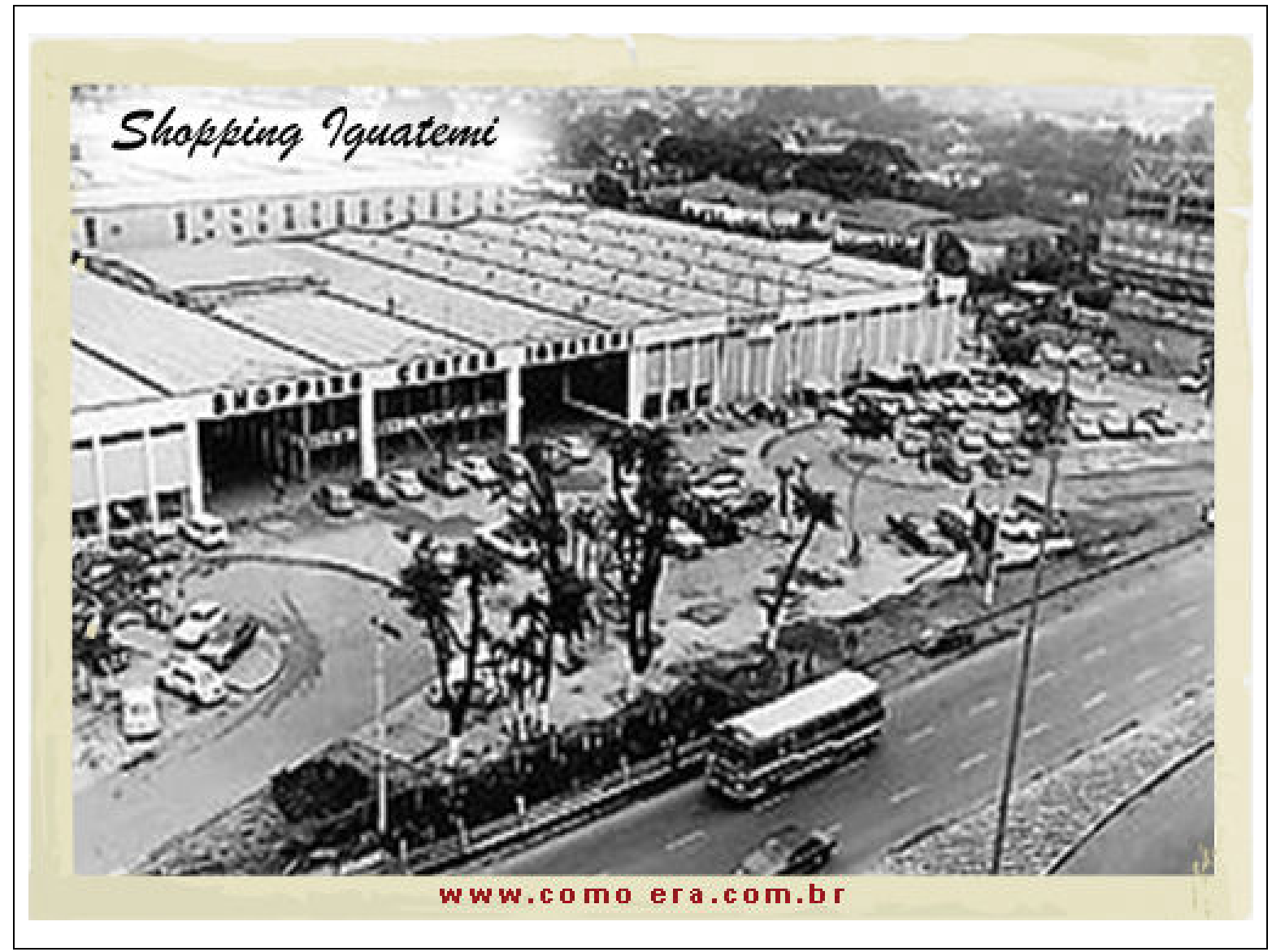

Detalhe da fachada234

234 Fonte: http://www.comoera.com.br/wp-content/uploads/shopping-iguatemi-1966.jpg 


\section{APÊNDICE W - Edifícios Monfort, Chatel, Avignon e Djon}

Projeto: João Henrique da Rocha e Crocce Aflallo Gasperini Construção: Alfredo Mathias - ano 1966

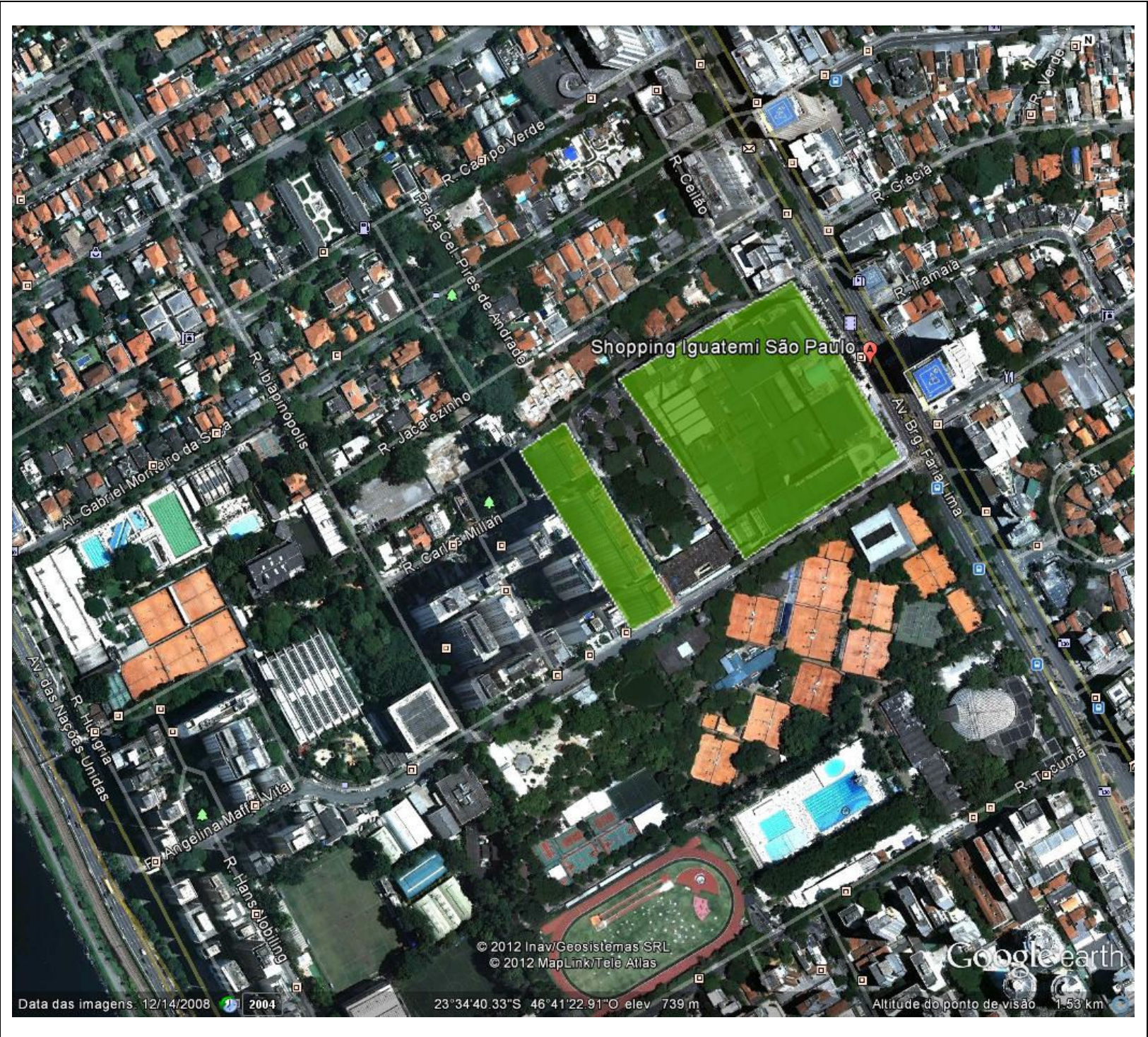

Localização235

235 Foto Google Earth - 2011 


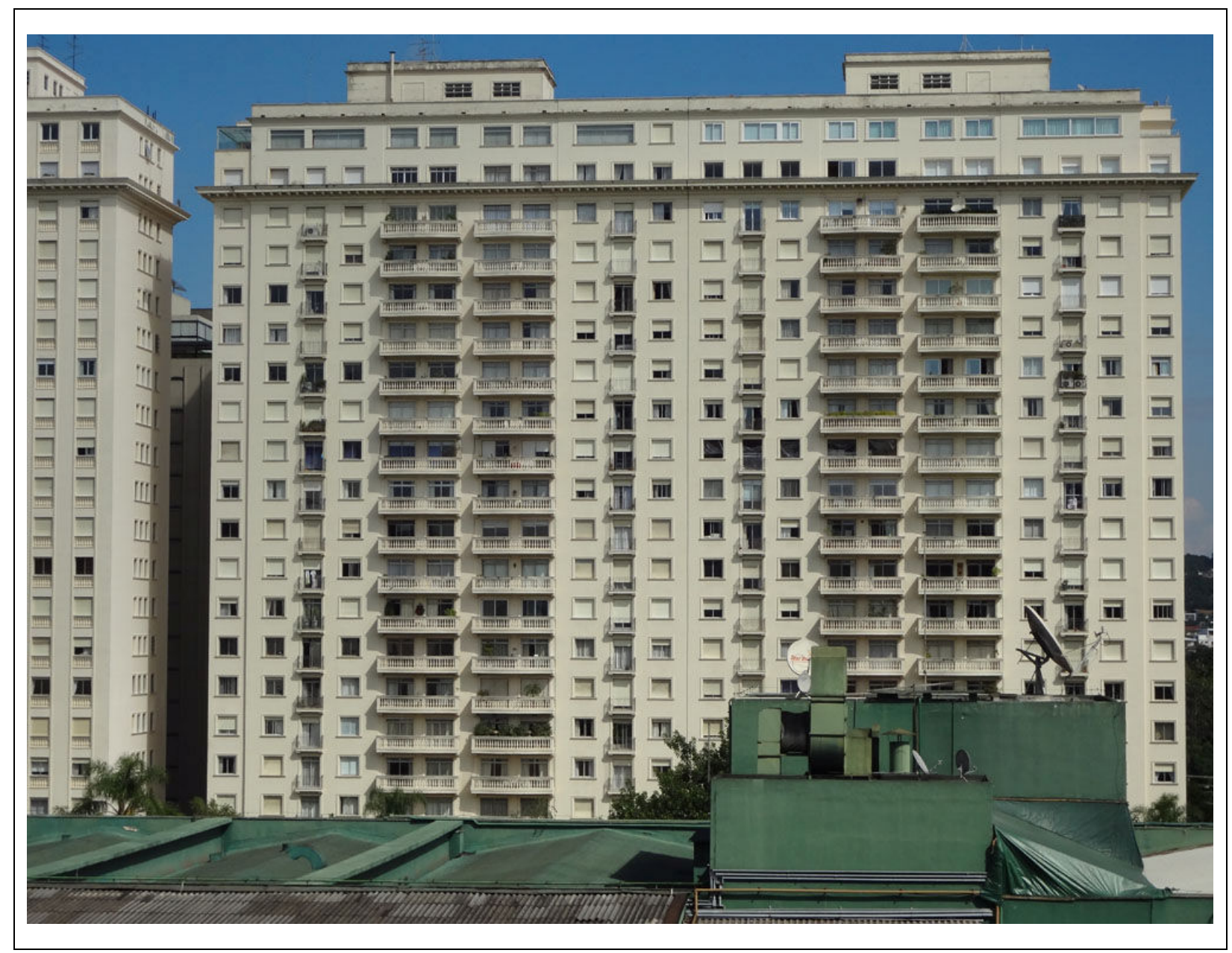

Detalhe da fachada 236

236 Foto: Demósthenes Magno Santos - maio 2012 


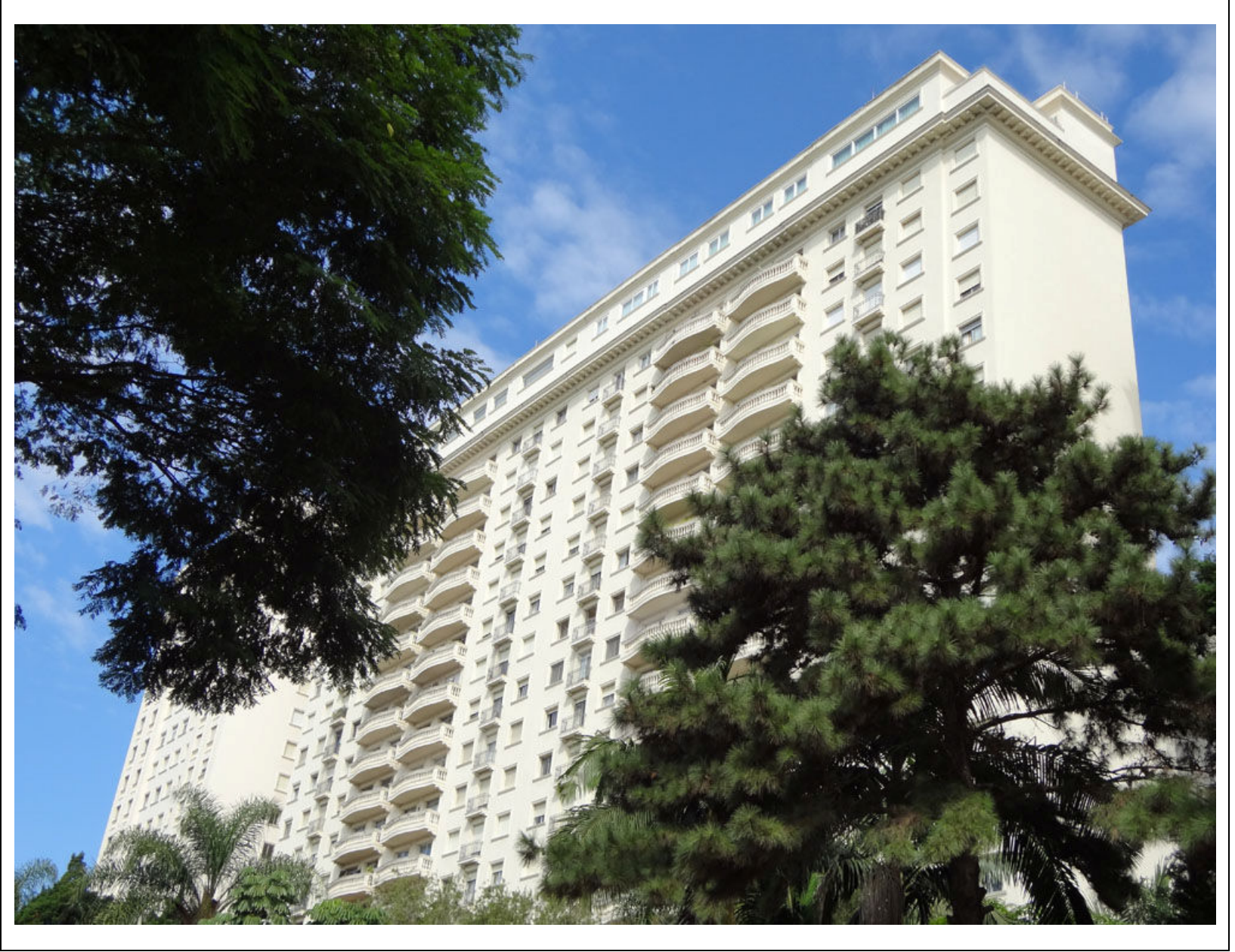

Detalhe da fachada ${ }^{237}$

237 Foto: Demósthenes Magno Santos - maio 2012 


\section{APÊNDICE X - Esplanada Granja Julieta Rua João Carlos da Silva Borges}

Projeto: João Henrique da Rocha

Construção: Alfredo Mathias - início dos anos 1970

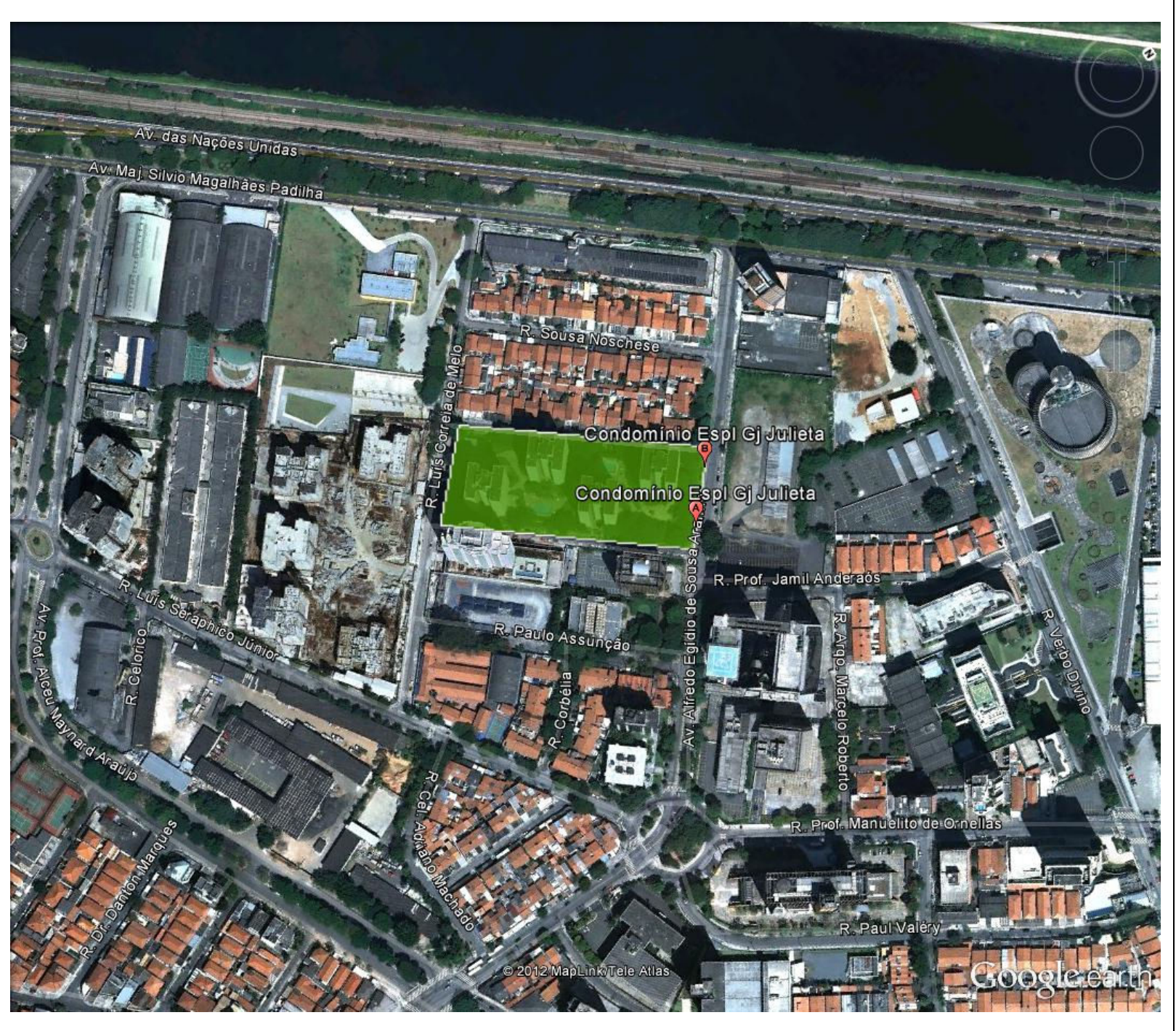

Localização238

238 Foto Google Earth - 2011 


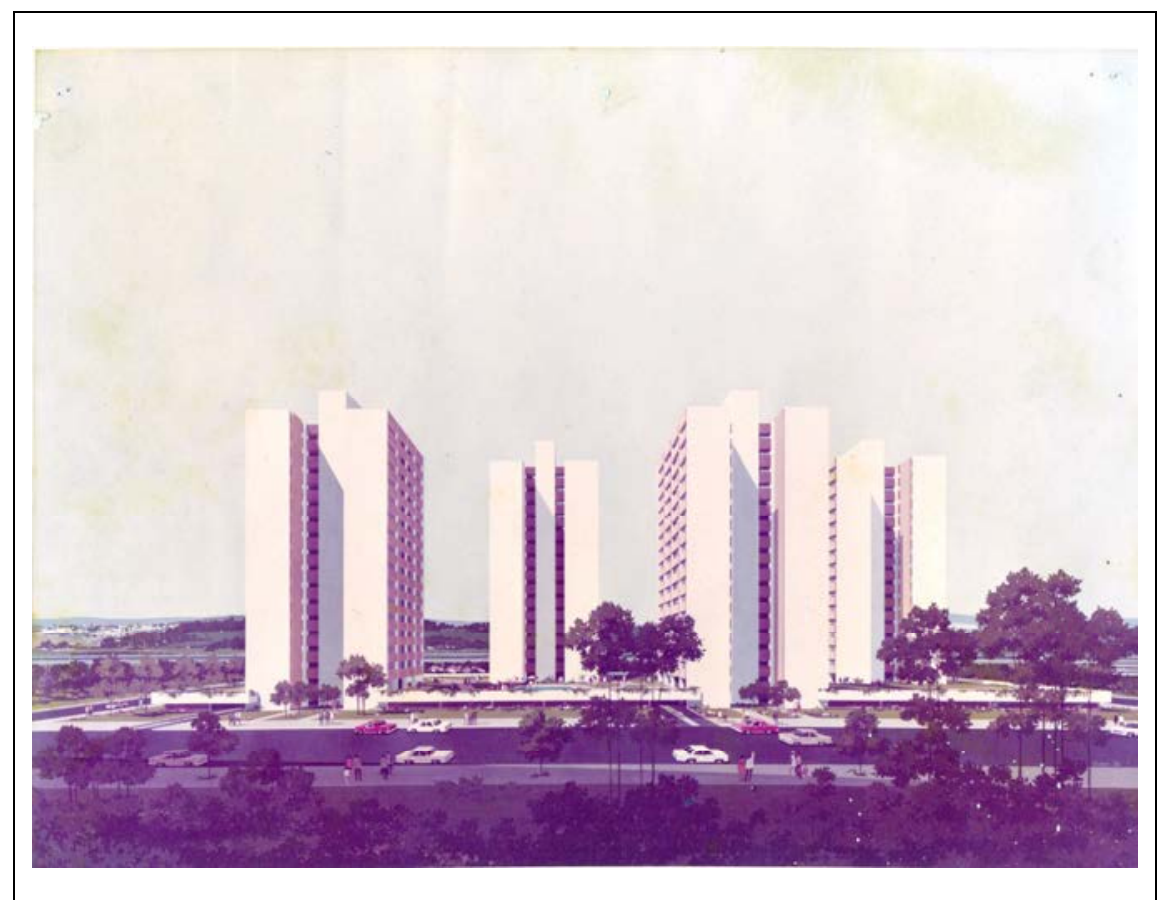

Figura 102: Perspectivas do empreendimento 239

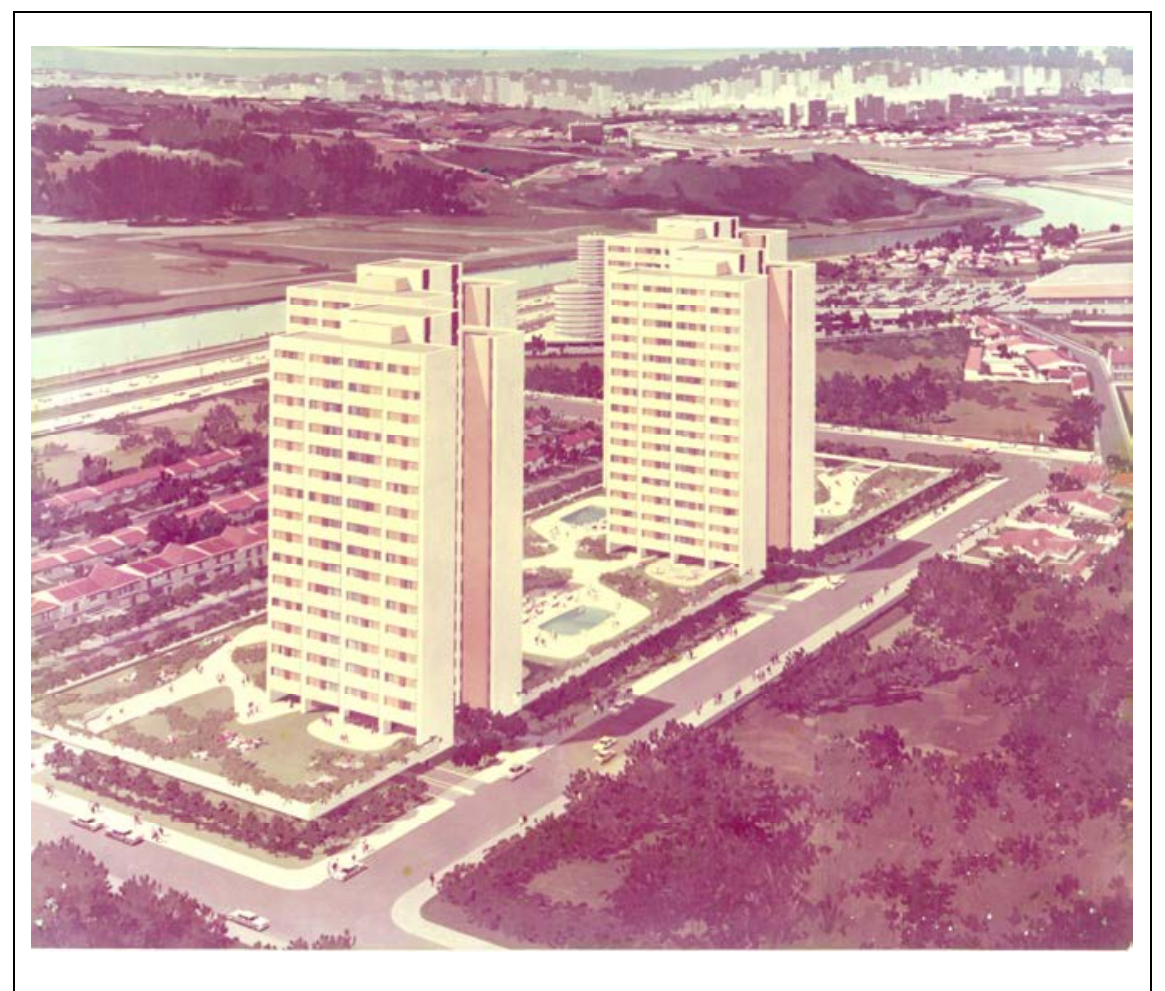

Figura 103: Perspectivas do empreendimento240

239 Fonte: autor Juan Cabeza Sastre, 1974 - Cópia do original, acervo Demósthenes Magno Santos 240 Fonte: autor Juan Cabeza Sastre, 1974 - Cópia do original, acervo Demósthenes Magno Santos 


\section{APÊNDICE Y - Condomínio Portal do Morumbi Avenida Guilherme Dumont Villares, 1269 - Morumbi}

Projeto: João Henrique da Rocha

Construção: Alfredo Mathias - 1973

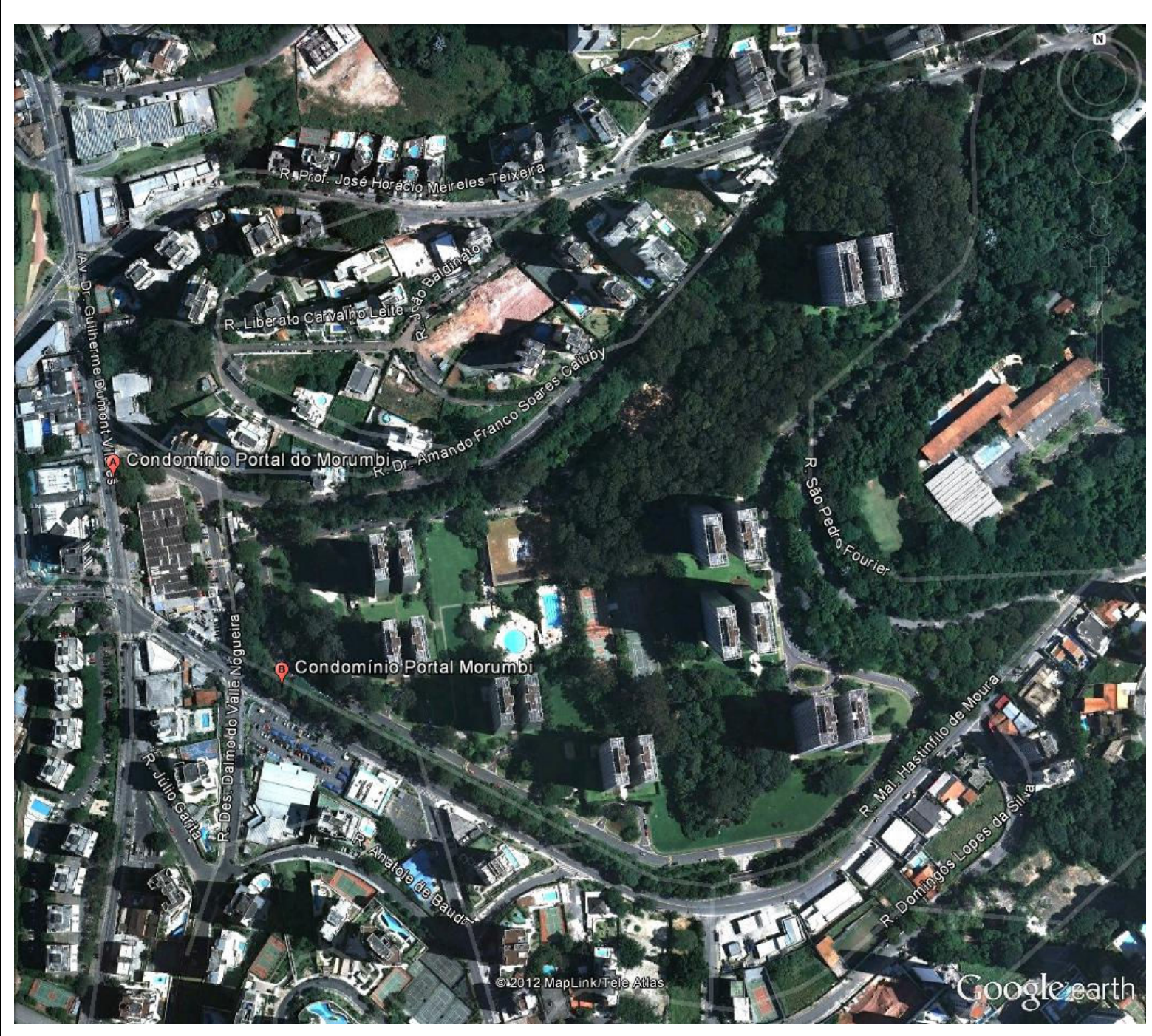

Localização24

241 Foto Google Earth - 2011 


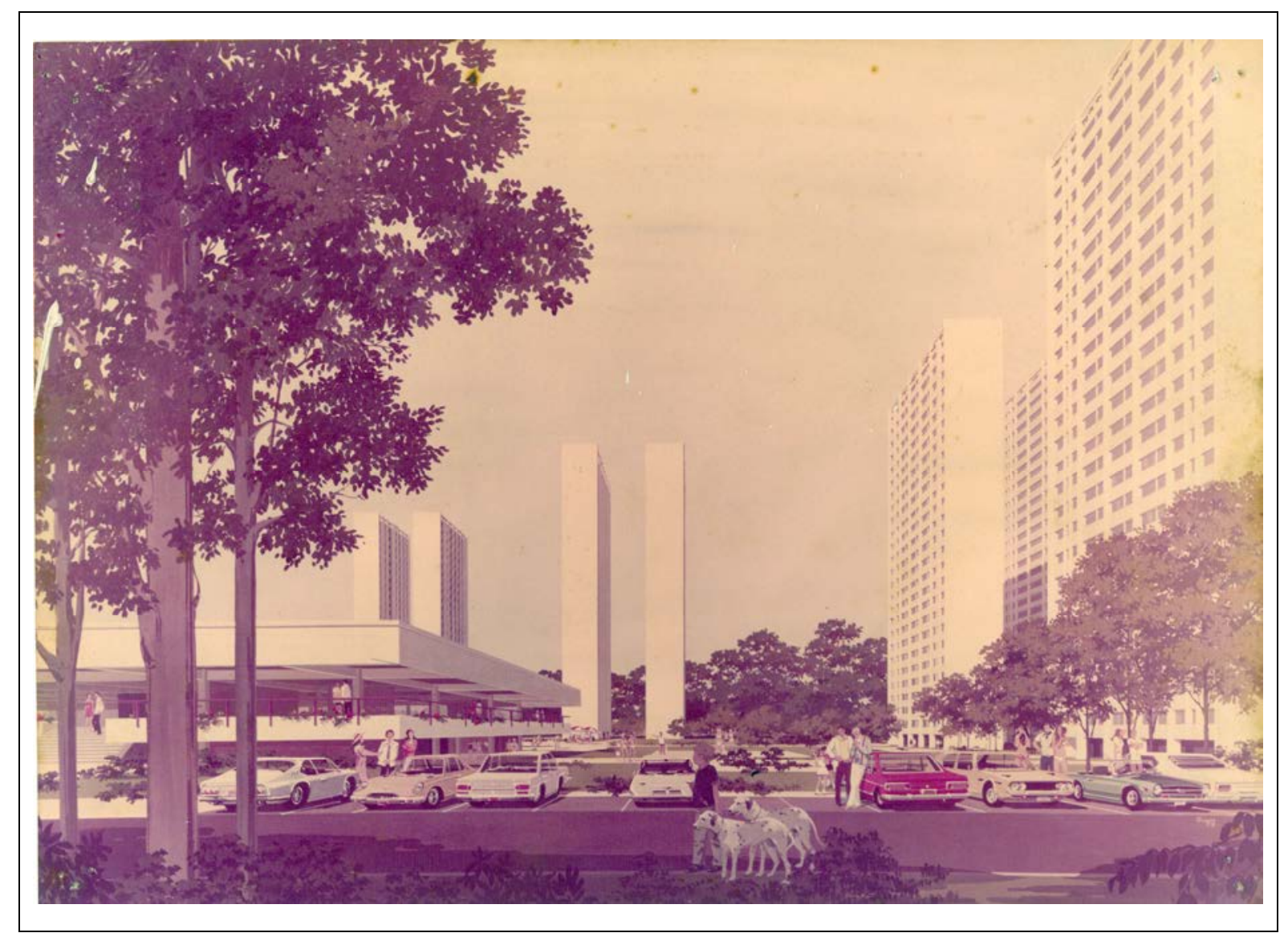

Figura 113: Portal do Morumbi, perspectiva do clube e prédios ao fundo242

242 Fonte: autor Juan Cabeza Sastre, 1974 - Cópia do original, acervo Demósthenes Magno Santos 


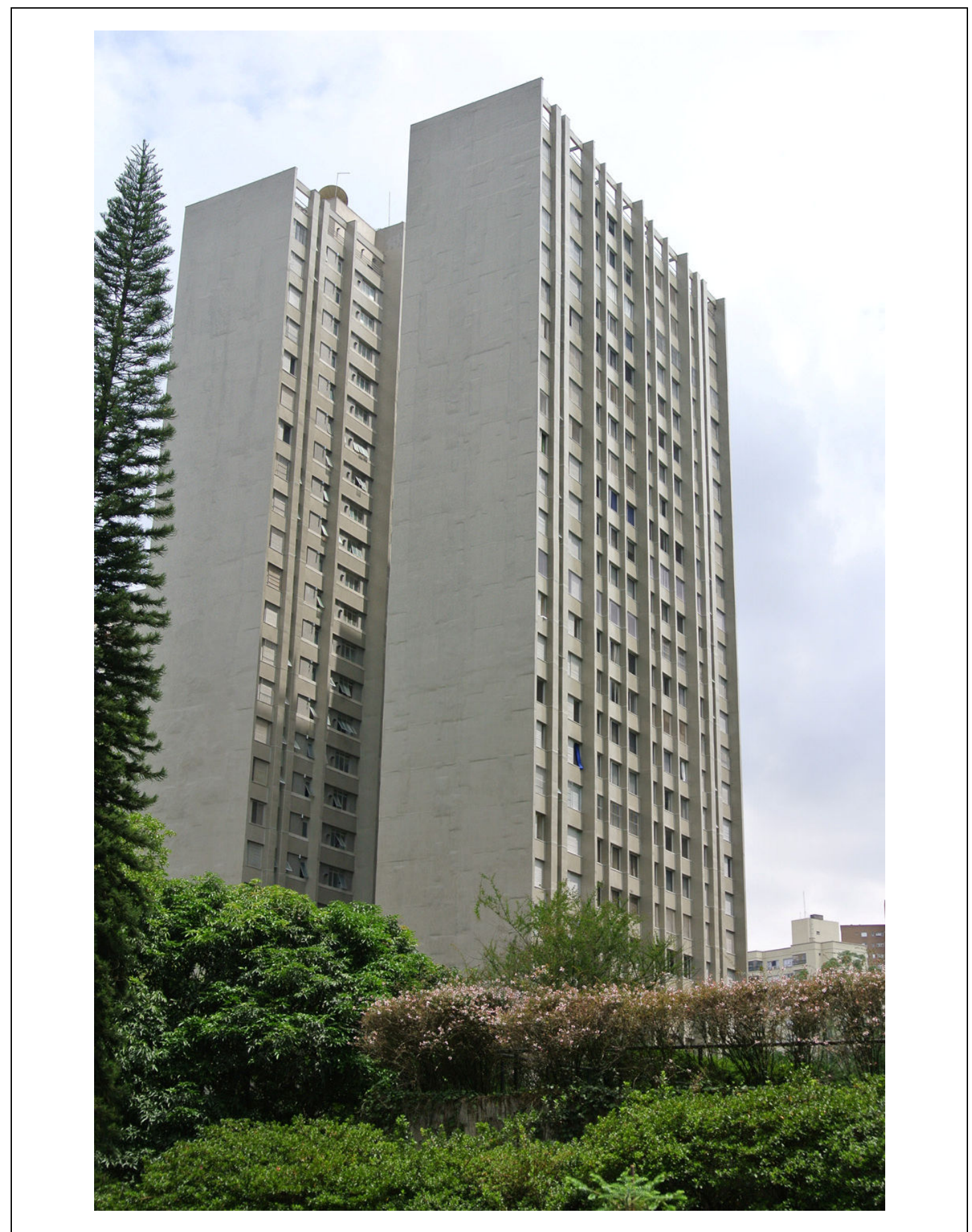

Figura 114: Portal do Morumbi - fachadas 243

243 Foto: Demósthenes Magno Santos - fevereiro 2013 


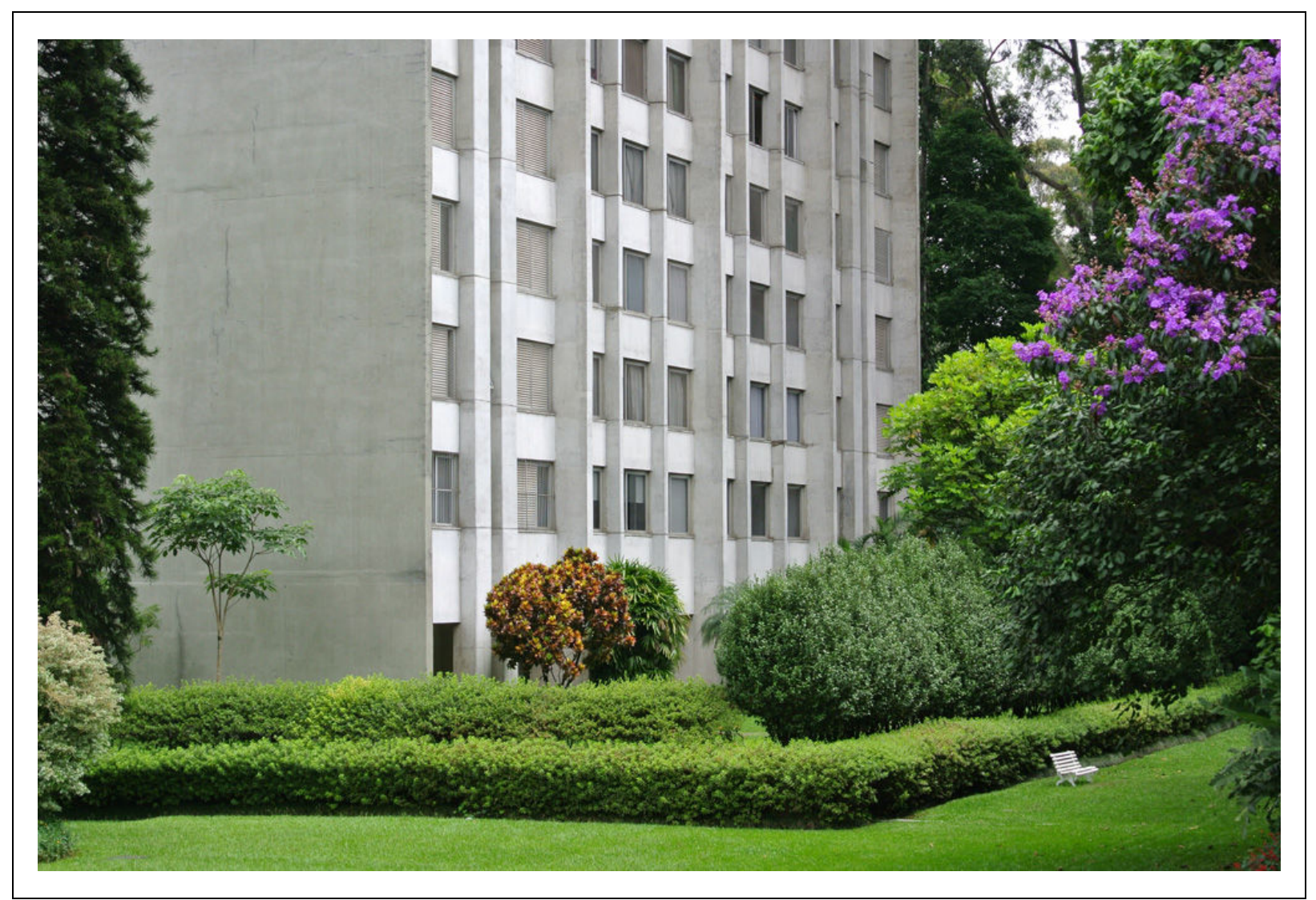

Figura 114: Portal do Morumbi - fachadas 244

244 Foto: Demósthenes Magno Santos - fevereiro 2013 
APÊNDICE Z - Centro Empresarial Lubeca

Atual Centro Empresarial São Paulo

Avenida Maria Coelho de Aguiar, 215 - Morumbi

Projeto: João Henrique da Rocha

Construção: Alfredo Mathias - 1973

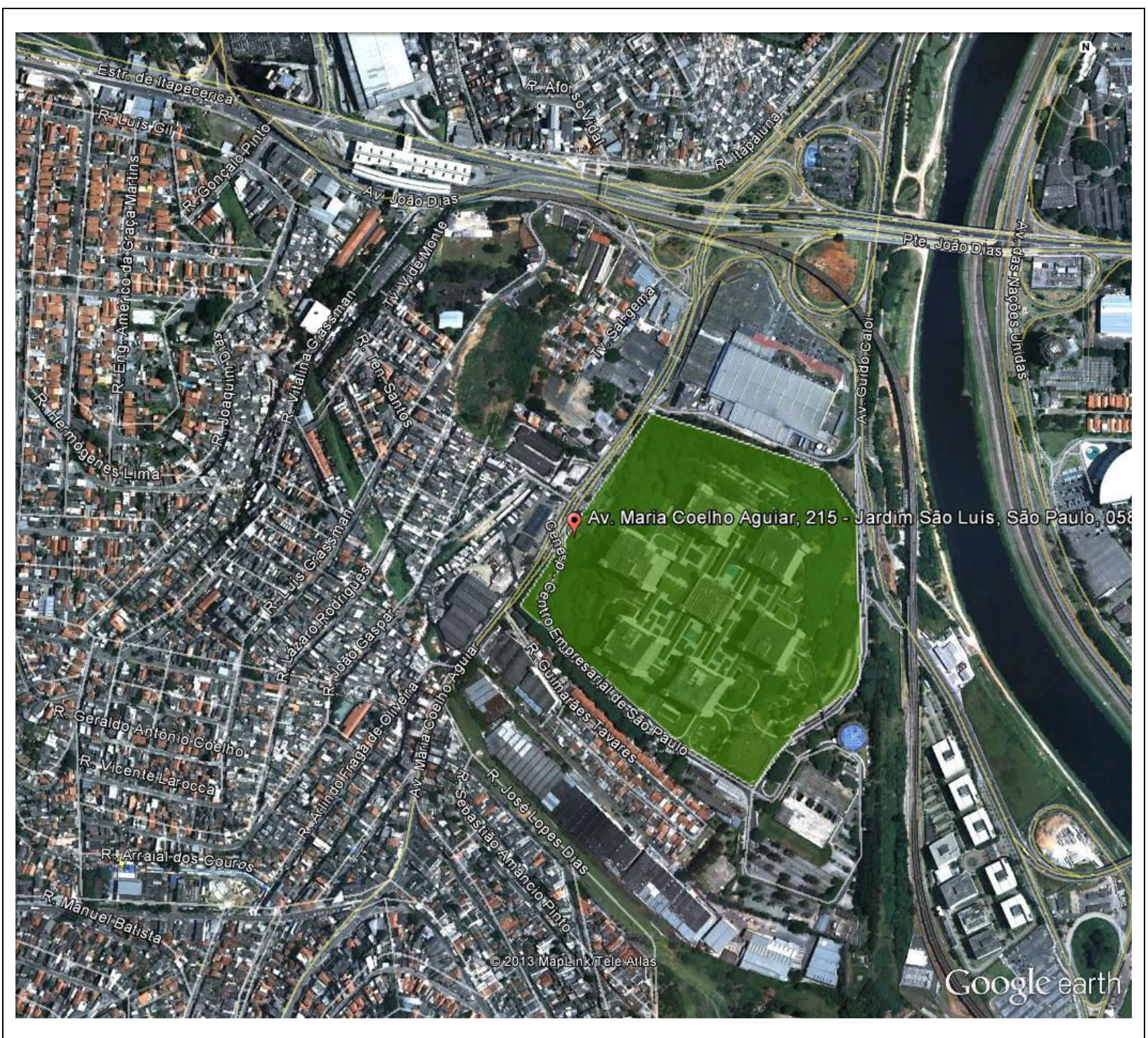

Localização245

245 Foto Google Earth - 2011 


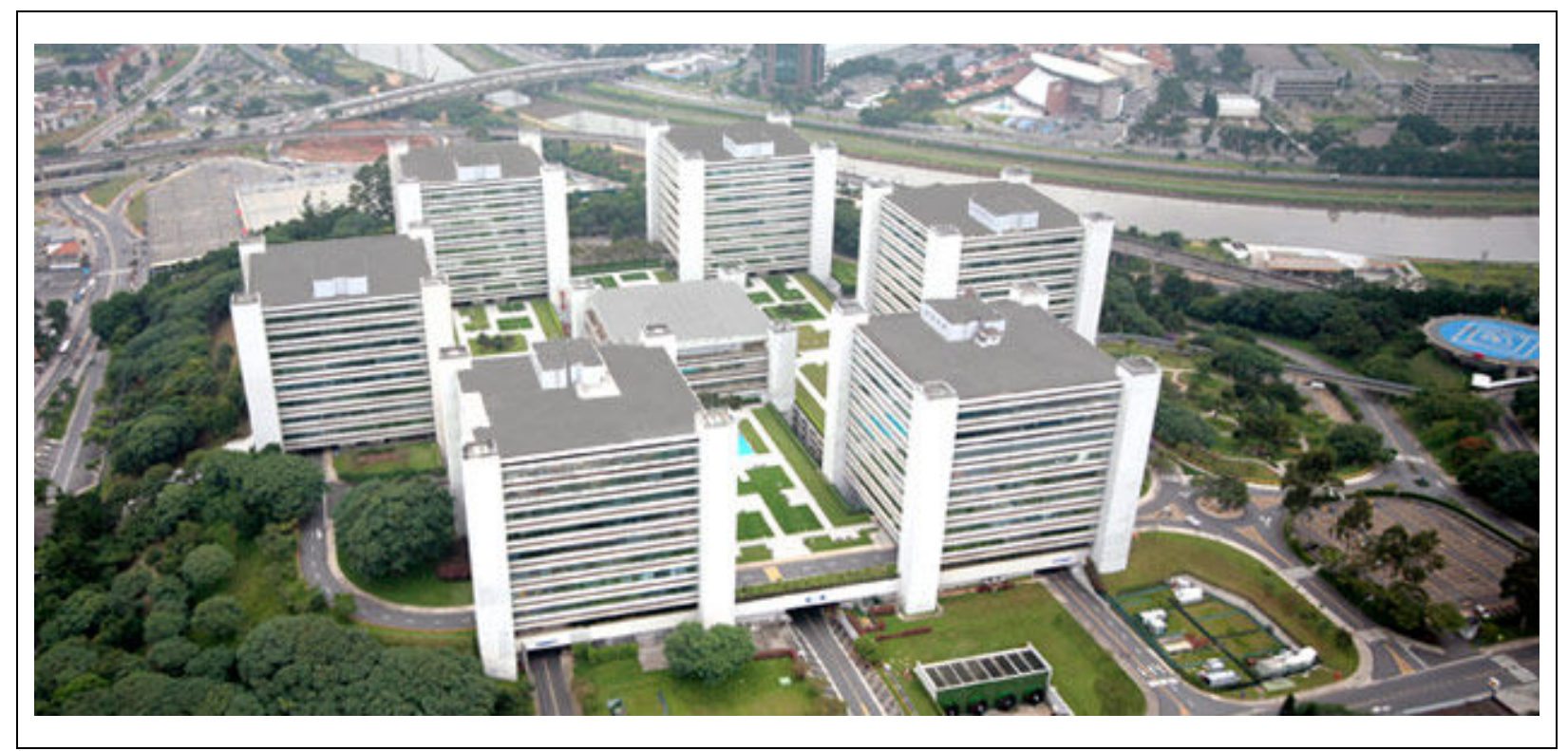

Foto do conjunto 246

246 Fonte: Centro Empresarial de São Paulo - Departamento de Manutenção. 


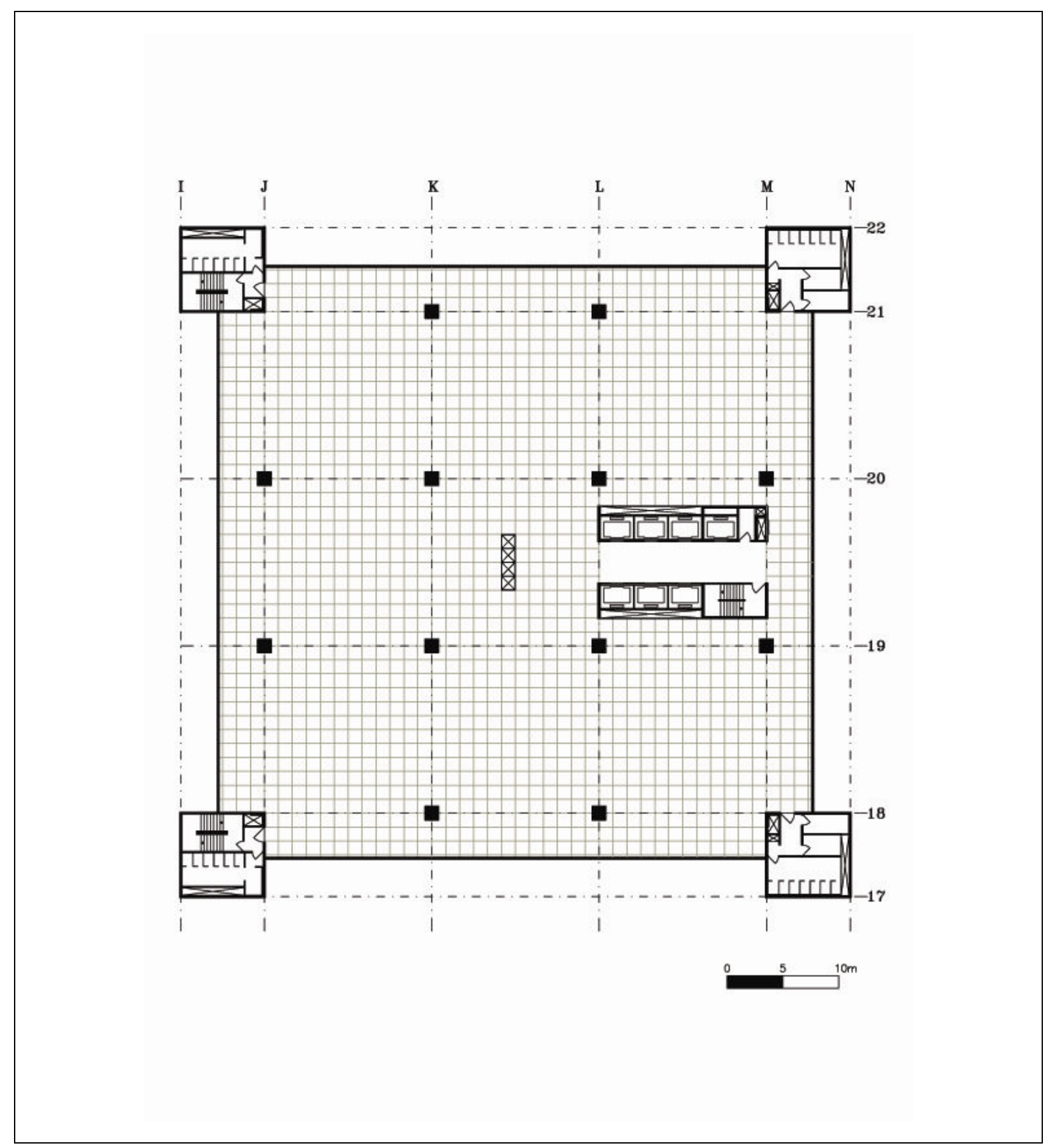

Planta do Andar Tipo 247

247 Fonte: Centro Empresarial de São Paulo - Departamento de Manutenção. 